МИНИСТЕРСТВО ЗДРАВООХРАНЕНИЯ РОССИЙСКОЙ ФЕДЕРАЦИИ РОСТОВСКИЙ ГОСУДАРСТВЕННЫЙ МЕДИЦИНСКИЙ УНИВЕРСИТЕТ

\author{
Е.В. Балязина
}

\title{
КЛАССИЧЕСКАЯ НЕВРАЛГИЯ ТРОЙНИЧНОГО НЕРВА
}




\section{Рецензенты:}

Бейн Б.Н., заведующий кафедрой неврологии, нейрохирургии ГБОу ВПО «Кировская государственная медицинская академия» Минздрава РФ, заслуженный врач РФ, д.м.н., профессор;

Maртиросян B.B., профессор кафедры нервных болезней и нейрохирургии ГБОУ ВПО «Ростовский государственный медицинский университет» Минздрава РФ, заслуженный работник высшей школы, д.м.н., профессор.

Балязина, E. В.

Б 20 Классическая невралгия тройничного нерва : монография / Е. В. Балязина. Рост. гос. мед. ун-т. - Новочеркасск : Лик , 2015. - 278 с. : ил. ISBN 978-5-906758-86-6

В монографии обобщен пятнадцатилетний опыт по изучению патогенеза, клиники, диагностики и лечения 298 больных, страдавших классической невралгией тройничного нерва. Изучение патогенеза проведено на большом морфологическом материале с применением макро- и микроанатомических методик и с использованием электронной микроскопии. Клинические особенности классической невралгии описаны с учетом выявленных интраоперационно вариантов васкулоневрального конфликта. Диагностика васкулоневрального конфликта осуществлялась с помощью мультиспиральной компьютерной ангиографии в режиме 3D. Описаны разработанные автором методы консервативной терапии. Описаны методики хирургического лечения невралгии тройничного нерва и проведено сопоставление их эффективности.

Книга предназначена для неврологов, нейрохирургов, лучевых диагностов, челюстно-лицевых хирургов и других специалистов, занимающихся диагностикой и лечением лицевых болей, а также слушателей ФУВа и студентов медицинских вузов.

УДК 616.8+616.833.15

ББК 56.12 


\section{ОГЛАВЛЕНИЕ}

СПИСОК СОКРАЩЕНИЙ

ВВЕДЕНИЕ 8

ГЛАВА 1. СОВРЕМЕННЫЕ ВЗГЛЯДЫ НА ПАТОГЕНЕЗ И ЛЕЧЕНИЕ КЛАССИЧЕСКОЙ НЕВРАЛГИИ ТРОЙНИЧНОГО HEPBA

1.1. КЛАССИФИКАЦИЯ ПРОЗОПАЛГИЙ ..................................................... 10

1.2. ОТ ИСТОКОВ К СОВРЕМЕННОМУ ВЗГЛЯДУ НА ПАТОГЕНЕЗ ...... 13

1.3. ПРИНЦИПЫ ЛЕЧЕНИЯ ТРИГЕМИНАЛЬНОЙ НЕВРАЛГИИ ........... 20

ГЛАВА 2. КЛИНИЧЕСКАЯ АНАТОМИЯ ТРОЙНИЧНОГО НЕРВА И ЕГО ВЗАИМООТНОШЕНИЯ С СОСУДАМИ МОЗЖЕЧКА

2.1. АНАТОМИЯ ТРОЙНИЧНОГО НЕРВА 27

2.2. ТОПОГРАФО-АНАТОМИЧЕСКИЕ ВЗАИМООТНОШЕНИЯ КОРЕШКА ТРОЙНИЧНОГО НЕРВА СО СМЕЖНЫМИ АРТЕРИЯМИ 38

2.3. ТОПОГРАФО-АНАТОМИЧЕСКИЕ ВЗАИМООТНОШЕНИЯ КОРЕШКА ТРОЙНИЧНОГО НЕРВА С ВЕРХНЕЙ КАМЕНИСТОЙ ВЕНОЙ И ЕЕ ПРИТОКАМИ

2.4. СРКТ-ИССЛЕДОВАНИЕ ОСОБЕННОСТЕЙ ОСНОВАНИЯ ЧЕРЕПА И ЛИЦЕВОГО СКЕЛЕТА У ЛИЦ, НЕ СТРАДАВШИХ ТРИГЕМИНАЛЬНОЙ НЕВРАЛГИЕЙ

ГЛАВА З. ПАТОГЕНЕЗ КЛАССИЧЕСКОЙ НЕВРАЛГИИ ТРОЙНИЧНОГО НЕРВА

3.1. АНАТОМИЧЕСКИЕ И ФИЗИЧЕСКИЕ ЗАКОНОМЕРНОСТИ ВАСКУЛОНЕВРАЛЬНОГО КОНФЛИКТА

3.2. РОЛЬ АНАТОМИЧЕСКИХ ОСОБЕННОСТЕЙ И ФИЗИЧЕСКИХ ЗАКОНОМЕРНОСТЕЙ В ЛОКАЛИЗАЦИИ БОЛЕЙ В ЗОНАХ ИННЕРВАЦИИ ПРЕИМУЩЕСТВЕННО ВТОРОЙ И ТРЕТЬЕЙ ВЕТВЕЙ ТРОЙНИЧНОГО НЕРВА

3.3. МОРФОЛОГИЧЕСКАЯ ОСНОВА ВОЗНИКНОВЕНИЯ ПАРОКСИЗМА И ФОРМИРОВАНИЯ ТРИГГЕРНЫХ ЗОН 
$4 \mid$ Классическая невралгия тройничного нерва

3.4. МОДЕЛЬ ПАТОГЕНЕЗА КЛАССИЧЕСКОЙ НЕВРАЛГИИ ТРОЙНИЧНОГО НЕРВА

ГЛАВА 4. СРАВНИТЕЛЬНАЯ ХАРАКТЕРИСТИКА КЛИНИЧЕСКИХ ПРОЯВЛЕНИЙ КЛАССИЧЕСКОЙ НЕВРАЛГИИ ТРОЙНИЧНОГО НЕРВА В ЗАВИСИМОСТИ ОТ АНАТОМИЧЕСКИХ ОСОБЕННОСТЕЙ ВАСКУЛОНЕВРАЛЬНОГО КОНФЛИКТА

4.1. КЛИНИЧЕСКИЕ ПРОЯВЛЕНИЯ НТН У БОЛЬНЫХ С ВАСКУЛОНЕВРАЛЬНЫМ КОНФЛИКТОМ, НЕ ПОДВЕРГШИХСЯ ДО МВД ДЕСТРУКТИВНЫМ ВМЕШАТЕЛЬСТВАМ

4.1.1. Клинические проявления НТН у больных с васкулоневральным конфликтом КТН с одним артериальным стволом

4.1.1.1. Клинические проявления НТН у больных с васкулоневральным конфликтом КТН с одним стволом ВМА

4.1.1.2. Клинические проявления НТН у больных с васкулоневральным конфликтом с одним стволом ПНМА

4.1.2. Клинические проявления НТН у больных с васкулоневральным конфликтом вентральной поверхности КТН с двумя стволами ВМА

4.1.3. Клинические проявления НТН у больных с васкулоневральным конфликтом КТН с тремя артериальными стволами

4.1.4 Клинические проявления НТН у больных с васкулоневральным конфликтом КТН с верхней каменистой веной . 118

4.1.5. Клинические проявления НТН у больных с васкулоневральнным конфликтом вентральной поверхности КТН с артериями мозжечка, а дорзальной - с верхней каменистой веной (артерио-венозный сэндвич)

4.1.6. Клинические проявления НТН у больных с васкулоневральным конфликтом вентральной поверхности КТН с ВMА и дорзальной - с ПНМА («артерио-артериальный сэндвич»)

4.2. КЛИНИЧЕСКИЕ ПРОЯВЛЕНИЯ НТН У БОЛЬНЫХ, КОТОРЫМ ДО МИКРОВАСКУЛЯРНОЙ ДЕКОМПРЕССИИ БЫЛИ ВЫПОЛНЕНЫ РАЗЛИЧНЫЕ ДЕСТРУКТИВНЫЕ ВМЕШАТЕЛЬСТВА 
4.2.1. Клинические проявления НТН у больных, ранее перенесших деструктивные вмешательства с васкулоневральным конфликтом с одним артериальным стволом

4.2.1.1. Клинические проявления HТН у больных, ранее перенесших деструктивные вмешательства с васкулоневральным конфликтом с одним стволом ВМА

4.2.1.2. Клинические проявления НТН у больных, ранее перенесших деструктивные вмешательства с васкулоневральным конфликтом с одним стволом ПНМА ... 134

4.2.2. Клинические проявления НТН у больных, ранее перенесших деструктивные вмешательства с васкулоневральным конфликтом с двумя стволами ВМА

4.2.3. Клинические проявления НТН у больных, ранее перенесших деструктивные вмешательства с васкулоневральным конфликтом КТН с верхней каменистой веной

4.2.4. Клинические проявления НТН у больных, ранее перенесших деструктивные вмешательства с васкулоневральным конфликтом с двумя артериями: базилярной и ПНМА с вентральной поверхностью КТН и ВКВ с его дорзальной поверхностью

4.2.5. Клинические проявления НТН у больных, ранее перенесших деструктивные вмешательства с васкулоневральным конфликтом с двумя артериальными стволами: одним стволом ВМА и стволом ПНМА с вентральной поверхностью КТН и ВКВ с его дорзальной поверхностью

4.3. РОЛЬ ВАСКУЛОНЕВРАЛЬНОГО КОНФЛИКТА В ПАТОГЕНЕЗЕ СИМПТОМАТИЧЕСКОЙ НЕВРАЛГИИ ТРОЙНИЧНОГО НЕРВА ... 143

4.3.1. Клинические проявления НТН у больных с петрокливальными менингиомами

4.3.2. Клинические проявления НТН у больных рассеянным склерозом

4.3.3. Клинические проявления НТН у больной с артериовенозной мальформацией задней черепной ямки 
$6 \mid$ Классическая невралгия тройничного нерва

4.4. СРАВНИТЕЛЬНЫЙ АНАЛИЗ ПОКАЗАТЕЛЕЙ ТЕЧЕНИЯ ЗАБОЛЕВАНИЯ С РАЗЛИЧНЫМИ ВАРИАНТАМИ ВАСКУЛОНЕВРАЛЬНЫХ КОНФЛИКТОВ

4.5. СРАВНИТЕЛЬНЫЙ АНАЛИЗ ПОКАЗАТЕЛЕЙ ПРОТЕКАНИЯ ЗАБОЛЕВАНИЯ В РАЗЛИЧНЫХ ВОЗРАСТНЫХ ГРУППАХ БОЛЬНЫХ С ВЕРИФИЦИРОВАННЫМ ДИАГНОЗОМ

4.6. СРАВНИТЕЛЬНЫЙ АНАЛИЗ ПОКАЗАТЕЛЕЙ ПРОТЕКАНИЯ ЗАБОЛЕВАНИЯ У ПАЦИЕНТОВ С РАЗЛИЧНОЙ ЧАСТОТОЙ ПРИСТУПОВ ЗА СУТКИ

ГЛАВА 5. ДИФФЕРЕНЦИАЛЬНАЯ ДИАГНОСТИКА КЛАССИЧЕСКОЙ И СИМПТОМАТИЧЕСКОЙ НЕВРАЛГИИ ТРОЙНИЧНОГО НЕРВА

5.1. РОЛЬ КЛИНИКО-НЕВРОЛОГИЧЕСКОГО МЕТОДА В ДИАГНОСТИКЕ КЛАССИЧЕСКОЙ И СИМПТОМАТИЧЕСКОЙ НЕВРАЛГИИ ТРОЙНИЧНОГО НЕРВА

5.2. ЗНАЧЕНИЕ МРТ В ДИФФЕРЕНЦИАЛЬНОЙ ДИАГНОСТИКЕ КЛАССИЧЕСКОЙ И СИМПТОМАТИЧЕСКОЙ НЕВРАЛГИИ ТРОЙНИЧНОГО НЕРВА

5.3. ЗНАЧЕНИЕ СПИРАЛЬНОЙ КОМПЬЮТЕРНОЙ АНГИОГРАФИИ В ДИАГНОСТИКЕ ВАСКУЛОНЕВРАЛЬНОГО КОНФЛИКТА

ГЛАВА 6. ДИФФЕРЕНЦИАЛЬНАЯ ДИАГНОСТИКА КЛАССИЧЕСКОЙ НЕВРАЛГИИ ТРОЙНИЧНОГО НЕРВА ОТ ДРУГИХ ВИДОВ ПРОЗОПАЛГИЙ

ГЛАВА 7. ЛЕЧЕНИЕ КЛАССИЧЕСКОЙ НЕВРАЛГИИ ТРОЙНИЧНОГО НЕРВА

7.1. МЕДИКАМЕНТОЗНАЯ ТЕРАПИЯ

7.2. ПУНКЦИОННЫЕ ДЕСТРУКТИВНЫЕ МЕТОДЫ ЛЕЧЕНИЯ 213

7.3. КРИТЕРИИ ОТБОРА БОЛЬНЫХ ДЛЯ МИКРОВАСКУЛЯРНОЙ ДЕКОМПРЕССИИ КОРЕШКА ТРОЙНИЧНОГО НЕРВА

7.4. МИКРОВАСКУЛЯРНАЯ ДЕКОМПРЕССИЯ 216

ЗАКЛЮЧЕНИЕ 227 


\section{СПИСОК СОКРАЩЕНИЙ}

НТН - невралгия тройничного нерва

КТН - корешок тройничного нерва

MPT - магнитно-резонансная томография

МВД - микроваскулярная декомпрессия

BMA - верхняя мозжечковая артерия

БА - базилярная артерия

ПНМА - передняя нижняя мозжечковая артерия

ЗНМА - задняя нижняя мозжечковая артерия

ВКВ - верхняя каменистая вена

ВКС - верхний каменистый синус

ПВМ - поперечная вена моста

PC - рассеянный склероз

PP - рецидивирующе-ремиттирующая

ВП - вторично прогрессирующая

ВАШ - визуальная аналоговая шкала

СКТ АГ - спиральная компьютерная ангиография

AАC - артерио-артериальный сендвич

ABC - артерио-венозный сендвич

РКТ - рентгенкомпьютерная томография 
$8 \mid$ Классическая невралгия тройничного нерва

\section{ВВЕДЕНИЕ}

Каждый человек в своей жизни испытывал боль. Остро возникшая боль, как правило, сигнализирует об опасности сохранения целостности организма, об угрозе его разрушения. Такую боль древние греки называли сторожевым псом здоровья. Страдающий от ноцицептивной боли человек ищет спасения и получает сочувствие и соучастие окружающих людей и адекватную их помощь. Биологическая целесообразность такой боли очевидна.

Другое дело - нейропатическая боль, когда болевые переживания не сопровождаются угрозой физического разрушения или повреждения организма. Такая боль носит субъективный характер без внешних проявлений, угрозы целостности и сохранности организма. Эта боль является следствием нарушений в системе проведения болевой информации как на уровне периферической, так и на уровне центральной нервной системы. Такая боль истощает человека душевно и физически, формирует глубокую депрессию, лишает перспективы на будущее, подавляет интерес ко всем сторонам жизни: семейной, трудовой; разрушает его духовный и моральный облик, и весь его мир сосредотачивается на этой мучительной боли. Еще знаменитый врач Амбруаз Паре говорил: «Ничто не в силах ослабить жизненные силы организма и дух человека, как боль».

Лицо является наиболее частым местом возникновения подобных болей. Самым тягостным страданием среди них является невралгия тройничного нерва, преобладающая по частоте среди других видов прозопалгий. Клиническая картина этого страдания хорошо известна и характеризуется приступообразными болями в лице, возникающими при малейшем раздражении кожи лица и слизистой оболочки полости рта. Больной лишается возможности умыться, обработать полость рта, проглотить пищу, разговари- 
вать, выйти на свежий воздух и пр. В отношении этиологии классической невралгии тройничного нерва были высказаны самые разнообразные суждения: перенесенные инфекционные заболевания, нарушения обмена веществ, экзогенная и эндогенная интоксикация, циркуляторные расстройства, слипчивый арахноидит, перипахименингит и микеллит, сдавление корешка тройничного нерва и прочее. Особенно примечательно то обстоятельство, что каждая гипотеза являлась мотивом для разработки новых и новых методов как консервативного, так и хирургического лечения. И хотя многие деструктивные операции себя не оправдали, в связи с высоким процентом рецидивов заболевания и причиняемыми ими дополнительными страданиями, из-за развивающегося деафферентационного синдрома, они продолжают выполняться во многих лечебных учреждениях и в настоящее время.

Изучению патогенеза классической невралгии тройничного нерва, а на его основе разработке более эффективных методов консервативного и хирургического лечения и посвящен наш скромный труд. 
$10 \mid$ Классическая невралгия тройничного нерва

\section{ГЛАВА 1}

\section{СОВРЕМЕННЫЕ ВЗГЛЯДЫ НА ПАТОГЕНЕЗ И ЛЕЧЕНИЕ КЛАССИЧЕСКОЙ НЕВРАЛГИИ ТРОЙНИЧНОГО НЕРВА}

\section{1. КЛАССИФИКАЦИЯ ПРОЗОПАЛГИЙ}

В настоящее время в литературе представлено большое количество классификаций прозопалгий. Среди них в нашей стране наибольшее распространение получили классификации, предложенные Ерохиной Л.Г. (1973), Карловым В.А. и Савицкой О.Н. (1990), Гречко В.Е. $(1981,1990)$ и Вейном А.М. (2001). В них в той или иной транскрипции рассматривается первичная (истинная или идиопатическая) невралгия тройничного нерва (НTH), симптоматическая и постгерпетическая.

Современная классификация прозопалгий была опубликована Международным обществом по изучению головной боли (HIS) в 1988 году, а в 1992 году «Международная классификация головных болей, краниальных невралгий и лицевых болей» была принята Всемирной Организацией Здравоохранения и включена в Международную классификацию болезней (МКБ - 10, 1995). Лицевые боли представлены в 6 классе «Поражения отдельных нервов, нервных корешков и сплетений» разделами G 50 - 50.9. Однако такая обобщенная классификация не отвечает клиническим требованиям. В 2003 году HIS опубликовано 2 издание международной классификации головных болей (МКГБ), в которой выделяется классическая тригеминальная невралгия, обусловленная 
васкулоневральным конфликтом без участия каких-либо других дополнительных факторов, и симптоматическая тригеминальная невралгия, а также невралгии других ветвей ТН и других черепно-мозговых нервов:

G 44.847 Тригеминальная невралгия;

G 44.847 Классическая тригеминальная невралгия;

G 44.847 Симптоматическая тригеминальная невралгия;

G 44.847 Глоссофарингеальная невралгия;

G 44.847 Классическая глоссофарингеальная невралгия;

G 44.847 Симптоматическая глоссофарингеальная невралгия;

G 44.847 Невралгия промежуточного нерва;

G 44.847 Невралгия верхнего нерва гортани;

G 44.847 Назоцилиарная невралгия;

G 44.847 Супраорбитальная невралгия;

G 44.847 Невралгии других ветвей тройничного нерва;

G 44.847 Персистирующая идиопатическая лицевая боль;

G 44.847 Синдром «пылающего рта»;

G 44.851 Шейно-язычный синдром.

Существенный вклад в понимание этих различий внесли Eller J.L. et al. (2005), предложив свою классификацию НTH, выделив 7 вариантов тригеминальных болей.

Классическую НТН они подразделяют на два подтипа:

1а) когда ведущим симптомом являются спонтанные эпизодические боли;

1б) когда боли изначально носят постоянный характер.

Далее выделены:

2) тригеминальная невропатическая боль в результате травмы или хирургического вмешательства;

3) тригеминальные деафферентационные боли в результате целенаправленного разрушения периферических ветвей, ганглиолизиса или ризотомии как способа лечения НТН;

4) симптоматическая НТН у больных рассеянным склерозом;

5) постгерпетическая НТН вследствие кожных высыпаний herpes zoster в зонах иннервации ТН;

6) атипичные лицевые боли психогенного характера. 
$12 \mid$ Классическая невралгия тройничного нерва

Развитие той или иной формы НТН обусловлено уровнем и характером поражения ТН. Некоторым недостатком предложенной классификации, с нашей точки зрения, является то, что авторы в разделе симптоматической НТН указали только рассеянный склероз, в то время как клиника классической НТН, в особенности первого типа, может наблюдаться у больных с опухолями мостомозжечкового угла, артериовенозными мальформациями, аневризмами, кистами и пр. Ранее один из авторов этой классификации [172] подчеркивал клиническое и патогенетическое отличие каждой из этих форм НТН.

Анализируя результаты собственных исследований Miller J.P. et al. (2009) подчеркивали, что для первого типа НТН характерен васкулоневральный конфликт с артериальным сосудом, в то время как для второго типа НТН более характерен конфликт с веной, либо отсутствие конфликта вообще. Sandell T., Eide P.K. (2010) подразделяют первый тип на два подтипа. При подтипе Ia возникают типичные внезапные приступообразные болевые пароксизмы (в виде «удара молнии» или «разряда электрического тока») длительностью от нескольких секунд до нескольких минут, стреляющего характера, выявляются триггерные точки. Подтип Іб характеризуется наличием типичных тригеминальных приступов на фоне постоянной лицевой боли ноющего, жгучего и пульсирующего характера. Эти два подтипа (Іа и Іб) соответствуют I типу, описанному Burchiel K.J. (2003) для классической НТН. Второй тип НТН характеризуется наличием постоянной боли ноющего, жгучего и стреляющего характера. Внезапные типичные приступы не вызываются, хотя могут иметь место приступообразные боли. Авторы подчеркивают, что у больных НTH I типа артериальный конфликт встречается в два раза чаще, а венозный, наоборот, в пять раз реже, чем у больных с HTH II типа. При этом отдаленные результаты хуже у больных с НTH II типа и количество рецидивов заболевания значительно выше. С учетом клинических различий между классической HTH I и II типов авторы рассматривают парадигму, способствующую выбору более адекватного метода ле- 
чения. О более худших результатах после МВД при атипичной HTH (II типе) сообщают также Sindou M. et al. (2007, 2010). Bagheri S.C. et al. (2004) подчеркивают, что больные с жалобами на лицевые боли обращаются к различным специалистам, и их задача своевременно и правильно распознать заболевание. Laurent B. et al. (2009) обращают внимание на трудности диагностики НТН при атипичных формах и/или при длительном течении заболевания. В то же время, несмотря на типичную клинику классической НТН, она может оказаться вторичной, обусловленной другими патологическими процессами (опухолями, аневризмами, кистами, метастазами, аномалиями развития черепа и мозга). Наиболее полной, с нашей точки зрения, является классификация тригеминальной невралгии, предложенная Eller J.L. et al. (2005), поскольку в ней рассматриваются не только клинические варианты невралгии, возникающие спонтанно, но и варианты невропатии, индуцированные широким применением деструктивных вмешательств в качестве лечебных мероприятий.

\section{2. ОТ ИСТОКОВ К СОВРЕМЕННОМУ ВЗГЛЯДУ НА ПАТОГЕНЕЗ}

Невралгия тройничного нерва была известна еще Гиппократу и Галену. Первое описание симптомов НТН принадлежит врачу, известному философу Джону Локку (John Locke). Во время пребывания в Париже в 1677 году он был приглашен осмотреть жену английского посла, которая страдала от нестерпимых болей в лице и нижнечелюстном суставе. Локк назначил широко известный препарат (слабительное средство), и через несколько недель больной стало лучше [189].

Немногим более столетия после этого события появились две серьезные публикации, выделившие это заболевание в отдельную нозологическую форму. В 1756 году Николя Андре (Nicolas André) описал два случая НTH, назвав заболевание болез- 
$14 \mid$ Классическая невралгия тройничного нерва

ненный тик (tic douloureux), отнеся его к группе судорожных состояний, таких как «истинные тонические судороги, тетанус и спазм». Андре предполагал, что причиной заболевания является «порочная нервная жидкость», которая повреждает нерв и вызывает приступы боли.

В 1773 году английский врач Джон Фозергилл (John Fothergill) представил 14 наблюдений. Он подробно описал болевой пароксизм, провокацию его едой, разговором и движением мышц, подчеркивая, что легкие раздражения (прикосновение носовым платком или рукой) вызывают пароксизм боли, в то время как сильное раздражение к болевому пароксизму не приводит [189]. Фозергилл настаивал на том, что НTH не относится к группе судорожных заболеваний (первое в истории изучения НТН противоречие во взгляде на патогенез), полагая, что она является симптомом рака. Благодаря подробному описанию клиники $\mathrm{HTH}$, заболевание называют болезнью Фозергилла.

В 1820 году Черлз Белл (Charles Bell) предположил, что причина «болевого спазма» кроется в патологии тройничного нерва, что послужило основанием называть болезнь тригеминальная невралгия [189].

Однако подобная клиническая картина может развиваться при различных патологических процессах в задней черепной ямке. К таким заболеваниям относятся: опухоли мосто-мозжескового угла [67, $145,181,211,244,248,287,319,347,348]$, арахноидиты задней черепной ямки $[142,323]$, аневризмы и артерио-венозные мальформации вертебробазилярного бассейна $[150,240,254,265,309,361$, $352,425]$, аномалии Арнольда-Киари [218, 405], платибазии [264, 357]. Клинически этот вид НТН отличается от классической нарастающим сенсорным дефицитом, не характерным для классической НТН. Такой вариант НТН в литературе называют симптоматической или вторичной $[63,116,316,391]$. В тех случаях, когда клиника классической НТН сопровождается чувствительным дефицитом, используют термин чувствительная тригеминальная нейропатия [331, 423]. У больных рассеянным склерозом также 
наблюдается НТН, которую многие авторы относят ко вторичной HTH $[63,74,154,158,169,170,184,340,354,365,366,378]$.

До настоящего времени продолжается дискуссия о причинах возникновения классической НТН. Некоторые авторы [72] рассматривали воздействие низкой температуры на ткани лица как возможную причину возникновения НТН. Другие авторы [116] связывали возникновение НТН с заболеваниями зубов. Л.Я. Лившиц (1968) у больных с ТН в 70\% случаев обнаружил высокое стояние пирамиды височной кости на стороне заболевания, что было расценено им как фактор, раздражающий корешок тройничного нерва. Позже [122] было установлено, что у практически здоровых лиц правое тройничное вдавление в области вершины пирамиды височной кости расположено выше, чем левое.

Рубин Л.Р. (1966) большое значение в возникновении ТН придавал патологии нижнечелюстного сустава, сопровождающейся синдромом патологического прикуса. Он рекомендовал при тригеминальной невралгии проводить ортопедическое лечение с помощью аппарата, корригирующего прикус. Но такое представление о патогенезе НТН не может объяснить возникновение невралгии первой и второй ветвей тройничного нерва.

Ряд новых методов лечения НТН был предложен в связи с компрессионной теорией происхождения заболевания. Причиной возникновения НTH Sicard A. (1925) считал сужение круглого и овального отверстий вследствие их склерозирования или образования остеофитов в пожилом возрасте. В пользу этого свидетельствовали клинические данные: преимущественное страдание лиц преклонного возраста и наиболее частое поражение второй и третьей ветвей, как в отдельности, так и вместе. Позже Савицкая О.Н. (1976) с помощью рентгенографии, а Щедренок В.В. и соавт. (2014) с помощью мультиспиральной рентгенкомпьютерной томографии обнаружили стеноз нижнечелюстного канала и сужение подглазничного и подбородочного отверстий на стороне болевых пароксизмов, расценивая его как причину невралгии третьей ветви тройничного нерва $[75,78,84,109]$. На основании данного предположения 
$16 \mid$ Классическая невралгия тройничного нерва

стали применяться хирургические методы лечения, направленные на расширение нижнечелюстного канала [55]. Однако высокий процент рецидивов заболевания дает основание сомневаться в этиопатогенетической значимости этого признака. Также имеются указания на то, что диаметр черепных отверстий с возрастом может увеличиваться [426], и это увеличение достигает существенных значений. Например, для круглого отверстия, если сравнивать подростков и взрослых, разница составляет свыше 0,5 мм в диаметре. Однако не было замечено, что НТН чаще возникает у лиц молодого возраста, более того, наблюдается обратная зависимость. Эти данные служат дополнительным доказательством того, что сам размер отверстий играет второстепенную (или даже минимальную) роль в развитии НТН.

В то же время среди стоматологов и челюстно-лицевых хирургов экстракраниальный генез лицевых болей сохраняет свои позиции до настоящего времени [136, 257]. Поэтому в ряде стоматологических и нейрохирургических клиник и в настоящее время продолжают выполнять расширение нижнечелюстного канала и подглазничного отверстия [74].

Важным фактором, приводящим к сужению каналов, в которых компремируются ветви тройничного нерва, многие авторы [78, 116, 118] считают воспалительные заболевания придаточных пазух носа. Воспалительный процесс в пазухах, по их мнению, приводит к уменьшению просвета каналов, компрессии ветвей тройничного нерва и, как следствие, развитию тригеминальной невралгии. Другие - $[52,54,93]$ за компремирующий фактор принимают спайки в области мосто-мозжечкового угла, образованию которых, по их мнению, способствуют перенесенные ранее синуиты, кариозные зубы, отиты и т.п.

В основе другой компрессионной теории возникновения НТН лежит сдавление корешка тройничного нерва каменистоклиновидной связкой твердой мозговой оболочки в тригеминальной вырезке Грубера в том месте, где нерв переходит из средней черепной ямки в заднюю [214]. 
Предлагавшаяся на основании этой гипотезы операция декомпрессии корешка тройничного нерва путем рассечения связки подкупала своей технической простотой и таким важным обстоятельством как сохранение чувствительности на лице. По мере накопления опыта применения подобных операций, было выявлено большое количество рецидивов болей [324]. Неудовлетворительные отдаленные результаты операции по рассечению каменисто-клиновидной связки поставили под сомнение ее компремирующее воздействие на тройничный нерв как причину НТН [399].

В отечественной литературе существует понятие о так называемой одонтогенной НТН. Сторонники этой гипотезы [61, 62, 63], придерживающиеся одонтогенной этиологии, связывают начало заболевания с травматичным удалением зубов, наличием костных отломков и остатков корней зубов в лунках, пульпитами и периодонтитами [62]. Следует отметить, что болевой синдром при этой форме умеренный, продолжительный, триггерные зоны отсутствуют, что является принципиальным отличием от классической НТН. В зарубежной литературе понятие одонтогенная НТН отсутствует.

Эволюция представлений о характере заболевания НТН нашла отражение в работах второй половины 20 века. Некоторые авторы [46] рассматривали НТН как функциональное заболевание. В то же время другие [69] утверждали, что в ее основе лежат органические изменения. Проведенные в ряде стран морфологические исследования выявили структурные изменения, как в корешке тройничного нерва, так и в его ветвях $[84,122,125,222$, 266, и др.], что положило конец дискуссии о том, является ли НТН функциональным или структурным заболеванием.

Обнаруженный Dandy W. еще в 1934 году конфликт между КТН и смежными сосудами мозжечка привлек внимание нейрохирургов лишь четверть века спустя. Впервые хирургическая декомпрессия КТН была выполнена Gardner W. и Miclos V. в 1959 году. Авторы описали сдавление парастволовой зоны КТН мозжечковыми артериями. Это легло в основу сформированной Gardner W. (1962) 
$18 \mid$ Классическая невралгия тройничного нерва

теории о сосудистой компрессии КТН, вблизи варолиева моста, как причины лицевого болевого пароксизмального синдрома. Эта мысль была горячо поддержана американским нейрохирургом Jannetta P.J. В 1967 году Peter Jannetta, взглянувший на черепномозговые нервы задней черепной ямки через операционный микроскоп, причиной НТН так же посчитал васкулоневральный конфликт. Однако он пошел дальше и разработал операцию (микроваскулярную декомпрессию корешка тройничного нерва), применив для устранения конфликта синтетический губчатый протез. Так родилась функциональная операция микроваскулярная декомпрессия (МВД), исключающая травму или пересечение КТН. Хорошие результаты МВД убедили большинство нейрохирургов в том, что ведущим фактором в этиологии НТН является васкулоневральный конфликт, а операция МВД является наиболее результативной.

Несмотря на успехи микроваскулярной декомпрессии в лечении НТН, в литературе продолжается дискуссия о роли васкулоневрального конфликта как причине НТН [143, 278, 324, 407]. Подвергая сомнению васкулоневральный конфликт как патогенетическую основу HTH, Adams S.D.T. (1989) приводит аргумент в виде контакта зрительного нерва и тракта с глазничной, внутренней сонной и передней мозговой артериями, и при этом отсутствует нарушение функции зрения. Глазодвигательный нерв проходит между задней мозговой и верхней мозжечковой артериями и никакого выпадения его функции не наблюдается. Мы полагаем, что эти контраргументы лишь подчеркивают тот факт, что контакт артерии с нервом принципиально отличается от конфликта, и эти отличия требуют изучения и поиска доказательной базы.

Kress B. et al. (2006) изучили взаимоотношение КТН со смежными сосудами на 48 добровольцах, не страдавших НТН, используя 1,5 Т МРТ, и обнаружили васкулоневральный контакт у 73\% обследованных, при этом у $61 \%$ - с артерией и у $27 \%$ - с веной. Авторы приходят к выводу о том, что контакт КТН с прилежащими со- 
судами является нормой и не служит доказательством васкулоневрального конфликта. Monstad P. (2007) обнаружил на МРТ контакт сосуда с КТН у большинства здоровых лиц. Benes L. et al. (2005) выразили сомнение в том, что высокопольная МРТ вообще может достоверно установить наличие компрессии КТН у больных НТН. Peker S. et al. (2009) и Miller J.P. et al. (2009) обнаружили васкулоневральный конфликт у здоровых лиц, используя 3Т МРТ, в то же время у большинства больных НТН ими также обнаружен васкулоневральный конфликт, подтвержденный при МВД. Это дало основание авторам утверждать, что васкулоневральный конфликт не обязательно приводит к патологическому процессу, хотя у больных он выражен более ярко.

Такие противоречивые выводы, по-видимому, связаны с неоднозначным восприятием понятий «васкулоневральный конфликт», «сосудистый контакт», «васкулярная компрессия», что требует дальнейшего изучения топографо-анатомических взаимоотношений КТН со смежными сосудами, как в норме, так и у больных КТН.

Позже Love S. и Cookhman H.B. (2002) в месте васкулоневрального конфликта между отдельными волокнами обнаружили как бы искусственные синапсы (эфапсы), в которых происходит «короткое замыкание»и раздражение афферентных волокон. Подобные же изменения были обнаружены ими у больных рассеянным склерозом, страдающих НТН. Экспериментальные исследования, проведенные авторами, показали, что анатомические изменения способствуют эктопической генерации спонтанных нервных импульсов и их эфаптическому распространению. Эта спонтанная нервная активность увеличивается по мере нарастания деформации КТН, обусловленной пульсовыми ударами сосуда. Исчезновение всех симптомов НТН сразу после устранения васкулоневрального конфликта (МВД) происходит потому, что в результате разъединения демиелинизированных волокон и их освобождения от постоянной пульсирующей компрессии прекращается спонтанная генерация импульсов и их эфаптическое 
$20 \mid$ Классическая невралгия тройничного нерва

распространение. Как отмечают авторы этой гипотезы, роль ремиелинизации волокон КТН после МВД до конца не ясна. В то же время ремиелинизация может способствовать устранению некоторых симптомов НТН, крайне редко сохраняющихся после МВД. Процессом спонтанной ремиелинизации авторы объясняют ремиссии, наблюдающиеся в течение заболевания, как спонтанные, так и в результате терапии. Трудно не согласиться с ними в утверждении о том, что демиелинизация и эфаптическое распространение тактильного импульса объясняет большинство, если не все в патогенезе НТН.

Поскольку истинная природа НТН остается до конца не установленной, особенности симптоматики и течения заболевания порождают множество новых способов лечения. Несмотря на неопределенность патофизиологических механизмов НТН, доказанным фактом является очаговая демиелинизация корешка в области воротной зоны (Obersteiner-Redlich zone) в месте компрессии его сосудом практически у всех больных. Разработка комплексных методов лечения, направленных на все звенья патогенетической цепи НТН, является актуальной проблемой современной терапии лицевых болей.

\section{3. ПРИНЦИПЫ ЛЕЧЕНИЯ ТРИГЕМИНАЛЬНОЙ НЕВРАЛГИИ}

Впервые, в 1942 году Bergouignan для лечения НТН использовал противосудорожный препарат (diphenylhydantoin), обосновывая это пароксизмальным характером лицевых болей [189]. В последующем фенитоин широко использовался вплоть до 1962 года до появления более эффективного противосудорожного средства - карбамазепина. После сообщения Blom S. (1962) об эффективности карбамазепина он сохранил свои позиции в терапии НТН вплоть до настоящего времени [164].

Начало 70-х годов прошлого века характеризуется широким применением противосудорожных препаратов группы карбама- 
зепина (финлепсин, тегретол, окскарбазепин). Положительный эффект, полученный у 70-90\% больных, принимавших препарат впервые, давал надежду на решение проблемы лечения НТН [63, $117,110,112,113,177,179,368,402,418,419]$.

C накоплением опыта применения карбамазепина стало очевидным, что при длительном применении препарата положительный эффект снижается и не превышает 50-60\% [87, 177]. В 1966 году RB King предложил использовать для лечения НТН миорелаксанты. Позже стал применяться баклофен, агонист $\gamma$-аминомаслянной кислоты. Более поздние публикации о применении баклофена подчеркивали синергизм этого препарата с карбамазепином [395, 435].

В целях усиления терапевтического эффекта от применения карбамазепина многие авторы рекомендуют сочетать его с другими препаратами. Карабамазепин в сочетании с баклофеном использовали Fromm G.H. et al. (1984); в сочетании с фоливой кислотой - Musaed A.A. et al. (1992) и др.

Появление новых противосудорожных препаратов сопровождается их применением и для лечения НТН. Об использовании для этих целей окскарбазепена сообщают ряд авторов [177, 222, $339,349,351]$.

В связи с большими надеждами, возлагавшимися на карбамазепин в период 60-х - 80-х годов прошлого века несколько снизился интерес к хирургическому лечению заболевания. Больные могли позволить себе воздержаться от хирургического лечения, входя в длительную ремиссию при использовании карбамазепина на ранних этапах развития заболевания. В течение этих 20 лет и в последующем был накоплен опыт о недостаточной эффективности препарата, осложнениях и побочных явлениях, обусловленных приемом препарата [217, 233, 371].

Несомненно, принцип нарастающего радикализма при лечении НТН вполне оправдан. Но в перечне лечебных мероприятий целесообразно ограничить деструктивные воздействия на тройничный нерв из-за необратимого нарушения чувствительности, 
$22 \mid$ Классическая невралгия тройничного нерва

развития деафферентационных осложнений, наиболее тяжкими из которых являются гиперпатия и дизестезия. Деструктивные методы лечения становятся причиной возникновения у больного, согласно классификации Eller J.L., et al. (2005), еще одного варианта НТН - «тригеминальных деафферентационных болей в результате целенаправленного разрушения периферических ветвей, ганглиолиза или ризотомии как способа лечения НТН». После деструктивных вмешательств последующие лечебные мероприятия менее эффективны.

С 1962 года и по настоящее время карбамазепин и его аналоги (окскарбазепин, финлепсин, тегретол) являются препаратами первой линии в лечении НТН $[177,220,250,255,269,402$, $404,418,419,429,433]$. За этот период накоплен большой опыт оценки эффективности и побочных явлений от длительного применения этого препарата. С каждым очередным обострением заболевания эффективность этих препаратов снижается, а наращивание дозы препарата ведет к увеличению побочных реакций в виде головной боли, головокружения, атаксии при ходьбе, потери аппетита, тошноте, иногда рвоте и пр. Описан случай тяжелой энцефалопатии, вследствие длительного приема карбамазепина, имитировавшей болезнь Крейтцфельда-Якоба [237].

Больные НТН вынуждены принимать карбамазепин и его аналоги годами и даже десятилетиями. Токсикологи рассматривают риск для здоровья людей от превышения концентрации карбамазепина в поверхностных водах Северной Америки и Европы [192]. Поэтому стремление к ограничению предельной суточной дозы карбамазепина вполне оправдано.

Отсутствие стойкого положительного эффекта от консервативной терапии вновь способствовало расширению и распространению различных деструктивных вмешательств на ветвях ТН и на полулунном узле: неврэктомия, феноловая, гидротермическая, радиочастотная или глицероловая деструкция [54, 91, 92, $106,117,129,196,201,328,370,408]$. 
Tanaka T., et al. (2009) предлагают больным с НТН выполнять МР-цистернографию и по степени выраженности васкулоневрального конфликта выбирать метод лечения: консервативный (карбамазепин) или МВД.

В мире проводятся масштабные исследования по эффективности других противосудорожных препаратов: окскарбазепин, клоназепам, ламотриджин, вальпроаты, габапентин [197, 255, 295, 304, 344, 379, 384, 421].

С появлением новых противосудорожных препаратов следует череда работ по их применению для лечения НТН. О применении габапентина для лечения НTH сообщают O.A. Khan (1999), ламотриджина - Lunardi G., et al. (1997), прегабалина - Obermann M., et al. (2007); Pérez C., et al. (2009), кепры (леветирацетам) - Jorns T.P., et al. (2009), топиромата - Domingues R.B., et al. (2007). Канабиоиды для лечения НTH рекомендуют Liang Y.C., et al. (2004).

Для усиления эффективности габапентина Lemos L., et al. (2008) рекомендуют сочетать его с блокадами триггерных точек. Этот способ лечения воздействует на два звена патогенеза НТН на структуры центральной нервной системы и на рецепторный аппарат в области триггерных зон.

Принятый в настоящее время в большинстве стран мира алгоритм лечения больных НТН: лекарственная терапия в начальной стадии заболевания, когда консервативная терапия оказывается не эффективной или повышение дозы препаратов грозит тяжелыми побочными явлениями, методом выбора становится МВД при отсутствии противопоказаний со стороны функции жизненно важных органов. Пожилым больным с тяжелой соматической патологией методом выбора являются менее инвазивные чрезкожные деструктивные вмешательства, Y-Knife и др. Применяемые как в нашей стране, так и во многих зарубежных странах пункционные деструктивные вмешательства направлены на разрушение тригеминальных структур как механическим путем, с использованием лазера, низких или высоких температур, химических агентов, баллонной компрессии полулунного узла, так и 
$24 \mid$ Классическая невралгия тройничного нерва

гамма излучением. Деструктивные вмешательства относятся к паллиативным, обеспечивающим непродолжительную ремиссию болевого синдрома, и сопровождаются высоким процентом рецидивов заболевания.

Острая дискуссия о показаниях к МВД развернулась на страницах зарубежной печати в связи с подразделением классической HТН на два варианта течения, предложенные Burchiel K.J. (2003), где автор выделяет первый вариант, характеризующийся острыми стреляющими болями, триггерными точками и неэффективностью медикаментозной терапии и второй - характеризующийся постоянными болями в зоне иннервации ТН. Развивая далее эту идею Miller J.P. et al. (2009) к клиническим симптомам НTH I типа добавляют, как обязательный признак, безболевой интервал (рефрактерный период). Авторы подчеркивают, что у больных НTH I типа артериальный конфликт встречается в два раза чаще, а венозный, наоборот, в пять раз реже, чем у больных с НТН II типа. При этом отдаленные результаты хуже у больных с НТН II типа и количество рецидивов заболевания значительно выше. Они высказали предположение о том, что при длительном течении заболевания, I тип НТН может переходить во II. В то же время они же приводят наблюдения, когда при многолетнем течении I типа заболевания НTH, боли не изменяют свой пароксизмальный характер. Авторы не считают противопоказанной МВД у больных со вторым типом течения НТН, однако рекомендуют нейрохирургу информировать больных со II типом течения НТН о более худших результатах и большей вероятности рецидива заболевания.

Heros R.S. (2009) считает показанной МВД у больных с клиникой классической МВД и подтвержденным при нейровизуализации васкулоневральным конфликтом. В то же время он ставит вопрос: остановит ли доктора Burchiel K.J. от МВД у больного с HTH II типа с постоянными болями и отсутствием при нейровизуализации васкулоневрального конфликта? «Я полагаю, что доктор Burchiel K.J., уважаемый лидер в своей области, не позво- 
лит открыть ящик Пандоры, который может подстрекать менее опытных нейрохирургов оперировать больных с лицевыми болями в зоне ТН, у которых нет типичных признаков НTH» (I am sure that Dr. Burchiel K.J with the respect that he commands in this field, does not wish to open a Pandora's box that could encourage lesexperienced neurosurgeons to operate indiscriminately in cases involving patients with facial pain in the trigeminal distributation, who do not have any of the typical features of TN).

В ответ на эту критику Miller J.P. (2009) предлагает разделить НТН II типа на два подтипа: подтип IIa и подтип IIб. При подтипе IIa в начале заболевания были пароксизмальные стреляющие боли, в последствии трансформировавшиеся в постоянную боль. При подтипе ІІб с самого начала заболевания у больных были только постоянные боли в лице. Такое дополнение, по мнению автора, может помочь в более правильном выборе метода лечения. И здесь же автор подчеркивает, что несмотря на 300-летнее изучение НТН остается ряд вопросов, не нашедших ответа по настоящее время:

1) почему при типичной НТН несмотря на выявление и устранение васкулоневрального конфликта возникает рецидив заболевания?

2) почему, если мы вылечили больного от патологической васкулоневральной компрессии, боль возвращается вновь много лет спустя после МВД?

Основными современными требованиями для рекомендации больному МВД являются: типичная клиническая картина классической НТН, отсутствие эффекта от медикаментозной терапии и подтверждение васкулоневрального конфликта при нейровизуализации [76, 82, 367]. При этом Колычева М.В. и соавт. (2012) подчеркивают, что «МРТ указывает на наличие васкулоневрального контакта между тройничным нервом и сосудом, чаще верхней мозжечковой артерией, но не является показанием к операции васкулярной декомпрессии». Это лишний раз подчерки- 
$26 \mid$ Классическая невралгия тройничного нерва

вает отсутствие единого понимания значений васкулоневрального конфликта и васкулоневрального контакта в патогенезе НТН.

В кратком анализе исторических событий отражено лишь появление новых взглядов на этиопатогенез НТН и порождаемые этими представлениями все новые и новые методы лечения, освещены лишь приоритеты. Каждая новая гипотеза становилась основой многолетних изучений и множества противоречивых публикаций, нередко противоположных в оценке событий.

Такое разнообразие лечебных приемов, нередко далеких от существующих гипотез патогенеза, свидетельствует не только о необходимости дальнейшего изучения патогенеза заболевания, но и о необходимости более интенсивного поиска новых, более эффективных, патогенетически обоснованных методов лечения.

Основными дискуссионными вопросами до настоящего времени остаются:

1. Почему сосудистый контакт находят при секционных и МРТ исследованиях у лиц, не страдавших НТН?

2. Почему преимущественно боли локализуются в зонах иннервации второй и третьей ветвей как вместе, так и поотдельности?

3. Почему чаще встречается НТН справа?

4. Почему преимущественно страдают НТН лица среднего и пожилого возраста?

Поиск ответов на эти и многие другие дискуссионные вопросы легли в основу нашего исследования. 


\section{ГЛАВА \\ 2}

\section{КЛИНИЧЕСКАЯ АНАТОМИЯ ТРОЙНИЧНОГО НЕРВА И ЕГО ВЗАИМООТНОШЕНИЯ С СОСУДАМИ МОЗЖЕЧКА}

Тройничный нерв (n. Trigeminus) по составу волокон является смешанным нервом. Чувствительные волокна иннервируют ткани лица, включая глазницу, полость носа с ее придаточными пазухами, полость рта, переднюю часть покровов головы и значительную часть твердой мозговой оболочки. Двигательные волокна иннервируют жевательные мышцы и некоторые мышцы дна ротовой полости. Вегетативные волокна обеспечивают секреторную, трофическую, вазомоторную и обменную функции в зоне иннервации.

\section{1. АНАТОМИЯ ТРОЙНИЧНОГО НЕРВА}

Первые чувствительные нейроны тройничного нерва находятся в полулунном узле, располагающемся в меккелевой полости (рис. 1).

Дендриты клеток первого нейрона группируются в три ветви: I ветвь - глазной нерв (n. ophthalmicus) выходит из полости черепа через верхнюю глазничную щель, а на поверхность лица - через надглазничное отверстие, II ветвь (n. maxillaries) выходит из полости черепа через круглое отверстие, а на поверхность лица - через подглазничное отверстие, III ветвь (n. mandibularis) выходит из по- 
$28 \mid$ Классическая невралгия тройничного нерва

лости черепа через овальное отверстие, а на поверхность лица - через подбородочное отверстие.

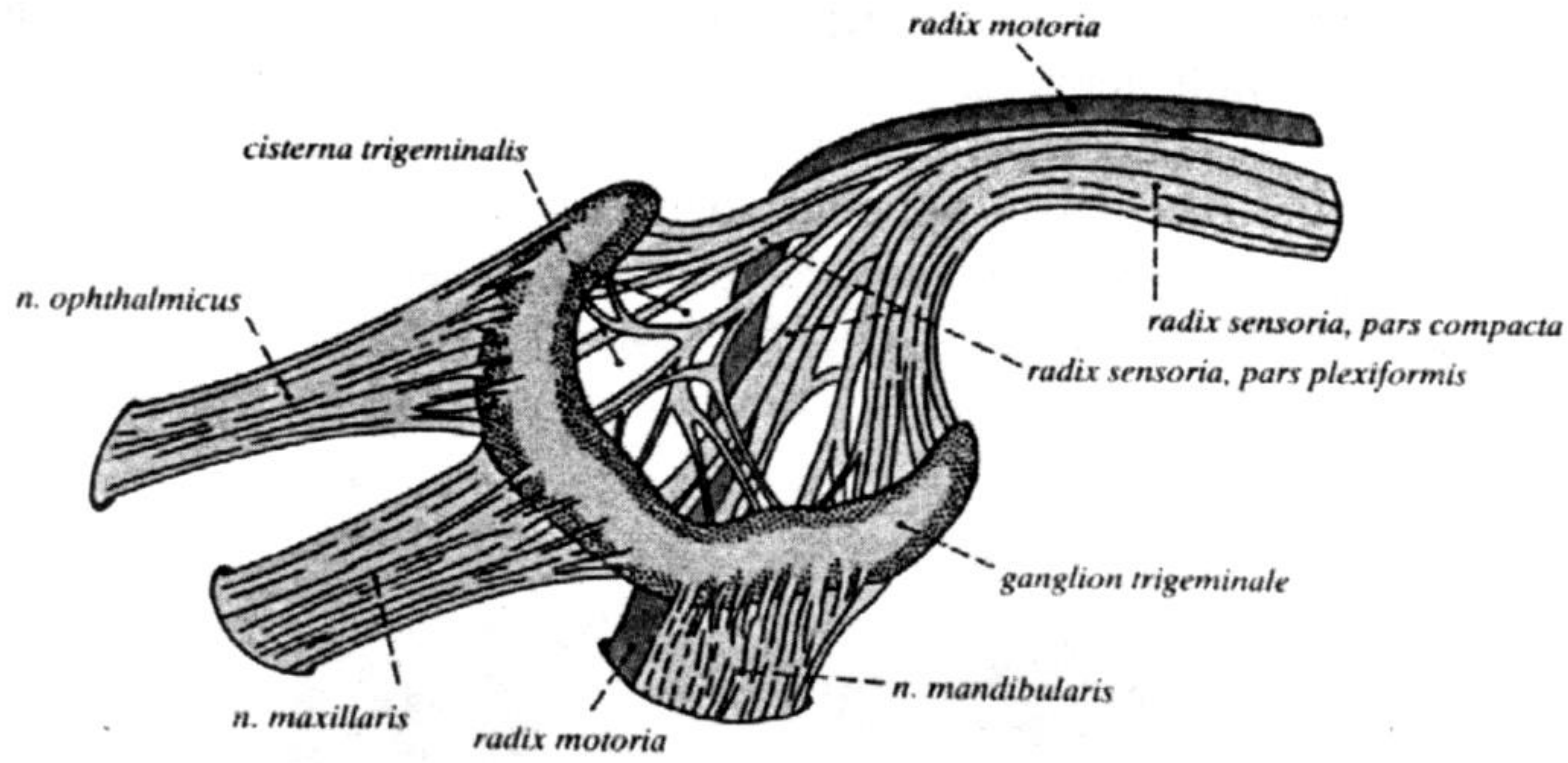

Рис. 1. Полулунный узел и его ветви (H. Ferner, 1982)

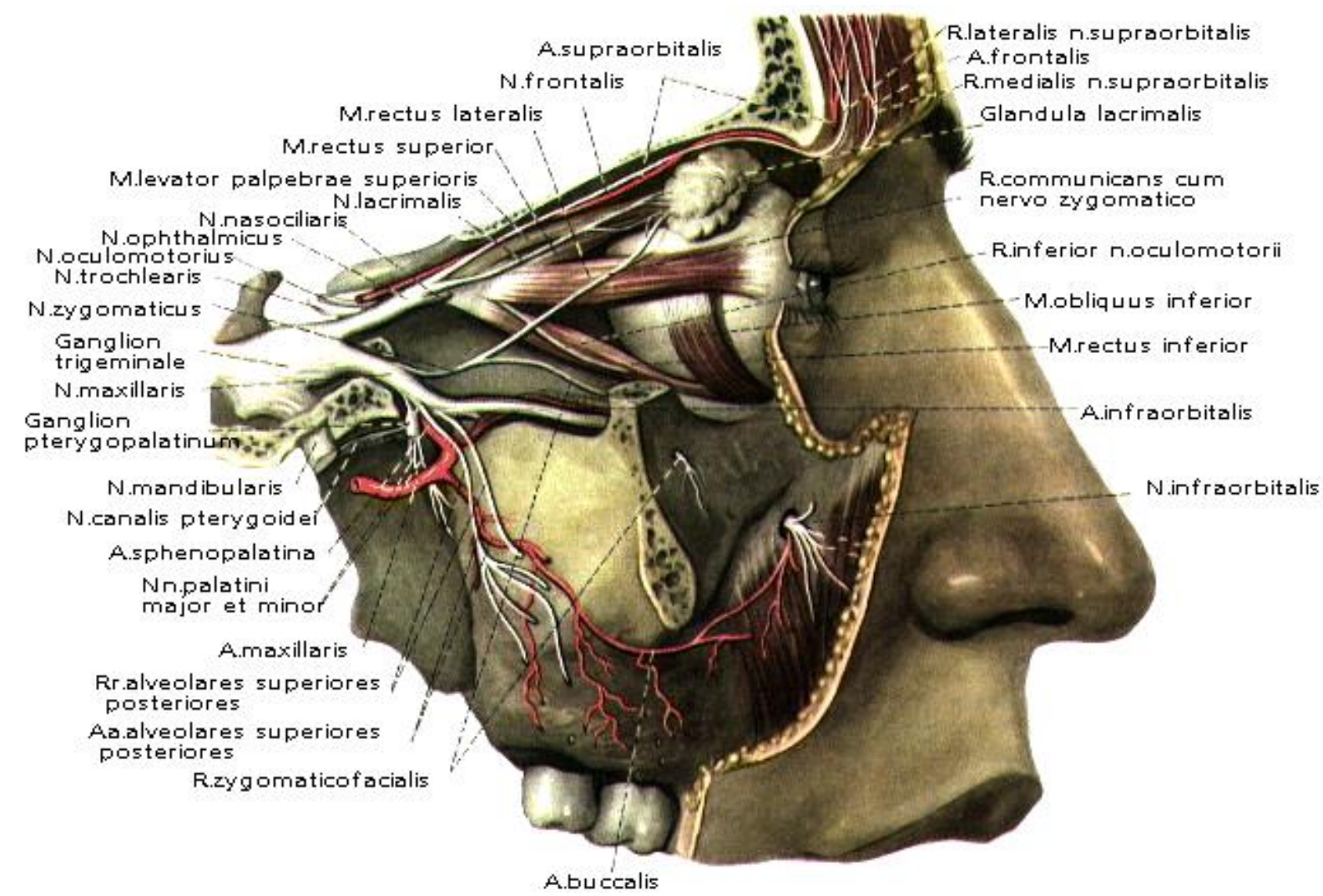

Рис. 2. Первая и вторая ветви тройничного нерва (Р.Д. Синельников, 2010) 
Глазной нерв на выходе из меккелевой ямки идет вверх и вперед, проходя через пещеристую пазуху, принимает симпатическую веточку от сплетения вдоль внутренней сонной артерии, располагаясь латеральнее отводящего нерва и ниже блоковидного. Глазной нерв иннервирует область лба и передней половины волосистой части головы, лобную пазуху, глазное яблоко, слизистую оболочку верхнего носового хода. В связи с тем, что многие лечебные манипуляции производят в области периферических ветвей $\mathrm{TH}$, детальное описание вариантов строения надглазничного отверстия или надглазничной вырезки приведено в монографии Щедренок В.В. и соавт. (2014), уделяющих большое внимание состоянию черепных костных отверстий в патогенезе тригеминальной невралгии.

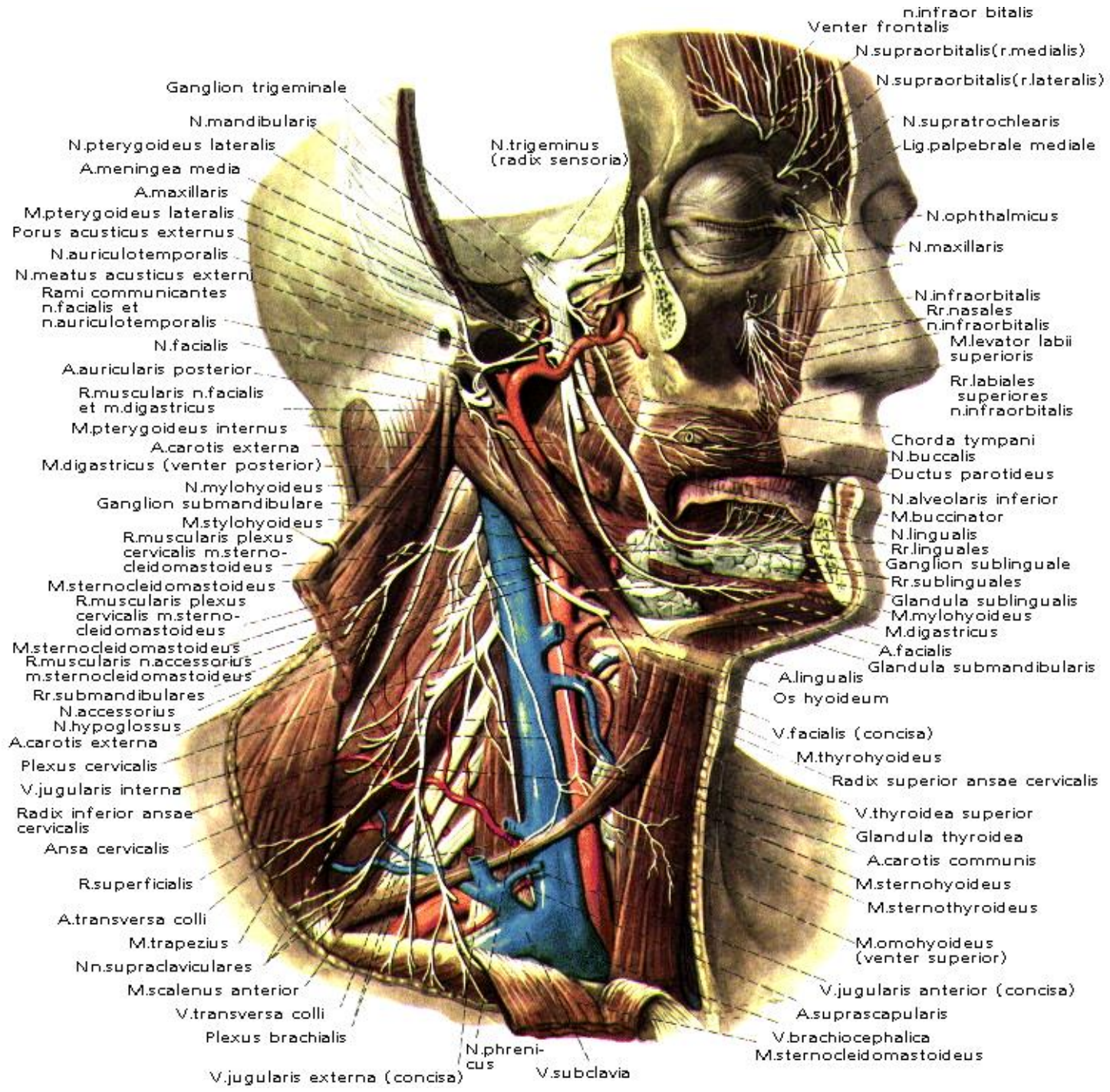

Рис. 3. Вторая и третья ветви тройничного нерва (язычная ветвь) (Р.Д. Синельников, 2010) 
$30 \mid$ Классическая невралгия тройничного нерва

Верхнечелюстной нерв, покинув меккелеву ямку, выходит из полости черепа через круглое отверстие и в крылонебной ямке делится на ветви, самой мощной из которых является подглазничный нерв, выходящий на поверхность лица через подглазничное отверстие. Отверстие подглазничного канала в половине случаев располагается на уровне скулочелюстного шва, реже кнаружи от него (до 9 мм) и совсем редко - кнутри (до 6 мм) (Щедренок В.В. с соавт., 2014). Подглазничный нерв делится на конечные ветви, как правило, у места выхода из одноименного отверстия, иннервируя среднюю область лица, включая верхнечелюстную пазуху, зубы верхней челюсти, небо и нижнюю часть слизистой оболочки носа.

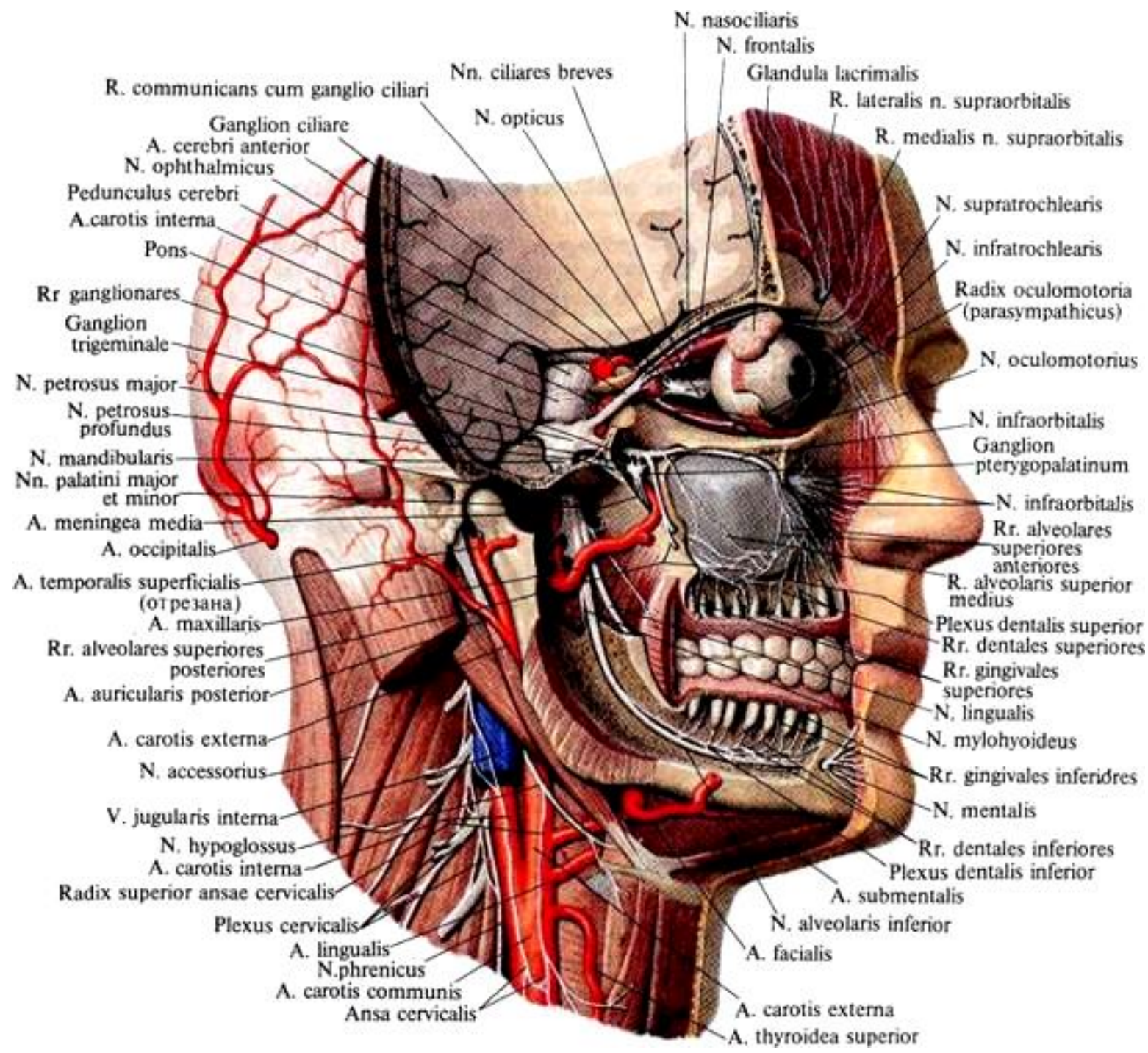

Рис. 4. Вторая и третья ветви тройничного нерва (нижняя альвеолярная ветвь) (Р.Д. Синельников, 2010) 
Нижнечелюстной нерв отходит от полулунного узла вместе с двигательным корешком тройничного нерва и через овальное отверстие покидает полость черепа, где вскоре делится на переднюю, преимущественно двигательную, и заднюю, преимущественно чувствительную, ветви. Наиболее мощными стволами задней ветви нижнечелюстного нерва являются нижний луночковый и язычный нервы. Нижний луночковый нерв идет вниз по медиальной поверхности латеральной крыловидной мышцы и, войдя через нижнечелюстное отверстие в одноименный канал из подбородочного отверстия, выходит на поверхность лица. По данным Щедренок В.В. с соавт., 2014, в 72\% подбородочное отверстие располагается ниже середины тела нижней челюсти (до 7 мм), в 16\% - выше (до 4 мм), и лишь в $12 \%$ случаев локализация его соответствует середине высоты тела нижней челюсти. Подбородочный нерв выходит из соименного канала обычно одним стволом, редко двумя. Нижнечелюстной нерв иннервирует самую нижнюю область лица, включая зубы нижней челюсти, передние 2/3 языка, дно слизистой оболочки полости рта, переднюю часть ушной раковины и наружного слухового прохода и значительную часть височной области.

Аксоны псевдоуниполярных клеток полулунного узла формируют чувствительную порцию корешка тройничного нерва, которая входит в мост мозга в средней части его переднелатеральной поверхности. Направление хода корешка от меккелевой полости к мосту: медиально, книзу и кзади. Диаметр корешка варьирует от 3 до 4,5 мм, длина от моста до микелевой полости - от 8 до 17 мм, а от моста до полулунного узла от 17 до 24 мм, в среднем 21 мм. У полулунного узла волокна соответствующие третьей ветви располагаются в задних отделах корешка, в то время как у варолиева моста в «воротной зоне» эти волокна составляют нижнюю порцию корешка.

Войдя в покрышку моста аксоны первого нейрона делятся на восходящие и нисходящие волокна. Эти волокна образуют синаптические связи со вторыми нейронами, представленными тремя ядрами: мезенцефалическим, находящимся в среднем мозге и верхней половине моста, главным чувствительным ядром (nucl. Terminalis), проводящим суставно-мышечное чувство, и ядром 
$32 \mid$ Классическая невралгия тройничного нерва

спинно-мозгового тракта (nucl. tractus spinalis nervi trigemini), участвущем в передаче болевых и температурных импульсов. Аксоны клеток всех чувствительных ядер тройничного нерва, перейдя на противоположную сторону, присоединяются к медиальной петле и направляются к зрительному бугру, где располагаются клетки третьего нейрона. Аксоны третьего нейрона, пройдя через заднее бедро внутренней капсулы, заканчиваются в нижних отделах постцентральной и прецентральной извилин.

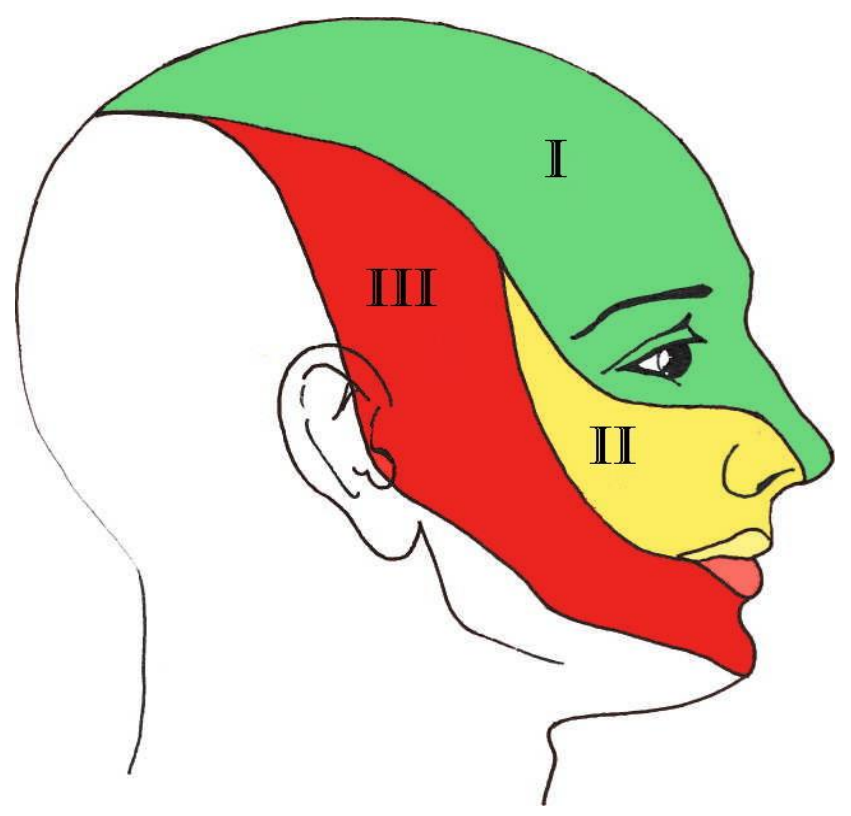

Рис. 5. Зоны иннервации ветвей тройничного нерва

Многочисленные публикации последних лет и результаты наших исследований свидетельствуют о том, что патогенетической основой классической тригеминальной невралгии является васкулоневральный конфликт между корешком ТН и смежными сосудами мозжечка. В связи с этим нами уделено большое внимание изучению анатомических особенностей корешка тройничного нерва и его взаимоотношениям со смежными артериями у лиц, не страдавших классической невралгией тройничного нерва.

Направление хода корешка от мекелевой полости к мосту: медиально, книзу и кзади (рис. 6). В наших наблюдениях диаметр корешка у моста варьировал от 3 до 4,5 мм, длина от моста до микелевой полости - от 8 до 17 мм, а от моста до полулунного узла - 
от 17 до 24 мм, в среднем 21 мм. У полулунного узла волокна, соответствующие третьей ветви, располагаются в задних отделах корешка, в то время как у варолиева моста - в «воротной зоне», эти волокна составляют нижнюю порцию корешка.

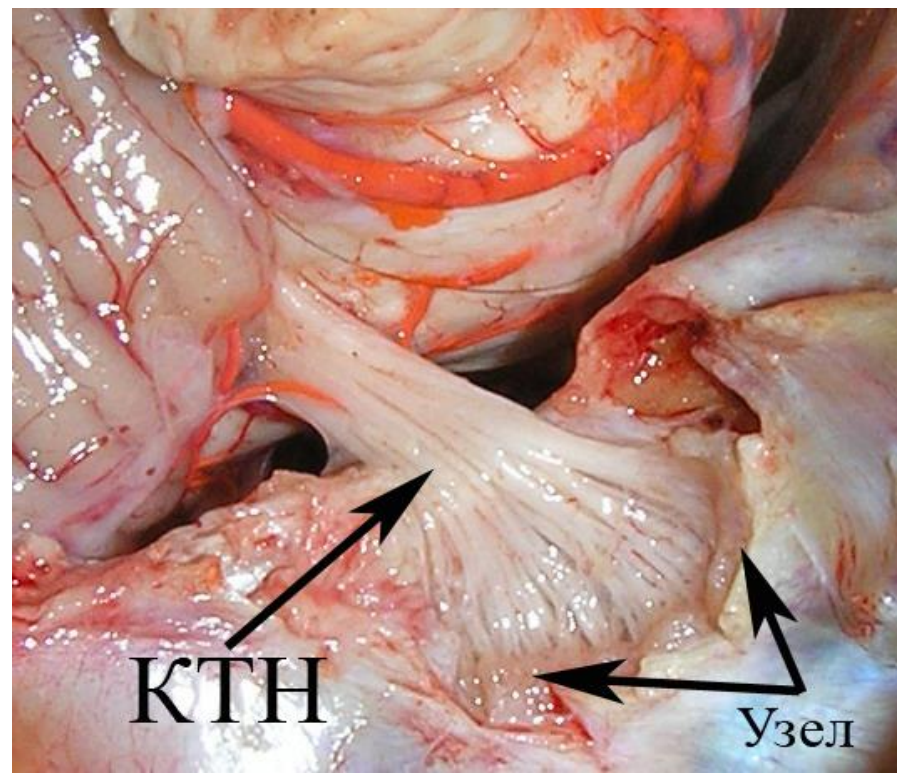

Рис. 6. Корешок левого тройничного нерва (стрелка), полулунный узел (две стрелки)

В клинической литературе большое внимание уделялось анатомии корешка тройничного нерва в первой половине прошлого века в связи с широким распространением для лечения тригеминальной невралгии (в то время - деструктивной операции) перерезке корешка тройничного нерва позади полулунного узла.

В литературе того времени сведения о внутрикорешковой топографии волокон трех ветвей противоречивы. Не вызывает особых разногласий топография волокон в корешке у гассерова узла, поскольку большинство авторов считают переднюю часть волокон соответствующей 1 ветви, заднюю - 3 ветви, а внутреннюю - 2 ветви. Суждение о топографии волокон этих ветвей при вхождении корешка в мост противоречивы. Так, Davis L., Haven H. (1933), полагают, что волокна 1 ветви при входе в мост располагаются в нижней и медиальной части корешка, а волокна 2 и 3 ветвей у входа в мозговой ствол оказываются в верхнелатеральном отделе корешка. Иоффе И.Л. (1949) обнаружил, что в 22 случаях из 40 пучки волокон 
$34 \mid$ Классическая невралгия тройничного нерва

корешка проходили, несколько закручиваясь. Группы пучков, которые у варолиева моста располагались ниже и латеральнее, постепенно приобретали медиальное направление и примыкали к внутреннему отделу гассерова узла. В 12 препаратах направление пучков было более прямолинейным и напоминало веник. В 6 препаратах внутриствольная топография была переходной между двумя этими типами. В то же время, Spiller W., Frazier Ch. (1933) показали, что нервные волокна чувствительного корешка сохраняют определенный порядок расположения, соответствуя в отдельных своих частях (медиальной, средней и латеральной) трем периферическим ветвям нерва и не перемешиваются между собой.

Gudmundson K. et al. (1971), детально изучив анатомию КТН, приходят к выводу о том, что между двигательной и чувствительной порциями корешка существуют множественные анастомозы, что объясняет неполное выпадение чувствительности при операциях ризотомии. У моста двигательная порция корешка располагается вблизи чувствительных волокон соответствующих первой ветви, чаще в области пердне-верхних отделов корешка, реже задне-верхних (рис. 7, а)

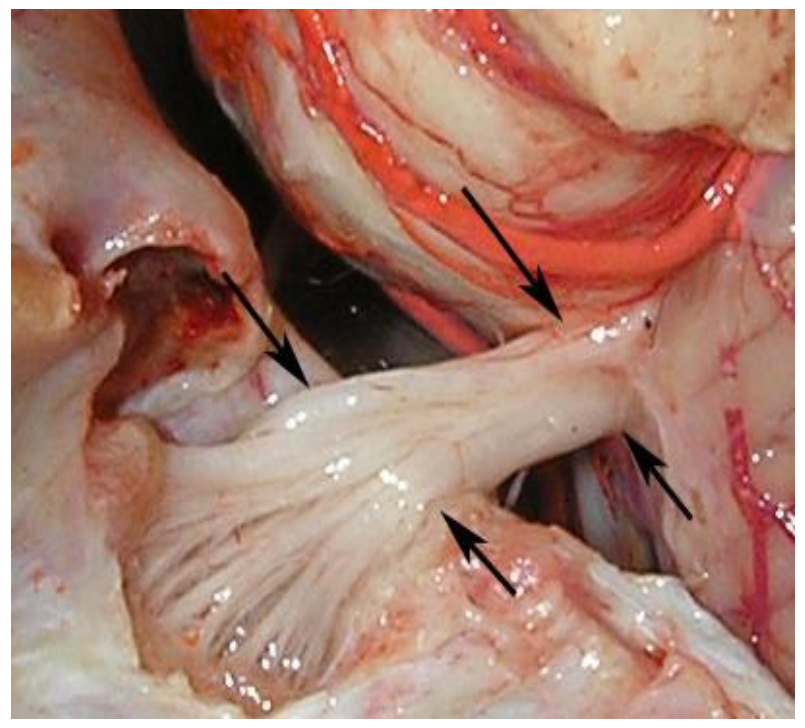

a)

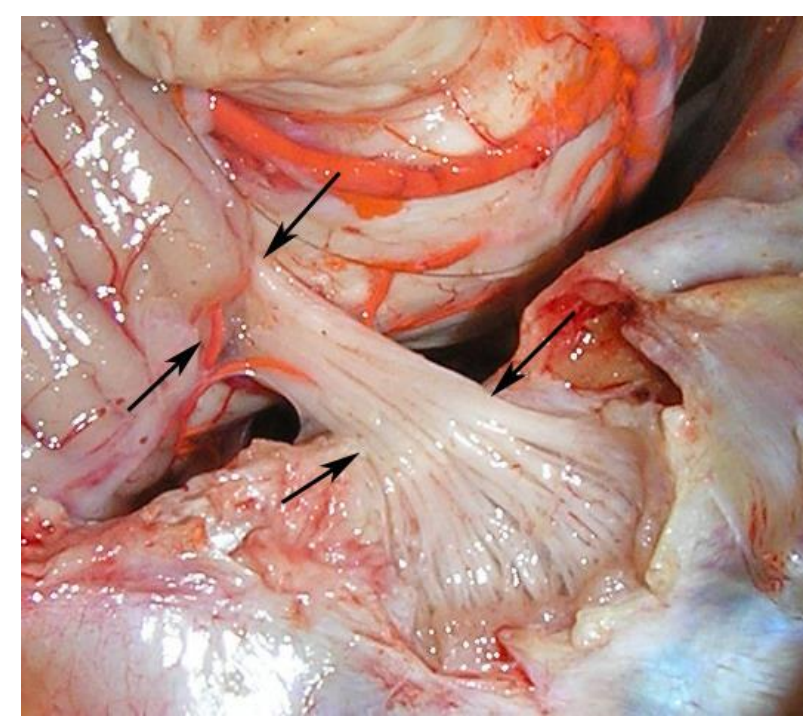

б)

Рис. 7. Стрелками отмечена ширина КТН у выхода из мекелевой полости и у входа в мост: а) слева (верхняя латеральная стрелка указывает на двигательную порцию корешка) ТH; б) справа 
Подойдя к полулунному узлу, двигательная порция пересекает его, направляясь латерально к слиянию с третьей ветвью. В наших секционных исследованиях 50 тригеминальных корешков лиц, не страдавших тригеминальной невралгией и другой внутричерепной патологией, установлено, что у моста корешок имеет эллипсовидную форму, по мере приближения к верхнему краю пирамиды КТН становится более плоским, а в мекелевой ямке он приобретает форму веерообразной пластины (рис. 6).

Аксоны клеток полулунного узла группируются в небольшие пучки, которые, переплетаясь между собой, соединяются у края пирамиды в общий ствол, представляющий собой пластину шириной от 6 до 9 мм в среднем 6,8 $\pm 1,4$ мм. Толщина корешка в месте выхода его из меккелевой полости составляла от 3 до 4,5 мм.

При дальнейшем ходе к мосту КТН становится более округлым и приобретает эллипсовидную форму с большим вертикальным диаметром. Поэтому в месте вхождения КТН в мост производилось измерение большего диаметра КТН. Диаметр КТН у моста составлял от 4 до 7 мм. Средние значения диаметра КТН слева 5,78 мм, а справа - 5,8 мм (Рис. 8).

Измерение длины КТН производилось от моста до верхнего края пирамиды и от моста до полулунного узла. Поскольку КТН напоминает форму веника (ручка у моста имеет верхний и нижний края, а широкая веерообразная часть КТН, в виде пластины, расположенная в мекелевой полости в горизонтальной плоскости, имеет передний и задний края), мы приняли следующие обозначения: передне-верхний и задне-нижний края КТН.

Длина КТН от моста до верхнего края пирамиды вдоль передне-верхнего края КТН составляла справа 17,6 $\pm 2,2$ мм (от 13 до 21 мм), и слева 17,5 $\pm 2,1$ мм (от 14 мм до 20 мм). Длина КТН от моста вдоль задне-нижнего края составляла справа 15,76 22,4 мм (от 11 мм до 18 мм) и слева 14,86ะ2,5 мм (от 12 мм до 18 мм) Такая же закономерность прослеживалась и при измерении длины КТН от моста до полулунного узла (Рис. 8). 


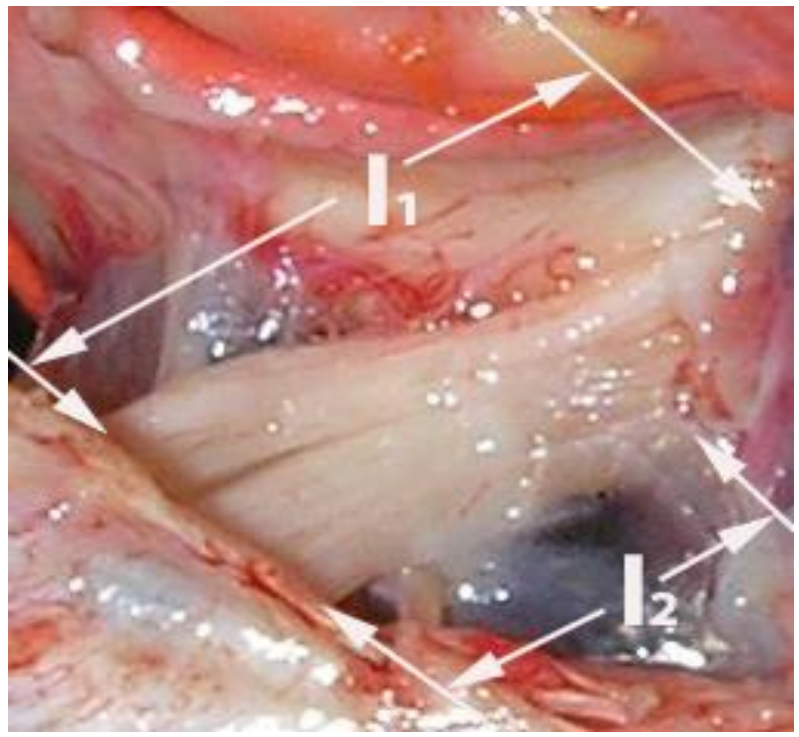

a)

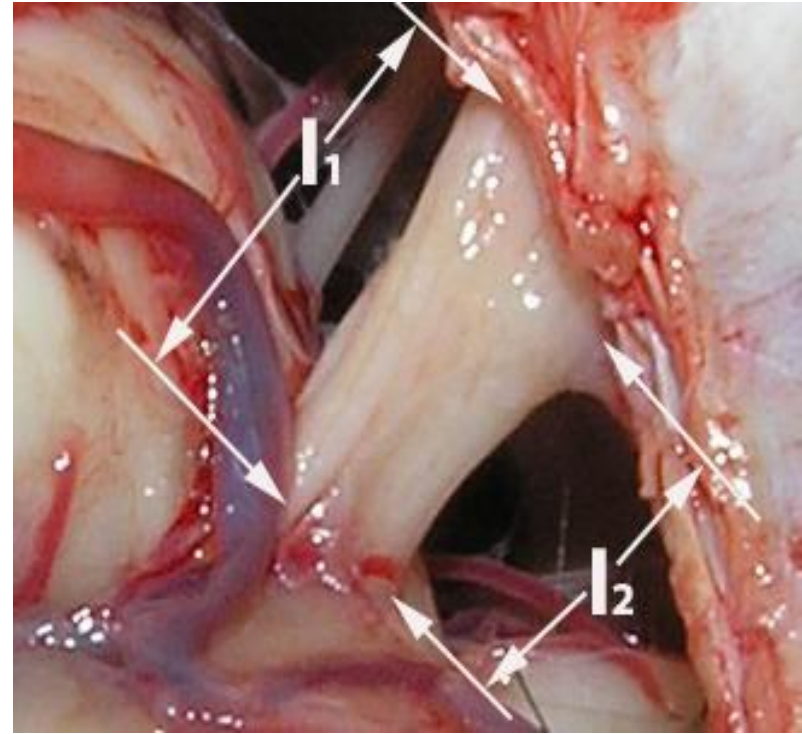

б)

Рис. 8. Разница в длине КTH вдоль передне-верхнего (L1) и задне-нижнего (L2) его краев от моста до верхнего края пирамиды височной кости:

а) слева, б) справа

Длина КТН от моста до полулунного узла вдоль его передневерхнего края составляла справа 22,04ะ2,1 мм (от 17 мм до 26 мм) и слева 23,2 22,3 мм (от 16 мм до 26 мм). Длина КТН от моста до полулунного узла вдоль задне-нижнего края составляла справа

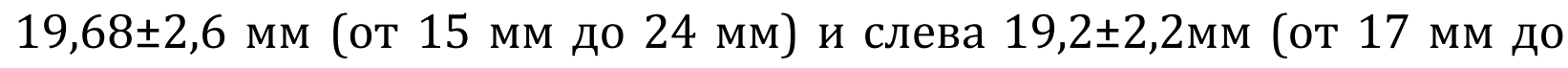
23 мм). Разница между длиной КТН от моста до верхнего края пирамиды вдоль передне-верхнего края и вдоль задне-нижнего края составила справа 1,84 мм и слева 2,64 мм. Разница между длиной КТН от моста до полулунного узла вдоль передне-верхнего края и вдоль задне-нижнего края составила справа 2,36 мм и слева 3,68 мм (рис. 9).

В 17 секционных наблюдениях (34 КТН) корешок плавно переходил из задней черепной ямки в меккелеву полость (рис. 9). В 8 наблюдениях (16 КТН) ввиду выраженной разницы в вертикальной плоскости между уровнем отхождения КТН из моста и верхним краем пирамиды у входа КТН в мекелеву полость корешок совершал изгиб через край пирамиды (рис. 10).

В 23 секционных наблюдениях (46 КТН) волокна первой ветви занимали передне-верхнюю часть КТН, волокна третьей ветви задне-нижнюю его часть, промежуточное положение занимали во- 
локна второй ветви. Аналогичная топография волокон в КТН описана в литературе [133, 134, 137, 265, 286]. В двух наблюдениях (4 KTH) обнаружена ротация волокон КТН, которая может объяснить в последующем особенности клинических проявлений НТН у некоторых больных (рис. 11).

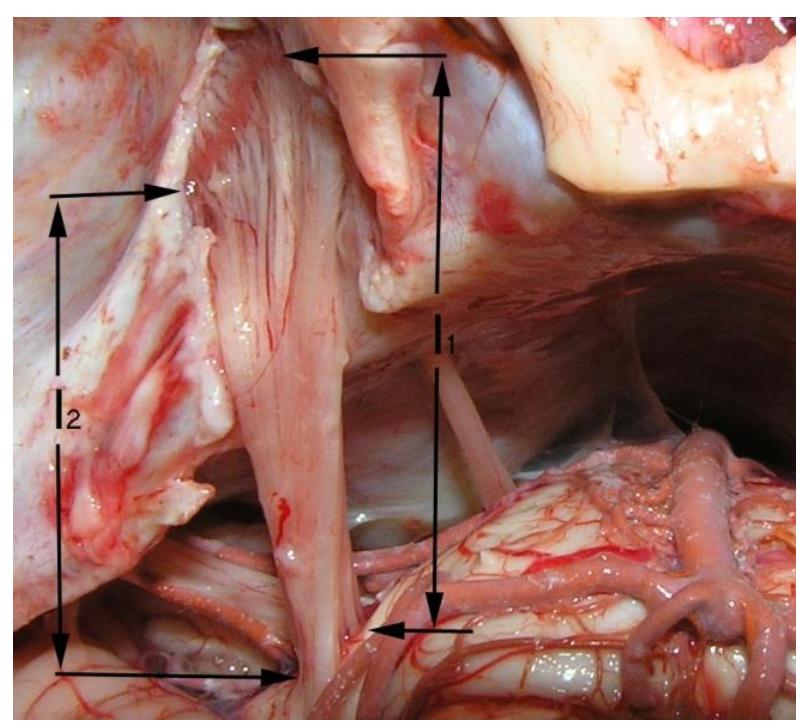

a)

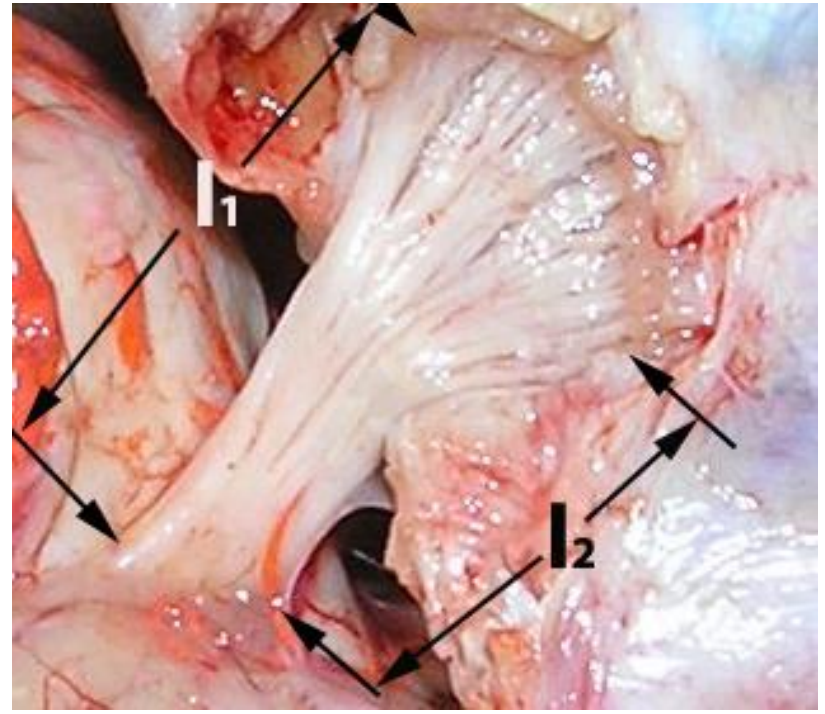

б)

Рис. 9. Разница в длине КTH вдоль передне-верхнего (L1) и задне-нижнего (L2) его краев от моста до полулунного узла: а) слева, б) справа

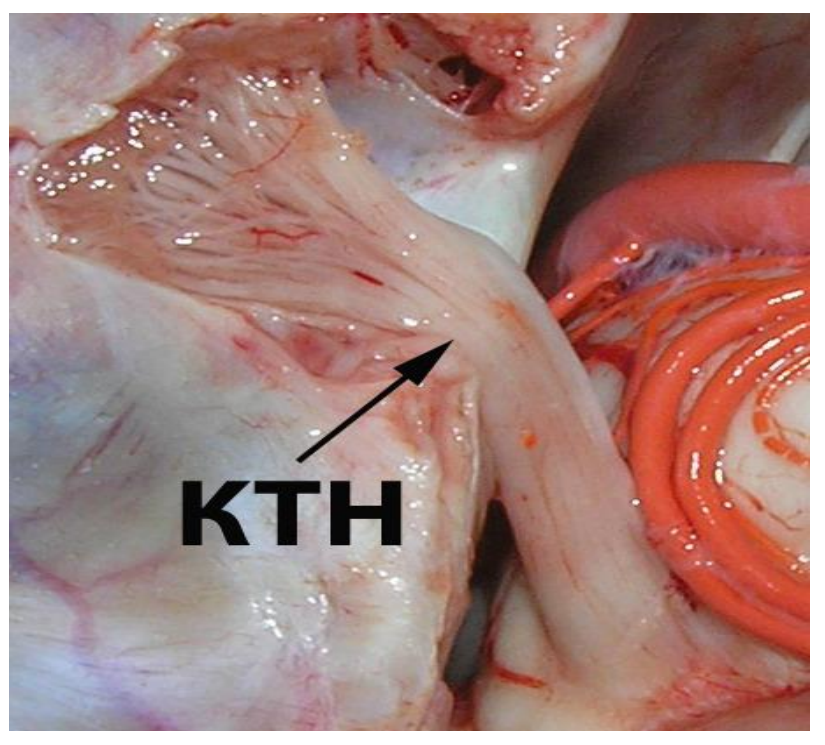

a)

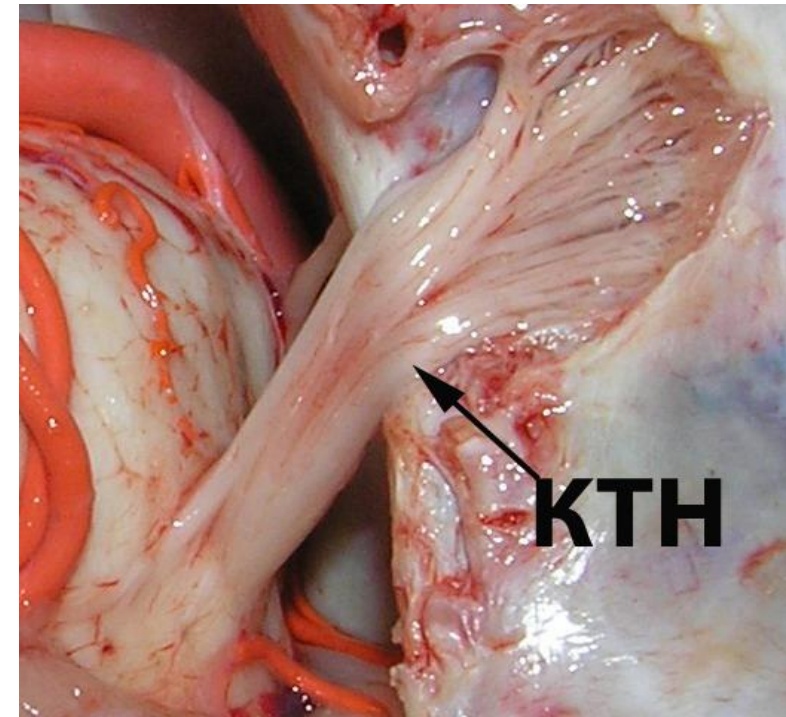

б)

Рис. 10. Изгиб КТН через верхний край пирамиды: а) слева, б) справа 


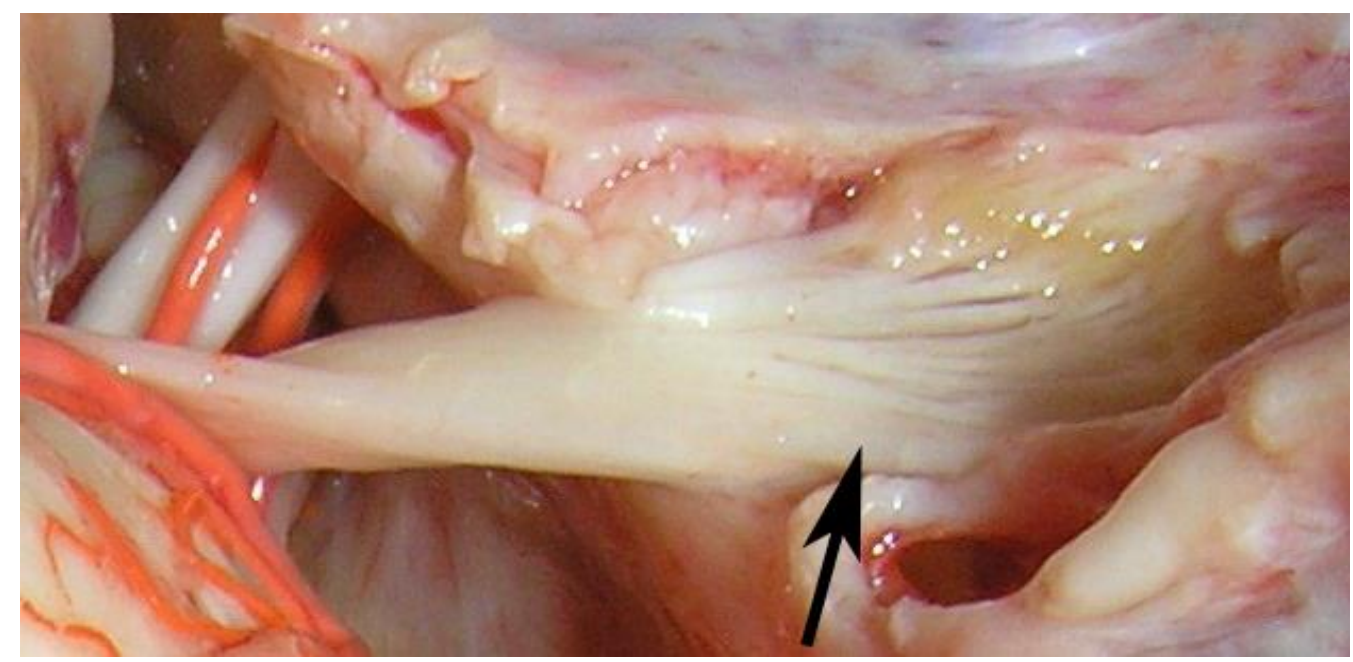

a)

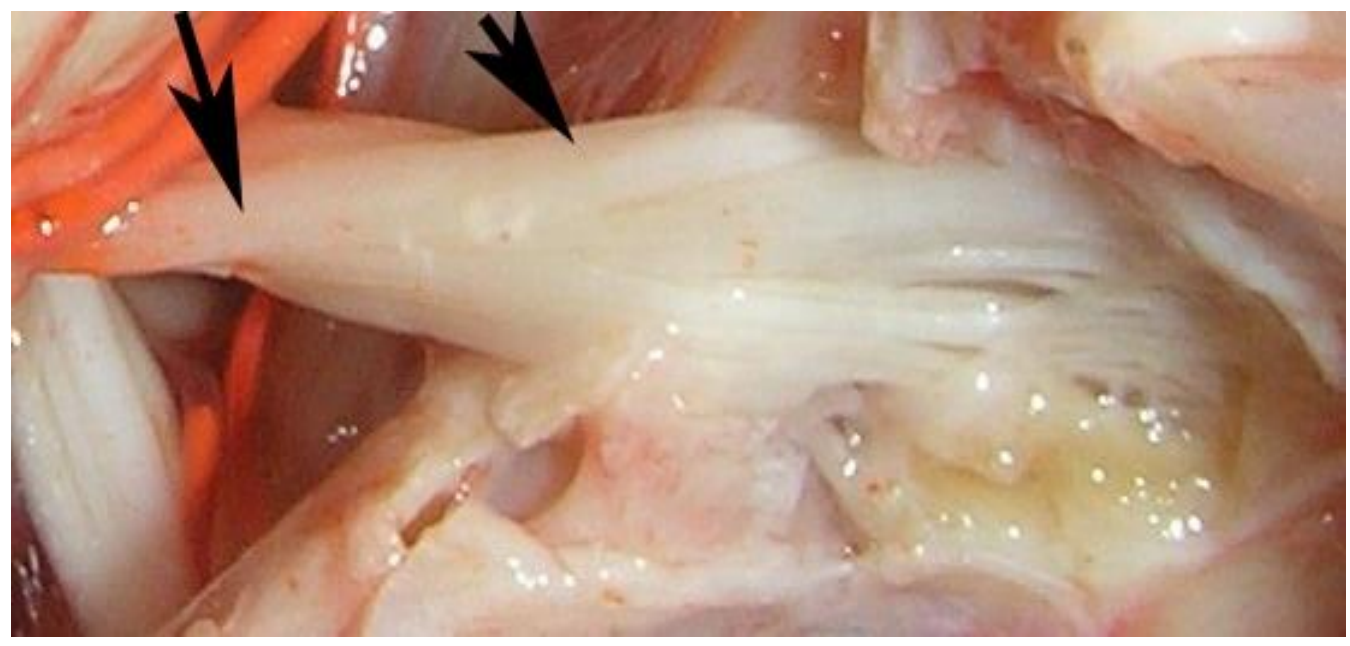

б)

Рис. 11. Ротация корешка: а) сверху вниз и кзади. Двигательная порция указана стрелкой; б) снизу верх и кпереди. Двигательная порция указана стрелками

\section{2. ТОПОГРАФО-АНАТОМИЧЕСКИЕ ВЗАИМООТНОШЕНИЯ КОРЕШКА ТРОЙНИЧНОГО НЕРВА СО СМЕЖНЫМИ АРТЕРИЯМИ}

Верхняя мозжечковая артерия (ВМА) является наиболее постоянной из всех артерий мозжечка. Описательная анатомия BMA представлена в работах первой половины прошлого века [38]. Основное внимание в этих исследованиях уделено особенностям деления сосуда на ветви первого, второго порядков вплоть до капиллярной сети и зонам их кровоснабжения. Клиническая анатомия ВМА детально изучена во второй половине прошлого века и 
посвящена особенностям идентификации отдельных ее сегментов на вертебральных ангиограммах с учетом ее анатомических вариантов. В последние десятилетия в связи с внедрением в нейрохирургическую практику микроваскулярной декомпрессии корешка тройничного нерва для лечения больных НТН вновь возник интерес к изучению анатомии ВМА и ее взаимоотношению с КТН [201, 202, 203, 282, 287, 288, 289, 384].

На основании этих исследований сложились общие представления о сегментах и петлях, образуемых как основным стволом BMA, так и ее ветвями второго и третьего порядков (рис. 12).

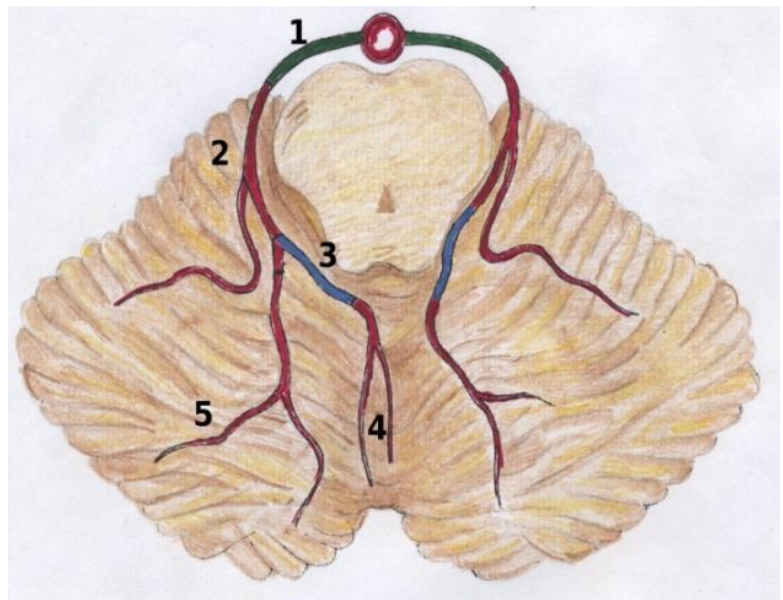

a)

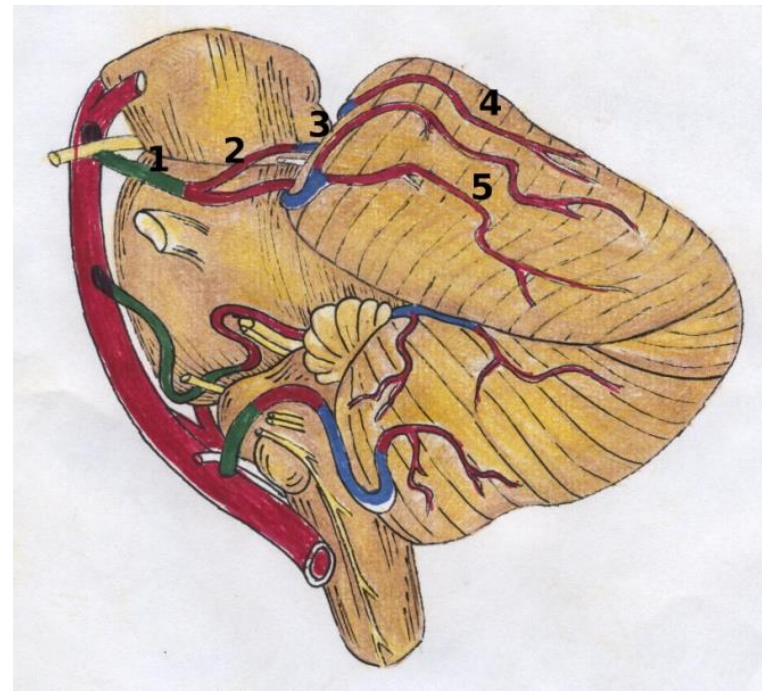

в)

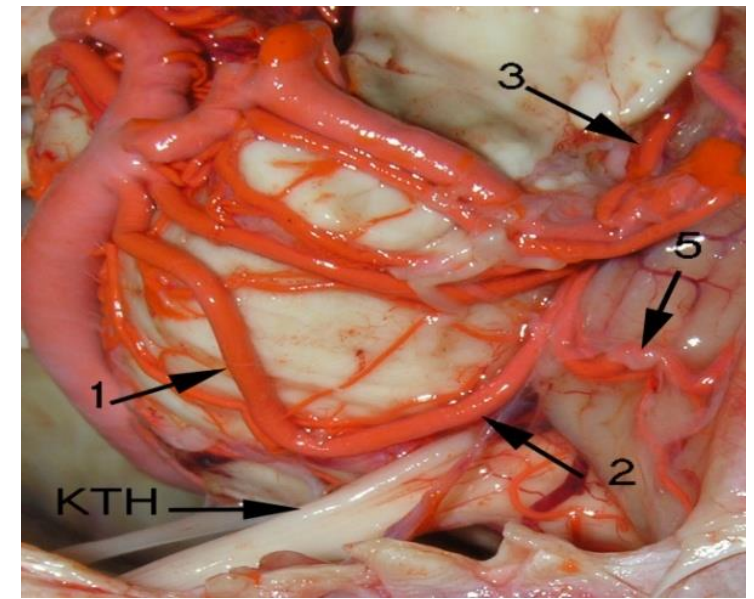

б)

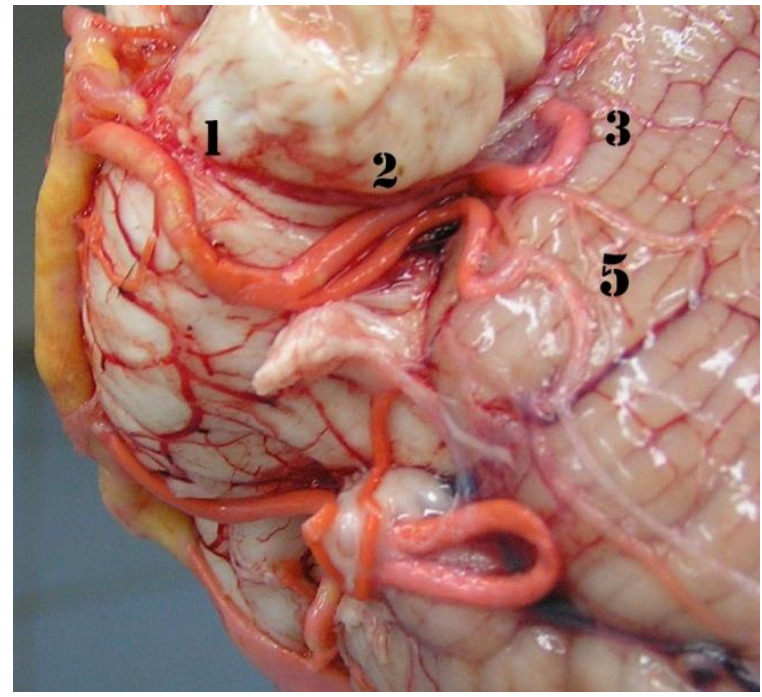

г)

Рис. 12. Верхняя мозжечковая артерия: а) схема сегментов ВМА вид сверху;

б) препарат ВМА вид спереди и сверху; в) схема сегментов ВМА вид сбоку

(по Rhoton A.L.); г) препарат BMA вид сбоку:

1 - передний понтомезенцефальный сегмент, 2 - латеральный понтомезенцефальный сегмент, 3 - церебелломезенцефальный, 4 и 5 - кортикальные 
$40 \mid$ Классическая невралгия тройничного нерва

Передний понтомезенцефальный сегмент - отрезок BMA, идущий от основной артерии кнаружи и окаймляющий переднюю поверхность моста. Ход этого сегмента, как правило, параллелен сегменту P1 задней мозговой артерии и разделяет их глазодвигательный нерв, проходящий между ними. Латеральный понтомезенцефальный сегмент - отрезок ВМА, окаймляющий боковую поверхность моста, направляющийся кзади и кверху в направлении четверохолмия.

Продолжением его является церебелло-мезенцефальный сегмент, окаймляющий нижнюю часть среднего мозга и достигающий области вершины червя мозжечка, где продолжением его является червячковая ветвь. По пути ВМА, в зависимости от ее варианта, отдает ветви второго и третьего порядка к верхней поверхности мозжечка. Между передним понтомезенцефальным и латеральным понтомезенцефальным сегментами BMA в месте крутого поворота сосуда, где он резко меняет направление с горизонтального от средней линии кнаружи на косое снизу вверх и к средней линии образуется угол (у некоторых авторов петля), вершина которого и есть место перехода преднего понтомезенцефального сегмента в латеральный понтомезенцефальный .

Нами установлено, что ВМА отходила от БА одним стволом в $84 \%$ случаях, и двумя стволами в 16\%. При отхождении ВМА от БА одним стволом деление его на ветви второго порядка в области латерального понтомезенцефального сегмента ВМА дорзальнее воротной зоны КТН имело место в 18 наблюдениях (36\%). Над воротной зоной или вблизи нее, в этих случаях, находился один, основной ствол ВМА (рис. 13).

При делении основного ствола ВМА на ветви второго порядка в области переднего понтомезенцефального сегмента (рис. 14), либо латерального понтомезенцефального, но кпереди от места вхождения КТН в мост (рис. 15), а также при отхождении ВМА от БА двумя стволами, при делении одного из них на ветви второго порядка дорзальнее места вхождения КТН в мост (рис. 16), в проекции воротной зоны или вблизи нее располагались две ветви ВМА, что имело место в 29 случаях (58\%). 


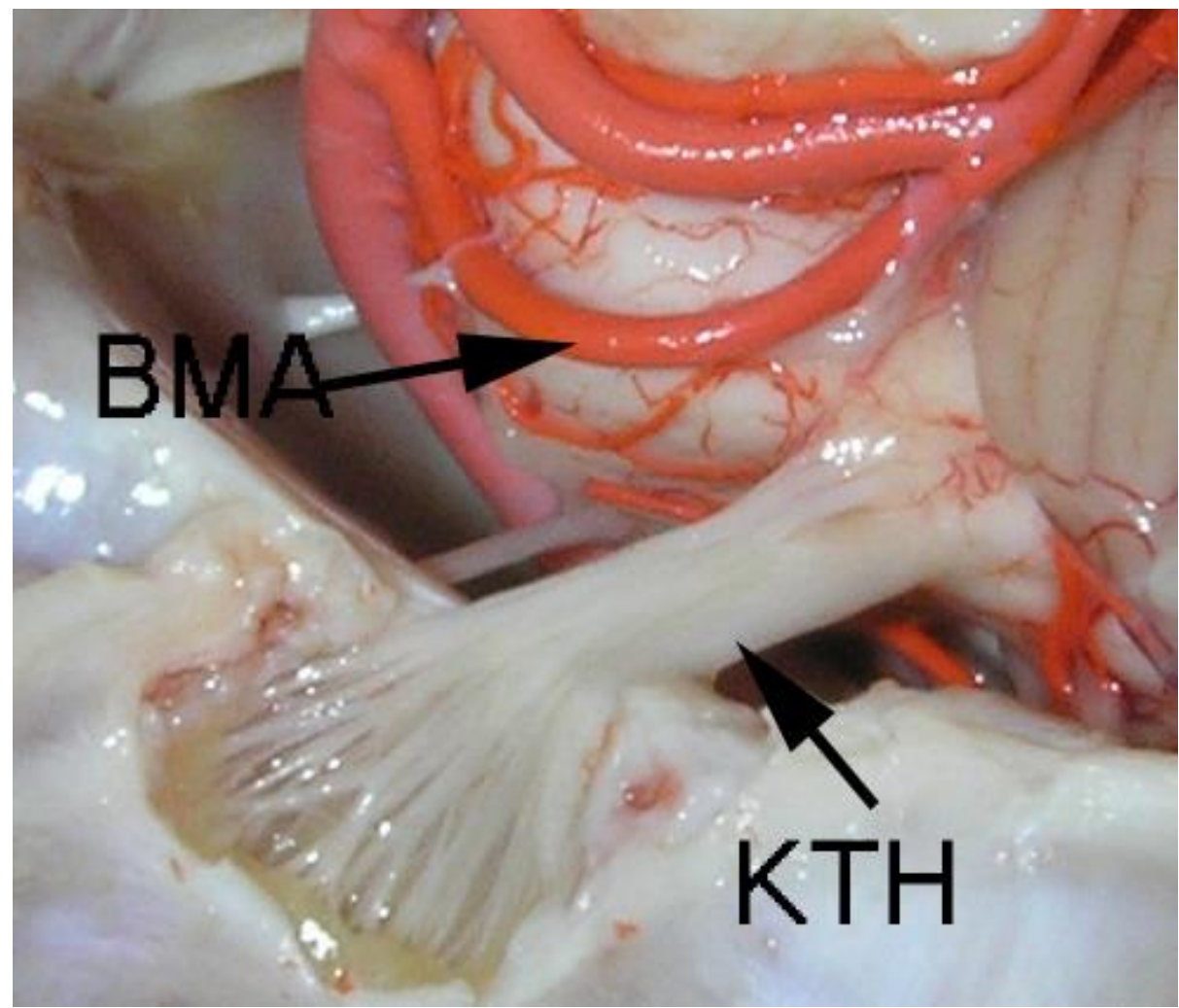

Рис. 13. ВМА отходит от БА одним стволом и в области КТН находится один ствол ВМА

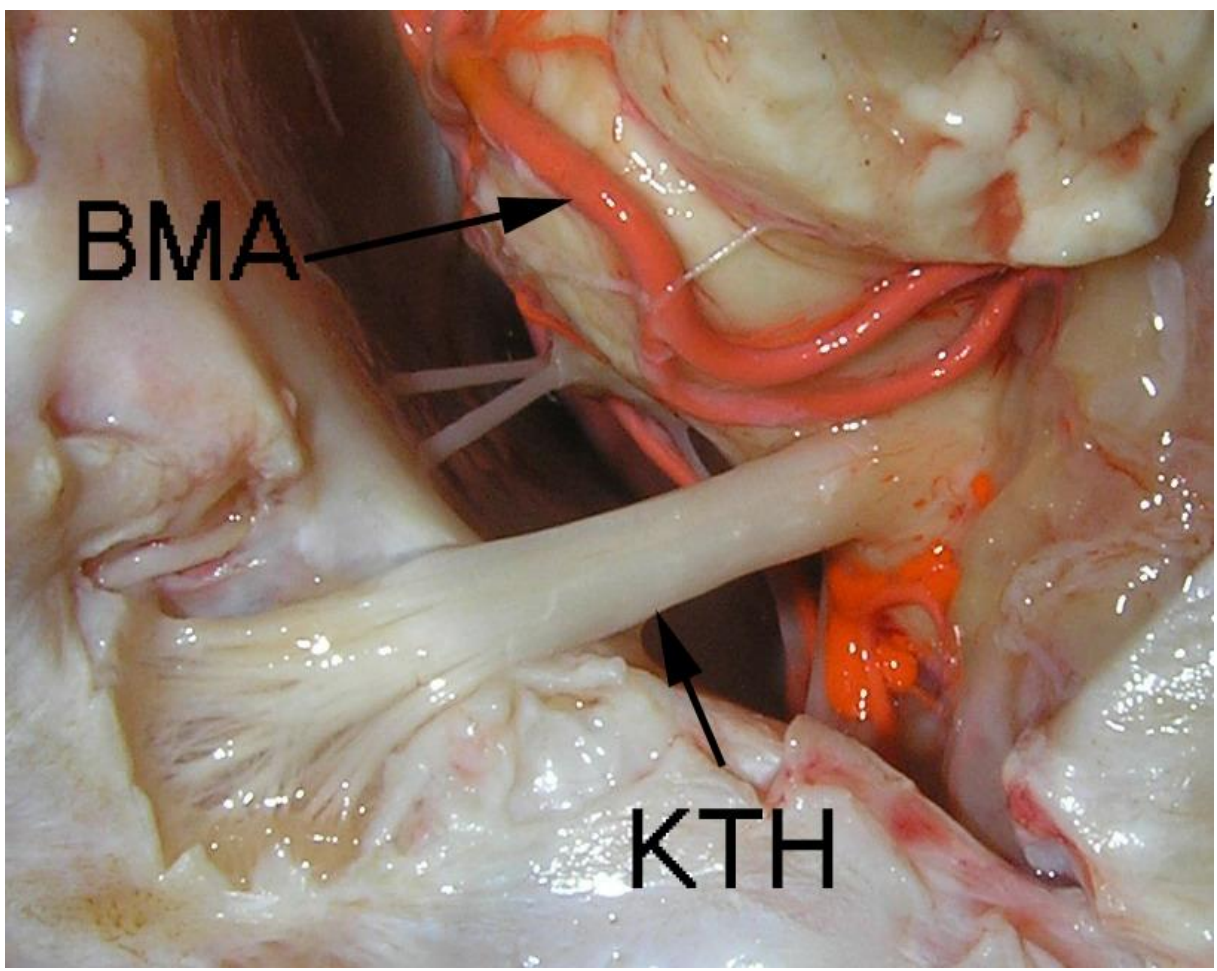

Рис. 14. Деления левой ВМА на ветви второго порядка в области предпонтинного сегмента, в проекции КТН два артериальных ствола 
$42 \mid$ Классическая невралгия тройничного нерва

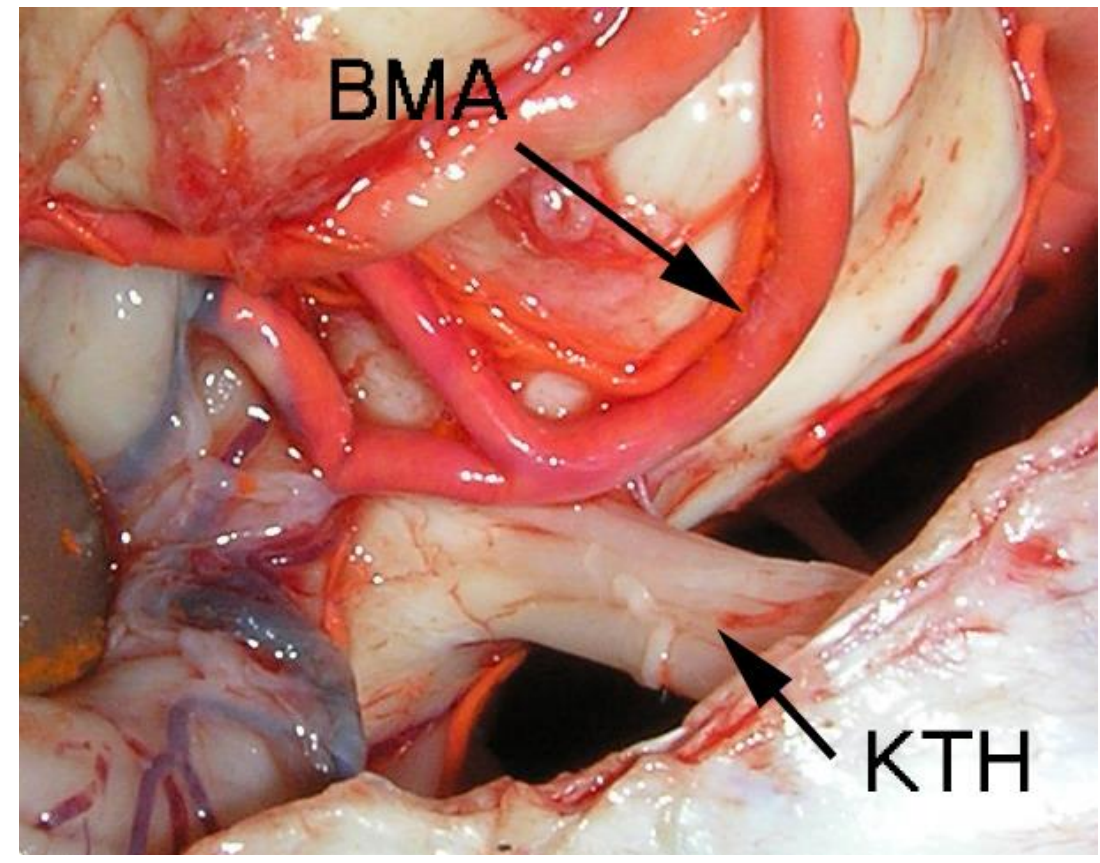

Рис. 15. Деление правой ВМА на ветви второго порядка в области латерального понтомезенцефального сегмента, но кпереди от места вхождения КТН в мост

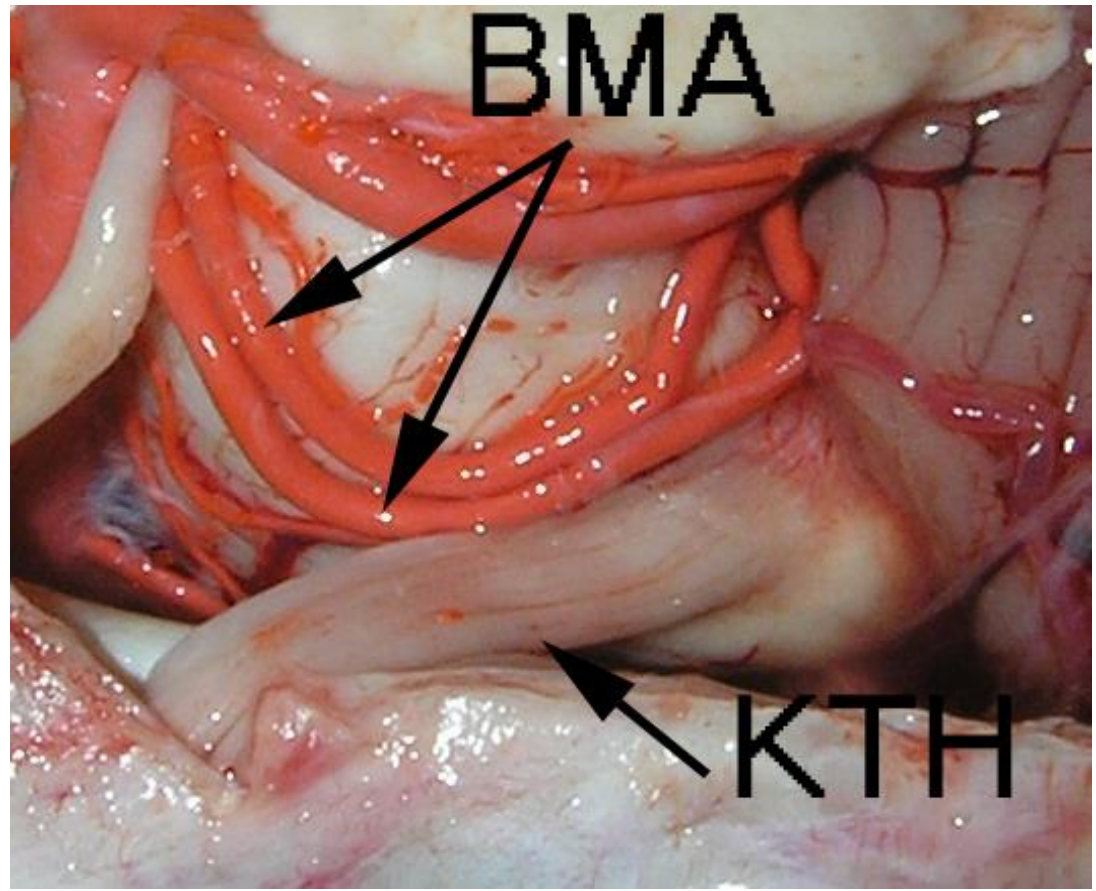

Рис. 16. Отхождение левой ВМА от БА двумя стволами, при делении на ветви второго порядка дорзальнее места вхождения КТН в мост. В проекции КТН находится два артериальных ствола

В трех наблюдениях (6\%) в проекции воротной зоны располагалось три ветви второго порядка ВМА (Рис. 17). 


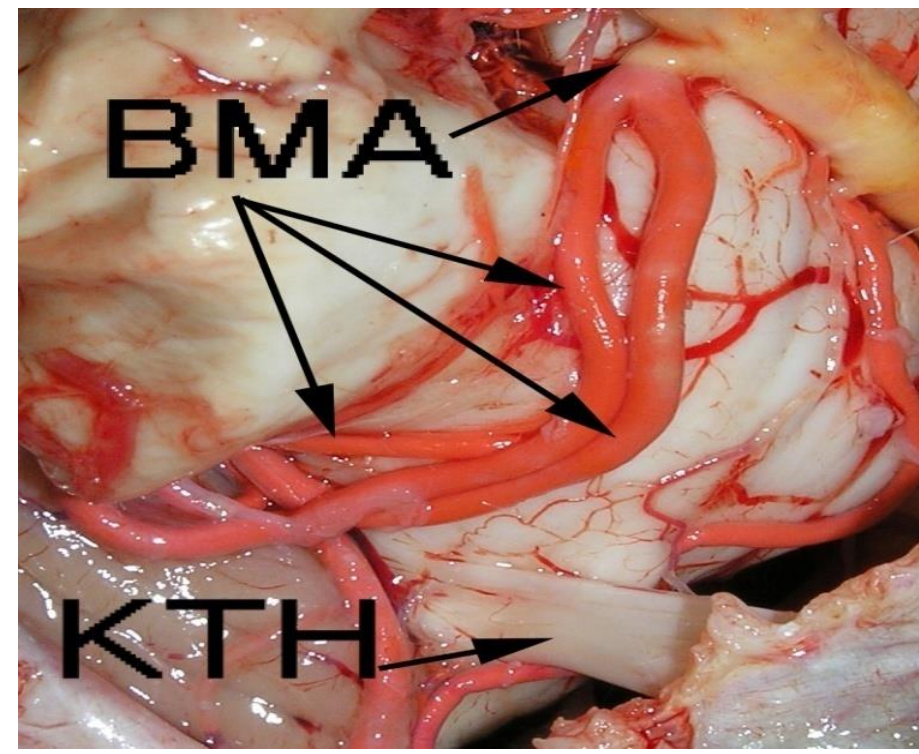

Рис. 17. Правая ВМА, отойдя от БА одним стволом, делится на ветви второго порядка на переднем понтомезенцефальном сегменте. Нижний ствол ВМА в дистальном отделе переднего понтомезенцефального сегмента делится на ветви третьего порядка. В проекции воротной зоны КТН располагается три ветви ВМА

В одном нашем наблюдении имела место выраженная долихоэктазия переднего и латерального понтомезенцефальных сегментов ВМА (рис. 18), однако артерия располагалась между КТН и наметом мозжечка и КТН не пересекала.

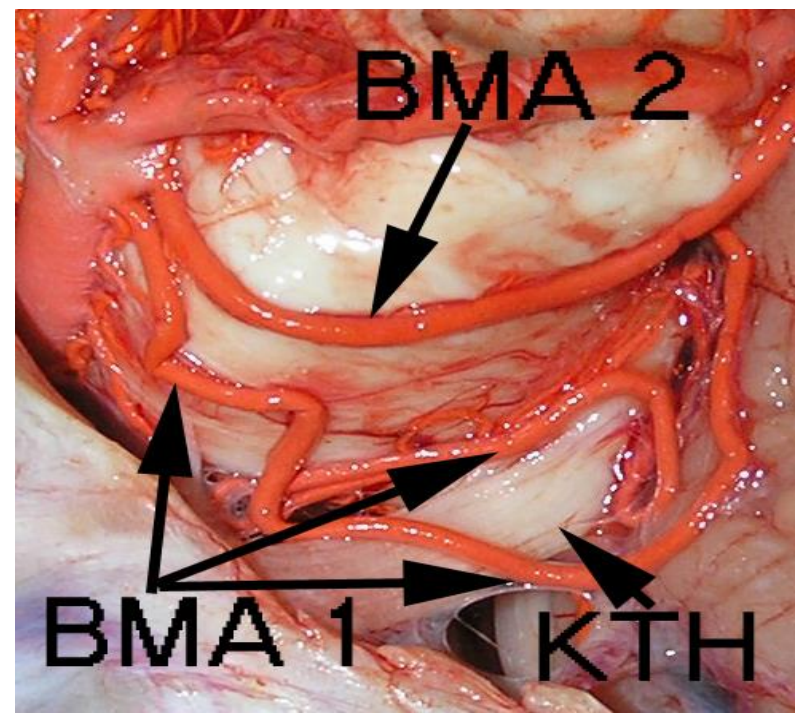

a)

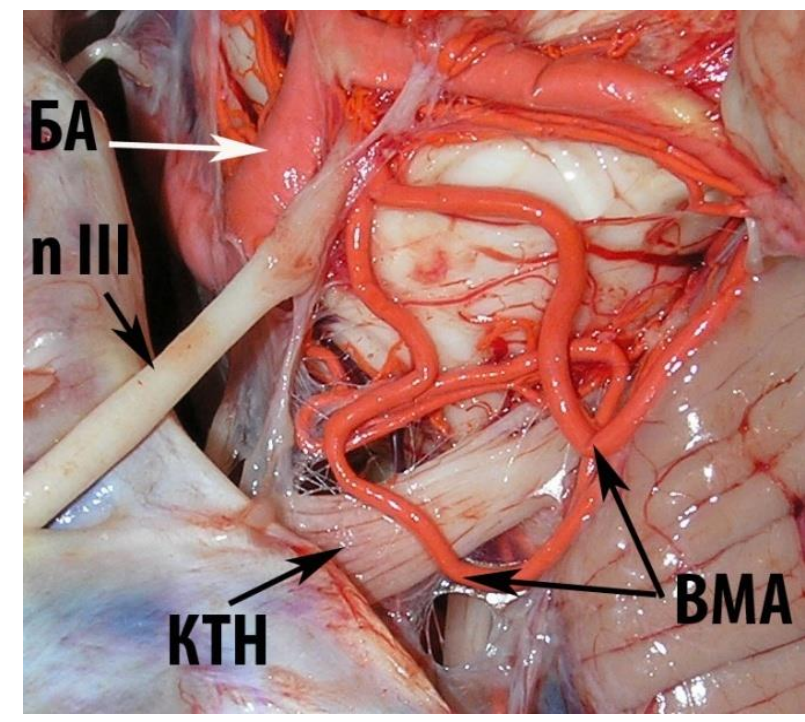

б)

Рис. 18. ВМА отходит от БА двумя столами (ВМА 1 и ВМА 2). При этом обнаружена выраженная долихоэктазия проксимального ствола ВМА, который делится на ветви второго порядка в области переднего понтомезенцефального сегмента и над КТН находится два артериальных ствола: а) вид сверху, б) вид сбоку 
$44 \mid$ Классическая невралгия тройничного нерва

Контакт ВМА и КТН имел место в 16 случаях (32\%) (см. рис. 14, $15,16)$. Близкое расположение ВМА и КТН (не более 2 мм) отмечено в $12 \%$ исследований (рис. 17, 20, 21). Расстояние между КТН и ВМА свыше 2 мм установлено в 56\% наблюдений (рис. 19).

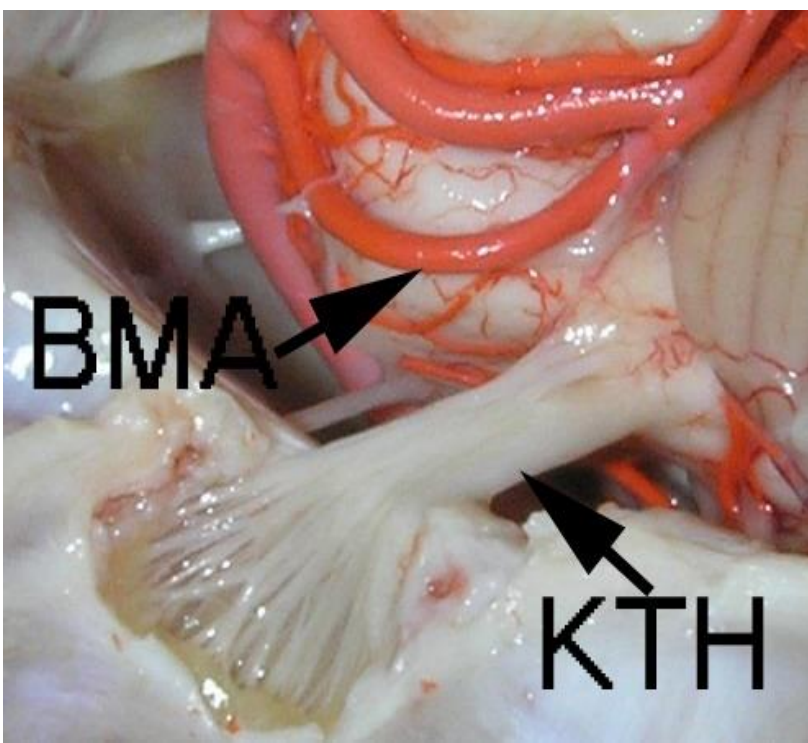

a)

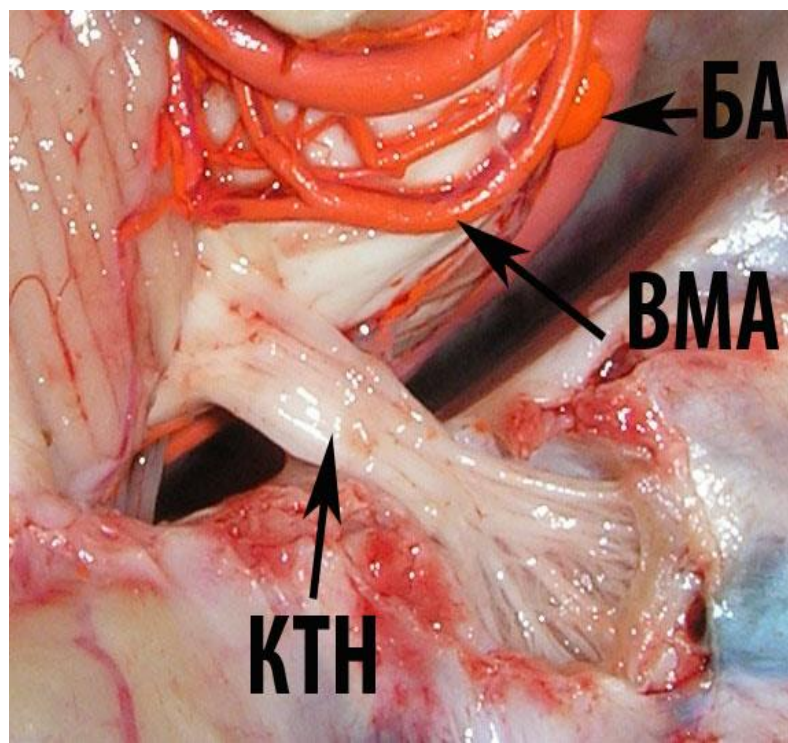

б)

Рис. 19. Расстояние между КТН и ВМА свыше 2 мм:

а) у воротной зоны - один ствол ВМА; б) у воротной зоны - две ветви второго порядка

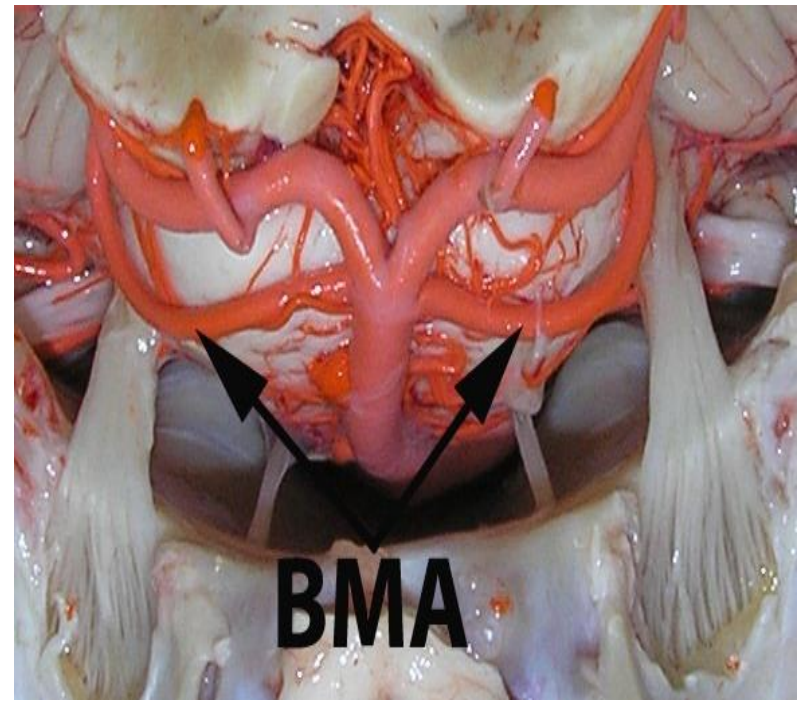

a)

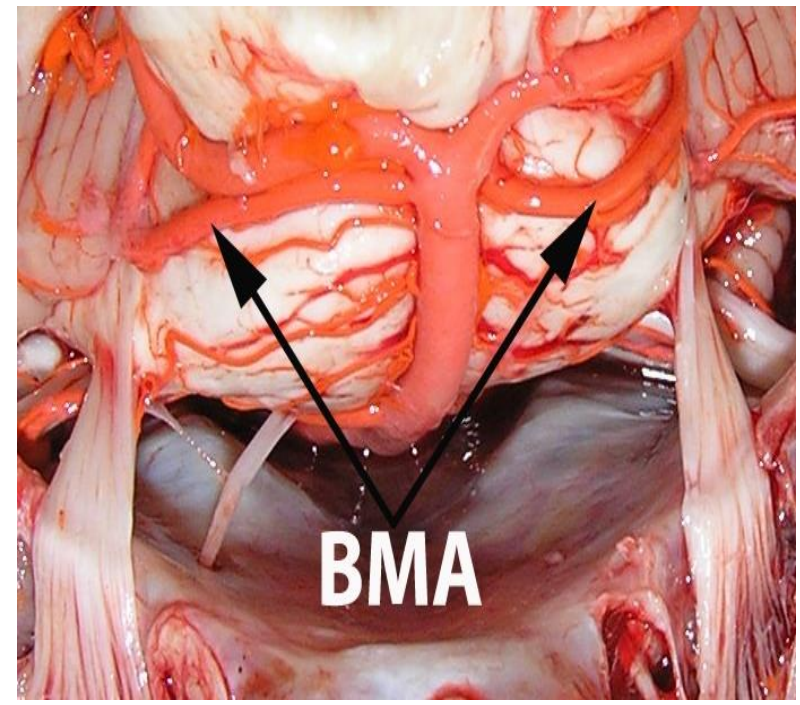

б)

Рис. 20. Вершина петли ВМА, образующаяся при переходе переднего понтомезенцефального сегмента артерии в латеральный понтомезенцефальный, располагается над КТН. Симметричный ход ВМА 


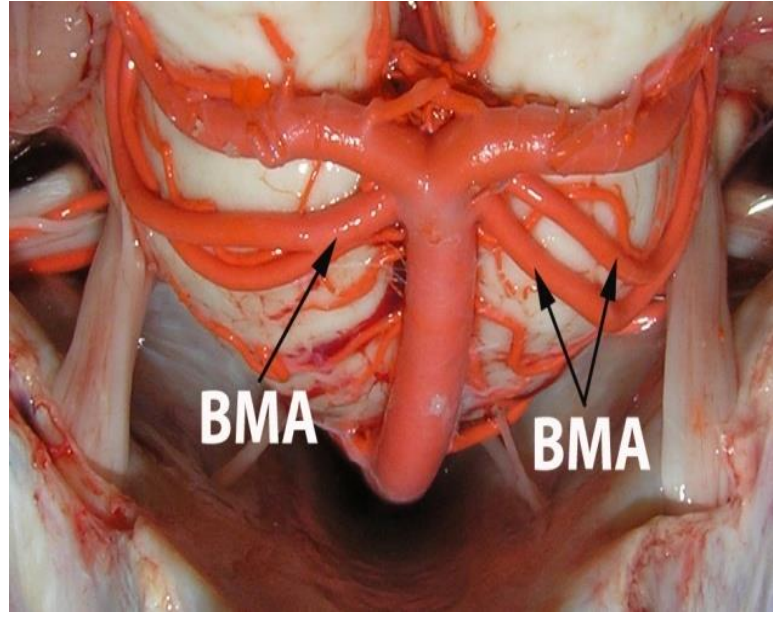

a)

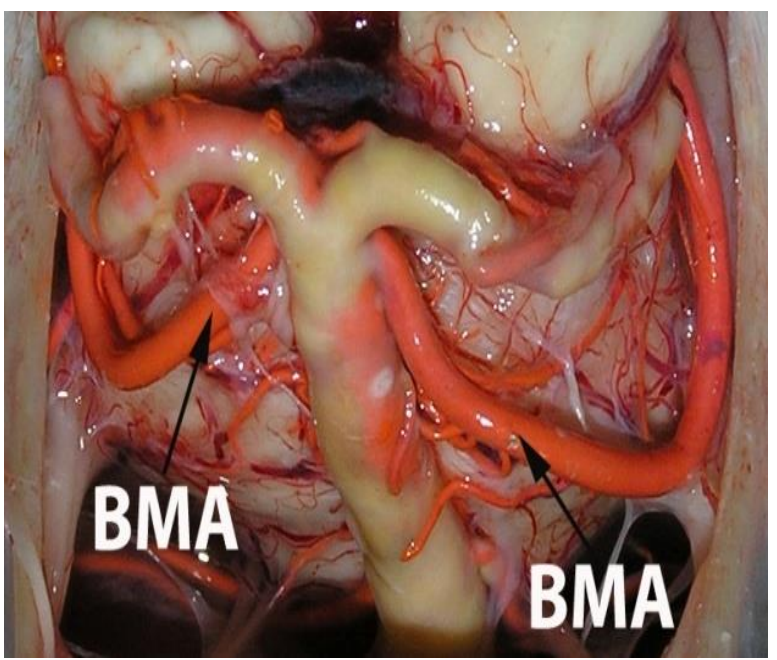

B)

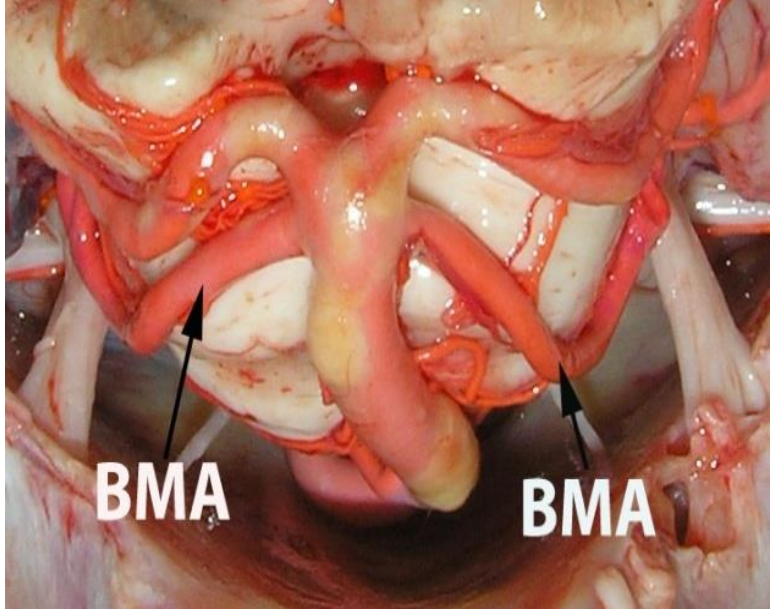

б)

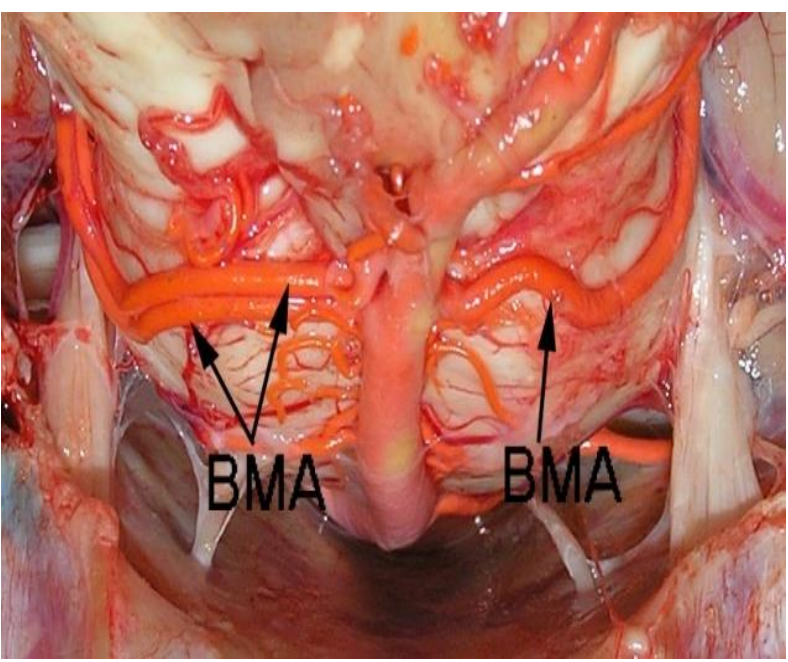

г)

Рис. 21. Вершина петли ВМА, образующаяся при переходе переднего понтомезенцефального сегмента артерии в латеральный понтомезенцефальный, располагается над КТН. Асимметричный ход ВМА

Во всех изученных нами секционных наблюдениях ВМА и ее ветви располагались над верхней поверхностью КТН между ним и наметом мозжечка и ни в одном случае ВМА и ее ветви не пересекали КТН в вертикальной плоскости, как при симметричном, так и при асимметричном ходе артерии (рис. 20, 21).

Нами проведена ангиометрия первых двух сегментов BMA: переднего понтомезенцефального и латерального понтомезенцефального, представляющих собой проксимальный и дистальный сегменты артериальной петли, вершина которой располагается 
$46 \mid$ Классическая невралгия тройничного нерва

вблизи от КТН. Длина переднего понтомезенцефального сегмента от базилярной артерии до вершины петли ВМА составила справа $18,4 \pm 2,7$ мм, а слева $18,4 \pm 2$ мм. Длина латерального понтомезенцефального сегмента от вершины петли ВМА до перехода в церебелломезенцефальный сегмент составила справа 11,5 \pm 3 мм, слева $12,1 \pm 3,6$ мм .

Ход передней нижней мозжечковой артерии (ПНМА) более вариабельный, по сравнению с ВМА. Обозначения сегментов ПНМА приведено на рис. 22 по Rhoton A.L. (2000). ПНМА в наших наблюдениях в 92\% отходила от базилярной артерии (рис. 22, 23), и в 8\% - от задней нижней мозжечковой артерии. В случаях отхождения ее от БА, от проксимальной половины базилярной артерии, ПНМА отходила в $56 \%$ случаев, а от дистальной - в 44\%. Степень развития ПНМА находилась в обратной зависимости от выраженности задней нижней мозжечковой артерии (ЗНМА) на той же стороне. Крайне редкий вариант отхождения ЗНМА от ПНМА (рис. 24, левая ПНМА).

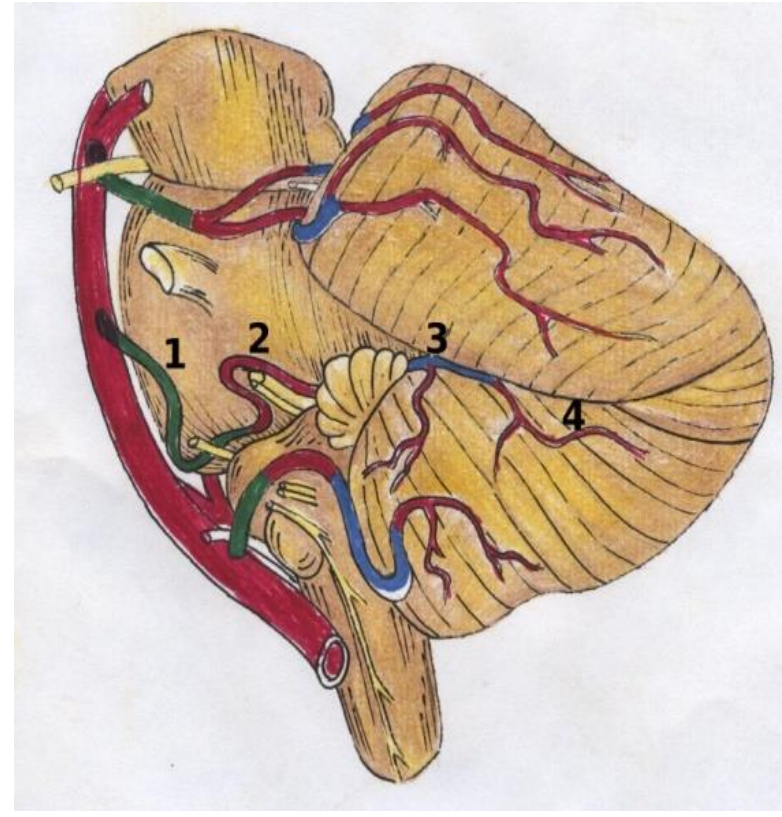

a)

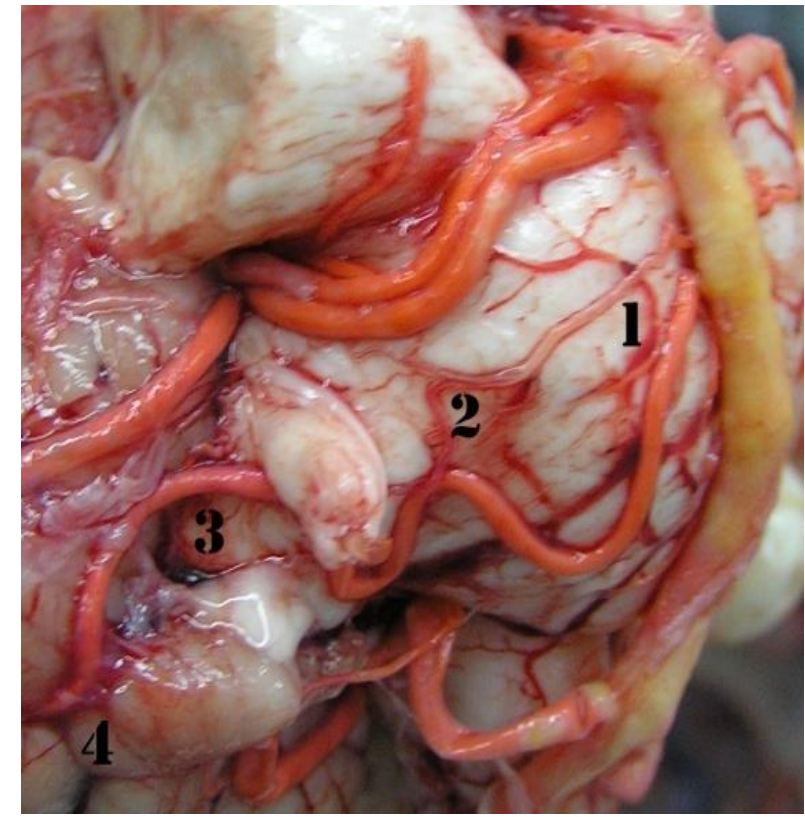

б)

Рис. 22. Сегменты ПнМА:

а) схема (по Rhoton A.L.); б) препарат:

1 - передний понтинный, 2 - латеральный понтинный, 3 - флоккулопедункулярный, 4 - кортикальный 


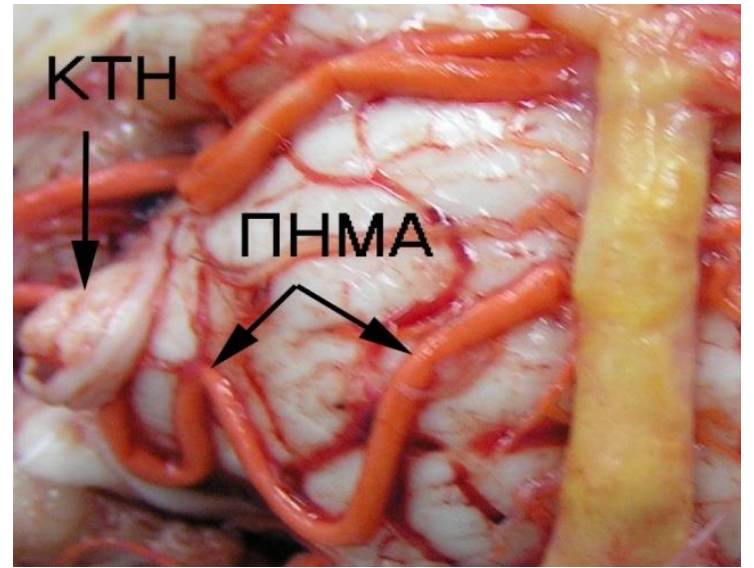

a)

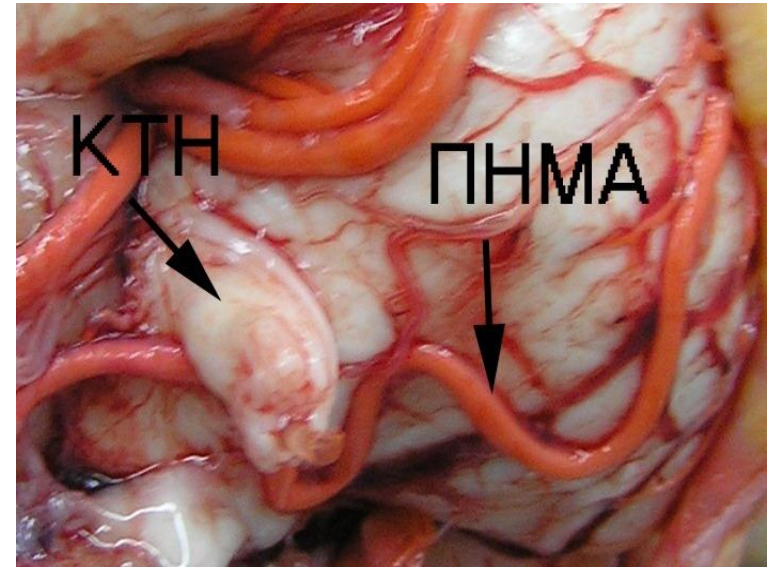

б)

Рис. 23. Передняя нижняя мозжечковая артерия отходит от основной артерии: а) вид спереди, б) вид сбоку

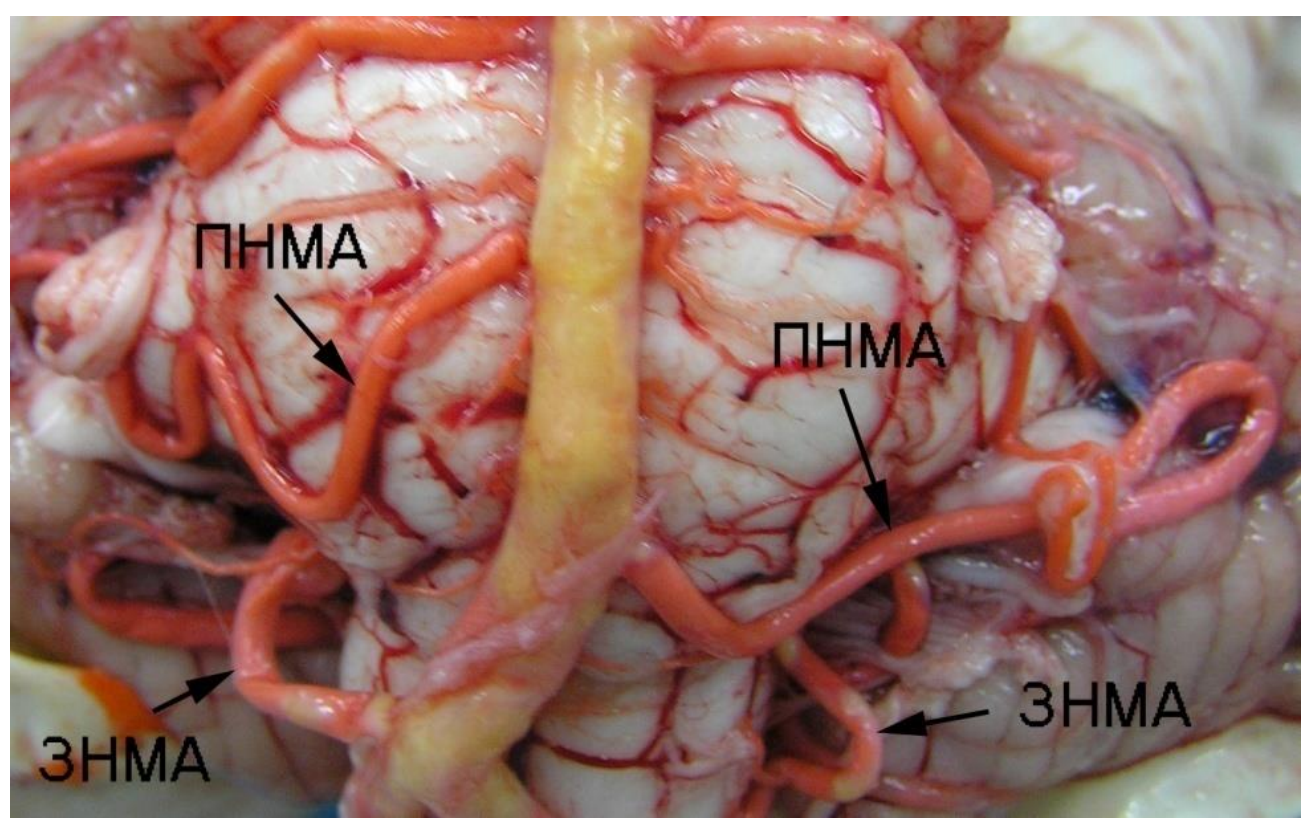

Рис. 24. Справа ПНМА отходит от средней трети БА. Слева ПНМА отходит от проксимальной трети БА, дополнительно кровоснабжая зону ЗНМА

Наиболее важными сегментами ПНМА относительно возможного контакта с КТН являются латеральный понтинный и флокулопедункулярный. Эти сегменты артерии склонны к петлеобразованию. Относительно более постоянной является петля, образуемая флокулопедункулярным сегментом, наиболее близко расположенным к дорзальной поверхности КТН. Петля образующаяся при переходе переднего понтинного сегмента ПНМА в латеральный понтинный располагается кпереди от КТН. Характер и направление 
$48 \mid$ Классическая невралгия тройничного нерва

флокулопедункулярной петли были вариабельны: купол ее был направлен латерально в 34\% (рис. 24 левая ПНМА), вверх - в 22\% (рис. 25), вниз - в 4\%, петля имела кольцевидно замкнутую форму в $20 \%$, ПНМА имела синусоидную форму, образуя несколько изгибовпетель - в 20\% (рис. 26), и в 2\% петлеобразование отсутствовало, поскольку артерия имела прямолинейный ход (рис. 27).

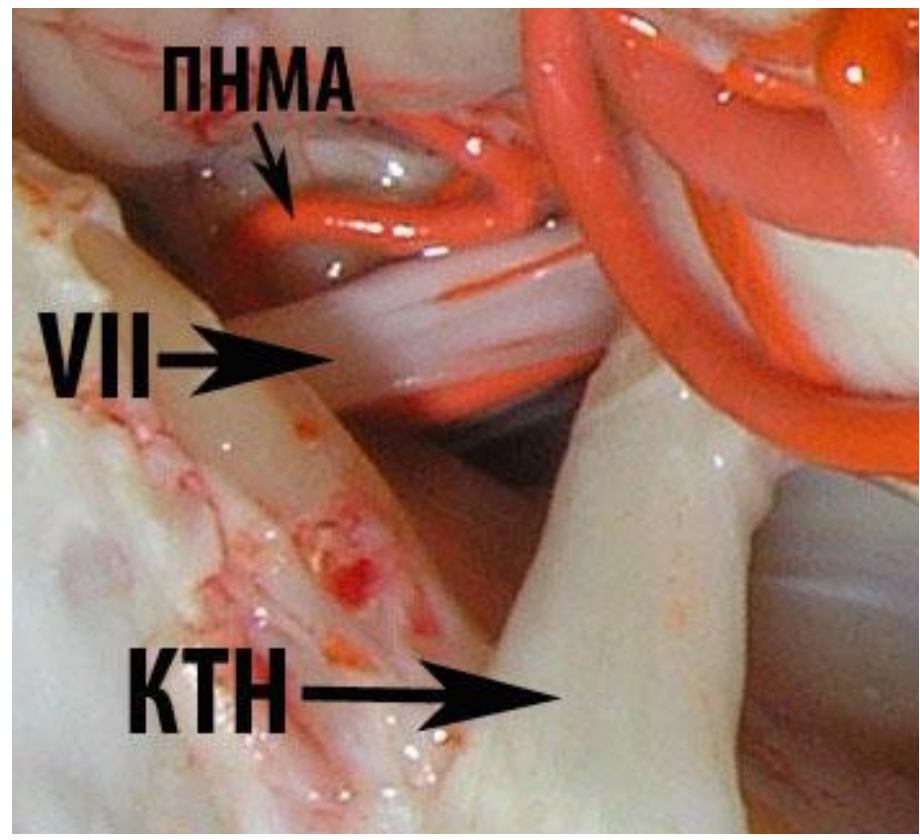

Рис. 25. Вид спереди. Флокулопедункулярная петля НПМА направлена латерально

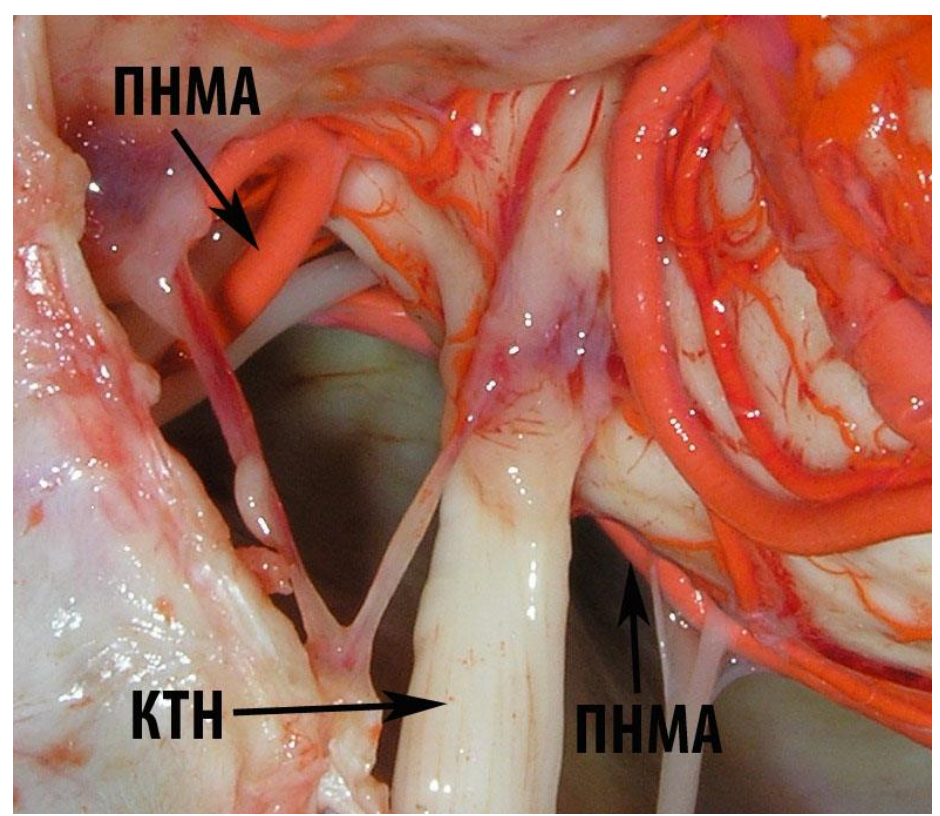

Рис. 26. Вид спереди. Вершина флокулопедункулярной петли ПНМА направлена вверх 


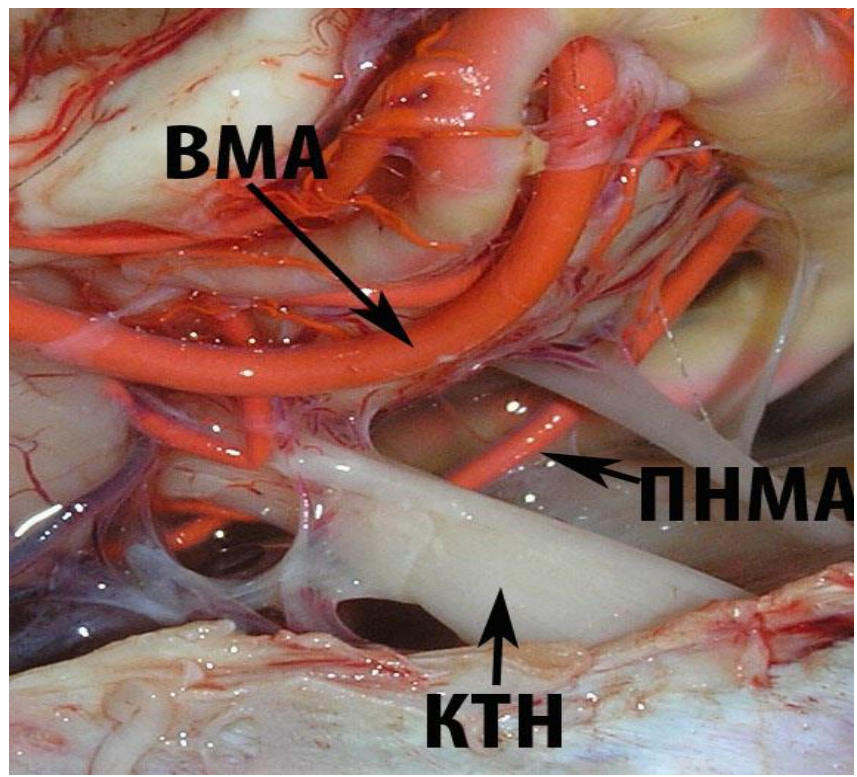

Рис. 27. Вид сбоку. Правая ПНМА имеет прямолинейный ход

Важным обстоятельством является тот факт, что ни в одном случае у лиц, не страдавших НТН, не отмечалось расположение вершины петель ПНМА выше КТН, с тем, чтобы при выпрямлении петли во время систолы ее дистальное плечо могло бы травмировать КТН.

Среди 40 исследований сосудов вертебробазилярного бассейна в сочетании с наливкой вен, в одном наблюдении выявлена долихоэктазия базилярной артерии (БА), при этом дистальный сегмент БА и ПНМА располагались в непосредственной близости к КТН (рис. 28).

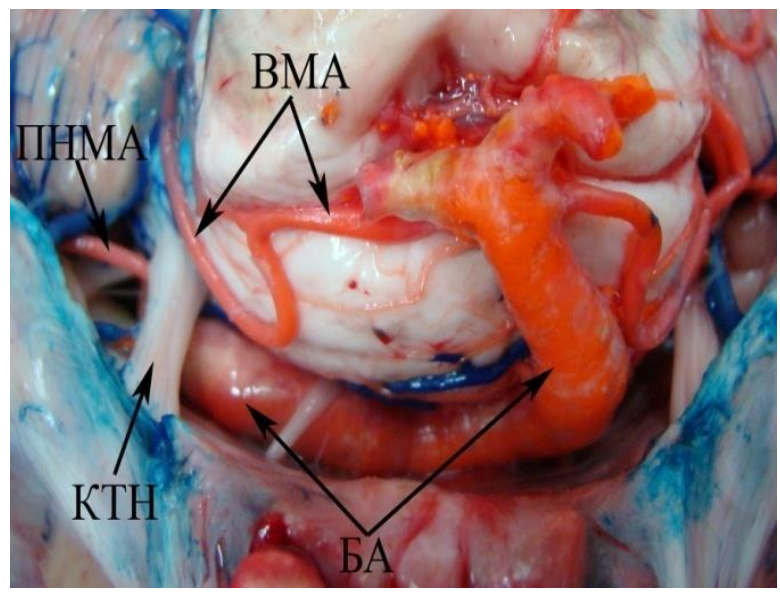

a)

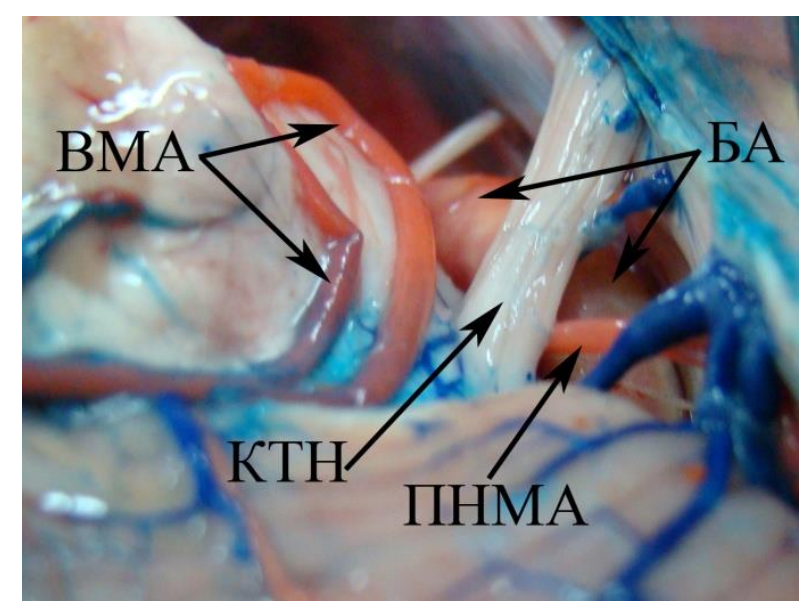

б)

Рис. 28. Долихоэктазия базилярной артерии: а) вид спереди, б) вид сзади и сверху 


\section{3. ТОПОГРАФО-АНАТОМИЧЕСКИЕ ВЗАИМООТНОШЕНИЯ КОРЕШКА ТРОЙНИЧНОГО НЕРВА С ВЕРХНЕЙ КАМЕНИСТОЙ ВЕНОЙ И ЕЕ ПРИТОКАМИ}

Многие исследователи одной из причин классической НТН считают компрессию КТН верхней каменистой веной (ВКВ) или ее притоками [276]. В то время как другие подчеркивают, что при венозной компрессии после МВД, почти у всех оперированных больных отмечаются рецидивы заболевания [133, 245, 257, 264, 371]. Нами проведено изучение топографо-анатомических взаимоотношений КТН с верхней каменистой веной и ее притоками на 20 аутопсиях (40 ВКВ). Заполнение ВКВ производилось через верхние каменистые синусы (ВКС) окрашенной в синий цвет силиконовой массой, с одновременной инъекцией артерий вертебробазилярного бассейна такой же массой, но окрашенной в красный цвет. Основные стволы ВКВ во всех 40 изученных наблюдениях формировались у переднего края мозжечка и направлялись вперед, кверху и латерально, впадая в верхний каменистый синус (ВКС) под разными углами, одним стволом (26) в $65 \%$ (рис. 29, а), двумя стволами (11) в 27,5\% (рис. 29) и тремя стволами (3) в 7,5\% (рис. 29, в).

Таким образом, стволов ВКВ у 20 исследованных лиц с двух сторон оказалось 57.

Расстояние между основными стволами ВКВ при впадении в ВКС двумя или тремя стволами составляло от 1 мм до 21,0 мм. Диаметр основного ствола ВКВ был от 1,0 мм до 4,5 мм и зависел от площади дренирования и не зависел от степени развития ВМА. Длина основного ствола ВКВ колебалась от 1 до 17 мм.

В связи с конкретной задачей изучения взаимоотношения КТН и ВКВ нами оценивались только основной ствол ВКВ и проксимальные сегменты ее притоков. В зависимости от места впадения ВКВ в верхний каменистый синус по отношению к внутреннему слуховому проходу они подразделяются на латеральные, промежуточные и медиальные. 


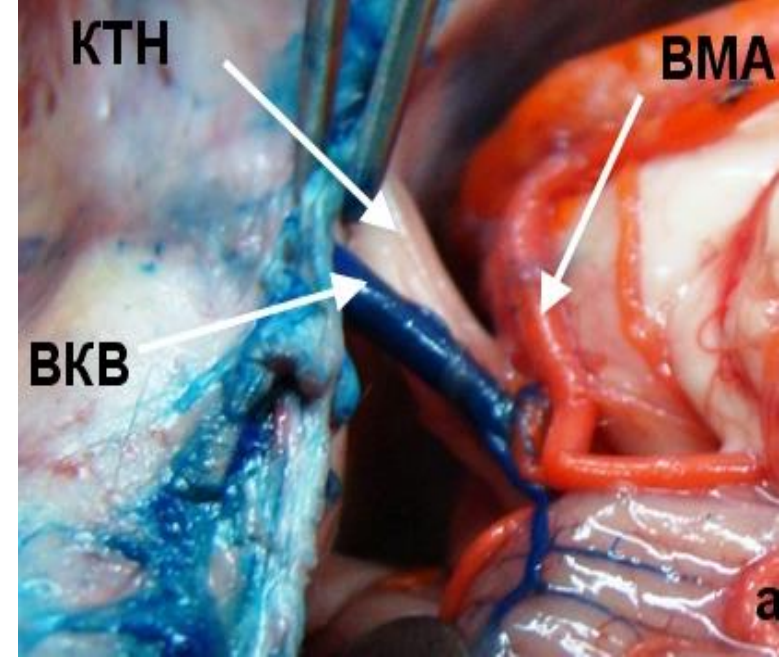

a)

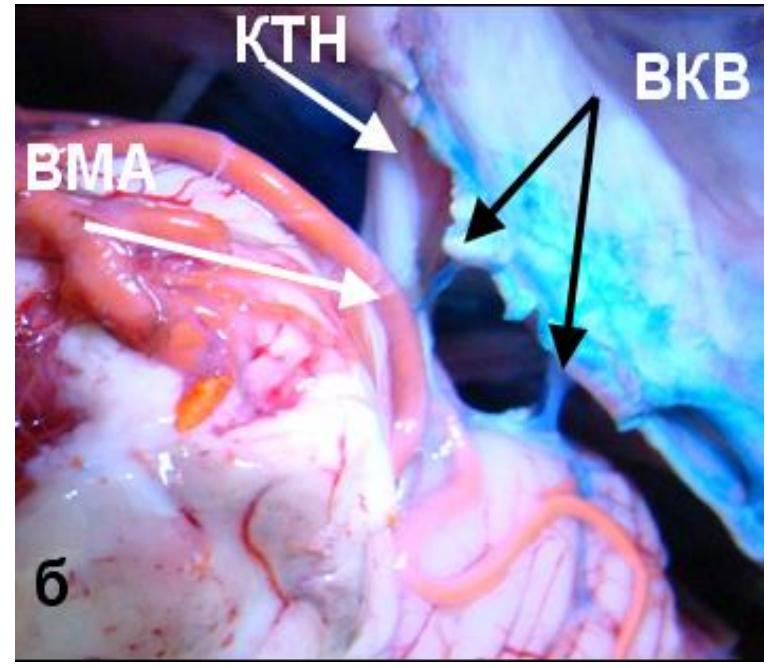

б)

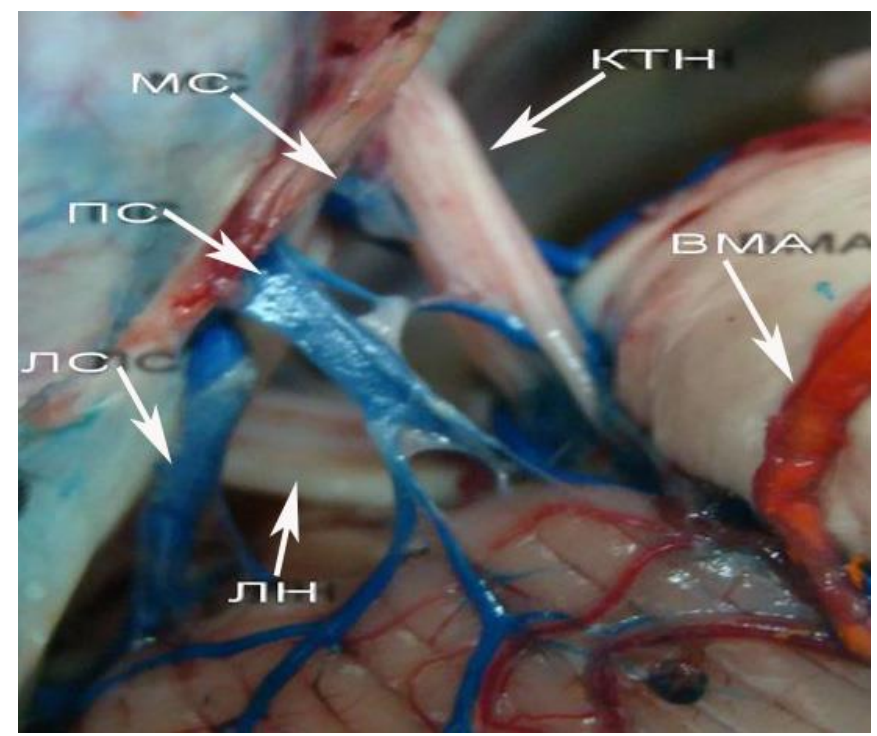

B

Рис. 29. Варианты впадения ВКВ в верхний каменистый синус: а) ВКВ представлена одним стволом, б) ВКВ представлена двумя стволами, в) ВКВ представлена тремя стволами

Промежуточные стволы ВКВ проецируются над внутренним слуховым проходом (рис. 30), медиальные стволы - медиальнее (рис. 31), а латеральные стволы - латеральнее внутреннего слухового прохода. Промежуточный тип впадения ВКВ в ВКС встречался в наших наблюдениях в 5 случаях, медиальный тип - в 46, а латеральный - в 6. При этом обращал на себя внимание тот факт, что дренируемая зона не зависела от места впадения ВКВ в верхний каменистый синус. 


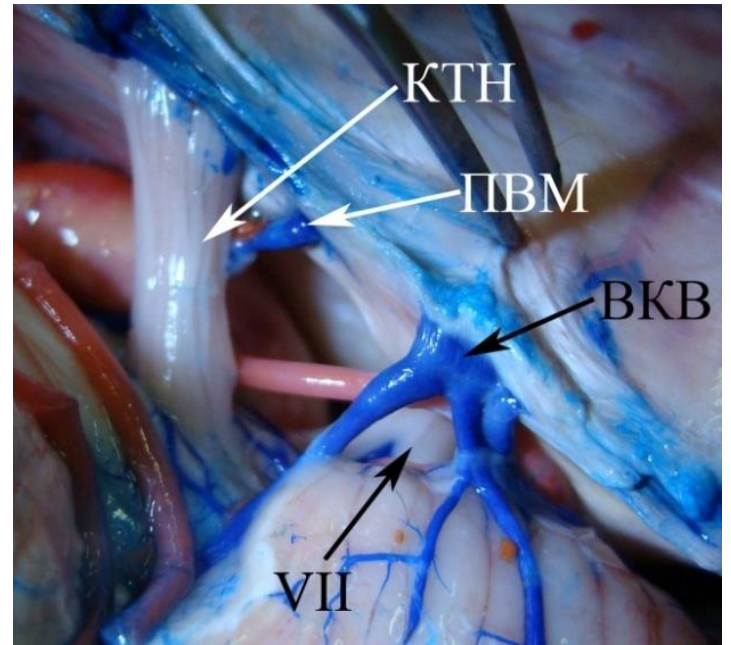

a)

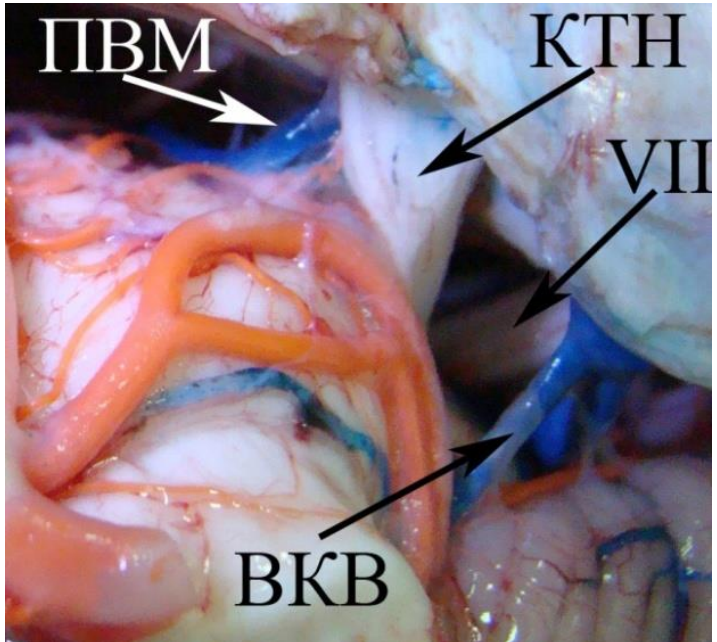

б)

Рис. 30. Варианты промежуточного типа впадения ВКВ в ВКС

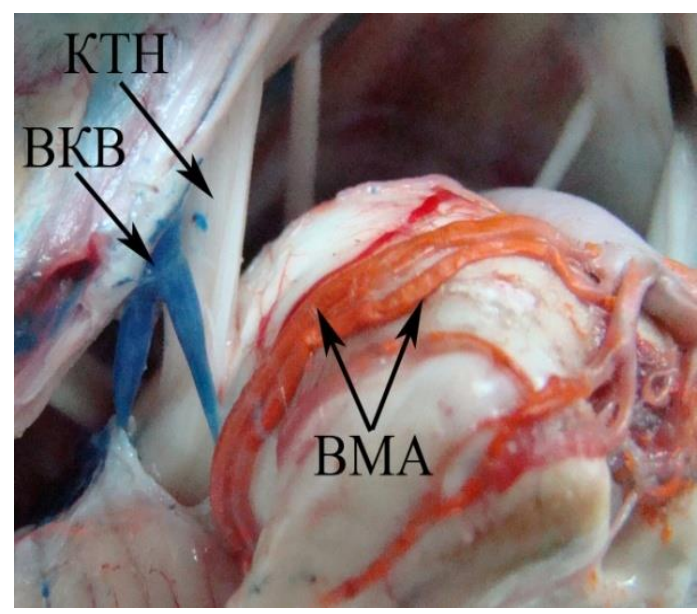

a)

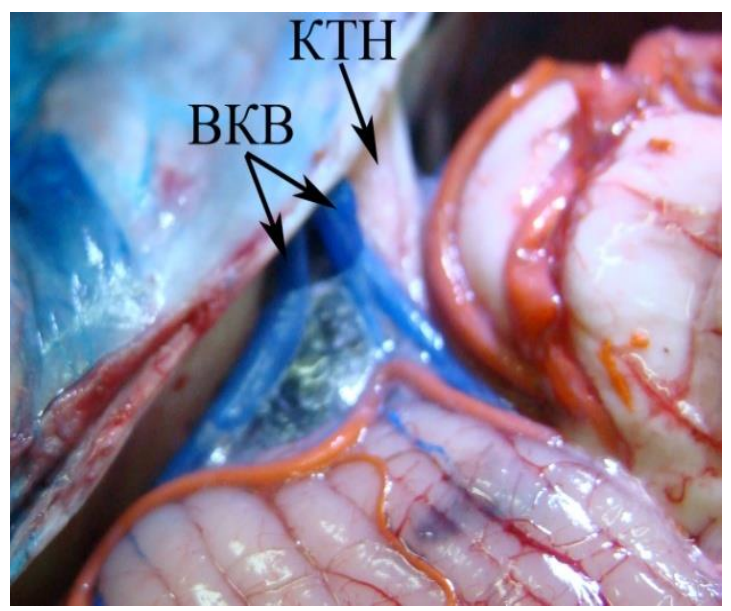

б)

Рис. 31. Варианты медиального типа впадения ВКВ в ВКС

Учитывая то обстоятельство, что многие авторы причиной классической НТН Считают также конфликт и с венозными сосудами, расположенными вблизи КТН $[83,127,128,146,192,193$, 275], нами проведено изучение взаимоотношений КТН с ВКВ и ее притоками у лиц, не страдавших НТН. Установлено, что при медиальном типе впадения ВКВ в ВКС расстояние между КТН и ВКВ составляло от 1 до 5 мм. В 4 из 40 КТН был выявлен контакт с основным стволом ВКВ. Кроме того, при медальном типе впадения ВКВ в ВКС в двух случаях обнаружен контакт ПВМ с верхней поверхностью КТН. Из 40 исследованных КТН трупов лиц, не страдавших 
НTH, у 10 (25\%) обнаружен контакт КТН с венозным сосудом: у 4 с основным стволом ВКВ и у 6 - с ПВМ. Такой высокий процент контакта вены с КТН ставит под сомнение значение подобного контакта как самостоятельного этиологического фактора в патогенезе НТН (рис. 31). При наличии контакта дорзальной поверхности КТН с ВКВ или ее притоками, в случае формирования нейроваскулярного конфликта с ВМА, КТН оказывается заключенным между двумя сосудами. С вентральной стороны по КТН наносит удары распрямляющаяся с каждой систолой петля ВМА, а с дорзальной ВКВ препятствует отклонению КТН от ударов артерии. При таком топографо-анатомическом взаимоотношении создаются условия для формирования феномена артериовенозного «сендвича», изменяющего клиническую картину классической НТН.

\section{4. СРКТ-ИССЛЕДОВАНИЕ ОСОБЕННОСТЕЙ ОСНОВАНИЯ ЧЕРЕПА И ЛИЦЕВОГО СКЕЛЕТА У ЛИЦ, НЕ СТРАДАВШИХ ТРИГЕМИНАЛЬНОЙ НЕВРАЛГИЕЙ}

Во второй половине 20 века некоторые нейрохирурги (Л.Я. Лившиц, 1968) полагали, что причиной НТН является высокое стояние вершины пирамиды височной кости, и перегиб корешка тройничного нерва через возвышенный край пирамиды является причиной заболевания. Позже [101] было установлено, что у многих практически здоровых лиц правое тройничное вдавление в области вершины пирамиды височной кости расположено выше, чем левое. Нами проведено изучение расположения вершин пирамид височных костей справа и слева у 50 лиц, не страдавших НТН при выполнении им спиральной компьютерной томографии режиме 3 D. Виртуальная краниометрия позволяет количественно оценить расположение симметричных структур черепа, а также определить площадь выходных отверстий и диаметр каналов, через которые проходят ветви тройничного нерва прижизненно. Мареев О.В., Николенко В.Н. (2014) считают метод виртуальной краниометрии 
$54 \mid$ Классическая невралгия тройничного нерва

перспективным и многообещающим. Метод виртуальной краниометрии используется нами с 2010 года. Среди лиц, не страдавших HTH, женщин было 28, мужчин - 22. Режим сканирования спиральный, толщина среза 1 мм. В костном окне выбирался аксиальный срез, проходящий через вершину левой пирамиды. На вершине левой пирамиды устанавливался "Rotation center" (рис. 32, a). Затем выводился на экран коронарный срез с сохранением "Rotation center" на вершине левой пирамиды. Изображение выравнивалось по симметрии височно-нижнечелюстных суставов.

Проводилась средняя линия с ориентиром на сагиттальный шов и середину ската. Перпендикулярно к средней линии, проводилась линия, проходящая через вершину левой пирамиды. Затем измерялось стояние вершины правой пирамиды, относительно этой линии (рис. 32, б).

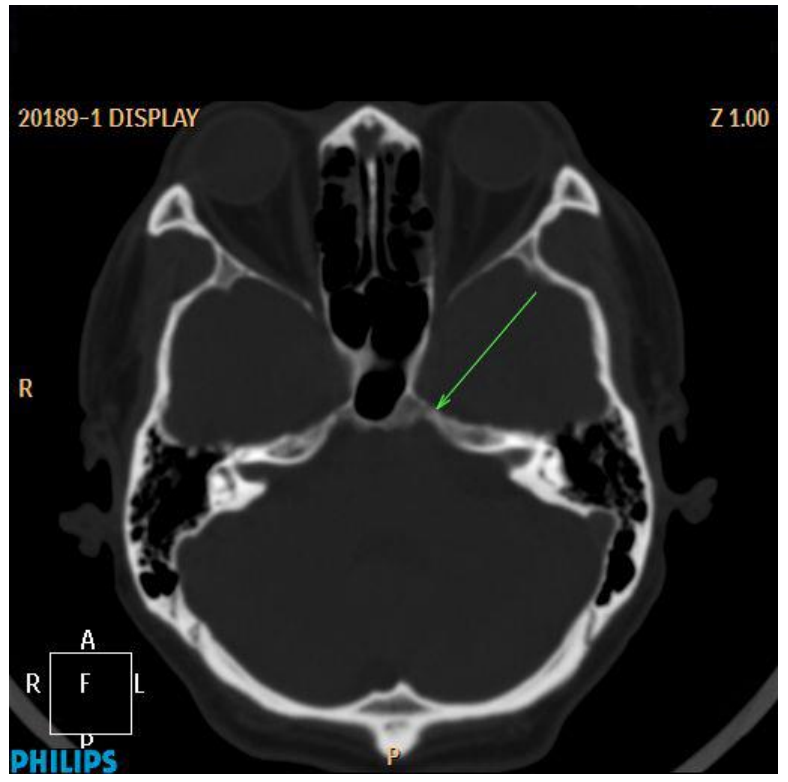

a)

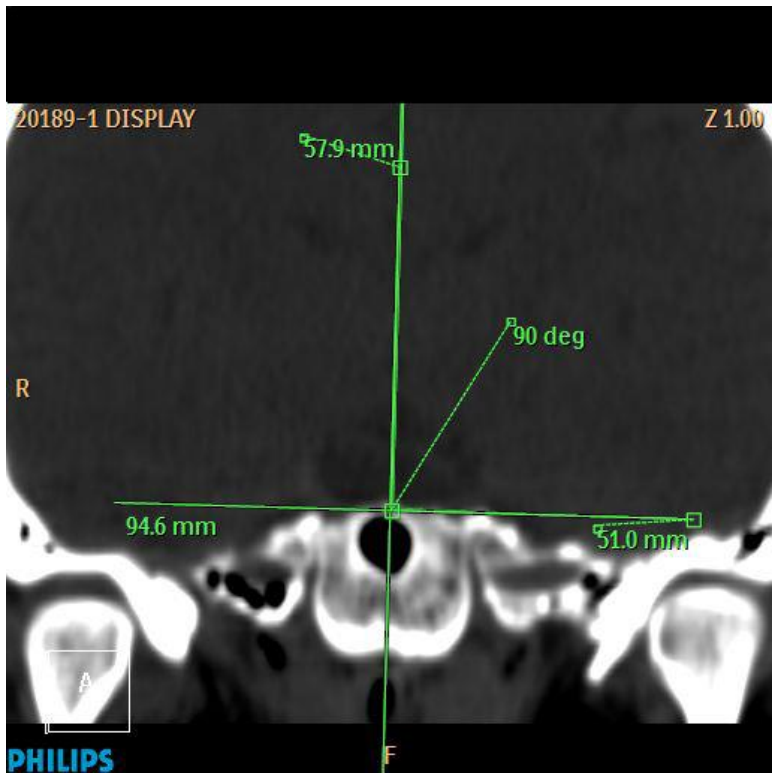

б)

Рис. 32. Этапы измерения расположения вершин пирамид височных костей: а) стрелка указывает центр ротации на вершине левой пирамиды височной кости; б) Вершины правой и левой пирамид расположены на одном уровне

Установлено, что у 77\% обследованных нами лиц, вершины пирамид располагались на одном уровне. У одной больной (2\%) вершина левой пирамиды оказалась на 1 мм выше правой. У 10 че- 
ловек (20\%) вершина правой пирамиды была выше левой от 0,5 до 6,5 мм (в среднем на 2,2 $\pm 1,56$ мм).

Среди них было 6 женщин и 4 мужчины. На рис. 33 и 34 приведены примеры более высокого стояния вершины правой пирамиды височной кости. На изученных 30 спиральных компьютерных томограммах лиц, страдавших НТН, нами обнаружено, что у 16 человек (53\%) задний край мекелевой ямки справа был выше, чем слева (рис. 33 и 34 ).

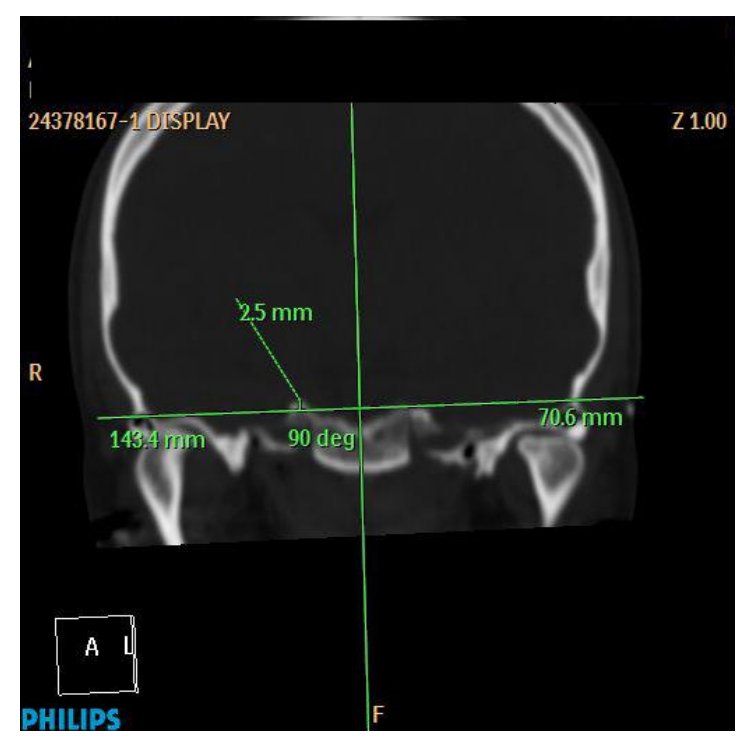

Рис. 33. Вершина пирамиды и край мекелевой ямки справа расположены выше, чем слева

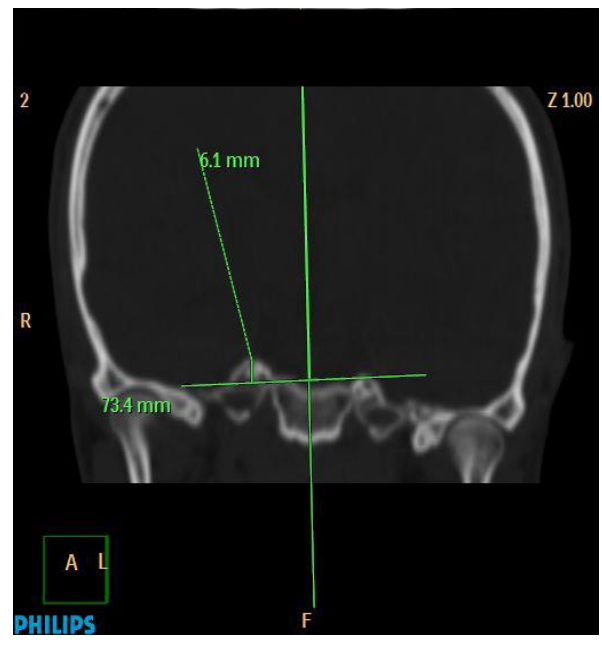

a)

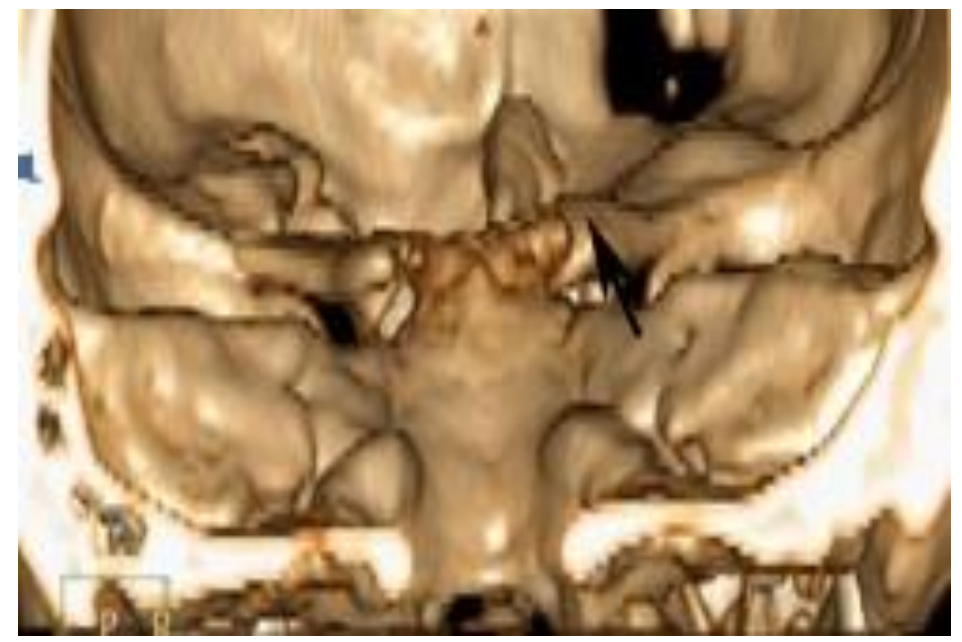

б)

Рис. 34. Вершина пирамиды и край мекелевой ямки справа расположены значительно выше, чем слева: а) в спиральном режиме, б) в режиме 3D 
$56 \mid$ Классическая невралгия тройничного нерва

Полость черепа ветви тройничного нерва покидают через отверстия в его основании. Первая ветвь проходит через верхнее глазничное отверстие вместе с нервами, обеспечивающими движение глазного яблока. Вторая ветвь выходит через круглое отверстие, а третья - через овальное отверстие. До настоящего времени сохраняется представление о тоннельном механизме НТН в результате компрессии второй и третьей ветвей в этих отверстиях. Нами проведено измерение площадей круглого, овального и подглазничного отверстий и диаметра подглазничного канала с правой и левой стороны у 20 лиц, не страдавших НТН (рис. 35).

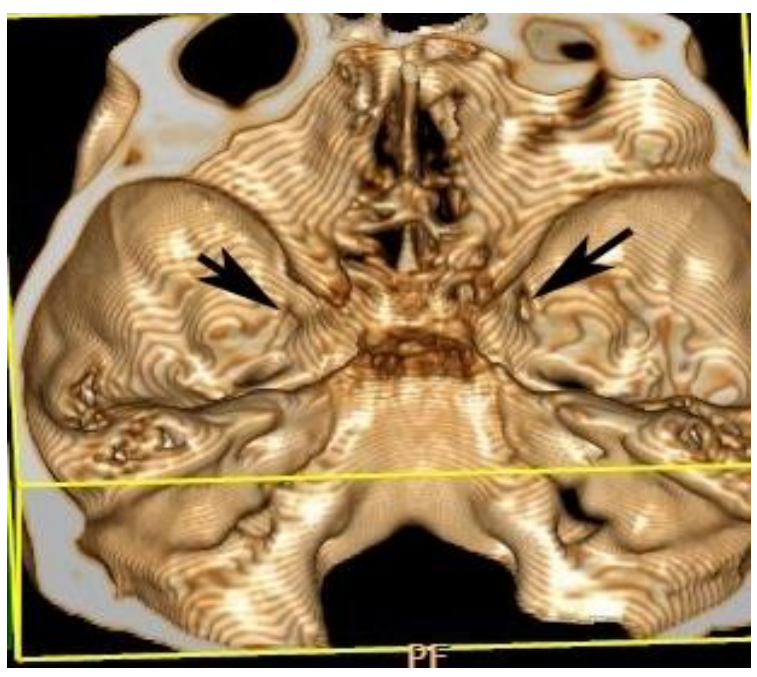

a)

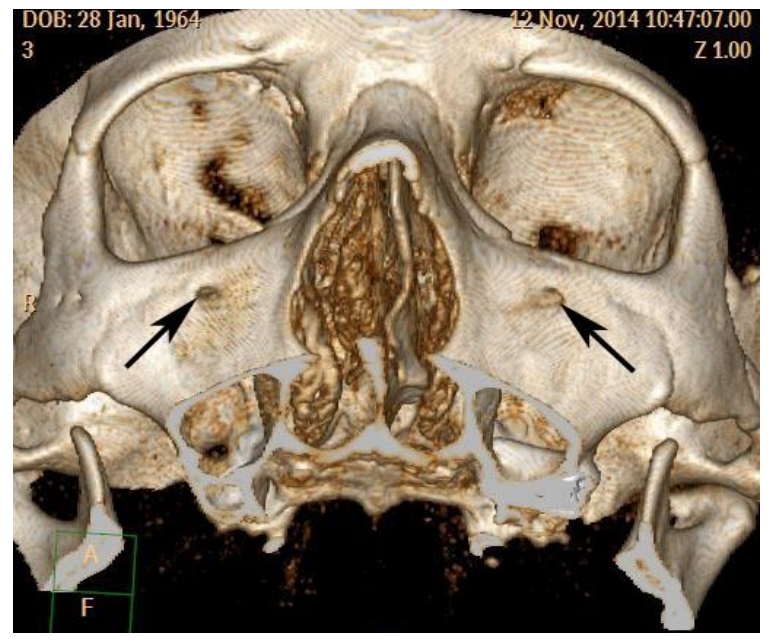

в)

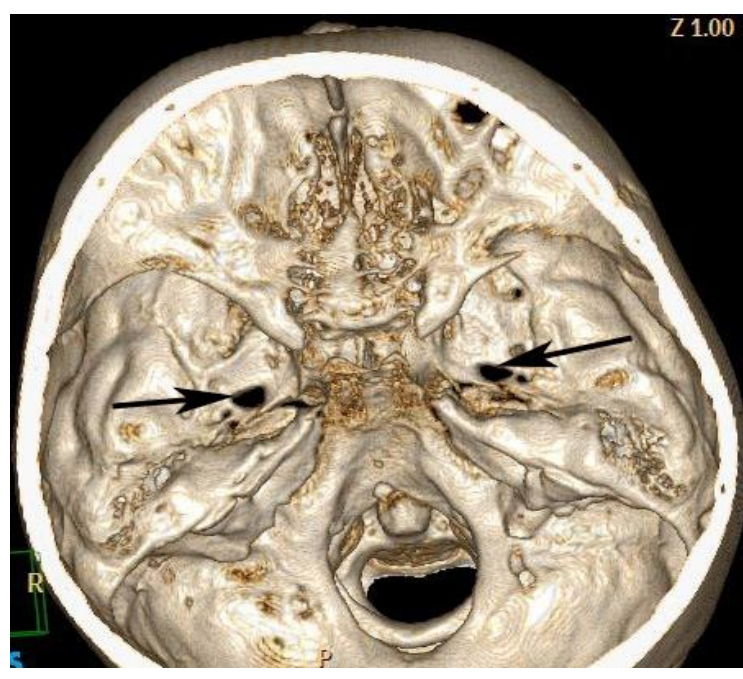

б)

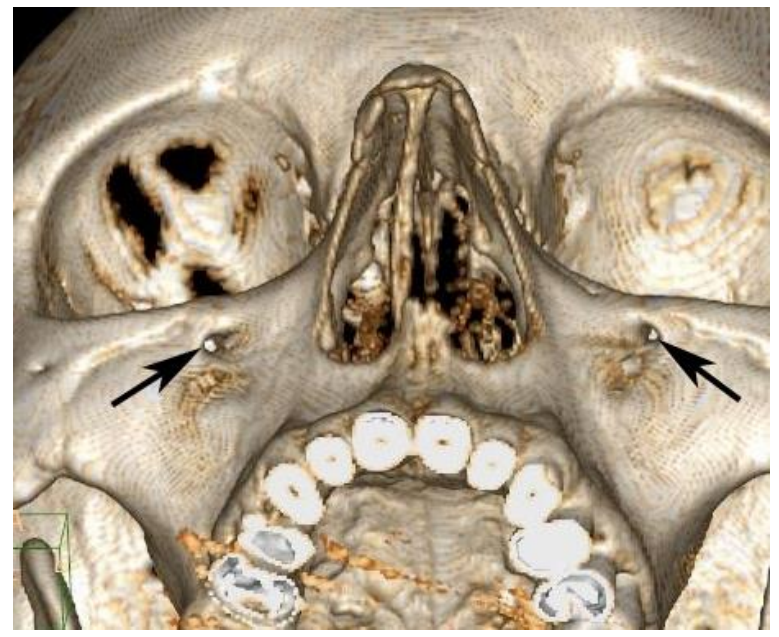

г)

Рис. 35. Выходные отверстия ветвей тройничного нерва: а) правое круглое отверстие больше левого; б) левое овальное отверстие больше правого; в) левое подглазничное отверстие больше правого; г) правый подглазничный канал больше левого 
Площадь круглого отверстия у них составила $-4,46 \pm 0,29$ мм² $^{2}$ при этом оказалось, что круглые отверстия справа были уже, чем слева у 60\%, слева уже, чем справа у 40\% обследованных. Площадь овального отверстия составила $25,52 \pm 1,11$ мм², при этом оказалось, что у 40\% справа овальное отверстие было уже, чем слева, и у 60\% слева было уже, чем справа. Площадь подглазничного отвер-

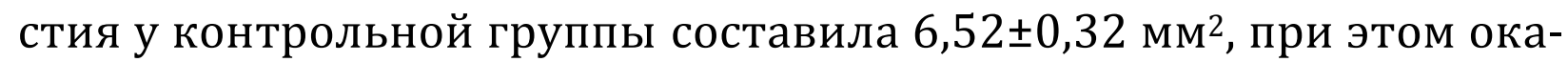
залось, что справа оно было уже у 63,2\% обследованных, а слева у 36,8\%. Средняя величина диаметра подглазничного канала со-

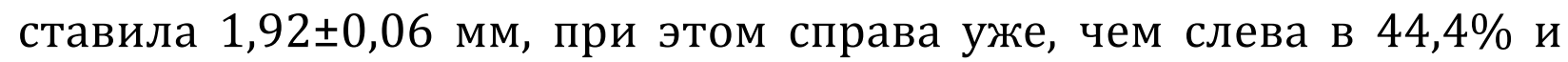
слева уже, чем справа в 55,6\% наблюдений. 
$58 \mid$ Классическая невралгия тройничного нерва

\section{ГЛАВА}

ПАТОГЕНЕЗ

\section{КЛАССИЧЕСКОЙ НЕВРАЛГИИ ТРОЙНИЧНОГО НЕРВА}

В результате анализа рецензируемых журналов и электронной базы данных за период с 1965 по 2012 годы Sabalys G et al. (2013) выделяют три самых распространенных теории этиологии и патогенеза невралгии тройничного нерва:

1) непосредственное повреждение тройничного нерва;

2) НТН, связанная с другими заболеваниями;

3) НТН как полиэтиологическое заболевание.

Как известно, НТН относится к хронической невропатической боли. К настоящему времени ушла в прошлое острота дискуссии о центральном или первично-периферическом происхождении $\mathrm{HTH}$. Еще в начале второй половины прошлого века была сформирована теория «короткого замыкания», когда в результате демиелинизации нервных волокон соприкасаются между собой оголенные осевые цилиндры А-дельта с немиелинизированными С-волокнами КТН и между ними возникает «короткое замыкание» в результате чего тактильный стимул распространяется на боль-проводящие C-волокна, следствием которого является тригеминальный болевой пароксизм. В клинике это находит подтверждение в функционировании триггерных зон, когда незначительные, нежные тактильные раздражения на лице или в полости рта провоцируют возникновение болевого пароксизма. 
Для своевременной диагностики и выбора адекватного метода лечения необходимо четко отграничить классическую невралгию тройничного нерва от других его поражений, характеризующихся клиникой невропатии. Согласно определению всемирной ассоциации по изучению боли (IASP-International Assosiation for the Study of Pain) невралгия тройничного нерва определяется как синдром, характеризующийся внезапными кратковременными интенсивными повторяющимися болями в зоне иннервации одной или нескольких ветвей тройничного нерва, обычно с одной стороны лица. При этом боли носят кратковременный характер от нескольких секунд до 2 минут, ограничены зоной иннервации обычно второй и/или третьей ветвей тройничного нерва. Во время приступа больные «замирают», боясь малейшим движением усилить боль. Частота приступов может варьировать от одного до сотен в день (невралгический статус). В межприступном периоде боль отсутствует. Приступы возникают при малейшем движении мимических мышц лица, разговоре, жевании, умывании, бритье, чистке зубов. Триггерные зоны обычно расположены в периоральной области. Страх возникновения приступа настолько велик, что при малейшей попытке врача при осмотре больного приблизится нежным предметом или рукой к триггерной зоне вызывает резкое отклонение головы от руки исследователя (симптом защиты триггерной зоны). В.А. Карлов называет этот признак «жест-антагонист», а А.В. Степанченко - «симптом Штернберга», впервые описавшего его.

К сожалению, несмотря на четко сформулированные критерии классической невралгии тройничного нерва, многие специалисты расценивают любую боль в лице как НТН. В результате пациенты годами безуспешно «лечатся» у неврологов, стоматологов, челюстно-лицевых хирургов и других специалистов. Пациентам выполняют экстракции зубов, деструктивные манипуляции в зоне выхода ветвей тройничного нерва (многократные спиртовые блокады, химические, термические методы воздействия, костные декомпрессии ветвей в месте выхода их на поверхность лица), тем самым переводя классическую НТН в «тригеминальные деафферентационные боли в 
$60 \mid$ Классическая невралгия тройничного нерва

результате целенаправленного разрушения периферических ветвей», в соответствии с классификацией Eller J.L. et al. (2005).

Компрессия периферических ветвей тройничного нерва (ТН) как основа патогенеза заболевания рассматривается с 1925 года после сообщения Sicard A. о сужении круглого и овального отверстий на стороне НТН [377]. Позже Савицкая О.Н., (1973) [109, 110, 111, 112] установила, что у 31\% больных невралгией 2 ветви ТН-заболевание связано с врожденным или приобретенным сужением подглазничного канала. Позже она же отмечала, что в результате переохлаждения в нерве возникает гиперергическая реакция, «приводящая к компрессии нерва в соответствующем канале даже в отсутствии стеноза последнего». Это замечание дает основание сомневаться в патогенетической роли сужения подглазничного канала и отверстия в возникновении классической НТН. В то же время Щедренок В.В. с соавт. $(2013,2014)[136,137,138,139]$ рассматривают сужение подглазничного отверстия как патогенетическую основу невралгии второй ветви ТН и рекомендуют «во всех случаях при обращении пациента с жалобами на лицевые боли, особенно в зоне иннервации ТН, осуществлять СКТ-метрию с измерением площади выходных отверстий периферических ветвей ТН с обеих сторон: овального и круглого отверстий на основании черепа, надглазничного, подглазничного и подбородочного отверстий в области лицевого скелета». Авторы утверждают, что «при уменьшении площади с больной стороны более чем на $25 \%$ имеются веские основания для диагностики компрессии периферических ветвей ТН в этой зоне». В качестве лечения этим больным предлагается осуществлять деструктивные вмешательства: высокочастотную электродеструкцию, хемодеструкцию с использованием фенола или лазерную деструкцию. Однако высокий процент рецидивов заболевания дает основание сомневаться в этиопатогенетической значимости этого признака. В то же время среди стоматологов, челюстно-лицевых хирургов и некоторых нейрохирургов экстракраниальный генез лицевых болей сохраняет свои позиции до настоящего времени [74, 75, 136, 257]. Поэтому в ряде клиник наряду с деструктивными операциями про- 
должают выполнять и в настоящее время расширение нижнечелюстного канала и подглазничного отверстия [74, 109, 139].

Возможно, туннельный механизм компрессии имеет место в тех случаях, когда заболеванию НТН предшествуют какие-либо факторы: травма лицевого скелета, хронические воспалительные заболевания придаточных пазух носа и пр. Сомнительна целесообразность измерения всех выходных отверстий ТН у больных без предшествующих возникновению НТН факторов с клинической картиной классической НТН. При компрессии ветвей тройничного нерва возникает невропатия с различными признаками нарушения чувствительности: болезненность точек выхода, гиперестезия или гипестезия, появление постоянных тупых болей в межприступном периоде. Клиника классической НТН характеризуется тяжелыми ланцинирующими, типа удара электрическим током, пароксизмами обычно односторонними и чаще в зоне второй и третьей ветвей и очень редко первой. Боль возникает спонтанно или в результате раздражения триггерных зон не болевыми раздражителями кожи или слизистой оболочки полости рта, зубов или языка. Приступ длится от нескольких секунд до нескольких минут, повторяясь через короткие интервалы, провоцируется не только сенсорными раздражителями, но и движением языка, челюсти, речью, жеванием и пр. Течение заболевания ремитирующее, причем продолжительность ремиссий с возрастом сокращается.

Нами были проанализированы величины площади черепных отверстий (подглазничного, круглого и овального) и просвета подглазничного канала у 20 больных НТН и 20 пациентов контрольной группы. Отбор больных НТН носил случайных характер, а отбор пациентов контрольной группы был основан исключительно на сходстве возраста, а также идентичного распределения по полу по сравнению с группой больных НТН.

В обеих группах мужчин - 8, женщин - 12. Средний возраст

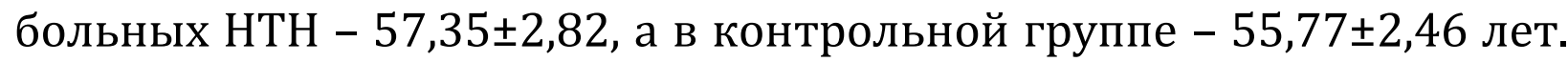
Медиана составляла 59,5 и 54 лет соответственно. 
$62 \mid$ Классическая невралгия тройничного нерва

\section{Сравнение площадей отверстий с двух сторон} при поражении второй ветви ТН

Среднее арифметическое площади круглого отверстия $(N=14)$ с

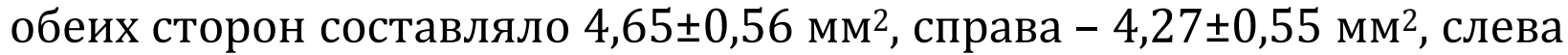

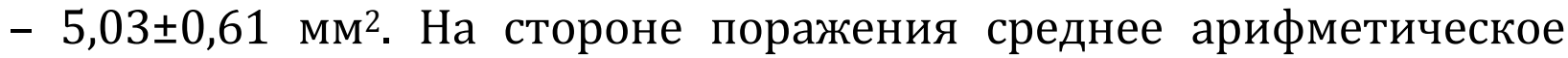

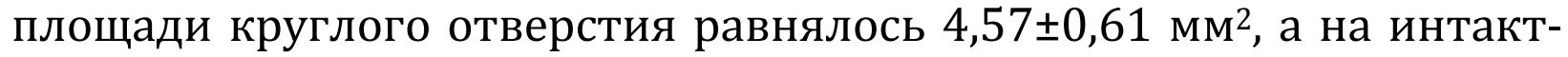
ной стороне - 4,72 $\pm 0,55$ мм² $^{2}$.

При правой стороне поражения среднее арифметическое пло-

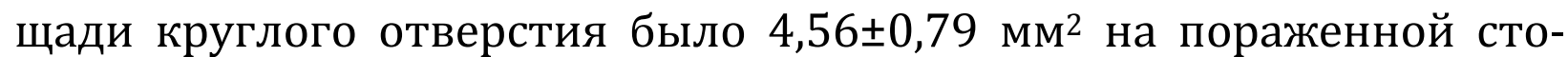
роне против $5,27 \pm 0,79$ мм² $^{2}$ на интактной стороне. При левой стороне поражения среднее арифметическое площади круглого отверстия

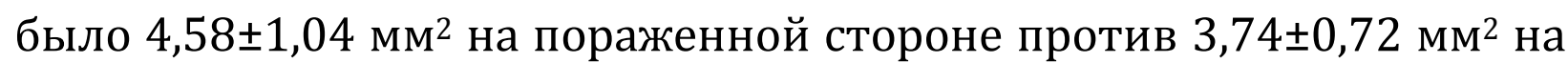
интактной стороне. Двухфакторный дисперсионный анализ не выявил статистически значимых отличий между площадью круглого отверстия на стороне поражения и на противоположной стороне $(F=0,005, p=0,94)$, между обеими сторонами независимо от наличия поражения $(F=0,76, p=0,39)$, а также между комбинацией этих факторов $(F=0,73, p=0,40)$.

Среднее арифметическое площади подглазничного отверстия с обеих сторон составляло 6,14 $\pm 0,32 \mathrm{Mm}^{2}$, справа - 6,22 $\pm 0,44 \mathrm{MM}^{2}$, слева $-5,97 \pm 0,44$ мм²$^{2}$. На стороне поражения среднее арифметиче-

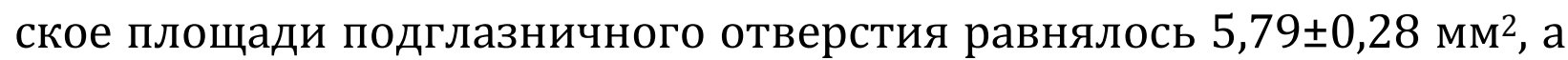

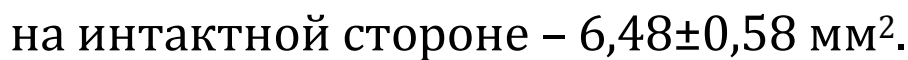

При правой стороне поражения среднее арифметическое пло-

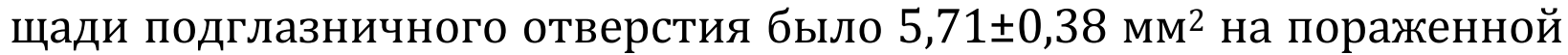
стороне против $6,74 \pm 0,79$ мм² $^{2}$ на интактной стороне. При левой стороне поражения среднее арифметическое площади подглазничного

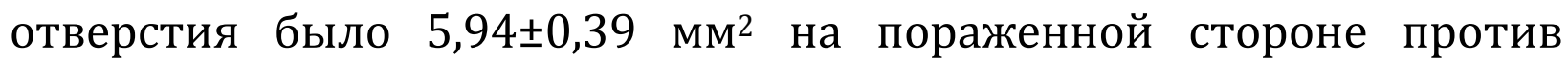
$6,00 \pm 0,85$ мм² $^{2}$ на интактной стороне. Двухфакторный дисперсионный анализ не выявил статистически значимых отличий между площадью подглазничного отверстия на стороне поражения и на противоположной стороне $(F=0,63, p=0,43)$, между обеими сторонами независимо от наличия поражения $(F=0,5, p=0,49)$, а также между 
комбинацией этих факторов $(F=0,14, p=0,71)$. На рис. 36 представлено наблюдение больной с невралгией второй ветви правого тройничного нерва, при этом отверстия и канал шире на пораженной стороне.

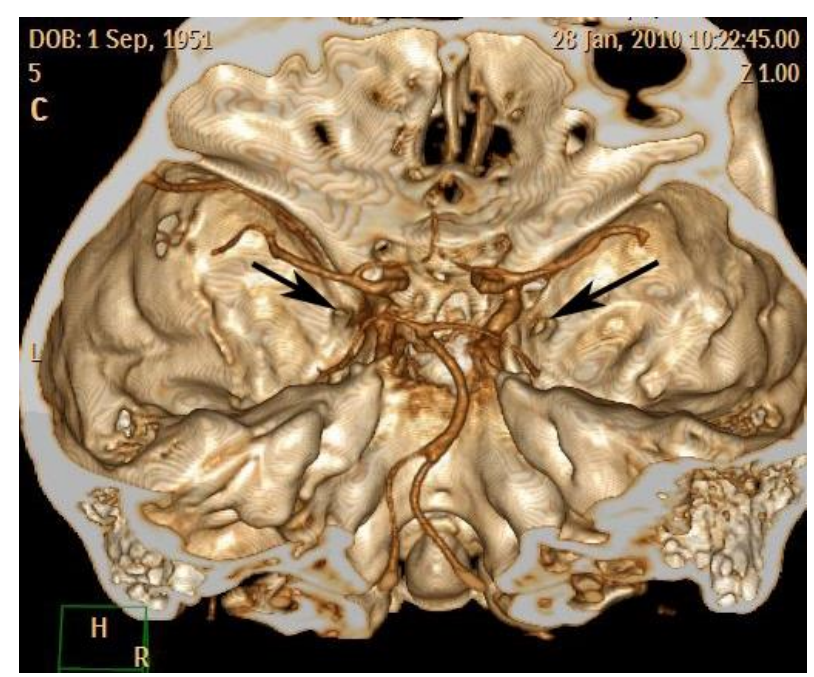

a)

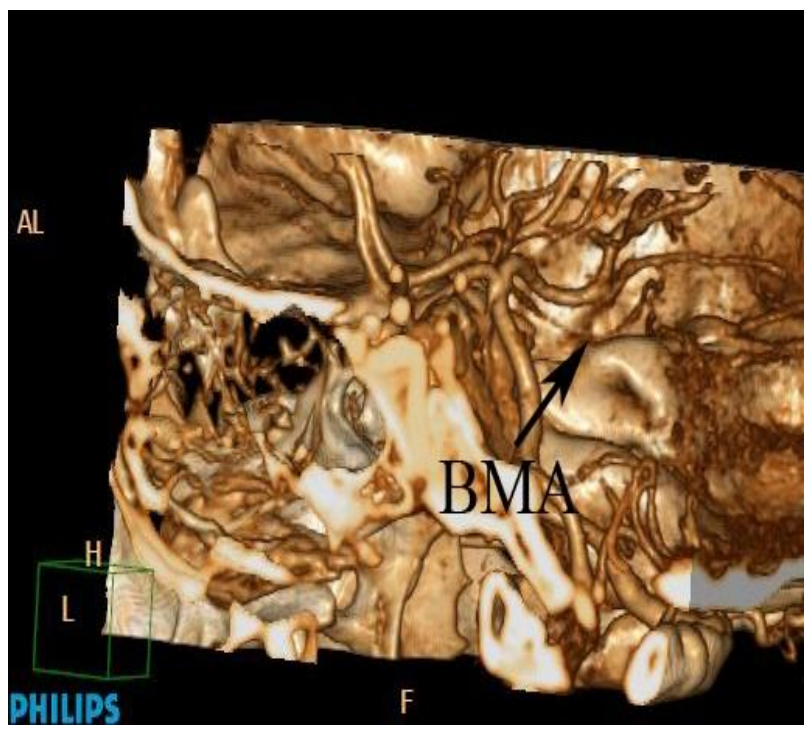

в)

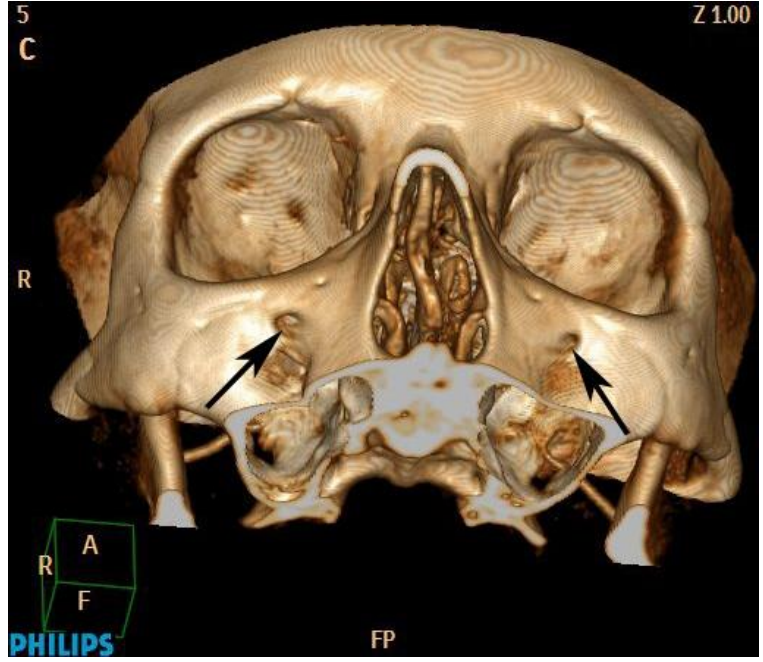

б)

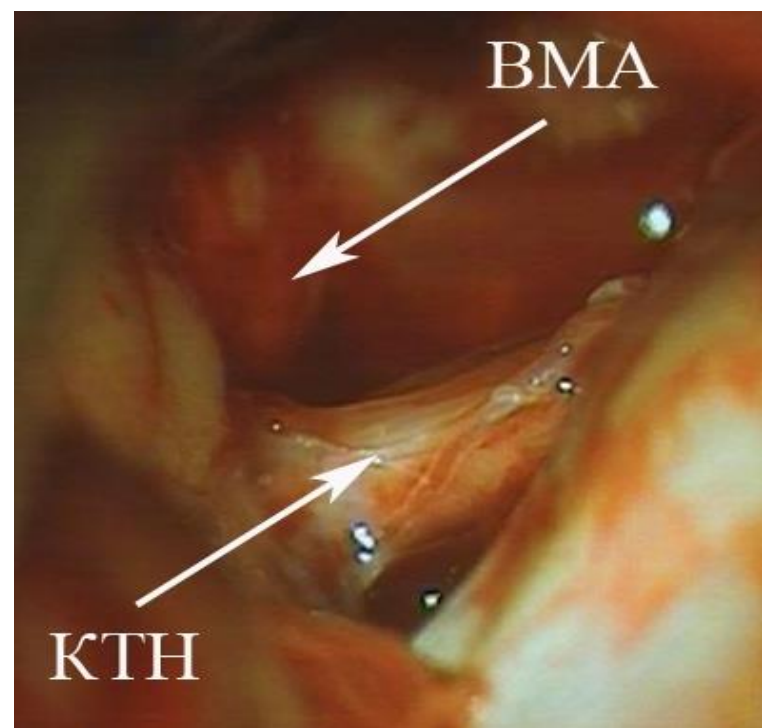

г)

Рис. 36. Больная К. Невралгия правого тройничного нерва с локализацией

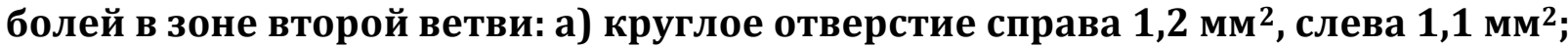

б) подглазничное отверстие справа 5,1, слева 4,2 мм²; в) петля правой верхней мозжечковой артерии лежит на верхнем крае пирамиды, что свидетельствует о вскулоневральном конфликте; г) операция - конфликт межу петлей верхней мозжечковой артерии и корешком тройничного нерва в воротной зоне 
$64 \mid$ Классическая невралгия тройничного нерва

Среднее арифметическое просвета подглазничного канала с

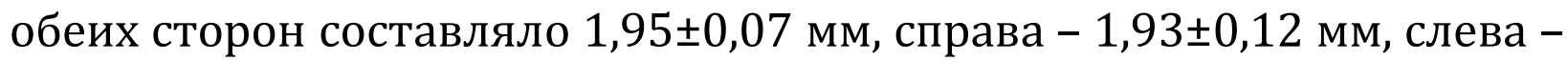
1,96 $\pm 0,08$ мм. На стороне поражения среднее арифметическое просвета подглазничного канала равнялось $2,01 \pm 0,10$ мм, а на интактной

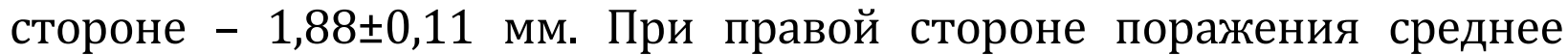

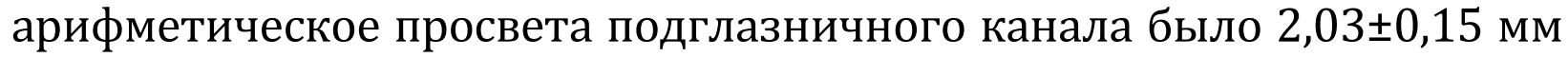
на пораженной стороне против $1,96 \pm 0,12$ мм на интактной стороне. При левой стороне поражения среднее арифметическое просвета

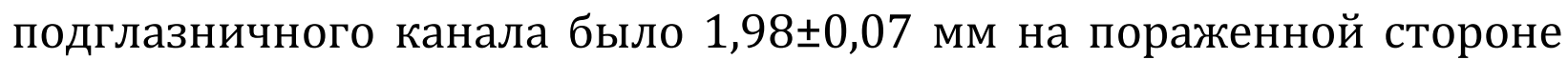

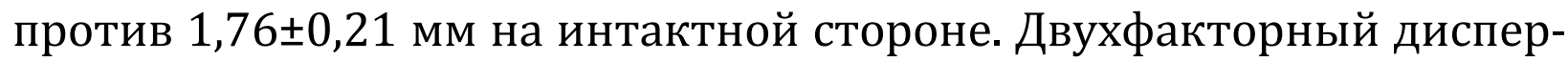
сионный анализ не выявил статистически значимых отличий между просветом подглазничного канала на стороне поражения и на противоположной стороне $(F=0,89, p=0,35)$, между обеими сторонами независимо от наличия поражения $(F=0,20, p=0,66)$, а также между комбинацией этих факторов $(F=0,62, p=0,44)$.

\section{Сравнение площади овального отверстия с двух сторон} при поражении третьей ветви ТН

Среднее арифметическое площади овального отверстия $(N=17)$

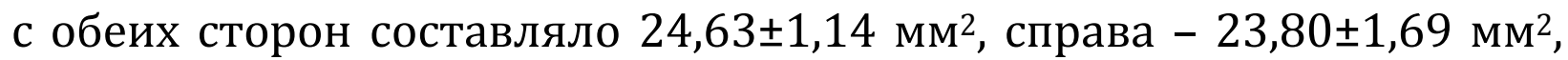

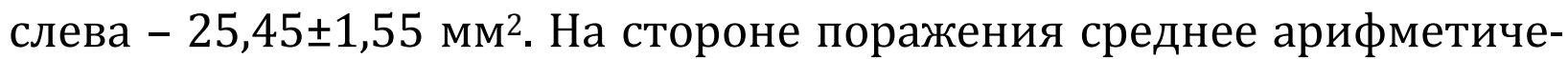
ское площади овального отверстия равнялось $24,41 \pm 1,62 \mathrm{Mm}^{2}$, а на

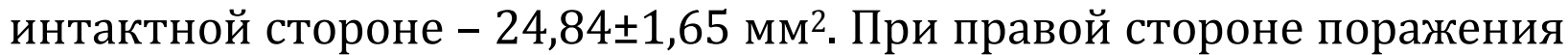
среднее арифметическое площади овального отверстия было

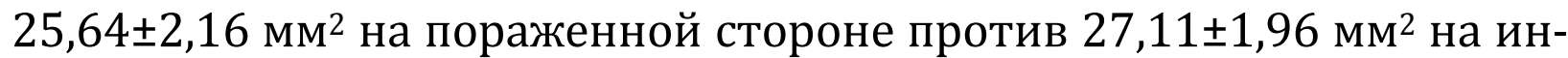
тактной стороне. Рис. 37 иллюстрирует это положение. После устранения конфликта боли исчезли сразу после пробуждения от наркоза, хотя размеры отверстий остались прежними. При левой стороне поражения среднее арифметическое площади овального отверстия

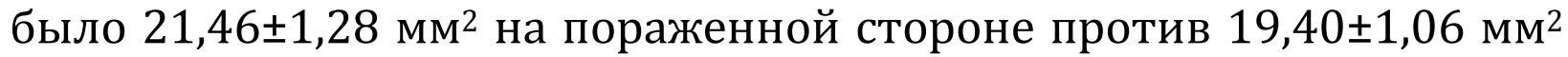
на интактной стороне. Двухфакторный дисперсионный анализ не выявил статистически значимых отличий между площадью овального отверстия на стороне поражения и на противоположной сто- 
роне $(F=0,015, p=0,90)$, между обеими сторонами независимо от наличия поражения $(F=0,55, p=0,46)$, но выявил различия между комбинацией этих факторов $(F=6,33, p=0,017)$.

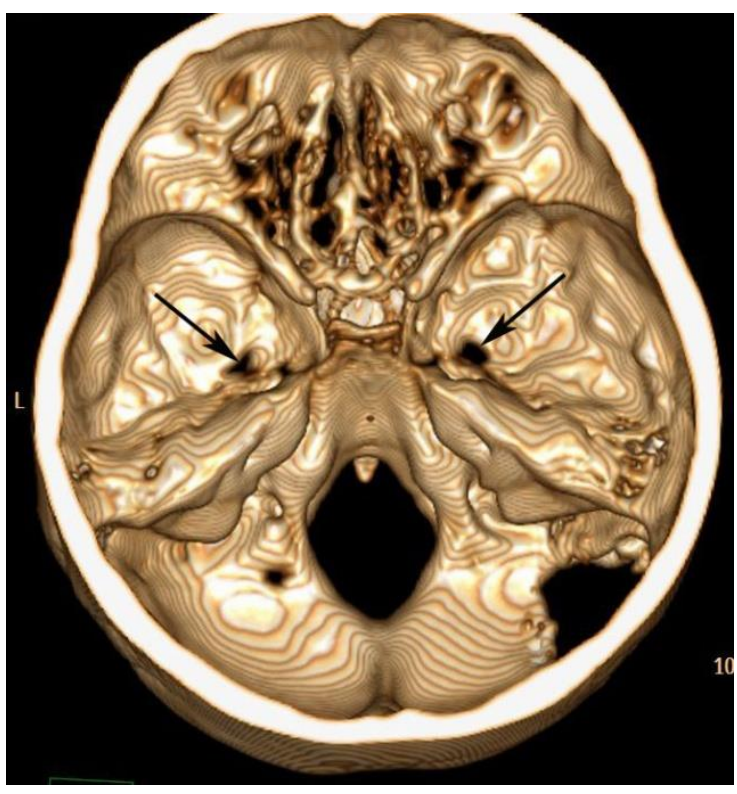

a)

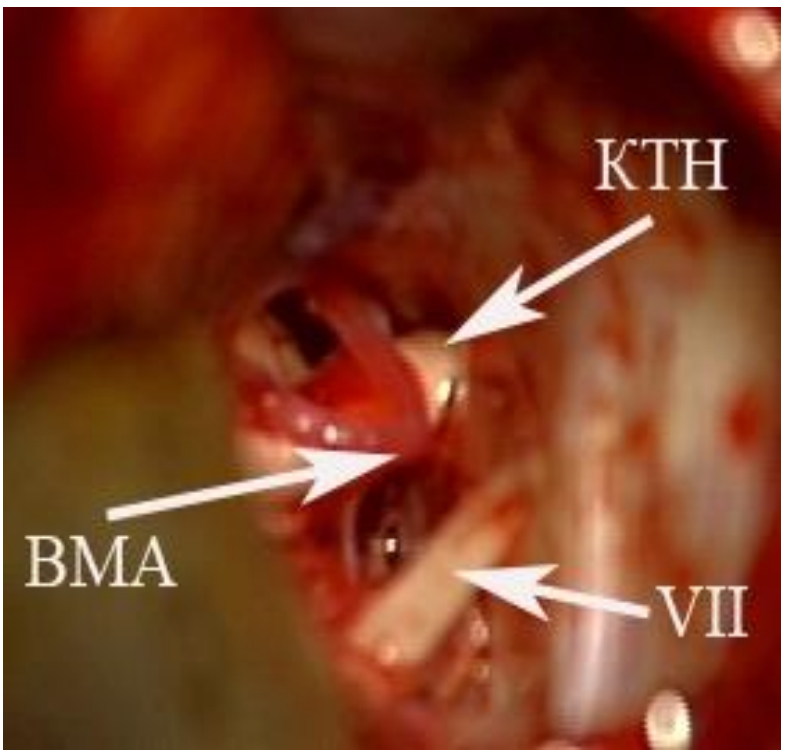

в)

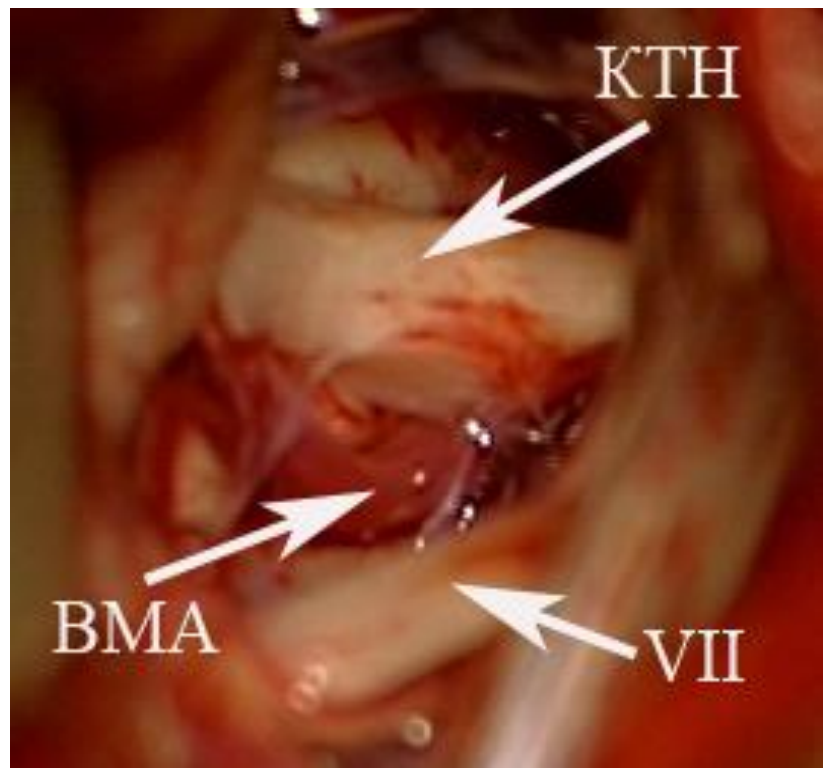

б)

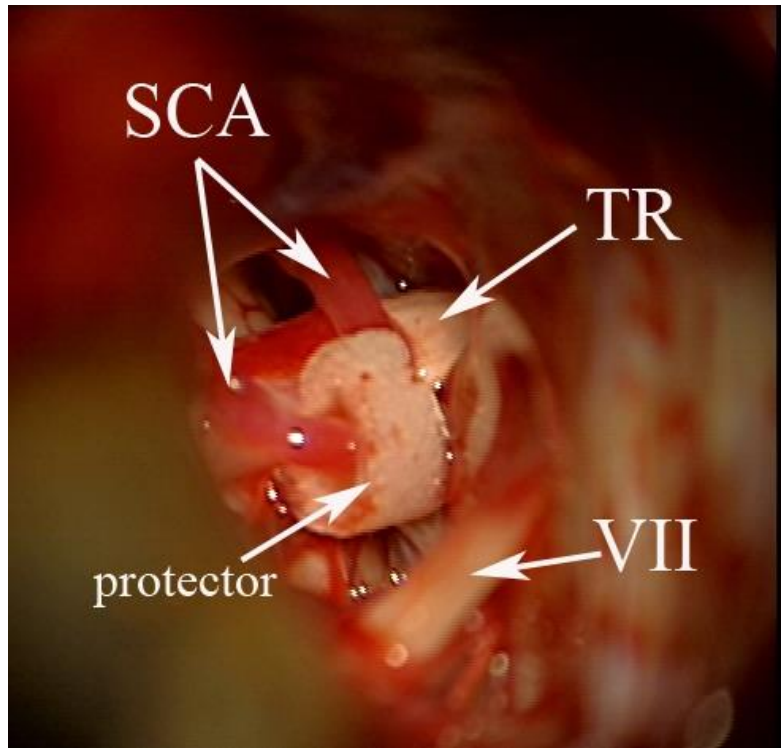

г)

Рис. 37. Больная С. Невралгия правого тройничного нерва с локализацией

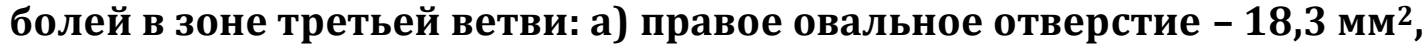
левое - 20,9 мм²; б) васкулоневральный конфликт правой верхней мозжечковой артерии с корешком тройничного нерва в воротной зоне;

в) конфликт устранен перемещением артериальной петли в бесконфликтное состояние в пространство между корешком и наметом мозжечка;

г) в целях профилактики рецидива конфликта, петля ВМА заключена в полипропиленовый пористый микропротектор 
$66 \mid$ Классическая невралгия тройничного нерва

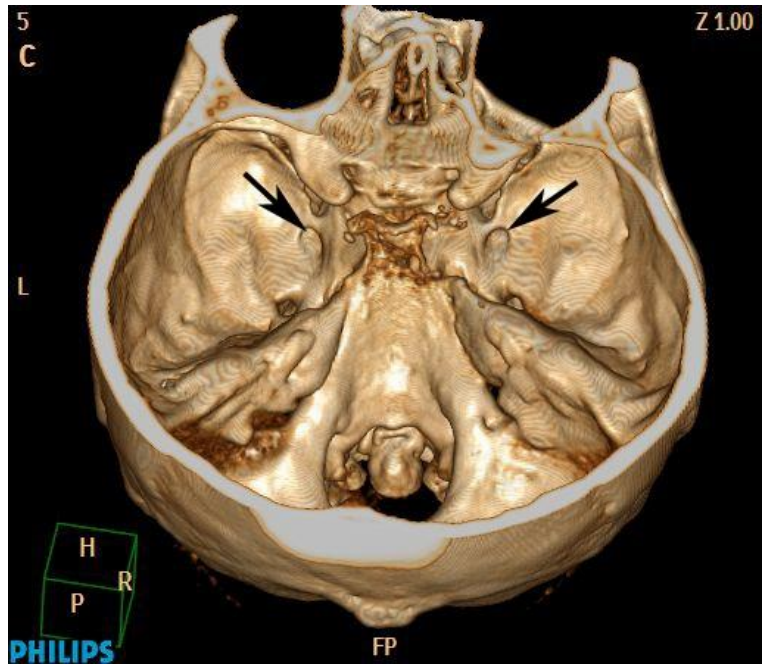

a)

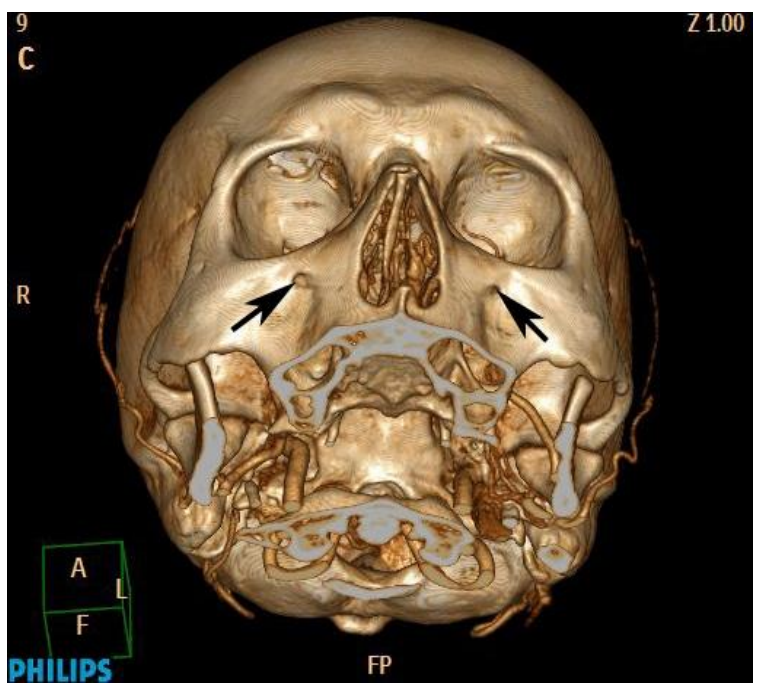

в)

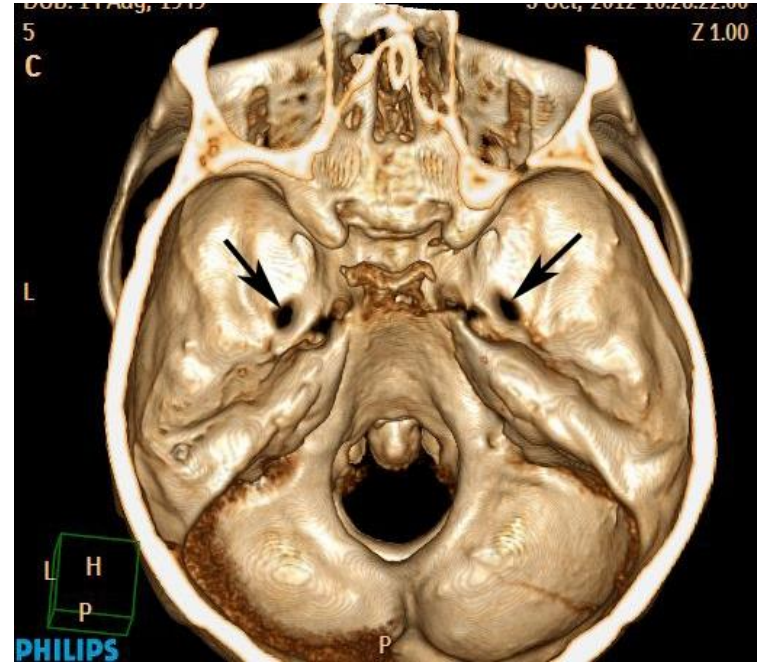

б)

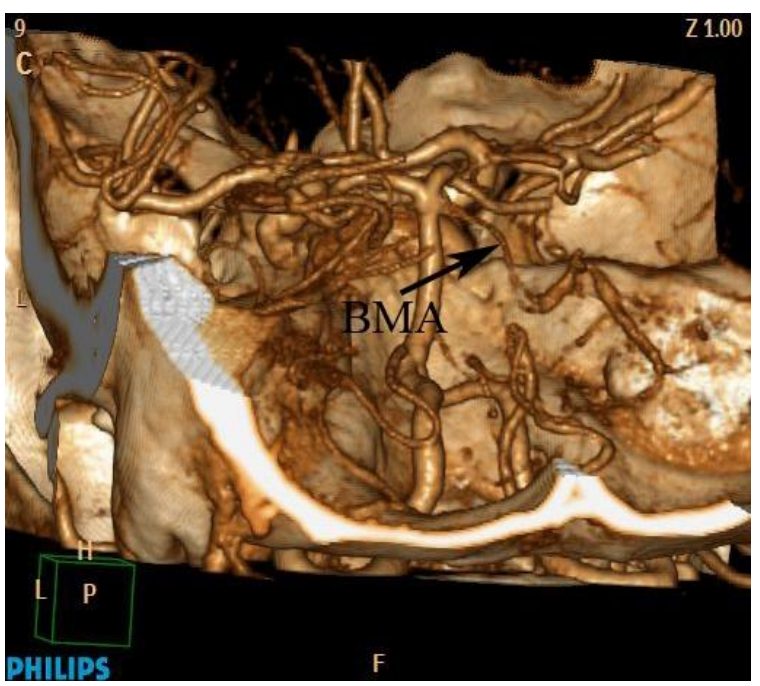

г)

Рис. 38. Больной Б. Невралгия правого тройничного нерва с локализацией болей в зонах второй и третьей ветвей: а) круглое отверстие справа 4,4 мм², $^{2}$

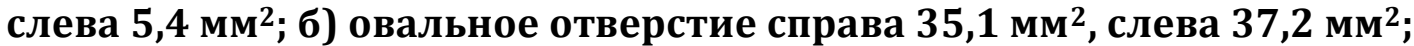

в) подглазничное отверстие справа 6,5 мм², слева 6,1 мм²; г) петля верхней мозжечковой артерии ниже края мекелевой ямки, что свидетельствует о васкулоневральном конфликте

Однако пост-хок тест, используемый для дальнейшего анализа, не показал никаких достоверных отличий. На рис. 38 представлено наблюдение больного с невралгией второй и третьей ветвей правого тройничного нерва. Несмотря на неизменность величин отверстий после устранения васкулоневрального конфликта боли исчезли. Катамнез после МВД от 3 до 5 лет. 


\section{Сравнение с контрольной группой}

Чтобы исключить вероятность того, что у больных НТН сужены черепные отверстия на обеих сторонах, независимо от стороны поражения, было произведено сравнение площадей этих отверстий с контрольной группой.

Площадь круглого отверстия у всей выборки больных с НTH

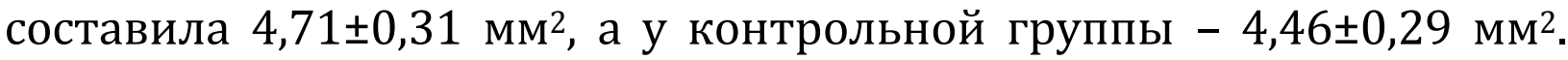
Однофакторный дисперсионный анализ не выявил статистически значимых отличий между двумя группами $(F=0,35, p=0,556)$. Площадь подглазничного отверстия у всей выборки больных с НTH со-

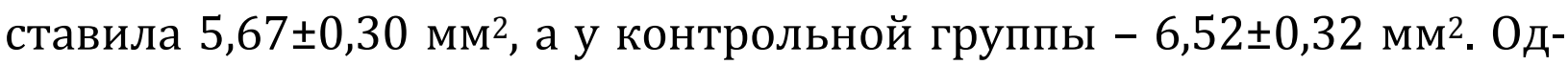
нофакторный дисперсионный анализ не выявил статистически значимых отличий между двумя группами $(F=3,67, p=0,059)$. Диаметр подглазничного канала у всей выборки больных с НТН составил

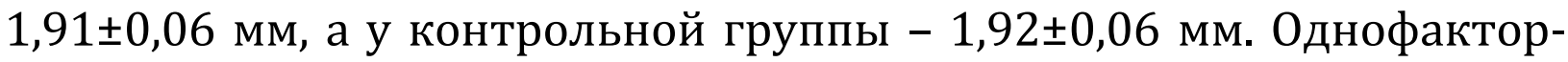
ный дисперсионный анализ не выявил статистически значимых отличий между двумя группами $(F=0,02, p=0,89)$. Площадь овального

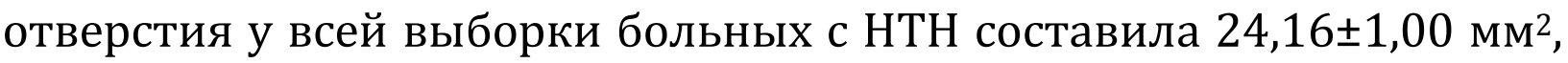
а у контрольной группы - 25,52 1,11 мм². Однофакторный дисперсионный анализ не выявил статистически значимых отличий между двумя группами $(F=0,826, p=0,366)$. На рис. 35 представлены варианты изучаемых отверстий у лиц, не страдавших НТН.

Проведенный сравнительный анализ измерений площадей круглого, овального и подглазничного отверстий и диаметра подглазничного канала у больных классической НТН и у лиц контрольной группы не выявил достоверных отличий между ними. Более того, у ряда больных на стороне НТН площадь отверстия и диаметр канала оказывались больше, чем на пораженной стороне. Обращало на себя внимание то обстоятельство, что у больных с невралгией второй и третьей ветвей круглое отверстие на стороне НТН могло быть несколько меньше, чем на здоровой, в то время как овальное отверстие было значительно шире на больной стороне. Проведенное исследование свидетельствует о том, что величина выходных отверстий не является патогномоничным призна- 
$68 \mid$ Классическая невралгия тройничного нерва

ком для возникновения классической НТН. В то же время, по данным Карлова В.А. (1991) [79] у большей части больных с невралгией второй ветви тройничного нерва сужение подглазничного канала вызвано утолщением его стенок (избыточный остеогенез, ведущий к гиперостозу) в результате местных хронических воспалительных процессов, чаще всего одонтогенных и риногенных. На основании этого делается вывод о том, что НТН имеет туннельное компрессионное происхождение. Этот вывод в полной мере относится к компрессионной нейропатии.

Дискуссии и разноречивые суждения о патогенезе НТН обусловлены, по нашему мнению, тем, что не всегда четко клинически выделяется классическая НТН от других видов прозопалгий. В соответствии с международной классификацией головных болей (2-е издание, 2004) с кодами МКБ - 10 NA BO3 выделяют классическую тригеминальную невралгию ( $\mathrm{G} 50,0)$, когда кроме боли отсутствуют другие признаки поражения тройничного нерва [191], и симптоматическую.

Международное общество головной боли (HIS) классической HТН считает невралгию, обусловленную васкулоневральным конфликтом, без участия каких-либо других дополнительных факторов.

Существенный вклад в понимание этих различий внесли Eller J.L. et al. (2005) [201], предложив свою классификацию НТН, выделив 7 вариантов тригеминальных болей. Классическую НТН они подразделяют на два типа: 1) когда ведущим симптомом являются спонтанные эпизодические боли; 2) когда боли изначально носят постоянный характер. Далее выделены: 3) тригеминальная нейропатическая боль в результате травмы или хирургического вмешательства; 4) тригеминальные деафферентационные боли в результате целенаправленного разрушения периферических ветвей, ганглиолизиса или ризотомии как способа лечения НTH; 5) симптоматическая НТН у больных рассеянным склерозом; 6) постгерпетическая НТН вследствие кожных высыпаний herpes zoster в зонах иннервации ТН; 7) атипичные лицевые боли психогенного характера. Развитие той или иной формы НТН обусловлено уровнем и характером поражения ТН. Анализируя результаты собственных иссле- 
дований [19] Miller J.P. et al. (2009) подчеркивали, что для первого типа НТН характерен васкулоневральный конфликт с артериальным сосудом, в то время как для второго типа НТН более характерен конфликт с веной, либо отсутствие конфликта вообще. Sandell T., Eide P.K. (2010) [365] подразделяют первый тип на два подтипа. При подтипе Іа возникают типичные внезапные приступообразные болевые пароксизмы (в виде «удара молнии» или «разряда электрического тока») длительностью от нескольких секунд до нескольких минут, стреляющего характера, выявляются триггерные точки. Подтип Іб характеризуется наличием типичных тригеминальных приступов на фоне постоянной лицевой боли ноюеег, жгучего и пульсирующего характера. Эти два подтипа (Іа и Іб) соответствуют I типу, описанному Burchiel K.J. (2003) [172] и Eller J.L. et al. (2005) [14] для классической НТН. Второй тип НТН характеризуется наличием постоянной боли ноющего, жгучего и стреляющего характера. Внезапные типичные приступы не вызываются, хотя могут иметь место приступообразные боли. Авторы подчеркивают, что у больных HТН I типа артериальный конфликт встречается в два раза чаще, а венозный, наоборот, в пять раз реже, чем у больных с HTH II типа. При этом отдаленные результаты хуже у больных с НTH II типа и количество рецидивов заболевания значительно выше. С учетом клинических различий между классической НТН первого и второго типов авторы рассматривают парадигму, способствующую выбору более адекватного метода лечения. О более худших результатах после МВД при атипичной НТН (втором типе) сообщают также Sindou M. et al. (2007, 2010) [382]. Laurent B. et al. [286] обращают внимание на трудности диагностики НТН при атипичных формах и/или при длительном течении заболевания. В то же время, несмотря на типичную клинику классической НТН, она может оказаться вторичной, обусловленной другими патологическими процессами (опухолями, аневризмами, кистами, метастазами, аномалиями развития черепа и мозга). Авторы рекомендуют всем больных с клиникой НТН выполнять МРТ с тем, чтобы отличить симптоматическую НТН от классической. Вторым исследованием должна быть СРКТ-ангиография, подтверждающая или исключающая васкуло- 
$70 \mid$ Классическая невралгия тройничного нерва

невральный конфликт. При необнаружении васкулоневрального конфликта, при втором типе НТН может возникнуть необходимость в измерении вышеназванных отверстий в целях уточнения этиологии заболевания и выбора адекватного метода лечения.

В патогенезе туннельного компонента важное значение должен иметь размер и форма черепных отверстий. Эти параметры могут варьироваться в зависимости от индивидуальных особенностей и возраста. Однако до сих пор наблюдается недостаток сообщений о том, что среди больных с классической НТН имеется статистически достоверное аномально высокое число тех, у кого черепные отверстия раздвоены и сужены. В нашей выборке больных с НТН ничего подобного также не наблюдалось. Также имеются указания на то, что диаметр черепных отверстий с возрастом может увеличиваться [426], и это увеличение достигает существенных значений. Например, для круглого отверстия, если сравнивать подростков и взрослых, разница составляет свыше 0,5 мм в диаметре. Однако не было замечено, что НТН чаще возникает у лиц молодого возраста, более того, наблюдается обратная зависимость. Эти данные служат дополнительным доказательством того, что сам размер отверстий играет второстепенную (или даже минимальную) роль в развитии НТН.

Из 220 больных классической НТН при сборе анамнеза 4 человека связывали начало заболевания с воспалением придаточных пазух носа, у 4 начало заболевания совпало с герпетическими высыпаниями на губах, у 9 - с удалением зубов, у 12 - со стрессовой ситуацией и у 32 человек - с переохлаждением. Все эти факторы могут быть одним из пусковых механизмов для начала функционирования васкулоневрального конфликта, т.е. способствовать возникновению или развитию обострения заболевания классической НТН. Воспалительные изменения в КТН и окружающих его оболочках, наряду с другими факторами (подъем артериального давления, снижение эластичности стенки артерии, вследствие атеросклероза) увеличивают с каждой систолой силу удара артериальной петли о корешок. В результате этого разрушается миелиновая оболочка миелинизированных А-волокон, соотношение миелинизированных и немиели- 
низированных волокон переходит критический рубеж и возникает заболевание или его очередное обострение. При этом осевые цилиндры не разрушаются [32, 300, 301], поэтому при классической НТН, в отличие от других видов лицевых болей, нет нарушений чувствительности. Компрессия КТН в этих случаях особая - прерывистая, синхронная систоле и диастоле, в отличие от туннельного механизма постоянной компрессии. Как показали в своих работах Савицкая О.Н. и Дзугаева С.Б. (1971) [111], рассматривающие туннельный механизм компрессии второй ветви в подглазничном канале, уже через 3-6 месяцев от начала заболевания в осевых цилиндрах пораженной ветви тройничного нерва обнаруживаются структурные изменения в виде набухания, фрагментации и вакуолизации. У больных классической НТН в месте васкулоневрального конфликта происходит лишь разрушение миелиновой оболочки при сохраненных осевых цилиндрах $[32,301]$, что объясняет отсутствие какихлибо неврологических симптомов при классической НТН, кроме типичных болевых пароксизмов. Можно предположить, что в сочетании болевых пароксизмов с постоянными болями при втором типе классической НТН и типе Іб кроме васкулоневрального конфликта, определенную роль может играть туннельный компонент в случае сужения отверстия или канала на стороне боли, что встречается редко, как и сами эти варианты классической НТН.

С середины 60-х годов прошлого века (Peter Jannetta, 1967) причиной НТН стали считать васкулоневральный конфликт. Хорошие результаты микроваскулярной декомпрессии, устраняющие конфликт, убедили большинство нейрохирургов в том, что ведущим фактором в этиологии НТН является васкулоневральный конфликт, а операция МВД является наиболее результативной.

Несмотря на большое число сторонников (Балязин В.А. с соавт., 1997, 2001, 2003; Григорян Ю.А., 1997; Jannetta P.J., 1990; Broggi G., Ferroli P, Franzini A., et al., 2000, 2004; Love S., Coakhman H.B., 2001; Shetter A.G., et al., 2005;), рассматривающих васкулневральный конфликт как причину невралгии тройничного нерва (НTH), дискуссия о роли нейроваскулярного конфликта в патогенезе заболевания про- 
$72 \mid$ Классическая невралгия тройничного нерва

должается по настоящее время (Hamlin P., 1997; Adams S.D.T., 1989; Truini A., et. al., 2005; Kress B., et al., 2006; Leclercq D., et al., 2013; Sabalys G.,' 2013; Ramesh V.G., 2014 и др.). Подвергая сомнению нейроваскулярный конфликт как патогенетическую основу НTH Adams S.D.T. (1989) приводит примеры контакта зрительного нерва и тракта с глазничной, внутренней сонной и передней мозговой артериями, и при этом нет нарушения функции зрения. Глазодвигательный нерв проходит между задней мозговой и верхней мозжечковой артериями и никакого выпадения функции его не наблюдаетcя. Benes L., et al. (2005) полагают, что выявление контакта сосуда c корешком тройничного нерва (КТН) в воротной зоне - это еще не показатель обязательного появления тригеминальной невралгии. Kress B., et al. (2006) у большинства добровольцев, не страдавших НTH, обнаружили контакт между КТН и смежными сосудами как проявление нормы, а не как доказательство васкулоневрального конфликта. Другим контраргументом, по мнению Adams S.D.T. (1989), является отсутствие четкого объяснения, почему у подавляющего большинства больных НТН триггерные зоны и болевые пароксизмы локализуются в области иннервации второй и третьей ветвей как в отдельности, так и вместе. Расположение триггерных зон перорально Fromm G.H. и Sessle B.T. (1991) объясняют большим представительством пероральной зоны в ядре спинального тракта ТН, что превращает эту область в излюбленный источник пароксизмальной активности. Truini A., et al. (2005) объясняют эту закономерность большим числом афферентов, иннервирующих эту часть лица. Другие авторы объясняют преимущественную локализацию болевых пароксизмов в зоне иннервации второй и третьей ветвей, проходящих через круглое и овальное отверстия склерозированием их краев и сужением просвета. Одной из причин противоречий, с нашей точки зрения, является отсутствие единого понимания топографоанатомических отличий «контакта» от «конфликта» между КТН и артериями мозжечка, а также недооценка анатомических особенностей КТН и роли нейроваскулярного конфликта, определяющих особенности клинических проявлений НТН. 


\section{1. АНАТОМИЧЕСКИЕ И ФИЗИЧЕСКИЕ ЗАКОНОМЕРНОСТИ ВАСКУЛОНЕВРАЛЬНОГО КОНФЛИКТА}

Варианты взаиморасположения КТН и артерий мозжечка подробно описаны в предыдущей главе (рис. 13-21, глава 2). Следует обратить внимание, что ни в одном наблюдении плоскость вершины артериальной петли не пересекала плоскости корешка в вертикальном направлении, несмотря на выявленный контакт корешка с артерией в 32\%. Следовательно, для формирования васкулоневрального конфликта и развития заболевания необходим ряд условий. Долихоэктазия артерий мозжечка с расположением плоскости сосудистых петель под углом к плоскости КТН. Если при развитии возрастной долихоэктазии верхней мозжечковой артерии сосуд располагается в пространстве между корешком тройничного нерва и наметом мозжечка, то васкулоневральный конфликт развиться не может, т.е. несмотря на долихоэктазию артерии невралгия у человека не разовьется (рис. 18, глава 2). При формировании васкулоневрального конфликта вершина петли ВМА должна располагаться ниже верхнего края КТН не менее половины его диаметра (рис. 39, а), а чаще значительно ниже (рис. 39, б).

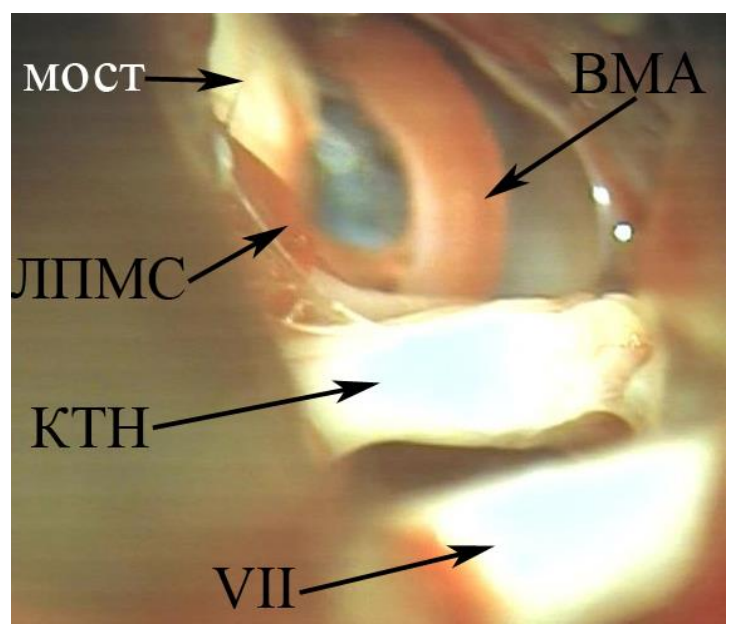

a)

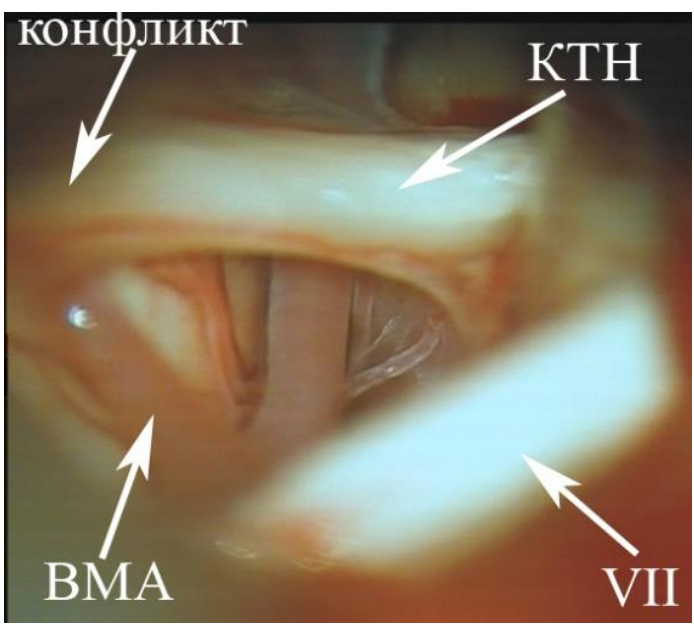

б)

Рис. 39. Конфликт с одной ветвью ВМА: а) Больная Р. 61 г. Ист. бол. № 5947. НТН справа. Вершина петли ВМА пересекает половину диаметра КТН снизу вверх в воротной зоне, основное давление оказывая на боковую поверхность моста; б) Больная С. 71 г. Ист. бол. № 5315. НТН справа. Вершина петли ВМА располагается значительно ниже КТН, а ее понтомезенцефальный сегмент - в воротной зоне 
$74 \mid$ Классическая невралгия тройничного нерва

В то время как при конфликте с ПНМА вершина ее петли располагалась выше нижнего края КТН не менее половины его диаметра (рис. 40).

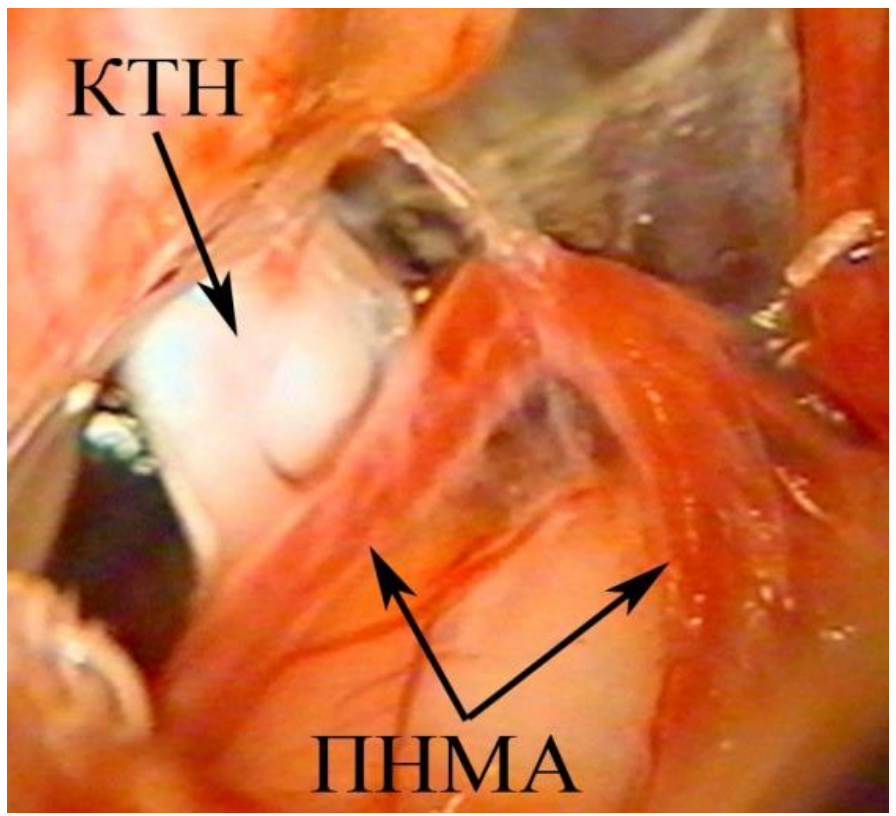

Рис. 40. Больная П. Ист. бол. № 7657. НТН слева с локализацией болей в зонах второй и третьей ветвей. Васкулоневральный конфликт между КТН и петлей флокуло-педункулярного сегмента ПНМА, плоскость которой расположена к КТН под углом, близким к прямому

Контакт с ВКВ и ее притоками обычно наблюдался в области задней или верхней поверхности КТН (рис. 41).

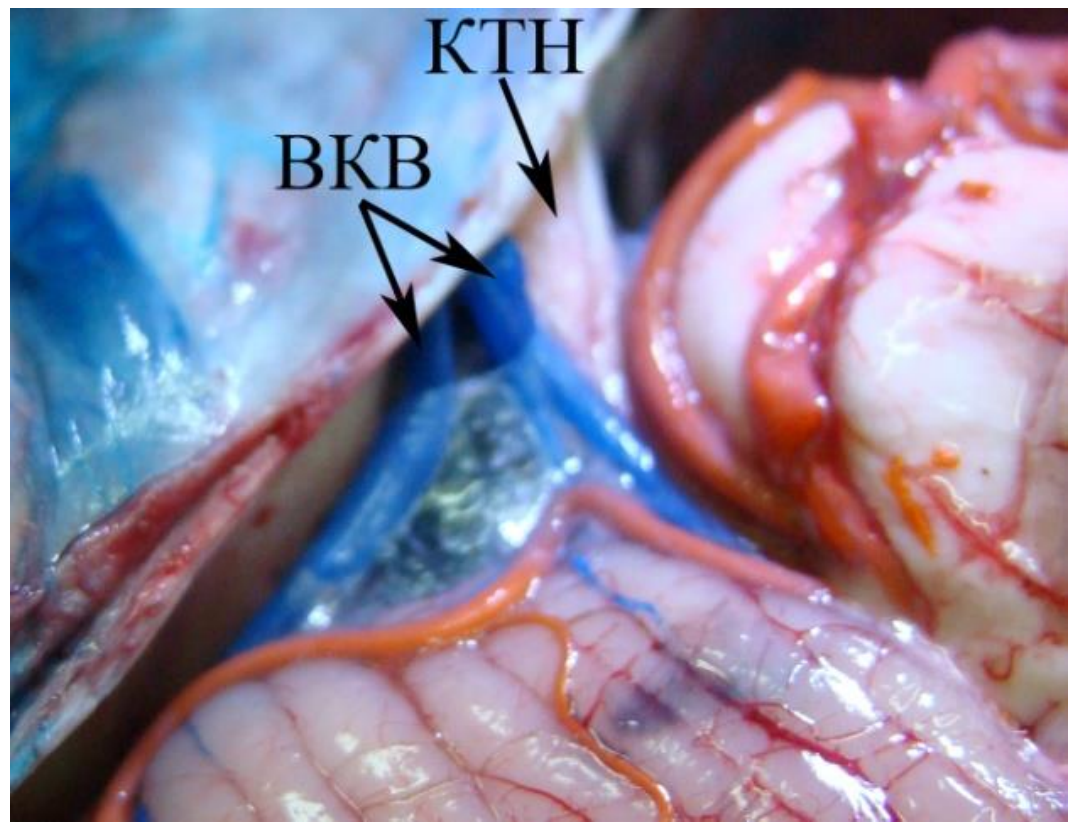

Рис. 41. Контакт верхней каменистой вены с корешком тройничного нерва 
Долихоэктазия ВМА как врожденная аномалия, при расположении ее в пространстве между КТН и наметом мозжечка без пересечения плоскостей расположения ВМА и КТН, не формирует васкулоневрального конфликта, а свидетельствует лишь о контакте сосуда с КТН (рис. 18, глава 2). Группой риска для развития васкулоневрального конфликта являются лица, преморбидно имеющие контакт артерии с корешком, при этом достаточно незначительной возрастной долихоэктазии для смещения вершины петли артерии ниже верхнего края корешка чтобы развился васкулоневральный конфликт.

Другим фактором, приводящим к формированию сосудистонервного конфликта, является укорочение арахноидальных, соединительно-тканных струн, растянутых между артериальными ветвями и КТН. У больных с отсутствием предшествующего заболеванию воспалительного фактора паутинная оболочка боковой цистерны моста была тонкая, полупрозрачная, легко разрываемая инструментом. Арахноидальные струны между артериями и КТН тонкие (рис. 42).

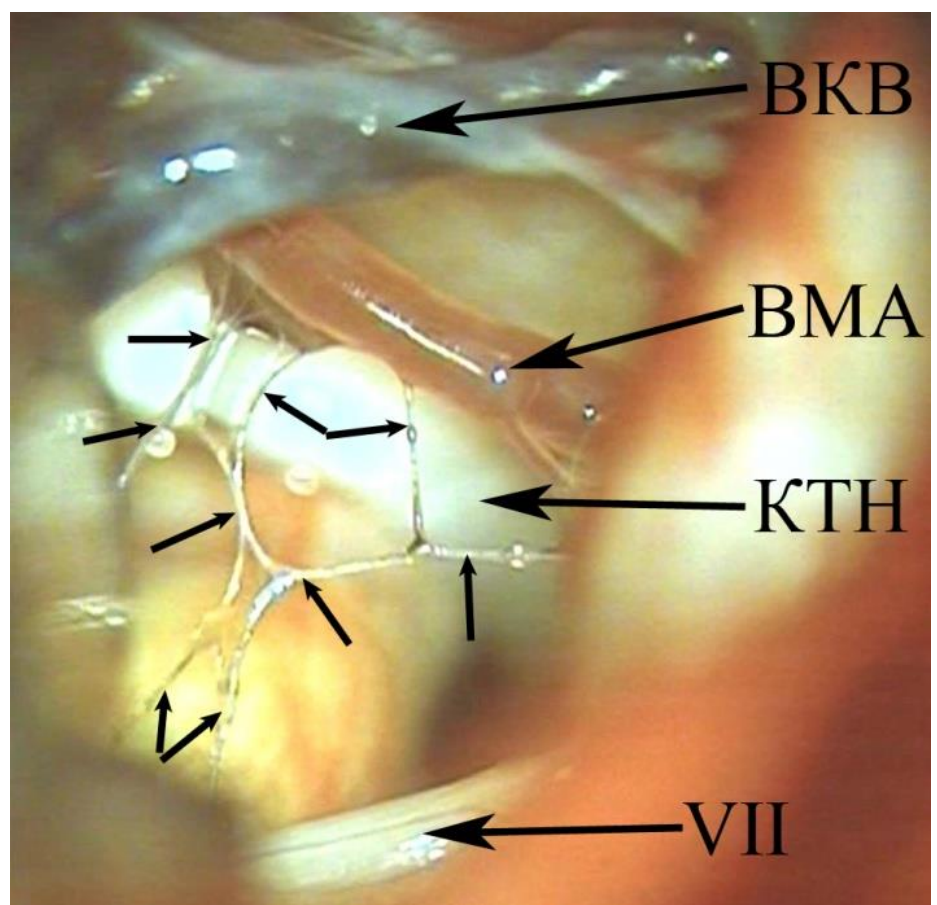

Рис. 42. Больная М. Ист. бол. № 9089. Невралгия левого троничного нерва. Предшестующих заболеванию факторов не отмечала. Нежные арахноидальные струны указаны малыми стрелками 
$76 \mid$ Классическая невралгия тройничного нерва

С одной стороны, укорочение арахноидальных струн обусловлено обезвоживанием организма вследствие естественного процесса старения, с другой - перенесенными воспалительными процессами (синуиты, хронические отиты, кариозные зубы, хронические тонзилиты и другие воспалительные заболевания), сопровождающимися реактивными изменениями в оболочках боковой цистерны моста, сближающими и замуровывающими в единый конгломерат КТН, чаще верхнюю мозжечковую артерию (BMA) и нередко ВКВ (рис. 43).

Не случайно ученные второй половины прошлого века этиологическим фактором НТН считали спайки в области мостомозжечкового угла, образованию которых способствовали перенесенные ранее синуиты, отиты, кариозные зубы, переохлаждения [34, 36, 54, 72$]$.

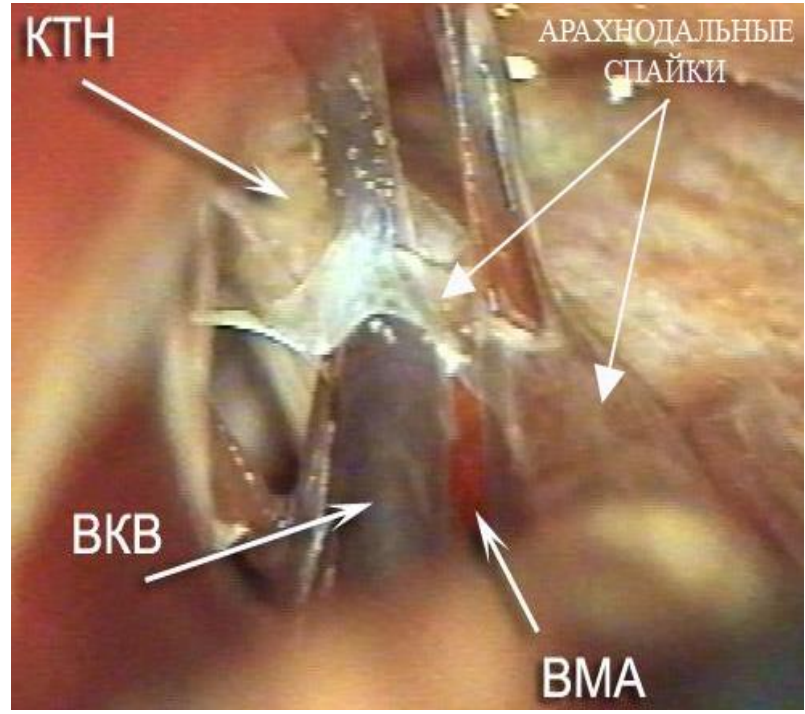

a)

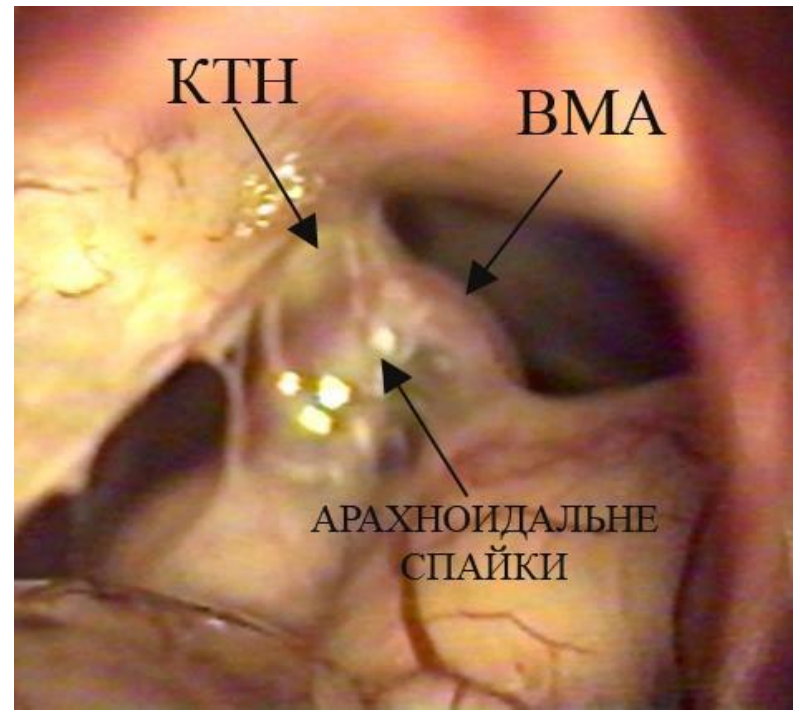

б)

Рис. 43. Выраженный арахноидит боковой цистерны моста:

а) Больной С. Ист. бол. № 7036. Невралгия левого ТН. В анамнезе частые переохлаждения. Утолщенная арахноидальная оболочка указана стрелками;

б) Больной М. Ист. бол № 208. Невралгия левого ТН. В анамнезе частые синуиты. НТН и ВМА запаяны резко утолщенной паутинной оболочкой в единый конгломерат

В соответствии с законами гидродинамики $[39,103]$, при движении жидкости по сосуду (рис. 44, где 1 обозначена петля ВМА) в месте его изгиба возникает сила $F$, которая стремится разогнуть 
(выпрямить) этот сосуд. Согласно формуле Эйлера сила $F$ определяется уравнением:

$$
F=Q \cdot V,
$$

где $Q$ - расход жидкости, проходящей через сосуд, $V$ - скорость жидкости в рассматриваемом сечении сосуда при давлении $P$.

Сила $F$, разгибающая сосуд, вызывает его перемещение во внешние стороны. Если на пути этого смещения встречается препятствие (2) (например, КТН), то сила $F$ будет оказывать механическое воздействие на это препятствие в соответствии с уравнением Мещерского:

$$
F=Q \cdot \frac{d v}{d t}-\varphi
$$

где $\frac{d v}{d t}-$ производное скорости движения жидкости в сосуде ко времени, $t$ - время воздействия, $\varphi$ - сила противодействия препятствия.

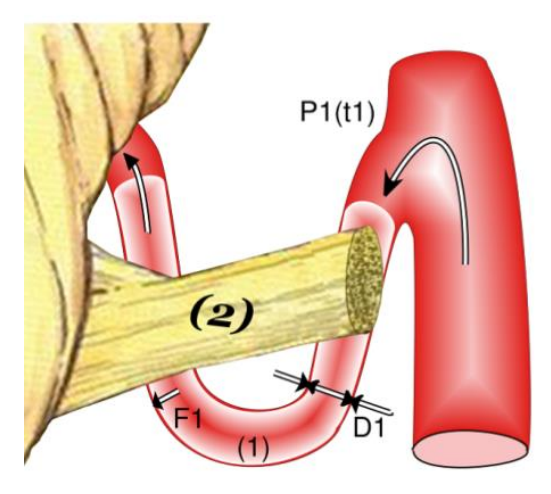

A

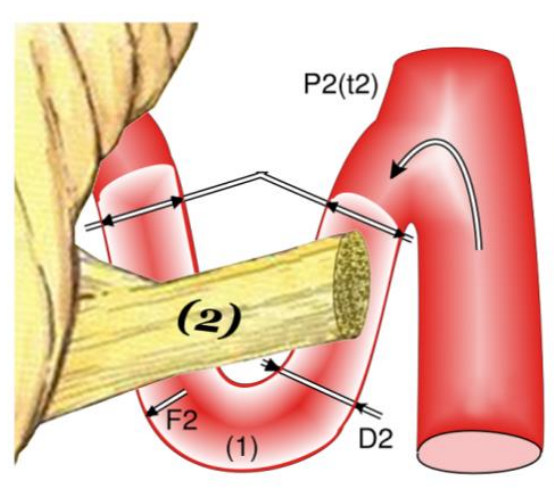

Б

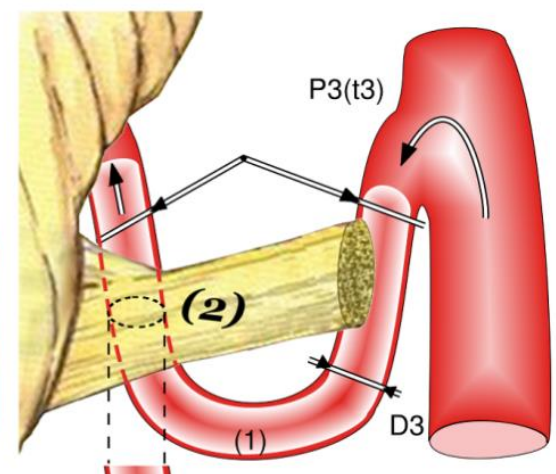

B

Рис. 44. Физическая составляющая васкулоневрального конфликта: 1 - петля BMA; 2 - KTH; D1 - диаметр сосуда в момент диастолы; D2 - диаметр эластичного сосуда в момент систолы увеличивается, за счет чего уменьшается сила, разгибающая петлю и травмирующая КTH, D3 -диаметр склерозированного сосуда практически не изменяется в момент систолы;

F1 - минимальная сила, создаваемая в сосуде в момент диастолы;

$F 2$ - сила, разгибающая сосуд, минимальна, поскольку расходуется

на увеличение диаметра сосуда за счет его эластичности; $\Delta F$ - сила, расходуемая на разгибание петли и механический удар дистального ее плеча

о КТН; $\varphi$ - сила противодействия препятствия (КТН). А - ВМА в момент диастолы, Б - ВМА в момент систолы в молодом возрасте, В - ВМА в момент систолы у пожилого человека 
$78 \mid$ Классическая невралгия тройничного нерва

Рис. 44 (а) показывает взаимоотношение КТН и ВМА в момент диастолы. Механическое воздействие дистального плеча артериальной петли на КТН минимальное, либо отсутствует.

Если сосуд обладает высокой эластичностью (в молодом и среднем возрасте), то возникающая при изменении давления жидкости в сосуде(пульсации) $\left(P_{\text {сист }}-P_{\text {диаст }}=\Delta P\right.$ ) сила $F$ компенсируется эластическими свойствами стенки сосуда. Сосуд за счет своей эластичности расширяется, давление внутри сосуда уменьшается, сила $F$ уменьшается и оказывается недостаточной для выпрямления apтериальной петли (рис. 44,6 ). В связи с этим механическое воздействие артериальной петли на корешок недостаточное, чтобы вызвать в нем морфологические изменения, и у субъекта не возникает клинических проявлений НТН.

Как известно, в старшем возрасте (после 50 лет) уменьшается эластичность сосудов и увеличивается их извитость [33]. Для подтверждения этого положения нами проведено изучение строения стенки ВМА в возрастном аспекте. Образцы препаратов извлекались у лиц в возрасте от 20 до 85 лет, умерших не от мозговой патологии. Отсекался участок ВМА в месте перехода переднего понтомезенцефального сегмента в латеральный. Участки удаленных артерий, зафиксированных в 10\% нейтральном формалине, длиной 0,5 см заливались в парафин по стандартной методике. Парафиновые срезы толщиной до 5 мкм окрашивались гематоксилином и эозином, пикрофуксином по Ван Гизон.

При гистологическом изучении стенок артерий у лиц молодого возраста (38 и 44 лет) было выявлено, что интима сосудов не утолщена (рис. 45), поверхность эндотелия образует многочисленные выпячивания. Подэндотелиальный слой тонкий, представлен отдельными мышечными клетками. На границе со средней оболочкой расположена внутренняя эластическая мембрана. Средняя оболочка артерий состоит из гладкой мышечной ткани, волокна которой идут в спиральном направлении.

Между мышечными волокнами залегают эластические волокна. На границе между средней и наружной оболочками находится 
наружная эластическая мембрана, состоящая из комплекса эластических волокон и пластин. Наружная оболочка артерии в основе содержит волокнистую соединительную ткань со множеством тонких эластических волокон в форме нежной сети, вытянутой в продольном направлении, а также единичные кровеносные сосуды, питающие стенку.

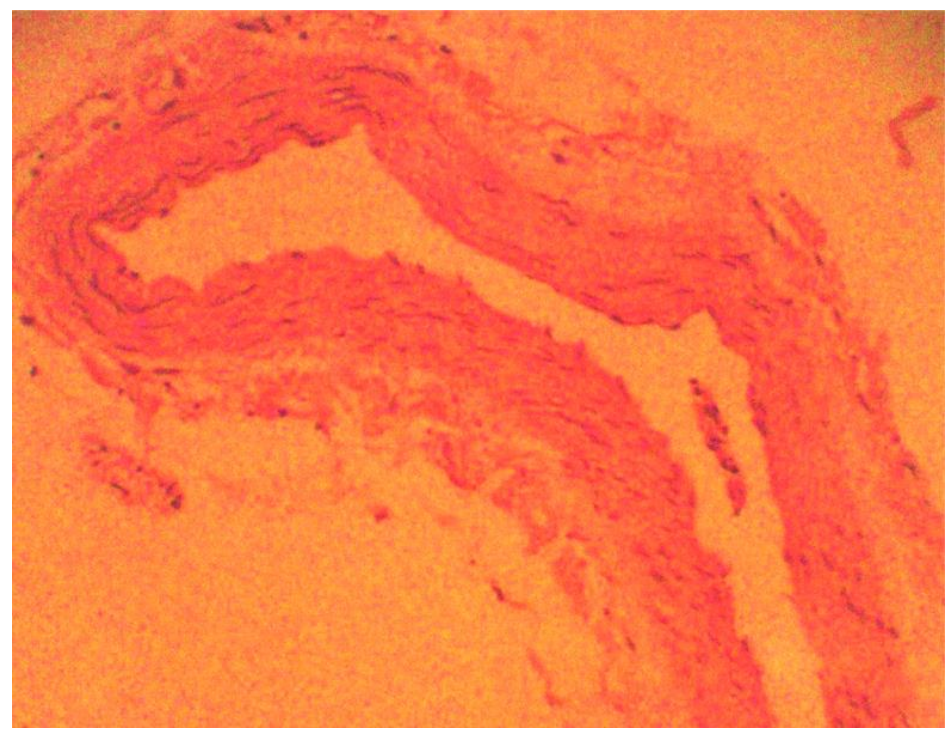

Рис. 45. Возраст исследуемого - 38 лет. Стенка артерии без признаков атеросклеротических изменений. Окр. гематоксилином и эозином, ув. х100

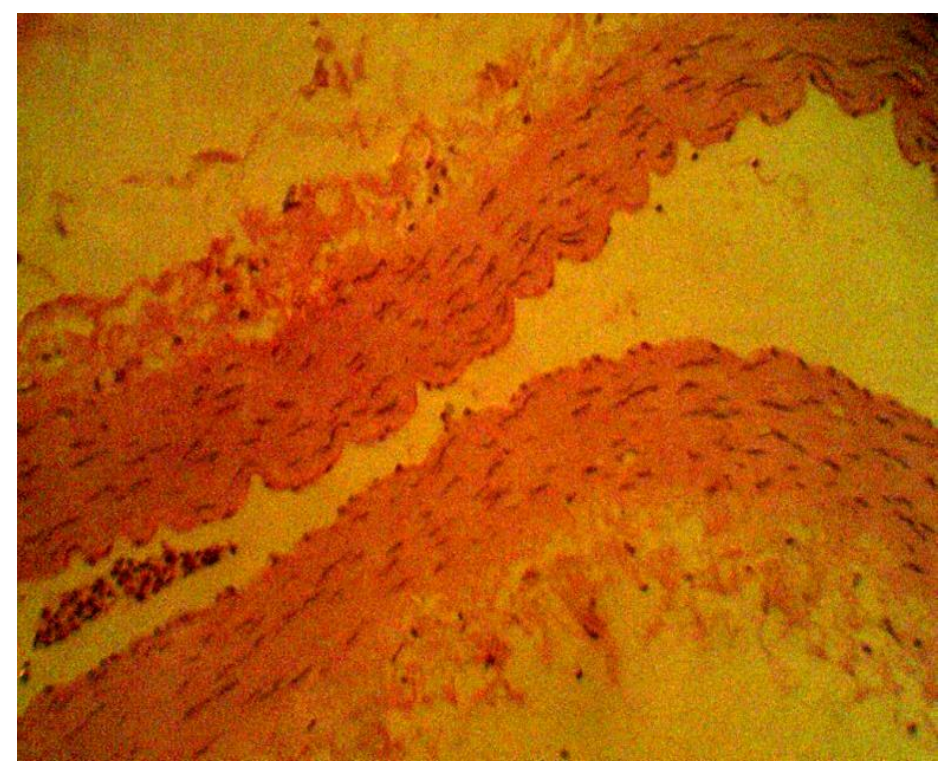

Рис. 46. Возраст исследуемого - 50 лет. Стенка артерии с признаками начальных атеросклеротических изменений. Окр. пикрофуксином по Ван Гизон, ув. х100 
$80 \mid$ Классическая невралгия тройничного нерва

Таким образом, у пациентов данной возрастной группы не наблюдалось признаков атеросклеротических изменений стенок артериальных сосудов.

У исследуемого 50 лет было выявлено диффузное неравномерное утолщение интимы за счет очагового липоматоза и склероза (рис. 46)

Эндотелий сохранен. Просвет артерии имеет неровные очертания и сужен незначительно. Внутренняя эластическая мембрана утолщена, имеет вид извилистой линии. Отмечается очаговая гипертрофия гладкомышечных клеток.

Снаружи сосуд окружен рыхлой волокнистой соединительной тканью с умеренным количеством сосудов.

Обнаруженные изменения свидетельствуют о начальной стадии атеросклеротического поражения стенки артерии.

У исследуемого 65 лет были выявлены признаки резко выраженного прогрессирующего атеросклероза.

В деформированной внутренней оболочке артерии определялись многочисленные разные по давности атероматозные бляшки, незначительно суживающие просвет (рис. 47).

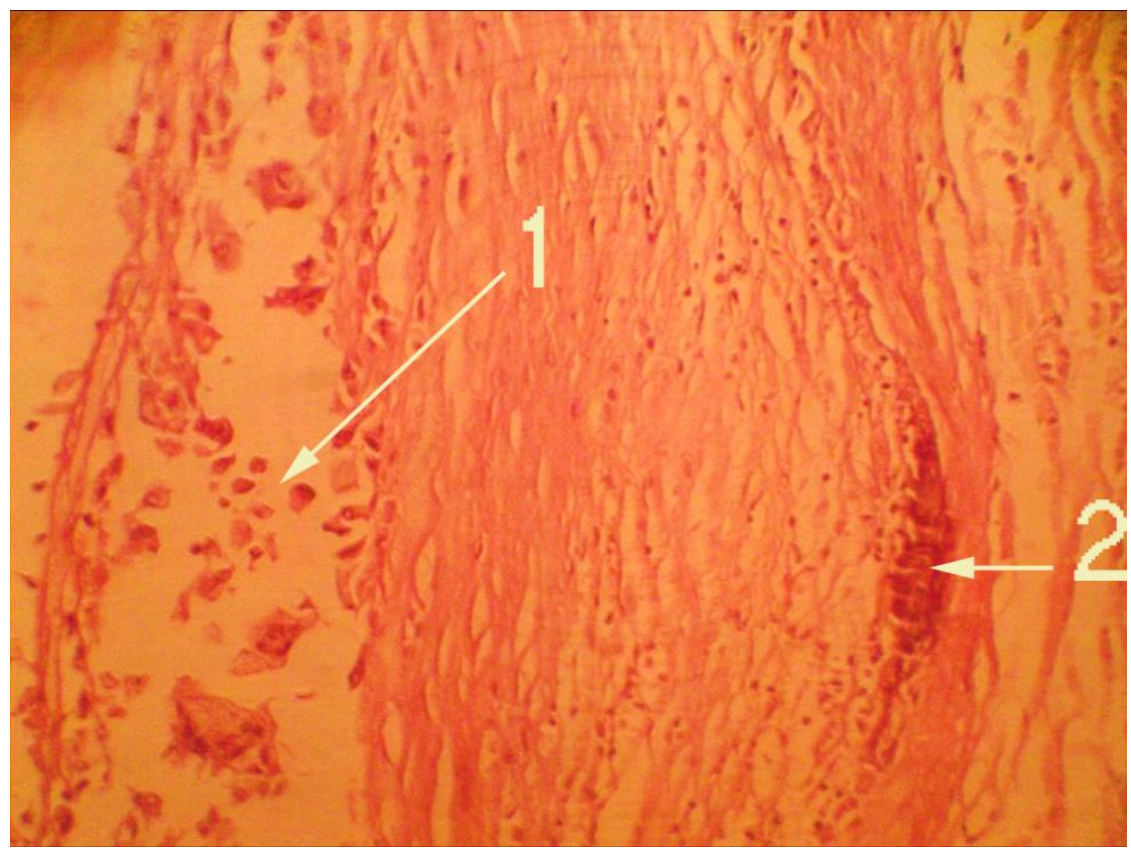

Рис. 47. Возраст исследуемого - 65 лет. Стенка артерии в области атероматозных бляшек (1 и 2) различной степени давности. Окр. гематоксилином и эозином, ув. х100 
Более старые бляшки, тонкие и длинные, содержали небольшое количество липидов, соединительнотканная часть их местами отечна. Более свежие бляшки толще, содержали много липидов и имели обильный клеточный компонент. Клеточный компонент, расположенный в соединительнотканной покрышке, включал в себя гладкомышечные клетки, макрофаги и одиночные лейкоциты, а в зоне под покрышкой и по бокам от нее преобладала смесь из макрофагов, гладкомышечных клеток и лимфоцитов (рис. 48).

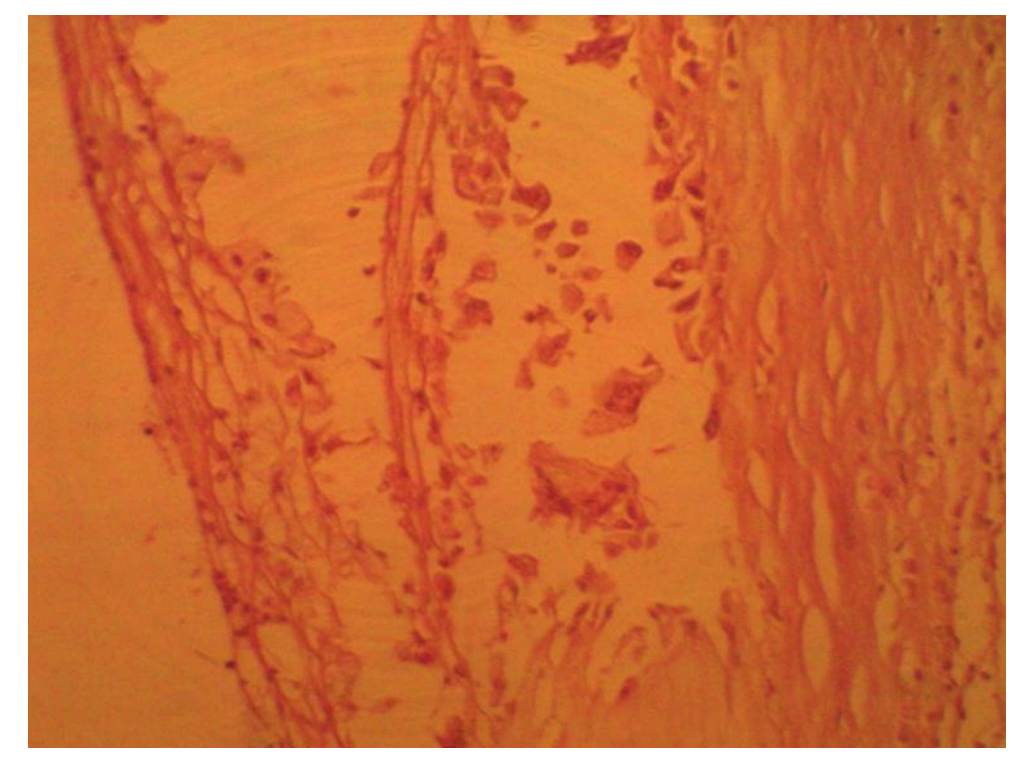

Рис. 48. Возраст Исследуемого - 65 лет. Стенка артерии в области формирующейся атероматозной бляшки. Клеточный компонент. Окр. гематоксилином и эозином, ув. $\mathbf{x} 400$

Средняя оболочка неравномерно истончена за счет атрофии мышечных волокон, сохраняющихся лишь на границе с наружной оболочкой. Во внутренних слоях средней оболочки преобладает соединительная ткань. Наружная эластическая мембрана утолщена, местами прерывается. Наружная оболочка содержит умеренное количество эластических волокон и кровеносных сосудов, наполненных кровью.

На рис. 49 видна крупная старая фиброзная бляшка, прерывающая внутреннюю эластическую мембрану и почти достигающая наружной оболочки, отделяясь от нее лишь двумя-тремя рядами мышечных волокон. 
$82 \mid$ Классическая невралгия тройничного нерва

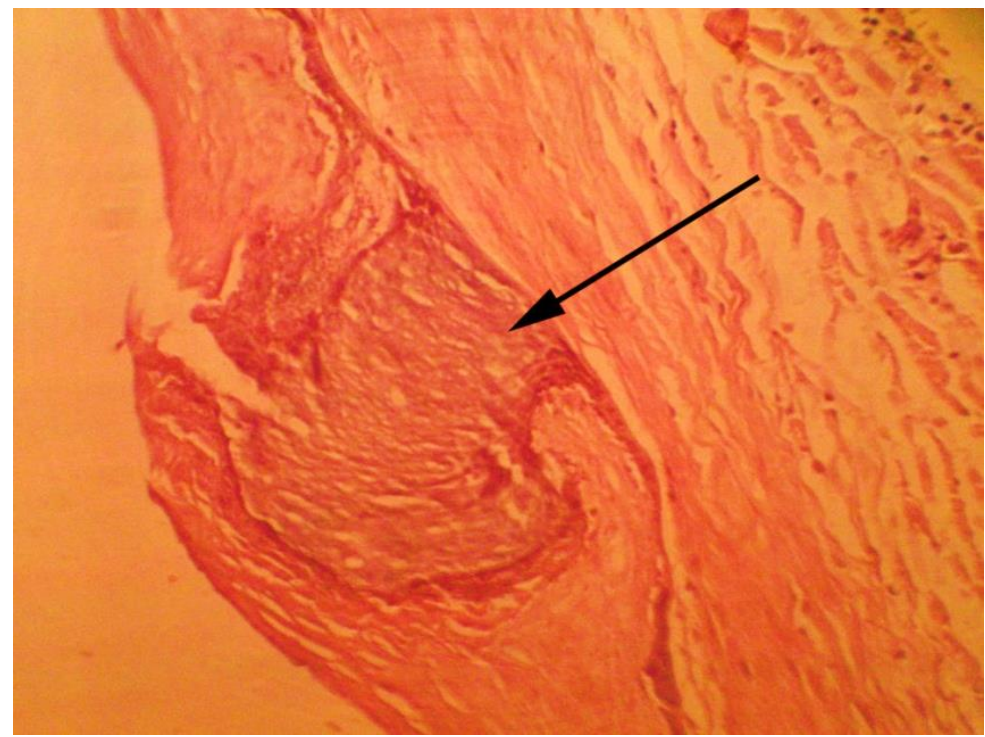

Рис. 49. Возраст исследуемого - 65 лет. Стенка артерии в области старой фиброзной бляшки

В наружном слое бляшки видны диффузные отложения извести. Внутренняя эластическая мембрана расслоена на несколько листков. Средняя оболочка под бляшками истончена, мышечные волокна ее атрофированы. В наружной мембране эластические волокна переплетаются с коллагеновыми.

В стенке артерии, на месте атероматозных бляшек были обнаружены скопления липидов, фиброз и отложение извести (рис. 50).

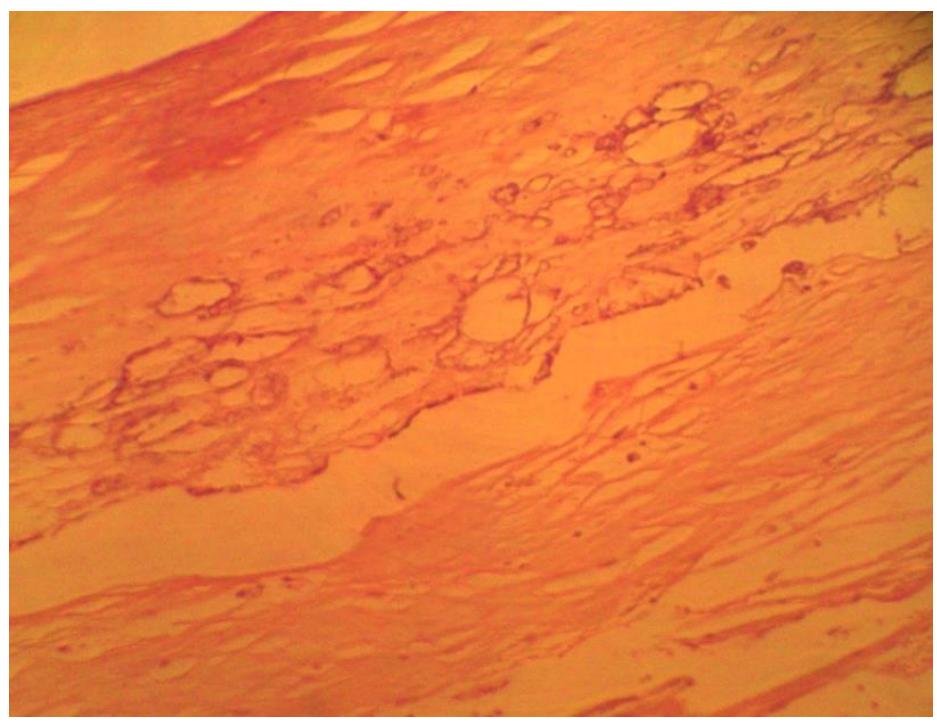

Рис. 50. Возраст исследуемого - 65 лет. Скопление липидов, фиброз и отложение извести в стенке артерии на месте атероматозной бляшки. Окр. гематоксилином и эозином, ув. х100 
Таким образом, у данного исследуемого в стенке артерии были обнаружены изменения, характерные для резко выраженного прогрессирующего атеросклероза.

У исследуемого 77 лет отмечается неравномерное утолщение стенки артерии и деформация просвета сосуда за счет пролиферации и гипертрофии гладкомышечных волокон (рис. 51). Стенка артерии уплотнена. Эндотелий складчатый. Подэндотелиальный слой определяется с трудом. На границе со средней оболочкой расположена внутренняя эластическая мембрана. Средняя оболочка артерии состоит из гладкой мышечной ткани, волокна которой увеличены в размерах (гипертрофированы).

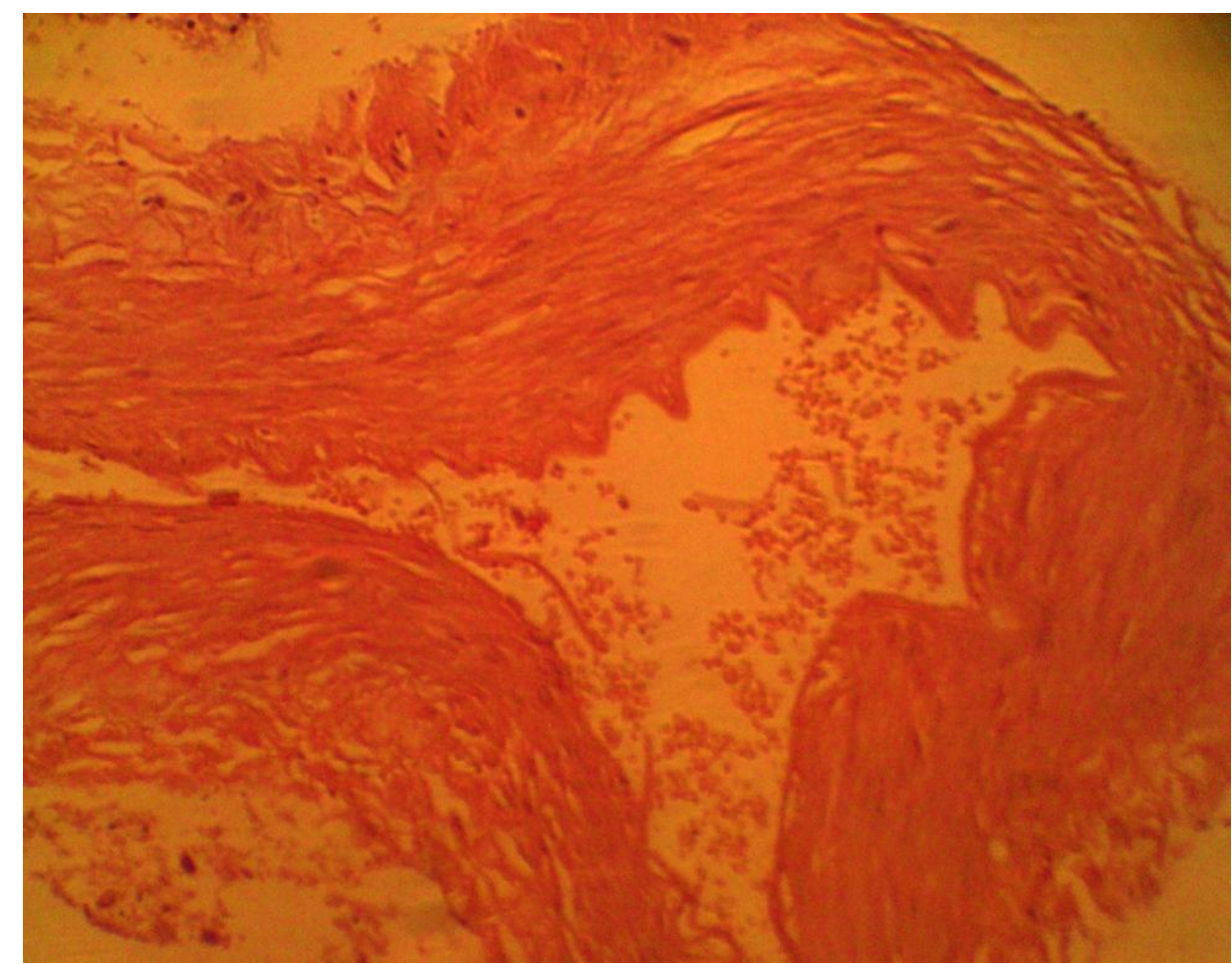

Рис. 51. Возраст исследуемого - 77 лет. Стенка артерии. Утолщение стенки и деформация просвета сосуда за счет пролиферации и гипертрофии гладкомышечных волокон. Окр. гематоксилином и эозином, ув. х100

Между отдельными гладкомышечными волокнами можно обнаружить соединительнотканные и немногочисленные эластические волокна. Наружная эластическая мембрана, в норме состоящая из комплекса эластических волокон и пластин, расслоена и частично 
$84 \mid$ Классическая невралгия тройничного нерва

разрушена. Наружная оболочка представлена волокнистой соединительной тканью со множеством эластических волокон различной толщины.

Таким образом, у исследуемого данной возрастной группы не наблюдалось признаков атеросклеротических изменений стенки артериального сосуда, однако были выявлены признаки уплотнения стенки, деформации просвета за счет пролиферации и гипертрофии гладкомышечных волокон.

У исследуемого 84 лет артерия расширена, уплотнена, отмечается почти полная утрата эластических волокон и атрофия гладкомышечных волокон. Эндотелий уплощен (рис. 52). Эти изменения могут быть связаны с возрастом больного.

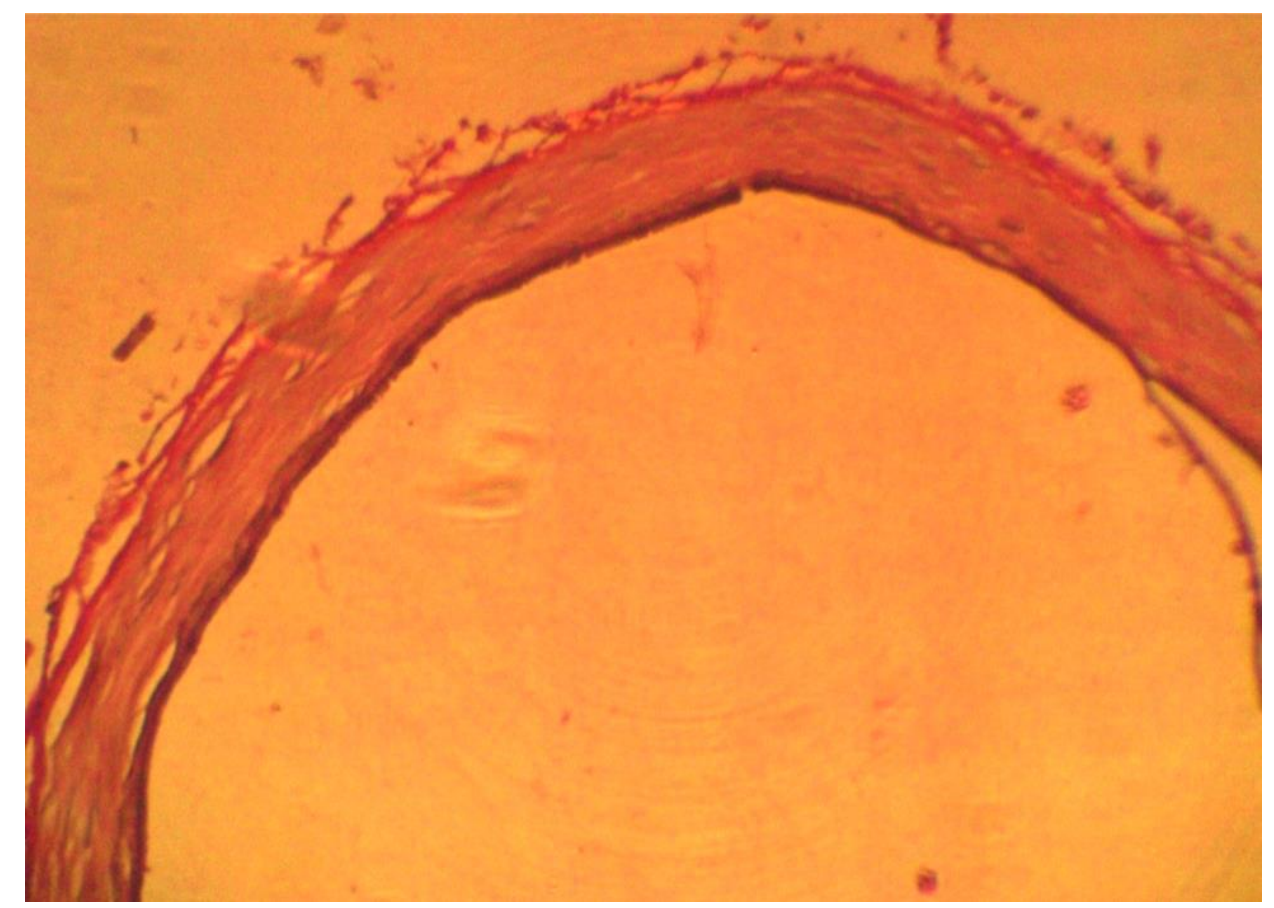

Рис. 52. Возраст исследуемого - 84 года. Выраженная атрофия всех слоев стенки артерии. Окр. пикрофуксином по Ван Гизон, ув. х100

Помимо указанных изменений в стенке артерии были обнаружены мелкие очаги фиброза на месте атероматозных бляшек. Приведенные примеры наглядно свидетельствуют о потере верхней мозжечковой артерией эластичности, прогрессивно нарастающей по мере увеличения возраста больного. 


\section{2. РОЛЬ АНАТОМИЧЕСКИХ ОСОБЕННОСТЕЙ И ФИЗИЧЕСКИХ ЗАКОНОМЕРНОСТЕЙ В ЛОКАЛИЗАЦИИ БОЛЕЙ В ЗОНАХ ИННЕРВАЦИИ ПРЕИМУЩЕСТВЕННО ВТОРОЙ И ТРЕТЬЕЙ ВЕТВЕЙ ТРОЙНИЧНОГО НЕРВА}

Как уже было сказано, если сосуд обладает неизменной малой эластичностью, то при изменении давления жидкости в сосуде (пульсации) $\left(P_{\text {сист }}-P_{\text {диаст }}=\Delta P\right)$ в зоне конфликта с КТН возникает некомпенсированная сила $\Delta F$, приводящая к выпрямлению петли и столкновению дистального плеча ее (1) с (КТН) препятствием (2). И так с каждым очередным перепадом давления (систолой) (рис. 44 в). Эти удары сосуда приводят к морфологическим изменениям в КТН: демиелинизации и даже гибели аксонов.

Как же распределяется сила удара дистального плеча артериальной петли по волокнам КТН? Как известно, волокна КТН расположены вплотную друг к другу. Разница между длиной волокон КТН от полулунного узла до моста вдоль передне-верхнего края и задне-нижнего края составила, по нашим данным, слева 3,68 мм и справа - 2,36 мм, а от верхнего края пирамиды до моста вдоль тех же краев КТН составила слева 2,64 мм и справа - 1,84 мм. Сила $F$ действует со стороны более длинных волокон КТН (т.е. со стороны волокон псевдоуниполярных клеток, дендриты которых формируют I ветвь) и имеет одно значение для всей системы волокон (рис. 53). Из области теоретической механики известны понятия «сосредоточенной силы», которая представлена в нашем случае силой $F$ и «распределенной нагрузкой» $(q)$, которая характеризуется распределением силы $F$ по длине рассматриваемых волокон (l) и определяется по формуле:

$$
q=\frac{F}{l}
$$



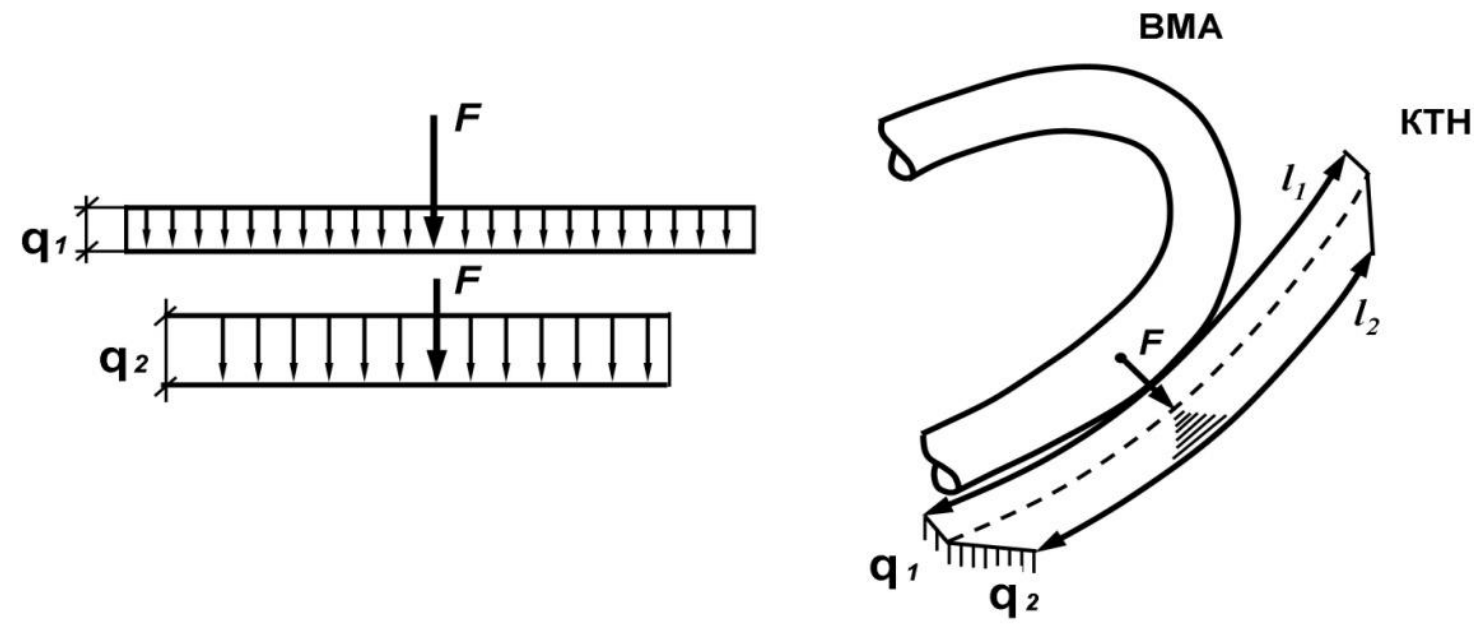

Рис. 53. Схема неравномерного повреждения волокон КТН в зависимости от их длины: $\boldsymbol{F}$ - сила механического воздействия дистального плеча артериальной петли ВМА на КТН; $l_{1}$ - длина волокон передне-верхнего края

КТН; $l_{2}$ - длина волокон заднее-нижнего края КТН; $q_{1}$ - распределенная нагрузка для более длинного волокна; $q_{2}$ - распределенная нагрузка для более короткого волокна

Рассмотрим самое длинное волокно в пучке КТН с длиной $l_{1}$ и самое короткое волокно с длиной $l_{2}$. Тогда, учитывая изложенные выше рассуждения для волокон длины $l_{1}$ :

$$
q_{1}=\frac{F}{l_{1}}
$$

а для волокон длины $l_{2}$ :

$$
q_{2}=\frac{F}{l_{2}}
$$

Так как сила $F$ имеет одно значение для всех волокон, то можем утверждать, что для более длинного волокна $q_{1}$ будет иметь меньшее значение, а для более короткого волокна $q_{2}$ будет иметь большее значение. Это объясняется меньшей величиной дроби при большем значении знаменателя в формуле (2) и наоборот большей величиной дроби при меньшем значении знаменателя в формуле (3).

Так как распределение нагрузки $q_{2}$ для более коротких волокон имеет большее количественное значение, то при силовом 
воздействии на рассматриваемый пучок волокон (КТН) вероятность механического повреждения будет значительно большей именно для «коротких волокон» (т.е. аксонов псевдоуниполярных клеток, дендриты которых формируют вторую и третью ветви), чем для длинных (т.е. аксонов псевдоуниполярных клеток, дендриты которых формируют первую ветвь). В то время как под воздействием нагрузки более длинные волокна прогибаются, более короткие волокна, претерпевая большую нагрузку, механически разрушаются. Вот почему невралгия II и III ветвей, как в отдельности, так и вместе, встречается более чем в 78\% случаев, в то время как невралгия I ветви встречается значительно реже (2\%). В связи с этим большинство исследователей считают ее, как правило, симптоматической.

Как следует из результатов наших исследований и данных литературы, НТН справа встречается чаще, чем слева (по нашим данным справа в 60\%). Однако объяснения этой закономерности в литературе мы не нашли.

На изученных нами 30 спиральных компьютерных томограммах лиц, страдавших НТН, нами обнаружено, что у 16 человек (53\%) задний край мекелевой ямки справа был выше, чем слева (рис. 54 и 55).

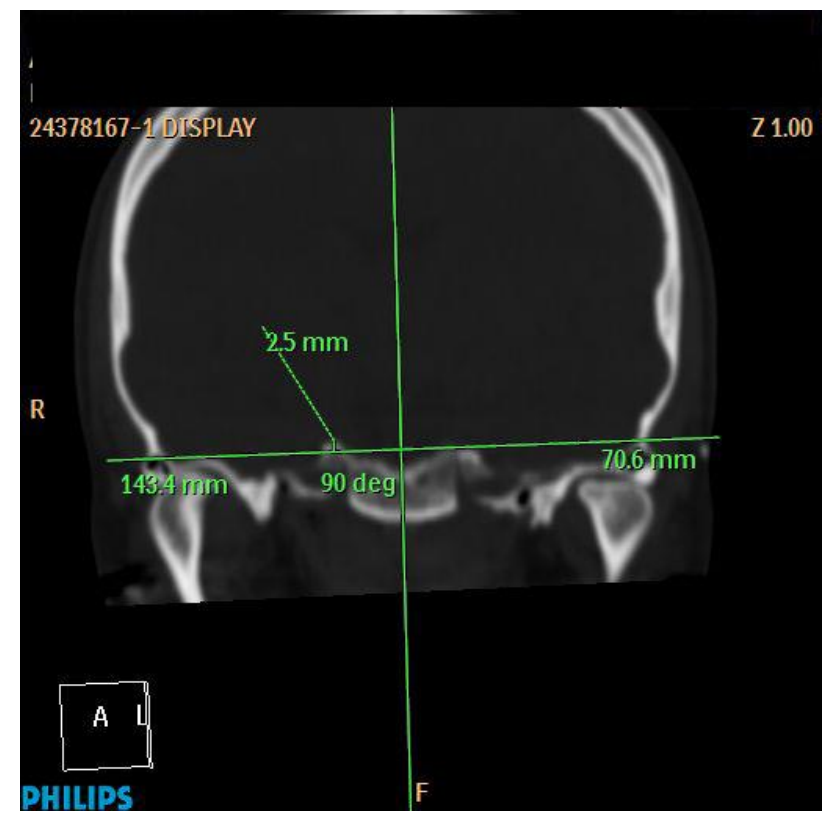

Рис. 54. Вершина пирамиды и край мекелевой ямки справа расположены выше, чем слева 
$88 \mid$ Классическая невралгия тройничного нерва

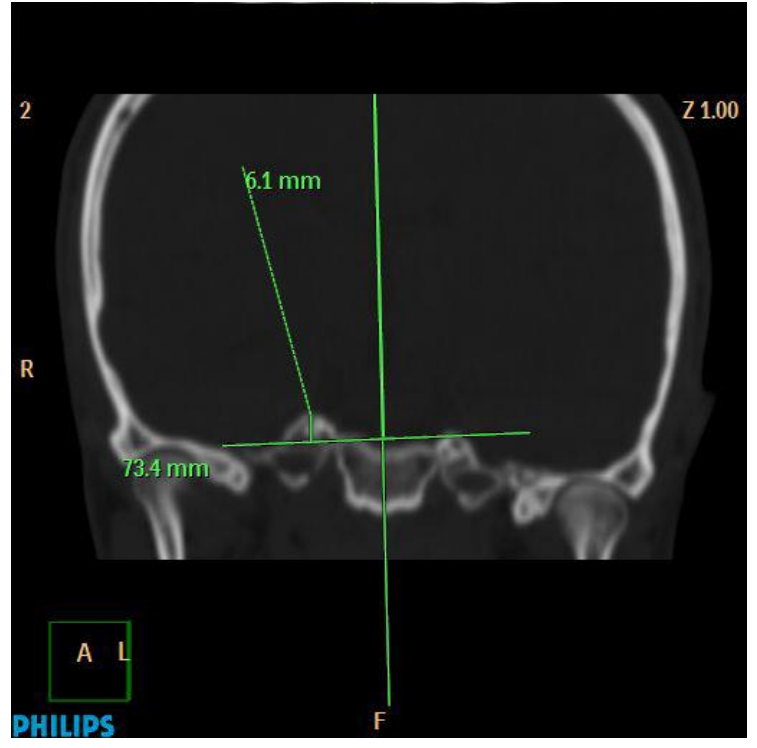

a)
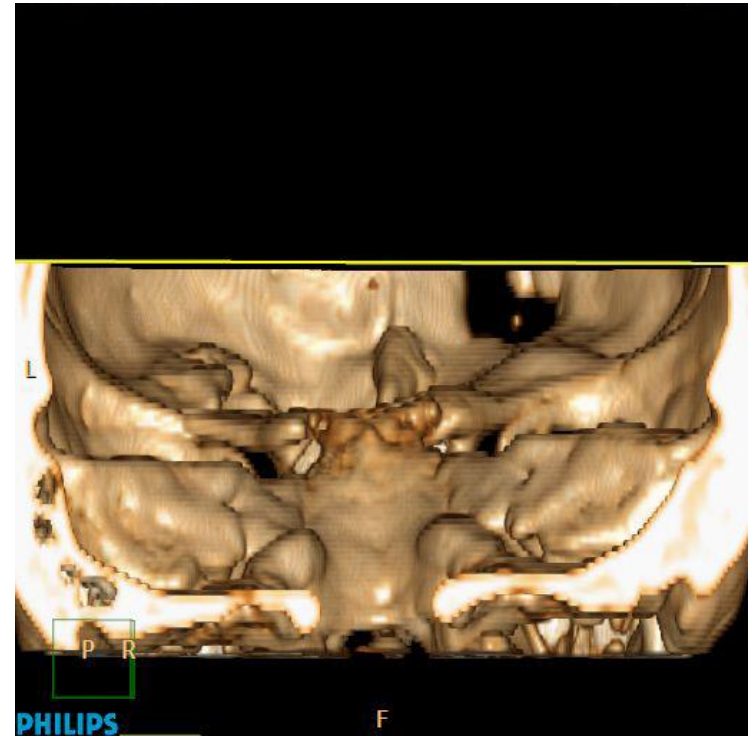

б)

Рис. 55. Вершина пирамиды и край мекелевой ямки справа расположены значительно выше, чем слева: а) в спиральном режиме, б) в режиме 3 D

Такая анатомическая особенность увеличивает вероятность формирования васкулоневрального конфликта справа, поскольку при возрастной долихоэктазии ВМА вершина ее петли, образующейся при переходе переднего понтомезенцефального сегмента в латеральный понтомезенцефальный сегмент, пересечет КТН в вертиркальной плоскости справа раньше, чем слева (рис. 56).

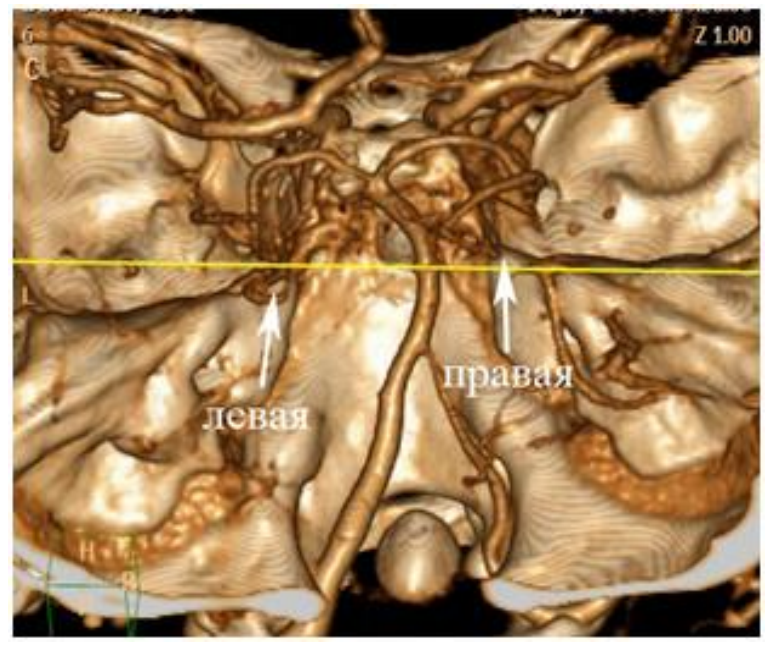

a)

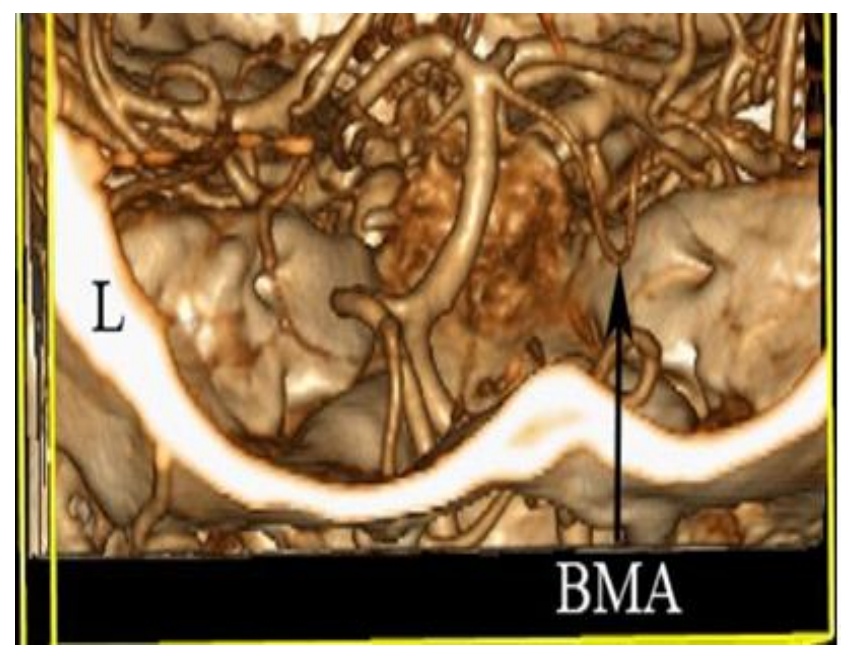

б)

Рис. 56. Взаимоотношение вершины петли ВМА с задним краем мекелевой ямки: а) правая пирамида выше левой вершина петли правой ВМА у края мекелевой ямки; б) при одинаковой высоте расположения вершин пирамид конфликт формируется раньше на стороне большей долихоэктазии ВМА 


\section{3. МОРФОЛОГИЧЕСКАЯ ОСНОВА ВОЗНИКНОВЕНИЯ ПАРОКСИЗМА И ФОРМИРОВАНИЯ ТРИГГЕРНЫХ ЗОН}

Разрушение миелиновой оболочки А-волокон в месте конфликта было изучено нами при электронной микроскопии участков КТН, взятых для исследования во время микроваскулярной декомпрессии, у больных, у которых ввиду невозможности надежного устранения васкулоневрального конфликта операция дополнена частичной ризотомией. Контрольные образцы взяты постмортально из области васкулоневрального контакта у лиц, не страдавших мозговой патологией.

Исследование контрольных образцов показало, что как на полутонких срезах, так и при ультраструктурном исследовании, строение миелинизированных нервных волокон в корешке тройничного нерва соответствовало обычному варианту (рис. 57).

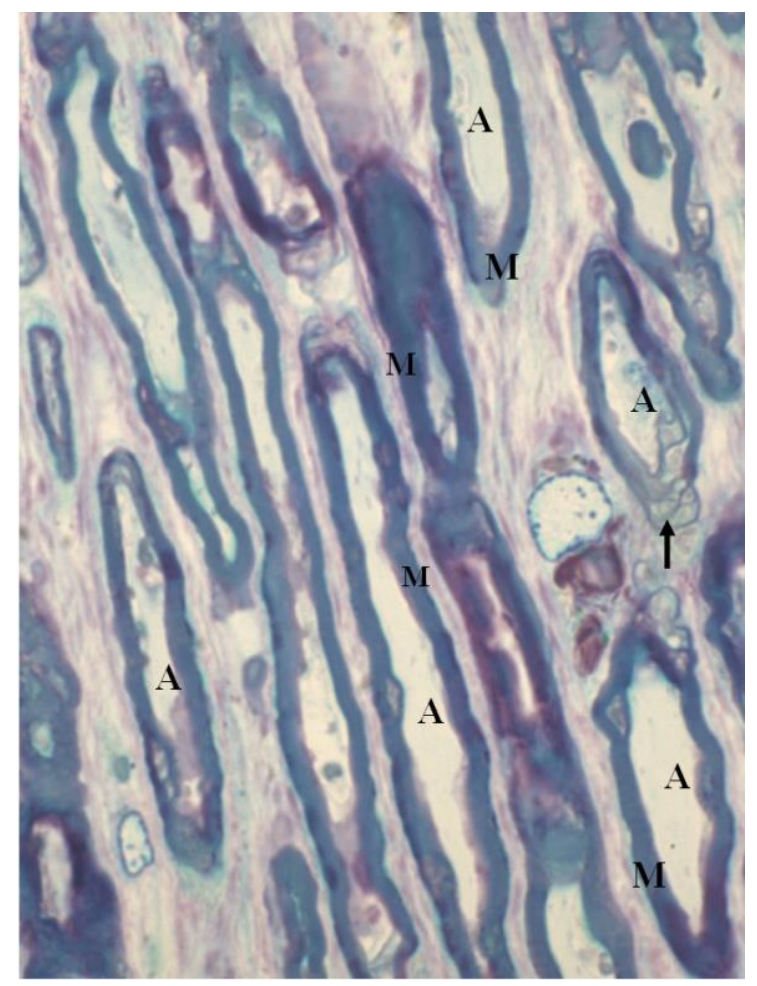

Рис. 57. Миелинизированные аксоны корешка тройничного нерва в контроле (возраст исследуемого 50 лет). Полутонкий срез. Ув. х1000.

А - аксон, М - миелин. Очаг разволокнения миелиновой оболочки указан стрелкой 
$90 \mid$ Классическая невралгия тройничного нерва

Отдельные нервные волокна покрыты плотной миелиновой оболочкой, обнаруживался небольшой отек аксонов, их отхождение от миелиновой оболочки, единичные мелкие очаги разволокнения миелина, однако значимого разрушения миелиновой оболочки аксонов, а тем более обнажения осевых цилиндров, не наблюдалось.

Изучение образцов трех пациентов с невралгией тройничного нерва позволило выявить во всех случаях признаки демиелинизации различной степени выраженности. На полутонких срезах во всех образцах определялось истончение миелиновых оболочек аксонов, их дезориентация, среди миелинизированных волокон просматривались очаги плотно упакованных осевых цилиндров, лишенных миелина (рис. 58).

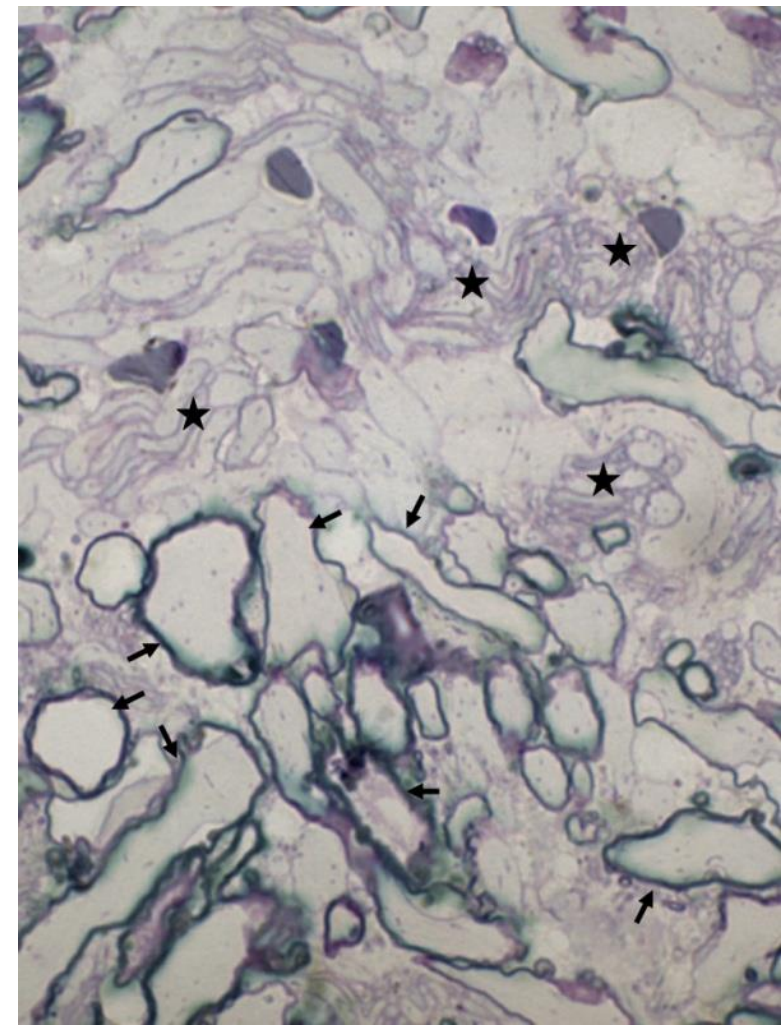

Рис. 58. Дезориентация аксонов, истончение миелиновых оболочек, демиелинизированные аксоны в корешке тройничного нерва при невралгии. Полутонкий срез. Ув. х1000. Стрелки - миелинизированные аксоны; звездочки - осевые цилиндры, лишенные оболочек

При электронномикроскопическом исследовании в двух случаях кроме выраженного истончения миелиновых оболочек наблюдалось очаговое разволокнение миелина, неплотное прилегание его к 
аксолемме, появление округлых остаточных телец - фигур дегенерации миелиновых слоев и осевых цилиндров аксонов (рис. 59).

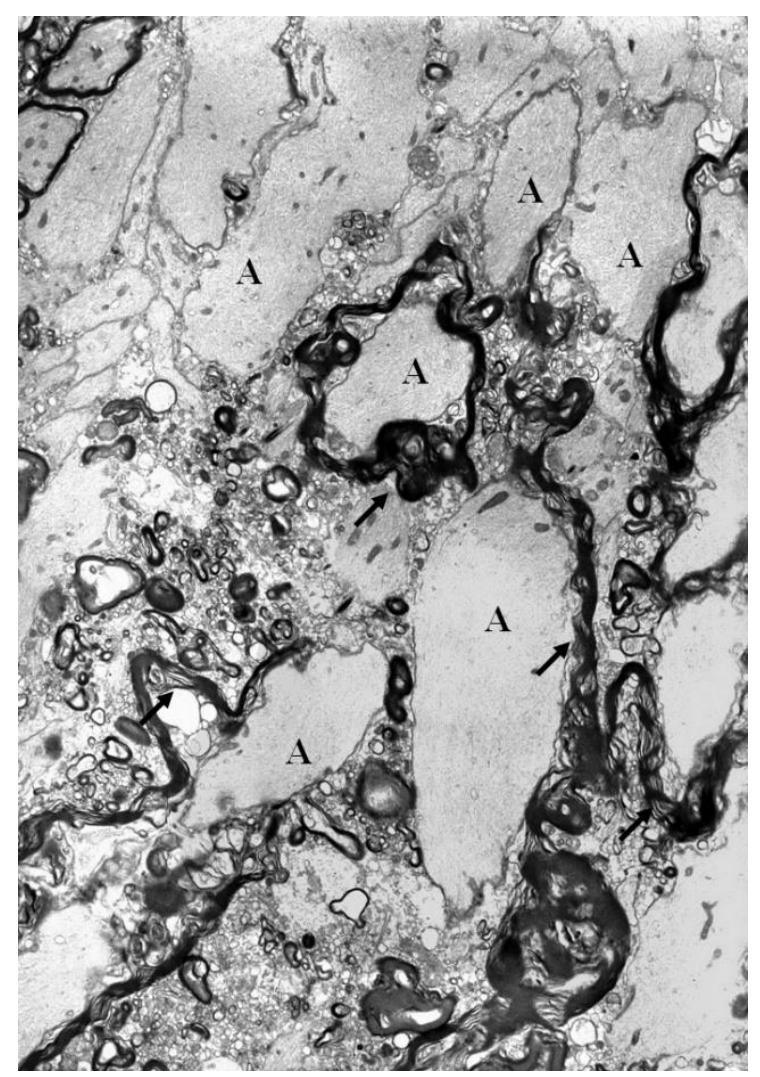

Рис. 59. Различные стадии разрушения миелиновой оболочки аксонов в корешке тройничного нерва при невралгии. Некоторые аксоны полностью лишены оболочки (верхняя часть рисунка). Исходное увел. х2000. А - аксон; фрагменты миелиновых оболочек показаны стрелками

Некоторые осевые цилиндры были полностью лишены миелиновой оболочки (рис. 58). В одном случае подобные изменения сочетались с наличием обширных полей, состоящих из довольно крупных аксонов, которые были полностью лишены миелиновых оболочек (рис. 59). Эти аксоны были плотно упакованы, их аксолеммы тесно контактировали друг с другом на значительном протяжении. При этом признаков повреждения самих аксонов (нарушения ориентации микротрубочек и микрофиламентов, дегенерации митохондрий, отека аксоплазмы) мы не наблюдали (рис. 59). На больших увеличениях контакты между аксолеммами аксонов не имели специализированного строения, мембраны соседних аксонов просто достаточно тесно прилежали друг к другу (рис. 61, 62). 
$92 \mid$ Классическая невралгия тройничного нерва

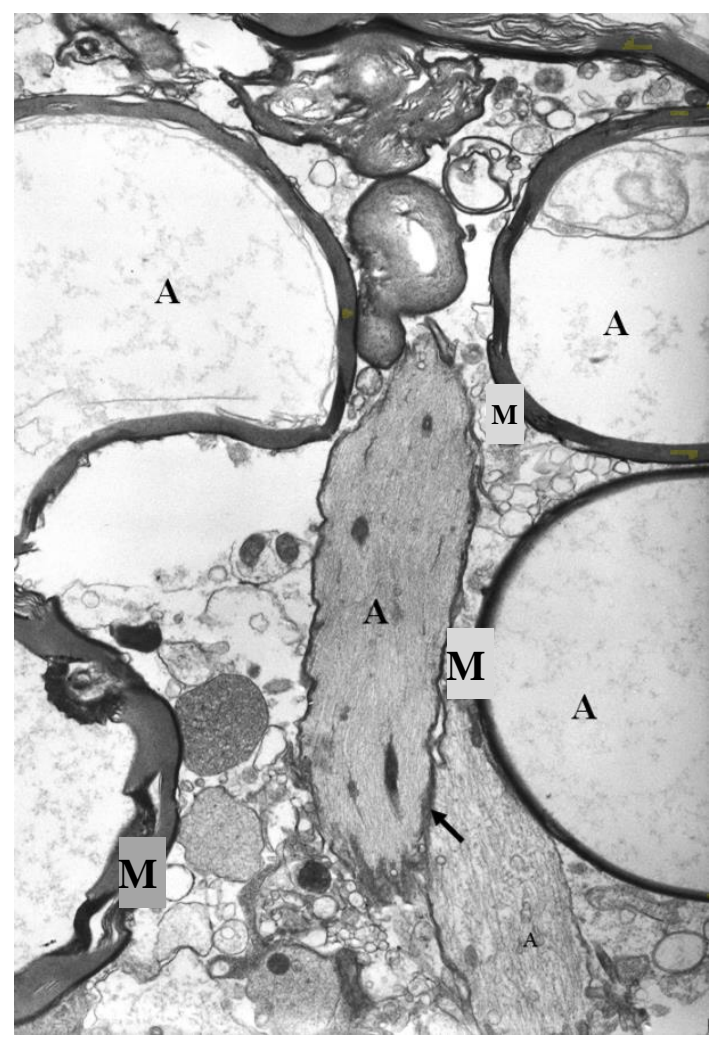

Рис. 60. Демиелинизированные и миелинизированные аксоны в корешке тройничного нерва при невралгии. Аксоны, лишенные оболочек, контактируют друг с другом (стрелка). Исходное увел. х5000. А - аксон, М - миелин

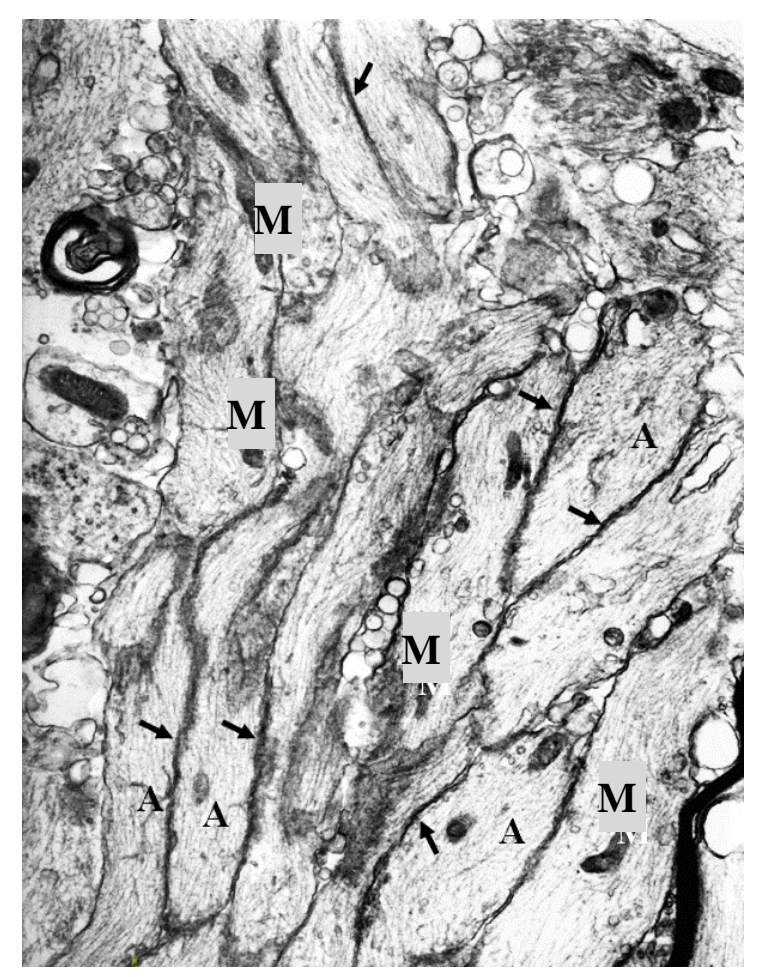

Рис. 61. Тесно контактирующие аксоны, лишенные миелиновых оболочек в корешке тройничного нерва при невралгии. Контакты обозначены стрелками. Исходное увел. х8000. А - аксон, М - миелин 


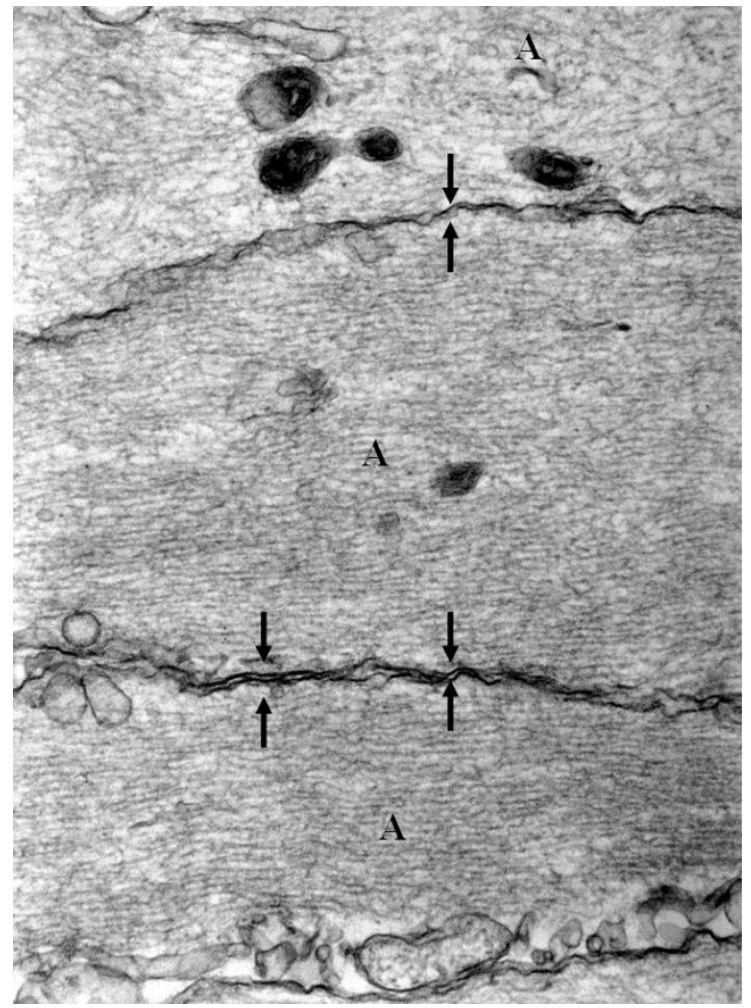

Рис. 62. Зона контакта плазматических мембран аксонов (стрелки), лишенных миелиновой оболочки. Исходное увел. х25000. А - аксон

Проведенное нами исследование показало, что при невралгии тройничного нерва наблюдается различная степень демиелинизации волокон, входящих в его состав, что проявляется различной выраженностью и частотой болевых пароксизмов. При этом часть аксонов полностью лишена миелиновой оболочки, и их тесный контакт друг с другом может способствовать возникновению эктопической спонтанной импульсной активности и ее эфаптическому распространению при этой патологии. Hilton D.A. et al. (1994) подчеркивали, что степень ультраструктурных нарушений в КТН зависит от степени его компрессии.

Таким образом, для возникновения васкулоневрального конфликта как патогенетической основы тригеминальной невралгии, необходим ряд условий:

1) Долихоэктазия ВМА или ПНМА как врожденная аномалия сосуда.

2) Расположение вершины петли ВМА, образующейся при переходе ее переднего понтомезенцефального сегмента в латераль- 
$94 \mid$ Классическая невралгия тройничного нерва

ный - на уровне не менее половины диаметра КТН и ниже для ВМА и выше для ПНМА. Если сосуд контактирует с КТН без пересечения плоскостей их расположения по вертикали, то такой контакт не может сформировать васкулоневральный конфликт с последующими морфологическими изменениями в корешке. При изучении секционного материала контакт ВМА с КТН был обнаружен нами в 32\% случаев. При этом ВМА располагалась в пространстве между КТН и наметом мозжечка, и пересечения артерией КТН в вертикальной плоскости не наблюдалось. Это обстоятельство является принципиальным отличием контакта от конфликта. НТН возникает при наличии васкулоневрального конфликта.

3) Возникновение НТН у лиц старшего возраста имеет ряд составляющих. Прежде всего, это уменьшение эластичности стенки артерии вследствие атеросклероза, гипертонии, возрастного уплотнения стенок сосудов и увеличения их извитости, развивающиеся у лиц старше 50 лет, в результате чего сила пульсовой волны расходуется не на увеличение диаметра сосуда, а на разгибание артериальной петли, дистальное плечо которой с каждой систолой наносит удары по КТН, запуская механизм демиелинизации. Кроме того, как было показано ранеe Gerdner E.D. (1940), миелинизированные волокна периферических нервов с возрастом дегенерируют, и к 65 годам погибает около 30\% этих волокон. В результате васкулоневрального конфликта наступает демиелинизация и в оставшейся части волокон КТН, что значительно повышает вероятность возникновения НТН в пожилом возрасте.

4) Преимущественная локализация болей в зонах иннервации второй и третьей ветвей, по-видимому, обусловлена тем, что более короткие волокна КТН, представленные аксонами клеток, дендриты которых образуют вторую и третью ветви подвержены большему механическому повреждению, чем волокна первой ветви, при равной величине силы повреждения.

Исчезновение боли непосредственно после операции МВД, устранившей васкулоневральный конфликт у всех 218 больных НТН, находившихся под нашим наблюдением, подтверждает тот факт, что в основе патогенеза заболевания лежит васкулоневральный конфликт. 


\section{4. МОДЕЛЬ ПАТОГЕНЕЗА КЛАССИЧЕСКОЙ НЕВРАЛГИИ ТРОЙНИЧНОГО НЕРВА}

Васкулоневральный конфликт ведет к демиелинизации А- $\beta$ и A- $\delta$ волокон, становящихся источником эктопических спонтанных импульсов. Кроме этого нормальные или эктопически генерируемые импульсы эфаптически распространяются на немиелинизированные С-волокна, проводящие болевую чувствительность. При этом с одной стороны, в связи с демиелинизацией А- $\beta$ и дельта волокон нарушается воротный контроль, с другой - оказывается дефективной функция нисходящего торможения. Одновременно с этим, в результате длительного ритмического раздражения волокон КТН, в ЦНС на клеточном уровне происходят дезадаптивные нейропластические изменения с понижением порога болевой чувствительности (центральная сенситизация) и формируется «феномен взвинчивания» [293]. В таких случаях говорят о вторичной гипералгезии. Эти патофизиологические процессы приводят к тому, что раздражение ТН, которое в норме не сопровождается возникновением боли (например, прикосновение кисточкой, дуновение ветра) может привести к возбуждению ноцицептивного нейрона. В таких случаях больные испытывают болевые пароксизмы при малейшем механическом раздражении. Это динамическая аллодиния при раздражении триггерных зон характерна для классической НТН.

На основании проведенных нами морфологических исследований и интраоперационных находок можно отметить, что патогенетической основой классической НТН является как периферический «нейропатический» компонент, так и центральный. Периферический компонент обусловлен васкулоневральным конфликтом КТН с артериями вертебробазилярного бассейна, очаговой демиелинизацией А-волокон КТН в области конфликта. Выявленные при электронной микроскопии очаги плотно упакованных демиелинизированных А-волокон могут включать в себя как A- $\beta$, так и A- $\delta$ волокна. Неболевой механический стимул при НTH, проводимый по A- $\beta$ волокнам в месте очаговой демиелинизации эфаптически распростра- 
$96 \mid$ Классическая невралгия тройничного нерва

няется на потерявшие миелиновую оболочку $\mathrm{A}-\delta$ волокна и С-волокна. В результате центральной сенситизации происходит уменьшение порога активации ноцицепторов. В такой ситуации незначительное механическое раздражение проявит себя пароксизмом боли. Очаг механического раздражения кожных покровов будет соответствовать зоне иннервации A- $\beta$ и A- $\delta$ волокон, потерявшим миелиновую оболочку в области васкулоневрального конфликта. Поскольку более короткие волокна (а это аксоны клеток, дендриты которых формируют вторую и третью ветви КТН) подвержены, по физическому закону о распределенной нагрузке, большему механическому повреждению, триггерные зоны, как правило, локализуются в области иннервации этих ветвей. Непосредственный рисунок расположения триггерных зон на поверхности лица зависит от того, какие группы аксонов были подвержены демиелинизации в области васкулоневрального конфликта. Это чаще всего периоральная область. Локализация триггерных зон в периоральной зоне объясняется высокой плотностью в этой области чувствительных окончаний и значительной представленностью её в чувствительном ядре тройничного нерва [207].

Однако возникновение болевого пароксизма объяснить только периферической сенситизацией можно частично. При небольшом количестве потерявших миелиновую оболочку А-волокон стимулы, идущие от возникающего эктопического очага, могут подавляться как с помощью воротного контроля, так и благодаря функционированию нисходящей антиноцицептивной системы. Известно, что к 65 годам погибает до 30\% миелинизированных А-волокон, а НТН развивается далеко не у всех пожилых людей. По-видимому, количественное соотношение демиелинизированных и сохранивших миелиновую оболочку А-волокон имеет решающее значение в возникновении болевых пароксизмов даже при наличии васкулоневрального конфликта. При демиелинизации волокон КТН одновременно происходят два процесса: демиелинизация и ремиелинизация. Так, Love S., et al. (2001) в некоторых наблюдениях при НТН, выявили единичные, плотно соприкасающиеся аксоны, которые окружала 
тонкая миелиновая оболочка, что позволило авторам сделать вывод о процессе ремиелинизации. Именно процессом ремиелинизации авторы объясняют возникновение ремиссий как спонтанно, так и в результате консервативной терапии. Поиск способа активации процесса ремиелинизации может быть перспективным направлением в медикаментозной терапии классической НТН.

Лишенные тормозного влияния вставочных нейронов вследствие демиелинизации А-волокон, релейные нейроны нисходящего спинального ядра ТН получают мощный поток сигналов из области демиелинизации. При этом прогрессивно нарастает активность в нейронах этого ядра (в зарубежной литературе именуемое как феномен «взвинчивания») и они становятся более чувствительными к последующим импульсам. Это явление сопровождается снижением порога возбуждения. В результате обычные незначительные механические раздражения вызывают болевые пароксизмы.

Особенность травмирующего воздействия артерии на КТН в области васкулоневрального конфликта состоит в том, что это не однократное повреждение нерва или не постоянная компрессия КТН, как это моделируется в экспериментальных исследованиях или при выполнении баллонной компрессии полулунного узла. Это ритмические удары по КТН дистального плеча артериальной петли, синхронные пульсу. Подобного механизма компрессии нервных стволов не наблюдается ни при каком другом виде нейропатической боли. Можно предположить, что под пульсовыми ударами артерии о КТН происходит постоянное сближение и расхождение демиелинизированных А-волокон и немиелинизированных C-волокон. По этим волокнам проходят, хотя и незначительные, субпороговые для возникновения боли, ритмические чувствительные стимулы в результате обычной жизнедеятельности человека. Эти постоянные ритмические стимулы поддерживают определенный уровень сенситизации вышележащих структур алгической системы не только на уровне ствола головного мозга, но и вышележащих структур (ретикулярная формация, зрительный бугор, лимбическая система, кора головного мозга). Вероятно, эти ритмические эктопические 
$98 \mid$ Классическая невралгия тройничного нерва

импульсы являются патофизиологическим механизмом фоновых парестезий, отмечаемых некоторыми больными в межприступном периоде или в начале заболевания до развития типичных невралгических приступов.

Для возникновения болевого пароксизма, видимо, недостаточно только эфаптического аксо-аксонального распространения импульса в области васкулоневрального конфликта, возникающего вследствие раздражения триггерной зоны. В эксперименте описана новая форма несинаптической, неэфаптической передачи возбуждения, имеющая место как в области повреждения аксонов, так и внутри чувствительного ганглия [149]. Импульсная активность в группе афферентов приводит к несинаптическому выделению алгогенных нейропептидов в интерстициальную жидкость. Алгогены, распространяясь путем пассивной диффузии, вызывают спонтанную деполяризацию в соседних нейронах, пролонгируя генерацию ими импульсов. По А- $\beta$ тактильным волокнам импульсы из тригеминального узла поступают в ноцицептивные центры. Amir R., Devor M. (2000) в эксперименте показали, что стимуляция низкопороговых A- $\beta$ волокон в большей степени способствует возникновению перекресных послеразрядов, чем стимуляция С-волокон. Результаты этих исследований позволяют объяснить, почему триггерные зоны более чувствительны к легким механическим раздражителям, в то время как грубые раздражения пароксизма боли не вызывают.

Клинический опыт применения атиконвульсанов в лечении НТН и их эффективность на ранних этапах развития заболевания позволяют предположить развитие нейропластических изменений на уровне коры головного мозга с образованием генетически измененных нейронов, формирующих центральный генератор патологически усиленного возбуждения, подобный очагу эпилептической активности. Не случайно при записи ЭЭГ с целью провокации эпилептического разряда на больного воздействуют ритмическими раздражителями (фото- и фоностимуляция). У больных НТН этими ритмическими стимулами являются удары артериальной петли о КТН, синхронные систоле, генерирующие поток патологических им- 
пульсов по вышеизложенной схеме. Эффективность антиконвульсантов (карбамазепин, финлепсин, тегретол, габапентин, тебантин, нейронтин, прегабалин и др.) в свое время послужила развитию концепции о центральном механизме патогенеза НТН.

С целью уточнения ведущей роли нейроваскулярного конфликта в возникновении болевого пароксизма у больных НТН нами проведено изучение изменений ЭЭГ у больных до и после операции МВД, а также выяснение, с точки зрения электрофизиологии, в чем именно проявляется болевой синдром, возникающий у пациентов при стимуляции триггерной зоны.

Электроэнцефалографическое обследование проведено в динамике у 20 больных невралгией тройничного нерва до и после микроваскулярной декомпрессии корешка тройничного нерва через 9-10 дней после операции. Так как в результате МВД исчезал болевой синдром, и больные далее не нуждались в приеме финлепсина, то повторная запись проводилась на фоне отмены препарата, в состоянии расслабленного бодрствования. Регистрация биопотенциалов осуществлялась в монополярном режиме с использованием электроэнцефалографа «Энцефолан 131-03», фирмы «Медиком» (г. Таганрог).

Исходные записи подвергались частичной фильтрации и удалялись артефакты. Нормированные спектры мощности (НСM) рассчитывались по 24 частотам в 16 отведениях для каждого пациента. Предварительно проводилось сравнение НСМ больных до и после МВД с помощью критерия Стьюдента. Каждому пациенту была проведена трехмерная локализация участков ЭЭГ значимых изменений биоритмики.

У всех обследуемых отмечались различной степени выраженности изменения диффузного и регионального характера. Преобладали у 14 больных (70\%) дезорганизованные дизритмические знаки с плохой выраженностью $\alpha$-активности, ее фрагментарностью, либо отсутствием, диффузным распределением медленных волн, нарушением регионального представительства $\beta$-колебаний, наличием во многих записях пароксизмальных билатеральных разрядов. 
$100 \mid$ Классическая невралгия тройничного нерва

У 2-х пациентов ЭЭГ условно можно отнести к организованному I типу по Жермундской. Десинхронизованная низкоамплитудная запись отмечалась у 4-х больных.

В 60\% (12 больных) до операции регистрировалась пароксизмальная активность, как правило, генерализованная, но могла быть и регионарной. Пароксизмы представляли собой вспышки $\theta$-волн, реже $\alpha$ - и $\beta$-диапазоны, чаще асинхронного характера. Причем амплитудное преобладание совпадало со стороной невралгической боли в $70 \%$.

В 65\% (13 больных) отмечалась региональная медленноволновая дизритмия. По этому показателю, так же как и с амплитудным акцентом в пароксизмальных разрядах, имело место большее количество совпадений со стороной боли.

Обнаруженные нами изменения биоритмики отражают общие закономерности, отмеченные рядом авторов в литературе о наличии патологических изменений на ЭЭГ больных с невралгией тройничного нерва. Обращает на себя внимание, что патологические ЭЭГ-знаки регистрировались в теменно-центральных областях мозга. Иногда зона патологического очага расширялась с вовлечением лобных и височных отделов.

После проведенной МВД корешка тройничного нерва у всех обследованных больных на ЭЭГ наблюдались изменения биоритмики. Сравнительный анализ показал следующее. У 15 из 20 обследованных отмечалась тенденция к нормализации диффузных нарушений: уменьшилась дизритмия, дезорганизация биоритмики, появились или увеличились количества $\alpha$-колебаний. У одного больного дизритмический фон трансформировался в десинхронизацию. У 4 пациентов записи остались без динамики.

Нивелировка локальных изменений - исчезновение коркового фокуса - имело место у 17 больных. Сравнение нормированных спектров мощности (HCM) тета-диапазона выявило значимые региональные изменения по полушариям, представленные снижением НСM (рис. 63). У 4 больных положительная локальная динамика сочеталась с исчезновением как амплитудной асимметрии пароксизмальных разрядов, так и самих пароксизмов (рис. 64). 


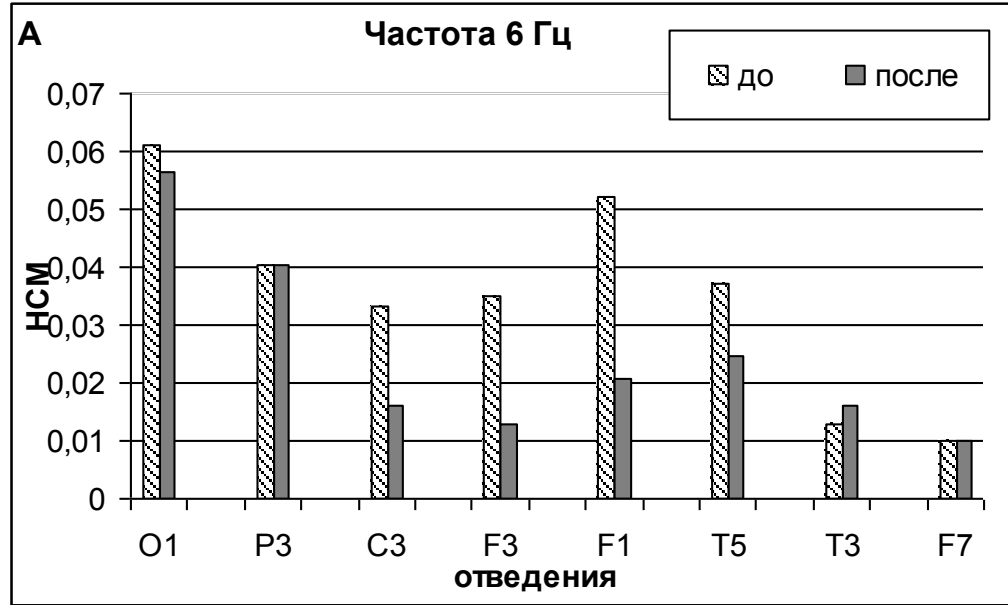

a)

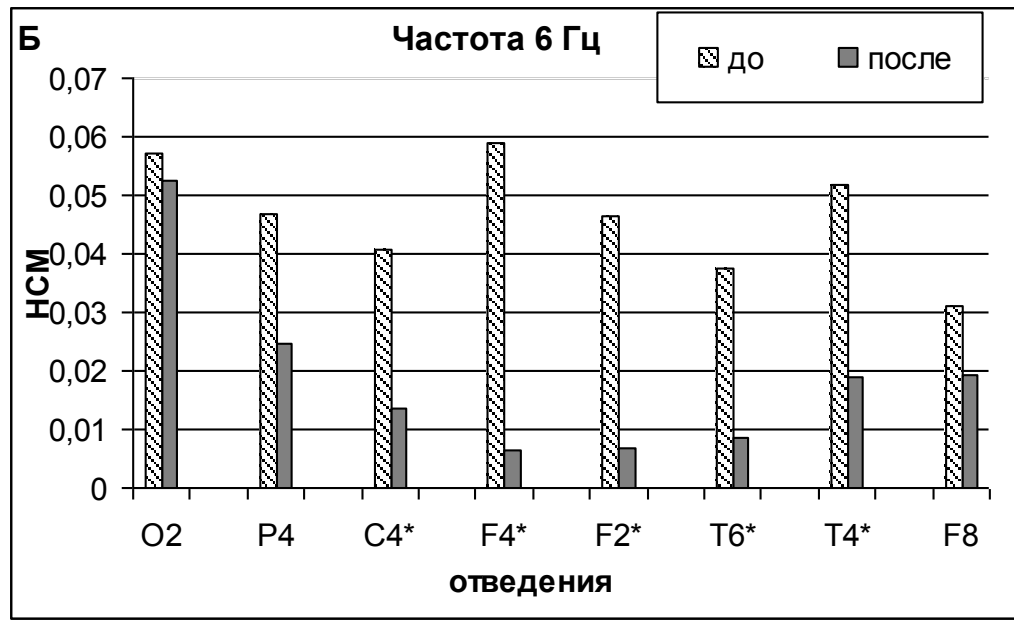

б)

Рис. 63. Значения НСМ 6 Гц частотной составляющей у больных НТН до и после операции: а) НТН слева; б) НТН справа

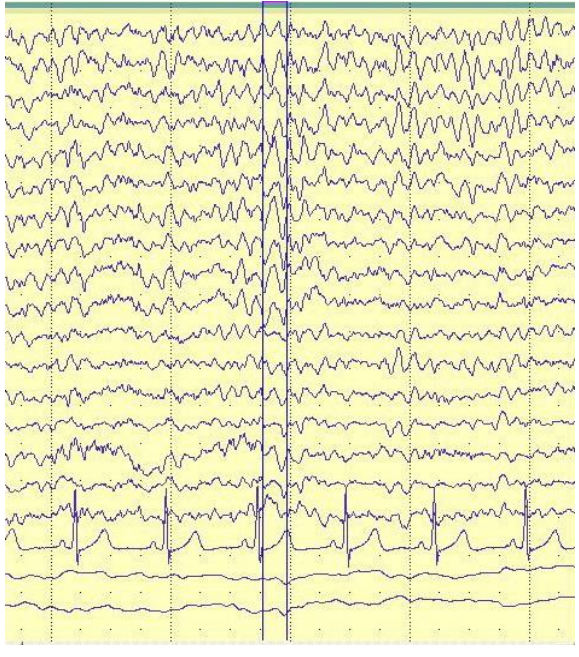

a)

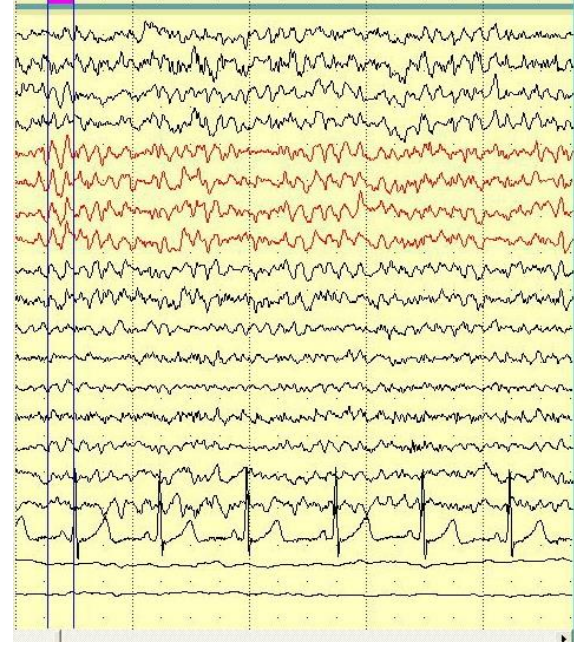

б)

Рис. 64. Больная К. Четко определяется исчезновение амплитудной асимметрии и пароксизмов после операции: а) до МВД; б) после МВД 
$102 \mid$ Классическая невралгия тройничного нерва

В целом снижение выраженности пароксизмальных разрядов стволовой локализации наблюдалось у 80\% больных. Метод трехмерной локализации позволяет выявить и иллюстрировать наличие динамики очагов патологической активности в стволе головного мозга до и после операции МВД (рис. 65).

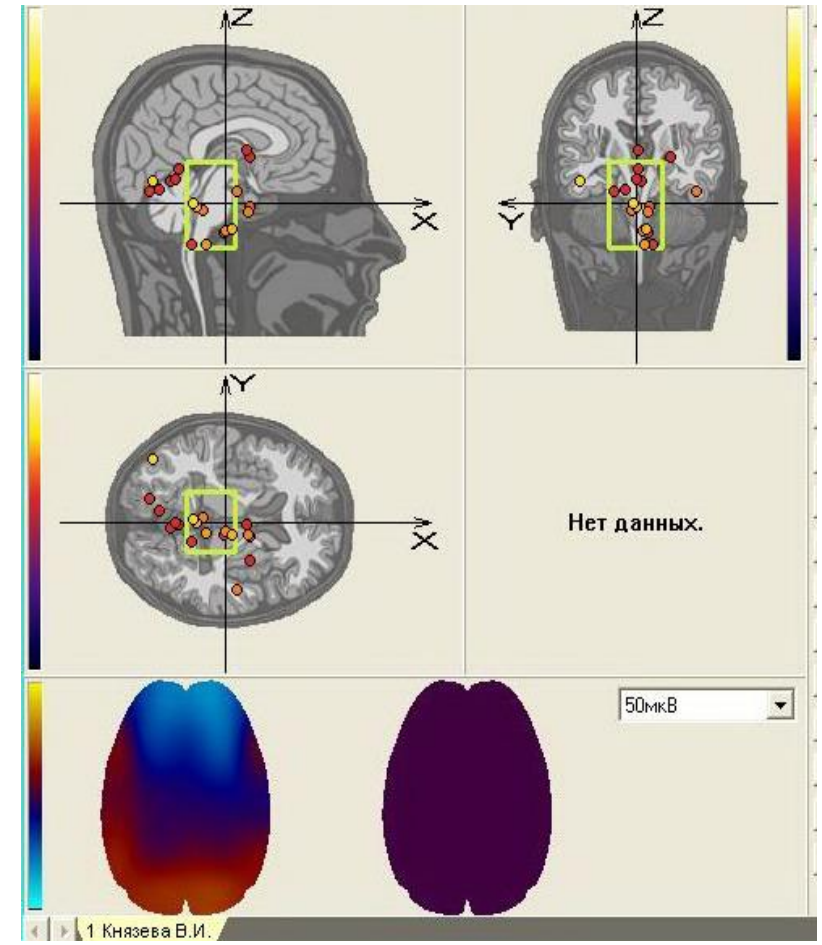

a)

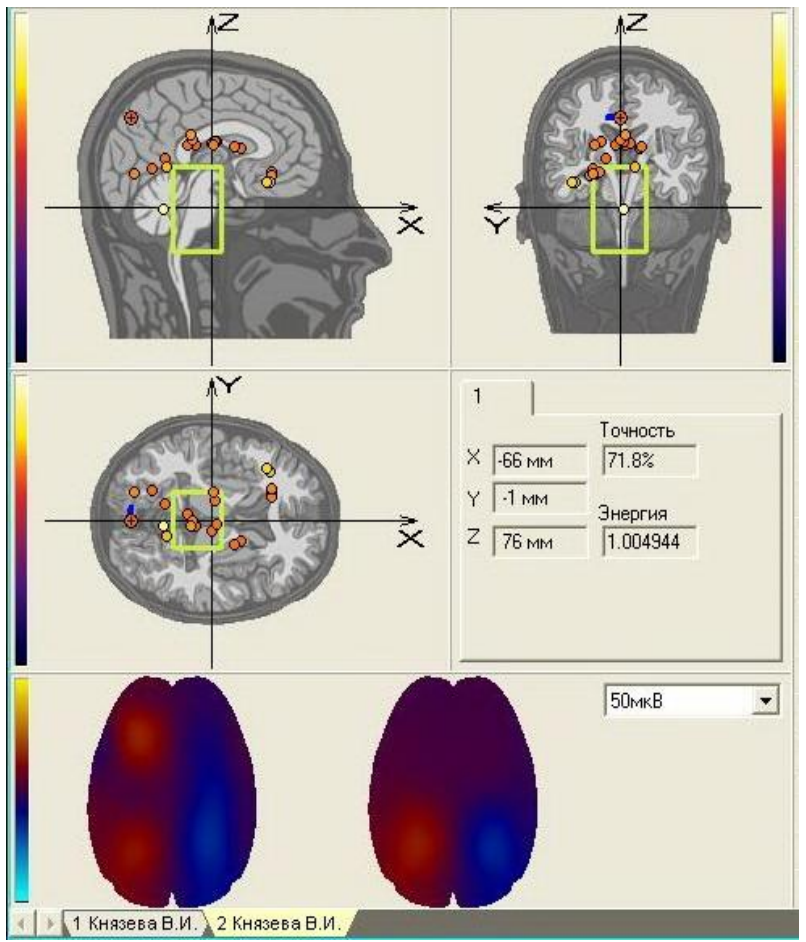

б)

Рис. 65. Метод трехмерной локализации очагов.

а) до операции видны очаги ирритации в мосту, продолговатом мозге и в коре лобной и теменной долей; б) после операции МВД очагов в стволе не определяется и значительно уменьшено их количество в коре

Исключение составили 4 человека. У 3 из них пароксизмальная активность отсутствовала в дооперационных записях, по-видимому, в связи с приемом больших доз карбамазепина (свыше 3 г. в сутки). У одного больного выраженность пароксизмов не изменилась.

На основании проведенных нами исследований и результатов исследований, представленных в современной литературе, можно очертить концепцию патогенеза классической НТН. Патогенез классической НТН определяется взаимодействием двух компонен- 
тов: центрального и периферического. Как было показано в наших исследованиях, периферический компонент представлен васкулоневральным конфликтом, очаговой демиелинизацией, формированием эктопического очага возбуждения и его эфаптическим распространением. Центральный компонент представлен формированием очагов патологически усиленного возбуждения (сенситизации) как на уровне ядра ТН, так и в области супрасегментарных структур головного мозга. 
$104 \mid$ Классическая невралгия тройничного нерва

\section{ГЛАВА 4}

СРАВНИТЕЛЬНАЯ ХАРАКТЕРИСТИКА КЛИНИЧЕСКИХ ПРОЯВЛЕНИЙ КЛАССИЧЕСКОЙ НЕВРАЛГИИ ТРОЙНИЧНОГО НЕРВА В ЗАВИСИМОСТИ ОТ АНАТОМИЧЕСКИХ ОСОБЕННОСТЕЙ ВАСКУЛОНЕВРАЛЬНОГО КОНФЛИКТА

Всего исследовано 298 человек с НТН. Из них женщин 208 (69,8\%), мужчин - 90 (30,2\%). Возрастной состав пациентов во время обращения в клинику РостГМУ показан на диаграмме (рис. 66).

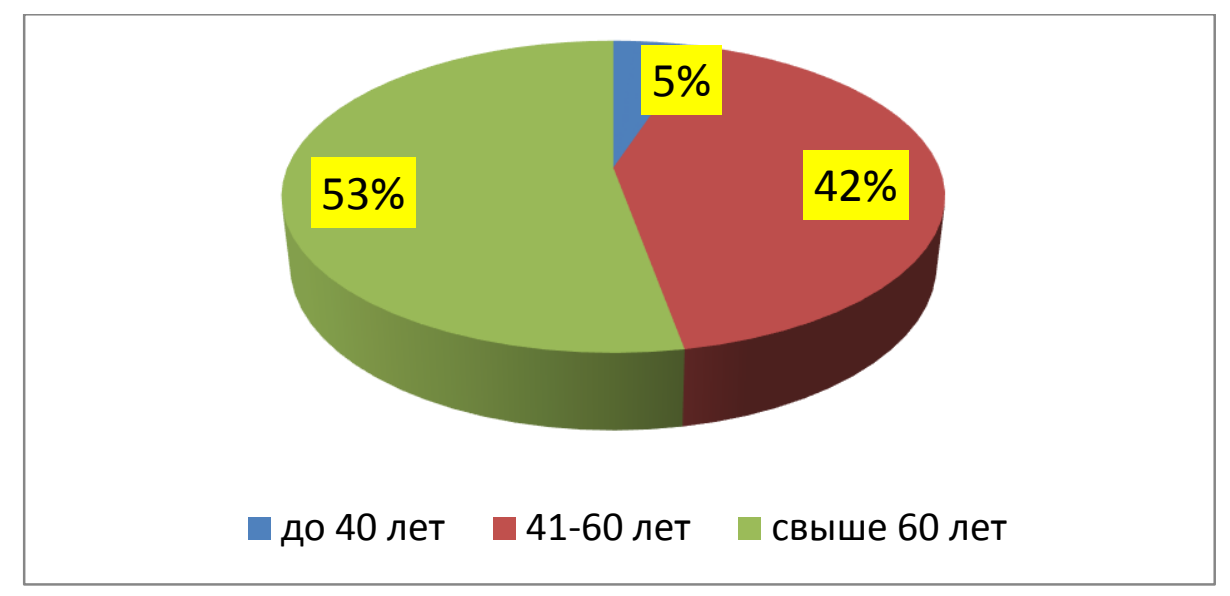

Рис. 66. Возрастной состав исследованного контингента больных

Как видно из рис. 66, 95\% больных были в возрасте старше 40 лет, а 53\% - старше 60 лет.

У большинства обследованных нами больных (68,5\%) заболевание началось в трудоспособном возрасте от 19 до 60 лет, старше 
61 года всего у 31,5\%. В то время как за специализированной медицинской помощью свыше половины больных (53\%) обратились в возрасте старше 61 года (рис. 67). Обращает на себя внимание тот факт, что пик начала заболевания приходится на возраст от 51 до 60 лет, а пик обращаемости за специализированной медицинской помощью (к неврологу и нейрохирургу) приходится на следующее десятилетие от 61 до 70 лет. Это обусловлено ухудшением течения заболевания, возможно связанным с состоянием нервной и сосудистой системы. Уточнение этого вопроса было одним из предметов нашего исследования.

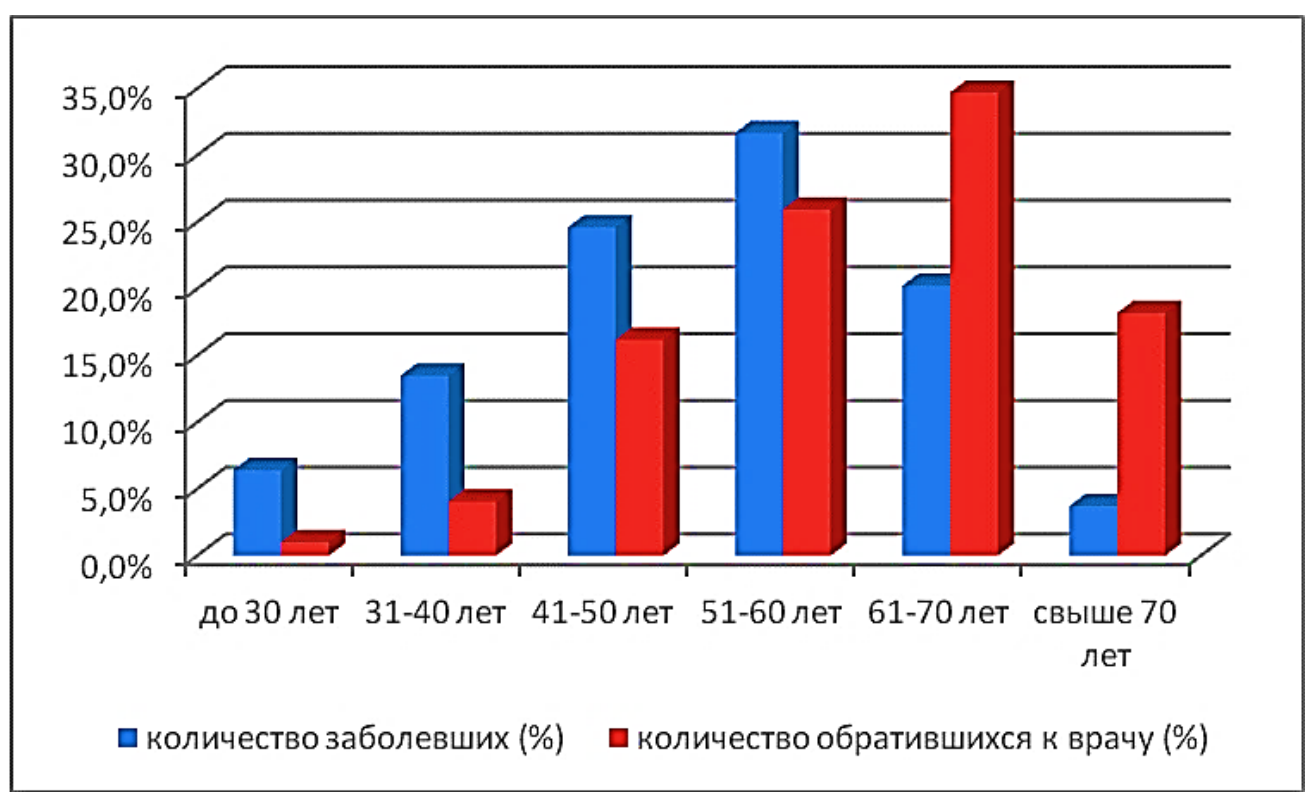

Рис. 67. Распределение (в \%) возраста больных в начале заболевания и во время обращения к исследователю

Исследованный контингент больных мы разделили на три группы.

Первая группа состояла из 200 человек, у которых васкулоневральный конфликт был верифицирован при выполнении им микроваскулярной декомпрессии КТН. Из них 163 человека не подвергались перед выполнением им МВД никаким деструктивным вмешательствам, у остальных 37 человек до поступления в нашу клинику в различных лечебных учреждениях были выполнены деструктивные вмешательства на тройничном нерве (алкоголизация перифериче- 
$106 \mid$ Классическая невралгия тройничного нерва

ских ветвей, деструкция полулунного узла, нервэкзерез, невротомия) с последующим рецидивом заболевания.

Во вторую группу вошли больные с сопутствующими заболеваниями (опухоли задней черепной ямки, рассеянный склероз, артериовенозная мальформация) «симптоматическая НТН» (20 человек), длительное время лечившиеся у различных специалистов как пациенты, страдающие классической НТН.

Третья группа состояла из 78 человек, получивших консервативное лечение в нашей клинике.

\section{1. КЛИНИЧЕСКИЕ ПРОЯВЛЕНИЯ НТН У БОЛЬНЫХ С ВАСКУЛОНЕВРАЛЬНЫМ КОНФЛИКТОМ, НЕ ПОДВЕРГШИХСЯ ДО МВД ДЕСТРУКТИВНЫМ ВМЕШАТЕЛЬСТВАМ}

Первая - основная группа больных (163 человека) представлена различными по структуре вариантами васкулоневрального конфликта. В связи с этим она разделена на 2 подгруппы:

1) механическое воздействие артериальный сосуд оказывал на одну из поверхностей КТН (вентральную или дорзальную);

2) одновременное воздействие сосуды оказывали на обе поверхности КТН вентральную и дорзальную.

Варианты васкулоневрального конфликта при воздействии на одну из поверхностей КТН были различными:

1) конфликт с одним артериальным стволом (1ВМА);

2) конфликт, с двумя артериальными стволами (2BMA);

3) конфликт, с тремя артериальными стволами (3 ВМА);

4) конфликт с веной (Вена).

Общими симптомами у больных всех этих групп были: пароксизмальный характер болей, продолжительность болевой атаки не более 3 минут, наличие триггерных зон, абсолютный рефрактерный период, эффект от терапии карбамазепином (финлепсином, тегретолом) в начальном периоде заболевания. 
Характерно болевое поведение пациента во время приступа. Больной замирает в момент возникновения приступа, стараясь не шевелиться. Во время самого болевого пароксизма лицо больного приобретает маску страдания за счет сокращения мимических и жевательных мышц (рис. 68). Практически у всех больных с верифицированным васкулоневральным конфликтом была защитная реакция на попытку врача прикоснуться к триггерной зоне. Больной либо резко уклоняется от руки врача, либо отстраняет руку исследующего от лица. Этот симптом защиты триггерной зоны описан Штернбергом в 1961 году (цит. по А.В. Степанченко, 1994). В.А. Карлов обозначил его как «симптом-антагонист». У больных с другими формами прозопалгий мы такого симптома не отмечали.
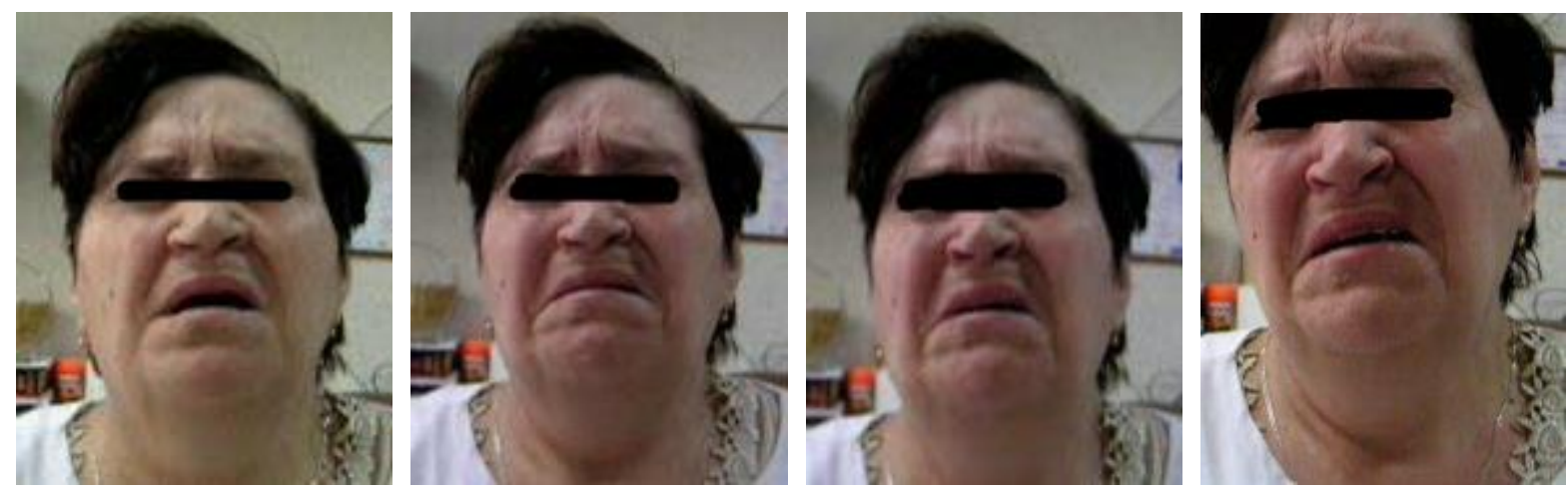

Рис. 68. Невралгия левого тройничного нерва. Этапы болевого пароксизма продолжительностью 10 секунд

\subsection{1. КЛИНИЧЕСКИЕ ПРОЯВЛЕНИЯ НТН У БОЛЬНЫХ С ВАСКУЛОНЕВРАЛЬНЫМ КОНФЛИКТОМ КТН С ОДНИМ АРТЕРИАЛЬНЫМ СТВОЛОМ}

Наиболее частым вариантом васкулоневрального конфликта был конфликт КТН с одним артериальным сосудом чаще ВМА, реже ПНМА. При этом латеральный понтомезенцефальный сегмент ВМА оказывал травмирующее воздействие на вентральную поверхность КТН. Флокулопедункулярный сегмент ПНМА оказывал травмирующее воздействие на дорзальную его поверхность. 


\subsubsection{1. Клинические проявления НТНу больных с васкулоневральным конфликтом КТН с одним стволом ВМА}

Васкулоневральный конфликт с одним артериальным стволом верхней мозжечковой артерии имел место у 111 больных НТН. К корешку в этих случаях прилежало дистальное плечо артериальной петли долихоэктазированной ВМА (латеральный понтомезенцефальный сегмент), причем купол артериальной петли располагался ниже верхнего края КТН. Стремящийся вверх и к средней линии латеральный понтомезенцефальный сегмент ВMА, пересекая КТН, оказывал давление не только на корешок, но и на мост в области воротной зоны корешка (рис. 69, а). С равной частотой ВМА оказывала давление на медиальную треть КТН (рис. 69, б).

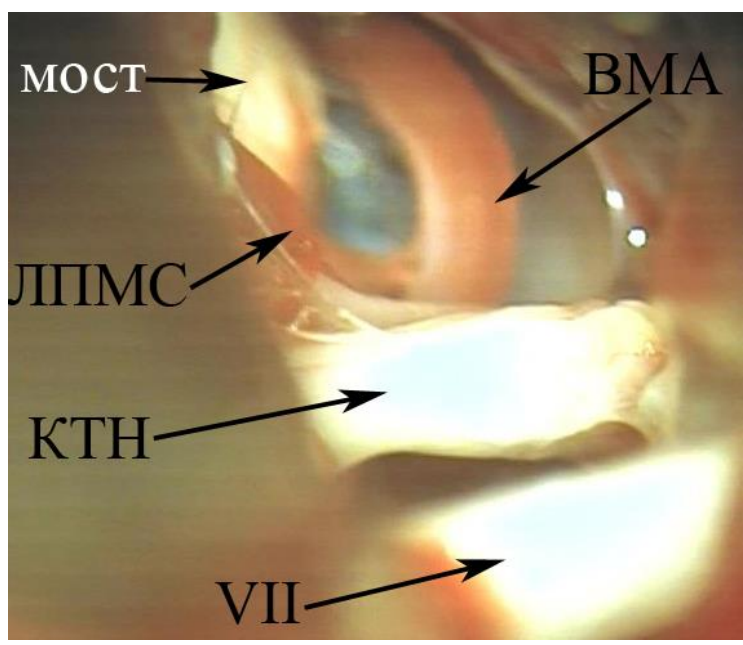

a)

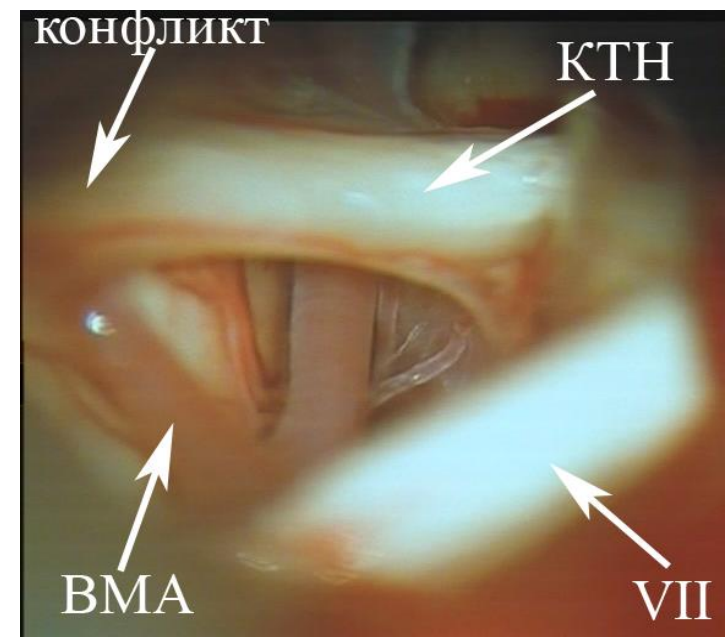

б)

Рис. 69. Конфликт с одной ветвью ВМА: а) больная Р. 61 г. Ист. бол. № 5947. НТН справа. Вершина петли ВМА пересекает половину диаметра КТН снизу вверх в воротной зоне, основное давление оказывая на боковую поверхность моста; б) больная С. 71. Ист. Бол. № 5315 НТН справа. Вершина петли ВМА располагается значительно ниже КТН, а ее понтомезенцефальный сегмент - в воротной зоне

Очень демонстративно механическое воздействие дистального плеча петли BMA на волокна КТН в случае, когда ВМА расщепляет КТН на две части. Повреждающее воздействие на волокна КТН выражено в наибольшей степени в том месте корешка, на которое воз- 
действует наибольшая сила, распрямляющая артериальную петлю в момент систолы (рис. 70). В данном наблюдении это воротная зона место вхождения КТН в мост. В этом месте четко видно истончение КТН и изменение его окраски в связи с демиелинизацией волокон.

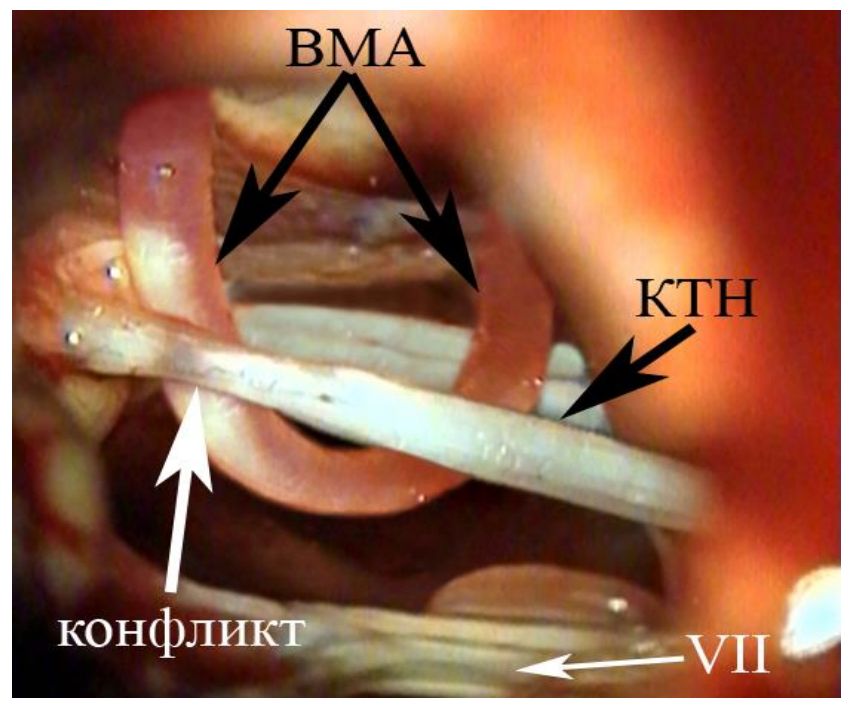

Рис. 70. Больная С. Ист. бол. № 8541. Невралгия правого ТН с локализацией болей в зоне второй ветви. Петля ВМА расщепила КТН на две части.

Очаг демиелинизации и гипотрофии КТН в месте наибольшего механического воздействия на петли артерии

В данной подгруппе 73\% составляли женщины (81 человек) и $27 \%$ - мужчины (30 человек). У 54,1\% (60 человек) боли локализовались справа, у 45,9\% (51 человек) - слева. Большинство больных (81 человека) начало заболевания не связывали с какими-либо предшествующими факторами. Некоторые больные за начало заболевания принимали переохлаждения (18), простудные заболевания (2), стрессовые ситуации (7), удаление зубов (3). Локализация болей по ветвям ТН и частота их встречаемости среди пациентов показана в табл. 1. Локализация триггерных зон приведена в табл. 2.

В табл. 3 приведены статистические показатели, отражающие особенности протекания заболевания у больных данной группы. Интенсивность болей оценивалась больными по ВАШ.

Характерным признаком НТН у этих больных было появление приступов только в дневное время. 
$110 \mid$ Классическая невралгия тройничного нерва

Таблица 1

Частота локализации боли по ветвям ТН у пациентов с васкулоневральным конфликтом с одним стволом ВМА

\begin{tabular}{|c|c|c|}
\hline Локализация боли & Количество пациентов & $\mathbf{\%}$ \\
\hline В области 1 ветви & 2 & 1,8 \\
\hline В области 1 и 2 ветвей & 7 & 6,3 \\
\hline В области 2 ветви & 18 & 16,2 \\
\hline В области 3 ветви & 22 & 19,8 \\
\hline В области 2 и 3 ветвей & 48 & 43,2 \\
\hline В области всех трех ветвей & 14 & 12,6 \\
\hline
\end{tabular}

Таблица 2

Локализация триггерных зон

\begin{tabular}{|l|c|c|}
\hline \multicolumn{1}{|c|}{ Локализация } & Количество пациентов & $\mathbf{\%}$ \\
\hline В области угла рта & 36 & 32,5 \\
\hline В области крыла носа & 21 & 18,9 \\
\hline $\begin{array}{l}\text { В области верхней } \\
\text { и нижней губы }\end{array}$ & 20 & 18 \\
\hline $\begin{array}{l}\text { В области десны верхней } \\
\text { или нижней челюсти }\end{array}$ & 26 & 23,4 \\
\hline В области подбородка & 2 & 1,8 \\
\hline В лобной области & 2 & 1,8 \\
\hline В области зубов & 4 & 3,6 \\
\hline
\end{tabular}

Как видно из табл. 1 и 2 локализация болей в зоне первой ветви была лишь у 2 больных. У этих больных во время микроваскулярной декомпрессии была обнаружена ротация корешка ТН. В остальных случах боли локализовались в зонах 2 и 3 ветвей.

В табл. 3 приведены статистические показатели, отражающие особенности протекания заболевания у больных данной группы. Можно видеть, что заболевание протекало довольно тяжело с сильными и частыми приступами боли, оказывавшими значительное воздействие на повседневную бытовую активность больных. Характерным признаком НТН у этих больных было появление приступов только в дневное время. 
Таблица 3

Особенности проявления НТН у больных с васкулоневральным конфликтом с одним стволом ВМА

\begin{tabular}{|l|c|c|}
\hline \multicolumn{1}{|c|}{ Показатели } & M.m & $\boldsymbol{\sigma}$ \\
\hline Возраст & $60,94 \pm 1,03$ & 10,81 \\
\hline $\begin{array}{l}\text { Продолжительность последнего } \\
\text { обострения (месяцы) }\end{array}$ & $3,73 \pm 0,28$ & 2,94 \\
\hline $\begin{array}{l}\text { Продолжительность } \\
\text { заболевания (годы) }\end{array}$ & $8,59 \pm 0,62$ & 6,53 \\
\hline Интенсивность боли по ВАШ (баллы) & $9,7 \pm 0,2$ & 2,1 \\
\hline $\begin{array}{l}\text { Длительность болевого } \\
\text { пароксизма (сек) }\end{array}$ & $35,50 \pm 3,4$ & 35,9 \\
\hline Частота приступов в течение суток & $36,76 \pm 3,32$ & 35,00 \\
\hline $\begin{array}{l}\text { Шкала оценки повседневной } \\
\text { активности больного до лечения (баллы) }\end{array}$ & $23,25 \pm 0,31$ & 3,30 \\
\hline
\end{tabular}

Провоцирующими факторами была повседневная бытовая активность больного: разговор, бритье (макияж), прием пищи и т.п. Двое больных $(1,8 \%)$ из этой группы поступили в клинику в состоянии невралгического статуса. Обе больные были женщинами в возрасте 50 лет и 63 лет. Возникновение невралгического статуса у них можно объяснить истощением антиноцицептивной системы в результате резкого смещения количественного соотношения миелинизированных и немиелинизированных волокон КТН в сторону увеличения демиелинизированных волокон как в результате возрастного апоптоза (больная 63 лет), так и в результате длительно функционировавшего васкулоневрального конфликта (продолжительность заболевания у другой больной - 23 года).

\subsubsection{2. Клинические проявления НТН у больных} с васкулоневральным конфликтом с одним стволом ПНМА

Конфликт с одним стволом передней нижней мозжечковой артерии (рис. 71) имел место у двух больных НТН. Обе пациентки женщины, боли локализовались у обеих больных с левой стороны, у одной - в зоне второй ветви, у другой - в зонах второй и третьей 
$112 \mid$ Классическая невралгия тройничного нерва

ветвей. Начало заболевания обе женщины не связывали с какимилибо факторами. У первой больной триггерная зона находилась в области десны верхней челюсти, у второй - в области угла рта. У первой больной продолжительность болевого пароксизма составляла 20 секунд с частотой свыше 20 приступов в день. У второй больной серия по 8-10 приступов на протяжении 3 минут с частотой 4 серии приступов в день.

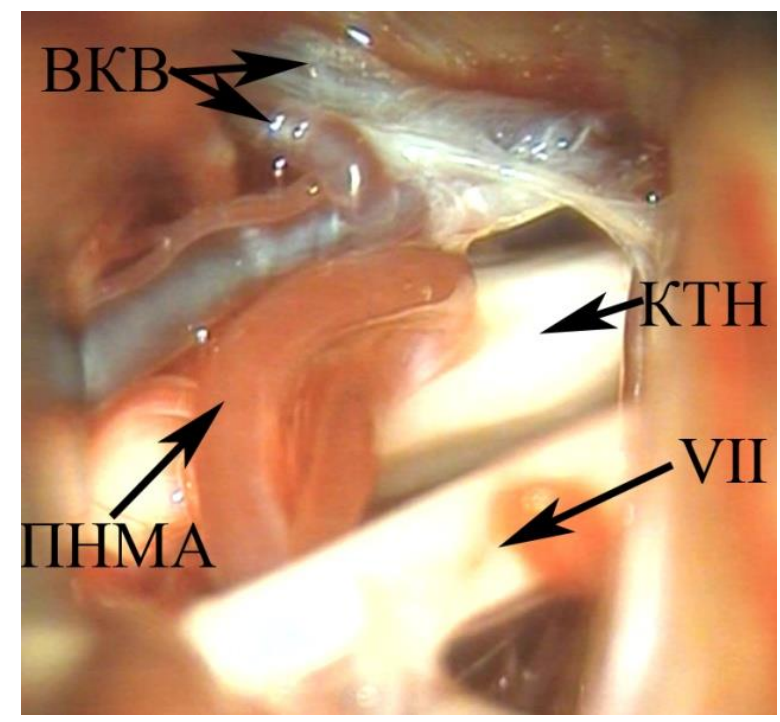

Рис. 71. Больная С. Ист. бол. № 1773. НТН справа с локализацией болей в зонах второй и третьей ветвей. Плоскость петли НПМА расположена перпендикулярно по отношению к плоскости КТН

В ночное время у обеих больных приступов не наблюдалось. Клинические проявления НТН у больных с конфликтом ПНМА с дорзальной поверхностью КТН не отличались от клиники НТН у больных с конфликтом ВМА с вентральной поверхностью КТН.

\subsection{2. КЛИНИЧЕСКИЕ ПРОЯВЛЕНИЯ НТН У БОЛЬНЫХ С ВАСКУЛОНЕВРАЛЬНЫМ КОНФЛИКТОМ ВЕНТРАЛЬНОЙ ПОВЕРХНОСТИ КТН С ДВУМЯ СТВОЛАМИ ВМА}

Конфликт КТН с двумя артериальными стволами ВМА обнаружен у 20 больных. Васкулоневральный конфликт с двумя стволами BMA может наблюдаться при нескольких вариантах ее строения: 
чаще всего в случае ее деления на ветви второго порядка в области переднего понтомезенцефального сегмента, реже - при двуствольном ее отхождении от базилярной артерии. На рис. 72 представлено наблюдение, когда вершины петель ВМА и ее ветви второго порядка находились ниже верхнего края КТН.

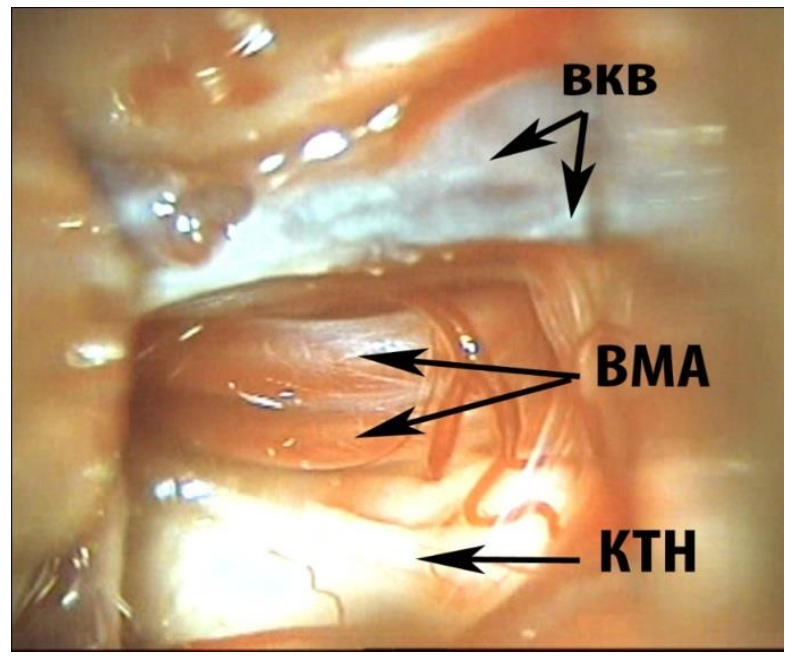

Рис. 72. Больная Е. Ист. бол. № 2070. НТН справа с локализацией болей в зонах второй и третьей ветвей. Конфликт с двумя ветвями ВМА. Вершины петель ВМА на уровне нижнего края КТН. Представлен этап МВД, когда оба ствола ВМА смещены в пространство между КТН и наметом мозжечка

На рис. 73 представлено наблюдение больной с НТН справа, когда вершины обеих петель ВМА располагались ниже нижнего края КТН.

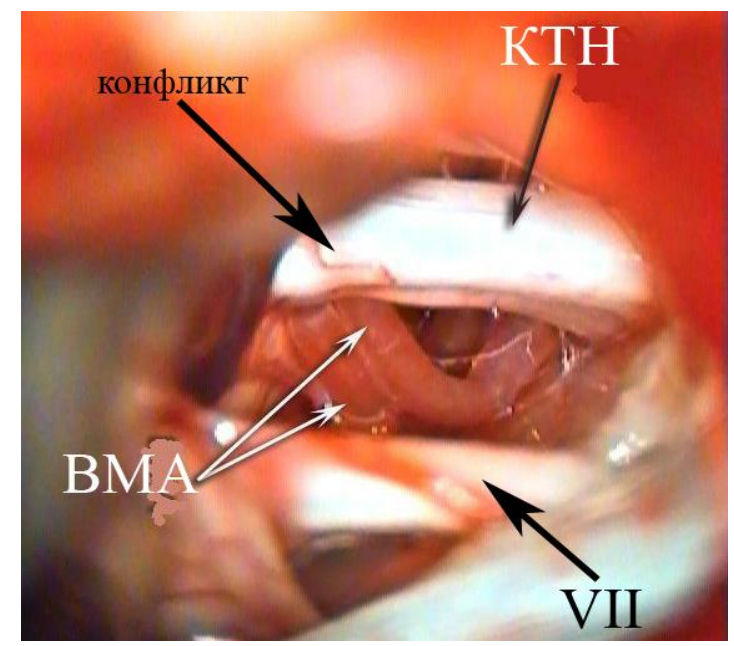

Рис. 73. Больная Т. Ист. бол. № 1191. НТН справа с локализацией болей в зоне второй ветви. Конфликт с двумя ветвями ВМА. Вершины петель ВМА значительно ниже нижнего края КТН. Латеральные плечи обеих петель оказывают механическое воздействие на КТН в области воротной зоны 
114 Классическая невралгия тройничного нерва

Рис. 74 иллюстрирует расположение петли ВМА значительно ниже нижнего края КТН, при этом деление артерии на ветви второго порядка происходит в области латерального понтомезенцефального сегмента ВМА и в конфликт с КТН вступают два артериальных ствола. Локализация болей по ветвям приведена в табл. 4.

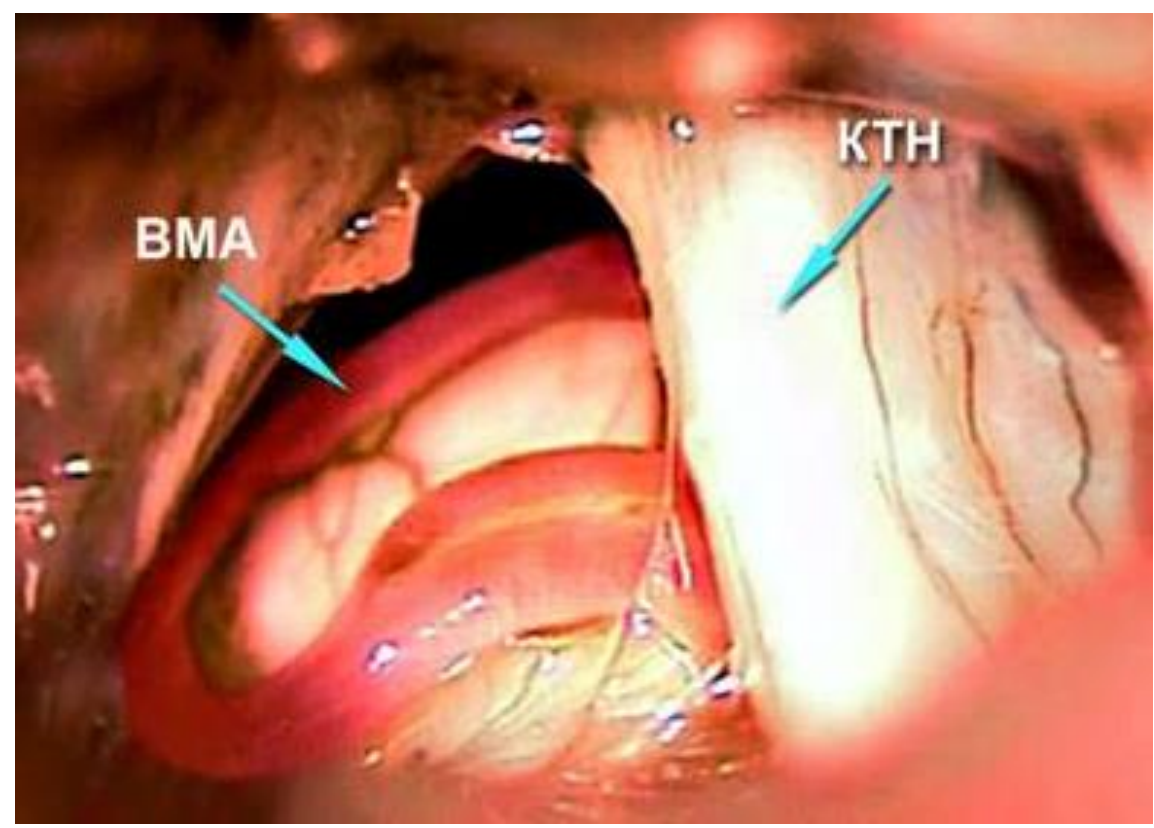

Рис. 74. Больная С. Ист. бол. № 2876. НТН слева с локализацией болей в зонах второй и третьей ветвей. Конфликт КТН с двумя вторичными стволами ВМА. Деление основного ствола ВМА происходит в области латерального понтомезенцефального сегмента

Таблица 4

Частота локализации боли по ветвям ТН у пациентов с васкулоневральным конфликтом с двумя стволами ВМА

\begin{tabular}{|l|c|c|}
\hline \multicolumn{1}{|c|}{ Локализация боли } & Количество пациентов & \% \\
\hline В области 1 ветви & 1 & 5 \\
\hline В области 1 и 2 ветвей & 2 & 10 \\
\hline В области 2 ветви & 2 & 10 \\
\hline В области 3 ветви & 3 & 15 \\
\hline В области 2 и 3 ветвей & 11 & 55 \\
\hline В области всех трех ветвей & 1 & 5 \\
\hline
\end{tabular}


Большинство больных (15 человек) начало заболевания не связывало с какими-либо предшествующими факторами. Некоторые больные за причину заболевания принимали переохлаждение (2), простудные заболевания (1), стрессовые ситуации (1), удаление зубов (2). У большинства больных этой группы триггерные зоны располагались в периоральной области (табл. 5)

Таблица 5

Локализация триггерных зон у больных с двумя стволами ВМА

\begin{tabular}{|l|c|c|}
\hline \multicolumn{1}{|c|}{ Локализация } & Количество пациентов & \% \\
\hline В области угла рта & 4 & 20 \\
\hline В области крыла носа & 7 & 35 \\
\hline В области верхней и нижней губы & 4 & 20 \\
\hline $\begin{array}{l}\text { В области десны верхней } \\
\text { или нижней челюсти }\end{array}$ & 4 & 20 \\
\hline В волосистой части лобной области & 1 & 5 \\
\hline
\end{tabular}

У двух человек, страдавших гипертонической болезнью, отмечалось увеличение частоты приступов (на 5 и 10 в день) и усиление интенсивности боли во время подъемов артериального давления, вероятно, в связи с усилением травмирующего воздействия артериальной петли на КТН при более высоких цифрах АД.

Количественные характеристики продолжительности последнего обострения заболевания, количества и продолжительности болевых пароксизмов у пациентов с васкулоневральным конфликтом с двумя стволами ВМА приведены в табл. 6.

Двое из этой группы больных (10\%) поступили в состоянии невралгического статуса. Одна больная - женщина 61 года с продолжительностью заболевания 8 лет, второй больной - мужчина 50 лет с продолжительностью заболевания 10 лет. Причиной невралгического статуса, как и в предыдущей группе больных, видимо, было истощение антиноцицептивной системы в результате смещения количественного соотношения волокон КТН в сторону преобладания немиелинизированных и потерявших миелиновую оболочку волокон. 
$116 \mid$ Классическая невралгия тройничного нерва

Таблица 6

Особенности проявления НТН у больных с васкулоневральным конфликтом с двумя стволами ВМА

\begin{tabular}{|l|c|c|}
\hline \multicolumn{1}{|c|}{ Показатели } & $\boldsymbol{M \pm m}$ & $\boldsymbol{\sigma}$ \\
\hline Возраст & $62,70 \pm 2,66$ & 11,89 \\
\hline $\begin{array}{l}\text { Продолжительность последнего } \\
\text { обострения (месяцы) }\end{array}$ & $3,30 \pm 0,34$ & 1,53 \\
\hline Продолжительность заболевания (годы) & $7,50 \pm 1,27$ & 5,70 \\
\hline Интенсивность боли по ВАШ (баллы) & $9,75 \pm 0,12$ & 0,55 \\
\hline Длительность болевого приступа (сек) & $30,90 \pm 10,01$ & 27,44 \\
\hline Частота приступов в течение суток & $27,05 \pm 5,42$ & 24,26 \\
\hline $\begin{array}{l}\text { Шкала оценки повседневной активности } \\
\text { больного до лечения (баллы) }\end{array}$ & $25,20 \pm 0,68$ & 3,04 \\
\hline
\end{tabular}

\subsection{3. КЛИНИЧЕСКИЕ ПРОЯВЛЕНИЯ НТН У БОЛЬНЫХ С ВАСКУЛОНЕВРАЛЬНЫМ КОНФЛИКТОМ КТН С ТРЕМЯ АРТЕРИАЛЬНЫМИ СТВОЛАМИ}

Васкулоневральный конфликт с участием трех артериальных стволов ВМА, оказывавших травмирующее воздействие на вентральную поверхность КТН, наблюдался у трех человек (рис. 75).

Среди них было двое женщин и один мужчина. Справа боли локализовались у двух человек, слева - у одного. В области второй и третьей ветвей боли были у 2 человек, в области третьей ветви у одного. Продолжительность заболевания у одного - 2 года, у двух - 6 лет. Двое больных начало заболевания связывали с переохлаждением.

Триггерные зоны локализовались у двух больных в области угла рта, у одного больного - в области нижней губы. Интенсивность боли по ВАШ у всех больных составляла 10 баллов. Продолжительность приступов от 3 до 10 секунд с частотой от 30 до 60 в день (табл. 7). 


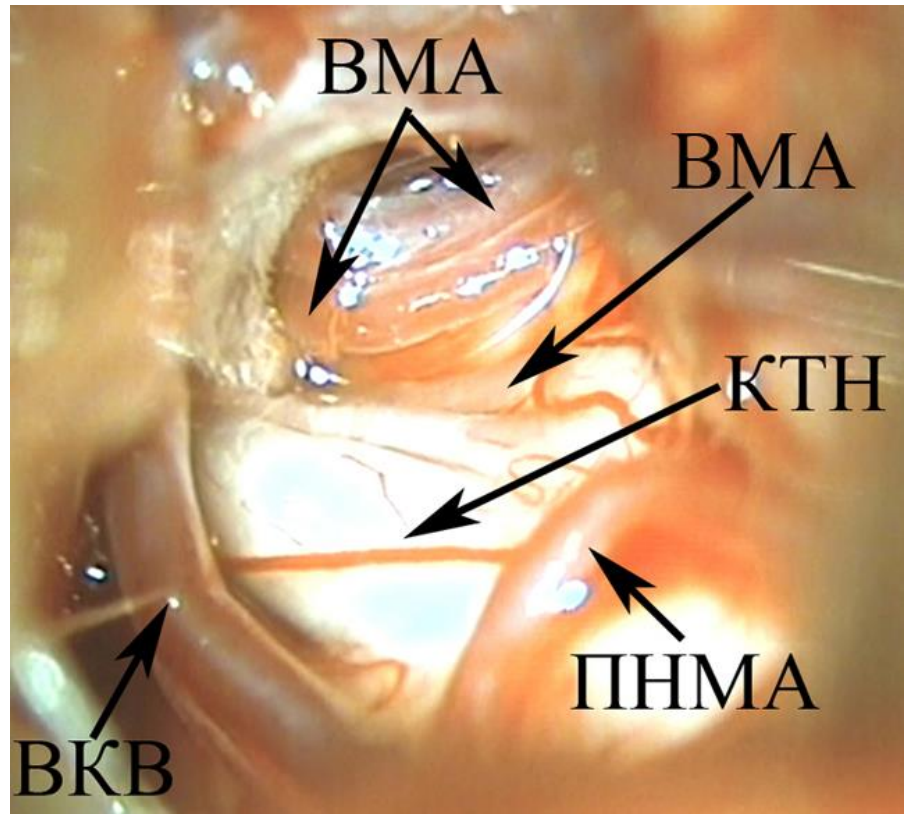

Рис. 75. Больной Е. Ист. бол. № 3144. НТН слева с локализацией болей в зонах второй и третьей ветвей. Конфликт с тремя стволами ВМА. Каждая стрелка указывает на один из стволов

Таблица 7

Особенности проявления НТН у больных с васкулоневральным конфликтом с тремя стволами ВМА

\begin{tabular}{|l|c|c|}
\hline \multicolumn{1}{|c|}{ Показатели } & $\boldsymbol{M \pm m}$ & $\boldsymbol{\sigma}$ \\
\hline Возраст & $53,3 \pm 3,2$ & 5,5 \\
\hline $\begin{array}{l}\text { Продолжительность последнего обострения } \\
\text { (месяцы) }\end{array}$ & $2,3 \pm 0,9$ & 1,5 \\
\hline Продолжительность заболевания (годы) & $4,7 \pm 1,3$ & 2,3 \\
\hline Интенсивность боли по ВАШ (баллы) & $10,0 \pm 0,0$ & 0,0 \\
\hline Длительность болевого пароксизма (сек) & $21,0 \pm 14,6$ & 25,4 \\
\hline Частота приступов в течение суток & $46,7 \pm 8,8$ & 15,3 \\
\hline $\begin{array}{l}\text { Шкала оценки повседневной активности } \\
\text { больного до лечения (баллы) }\end{array}$ & $25,3 \pm 1,5$ & 2,5 \\
\hline
\end{tabular}

При конфликте вентральной поверхности КТН с тремя артериальными стволами ВМА сохраняются основные особенности, характерные для ноциогенного воздействия артериального сосуда на КТН с одной стороны: локализация триггерных зон в перио- 
118 Классическая невралгия тройничного нерва

ральной области, преобладание локализации болей в зонах третьей и второй ветвей как вместе, так и в отдельности, возникновение приступов в дневное время. Обращает на себя внимание высокая частота приступов.

\subsection{4. КЛИНИЧЕСКИЕ ПРОЯВЛЕНИЯ НТН У БОЛЬНЫХ С ВАСКУЛОНЕВРАЛЬНЫМ КОНФЛИКТОМ КТН С ВЕРХНЕЙ КАМЕНИСТОЙ ВЕНОЙ}

Васкулоневральный конфликт КТН с верхней каменистой веной имел место у 6 больных, среди них мужчин было 4 человека и женщин - 2, в возрасте от 36 до 71 года. У всех шестерых больных боли локализовались справа, по-видимому, это обусловлено большим диаметром ВКВ и правого сигмовидного синуса. Возникновение НТН один больной связывал с переохлаждением, двое - с перенесенной стрессовой ситуацией. Трое больных не связывали с каким-либо предшествующим фактором начало своего заболевания.

Количественные характеристики продолжительности последнего обострения, заболевания, количества и продолжительности болевых пароксизмов у пациентов с васкулоневральным конфликтом с верхней каменистой веной приведены в табл. 8, локализация триггерных зон - в табл. 9, особенности клинических проявления НТН в табл. 10.

Таблица 8

Частота локализации боли по ветвям ТН у пациентов с васкулоневральным конфликтом КТН с верхней каменистой веной

\begin{tabular}{|l|c|c|}
\hline \multicolumn{1}{|c|}{ Локализация боли } & Количество пациентов & $\mathbf{\%}$ \\
\hline В области 1 ветви & 1 & 17 \\
\hline В области 2 ветви & 2 & 33 \\
\hline В области 2 и 3 ветвей & 3 & 50 \\
\hline Всего & 6 & 100 \\
\hline
\end{tabular}


Локализация триггерных зон у пациентов с васкулоневральным конфликтом КТН с верхней каменистой веной

\begin{tabular}{|l|c|c|}
\hline \multicolumn{1}{|c|}{ Локализация } & Количество пациентов & \% \\
\hline В области угла рта & 2 & 33 \\
\hline В области крыла носа & 1 & 17 \\
\hline В области подбородка и нижней губы & 2 & 33 \\
\hline В лобной области & 1 & 17 \\
\hline Всего & 6 & 100 \\
\hline
\end{tabular}

Особенности проявления НТН у больных с васкулоневральным конфликтом КТН с верхней каменистой веной

\begin{tabular}{|l|c|c|}
\hline \multicolumn{1}{|c|}{ Показатели } & $\boldsymbol{M \pm m}$ & $\boldsymbol{\sigma}$ \\
\hline Возраст & $55,33 \pm 5,65$ & 13,84 \\
\hline $\begin{array}{l}\text { Продолжительность последнего обострения } \\
\text { (месяцы) }\end{array}$ & $3,50 \pm 0,62$ & 1,52 \\
\hline Продолжительность заболевания (годы) & $8,00 \pm 3,73$ & 9,14 \\
\hline Активность боли по ВАШ (баллы) & $9,00 \pm 0,63$ & 1,55 \\
\hline Длительность болевого пароксизма (сек) & $25,33 \pm 6,46$ & 15,83 \\
\hline Частота приступов в течение суток & $23,83 \pm 6,83$ & 16,74 \\
\hline $\begin{array}{l}\text { Шкала оценки повседневной активности } \\
\text { больного до лечения (баллы) }\end{array}$ & $24,83 \pm 0,98$ & 2,40 \\
\hline
\end{tabular}

В отличие от больных с конфликтом КТН с артериальным сосудом, у трех из 6 пациентов с конфликтом КТН с веной отмечалось учащение приступов и увеличение интенсивности болевых пароксизмов в горизонтальном положении, в ночное время. Можно отметить также относительно меньшую интенсивность и длительность болевых пароксизмов, частоту приступов в этой группе больных. 


\subsection{5. КЛИНИЧЕСКИЕ ПРОЯВЛЕНИЯ НТН У БОЛЬНЫХ С ВАСКУЛОНЕВРАЛЬННЫМ КОНФЛИКТОМ ВЕНТРАЛЬНОЙ ПОВЕРХНОСТИ КТН С АРТЕРИЯМИ МОЗЖЕЧКА, А ДОРЗАЛЬНОЙ - С ВЕРХНЕЙ КАМЕНИСТОЙ ВЕНОЙ (АРТЕРИО-ВЕНОЗНЫЙ СЭНДВИЧ)}

У 12 больных при МВД выявлен феномен «сэндвича» (как его называют в англоязычной литературе), т.е. КТН оказался заключенным между артериальным стволом (или стволами) спереди и верхней каменистой веной сзади (рис. 76, 77, 78). У 9 больных в конфликте принимал участие один ствол ВМА, у одной больной - два ствола ВМА, у двух больных помимо этих сосудов в конфликте принимала участие базилярная артерия. Трое (25\%) из этой группы больных поступили в состоянии невралгического статуса.

Если принять во внимание, что артериальный сосуд осуществляет ритмические удары по корешку, синхронно систоле («молот»), а ВКВ препятствует возможности смещения корешка от этих ударов («наковальня), то этот феномен можно назвать феноменом «молота и наковальни» (рис. 76, 77).

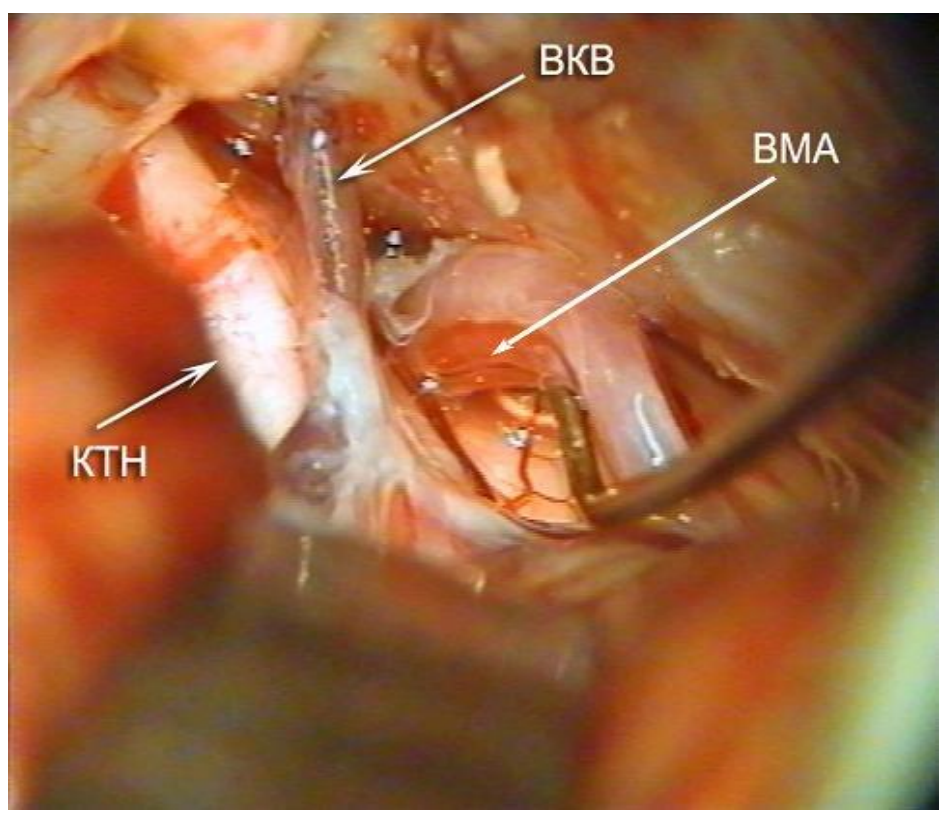

Рис. 76. Больной С. Ист. бол. № 7036. Невралгия левого тройничного нерва. Артериовенозный «сэндвич» (феномен «молота и наковальни») 
Из 10 больных, у которых в конфликте с передней поверхностью КТН принимала участие ВМА, а с дорзальной - ВКВ, женщин было 7, мужчин - 3. Боли локализовались справа у 7 и слева у 3 больных. Боли были в зоне второй ветви у 2 человек, второй и третьей ветви - у 6, в зоне всех трех ветвей - у 2. В табл. 11 приведены статистические показатели, отражающие особенности протекания заболевания с данным видом конфликта.

Таблица 11

Особенности проявления НТН у больных с васкулоневральным конфликтом вентральной поверхности КТН с артериями мозжечка, а дорзальной - с верхней каменистой веной

\begin{tabular}{|l|c|c|}
\hline \multicolumn{1}{|c|}{ Показатели } & $\boldsymbol{M \pm m}$ & $\boldsymbol{\sigma}$ \\
\hline Возраст & $59,33 \pm 2,66$ & 9,22 \\
\hline $\begin{array}{l}\text { Продолжительность последнего обострения } \\
\text { (месяцы) }\end{array}$ & $3,17 \pm 0,53$ & 1,85 \\
\hline Продолжительность заболевания (годы) & $7,83 \pm 1,57$ & 5,42 \\
\hline Интенсивность боли по ВАШ (баллы) & $9,92 \pm 0,08$ & 0,29 \\
\hline Длительность болевого пароксизма (сек) & $39,20 \pm 10,8$ & 37,3 \\
\hline Частота приступов в течение суток & $84,4 \pm 28,23$ & 90,80 \\
\hline $\begin{array}{l}\text { Шкала оценки повседневной активности } \\
\text { больного до лечения (баллы) }\end{array}$ & $26,42 \pm 0,88$ & 3,06 \\
\hline
\end{tabular}

В качестве клинических особенностей течения заболевания в этой группе больных можно отметить очень высокую частоту приступов. В отличие от других форм конфликта при артериовенозном «сэндвиче» болевые пароксизмы отмечались круглосуточно. При этом учащение приступов у этих больных происходило в горизонтальном положении тела независимо от времени суток. Известно, что в вертикальном положении человека венозное давление в системе верхней полой вены отрицательное, в то время как в горизонтальном - положительное. В горизонтальном положении ВКВ наполняется кровью и оказывает давление на КТН, приближая его к артериальной петле, что усиливает при каждой систоле механическое 
$122 \mid$ Классическая невралгия тройничного нерва

воздействие артериального сосуда на КТН. Этой анатомической особенностью васкулоневрального конфликта («сэндвич») можно объяснить увеличение частоты приступов и усиление интенсивности боли в горизонтальном положении. В качестве примера приводим одно из наших наблюдений.

Больная С. 57 лет. История болезни № 5422. Поступила в клинику РостГМУ 10.06.2009 г. с жалобами на резкие боли стреляющего характера «как удар электрическим током» продолжительностью около 1 секунды в области нижней губы и десны нижней челюсти справа.

На фоне приема финлепсина в суточной дозе 600 мг частота приступов составляла свыше 20 в сутки. Увеличивать дозу финлепсина больная не могла из-за выраженных побочных явлений в виде головокружения и неустойчивости при ходьбе. В ночное время болевые пароксизмы провоцировались положением головы на правой стороне. Днем в вертикальном положении наклон головы вперед и вниз также провоцировал болевой пароксизм. Болеет в течение 3 лет с обострениями весной и осенью. Интенсивность боли по ВАШ оценивала в 7 баллов. Ввиду выраженного болевого синдрома и отсутствия эффекта от приема финлепсина больная настаивала на хирургическом лечении. Ей была выполнена СКТ ангиография, подтвердившая васкулоневральный конфликт ВМА и КТН. С диагнозом «классическая невралгия правого тройничного нерва с локализацией болей в зоне 3 ветви» 10.06.2009 г. больной была выполнена микроваскулярная декомпрессия КТН. При этом обнаружен васкулоневральный конфликт в виде «молота и наковальни»: с вентральной стороны на КТН ноциогенное воздействие оказывала ВМА. Прилежащие к дорзальной поверхности КТН два ствола ВКВ препятствовали компенсаторному смещению КТН дорзально (рис. 77, а). Медиальный ствол ВКВ был коагулирован и пересечен (рис. 77, б), после чего обнаружен второй васкулоневральный конфликт - с ВМА, который также был устранен. Сразу после пробуждения от наркоза боли исчезли. В удовлетворительном состоянии 22.06.2009 г. больная выписана домой. При осмотре в феврале 2012 года жалоб не предъявляла. 


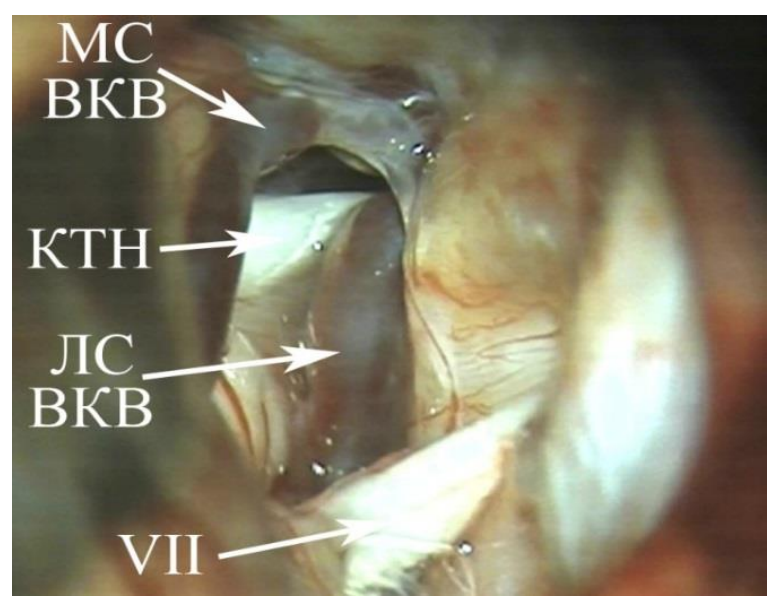

a)

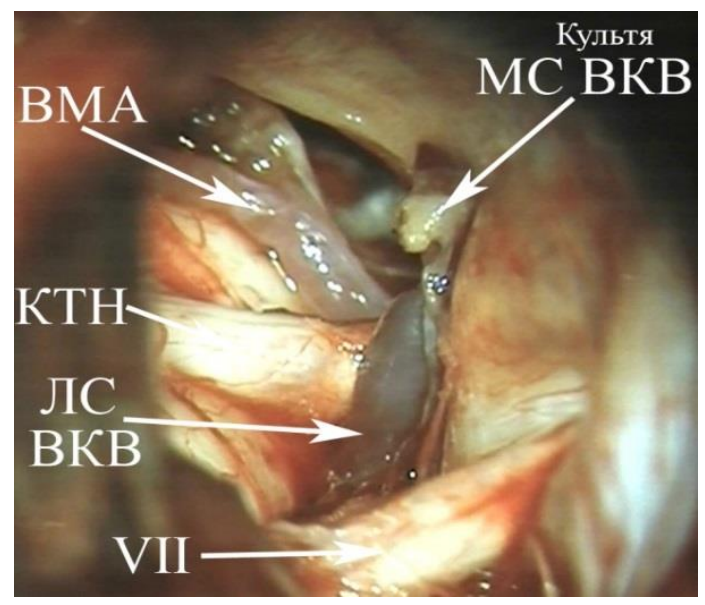

б)

Рис. 77. Больная С. 57 лет. Ист. бол. № 5422. НТН справа. Васкулоневральный конфликт с одной ветвью ВМА: а) ВКВ препятствует смещению КТН от Ударов

ВМА и поиску васкулоневрального конфликта; б) после пересечения ВКВ обнаружен конфликт ВМА с латеральной третью КТН. Феномен «молота и наковальни»

Данное наблюдение иллюстрирует вклад венозного компонента васкулоневрального конфликта в особенности течения заболевания - возникновение приступов боли во время сна и поворота головы направо и при опускании головы в дневное время, оба эти фактора вызывает большее наполнение ВКВ.

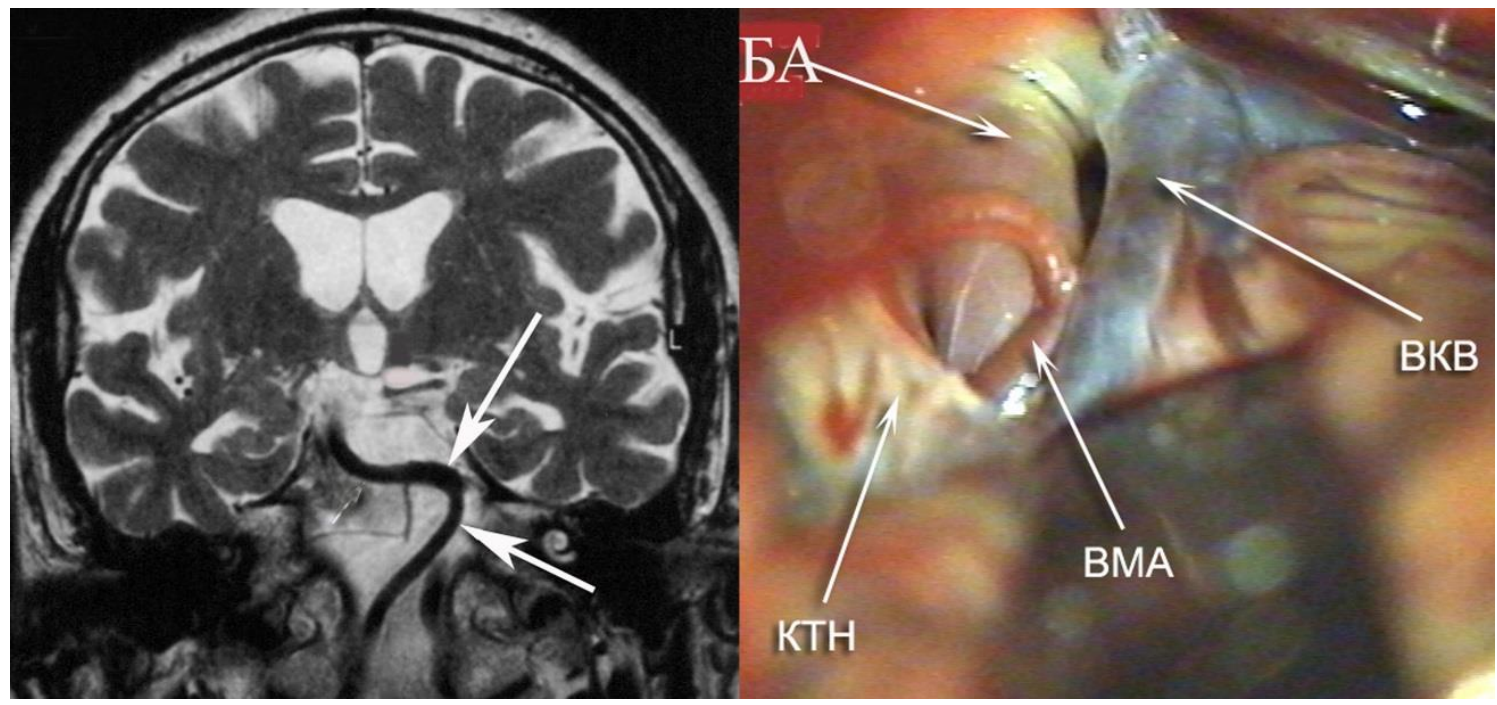

a)

б)

Рис. 78. Больной Ф. 67 лет. Ист. Бол. № 210/35 петля ВМА и долихоэктазированная БА оказывают травмирующее воздействие на левый

КТН: а) МРТ; б) интраоперационная верификация васкулоневрального конфликта: БА - базилярная артерия, ВМА - верхняя мозжечковая артерия, ВКВ - верхняя каменистая вена, КТН - корешок тройничного нерва 
124 Классическая невралгия тройничного нерва

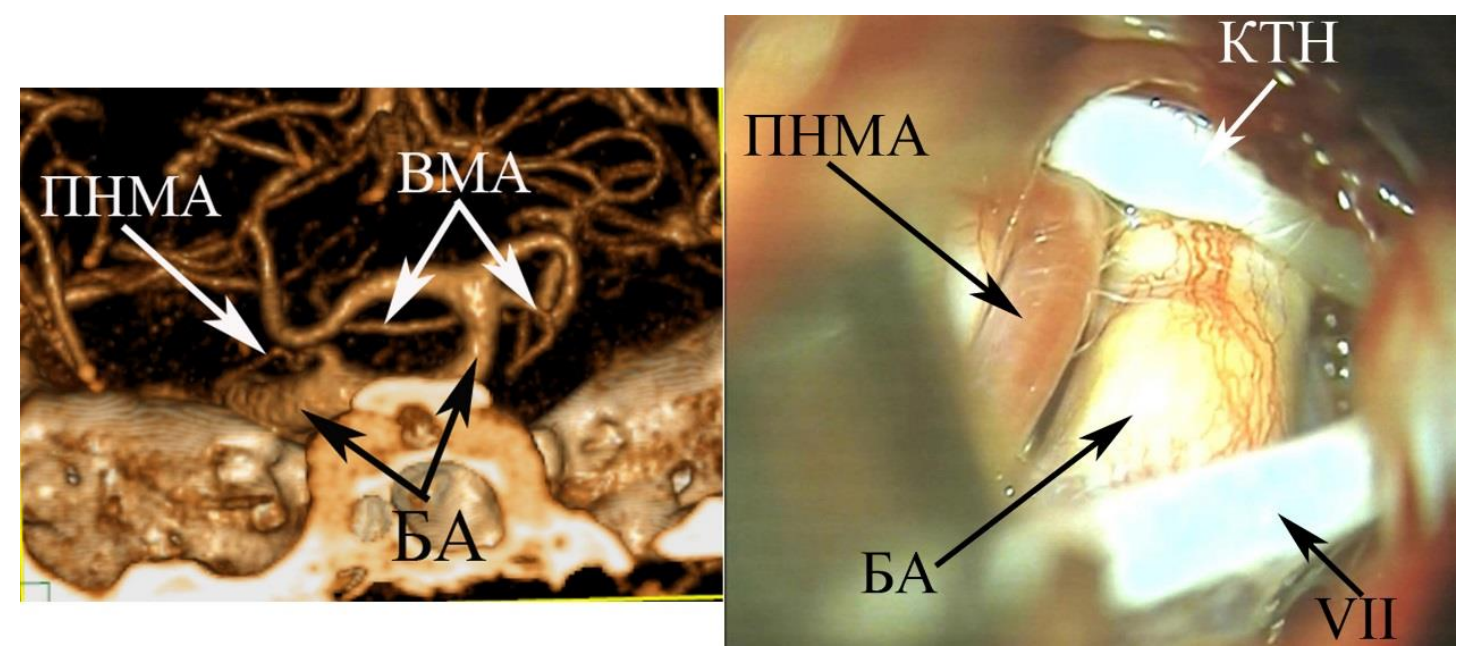

a)

б)

Рис. 79. Больная Т. 55 лет. Ист. бол. № 914/149, ПНМА и долихоэктазированная БА оказывают травмирующее воздействие на правый КТН: а) спиральная компьютерная ангиография; б) БА - базилярная артерия, ПНМА - передняя нижняя мозжечковая артерия, КТН - корешок тройничного нерва

У двух наблюдавшихся нами больных в васкулоневральноном конфликте с вентральной поверхности КТН принимала участие, кроме ПНМА и ВМА, долихоэктазированная базилярная артерия, а ВКВ - с дорзальной (рис. 78, 79). Краткое содержание историй болезней пациентов с долихоэктазией БА отображает клинические особенности изучаемой структуры васкулоневрального конфликта. Приводим одно наблюдение.

Больная Т. 55 лет. Ист. бол. № 914/149. Больна в течение 7 лет, когда после стрессовой ситуации (смерть отца) возникли постоянные ноющие боли в области правой половины лба, верхнего века, щеки и крыла носа, на фоне которых возникали прострелы сильнейших болей продолжительностью несколько секунд по типу «удара молнии» с частотой до 100 прострелов в сутки.

Приступы боли возникали круглосуточно, хотя в ночное время интенсивность их была меньше. Лечилась амбулаторно, постоянно принимая финлепсин. Периодически получала витамины группы В, капельницы с аналгетиками, амитриптилин. Медикаментозные ремиссии были короткими - от 1 до 3 месяцев. При поступлении в клинику нервных болезней и нейрохирургии РостГМУ частота болевых пароксизмов более 100 в сутки. Интенсивность боли по ВАШ - 
10 баллов. При неврологическом обследовании выявлена гипералгезия в зонах первой и второй ветвей ТН справа. При повышении АД (до 220/170 мм рт. ст.) частота и интенсивность болевых пароксизмов нарастала. Приступы провоцировались разговором, туалетом полости рта, приемом пищи. Триггерные зоны в области крыла носа, щеки, верхней губы, верхнего века и брови. Пациентке была выполнена СРК ангиография, которая выявила не только конфликт КТН с БА, но и участие в васкулоневральном конфликте ПНМА. Интраоперационно при МВД подтвержден конфликт КТН с долихоэктазированной БА и ПНМА. ПНМА проходила в месте васкулоневрального конфликта вдоль БА ближе к воротной зоне КТН (рис. 79). Обе артерии оказывали травмирующее воздействие на КТН. После пробуждения от наркоза приступов болей не отмечалось. При осмотре через год состояние удовлетворительное, болей нет.

В приведенном наблюдении характерными для классической HТН были: пароксизмальных характер приступов, наличие триггерных зон, длительный ремитирующий характер заболевания, относительная эффективность на ранних этапах заболевания карбамазепина. В то же время, у больной были выявлены признаки невропатии: гипоалгезия в зонах боли, постоянный характер болей в межприступном периоде, наличие болевых пароксизмов и в ночное время с нарушением сна. В отличие от симптоматической НTH, у больных с конфликтом КТН с БА, симптомы, характерные для НТН, сочетались с симптомами, присущими невропатии тройничного нерва, однако при этом отсутствовали признаки поражения смежных мозговых структур. Эти клинические особенности дают возможность заподозрить участие в конфликте базилярной артерии уже на стадии неврологического осмотра.

4.1.6. КЛИНИЧЕСКИЕ ПРОЯВЛЕНИЯ НТН У БОЛЬНЫХ С ВАСКУЛОНЕВРАЛЬНЫМ КОНФЛИКТОМ ВЕНТРАЛЬНОЙ ПОВЕРХНОСТИ КТН С ВМА И ДОРЗАЛЬНОЙ - С ПНМА («АРТЕРИО-АРТЕРИАЛЬНЫЙ СЭНДВИЧ»)

Этот тип васкулоневрального конфликта наблюдался у 9 больных. В трех случаях с вентральной поверхностью КТН имел место 
$126 \mid$ Классическая невралгия тройничного нерва

конфликт с одним стволом ВМА, а в 6 случаях - с двумя. При такой структуре васкулоневрального конфликта травмирующее воздействие на корешок с вентральной стороны оказывает понтомезенцефальный сегмент ВМА, а с дорзальной стороны ПНМА. КТН в этой ситуации оказывается под травмирующим воздействием с двух сторон, находясь как бы между двумя «молотами» своего рода «артериоартериальный сэндвич» (ААсэндвич). Конфликт с одним стволом ВМА и ПНМА был у трех мужчин, у одного боли локализовались справа и у двух - слева. В области 1 и 2 ветвей боли локализовались у 1 человека, в области 2 и 3 ветвей - у 1, и в области всех трех ветвей - у 1 больного.

Начало заболевания не связывали с какими-либо предшествующими факторами 2 человека, с удаление зуба развитие болезни связывал 1 больной.

Локализация триггерных зон была различной: в области угла рта - у 1 человека, крыла носа - у 1 и десны нижней челюсти - у 1 больного.

У одного пациента, страдавшего гипертонической болезнью, отмечалось увеличение частоты приступов (на 15 в день) и усиление интенсивности боли во время подъемов артериального давления. Продолжительность заболевания у них составляла 6, 8 и 15 лет. Частота приступов 30, 60 и 150 в день. Продолжительность приступов от 2 до 10 секунд. В качестве примера тяжести клинического течения НТН при наличии компрессии КТН двумя сосудами с разных сторон («артерио-артериальный сэндвич») приводим одно из наших наблюдений.

Больной П. 67 лет. История болезни № 10460/160. Поступил в клинику нейрохирургии РостГМУ 11.04.2002 г. с жалобами на постоянные боли режущего, жгучего характера в правой половине лица, на фоне которых проходили до 60-100 раз в день острые боли стреляющего характера по типу «удара электрическим током», продолжительностью 1-2 секунды. Приступы провоцировались прикосновением к левой носогубной складке, десне нижней челюсти, приемом пищи, разговором, туалетом лица и полости рта. Болен в тече- 
ние 8 лет. Впервые прострелы появились в правой половине лица, со временем становились интенсивнее и чаще. В течение последних 5 лет кроме прострелов стали беспокоить постоянные режущие, жгучие боли. Прием финлепсина до 1000 мг в день существенного облегчения не приносил.

Подобное состояние продолжалось в течение последнего года перед поступлением в клинику. Потеря массы тела за последние месяцы составила 16 кг. Интенсивность боли по ВАШ была 10 баллов. При неврологическом обследовании очаговых симптомов не было выявлено. Во время операции МВД (рис. 80) обнаружен и устранен васкулоневральный конфликт с двумя артериальными стволами: с вентральной стороны на КТН ноциогенное воздействие оказывал понтомезенцефальный сегмент ВМА, с дорзальной - ствол ПНМА (артериальный «сэндвич»). После операции боли исчезли. При осмотре через 5 лет жалоб больной не предъявлял, работает на ответственной работе.

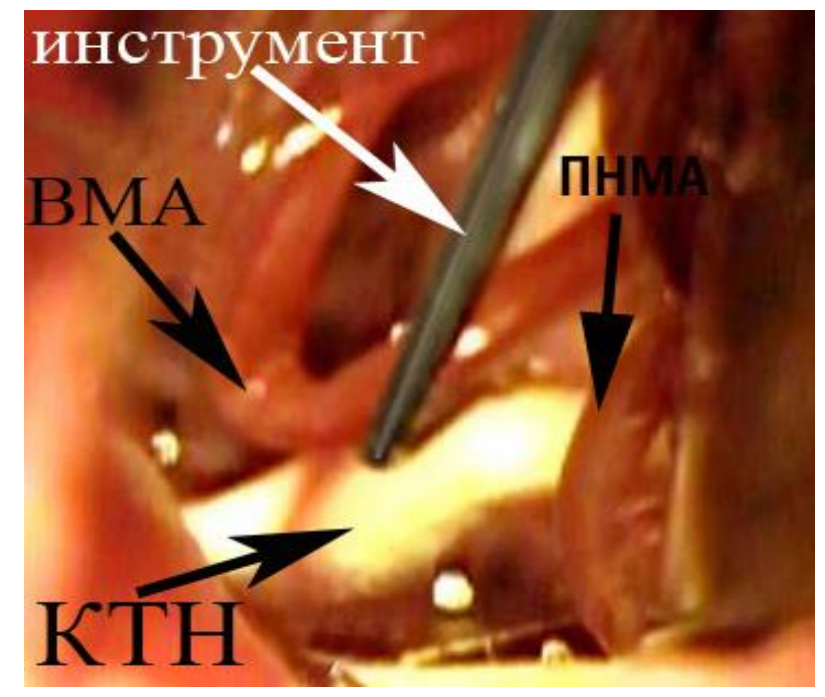

Рис. 80. Больной П. 67 лет. История болезни № 10460/160. Невралгия трех ветвей правого ТН. Конфликт с ВМА и ПНМА. Инструментом артериальная петля приподнята и смещена верх от места ВНК

Васкулоневральный конфликт вентральной поверхности КТН с двумя стволами ВМА и дорзальной со стволом ПНМА (рис. 81) имел место у 6 больных, все они были мужчинами в возрасте от 41 до 72 лет. 
$128 \mid$ Классическая невралгия тройничного нерва

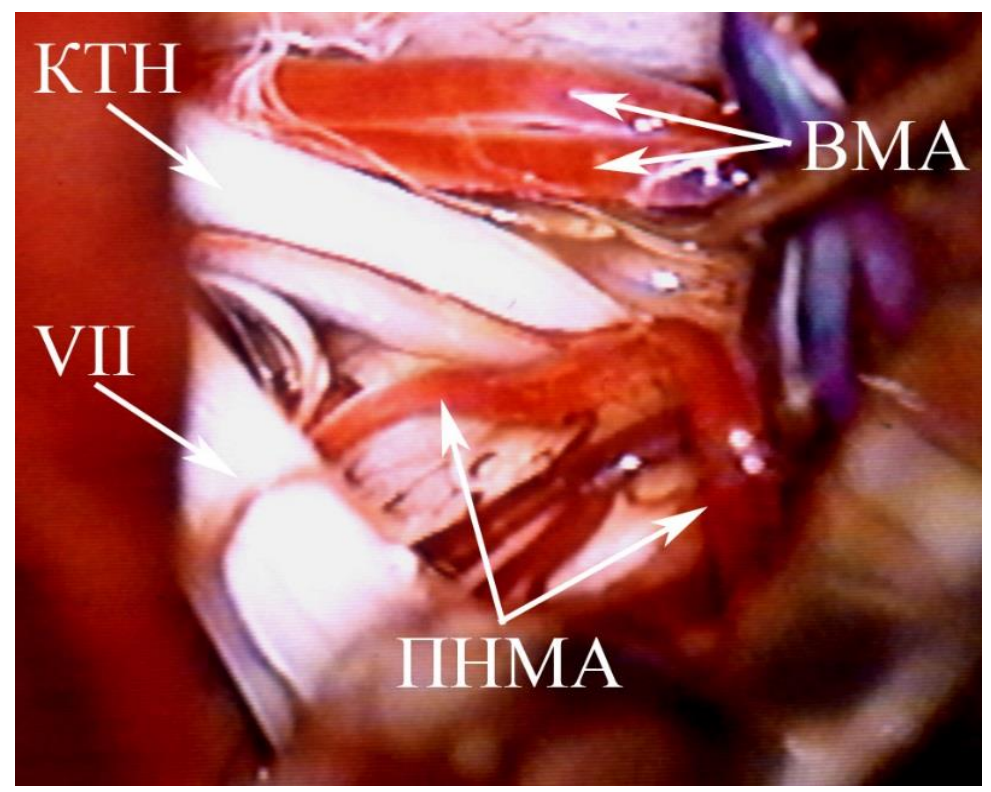

Рис. 81. Больной П. Ист. бол. № 6165. Невралгия левого тройничного нерва

с локализацией болей в зоне третьей ветви. Конфликт КТН с двумя ветвями ВМА и ПНМА (КТН заключен как бы между двумя «молотами»)

Справа боли локализовались у 5 человек, слева - у одного. Возникновение НТН двое больных связывали с простудными заболеваниями, двое - с переохлаждением, и двое больных не усматривают какого-либо предшествующего заболеванию фактора.

У всех пациентов приступы отмечались в дневное время. $\mathrm{y}$ двух больных боли локализовались в зоне иннервации третьей ветви ТН, у 2 - в зонах второй и третьей ветвей, и у 2 - в зонах всех трех ветвей.

У одного больного, страдавшего гипертонической болезнью, отмечалось увеличение частоты болевых пароксизмов на 15 приступов в день при повышении артериального давления. Триггерные зоны локализовались в области угла рта у двух больных, в области подбородка - у двух, в области зубов нижней челюсти - у одного, и в области крыла носа - у одного. Интенсивность боли по ВАШ составила 9,8 балла. Количественные характеристики заболевания с описанным видом конфликта приведены в табл. 12. Из нее видно, что для больных с ААсэндвичем характерна очень высокая частота приступов. Кроме этого, в данной группе больных была самая высокая представительность правосторонней НТН. 
Особенности проявления НТН у больных с васкулоневралным конфликтом КТН с вентральной поверхностью с ВМА и с дорзальной с ПНМА

\begin{tabular}{|l|c|c|}
\hline \multicolumn{1}{|c|}{ Показатели } & $\boldsymbol{M \pm m}$ & $\boldsymbol{\sigma}$ \\
\hline Возраст & $63,11 \pm 3,55$ & 10,66 \\
\hline $\begin{array}{l}\text { Продолжительность последнего обострения } \\
\text { (месяцы) }\end{array}$ & $4,8 \pm 0,80$ & 2,32 \\
\hline Продолжительность заболевания (годы) & $9,00 \pm 1,74$ & 5,22 \\
\hline Интенсивность боли по ВАШ (баллы) & $9,89 \pm 0,11$ & 0,33 \\
\hline Длительность болевого пароксизма (сек) & $10,33 \pm 3,30$ & 9,89 \\
\hline Частота приступов в течение суток & $64,89 \pm 18,67$ & 56,00 \\
\hline $\begin{array}{l}\text { Шкала оценки повседневной активности } \\
\text { больного до лечения (баллы) }\end{array}$ & $26,67 \pm 1,17$ & 3,50 \\
\hline
\end{tabular}

Из 9 больных с артерио-артериальным сэндвичем в состоянии невралгического статуса поступило 2 больных.

Таким образом, развитие невралгического статуса у больных НТН зависит от структуры васкулоневрального конфликта. Чаще всего невралгический статус развивается при одновременном воздействии участвующих в васкулоневральном конфликте сосудов, как на вентральную, так и на дорзальную поверхности КТН, т.е. при артерио-артериальном и артерио-венозном сэндвиче.

\section{2. КЛИНИЧЕСКИЕ ПРОЯВЛЕНИЯ НТН У БОЛЬНЫХ, КОТОРЫМ ДО МИКРОВАСКУЛЯРНОЙ ДЕКОМПРЕССИИ БЫЛИ ВЫПОЛНЕНЫ РАЗЛИЧНЫЕ ДЕСТРУКТИВНЫЕ ВМЕШАТЕЛЬСТВА}

В эту группу включены больные, которые страдали классической НТН и в других лечебных учреждениях в качестве лечебного воздействия им были применены различные деструктивные 
$130 \mid$ Классическая невралгия тройничного нерва

вмешательства. В дальнейшем у них развился рецидив НТН, по поводу которого в нашей клинике им была выполнена микроваскулярная декомпрессия КТН. К тому же у них возникли дополнительные симптомы, обусловленные деструктивным вмешательством. Eller J.L. et al. (2005) эти симптомы классифицируют как «тригеминальные деафферентационные боли». При неврологическом обследовании у этих больных выявляются как симптомы классической НТН, так и симптомы невропатии.

Из 37 больных, подвергшихся деструктивным вмешательствам, 62,2\% составляли женщины и 37,8\% - мужчины. Всем им до поступления в клинику РостГМУ были выполнены деструктивные вмешательства, показанные в табл. 13. Справа боли локализовались у 27 человек (73\%) и слева у - 10 человек (27\%), в соответствии со стороной НТН и ранее выполненной деструктивной операции. 2 человека подверглись деструктивному вмешательству однократно и 5 человек - дважды с промежутками от 2 до 7 лет между деструктивными вмешательствами. Продолжительность ремиссии после первичной алкоголизации периферических ветвей ТН составила

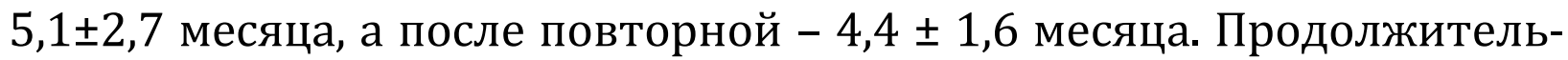
ность ремиссии после нервэкзереза составила 5,4 $\pm 3,3$ месяца.

Таблица 13

Деструктивные вмешательства, выполненные у группы исследованных больных

\begin{tabular}{|l|c|c|}
\hline \multicolumn{1}{|c|}{ Виды деструкций } & $\begin{array}{c}\text { Количество } \\
\text { пациентов }\end{array}$ & \% \\
\hline Алкоголизация периферических ветвей & 25 & 67,6 \\
\hline Нервэкзерез & 5 & 13,5 \\
\hline Гидротермическая деструкция полулунного узла & 3 & 8,1 \\
\hline Перерезка КТН позади полулунного узла & 2 & 5,4 \\
\hline Лазерная деструкция полулунного узла & 2 & 5,4 \\
\hline
\end{tabular}

У трех больных после гидротермической деструкции полулунного узла продолжительной ремиссии была 1 месяц, 2 месяца и 1 год. 
У двух больных после лазерной деструкции полулунного узла продолжительность ремиссии составила 9 месяцев и 1 год.

Наиболее продолжительная ремиссия была у двух больных, перенесших перерезку корешка тройничного нерва позади полулунного узла. Она составила у одного больного 1 год и у другого - 2 года. Сразу после выполнения деструктивных вмешательств у 33 больных появились чувствительные нарушения в виде гипо- или анестезии в ипсилатеральной половине лица. Гипестезия не выявлена у 4 больных: у двух больных после лазерной деструкции полулунного узла и у двух после алкоголизации периферических ветвей. По-видимому, сохранение чувствительности у этих больных можно объяснить неполным разрушением структур в связи с техническими погрешностями выполнения деструктивных процедур данным больным. В течение от 6 месяцев до полутора лет у больных, перенесших деструктивные вмешательства, нарастали явления гиперпатии и дизестезии, значительно утяжелявшие страдания больных.

Один больной после ранее выполненной перерезки КТН позади полулунного узла просил «вернуть ему приступы невралгии, только устранить бы возникшие после этой деструктивной операции боли».

В дневное время постоянные боли имели место у 21 больного $(56,8 \%)$ и круглосуточно - у 16 больных (43,2\%). У 33 человек выявлена гипестезия в зоне иннервации ТН, у 4 больных ее не было. Чувствительные нарушения у больных этой группы распространялись за пределы зоны болевых пароксизмов и сопровождались явлениями гиперпатии и дизестезии. Были типичны жалобы на чувство жжения, прикосновения или поглаживания «горячим утюгом», «переливания кипятка».

Локализация болевых пароксизмов по ветвям ТН представлена в табл. 14.

Разнообразны были и триггерные зоны. Однако проявлялась общая закономерность преимущественной их локализации в периоральной области. Локализация триггерных зон представлена в табл. 15. 
132 Классическая невралгия тройничного нерва

Таблица 14

Частота локализации боли по ветвям ТН у пациентов с васкулоневральным конфликтом с одним стволом ВМА, ранее перенесших деструктивные вмешательства

\begin{tabular}{|l|c|c|}
\hline \multicolumn{1}{|c|}{ Локализация боли } & $\begin{array}{c}\text { Количество } \\
\text { пациентов }\end{array}$ & \% \\
\hline в области 1 и 2 ветвей & 3 & 8 \\
\hline в области 2 ветви & 3 & 8 \\
\hline в области 3 ветви & 5 & 14 \\
\hline в области 2 и 3 ветвей & 22 & 59 \\
\hline в области всех трех ветвей & 4 & 11 \\
\hline
\end{tabular}

Таблица 15

Локализация триггерных зон у пациентов с васкулоневральным конфликтом с одним стволом ВМА, ранее перенесших деструктивные вмешательства

\begin{tabular}{|l|c|c|}
\hline \multicolumn{1}{|c|}{ Локализация } & $\begin{array}{c}\text { Количество } \\
\text { пациентов }\end{array}$ & \% \\
\hline в области угла рта & 20 & 54,1 \\
\hline в области крыла носа & 3 & 8,1 \\
\hline в области верхней и нижней губы & 3 & 8,1 \\
\hline в области подбородка & 3 & 8,1 \\
\hline в области десны верхней или нижней челюсти & 7 & 18,9 \\
\hline в области верхней и нижней губы и подбородка & 1 & 2,7 \\
\hline
\end{tabular}

4.2.1. КЛИНИЧЕСКИЕ ПРОЯВЛЕНИЯ НТН У БОЛЬНЫХ, РАНЕЕ ПЕРЕНЕСШИХ ДЕСТРУКТИВНЫЕ ВМЕШАТЕЛЬСТВА С ВАСКУЛОНЕВРАЛЬНЫМ КОНФЛИКТОМ С ОДНИМ АРТЕРИАЛЬНЫМ СТВОЛОМ

Конфликт с одним артериальным стволом обнаружен у 22 больных. Среди них у 19 больных выявлен конфликт КТН с одним стволом ВМА и у 3 человек - конфликт КТН с одним столом ПНМА. 
4.2.1.1. Клинические проявления НТНу больных, ранее перенесиих деструктивные вмешательства с васкулоневральным конфликтом с одним стволом ВМА

В этой группе больных женщин было 12, мужчин - 7 (соотношение 1,5:1). Возраст больных - от 38 до 68 лет. Справа боли локализовались у 11 больных, слева - у 8 (соотношение 1,5:1). В соответствиии со стороной локализациии болей ранее были выполнены деструктивные вмешательства. Частота локализации боли по ветвям ТН у пациентов с васкулоневральным конфликтом с одним стволом ВМА, ранее перенесших деструктивные вмешательства, представлена в табл. 16.

Таблица 16

Частота локализации боли по ветвям ТН у пациентов с васкулоневральным конфликтом с одним стволом ВМА, ранее перенесших деструктивные вмешательства

\begin{tabular}{|l|c|c|}
\hline Локализация боли & Количество пациентов & \% \\
\hline в области 1 и 2 ветвей & 3 & 16 \\
\hline в области 2 ветви & 2 & 11 \\
\hline в области 3 ветви & 2 & 11 \\
\hline в области 2 и 3 ветвей & 9 & 46 \\
\hline в области всех трех ветвей & 3 & 16 \\
\hline
\end{tabular}

Начало заболевания с переохлаждением связывали 3 больных, с простудными заболеваниями - 1 , со стрессовой ситуацией - 1 .

Локализация триггерных зон представлена в табл. 17.

Таблица 17

Локализация триггерных зон у больных с васкулоневральным конфликтом с одним стволом ВМА, ранее перенесших деструктивные вмешательства

\begin{tabular}{|l|c|c|}
\hline \multicolumn{1}{|c|}{ Локализация } & $\begin{array}{c}\text { Количество } \\
\text { пациентов }\end{array}$ & \% \\
\hline в области угла рта & 10 & 52,5 \\
\hline в области крыла носа & 3 & 15,8 \\
\hline в области верхней губы & 1 & 5,3 \\
\hline в области десны верхней или нижней челюсти & 3 & 15,8 \\
\hline в области подбородка & 2 & 10,5 \\
\hline
\end{tabular}


$134 \mid$ Классическая невралгия тройничного нерва

Один из этих больных поступил в клинику в состоянии невралгического статуса с частотой приступов 120 в день и потерей массы тела на 15 кг в течение 3 недель в связи с невозможностью принимать пищу.

Количественные характеристики заболевания этой группы больных приведены в табл. 18.

Таблица 18

Особенности проявления НТН у больных, ранее перенесших деструктивные вмешательства, с васкулоневральным конфликтом КТН с одним стволом ВМА

\begin{tabular}{|l|c|c|}
\hline \multicolumn{1}{|c|}{ Показатели } & $\boldsymbol{M \pm m}$ & $\boldsymbol{\sigma}$ \\
\hline Возраст & $53,6 \pm 2,3$ & 9,9 \\
\hline $\begin{array}{l}\text { Продолжительность последнего обострения } \\
\text { (месяцы) }\end{array}$ & $5,6 \pm 1,5$ & 6,3 \\
\hline Продолжительность заболевания (годы) & $12,2 \pm 1,6$ & 6,9 \\
\hline Интенсивность боли по ВАШ (баллы) & $9,6 \pm 0,2$ & 1,0 \\
\hline Длительность болевого пароксизма (сек) & $28,4 \pm 6,2$ & 26,9 \\
\hline Частота приступов в течение суток & $51,8 \pm 8,8$ & 38,2 \\
\hline $\begin{array}{l}\text { Шкала оценки повседневной активности } \\
\text { больного до лечения (баллы) }\end{array}$ & $24,7 \pm 0,7$ & 3,3 \\
\hline
\end{tabular}

Продолжительность заболевания у больных перенесших деструктивные вмешательства с васкулоневральным конфликтом с одним артериальным стволом значительно продолжительнее до обращения за МВД $(12,2 \pm 1,6)$ по сравнению с продолжительностью заболевания у больных с такой же структурой васкулоневрального конфликта, но без деструктивных вмешательств $(8,59 \pm 0,62)$. Это, повидимому, обусловлено надеждой больных на исцеление после выполненных им деструктивных операций.

4.2.1.2. Клинические проявления НТН у больных, ранее перенесших деструктивные вмешательства с васкулоневральным конфликтом с одним стволом ПНМА

Конфликт КТН с ПНМА имел место у трех больных, ранее перенесших деструктивные вмешательства. Все трое были женщи- 
нами в возратсе 52, 57 и 68 лет. Продолжительность последнего обострения составляла у них от 1 до 3 месяцев, а продолжительность заболевания - 7, 9 и 20 лет.

Интенсивность болевых пароксизмов у всех троих составляла по ВАШ 10 баллов.

Боли у двух больных локализовались в зонах второй и третьей ветвей и у одной - в зоне третьей ветви. Триггерные точки у одной больной были в области угла рта, у второй - в области десны нижней челюсти и подбородка, и у третьей больной - в области десны верхней челюсти.

Гипестезия в зонах локализации болей была выявлена у двух больных. У одной больной, перенесшей ранее лазерную деструкцию полулунного узла, нарушений чувствительности не было выявлено. Все трое больных жаловась на сохраняющиеся в межприступном периоде болевые ощущения в зонах локализации болевых пароксизмов, жгучего, пекущего характера. Продолжительность болевых пароксизмов составляла у одной больной 7 секунд, у второй - 1 минуту и у третьей больной - 2 минуты. Количество приступов боли у двух больных достигало 30 в день, у одной больной - свыше 50. Обращает на себя внимание увеличение продолжительности приступов у больных после деструктивных вмешательств с больными с аналогичным васкулоневральным конфликтом, но не подвергавшихся деструктивным операциям.

\subsection{2. КЛИНИЧЕСКИЕ ПРОЯВЛЕНИЯ НТН У БОЛЬНЫХ, РАНЕЕ ПЕРЕНЕСШИХ ДЕСТРУКТИВНЫЕ ВМЕШАТЕЛЬСТВА С ВАСКУЛОНЕВРАЛЬНЫМ КОНФЛИКТОМ С ДВУМЯ СТВОЛАМИ ВМА}

Васкулоневральный конфликт с двумя стволами ВМА обнаружен у 11 человек, ранее, до МВД, перенесших деструктивные вмешательства. Среди них было 7 женщин и 4 мужчин в возрасте от 45 до 74 лет. Справа боли локализовались у 10 человек и слева - у одного (соотношение 10:1). 
136 К Классическая невралгия тройничного нерва

Зоны локализации боли представлены в табл. 19.

Таблица 19

Частота локализации боли по ветвям ТН у пациентов с васкулоневральным конфликтом с одним стволом ВМА, ранее перенесших деструктивные вмешательства

\begin{tabular}{|l|c|c|}
\hline \multicolumn{1}{|c|}{ Локализация боли } & Количество пациентов & \% \\
\hline в области 2 ветви & 1 & 9 \\
\hline в области 3 ветви & 2 & 18 \\
\hline в области 2 и 3 ветвей & 7 & 64 \\
\hline в области всех трех ветвей & 1 & 9 \\
\hline
\end{tabular}

Триггерные зоны имели различную локализацию (табл. 20).

Таблица 20

Локализация триггерных зон у пациентов с васкулоневральным конфликтом с одним стволом ВМА, ранее перенесших деструктивные вмешательства

\begin{tabular}{|l|c|c|}
\hline \multicolumn{1}{|c|}{ Локализация триггерных зон } & $\begin{array}{c}\text { Количество } \\
\text { пациентов }\end{array}$ & $\mathbf{\%}$ \\
\hline в области угла рта & 6 & 55 \\
\hline в области верхней губы & 1 & 9 \\
\hline в области десны нижней челюсти & 1 & 9 \\
\hline в области десны верхней челюсти & 1 & 9 \\
\hline $\begin{array}{l}\text { в области десны верхней и нижней } \\
\text { челюсти и подбородка }\end{array}$ & 1 & 9 \\
\hline в области подбородка & 1 & 9 \\
\hline
\end{tabular}

Количественные характеристики заболевания у пациентов с васкулоневральным конфликтом с двумя стволами ВМА, ранее перенесших деструктивные вмешательства, представлены в табл. 21.

Отличительным признаком больных этой группы от больных с аналогичной структурой васкулоневрального конфликта, но без предшествовавших деструктивных вмешательтств также является большая продолжительность заболевания до обращения за МВД

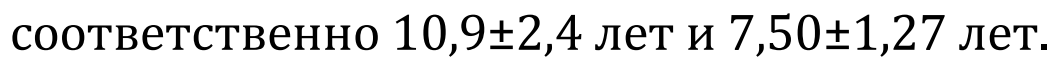


Особенности проявления НТН у больных, ранее перенесших деструктивные вмешательства, с васкуоневральным конфликтом КТН с двумя стволами ВМА

\begin{tabular}{|l|c|c|}
\hline \multicolumn{1}{|c|}{ Показатели } & $\boldsymbol{M \pm m}$ & $\boldsymbol{\sigma}$ \\
\hline Возраст & $58,5 \pm 2,8$ & 9,3 \\
\hline $\begin{array}{l}\text { Продолжительность последнего } \\
\text { обострения (месяцы) }\end{array}$ & $4,7 \pm 1,9$ & 6,5 \\
\hline Продолжительность заболевания (годы) & $10,9 \pm 2,4$ & 8,1 \\
\hline Интенсивность боли по ВАШ (баллы) & $9,9 \pm 0,1$ & 0,3 \\
\hline Длительность болевого пароксизма (сек) & $41,4 \pm 4,9$ & 16,1 \\
\hline Частота приступов в течение суток & $43,6 \pm 16,2$ & 53,7 \\
\hline $\begin{array}{l}\text { Шкала оценки повседневной активности } \\
\text { больного до лечения (баллы) }\end{array}$ & $26,0 \pm 0,5$ & 1,8 \\
\hline
\end{tabular}

\subsection{3. КЛИНИЧЕСКИЕ ПРОЯВЛЕНИЯ НТН У БОЛЬНЫХ, РАНЕЕ ПЕРЕНЕСШИХ ДЕСТРУКТИВНЫЕ ВМЕШАТЕЛЬСТВА С ВАСКУЛОНЕВРАЛЬНЫМ КОНФЛИКТОМ КТН С ВЕРХНЕЙ КАМЕНИСТОЙ ВЕНОЙ}

У двух больных, ранее перенесших деструктивные вмешательсьтва, верифицирован васкулоневральный конфликт с верхней каменистой веной. Среди них одна женщина и один мужчина в возрасте соответственно 69 и 47 лет.

Продолжительность последнего обострения у женщины составляла 4 месяца, а продолжительность заболевания - 13 лет, у мужчины соответственно - 2 и 4 года.

У обоих больных болевые пароксизмы были с правой стороны в зонах второй и третьей ветвей ТН. У женщины приступы были круглосуточно, в то время как у мужчины - только в дневное время.

У обоих больных была выявлена гипестезия в зонах иннервации второй и третьей ветвей, развившаяся после выполненных им на этапах лечения алкоголизаций. 
138 К Классическая невралгия тройничного нерва

Продолжительность болевых пароксизмов у больной женщины не превышала 3 секунд, в то время как у мужчины болевой пароксизм продолжался до 1 минуты. Частота болевых пароксизмов у обоих больных достигала 10 в сутки.

Оба больных этой группы, как и больные без деструктивных вмешательств, при конфликте с верхней каменистой веной отмечали усиление болей и учащение болевых пароксизмов в горизонтальном положении, в особенности это было выражено у женщины, которая просыпалась ночью из-за болей в области лица. Больные после деструктивных вмешательств в межприступном периоде отмечали чувство «жжения» в ипсилатеральной половине лица.

\subsection{4. КЛИНИЧЕСКИЕ ПРОЯВЛЕНИЯ НТН У БОЛЬНЫХ, РАНЕЕ ПЕРЕНЕСШИХ ДЕСТРУКТИВНЫЕ ВМЕШАТЕЛЬСТВА С ВАСКУЛОНЕВРАЛЬНЫМ КОНФЛИКТОМ С ДВУМЯ АРТЕРИЯМИ: БАЗИЛЯРНОЙ И ПНМА С ВЕНТРАЛЬНОЙ ПОВЕРХНОСТЬЮ КТН И ВКВ С ЕГО ДОРЗАЛЬНОЙ ПОВЕРХНОСТЬЮ}

Такой вариант васкулоневрального конфликта имел место у двух больных, не подвергавшихся деструктивным вмешательсьтвам (рис. 82), и у одной больной, ранее перенесшей повторные спиртовые блакады в корень языка. Приводим это наблюдение.

Больная Т. 74 лет. Ист. бол. № 11699/1771. Болеет в течение 7 лет, когда без видимой причины возникли сильные стреляющие боли в области правой половины языка, с постприступным ощущением сжатия языка «как в зажиме», ощущением болей жгучего характера в области правой половины подбородка. После прострела у больной сохранялась жгучая боль в языке, и больная старалась не двигать языком. Продолжительность приступов несколько секунд, частота свыше 60 в сутки. В течение последних трех лет интенсивность и частота приступов нарастали. Приступы стали отмечаться и в ночное время. За время болезни постоянно получала финлепсин до 1000 мг в сутки, практически без эффекта. Многократно выполня- 
лись блокады с аналгетиками. По месту жительства проведено две алкоголизации в область третьей ветви ТН, после чего появились жгучие боли в языке «печет как от утюга». Продолжительность последнего обострения 1 месяц, в течение последних 2 недель практически не принимала пищу. Прием финлепсина облегчения не приносил. При неврологическом исследовании в клинике нейрохирургии РостГМУ интенсивность боли по ВАШ - 10 баллов. Гиперестезия в зоне иннервации 3 ветви ТН справа. Для исключения симптоматической природы НТН больной выполнена МРТ, выявившая долихоэктазию БА. Однако визуализировать ПНМА, участвующую в васкулоневральном конфликте при МРТ ангиографии, не представилось возможным. Во время выполненной МВД подтверждена долихоэктазия БА, участвующая в васкулоневральном конфликте, и обнаружен конфликт с ПНМА и ВКВ (рис. 82).

В отличие он клинических проявлений НТН у двух больных без деструктивных вмешательств с аналогичным васкулоневральным конфликтом, больную после спиртовых блокад стали беспокоить в межприступном периоде жгучие боли в корне языка и гипестезия в зоне иннервации третьей ветви ТН, т.е. сочетание симптомов невралгии и невропатии.

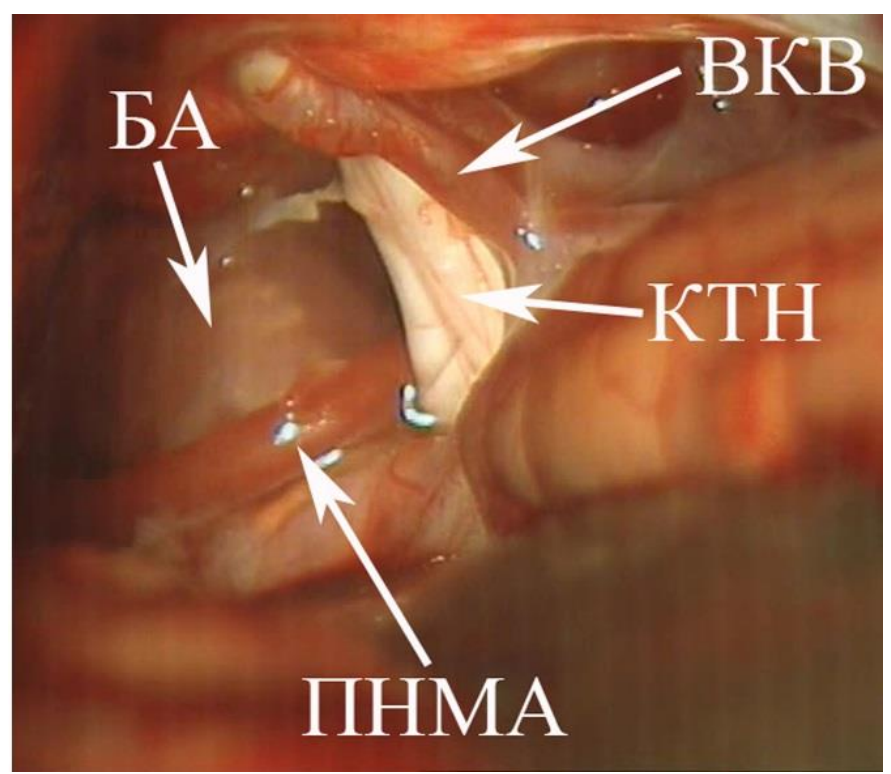

Рис. 82. Больная Т. 74 лет. Ист. бол. № 11699/1771, петля НПМА и долихоэктазированная БА оказывают травмирующее воздействие на правый КТН 
$140 \mid$ Классическая невралгия тройничного нерва

4.2.5. КЛИНИЧЕСКИЕ ПРОЯВЛЕНИЯ НТН У БОЛЬНЫХ, РАНЕЕ ПЕРЕНЕСШИХ ДЕСТРУКТИВНЫЕ ВМЕШАТЕЛЬСТВА С ВАСКУЛОНЕВРАЛЬНЫМ КОНФЛИКТОМ С ДВУМЯ АРТЕРИАЛЬНЫМИ СТВОЛАМИ: ОДНИМ СТВОЛОМ ВМА И СТВОЛОМ ПНМА С ВЕНТРАЛЬНОЙ ПОВЕРХНОСТЬЮ КТН И ВКВ С ЕГО ДОРЗАЛЬНОЙ ПОВЕРХНОСТЬЮ

Среди больных, ранее перенесших деструктивные вмешательстьва, под наблюдением находился один больной, у которого при МВД был верифицирован артериоартериальный «сэндвич» васкулоневральный конфликт между ВМА с вентральной поверхностью КТН и ПНМА с его дорзальной поверхностью (рис. 83). Обращало на себя внимание более тяжелое течение заболевания у этого больного по сравнению с аналогичными больными с аретриоартериальным «сендвичем», но не подвергавшихся деструктивным вмешательствам. В состоянии невралгического статуса, он поступил в клинику нейрохирургии РостГМУ. Приводим это наблюдение.

Больной Б. 1950 года рождения, история болезни № 3612, поступил в клинику нейрохирургии РостГМУ 13.06.02 г. с жалобами на серии болевых пароксизмов в правой половине лица стреляющего, жгучего характера, продолжительностью до 3 минут, провоцируемые приемом пищи, туалетом полости рта, разговором, прикосновением к правой половине лица, сопровождающиеся слезотечением из правого глаза. Триггерная зона - периоральная область. В связи с невозможностью из-за боли принимать пищу, больной поступил в клинику с установленным на этапах назогастральным зондом, с помощью которого осуществлялось его питание уже более двух недель. Считает себя больным с 1986 года, когда впервые без видимой причины возникли стреляющие боли в правой половине лица, повторявшиеся один раз в неделю. Обострения происходили, как правило, в холодное время года. С 1991 года частота приступов резко возросла, в связи с чем ему было выполнено 5 спиртовоновокаиновых блокад, после чего появилась гипестезия правой половины лица. В 1997 году выполнена $\gamma$-лучевая терапия на область 
полулунного узла. Многократно получал ФТЛ, ИРТ, блокады, доза финлепсина составляла 3600 мг в сутки.

НТН у больного пытались связать с имеющейся у него синдактилией третьего и четвертого пальцев кистей как проявления дизрафии. Консультирован генетиком, отнесшим выявленные признаки дизрафии в группу акроцефалосиндактилий, в рамках которой возможна невралгия тройничного нерва, обусловленная аномалиями развития черепа. На РКТ от 11.10.1999 г. патологических изменений плотности мозгового вещества и костных структур черепа не выявлено. Проводившееся лечение не привело к улучшению в состоянии больного, и частота приступов достигла 50 в день.

В связи со стойким болевым синдромом, ригидным к консервативной терапии и деструктивным блокадам, больному в г. N. выполнена субокципитальная краниотомия справа с попыткой выполнить МВД. В течение двух месяцев после вмешательства интенсивность болей и частота пароксизмов несколько уменьшились. Затем частота и интенсивность болевых пароксизмов наросли и превысили дооперационный уровень. Больной не мог принимать пищу, потеря массы тела составила 16 кг. Для осуществления энтерального питания ему по месту жительства был установлен назогастральный зонд. Через две недели после этого он поступил в клинику нейрохирургии РостГМУ. Состояние расценено как невралгический статус. Ярко выражен симптом «защиты триггерной зоны». 17.06.02 г. МРТ выявила диффузную полушарную атрофию, частичную гипогенезию мозолистого тела, васкулоневральный конфликт между КТН ВМА и ПНМА справа.

18.06.02 г. выполнена повторная ревизия правого мостомозжечкового угла, обнаружен и устранен васкулоневральный конфликт между латеральным понтомезенцефальным сегментом ВМА и передней поверхностью КТН, между ПНМА и задней поверхностью КТН. КТН в этих случаях находился под ноцицептивным воздействием артериальных ударов с двух сторон (рис. 83).

Боли исчезли сразу после пробуждения больного от наркоза. При осмотре больного через 3 года очаговой неврологической симптоматики не выявлено, за исключением гипестезии в зонах 2 и 3 
$142 \mid$ Классическая невралгия тройничного нерва

ветвей ТН, развившихся после спиртовых блокад. Больной вернулся на прежнюю работу.

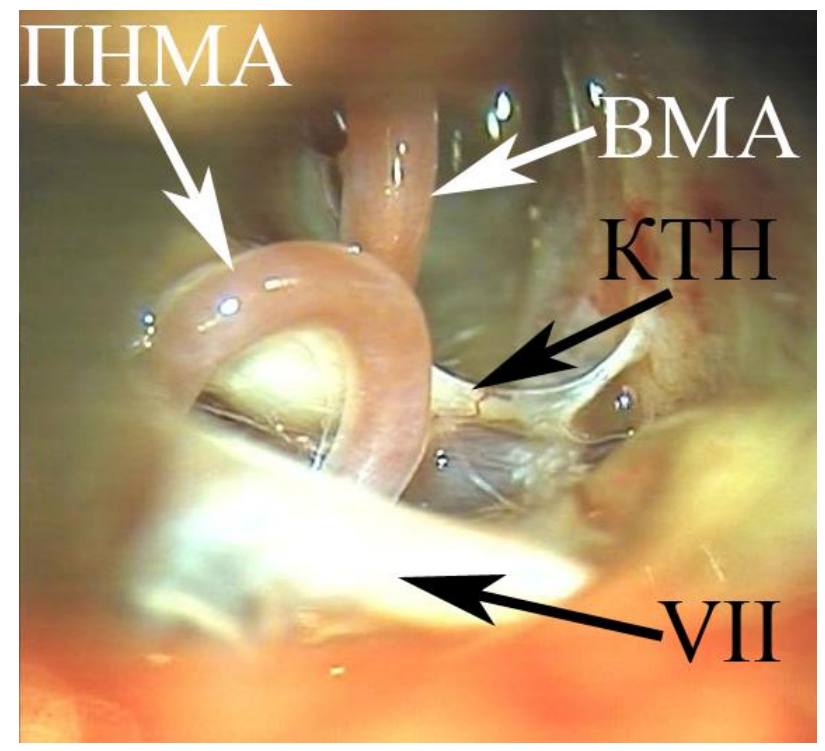

Рис. 83. Больной Б. Ист. бол. № 3612. Невралгия правого тройничного нерва с локализацией болей в зонах второй и третьей ветвей. Конфликт КТН с ВМА и ПНМА

Тяжесть состояния больного определялась потерей массы тела в течение последнего обострения на 16 кг, высокой частотой болевых пароксизмов до 50 в день, невозможностью принимать пищу, отсутствием лечебного эффекта от высоких доз карбамазепина (до 3600 мг в сутки). Это наблюдение подтверждает тот факт, что к развитию невралгического статуса предрасполагает форма васкулоневрального конфликта в виде «сэндвича».

При сравнении клинических проявлений НТН у больных без и после деструктивных вмешательств с аналогичной структурой васкулоневрального конфликта выявлены четкие различия. Продолжительность заболевания у больных после деструктивных вмешательств в группе с васкулоневральным конфликтом с одним стволом ВМА в 1,5 раза дольше, а при конфликте с двумя стволами ВМА в 2 раза дольше, по сравнению с теми, кто не подвергался деструктивным вмешательствам. Такое же соотношение и по продолжительности последнего обострения при обращении за МВД. Больные с рецидивом классической НТН после перенесенных деструктивных 
вмешательств наряду с симптомами классической НТН имеют дополнительные симптомы в виде: гипо-или анестезии, гиперпатии и дизестезии. Наличие дополнительной симптоматики переводит их из категории классической НТН, которой они страдали первоначально, в категорию классической НТН, сочетающейся с тригеминальными невропатическими болями, в результате целенаправленного разрушения периферических ветвей, ганглиолизиса или ризотомии как способа лечения НТН» в соответствии с классификацией Eller J.L., et al. (2005).

Полученные данные показывают низкий эффект деструктивных операций, утяжеление течения заболевания и эффективность и патогнетическую направленность операции микроваскулярной декомпрессии КТН.

\section{3. РОЛЬ ВАСКУЛОНЕВРАЛЬНОГО КОНФЛИКТА В ПАТОГЕНЕЗЕ СИМПТОМАТИЧЕСКОЙ НЕВРАЛГИИ ТРОЙНИЧНОГО НЕРВА}

В соответствии с международной классификацией головных болей (2-е издание, 2004) с кодами МКБ - 10 NA BО3, выделяют классическую тригеминальную невралгию (G 44.847), когда отсутствуют признаки поражения тройничного нерва $[167,168,209]$ и симптоматическую, которая сочетается с различными заболеваниями: опухолями задней черепной ямки, рассеянным склерозом, артериовенозными мальформациями, аномалией Арнольда-Киари, платибазией и пр. До настоящего времени продолжается дискуссия о том, что является причиной НТН при этих заболеваниях: например, компрессия КТН опухолью или формирование васкулоневрального конфликта между КТН и артериями мозжечка. Поиск ответа на этот вопрос также был предметом нашего исследования.

Дифференциальный диагноз между классической и симптоматической НТН по данным клинического обследования затруднителен, особенно при типичной клинике тригеминальной невралгии, 
$144 \mid$ Классическая невралгия тройничного нерва

значительной длительности заболевания и отсутствии симптомов поражения смежных структур. Продолжительность болевого тригеминального синдрома по данным анамнеза заболевания у 20 пациентов симптоматической НTH в наших наблюдениях достигала 9 лет. Этот факт свидетельствует о том, что в течение многолетнего периода болезни объемный процесс не проявляет себя, кроме $\mathrm{HTH}$, симптомами поражения смежных структур.

Клиника классической НТН наблюдалась у 13 больных, у которых нами были диагностированы петрокливальные менингиомы, у 6 - рассеянный склероз, и у одной больной - артерио-венозная мальформация задней черепной ямки.

\subsection{1. КЛИНИЧЕСКИЕ ПРОЯВЛЕНИЯ НТН У БОЛЬНЫХ С ПЕТРОКЛИВАЛЬНЫМИ МЕНИНГИОМАМИ}

Среди 13 больных с петрокливальными менингиомами, диагностированными при МРТ исследовании, обнаружен во время операции васкулоневральный конфликт между КТН и ВМА. Объемные патологические процессы боковой цистерны моста, сдавливая и смещая прилежащие к нему анатомические структуры (варолиев мост и мозжечок с окаймляющими их артериями), способствовали смещению вершины петли ВМА ниже верхнего края КТН. Формирование васкулоневрального конфликта в этих случаях происходило как за счет дислокации КТН кверху, так и за счет смещения вершины петли ВМА ниже верхнего края КТН. Такой механизм формирования васкулоневрального конфликта, вследствие увеличения объема растущей опухоли отличается от ВНК при классической НТН, где основной причиной являются атеросклеротические изменения артерий мозжечка, их врожденная долихоэктазия или укорочение арахноидальных струн, между КТН и ВМА (см. гл. 3, рис. 42). После удаления опухолей у этих больных образовывалось большое резервное пространство, в котором латеральный понтомезенцефальный сегмент BMA уже не оказывал механического воздействия на КТН. Между 
ними появлялось расстояние, устранявшее васкулоневральный конфликт (рис. 84). После операции болевые пароксизмы у всех больных этой группы больше не возникали.

Bсе 13 больных, поступивших в клинику с диагнозом НTH, с верифицированной менингиомой петрокливальной локализации, были женщины в возрасте от 47 до 70 лет. Справа боли и опухоли локализовались у 4 и слева у 9 человек. Зоны локализации болей представлены в табл. 22.

Таблица 22

Частота локализации боли по ветвям ТН у пациентов с менингиомами петрокливальной локализации

\begin{tabular}{|l|c|c|}
\hline \multicolumn{1}{|c|}{ Локализация боли } & Количество пациентов & $\mathbf{\%}$ \\
\hline в области 1 и 2 ветвей & 1 & 7,7 \\
\hline в области 3 ветви & 1 & 7,7 \\
\hline в области 2 и 3 ветвей & 11 & 84,6 \\
\hline
\end{tabular}

Из табл. 22 видно, что и в этой группе больных НТН с менингиомами петрокливальной локализации боли в зоне иннервации первой ветви наблюдались только в одном случае.

Локализация триггерных зон также не отличалась от больных с классической НТН (табл. 23).

Таблица 23

Локализация триггерных зон у пациентов с менингиомами петрокливальной локализации

\begin{tabular}{|l|c|c|}
\hline \multicolumn{1}{|c|}{ Локализация } & Количество пациентов & \% \\
\hline в области угла рта & 6 & 46,1 \\
\hline в области крыла носа & 2 & 15,4 \\
\hline в области верхней губы & 2 & 15,4 \\
\hline в области десны нижней челюсти & 3 & 23,1 \\
\hline
\end{tabular}

Начало заболевания связывали с удалением зубов 5 человек, со стрессовой ситуацией - 1 человек, с простудными заболеваниями - 
$146 \mid$ Классическая невралгия тройничного нерва

1 больная, с переохлаждением - 2 больных, и не усматривали начало заболевания с какими-либо предшествующими факторами 3 женщины.

На круглосуточный характер болей жаловались 5 больных и у 7 пациенток боли были только в дневное время. В отличие от больных с васкулоневральный конфликтом в виде «сендвича», где смещению КТН от ударов артериальной петли препятствует ВКВ, у больных с менингиомами смещению КТН от артерии препятствовала опухоль, способствовавшая сближению КТН не только с ВМА, но еще и с ВКВ. Этой анатомической особенностью васкулоневрального конфликта (участие в конфликте ВКВ) можно объяснить появление у 5 больных ночных приступов боли. У 6 больных обнаружена гипестезия в зоне болевых пароксизмов, у 7 чувствительных нарушений не выявлено.

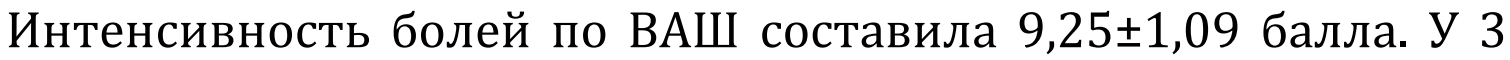
больных отмечалось увеличение частоты болевых пароксизмов на 5-10 приступов в день при подъемах артериального давления свыше 210/120 мм рт. ст. Количественные характеристики продолжительности последнего обострения, заболевания, количества и продолжительности болевых пароксизмов у пациентов со вторичной НТН, обусловленной петрокливальными менингиомами представлены в табл. 24.

Таблица 24

\section{Особенности проявления НТН у больных} с петрокливальными менингиомами

\begin{tabular}{|l|c|c|}
\hline \multicolumn{1}{|c|}{ Показатели } & M.m & $\boldsymbol{\sigma}$ \\
\hline Возраст & $62,2 \pm 2,6$ & 9,2 \\
\hline $\begin{array}{l}\text { Продолжительность последнего } \\
\text { обострения (месяцы) }\end{array}$ & $4,9 \pm 0,4$ & 1,5 \\
\hline Продолжительность заболевания (годы) & $7,0 \pm 1,7$ & 6,2 \\
\hline Интенсивность боли по ВАШ (баллы) & $9,0 \pm 0,3$ & 1,2 \\
\hline Длительность болевого пароксизма (сек) & $83,8 \pm 16,7$ & 60,1 \\
\hline Частота приступов в течение суток & $29,5 \pm 7,0$ & 25,3 \\
\hline $\begin{array}{l}\text { Шкала оценки повседневной активности } \\
\text { больного до лечения (баллы) }\end{array}$ & $22,6 \pm 0,9$ & 3,3 \\
\hline
\end{tabular}


Клиническая картина НТН у больных с менингиомами задней черепной ямки в течение многих лет, до появления симптомов, обусловленных заинтересованностью смежных мозговых структур, не отличалась от классической НТН, как в преимущественной локализации болей в зонах второй и третьей ветвей ТН, так и в периоральной локализации триггерных зон, что подчеркивает трудности распознавания ее симптоматической природы. В качестве примера приводим одно из наших наблюдений.

Больная Н. 38 лет. История болезни № 2382/436. Поступила в клинику нейрохирургии РостГМУ 03.04.2000 г. с жалобами на приступы сильных стреляющих болей в левой половине верхней и нижней челюстей продолжительностью от нескольких до 20 секунд, с периодичностью через 10-15 минут (до 100 приступов в день). Продолжительность заболевания 5 лет, когда после удаления зуба из правой половины нижней челюсти возникли сильные болевые пароксизмы. Триггерные зоны - в области левой верхней губы, угла рта и слизистой оболочки правой половины нижней челюсти. Прием финлепсина по 200 мг 6 раз в день способствовал уменьшению частоты приступов до одного раза в неделю. В 1998 году вновь участились приступы, прием финлепсина привел к очередной ремиссии. В течение последнего обострения, длившегося до поступления в клинику свыше 3 месяцев, больная потеряла 15 кг массы тела из-за невозможности адекватного питания. Неврологическое обследование симптомов выпадения не выявило. Определялась лишь болезненность точек выхода левых второй и третьей ветвей ТН на поверхность лица. Степень интенсивности боли по ВАШ 10 баллов. Для исключения симптоматической природы НТН больной выполнена МРТ, выявившая менингиому петрокливальной локализации слева. Больной выполнена субокципитальная краниотомия с удалением менингиомы. При этом КТН и ВМА, прилежавшие друг к другу, разведены, чем и устранен нейроваскулярный конфликт (рис. 84).

Болевой синдром исчез сразу после операции. Приступов болей у пациентки не отмечается по настоящее время. Данное наблюдение подчеркивает трудности распознавания симптоматической приро- 
$148 \mid$ Классическая невралгия тройничного нерва

ды НТН при отсутствии клинических признаков поражения смежных структур головного мозга.

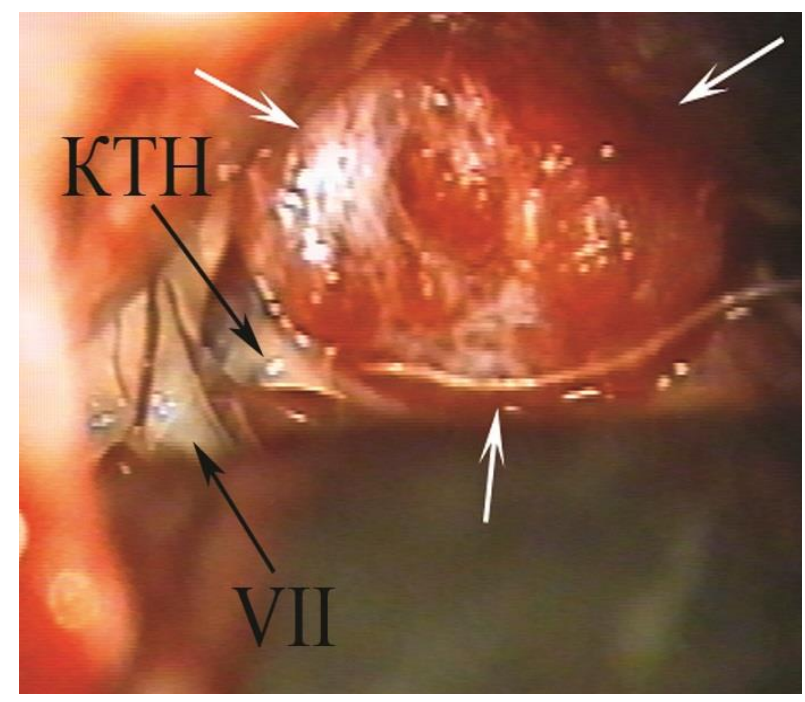

a)

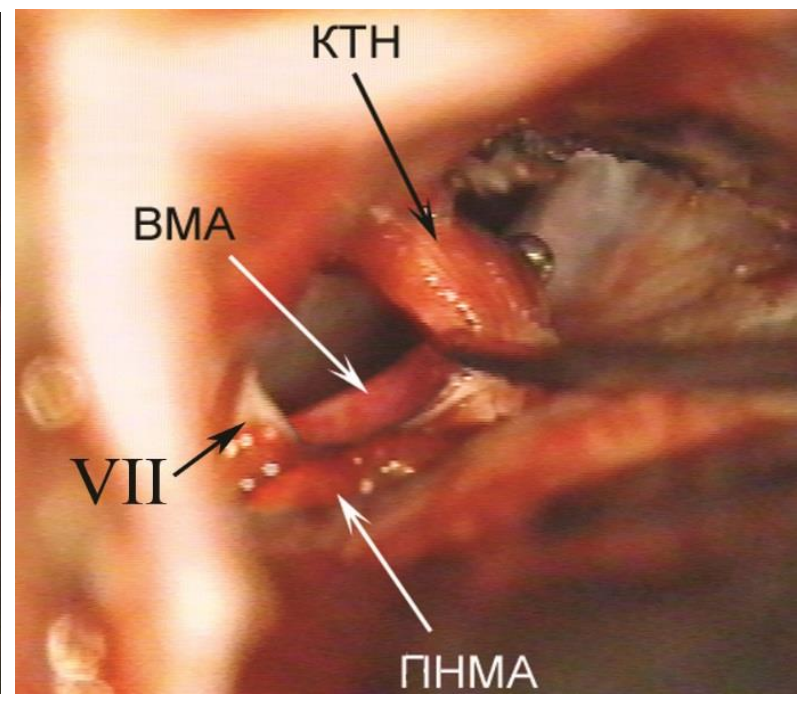

б)

Рис. 84. Больная Н. 38 лет. Ист. бол. № 2382/436. Петрокливальная менингиома слева: а) перед удалением опухоли; б) опухоль удалена, обнаружен васкулоневральный конфликт между петлей ВМА и КТН, который за счет освобождения КТН от опухолевой компрессии перестал функционировать

\subsection{2. КЛИНИЧЕСКИЕ ПРОЯВЛЕНИЯ НТН У БОЛЬНЫХ РАССЕЯННЫМ СКЛЕРОЗОМ}

Нами изучено 6 пациентов НТН, страдавших рассеянным склерозом, которым была выполнена МВД, из них было 5 женщин и 1 мужчина. В правой половине лица боли были у четырех, в левой - у двух. У 4 пациентов была вторично-прогрессирующая форма РС, и у двух рецидивирующее ремитирующая форма РС (табл. 25).

У всех шестерых больных клиническая картина НТН соответствовала критериям диагностики классической НТН. Пятеро больных не связывали появление НТН с какими-либо предшествующими факторами и лишь 1 больной начало НТН связывал с кариесом зубов. У двух больных НТН возникла после 50 лет, у двух других - после 40 лет, у остальных двух больных - в возрасте 33 и 39 лет. У трех 
больных, длительно лечившихся по поводу НТН до поступления в клинику нервных болезней РостГМУ, неврологических проявлений PC не было констатировано. Диагноз РС был установлен при обследовании во время подготовки их к операции микроваскулярной декомпрессии. После выполнения им МРТ, с целью исключения симптоматической природы НТН, обнаружены очаги демиелинизации в больших полушариях головного мозга, характерные для РС. Как локализация болей (табл. 25), так и локализация триггерных зон (табл. 26) соответствовали описанным нами при классической НТН. Количественные характеристики заболевания у пациентов с НTH, с верифицированным НВК и рассеянным склерозом, приведены в табл. 27.

Таблица 25

Клиническая характеристика больных РС с НTH (n=6)

\begin{tabular}{|c|c|c|c|c|c|c|c|c|}
\hline $\begin{array}{c}\text { Номер } \\
\text { пациента }\end{array}$ & Пол & $\begin{array}{c}\text { Возраст } \\
\text { (лет) }\end{array}$ & \begin{tabular}{|c} 
Длитель- \\
ность РС \\
(лет)
\end{tabular} & \begin{tabular}{|c|} 
Тип \\
тече- \\
ния РС
\end{tabular} & $\begin{array}{c}\text { Длитель- } \\
\text { ность НTH } \\
\text { (лет) }\end{array}$ & $\begin{array}{c}\text { EDSS } \\
\text { (баллов) }\end{array}$ & $\begin{array}{c}\text { Сторона } \\
\text { НТН }\end{array}$ & $\begin{array}{l}\text { Ветвь } \\
\text { TH }\end{array}$ \\
\hline 1 & M & 41 & 19 & PP & 8 & 2 & правая & 1,2 \\
\hline 2 & ж & 47 & 18 & PP & 3 & 4,5 & слева & 3 \\
\hline 3 & ж & 59 & 27 & ВП & 20 & 6,5 & слева & 2,3 \\
\hline 4 & ж & 61 & 15 & ВП & 11 & 4,5 & правая & $1,2,3$ \\
\hline 5 & ж & 54 & 17 & ВП & 5 & 8,5 & правая & 2,3 \\
\hline 6 & ж & 55 & 6 & ВП & 3 & 3,5 & правая & 3 \\
\hline
\end{tabular}

PP - рецидивирующе-ремиттирующая форма PC

ВП - вторично-прогрессирующая форма РС

Таблица 26

Локализация триггерных зон у больных НТН с рассеянным склерозом

\begin{tabular}{|l|c|c|}
\hline \multicolumn{1}{|c|}{ Локализация } & $\begin{array}{c}\text { Количество } \\
\text { пациентов }\end{array}$ & $\mathbf{\%}$ \\
\hline в области угла рта & 1 & 16,7 \\
\hline в области верхней губы & 2 & 33,3 \\
\hline в области десны нижней челюсти & 1 & 16,7 \\
\hline в области десны верхней челюсти & 1 & 16,7 \\
\hline в лобной области & 1 & 16,7 \\
\hline
\end{tabular}


$150 \mid$ Классическая невралгия тройничного нерва

Таблица 27

Особенности проявления НТН у больных с рассеянным склерозом

\begin{tabular}{|l|l|l|}
\hline \multicolumn{1}{|c|}{ Показатели } & \multicolumn{1}{c|}{$\boldsymbol{M \pm m}$} & \multicolumn{1}{c|}{$\boldsymbol{\sigma}$} \\
\hline Возраст & $51,7 \pm 2,8$ & 6,9 \\
\hline $\begin{array}{l}\text { Продолжительность последнего обострения } \\
\text { (месяцы) }\end{array}$ & $6,5 \pm 3,6$ & 8,7 \\
\hline Продолжительность заболевания (годы) & $7,7 \pm 2,6$ & 6,4 \\
\hline Интенсивность боли по ВАШ (баллы) & $8,8 \pm 0,6$ & 1,47 \\
\hline Длительность болевого пароксизма (сек) & $14,2 \pm 3,7$ & 9,2 \\
\hline Частота приступов в течение суток & $29,5 \pm 7,5$ & 18,3 \\
\hline $\begin{array}{l}\text { Шкала оценки повседневной активности } \\
\text { больного до лечения (баллы) }\end{array}$ & $25,0 \pm 1,2$ & 2,9 \\
\hline
\end{tabular}

В качестве примера приводим одно из наших наблюдений.

Больная Р. 55 лет, поступила в клинику РостГМУ с жалобами на острые, стреляющие боли «по типу удара электрическим током» в области нижней челюсти справа, иррадиирующие к наружному слуховому проходу. Частота приступов свыше 10 в день, длительность приступа до 2 минут.

Считает себя больной с 2007 года, когда впервые появились стреляющие боли в области нижней челюсти справа. Обратилась к стоматологу, который исключил стоматологическую патологию и направил больную к неврологу. Неврологом по месту жительства был поставлен диагноз невралгия тройничного нерва и назначен карбамазепин по 200 мг 3 раза в день. В течение двух лет при обострении заболевания принимала карбамазепин. С февраля 2010 года в связи с нарастанием интенсивности и частоты болевых пароксизмов вынуждена была увеличить суточную дозу карбамазепина до 2400 мг. При неврологическом обследовании патологии со стороны черепно-мозговых нервов не обнаружено. Сухожильные рефлексы с верхних и нижних конечностей высокие с расширением рефлексогенной зоны. Симптом Бабинского справа, в позе Ромберга не устойчива. Тазовые функции контролирует. С целью проведения дифференциальной диагностики между классической НТН и симптоматической больной выполнена МРТ, выявившая признаки демиелинизирующего заболевания (рис. 85). 

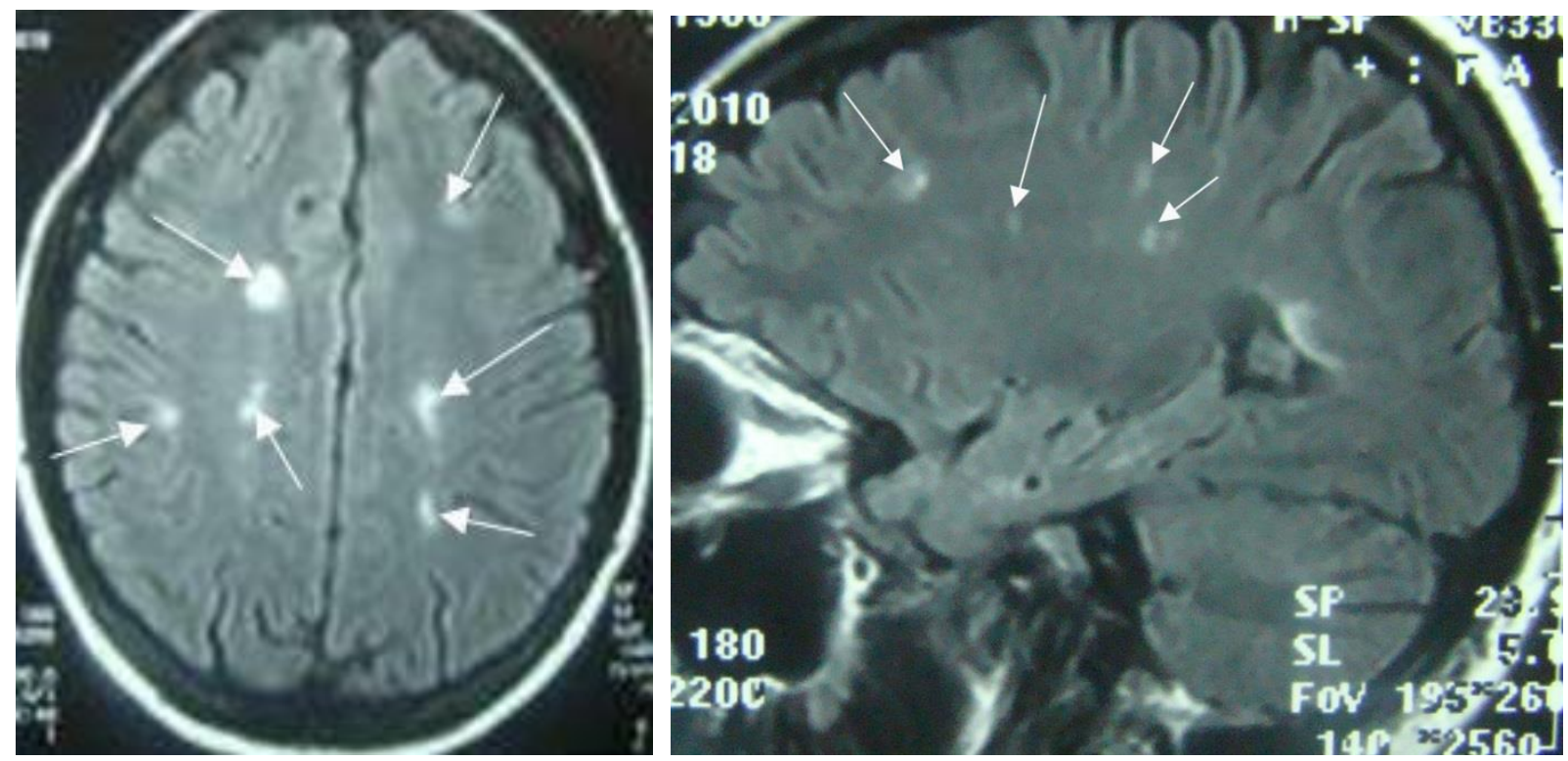

Рис. 85. Больная Р. НТН с локализацией болей в трех ветвях правого ТН в сочетании с рассеянным склерозом. Стрелками указаны очаги демиелинизации

14.05.2010 г. выполнена СКТ ангиография, выявившая васкулоневральный конфликт между КТН и ВМА. 25.05.2010 больной выполнена микроваскулярная декомпрессия правого КТН (рис. 86), выявившая и устранившая васкулоневральный конфликт между КТН и ВМА.

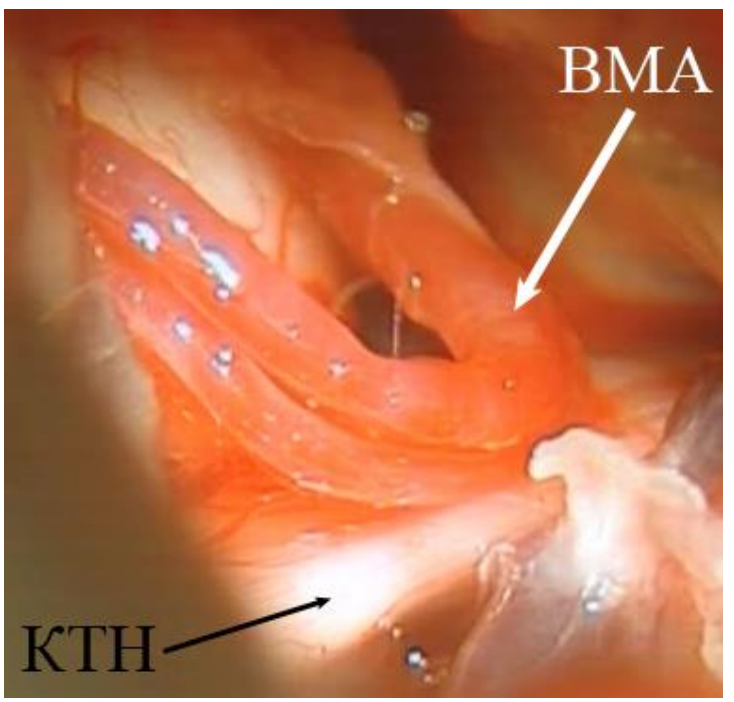

a)

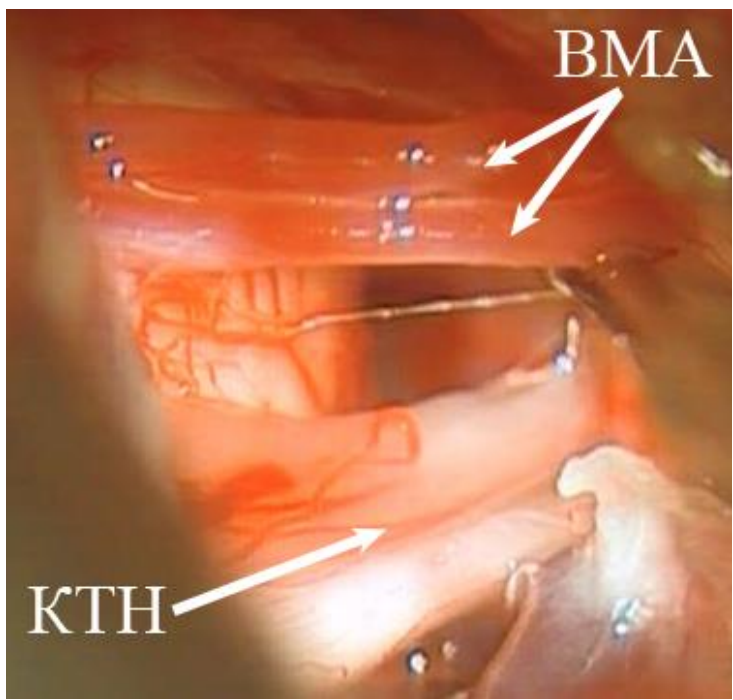

б)

Рис. 86. Больная Р. НТН с локализацией болей в трех ветвях правого ТН: а) васкулоневральный конфликт между КТН и ВМА; б) после смещения обеих стволов ВМА вверх к намету мозжечка открылось место васкулоневрального конфликта. Четко виден серый цвет КТН в месте конфликта, свидетельствующий о демиелинизации волокон КТН у больной рассеянным склерозом в сочетании с НТН 
$152 \mid$ Классическая невралгия тройничного нерва

Сразу после пробуждения от наркоза приступы болей не возникали. При осмотре через 2 года жалоб на болевые пароксизмы пациентка не предъявляла, однако отмечает нарастание неустойчивости при ходьбе.

У всех 6 больных РС при МВД верифицирован васкулоневральный конфликт между КТН и ВМА (рис. 86). У больных РС КТН в месте васкулоневрального конфликта имел сероватый оттенок и был более истончен, чем у больных классической НТН, что, по-видимому, можно объяснить общей аутоиммунной агрессией к миелину при PC. Исчезновение болей после МВД у больных РС свидетельствует о роли всакулоневрального конфликта в возникновении НТН и у этой группы больных.

\subsection{3. КЛИНИЧЕСКИЕ ПРОЯВЛЕНИЯ НТН У БОЛЬНЫХ} С АРТЕРИОВЕНОЗНОЙ МАЛЬФОРМАЦИЕЙ ЗАДНЕЙ ЧЕРЕПНОЙ ЯМКИ

В доступной нам литературе мы встретили описания по одному лишь наблюдению мальформаций задней черепной ямки, клиническим дебютом которых была невралгия тройничного нерва [125, $129,241,283,388]$. При этом в некоторых наблюдениях от первого симптома невралгии до постановки правильного диагноза проходило более года (Deshmukh VR, 2005). Все время до постановки правильного диагноза больные получали медикаментозное лечение, обычно безуспешное, как страдающие классической невралгией.

Приводим собственное наблюдение больной с артериовенозной мальформацией, дебютом которой была НТН.

Больная К. 46 лет обратилась 30.06.08 г. с жалобами на приступообразные стреляющие боли, сравнимые с ударом электрическим током, в области нижней челюсти нижней губы и подбородка справа. Продолжительность болевого пароксизма несколько секунд. Приступы боли провоцировались разговором, приемом пищи, туалетом полости рта. Впервые прострелы возникли в сентябре 2007 года, когда возникшие боли в области нижней челюсти в проекции пя- 
того зуба привели ее к стоматологу, который удалил «болевший» зуб, однако через две недели боли возобновились. Невролог расценил заболевание как классическую невралгию третьей ветви правого тройничного нерва и назначил карбамазепин. Интенсивность и частота болевых пароксизмов уменьшилась. Однако в мае 2008 года после стрессовой ситуации приступы болей усилились и участились до 80-100 приступов в день. Прием 1000 мг карбамазепина лишь на время уменьшал частоту приступов, и больная могла с трудом принимать пищу. В клинику нервных болезней и нейрохирургии РостГМУ обратилась в связи с неэффективностью проводимой по месту жительства терапии.

При осмотре установлено: интенсивность болей по ВАШ - 10 баллов, триггерные точки - десна нижней челюсти и нижняя губа справа. Нарушений чувствительности на лице не выявлено. Расстройств координации и других двигательных нарушений не обнаружено. Учитывая молодой возраст больной возникло подозрение о симптоматической невралгии тройничного нерва, и больная была направлена на МРТ ангиографию, которая выявила артериовенозную мальформацию правой половины задней черепной ямки (рис. 87), где долихоэктазированная и извитая ВМА, наряду с другими патологическими сосудами, принимали участие в васкулоневральном конфликте с правым КТН.

Учитывая большой объем мальформации и обширность зоны ее распространения, больная была направлена в НИИ нейрохирургии им. Н.Н. Бурденко, где путем введения адгезивной массы мальформация была выключена из кровотока. После этого лицевые боли не возобновлялись.

Данное наблюдение является примером трудности дифференциальной диагностики классической невралгии тройничного нерва от симптоматической, когда отсутствуют симптомы выпадения функций смежных структур. Однако молодой возраст больной (моложе 40 лет) и относительно короткий анамнез заболевания определили показания к интраскопическому исследованию, что и разрешило диагностическую задачу. 

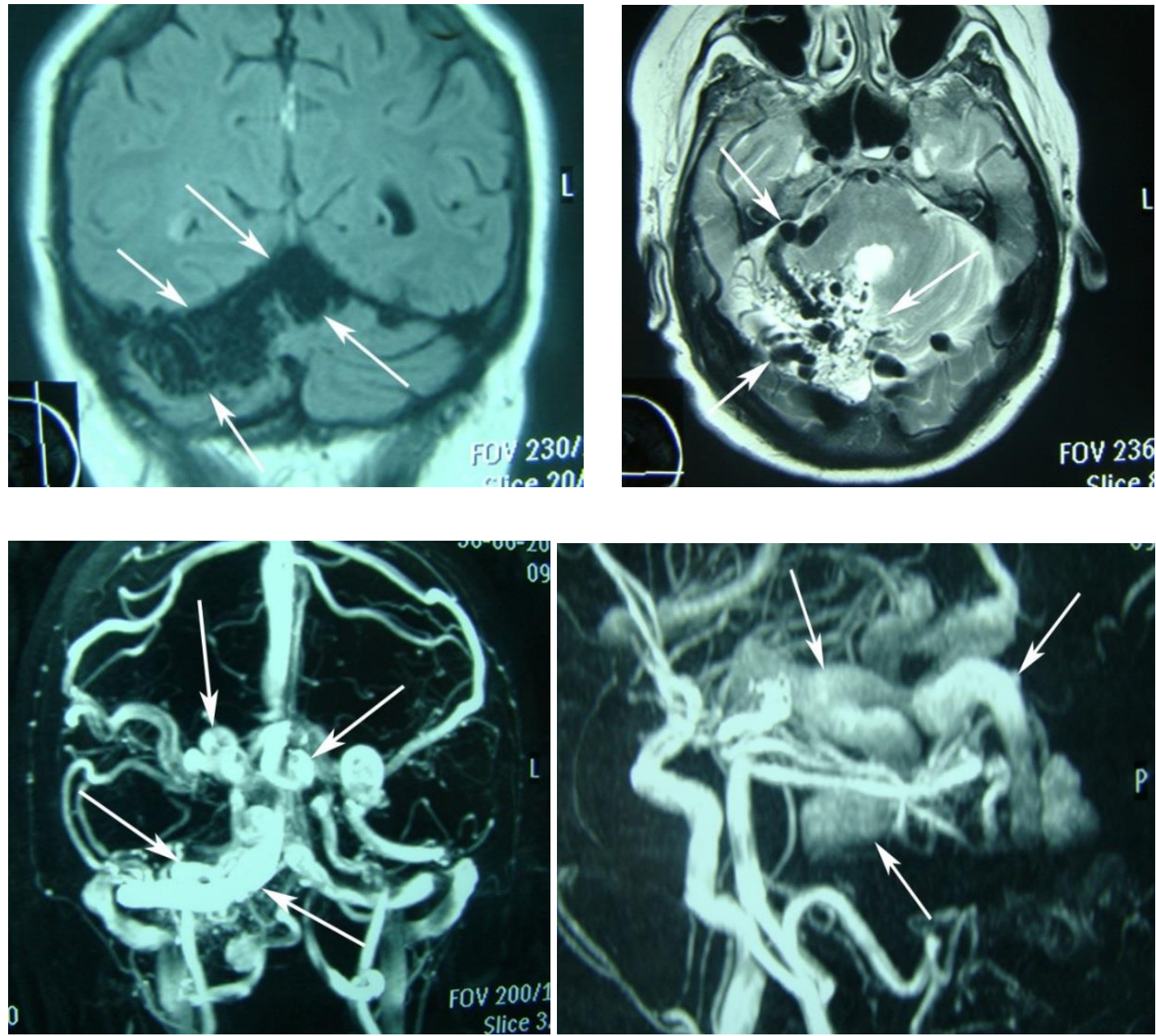

Рис. 87. Больная К. Симптоматическая НТН справа. Артериовенозная мальформация правой половины задней черепной ямки

\section{4. СРАВНИТЕЛЬНЫЙ АНАЛИЗ ПОКАЗАТЕЛЕЙ ТЕЧЕНИЯ ЗАБОЛЕВАНИЯ С РАЗЛИЧНЫМИ ВАРИАНТАМИ ВАСКУЛОНЕВРАЛЬНЫХ КОНФЛИКТОВ}

Сравнительный анализ особенностей исследованных групп конфликтов (1ВМА, 2BMA, 3ВМА, «артериовенозный сендвич» (ABC), «артериальный сендвич» (AAC)) проводился по средним значениям возраста пациентов, продолжительности последнего обострения, продолжительности заболевания, интенсивности боли по ВАШ, длительности болевого пароксизма, частоты приступов в течение суток, баллам по шкале повседневной активности больного до лечения. 
Статистически значимых отличий средних значений возраста пациентов с различными видами конфликтов, а также интенсивности боли по ВАШ не обнаружено.

Сравнение по частоте приступов (рис. 88) выявило статистически значимое различие между средними значениями частоты у пациентов с конфликтом 2ВМА и «АВ сэндвич» $(p=0,01)$, с конфликтом $2 \mathrm{BMA} \mathrm{и} \mathrm{«АА} \mathrm{сэндвич»}(p=0,02)$, с конфликтом 1ВМА и «АAC» $(p=0,02)$.

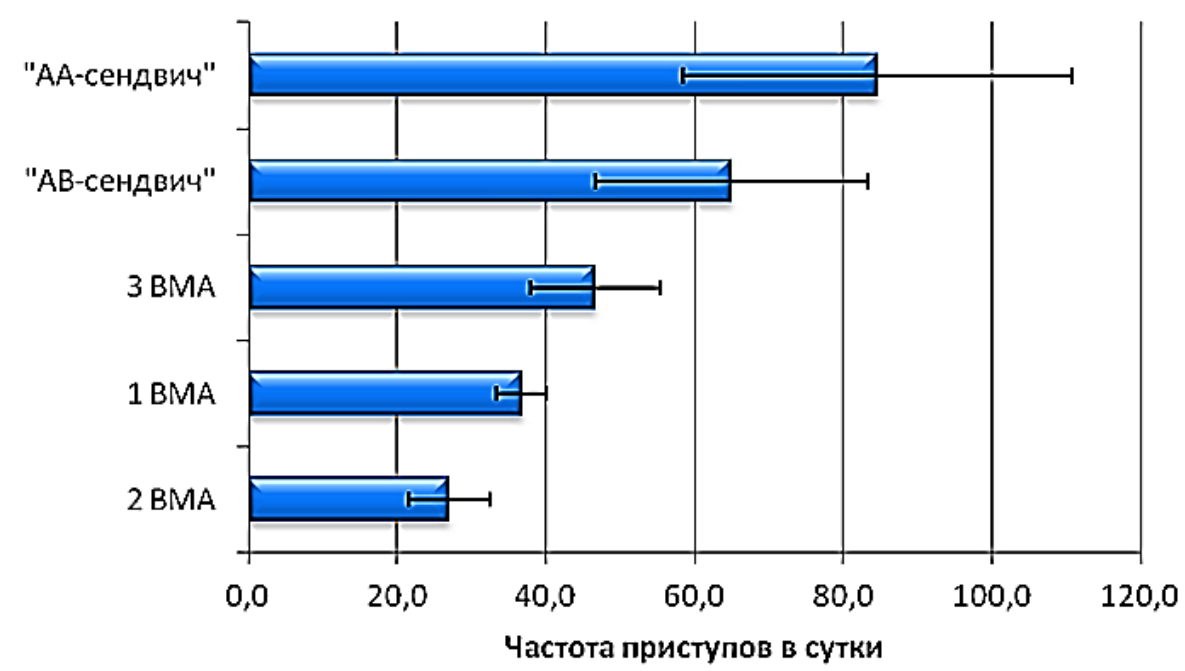

Рис. 88. График средних значений частот приступов у пациентов с различными видами конфликтов. Планки погрешностей соответствуют ( $\pm m)$

У пациентов с «сендвич»-конфликтами частота приступов статистически достоверно выше, чем у пациентов с иными видами конфликтов. Между другими группами с конфликтами КТН с несколькими ветвями ВМА статистически значимых различий по частоте приступов не выявлено.

Сравнение средних значений продолжительности приступа (рис. 89) выявило статистически значимые различия между этими величинами для пациентов с конфликтом «ААсэндвич» и «АВсэндвич» $(p=0,04)$, а также «ААсендвич» и 1ВМА-конфликт $(p=0,03)$. Заметны различия в длительности приступов у пациентов с другими видами конфликтов, однако, из-за значительных величин сигмы, статистически значимые различия не получены. 
$156 \mid$ Классическая невралгия тройничного нерва

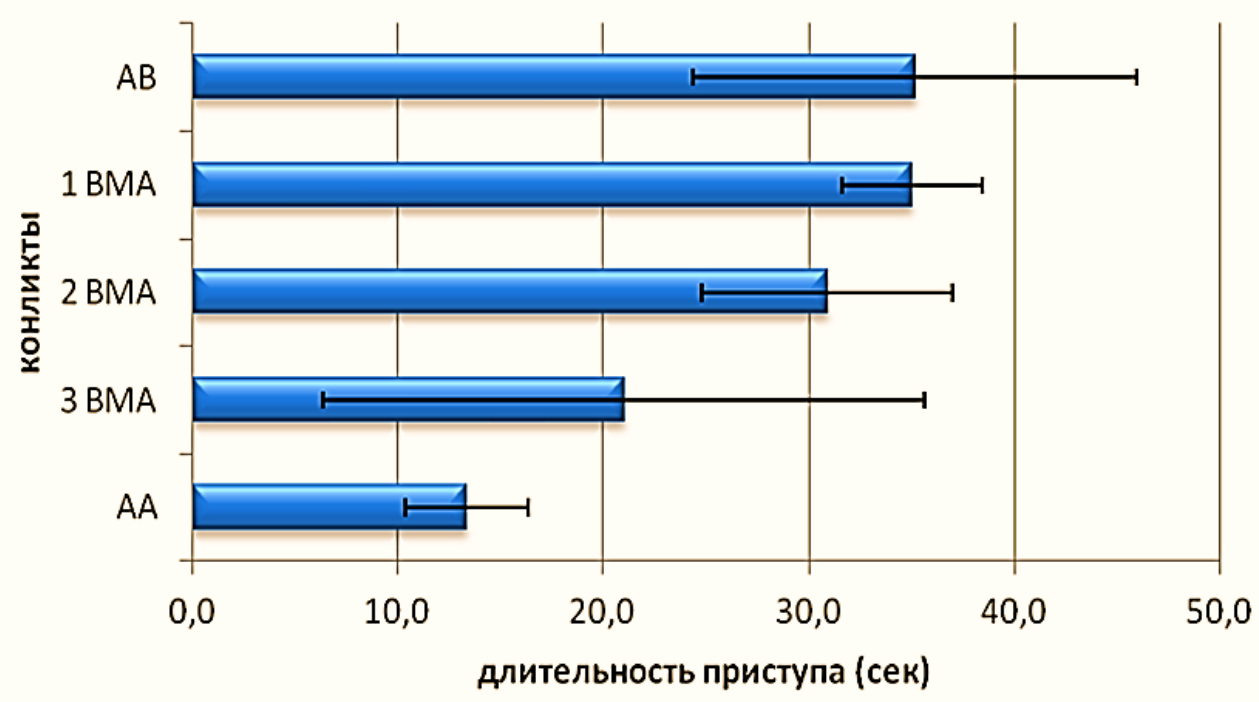

Рис. 89. Средние значения продолжительности приступа при различных вариантах васкулоневрального конфликта

На графике (рис. 90) отображены средние значения баллов повседневной активности больного до лечения у пациентов с различными видами конфликтов. Значения баллов при конфликте «1 ВМА» статистически значимо различаются с баллами для остальных групп конфликтов. Уровень значимости $p<0,01$. Следовательно, качество жизни пациентов с конфликтом «1 ВМА» выше, чем у пациентов с другими видами конфликтов. Это может быть обусловлено более низкой частотой приступов при этой форме васкулоневрального конфликта.

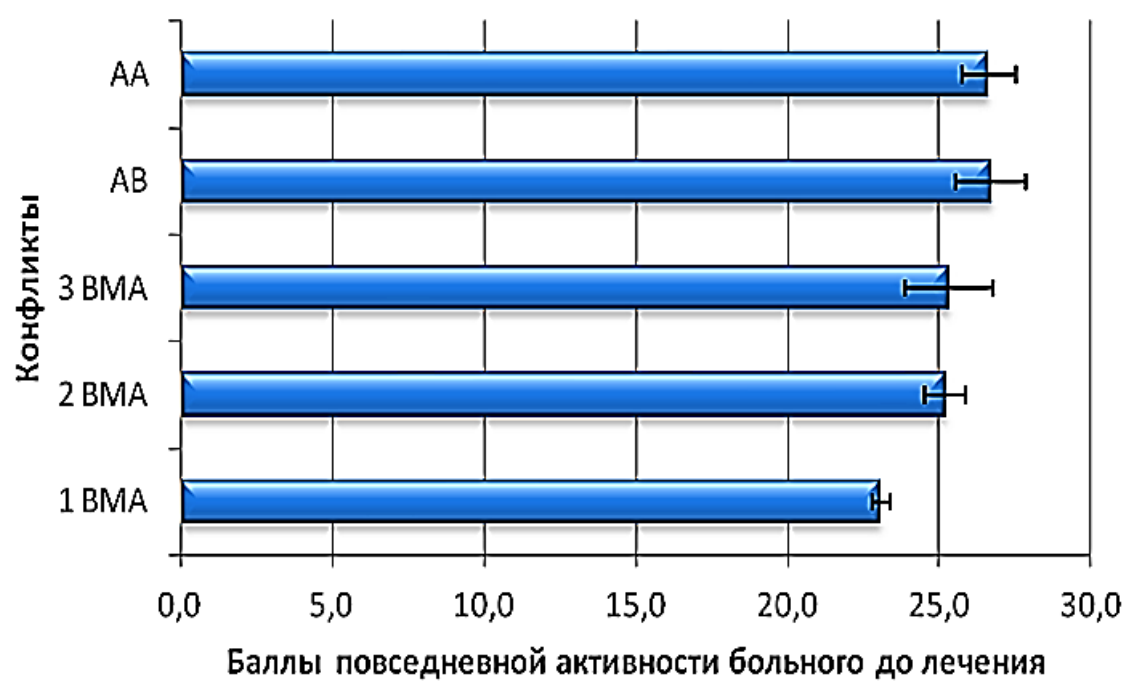

Рис. 90. Показатель повседневной активности больного в зависимости от особенностей васкулоневрального конфликта 
Сравнивая распределение по видам конфликтов средней частоты приступов и баллов повседневной активности больного до лечения можно заметить, что большей частоте приступов соответствует больший балл повседневной активности, величина которого обратно пропорциональна качеству жизни пациента. Следовательно, при большей частоте приступов качество жизни снижается.

\section{5. СРАВНИТЕЛЬНЫЙ АНАЛИЗ ПОКАЗАТЕЛЕЙ ПРОТЕКАНИЯ ЗАБОЛЕВАНИЯ В РАЗЛИЧНЫХ ВОЗРАСТНЫХ ГРУППАХ БОЛЬНЫХ С ВЕРИФИЦИРОВАННЫМ ДИАГНОЗОМ}

Для проведения сравнительного анализа зависимости показателей протекания болезни от возраста пациента, исследованный контингент больных с верифицированным диагнозом был разделен на следующие возрастные группы: до 40 лет, 41-50 лет, 51-60 лет, 61-70 лет, свыше 70 лет. На рис. 91 показано распределение больных по указанным возрастным группам. Видно, что имеет место наибольшее представительство больных в возрасте от 51 до 70 лет (26\% и 33\%). На долю больных до 40 лет приходится 5\%, старше 70 лет - 18\%.

\section{Возрастной состав больных}
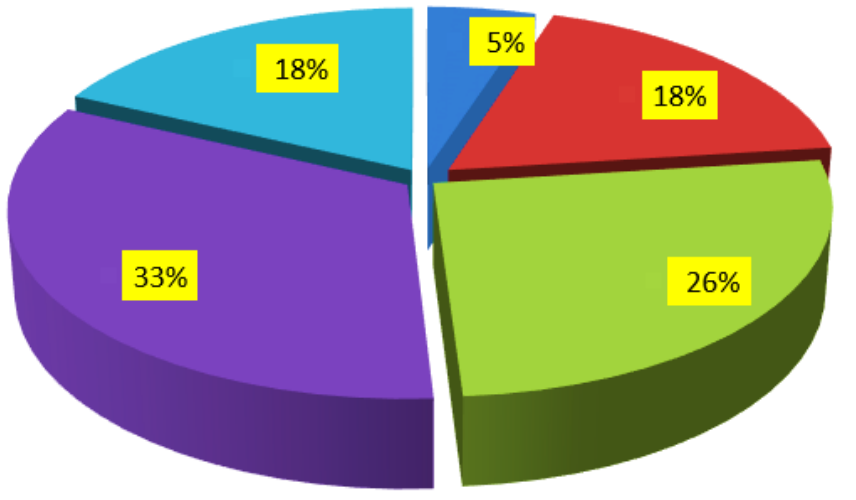

$$
\begin{aligned}
& \text { 口 до } 40 \text { лет } \\
& \text { п от } 41 \text { до } 50 \\
& \text { Шот } 51 \text { до } 60 \\
& \text { ш от } 61 \text { до } 70 \\
& \text { швыше } 71
\end{aligned}
$$

Рис. 91. Распределение по возрасту больных классической НТН с верифицированным васкулоневральным конфликтом 
Сравнение таких показателей, как средняя продолжительность заболевания, интенсивность боли по ВАШ, статистически значимых различий между возрастными группами не выявило.

Сравнение средних показателей длительности пароксизма (табл. 28, рис. 92) выявило статистически значимое различие этого показателя у возрастной группы 51-60 лет и возрастной группы до 40 лет $(p=0,034)$. В первой из этих групп длительность приступа со-

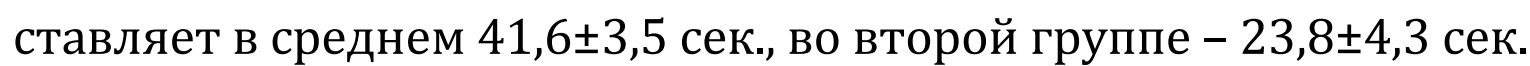

Таблица 28

\section{Распределение средней длительности приступа по возрастным группам}

\begin{tabular}{|c|c|c|}
\hline Группы пациентов & $\boldsymbol{M} \boldsymbol{m}, \mathbf{( с е к )}$ & $\boldsymbol{\sigma , ~ ( с е к ) ~}$ \\
\hline До 40 лет & $23,8 \pm 4,3$ & 13,6 \\
\hline $41-50$ лет & $30,1 \pm 5,6$ & 33,6 \\
\hline $51-60$ лет & $41,6 \pm 3,5$ & 25,0 \\
\hline $61-70$ лет & $34,8 \pm 4,2$ & 33,9 \\
\hline Свыше 70 лет & $27,5 \pm 5,0$ & 30,0 \\
\hline
\end{tabular}

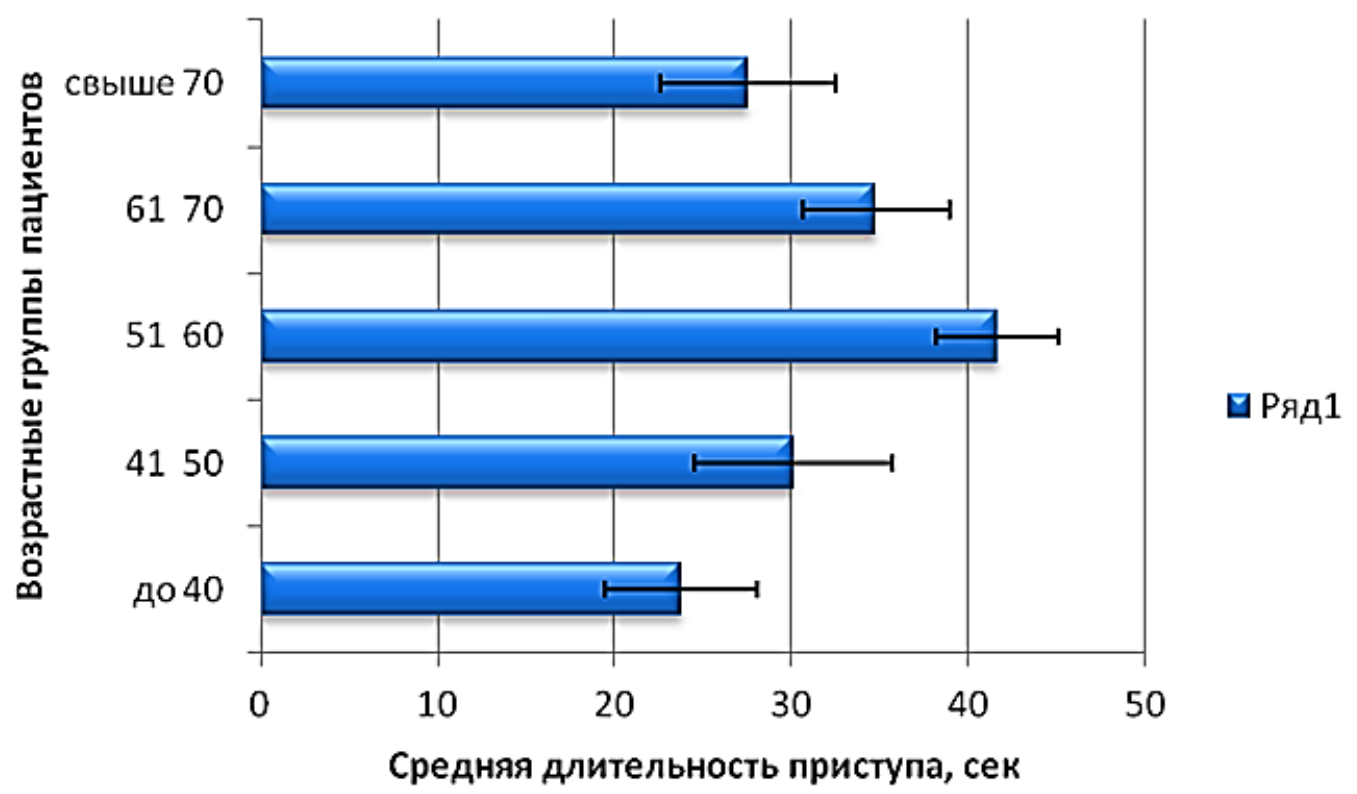

Рис. 92. График распределения средней длительности приступа по возрастным группам. Планка погрешностей соответствует $( \pm m)$ 
Сравнение средних значений частоты приступов у различных возрастных групп (табл. 28) выявило статистически значимое отличие частоты в группе до 40 лет по сравнению со всеми остальными группами. Значение частоты в этой группе значительно меньше, чем в остальных группах при том, что длительность приступов наибольшая.

Таблица 28

Распределение средней частоты приступов по возрастным группам

\begin{tabular}{|l|c|c|c|}
\hline Группы пациентов & $\begin{array}{c}\boldsymbol{M} \pm \boldsymbol{m}, \text { (колич. } \\
\text { за сутки) }\end{array}$ & $\begin{array}{c}\text { б, (колич. } \\
\text { за сутки }\end{array}$ & $\boldsymbol{p}$ \\
\hline До 40 лет & $17,6 \pm 3,4$ & 10,9 & 0,036 \\
\hline $41-50$ лет & $44,1 \pm 6,3$ & 37,8 & 0,026 \\
\hline $51-60$ лет & $38,2 \pm 4,4$ & 31,6 & 0,034 \\
\hline $61-70$ лет & $42,23 \pm 4,54$ & 36,88 & 0,035 \\
\hline Свыше 70 лет & $43,2 \pm 6,9$ & 41,3 & 0,028 \\
\hline
\end{tabular}

Указанные особенности отражены на рис. 93.

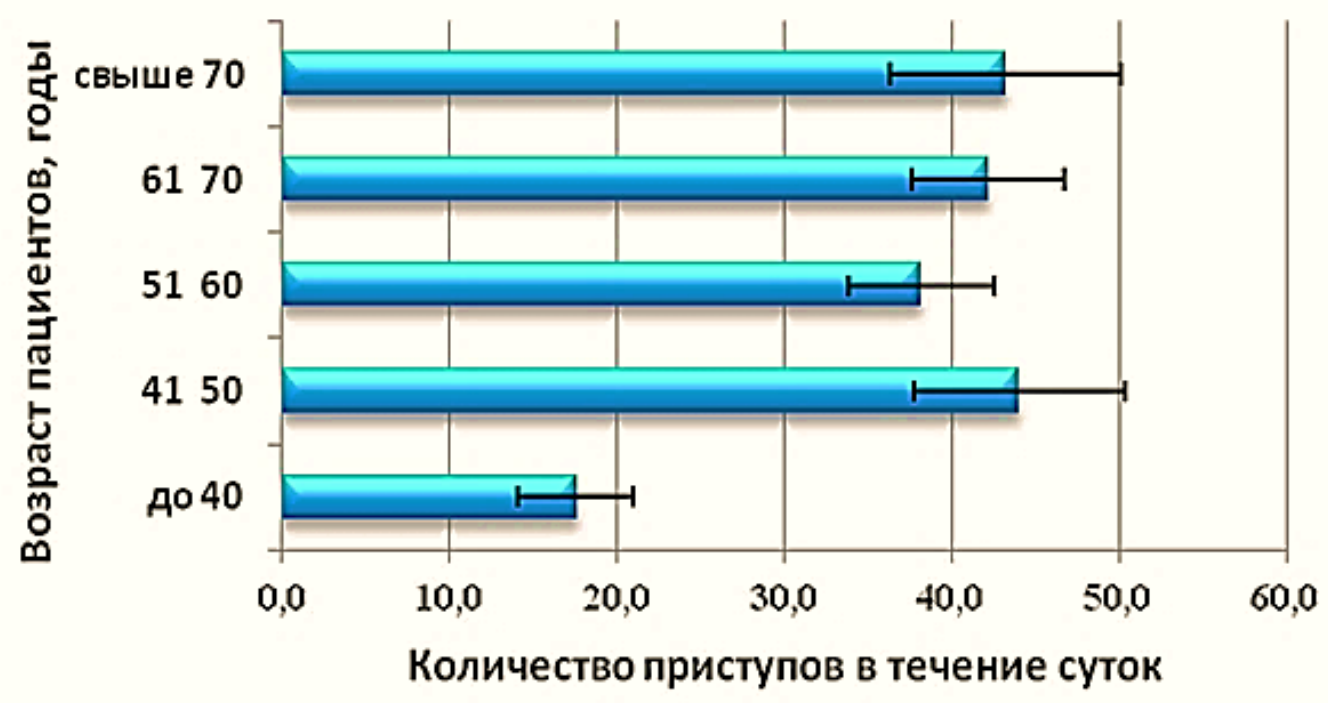

Рис. 93. Распределение средней частоты приступов по возрастным группам

В табл. 29 приведены средние величины баллов оценки повседневной активности больного для различных возрастных групп, а также значения уровней значимости отличий этих величин при 
$160 \mid$ Классическая невралгия тройничного нерва

сравнении группы до 40 лет со всеми остальными группами. Наименьший балл (соответствующий лучшему качеству жизни) отмечается у больных до 40 лет, при том, что в этой группе больных была наименьшая частота приступов, хотя и при большей их длительности. Можно полагать, что качество жизни больше связано именно с частотой приступов (различий по тяжести боли не было).

Таблица 29

Распределение среднего балла оценки повседневной активности больного по возрастным группам

\begin{tabular}{|l|c|c|c|}
\hline Группы пациентов & $\boldsymbol{M} \pm \boldsymbol{m}$ (балл) & $\boldsymbol{\sigma}$ (балл) & $\boldsymbol{p}$ \\
\hline До 40 лет & $23,20 \pm 0,61$ & 1,93 & \\
\hline $41-50$ лет & $24,86 \pm 0,41$ & 2,49 & 0,042 \\
\hline $51-60$ лет & $24,75 \pm 0,33$ & 2,37 & 0,042 \\
\hline $61-70$ лет & $24,91 \pm 0,41$ & 3,31 & 0,040 \\
\hline Свыше 70 лет & $25,03 \pm 0,49$ & 2,94 & 0,037 \\
\hline
\end{tabular}

Сравнение распределения средних величин длительности периода обострения не выявило статистически значимых различий этого параметра в разных возрастных группах (табл. 30). Можно лишь отметить тенденцию к увеличению данного показателя в группах от 41 года до 70 лет по сравнению с крайними возрастными группами (до 40 и старше 70 лет).

Таблица 30

Распределение средней длительности периода обострения по возрастным группам

\begin{tabular}{|l|c|c|}
\hline Группы пациентов & $\boldsymbol{M} \boldsymbol{m}$ (месяцы) & $\boldsymbol{\sigma}$ (месяцы) \\
\hline До 40 лет & $2,8 \pm 0,3$ & 0,9 \\
\hline $41-50$ лет & $4,8 \pm 0,9$ & 5,1 \\
\hline $51-60$ лет & $4,1 \pm 0,6$ & 4,6 \\
\hline $61-70$ лет & $4,6 \pm 0,5$ & 4,3 \\
\hline Свыше 70 лет & $3,3 \pm 0,4$ & 2,5 \\
\hline
\end{tabular}




\section{6. СРАВНИТЕЛЬНЫЙ АНАЛИЗ ПОКАЗАТЕЛЕЙ ПРОТЕКАНИЯ ЗАБОЛЕВАНИЯ У ПАЦИЕНТОВ С РАЗЛИЧНОЙ ЧАСТОТОЙ ПРИСТУПОВ ЗА СУТКИ}

Далее был предпринят сравнительный анализ показателей протекания заболевания у пациентов с различной частотой приступов. Контингент больных разделили на следующие группы: с частотой приступов до 50 в сутки, от 51 до 100 и свыше 100 за сутки. Распределение больных по данным группам показано на рис. 94.

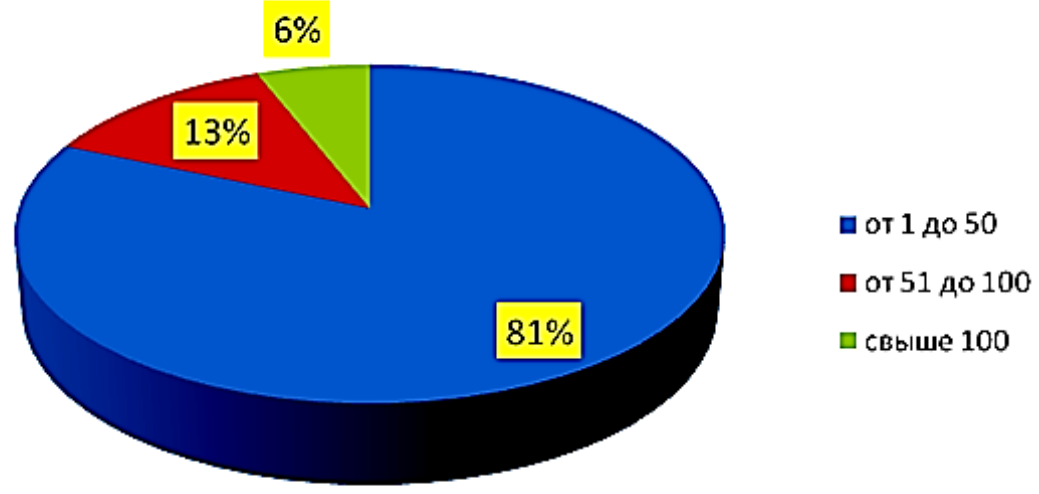

Рис. 94. Распределение больных НТН по частоте приступов

Из рис. 94 видно, что бо́льшая часть обследованных больных (81\%) имела частоту приступов до 50 в сутки. У 13\% больных частота лежала в диапазоне от 51 до 100 приступов за сутки. У 6\% процентов больных она была свыше 100 приступов за сутки. В основном это больные, поступившие в клинику в состоянии невралгического статуса.

Статистически значимых различий по возрасту, длительности периода обострения, длительности заболевания и интенсивности боли по ВАШ в указанных частотных группах обнаружено не было.

Для средних значений длительности приступов (табл. 31) и баллов повседневной активности пациентов (табл. 32) выявлены следующие особенности. 
162 Классическая невралгия тройничного нерва

Таблица 31

Распределение средней длительности приступа по частотным группам

\begin{tabular}{|l|c|c|c|}
\hline \multicolumn{1}{|c|}{ Группы пациентов } & $\boldsymbol{M} \mathbf{m}$ (сек) & $\boldsymbol{\sigma}$ (сек) & $\boldsymbol{p}$ \\
\hline от 1 до 50 приступов & $35,71 \pm 2,43$ & 31,06 & 0,003 \\
\hline от 51 до 100 приступов & $18,84 \pm 2,50$ & 12,51 & 0,01 \\
\hline свыше 100 приступов & $45,0 \pm 11$ & 37,3 & 0,009 \\
\hline
\end{tabular}

Таблица 32

Распределение средних величин баллов повседневной активности пациентов в группах с разной частотой приступов

\begin{tabular}{|l|c|c|}
\hline \multicolumn{1}{|c|}{ Группы пациентов } & $\boldsymbol{M \pm m}$ (баллы) & б (баллы) \\
\hline от 1 до 50 приступов & $24,15 \pm 0,20$ & 2,60 \\
\hline от 51 до 100 приступов & $26,68 \pm 0,50$ & 2,48 \\
\hline свыше 100 приступов & $28,67 \pm 0,36$ & 1,23 \\
\hline
\end{tabular}

Длительность приступа у пациентов в группе с частотой от 51 до 100 приступов за сутки была статистически значимо ниже $(p<0,01)$ по сравнению с этим показателем в двух других группах. Распределение величины длительности по группам показано на рис. 95.

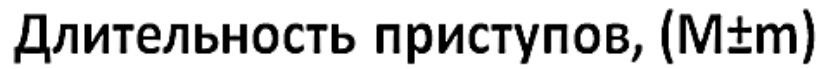

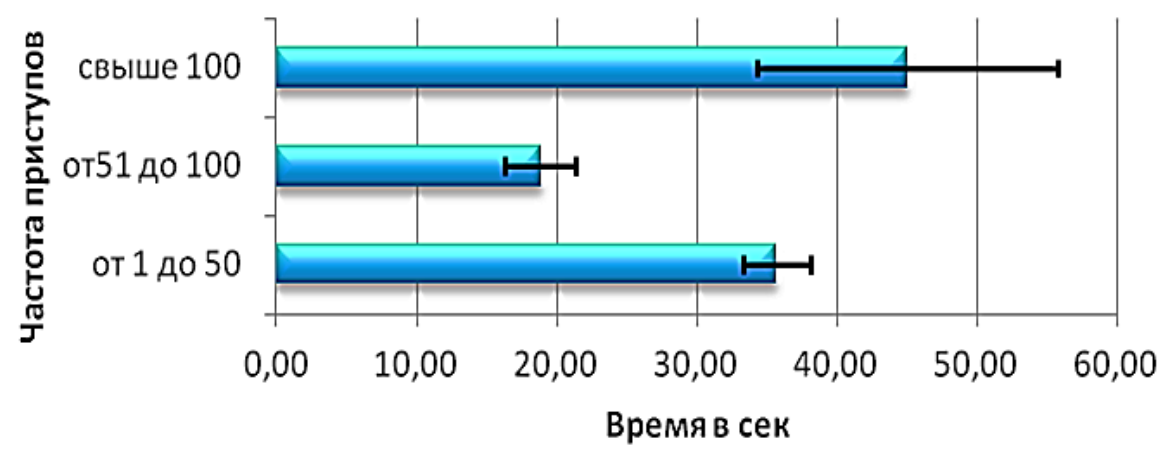

Рис. 95. Распределение средней длительности приступа по частотным группам 
Сравнение баллов оценки повседневной активности пациента выявляет статистически значимое $(p<0,001)$ отличие величины этого показателя во всех рассмотренных группа. При этом в группе с частотой до 50 приступов за сутки данный показатель ниже по сравнению с другими группами, а в группе с частотой более 100 приступов за сутки - больше, чем в остальных группах. Вновь просматривается закономерность роста балла повседневной активности пациента (ухудшение состояния) с ростом частоты приступов за сутки.

График распределения средних величин баллов повседневной жизненной активности пациентов в группах с разной частотой приступов дан на рис. 96.

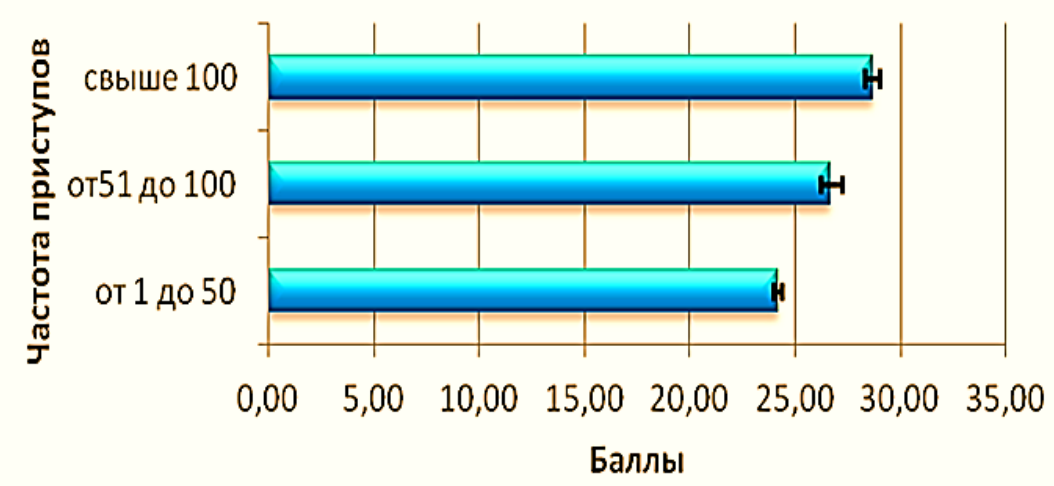

Рис. 96. Распределение средних величин баллов повседневной активности пациентов в группах с разной частотой приступов

Из этого следует, что у пациентов первой подгруппы, несмотря на большую длительность приступов по сравнению со второй подгруппой, качество жизни выше. Видимо, меньшее число приступов является более значимым фактором, влияющим на качество жизни, чем продолжительность приступов.

В табл. 33 приведено процентное распределение числа различных видов конфликтов в группах пациентов с различными значениями частоты приступов. В таблице не отражены конфликты, наблюдаемые у малого числа пациентов «3 ВМА», «ПНМА» и конфликт с веной, представленные 3-6 наблюдениями. Из таблицы видно доминирование конфликта «1 BMA» во всех группах, а также увеличение числа пациентов с конфликтами «АВС» и «AAC» в группе с частотой приступов более 100 за сутки. 
$164 \mid$ Классическая невралгия тройничного нерва

Таблица 33

Распределение видов конфликтов по частотным группам

\begin{tabular}{|c|c|c|c|}
\hline \multirow{2}{*}{$\begin{array}{c}\text { Виды } \\
\text { конфликтов }\end{array}$} & \multicolumn{3}{|c|}{ Группы пациентов } \\
\hline & $\begin{array}{l}\text { от } 1 \text { до } 50 \\
\text { приступов }\end{array}$ & $\begin{array}{c}\text { От } 51 \text { до } 100 \\
\text { приступов) }\end{array}$ & $\begin{array}{l}\text { свыше } 100 \\
\text { приступов }\end{array}$ \\
\hline $1 \mathrm{BMA}$ & $65 \%$ & $72 \%$ & $50 \%$ \\
\hline $2 \mathrm{BMA}$ & $17,2 \%$ & $8,0 \%$ & $8,3 \%$ \\
\hline $3 \mathrm{BMA}$ & $1,2 \%$ & $4,0 \%$ & \\
\hline ПНМА & $3,1 \%$ & & \\
\hline Вена & $4,9 \%$ & & \\
\hline $\mathrm{ABC}$ & $4,3 \%$ & $8,0 \%$ & $25,0 \%$ \\
\hline AAC & $4,3 \%$ & $8,0 \%$ & $16,7 \%$ \\
\hline
\end{tabular}

Для выявления тесноты связи и направления связи между параметрами был применен корреляционный анализ. Рассчитывался ранговый коэффициент корреляции Спирмена между всеми описанными параметрами для групп пациентов, различающихся типом конфликта. Установлены следующие особенности (табл. 34).

Таблица 34

\section{Результаты применения корреляционного анализа}

\begin{tabular}{|c|c|c|c|c|}
\hline $\begin{array}{c}\text { Группы } \\
\text { пациентов }\end{array}$ & $\begin{array}{c}\text { Параметры, между } \\
\text { которыми установлено } \\
\text { наличие связи }\end{array}$ & $\begin{array}{l}\text { Коэфф. } \\
\text { корреля- } \\
\text { ции, } r\end{array}$ & $\begin{array}{l}\text { Уровень } \\
\text { значи- } \\
\text { мости, } p\end{array}$ & $\begin{array}{c}\text { Характеристика } \\
\text { связи }\end{array}$ \\
\hline 1 & 2 & 3 & 4 & 5 \\
\hline \multirow[t]{4}{*}{$\begin{array}{l}\text { конфликт } \\
\text { "1 ВМА" }\end{array}$} & $\begin{array}{l}\text { Частота приступов и баллы } \\
\text { оценки повседневной } \\
\text { жизни пациента }\end{array}$ & 0,532 & 0,0001 & $\begin{array}{c}\text { средняя } \\
\text { положительная }\end{array}$ \\
\hline & \multicolumn{4}{|c|}{$\begin{array}{l}\text { Комментарий: чем выше частота приступов, тем выше балл оценки } \\
\text { повседневной жизни пациента, т.е. тем ниже качество жизни }\end{array}$} \\
\hline & $\begin{array}{l}\text { Длительность обострения } \\
\text { и длительность заболевания }\end{array}$ & 0,192 & 0,043315 & $\begin{array}{c}\text { слабая } \\
\text { положительная }\end{array}$ \\
\hline & \multicolumn{4}{|c|}{$\begin{array}{l}\text { Комментарий: большему периоду заболевания соответствует } \\
\text { больший период последнего обострения }\end{array}$} \\
\hline
\end{tabular}


Глава 4. Сравнительная характеристика клинических проявлений классической невралгии тройничного нерва в зависимости от анатомических особенностей васкулоневрального конфликта

Продолжение таблицы 34

\begin{tabular}{|c|c|c|c|c|}
\hline 1 & 2 & 3 & 4 & 5 \\
\hline \multirow[t]{4}{*}{$\begin{array}{l}\text { конфликт } \\
\text { "2 ВМА" }\end{array}$} & $\begin{array}{l}\text { Частота приступов и баллы } \\
\text { оценки повседневной } \\
\text { жизни пациента }\end{array}$ & 0,57 & 0,00496 & $\begin{array}{c}\text { средняя } \\
\text { положительная }\end{array}$ \\
\hline & \multicolumn{4}{|c|}{$\begin{array}{l}\text { Комментарий: чем выше частота приступов, тем выше балл оценки } \\
\text { повседневной жизни пациента, т.е. тем ниже качество жизни }\end{array}$} \\
\hline & $\begin{array}{l}\text { Длительность приступа } \\
\text { и возраст пациента }\end{array}$ & $-0,48$ & 0,032619 & $\begin{array}{c}\text { средняя } \\
\text { отрицательная }\end{array}$ \\
\hline & \multicolumn{4}{|c|}{$\begin{array}{l}\text { Комментарий: чем старше пациент, тем короче длительность } \\
\text { приступа }\end{array}$} \\
\hline \multirow[t]{6}{*}{$\begin{array}{l}\text { конфликт } \\
\text { "Вена" }\end{array}$} & $\begin{array}{l}\text { Длительность приступа и } \\
\text { длительность заболевания }\end{array}$ & 0,88 & 0,01982 & $\begin{array}{c}\text { существенная } \\
\text { положительная }\end{array}$ \\
\hline & \multicolumn{4}{|c|}{$\begin{array}{l}\text { Комментарий: большему периоду заболевания соответствует } \\
\text { большее время приступа }\end{array}$} \\
\hline & $\begin{array}{l}\text { Частота приступов } \\
\text { и длительность приступа }\end{array}$ & $-0,89$ & 0,015774 & $\begin{array}{l}\text { существенная } \\
\text { отрицательная }\end{array}$ \\
\hline & \multicolumn{4}{|c|}{$\begin{array}{l}\text { Комментарий: большей частоте приступов соответствует меньшая } \\
\text { длительность приступа }\end{array}$} \\
\hline & $\begin{array}{l}\text { Возраст пациента } \\
\text { и длительность заболевания }\end{array}$ & $-0,77$ & 0,072397 & $\begin{array}{l}\text { существенная } \\
\text { отрицательная }\end{array}$ \\
\hline & \multicolumn{4}{|c|}{$\begin{array}{l}\text { Комментарий: чем старше пациент, тем короче длительность } \\
\text { заболевания }\end{array}$} \\
\hline \multirow[t]{2}{*}{$\begin{array}{l}\text { конфликт } \\
\text { "АAC" }\end{array}$} & $\begin{array}{l}\text { Частота приступов } \\
\text { и длительность заболевания }\end{array}$ & 0,86 & 0,002603 & $\begin{array}{c}\text { существенная } \\
\text { положительная }\end{array}$ \\
\hline & \multicolumn{4}{|c|}{$\begin{array}{l}\text { Комментарий: большему периоду заболевания соответствует бо́льшая } \\
\text { частота приступов }\end{array}$} \\
\hline \multirow[t]{2}{*}{$\begin{array}{l}\text { конфликт } \\
\text { "ABC" }\end{array}$} & $\begin{array}{l}\text { Частота приступов и баллы } \\
\text { оценки повседневной } \\
\text { жизни пациента }\end{array}$ & 0,88 & 0,000133 & $\begin{array}{c}\text { существенная } \\
\text { положительная }\end{array}$ \\
\hline & \multicolumn{4}{|c|}{$\begin{array}{l}\text { Комментарий: чем выше частота приступов, тем выше балл оценки } \\
\text { повседневной жизни пациента, т.е. тем ниже качество жизни }\end{array}$} \\
\hline
\end{tabular}

Таким образом, в результате проведенного анализа клинических наблюдений НТН 200 больных с клиникой классической НTH, васкулоневральный конфликт у которых верифицирован интраоперационно, установлено: 
$166 \mid$ Классическая невралгия тройничного нерва

1) пик начала заболевания приходится на 6 десятилетие жизни (от 51 до 60 лет), в то время как пик обращаемости за МВД приходится на 7 десятилетие жизни (от 61 до 70 лет);

2) классической НТН болеют чаще женщины 68\% (136 женщин из 200 верифицированных наблюдений НTH);

3) преимущественно страдает третья ветвь как изолировано, так и в сочетании со второй ветвью 74\% (у 148 больных из 200);

4) чаще всего боли локализуются с правой стороны 62,5\% (из 200 больных у 125 - справа и у 75 - слева).

5) чем выше частота приступов, тем хуже показатели повседневной активности больного;

6) чем в более старшем возрасте начинается заболевание, тем короче его продолжительность до обращения за медицинской помощью;

7) большей продолжительности заболевания соответствует большая продолжительность последнего обострения и большая частота приступов;

8) большей частоте приступов соответствует меньшая продолжительность приступа;

9) предшествующие МВД деструктивные вмешательства, при рецидиве НТН, утяжеляют течение основного процесса, а после МВД сохраняется клиника невропатического синдрома.

Поиск причин ряда этих фактических данных был предметом нашего исследования.

В результате проведенного анализа клинических проявлений классической НТН, в зависимости от особенностей васкулоневрального конфликта, выявлены следующие особенности:

1) в подавляющем большинстве наблюдений в конфликте с КТН принимают участие артерии мозжечка (96\%) и только в 4\% был конфликт с веной;

2) при конфликте с несколькими артериальными стволами, когда травматическое воздействие на КТН один сосуд оказывает с вентральной стороны, а другой с дорзальной («артерио-артериальный сендвич») значительно чаще возникает невралгический статус; 
3) при конфликте КТН с артериальным стволом с вентральной стороны и ограничением его смещения дорзально, прилежащей к нему ВКВ («артерио-венозный сендвич») наблюдается учащение и усиление интенсивности болевых пароксизмов в горизонтальном положении больного и появление приступов в ночное время;

4) сочетание классической клинической картины НТН с постоянными болями в межприступном периоде, нарушениями чувствительности в зоне иннервации ТН и слабостью жевательной мускулатуры, без признаков поражения смежных структур, с высокой долей вероятности может свидетельствовать об участии в васкулоневральном конфликте долихоэктазированной БА.

Изучение физического механизма воздействия артериальных петель на КТН и обусловленных им морфологических изменений в КТН позволило уточнить сущность патогенеза заболевания и разработать более эффективные методы лечения. 
$168 \mid$ Классическая невралгия тройничного нерва

\section{ГЛАВА 5}

ДИФФЕРЕНЦИАЛЬНАЯ ДИАГНОСТИКА КЛАССИЧЕСКОЙ И СИМПТОМАТИЧЕСКОЙ НЕВРАЛГИИ ТРОЙНИЧНОГО НЕРВА

Как показали наши исследования, при классической НТН формирование васкулоневрального конфликта происходит в результате долихоэктазии ВМА (как врожденной, так и в результате увеличения извитости сосудов после 50 лет. Сближение корешка с артерией происходит также в результате укорочения арахноидальных струн, растянутых между ней и КТН, вследствие перенесенных воспалительных заболеваний (синуиты, тонзиллиты, кариозные зубы, частые простудные заболевания). Сезонность в возникновении обострений заболевания может быть связана с активацией герпетической инфекции (вирус простого герпеса 1), способствующей сближению артерии с корешком за счет его отека. При опухолях петрокливальной локализации и мостомозжечкового угла по мере увеличения их объема происходит сближение петли ВМА и КТН с формированием васкулоневральнго конфликта, что было верифицировано при удалении этих новообразований. При симптоматической НТН лицевые боли становятся одним из первых симптомов заболевания, при котором, в результате формирования васкулоневрального конфликта, НТН клинические проявляет себя раньше, чем те заболевания, с которыми она сочетается. Небольшого размера опухоли бывает достаточно 
для формирования васкулоневрального конфликта, в то время как объемного воздействия на соседние структуры мозга и смежные черепно-мозговые нервы она еще не оказывает воздействия. Поскольку в основе НТН как классической, так и симптоматической лежит васкулоневральный конфликт, чрезвычайно важным является уточненная диагностика самого конфликта и причин, его обусловивших.

Трудность дифференциальной диагностики классической и симптоматической НТН, прежде всего, кроется в общности клинических проявлений заболевания, особенно на ранних этапах его развития. Больные симптоматической НТН длительное время (годами) лечатся как больные классической НТН, принимая большие дозы противосудорожных препаратов и при их неэффективности подвергаясь различным деструктивным вмешательствам, также не приносящим облегчения, с высоким риском рецидивов болей. И лишь тогда, когда опухоль достигает значительных размеров, воздействуя на смежные структуры мозга, проявляется неврологическая симптоматика, как результат объемного воздействия на них.

\section{1. РОЛЬ КЛИНИКО-НЕВРОЛОГИЧЕСКОГО МЕТОДА В ДИАГНОСТИКЕ КЛАССИЧЕСКОЙ И СИМПТОМАТИЧЕСКОЙ НЕВРАЛГИИ ТРОЙНИЧНОГО НЕРВА}

При классической невралгии, как правило, в межприступном периоде отсутствует какая-либо симптоматика, и причиной ее является сосудистая компрессия КТН без других дополнительных факторов.

Продолжительность приступов боли была разнообразной, однако в большинстве случаев она составляла от нескольких секунд до 3 минут. Частота приступов колебалась в широких пределах: от нескольких приступов в течение дня, в основном провоцируемых раздражением триггерных зон, до 100 - 200 приступов в день, следующих один за другим. Обращало на себя внимание учащение и 
$170 \mid$ Классическая невралгия тройничного нерва

утяжеление приступов при повышении артериального давления у больных, страдающих артериальной гипертензией.

Иногда приступы болей сопровождались сокращением мускулатуры лица и, прежде всего, жевательной. У некоторых больных приступы тригеминальной невралгии сопровождались различными вегетативными симптомами: гиперемией лица, потливостью, усилением саливации и слезотечением. $\mathrm{C}$ целью уменьшения интенсивности и частоты приступов больные принимали препараты дибензазепинового ряда (карбамазепин, финлепсин, тегретол) от 400 мг до 4000 мг в сутки. Продолжительность безболевых периодов у обследованных нами больных была различной - от нескольких недель до нескольких месяцев. В редких случаях ремиссии достигали 1 года и более.

Симптомы выпадения, в виде гипестезии различной степени выраженности в зонах пораженных ветвей ТН, выявлены у 4 из 220 обследованных больных: у 10 пациентов, у которых были верифицированы менингиомы петрокливальной локализации, у 33 больных, которым на этапах были выполнены деструктивные вмешательства (алкоголизация, невротомия, нервэкзерез, ретрогассериальная радикотомия, гидротермическая и лазерная деструкция полулунного узла), и у 11 пациентов, которым до поступления в клинику выполнялись блокады периферических ветвей ТН на лице с различными лекарственными препаратами. Незначительная гипестезия, выявленная у последней группы больных, по-видимому, обусловлена травмой нервных стволов иглой. Средняя продолжительность заболевания у больных симптоматической невралгией была короче по сравнению с больными классической НТН (соответствен-

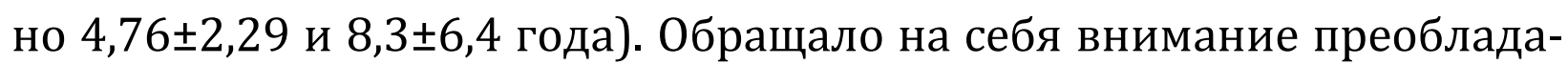
ние женщин среди больных симптоматической НТН (соотношение 9:1). Следует отметить еще одну особенность: у больных классической НТН преобладало поражение правого ТН в 1,56 раза (122:78), в то время как у больных вторичной НTH боли в 1,5 раза чаще наблюдались слева (12:8). Существенных различий в частоте и количестве болевых пароксизмов у больных классической и вторич- 
ной невралгией не было выявлено. Трудности клинической дифференциальной диагностики классической и вторичной НТН подчеркивались многими авторами [165, 167, 225, 307].

\section{2. ЗНАЧЕНИЕ МРТ В ДИФФЕРЕНЦИАЛЬНОЙ ДИАГНОСТИКЕ КЛАССИЧЕСКОЙ И СИМПТОМАТИЧЕСКОЙ НЕВРАЛГИИ ТРОЙНИЧНОГО НЕРВА}

Вторым этапом дифференциальной диагностики НТН является выявление причин, обусловивших развитие васкулоневрального конфликта, которое и определяет выбор метода лечения. Общность клинической картины классической и симптоматической НТН требует обязательного исключения вторичной природы заболевания. Такие симптоматические НТН как посттравматическая, обусловленная травмой или хирургическим вмешательством на лице или костях лицевого скелета, ятрогенная - деафферентационные боли в результате целенаправленного разрушения периферических ветвей, ганглиолиза или ризотомии как способа лечения НТН распознаются при сборе анамнеза и выявлении признаков невропатии. Диагностика же симптоматической НТН вызывает очень большие трудности. В этом отношении справедливо замечание Laurent B., et al. (2009) о том, что МРТ является самым важным методом в проведении дифференциального диагноза между классической и симптоматической НТН. Всем обследованным нами больным была выполнена РКТ или МРТ для исключения вторичной природы заболевания.

Клиника классической НТН в сочетании с возрастной нормой на РКТ или МРТ давала основание на ранних этапах нашего исследования для подтверждения диагноза классической НТН.

МРТ исследование в стандартном режиме давала возможность визуализировать долихоэктазию базилярной артерии, когда за счет избыточной длинны извивающейся артерии формируется конфликт как с самой базилярной артерией, так и со смещаемой ее в сторону КТН ВМА или ПНМА (рис. 97). 
172 Классическая невралгия тройничного нерва

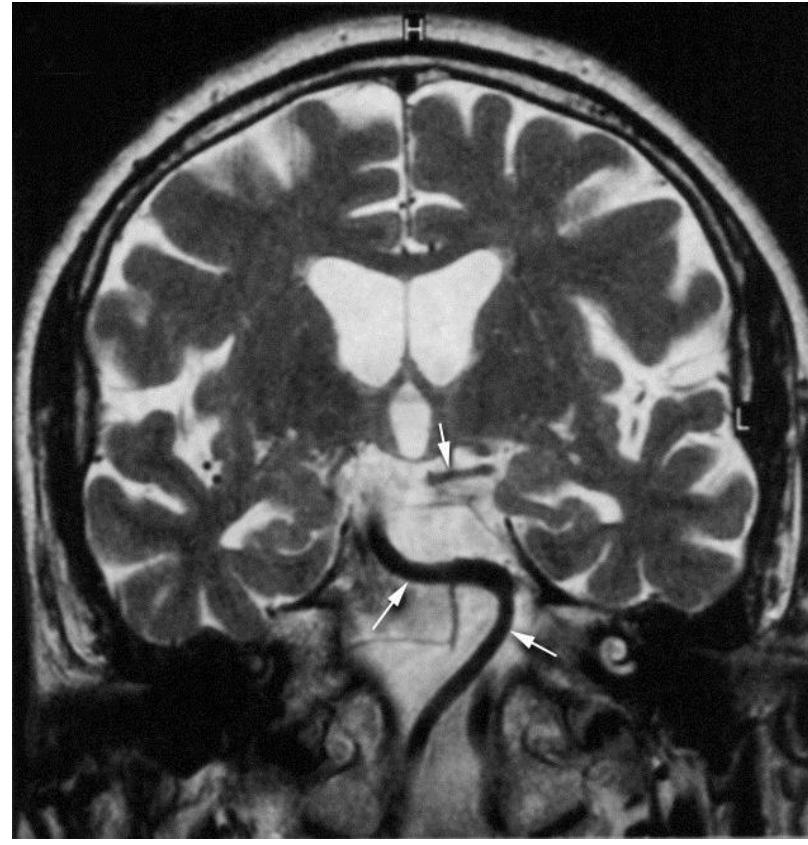

a)

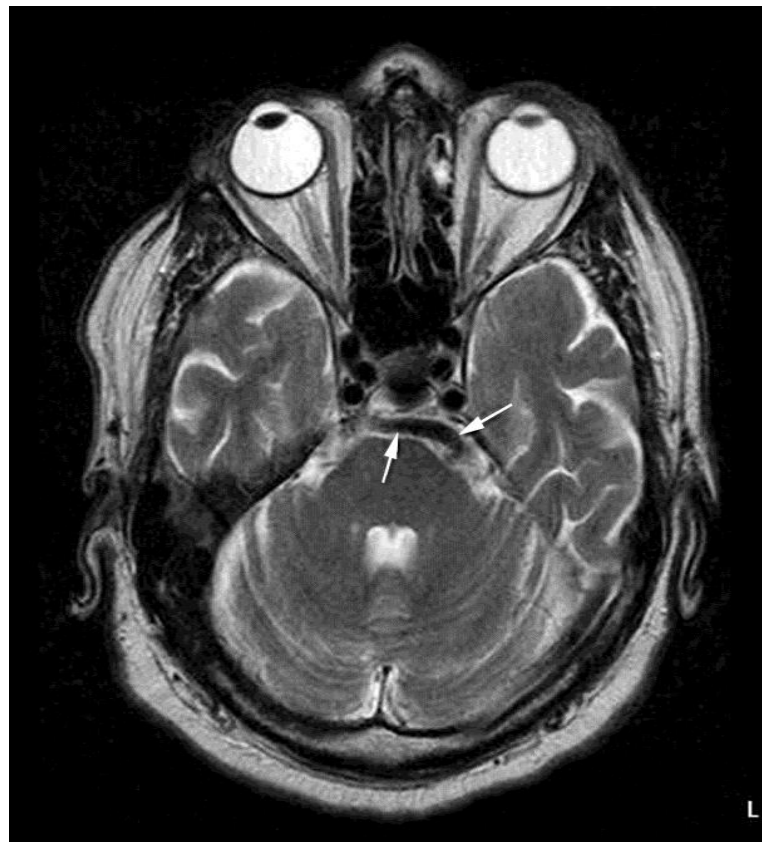

б)

Рис. 97. Больная Т. Ист. бол. № 11699. НТН справа с локализацией болей

в зоне третьей ветви. Долихоэктазия базилярной артерии, формирующая васкулоневральный конфликт с КТН

Общность клинической картины классической и симптоматической невралгии у обследованных нами больных не позволила стоматологам и неврологам, длительно наблюдавшим этих больных, до применения методов нейровизуализации установить правильных диагноз симптоматической природы заболевания. Больные с симптоматической невралгией получали лечение как больные классической невралгией на протяжении от 2 до 9 лет, принимая от 1000 до 2400 мг карбамазепина (финлепсина) в сутки, блокады, иглорефлексотерапию, физиотерапию, деструктивные хирургические вмешательства на периферическом нейроне и пр. При обследовании в клинике нервных болезней и нейрохирургии РостГМУ у 9 из 20 больных симптоматической НТН были обнаружены очаговые симптомы, позволившие до применения интраскопических методов исследования заподозрить вторичный характер заболевания. У 5 пациентов этой группы симптоматическая природа НТН установлена только с помощью РКТ или МРТ, поскольку единственным клиниче- 
ским проявлением заболевания были болевые пароксизмы без симптомов выпадения в начальном этапе заболевания. В качестве примера приводим одно из наших наблюдений.

Больная Я. 77 лет. История болезни № 8610. Поступила в клинику нейрохирургии РостГМУ 26.10.2007 г. с жалобами на приступообразные боли стреляющего характера в области правой щеки, верхней и нижней губы и подбородка справа. Болевые пароксизмы провоцировались приемом пищи, разговором, туалетом полости рта. Больна с 5 июня 1984 года, когда после постановки зубного протеза через 4 дня появилась боль в области правой щеки, подбородка и верхней и нижней губ справа стреляющего характера продолжительностью несколько секунд. Проведенные стоматологом блокады облегчения не принесли, интенсивность болей усиливалась. После приема финлепсина и курса ИРТ наступила ремиссия до 1987 года. Очередное обострение заболевания, несмотря на проводившееся лечение (ИРТ, финлепсин, электрофорез с лидокаином и др.), к полному исчезновению болей не приводило. Очередное обострение сопровождалось появлением шума в правом ухе и нарастанием неустойчивости походки. В 2004 году в ОКБ РО выполнена РКТ, выявившая кисту прозрачной перегородки и признаки энцефалопатии. Больная продолжала принимать финлепсин, что на некоторое время приносило облегчение. При неврологическом обследовании в клинике нейрохирургии РостГМУ выявлено: триггерные зоны (правый угол рта, правая щека), гипестезия в зоне 2 и 3 ветвей ТН, горизонтальный нистагм в обе стороны, интенционный тремор в правых конечностях при выполнении пальце-носовой и коленно-пяточной проб. АД - 160/90 - 180/95 мм рт.ст. Потеря массы тела за последний месяц - 8 кг. На выполненных 29.10.2007 г. МРТ выявлена менингиома медиальных отделов правого верхнего каменистого синуса, киста прозрачной перегородки (полость Верге), и признаки энцефалопатии в виде выраженной атрофии больших полушарий и заместительной гидроцефалии (рис. 98). 30.10.2007 г. выполнена субокципитальная краниотомия с удалением опухоли. 
174 Классическая невралгия тройничного нерва

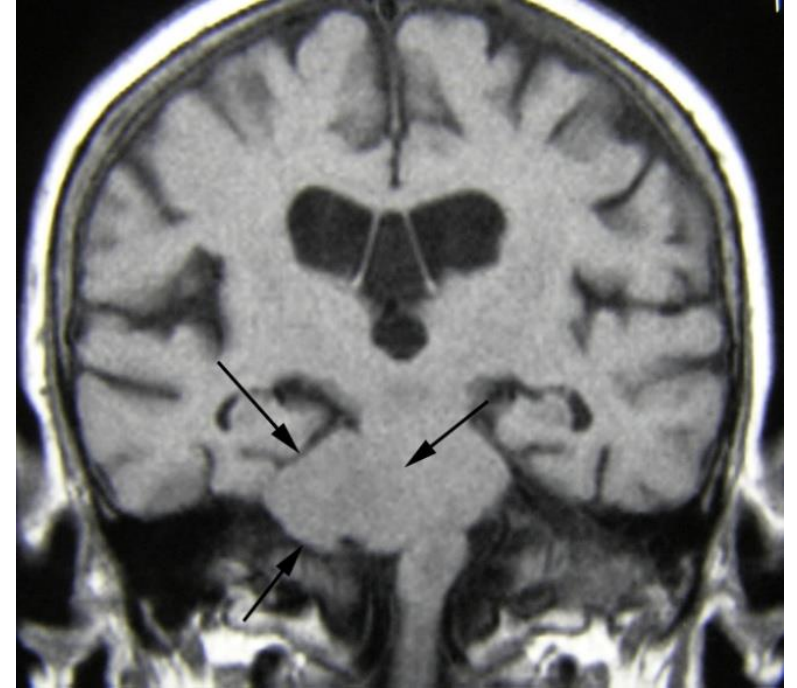

a)

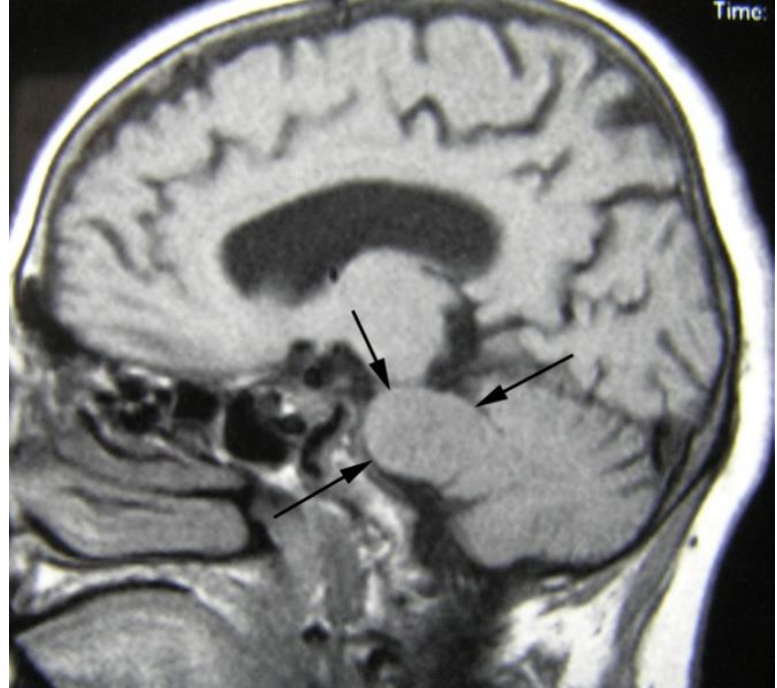

б)

Рис. 98. Больная Я. Ист. бол. № 8610. Симптоматическая невралгия правого ТН с локализацией болей в зонах 2 и 3 ветвей. Менингиома медиальных отделов правого верхнего каменистого синуса

После удаления опухоли обнаружен васкулоневральный конфликт между КТН и ВМА, которые были разъединены друг от друга на значительном расстоянии. Для устранения условий возобновления васкулоневрпального конфликта петля ВМА была перемещена в пространство между КТН и наметом мозжечка. После пробуждения от наркоза лицевые боли исчезли.

Интерес данного наблюдения в том, что НТН у больной появилась в 1984 году, задолго до выявления у нее опухоли. На выполненных РКТ в 2004 году опухоль не была обнаружена. И только 2007 году диагностирована менингиома верхнего каменистого синуса. Это наблюдение с равной долей вероятности можно рассматривать как классическую НТН, в процессе течения которой у больной возникла опухоль головного мозга, так как трудно себе представить, что относительно небольшая менингиома росла в течение 21 года и не была замечена на РКТ через 20 лет после начала лицевых болей.

Более трагична судьба другой больной, со сфенопетрокливальной менингиомой, которая под флагом классической невралгии тройничного нерва трижды подверглась деструктивным операциям в различных лечебных учреждениях. И, несмотря на полное отсутствие эффекта от проводившихся операций, ни в одном из учрежде- 
ний, пользовавших больную, не возникло мысли о вторичной природе заболевания.

Больная Т. 47 лет. Ист. бол. № 8630. Поступила в клинику нейрохирургии РостГМУ 26.10.2007 г. с жалобами на приступообразные стреляющие боли в левой щеке, верхней губе, левом крыле носа и в области левого верхнего века. Боли провоцировались разговором, приемом пищи, туалетом полости рта. Продолжительность приступов до 5 минут с частотой до 15-20 раз в сутки. Болеет с 1999 года, когда впервые появились стреляющие боли во время туалета полости рта. Больная обратилась к стоматологу по месту жительства, где в течение четырех месяцев ей были удалены все зубы левой половины верхней челюсти, однако ремиссии болей не наступило, а интенсивность и частота приступов нарастала. Затем ей выполнен нервэкзерез верхнечелюстного нерва. Прием финлепсина по 200 мг 3 раза в день сократил число приступов до 3 раз в день. В конце 2000 года появилась слабость в левой руке и ноге и чувство онемения в них. Неврологом процесс был расценен как остеохондроз шейного отдела позвоночника. После нескольких капельниц с дексаметазоном слабость и онемение в левых конечностях на некоторое время уменьшились. В связи с непрекращающимися болевыми пароксизмами в лице больной выполнены три спиртовые блокады в инфраорбитальное и ментальное отверстия. Однако ожидаемого результата они не принесли. С 2004 года появилась неустойчивость при ходьбе, шаткость больше влево. В 2006 году в НИИ лазерной хирургии больной выполнена лазерная деструкция полулунного узла. После этой операции лицевые боли усилились и развился парез левого отводящего нерва. При неврологическом обследовании в клинике нейрохирургии РостГМУ выявлена слабость в левых конечностях до 4 баллов, неустойчивость в позе Ромберга (падает влево), интенционный тремор в левых конечностях при выполнении пальце-носовой и колено-пяточной проб, сухожильная анизорефлексия $S>D$, гипестезия в зоне иннервации I и II ветвей ТН (которая могла быть следствием предыдущих деструктивных вмешательств) потеря массы тела свыше 6 кг. Триггерные зоны: левое крыло носа, угол 
$176 \mid$ Классическая невралгия тройничного нерва

рта, верхнее веко. Учитывая молодой возраст больной и наличие выраженной очаговой симптоматики была заподозрена вторичная НТН. На выполненной МРТ выявлена большая сфенопетрокливальная менингиома с супра-и субтенториальным ростом (рис. 99).

29.10.2007 г. больной выполнена операция удаления менингиомы указанной локализации через подвисочный доступ. Опухолевый узел удалялся кускованием с иссечением проращенной части намета мозжечка от области свободного края латерально вдоль верхнего каменистого синуса до его наружной трети. Зона роста опухоли из основания средней черепной ямки и стенки кавернозного синуса коагулирована.
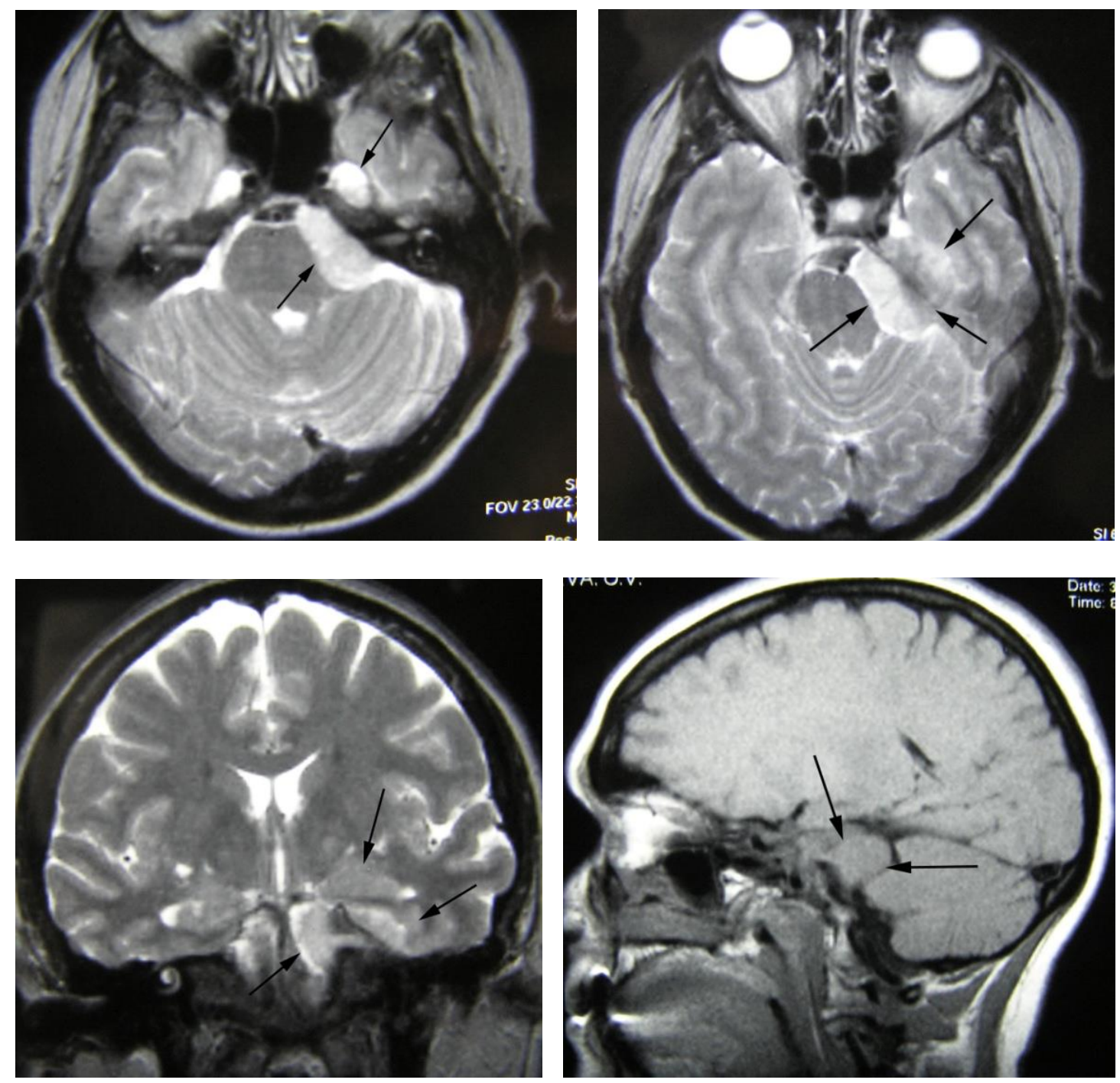

Рис. 99. Больная Т. 47 лет. Ист. бол. № 8630. Невралгия левого ТН всех трех ветвей. Сфенопетрокливальная менингиома слева 
Степень радикальности Симпсон 2. После удаления опухоли обнаружен васкулоневральный конфликт между КТН и ВМА. С целью профилактики возобновления васкулоневрального конфликта BMA перемещена в пространство между КТН и наметом мозжечка. После пробуждения от наркоза у пациентки лицевые боли исчезли, однако сохранялся парез левого отводящего нерва, развившийся после лазерной деструкции полулунного узла. В удовлетворительном состоянии больная выписана из клиники и добиралась до места жительства самостоятельно.

Данное наблюдение свидетельствует о том, что классический клинический синдром НТН гипнотически действовал на курировавших больную врачей. Несмотря на наличие очаговых неврологических симптомов, больную упорно продолжали лечить от классической невралгии, хотя положительного результата от выполненных деструктивных вмешательств не было. Это наблюдение лишний раз подчеркивает необходимость подумать о симптоматической природе заболевания у лиц молодого возраста с упорными болями и неврологическим дефицитом.

Большие трудности представляют вторичные НТН при наличии классической картины НТН и отсутствии других неврологических симптомов. В качестве примера приводим еще одно из наших наблюдений.

6 пациентам НТН, страдавшим рассеянным склерозом, выполнена МВД, из них было 5 женщин и 1 мужчина. Все они до поступления в клинику проходили лечение по поводу НТН у стоматологов, неврологов, специалистов ИРТ и др. как больные, страдающие классической НТН. В правой половине лица боли были у четырех и в левой - у двух. У 4 пациентов была вторично-прогрессирующая форма PC, и у двух - ремитирующая форма РС. У всех шестерых больных клиническая картина НТН соответствовала критериям диагностики классической НТН и при МВД верифицирован васкулоневральный конфликт между КТН и ВМА, что подтверждает его патогенетическую роль в возникновении НТН и у больных рассеянным склерозом. Обнаружение на МРТ очагов демиелинизации в больших полушари- 
$178 \mid$ Классическая невралгия тройничного нерва

ях головного мозга и мозжечке подтвердили диагноз рассеянного склероза. Ни у одного из наблюдавшихся нами больных с РС и НТН очагов демиелинизации в мосту не было обнаружено. В качестве примера приводим одно из наших наблюдений НТН у больной рассеянным склерозом.

Больная К. 47 лет. История болезни № 1513/261 поступила в клинику нейрохирургии РГМУ с жалобами на приступы жгучих стреляющих болей в зоне 2 и 3 ветвей левого тройничного нерва продолжительностью от 3-4 до 20 секунд с частотой через каждые 3-4 минуты. На фоне приема 12 таблеток финлепсина в сутки частота приступов уменьшалась до 4 раз в сутки. Триггерные зоны: область точки выхода 2 и 3 ветвей на лицо, область левого козелка. Приступ провоцировали ветер, жевание, чистка зубов, умывание и пр. За последнее время отмечает подавленность настроения, утрату обычных интересов, уменьшение массы тела на 8 кг.

Считает себя больной с ноября 2001 года, когда появились приступы незначительных болей в верхней челюсти. После удаления зубов наступило временное облегчение. Начало заболевания связывает с переохлаждением, стрессом. Через 6 месяцев вновь возобновились приступы болей. Удаление оставшихся зубов нижней челюсти слева в ноябре 2001 года облегчения не принесло. Для исключения симптоматической природы НТН больной выполнена MPT, выявившая множественные очаги демиелинизации паравентрикулярно и в области мозолистого тела. Местами очаги сливаются, размеры их - 4-9 мм. Боковые желудочки и конвексительные субарахноидальные щели незначительно расширены (рис. 100). До поступления в клинику нейрохирургии РГМУ диагноз рассеянного склероза больной никогда не устанавливался. С учетом данный МРТ повторно целенаправленно собран анамнез заболевания. При этом установлено, что 18 лет тому назад больная перенесла ретробульбарный неврит слева. 8 лет назад у нее отмечались преходящие онемения левой половины лица и языка, которые держались около 1 месяца. 
Объективно: наряду с прозопалгией в виде тригеминальной невралгии слева у больной выявлено повышение сухожильных рефлексов и симптом Бабинского с двух сторон. Острота зрения 0,3 с двух сторон с коррекцией до 0,8. На глазном дне - частичная атрофия зрительных нервов обоих глаз, что позволило поставить диагноз невралгии левого тройничного нерва у больной страдающей рассеянным склерозом. Больной выполнена микроваскулярная декомпрессия КТН (рис. 86), выявившая нейроваскулярный конфликт между КТН и ВМА. После устранения конфликта и пробуждения от наркоза - полное исчезновение болей.

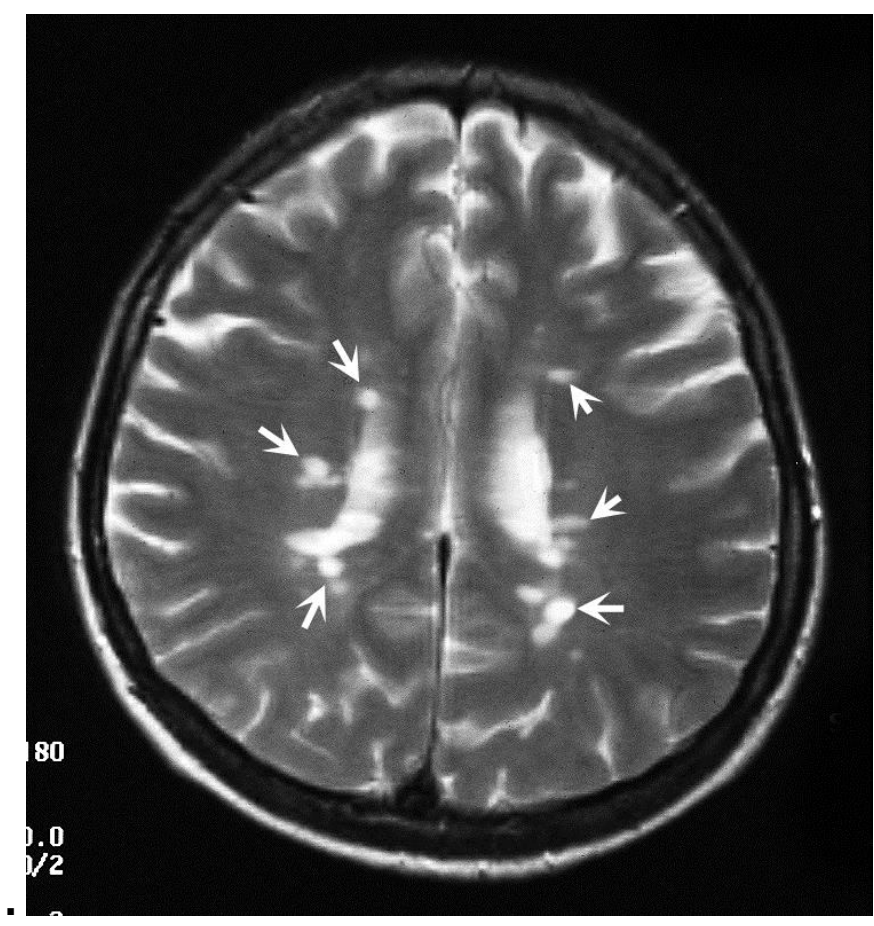

a)

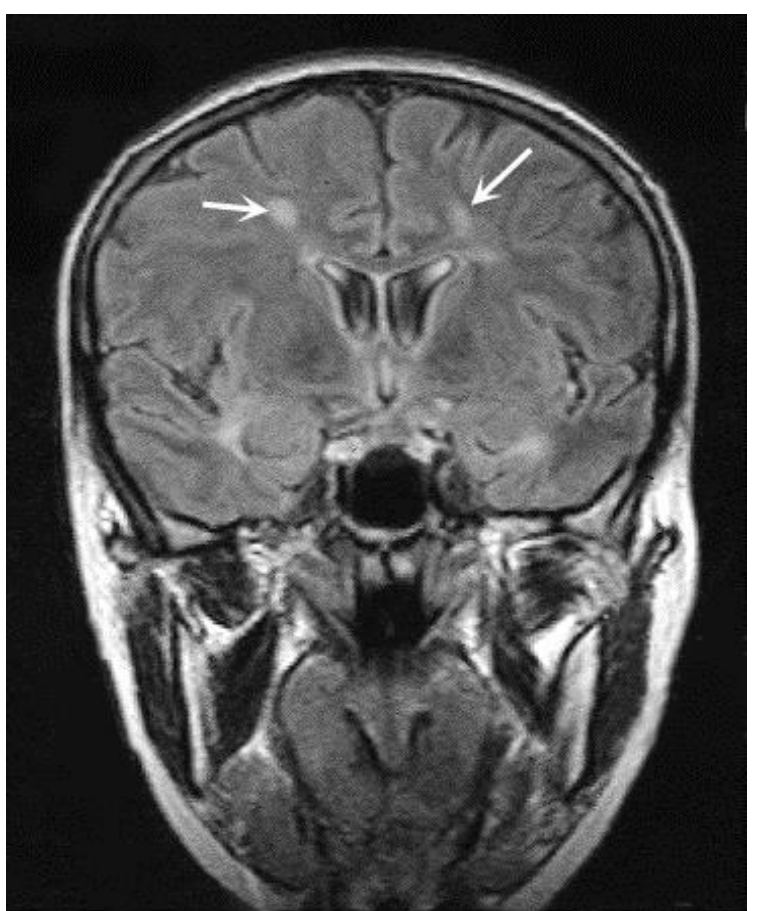

б)

Рис. 100. Больная К. 47 лет. Ист. бол. № 1513. Диагноз: НТН слева с локализацией болей в зонах второй и третьей ветвей у больной рассеянным склерозом (стрелками показаны очаги демиелинизации)

Таким образом, из 220 изученных нами больных с НТН у 200 была классическая невралгия, а у 20 - симптоматическая, т.е. каждый десятый больной с невралгией тройничного нерва имел симптоматическую природу заболевания. 
$180 \mid$ Классическая невралгия тройничного нерва

\section{3. ЗНАЧЕНИЕ СПИРАЛЬНОЙ КОМПЬЮТЕРНОЙ АНГИОГРАФИИ В ДИАГНОСТИКЕ ВАСКУЛОНЕВРАЛЬНОГО КОНФЛИКТА}

Продолжающаяся дискуссия о роли васкулоневрального конфликта в происхождении классической $\mathrm{HTH}$, принципах лечения диктуют необходимость объективного подтверждения васкулоневрального конфликта. Противоречивые данные об обнаружении контакта КТН с ВМА при МРТ исследовании как у больных НТН, так и у здоровых лиц ставят под сомнение диагностические возможности этого метода в выявлении нейроваскулярного конфликта [140].

Визуализация васкулоневрального конфликта подтверждает клинический диагноз классической НТН и исключает симптоматическую природу заболевания, что чрезвычайно важно при планировании лечебной тактики. 0 необходимости нейровизуализационного подтверждения конфликта КТН со смежными сосудами, свидетельствуют описанные в литературе случаи необнаружения васкулоневрального конфликта во время операции и необходимости коррекции лечебной тактики [331]. В наших наблюдениях во всех случаях классической НТН на операции выявлен васкулоневральный конфликт.

Результаты многих исследований по распознаванию васкулоневрального конфликта с использованием МРТ ангиографии на аппаратах с большой мощностью магнитного поля, МРТ цистернографии противоречивы настолько, что Benes L, et al. (2005) приходят к выводу о том, что МРТ не дает веских оснований для утверждения о васкулоневральном конфликте. Единичные оптимистичные сообщения о том, что МРТ позволяет по особенностям конфликта выбирать метод лечения и прогнозировать возможные рецидивы заболевания $[125,261]$ меркнут на фоне значительного количества работ, ставящих под сомнение васкулоневральный конфликт как патогенетическую основу заболевания. Так, Kress B, et al. (2006) у 73\% добровольцев, не страдавших НТН, обнаружили контакт между КТН и смежными сосудами: в 61\% это была артерия и в 39\% - вена. Ре- 
зультаты этих исследований позволили авторам сделать вывод о том, что контакт сосуда с артерией - это скорее норма, а не патология. Такой же точки зрения, по результатам интраскопии, придерживается большинство исследователей [140, 262, 331, 376].

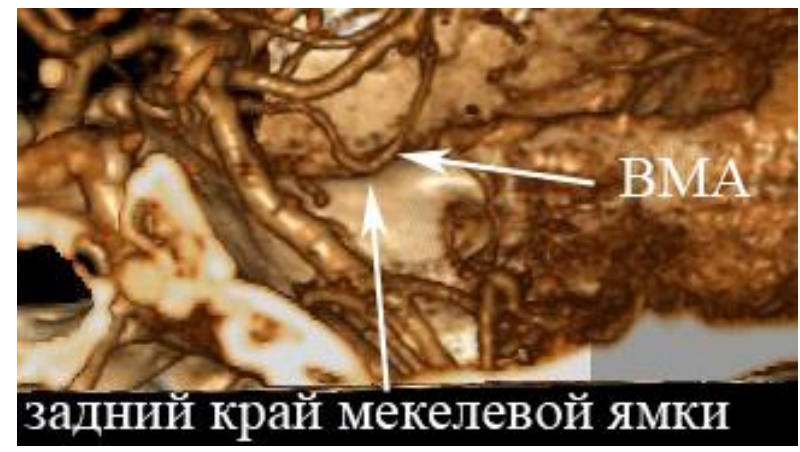

a)

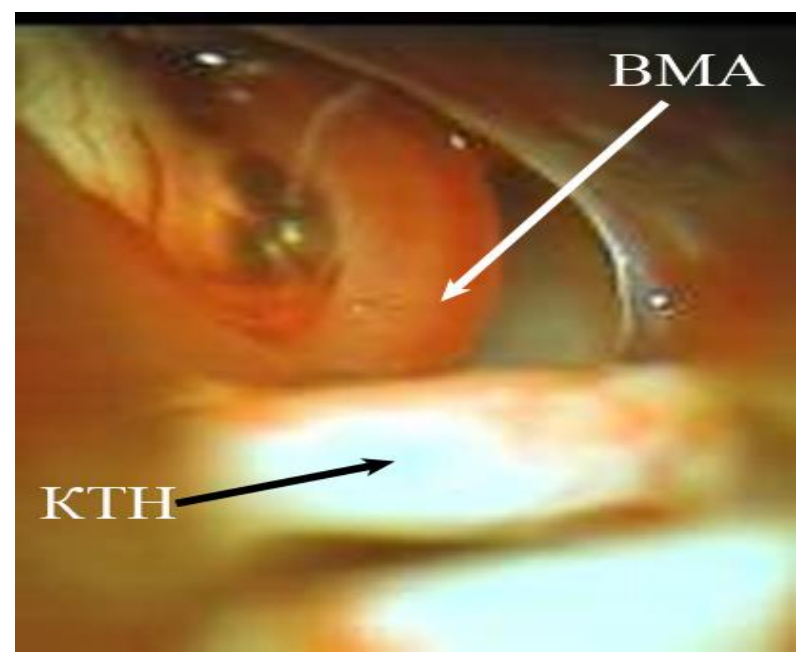

B)

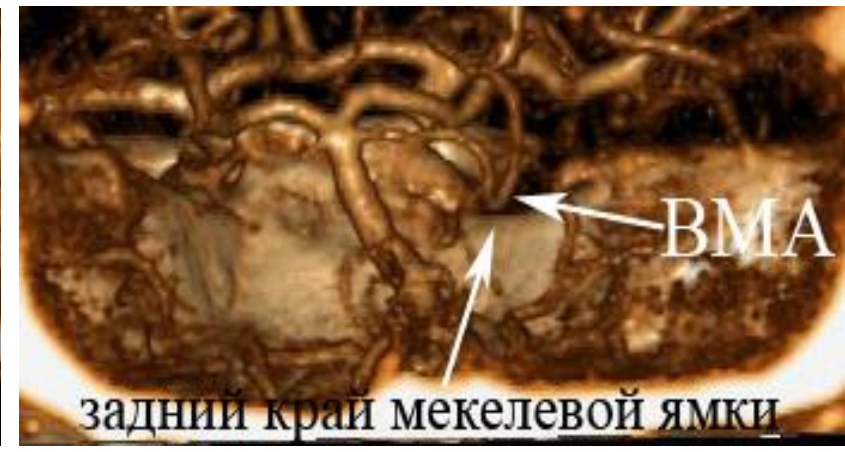

б)

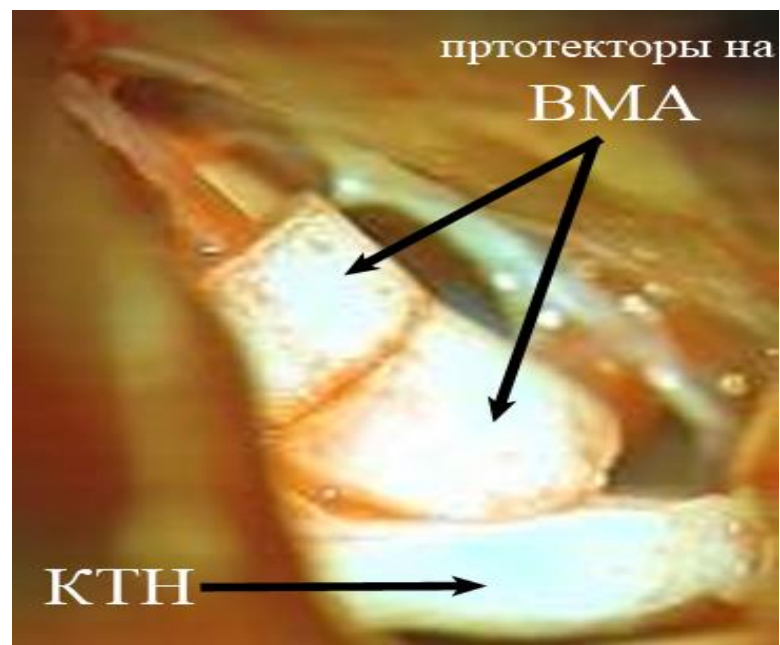

г)

Рис. 101. Больная Р. 55 лет. НТН справа 3 ветвь: а) и б) СКАГ: петля ВМА лежит на заднем крае мекелевой ямки, что подтверждает конфликт ВМА и КТН;

в) МВД конфликт ВМА и КТН; г) конфликт устранен заключением в протектор ВМА

С учетом таких противоречий, понятны высказанные Cheshire W.P. (2005) сомнения о том, что может ли вообще МРТ отличить безобидный васкулоневральный контакт от контакта, повреждающего КТН (т.е. отличить контакт от конфликта). Анатомофизиологическая сущность отличия васкулоневрального контакта от васкулоневрального конфликта была описана нами в 4 главе. 
$182 \mid$ Классическая невралгия тройничного нерва

Для выявления васкулоневрального конфликта нами используется ангиография с помощью спирального компьютерного томографа Briliance CT 64 slice (Philips Medical Systems). После выполнения нативного сканирования в спиральном режиме производилось спиральное сканирование с болюсным контрастированием сосудов головного мозга.

Интраоперационная верификация васкулоневрального конфликта документировалась видеокамерой операционного микроскопа при выполнении микроваскулярной декомпрессии КТН (рис. 101). Устранение васкулоневрального конфликта КТН с ВМА интраскопически подтверждено путем спирального сканирования с визуализацией расположения муфтообразного протектора, окружающего конфликтовавший артериальный сосуд. Такая последовательность нейровизуализацационного исследования позволила документировать доказательные интраскопические признаки васкулоневрального конфликта, что послужило основанием для выдачи патента РФ № 2438578.

Как было описано нами в 2 главе, толщина КТН у верхнего края пирамиды в месте выхода его из мекелевой ямки составляет 2,5-3 мм.

У лиц, не страдающих НТН, вершина петли ВМА, образующейся при переходе переднего понтомезенцефального сегмента в латеральный понтомезенцефальный сегмент располагается выше КТН под наметом мозжечка. За маркерную точку (MT), отражающую положение петли верхней мозжечковой артерии (BMA) относительно КТН нами принята точка в области заднего края мекелевой ямки, отстоящая на 4 мм от вершины пирамиды височной кости. Эта точка располагается в центре поперечника КТН при входе его в мекелеву полость. На рис. 102 представлены варианты взаимоотношений КТН и ВМА у лиц, не страдавших НТН. Во всех случаях вершина петли BMA, образующейся при переходе переднего понтомезенцефального сегмента в латеральный понтомезенцефальный сегмент, располагается выше КТН, несмотря на наличие контакта артерии с корешком (рис. 102, а и 102, г). 


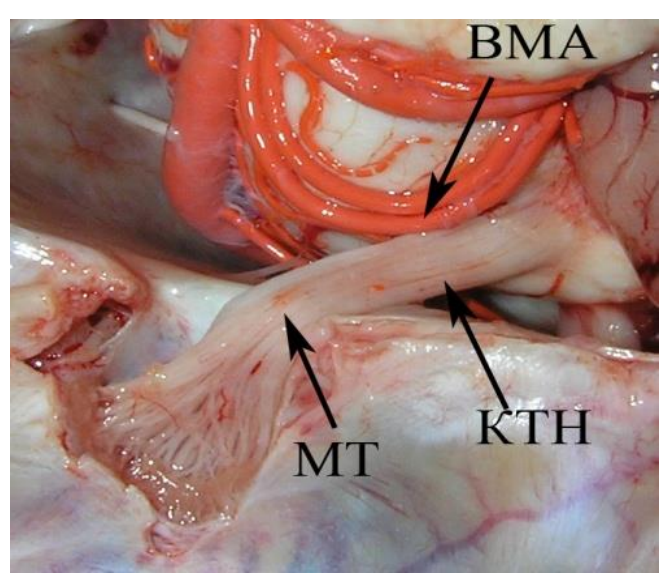

a)

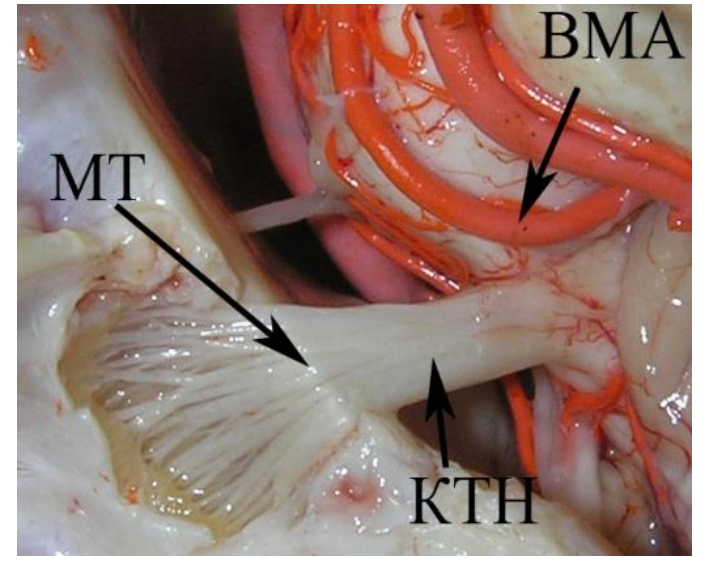

б)

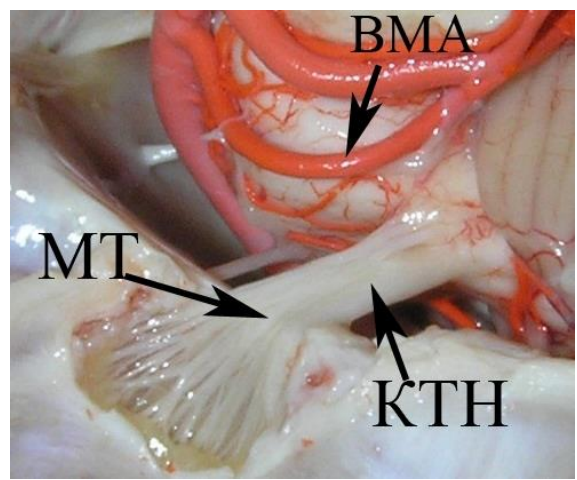

в)

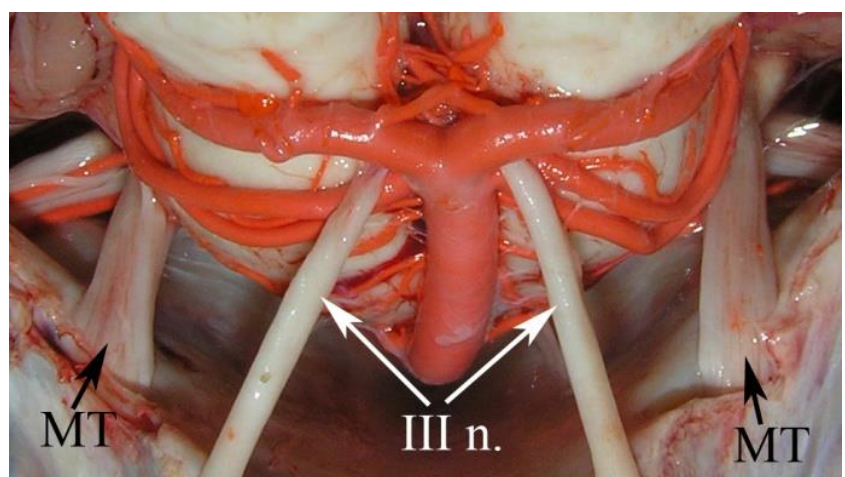

г)

Рис. 102. Варианты взаимоотношения КТН с ВМА у лиц, не страдавших НТН: а) и г) контакт ВМА с КТН; б) близкое расположение петли ВМА к КТН; в) ВМА расположена на значительном расстоянии от КТН. МТ - маркерная точка

При анализе РКТ ангиографии установлено, что во всех случаях у больных классической НТН вершина петли ВМА располагалась в области маркерной точки на уровне заднего края мекелевой ямки, а у 6 других больных значительно ниже его. Учитывая особенность пробега латерального понтомезенцефального сегмента (от вершины петли - к средней линии и вверх), а также толщину дубликатуры твердой мозговой оболочки и самого КТН, во всех наблюдениях больных классической НТН вершина петли ВМА оказывалась ниже верхнего края КТН, и дистальное плечо петли ВМА пересекало КТН в вертикальной плоскости.

Травмирующее воздействие на КТН, раскрывающейся при каждой систоле артериальной петли, оказывал латеральный понто- 
$184 \mid$ Классическая невралгия тройничного нерва

мезенцефальный сегмент. Обнаруженные при РКТ изменения были подтверждены интраоперационными находками.

На рис. 103 представлена РКТ ангиография больной С. 65 лет, страдавшей НТН справа в сопоставлении с операционной картиной нейроваскулярного конфликта.

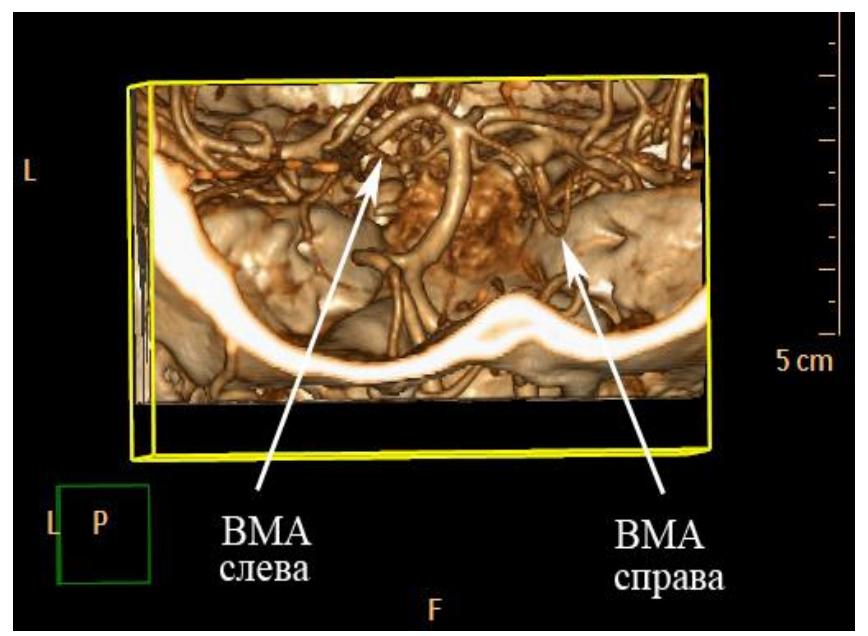

a)

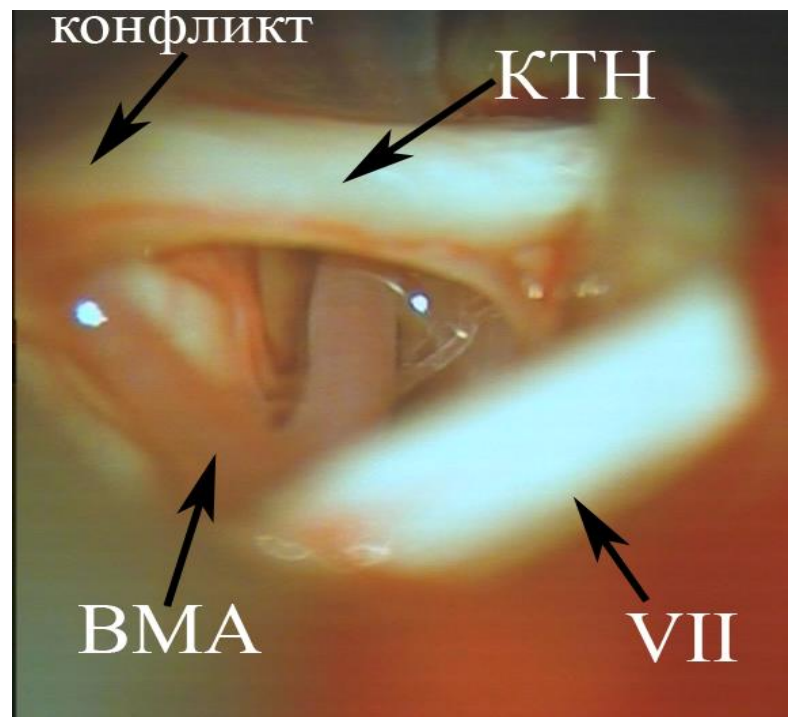

в)

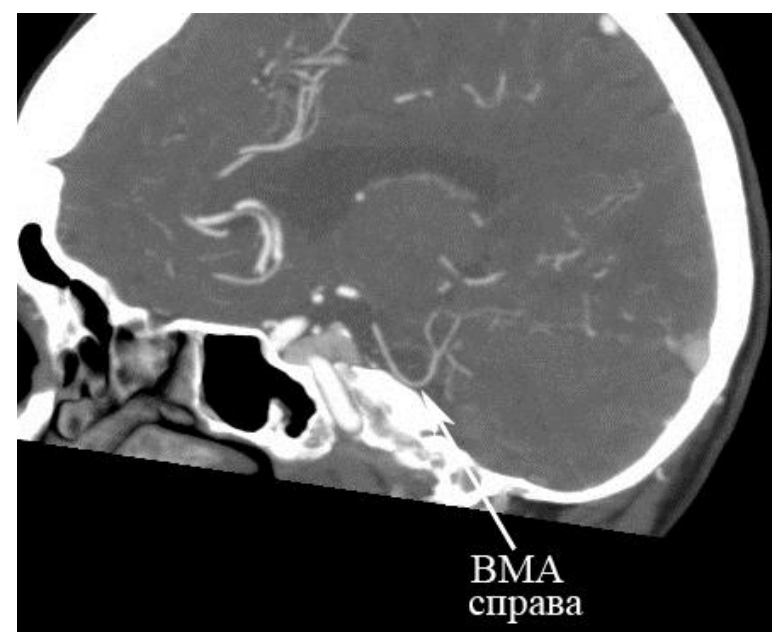

б)

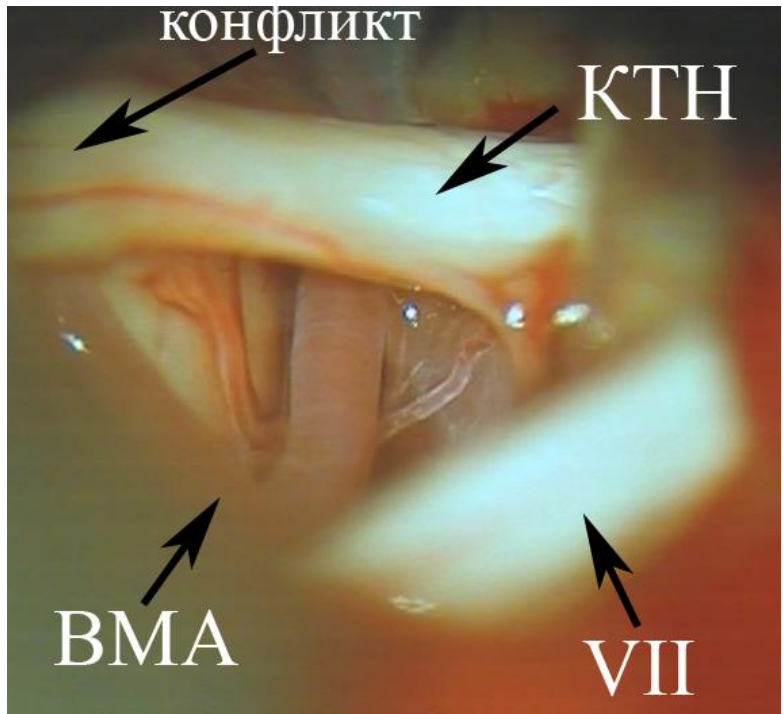

г)

Рис. 103. Больная С. 65 лет. Невралгия правого тройничного нерва. КТ ангиография: а) и б) вершина правой петли ВМА располагается значительно ниже маркерной точки в области верхнего края пирамиды височной кости. МВД увеличение х10; в) вершина петли ВМА располагается значительно ниже КТН в момент диастолы; г) в момент систолы раствор петли значительно увеличился, в результате чего ее дистальное плечо травмирует КТН 
На 9 сутки после хирургического вмешательства и устранения нейроваскулярного конфликта больной выполнена контрольная компьютерная ангиография. На рис. 104 представлена послеоперационная ангиографическая картина взаимоотношения КТН и ВМА.

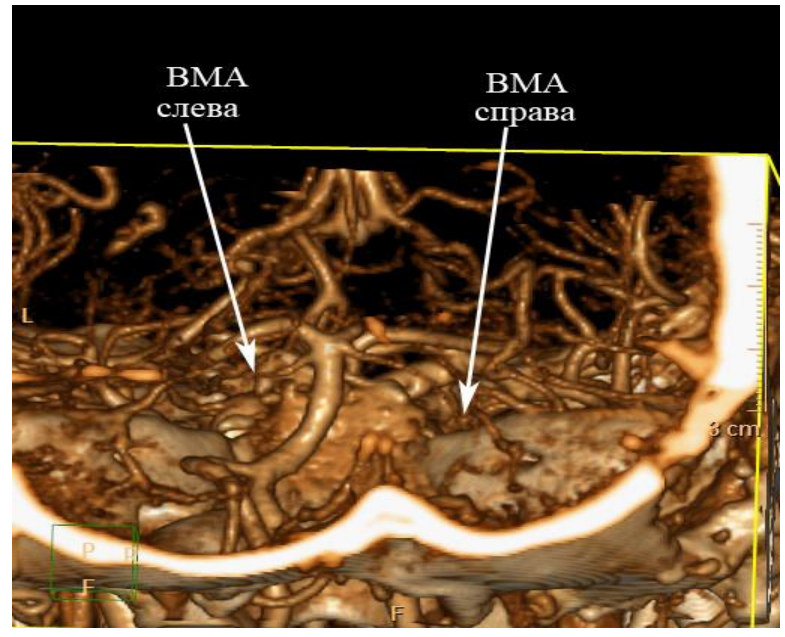

a)

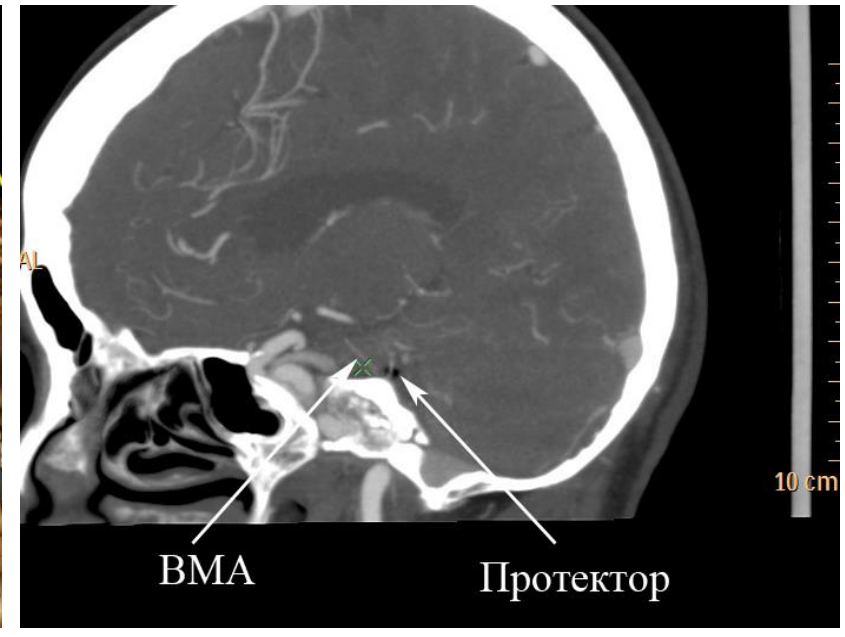

б)

Рис. 104. Больная С. 65 лет. Невралгия правого тройничного нерва. КТ ангиография: а) и б) вершина правой петли ВМА располагается значительно ниже маркерной точки в области верхнего края пирамиды височной кости. МВД увеличение х 10; в) вершина петли ВМА располагается значительно ниже КТН в момент диастолы; г) в момент систолы раствор петли значительно увеличился, в результате чего ее дистальное плечо травмирует КТН

Поскольку предлагаемая нами маркерная точка находится стабильно на костной структуре, то малейшие смещения сосуда относительно этой точки могут быть обнаружены в 3D режиме. Интраоперационная верификация степени смещения ВМА по отношению к маркерной точки является доказательным фактором достоверности диагностики нейроваскулярного конфликта с помощью спиральной компьютерной ангиографии.

Чрезвычайно важно получение информации о наличии или отсутствии нейроваскулярного конфликта при отклонениях в клинической картине от типичных признаков классической НТН (тип 2): отсутствие триггерных зон, постоянный характер лицевых болей, наличие в анамнезе травматических повреждений ветвей ТН, воз- 
$186 \mid$ Классическая невралгия тройничного нерва

никновение заболевания после экстракции зубов и пр. Ниже приводимое наблюдение иллюстрирует подобную ситуацию.

Больная Г. 70 лет. История болезни № 2248/261. Поступила в клинику нейрохирургии РостГМУ 01.03.2010 г. с жалобами на резкие в виде «удара электрическим током» боли в правой лобной области, впервые появившиеся в 2005 году без видимой причины.

Продолжительность приступа составляла от нескольких секунд до 1-2 минут с частотой до 20-30 приступов в день. Триггерные точки - верхняя губа и бровь. На фоне приемы 400-600 мг финлепсина наступала ремиссия в течение нескольких месяцев. Каждое последующее обострение болей сопровождалось учащением приступов и увеличением их продолжительности до 3 минут. После сильного стресса в течение последнего года приступы стали носить постоянный характер. На выполненной спиральной компьютерной ангиографии исключена симптоматическая НТН и обнаружены признаки васкулоневрального конфликта правого КТН с BMA (рис. 105, а, б). При этом обнаружено, что вершина петли правой ВМА располагается на 4 мм ниже заднего края мекелевой ямки. В то время как левая ВМА располагается выше заднего края пирамиды височной кости.

Во время операции микроваскулярной декомпрессии правого КТН обнаружено, что вершина петли правой ВМА располагается значительно ниже нижнего края КТН, а ее латеральный понтомезенцефальный сегмент пересекает КТН в вертикальной плоскости (рис. 105, в).

После извлечения инструментом ВМА из-под КТН, ее понтомезенцефальный сегмент помещен между КТН и наметом мозжечка, т.е. ему придано бесконфликтное положение, занимаемое ВМА в норме (рис. 105, г).

Особенность данного наблюдения состоит в том, что при поступлении в стационар лицевые боли у больной носили постоянный характер. При сборе анамнеза было уточнено, что в начале заболевания приступы у нее носили пароксизмальный кратковременный характер при наличии триггерных зон. 


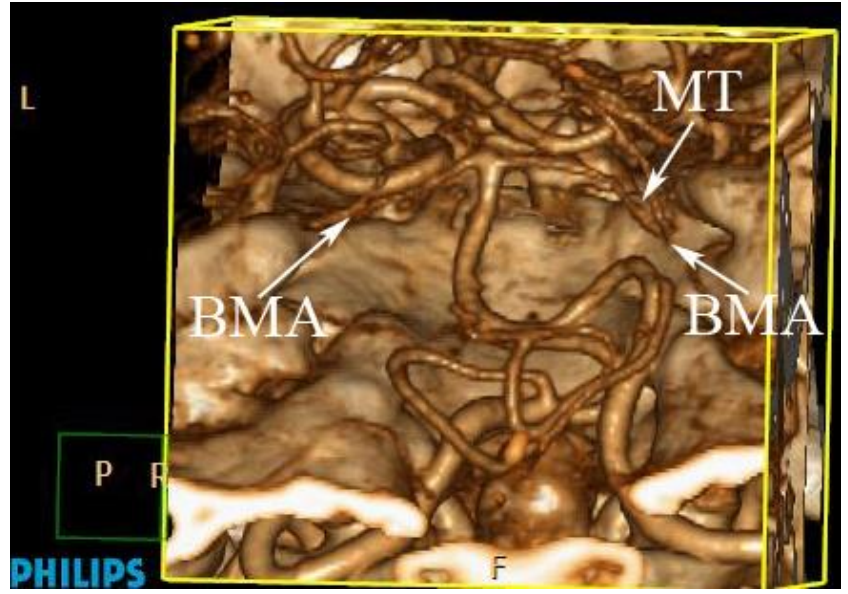

a)

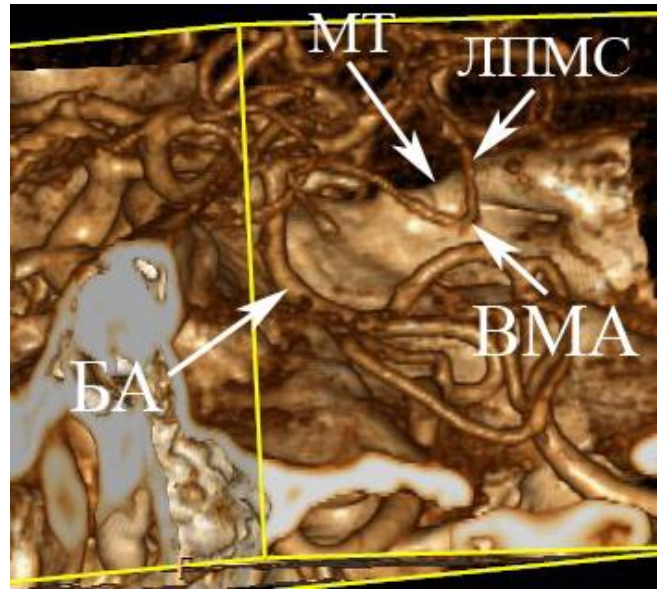

б)

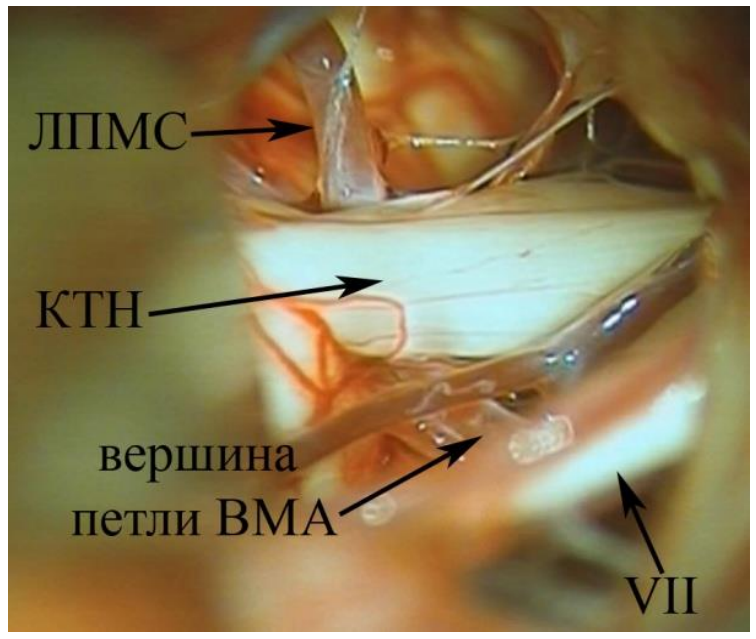

B)

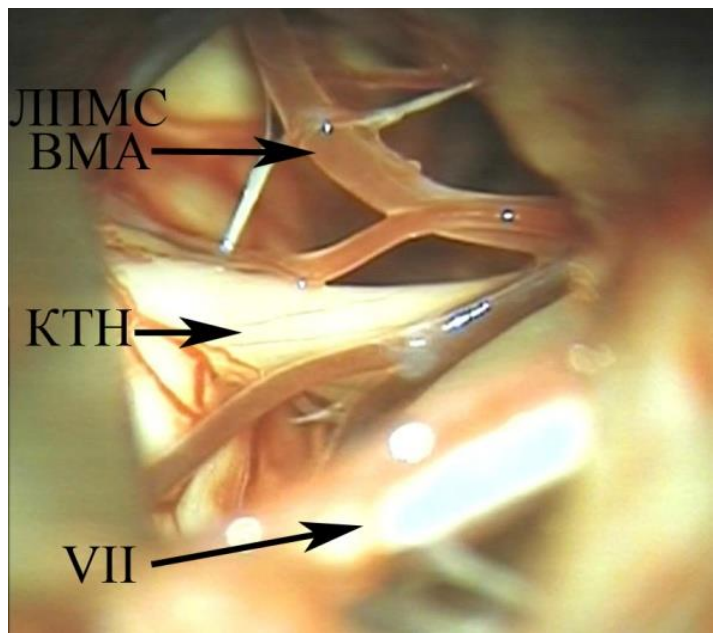

г)

Рис. 105. Больная Г. 70 лет. Ист. бол. № 2248, диагноз: классическая невралгия правого тройничного нерва: а) и б) спиральная компьютерная ангиография в режиме 3D (вершина петли правой BMA смещена значительно ниже маркерной точки в области заднего края мекелевой ямки);

в) этап микроваскулярной декомпрессии, увел. х10. Латеральный понтомезенцефальный сегмент ВМА пересекает КТН в вертикальной плоскости; г) петля ВМА перемещена с помощью микроинструмента в бесконфликтное положение в пространство между КТН и наметом мозжечка

При подтипе Іа возникают типичные внезапные приступообразные болевые пароксизмы (в виде «удара молнии» или «разряда электрического тока») длительностью от нескольких секунд до нескольких минут, стреляющего характера, выявляются триггерные точки и симптом «защиты триггерной зоны». У этих больных при МВД всегда обнаруживался нейроваскулярный конфликт. Подтип Іб 
$188 \mid$ Классическая невралгия тройничного нерва

характеризуется наличием типичных тригеминальных приступов на фоне постоянной лицевой боли ноющего, жгучего и пульсирующего характера. Эти два подтипа (Іа и Іб) соответствуют I типу, описанномy Burchiel K.J. (2003) и Eller J.L., et al. (2005) для классической HTH. В виду атипичности клиники в подтипе Іб необходимо подтверждение васкулоневрального конфликта с помощью нейровизуализации. Второй тип НТН характеризуется наличием постоянной боли ноющего, жгучего и стреляющего характера. Внезапные типичные приступы не вызываются, хотя могут иметь место приступообразные боли. Больных, у которых изначально были постоянные лицевые боли, отсутствовали триггерные зоны и симптом «защиты триггерной зоны» мы в группу исследования не включали.

Подобных больных невролог должен лечить консервативно и не направлять к нейрохирургам для выполнения МВД, поскольку при интраскопическом исследовании у таких больных васкулоневральный конфликт не обнаруживается. Такой подход может помочь в более правильном выборе метода лечения. Наша больная (рис. 105), в соответствии с этим, относится к подтипу Іб, и ей была выполнена МВД, подтвердившая выявленный при КТ ангиографии васкулоневральный конфликт. Heros R.S. (2009) также считает МВД показанной у больных с клинической картиной классической МВД и подтвержденным при нейровизуализации васкулоневральным конфликтом. 


\section{ГЛАВА 6}

\section{ДИФФЕРЕНЦИАЛЬНАЯ ДИАГНОСТИКА КЛАССИЧЕСКОЙ НЕВРАЛГИИ ТРОЙНИЧНОГО НЕРВА ОТ ДРУГИХ ВИДОВ ПРОЗОПАЛГИЙ}

Нередко специалисты поликлинического звена за НТН принимают лицевые боли другой природы. Диагностические трудности возникали часто при первичном обращении больного, когда еще отсутствовали такие важные дифференциально-диагностические критерии как ремиссии в течение заболевания и эффективность от применения противосудорожных препаратов (карбамазепин, финлепсин, тегретол, габапентин, тебантин, прегабалин и др.). Первым этапом дифференциальной диагностики НТН является распознавание ее из множества, на первый взгляд, внешне похожих лицевых болей.

Краткое описание клинических особенностей некоторых прозопалгий, напоминающих НТН, позволит отличить их от классической НТН. Невралгия первой ветви ТН нередко ошибочно диагностируется при невралгии ресничного узла, невралгии носоресничного нерва, синдроме Сладера, невралгии Видиева нерва.

Невралгия ресничного узла (синдром Оппенгейма) характеризуется частыми приступами резких болей в области глазного яблока или ретробульбарно, продолжительностью от получаса до нескольких часов. Приступ боли сопровождается слезотечением, светобоязнью, покраснением конъюнктивы глаза. Кроме продолжительности приступа отличительными от НТН признаками являются герпетические высыпания на коже лба и носа и сопровождающие их кератиты и конъюнктивиты. 
$190 \mid$ Классическая невралгия тройничного нерва

Невралгия носо-ресничного нерва (синдром Шарлена, в других транскрипциях Чарлина) описана Charlin С. в 1931 году. Носоресничный нерв является продолжением первой ветви ТН, иннервируя слизистую оболочку лобной пазухи, глазное яблоко и область корня носа. Заболевание характеризуется приступами острых болей в области глазного яблока, преимущественно с медиальной стороны, надбровья и соименной половины носа. В основном приступы возникают в ночное время, лишая больных сна и истощая их. Характерна яркая вегетативная составляющая приступа: обильное слезотечение, отек слизистой полости носа на ипсилатеральной стороне, выделение жидкого секрета из этой же половины носа. Кроме того, может наблюдаться гиперемия склер, светобоязнь. Офтальмологом диагностируется иридоциклит, кератит (рис. 106).

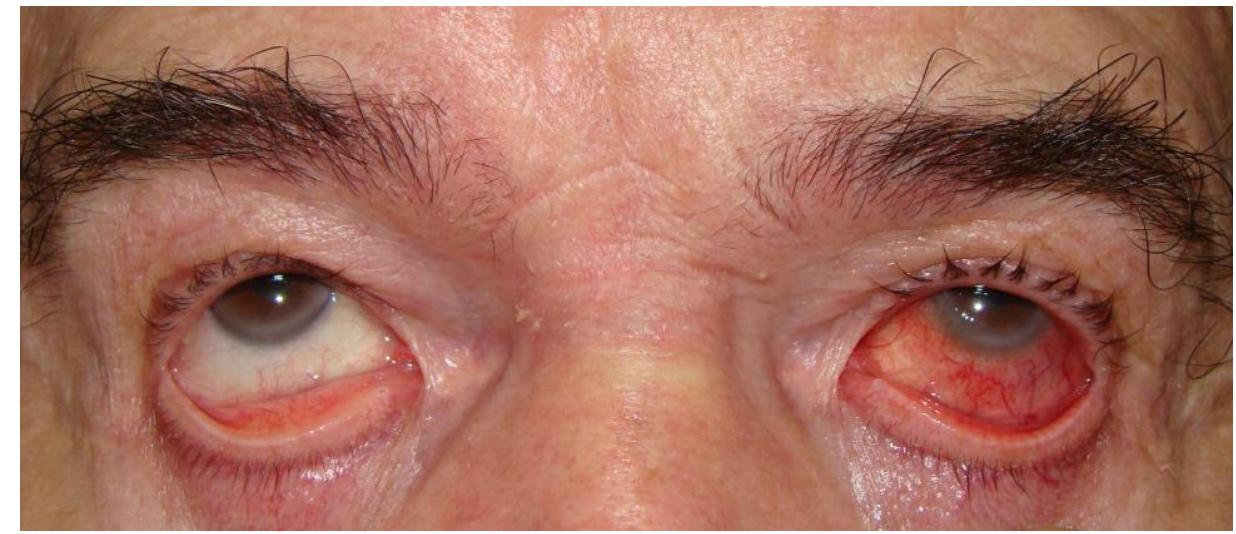

Рис. 106. Синдром Шарлена (Чарлина) слева.

Гиперемия склеры, светобоязнь, слезотечение

Усложняют дифференциальную диагностику случаи, когда вегетативный компонент отсутствует или проявления его незначительны. Основными отличительными признаками от классической НТН являются: продолжительность приступа, не характерная для классической НТН (десятки минут), время суток их проявления (чаще во второй половине дня, вечером или ночью), отсутствие триггерных зон и ремиссий в анамнезе.

Синдром крылонебного узла (описан Канадским ларингологом Sluder в 1908 году) иногда ошибочно диагностируется как НТН. Вариабельность клинических проявлений этого синдрома обуслов- 
лена обширными анастомозами этого вегетативного узла с другими неврологическими структурами. Основными жалобами пациента являются остро возникающие жгучие боли в глазном яблоке, вокруг орбиты, корня носа и верхней челюсти с обширной их иррадиацией: в височную область, ушную раковину, затылок, плече-лопаточную область. Болевой пароксизм сопровождается вегетативной составляющей: слезотечением, обильным выделением жидкого секрета из соименной половины носа, покраснением и отечностью половины лица. Продолжительность приступа от нескольких часов, до 1-2 суток, преимущественно в ночное время. Чаще всего невралгия крылонебного узла возникает при воспалительных заболеваниях придаточных пазух носа, близко расположенных к узлу. Приступ может провоцироваться физическим или эмоциональным напряжением, повышением АД или приемом алкоголя, а также изменением метеоусловий. Синдром Сладера от классической НТН позволяют отличить несколько признаков. Прежде всего, продолжительность болевого пароксизма, сопровождающаяся выраженными вегетативными расстройствами, преимущественно в ночное время, более молодой возраст больных (от 30 до 50 лет), а также быстрое купирование приступа после блокады крылонебного узла. Важным дифференцильно-диагностическим тестом может служить введение в задние отделы носовых ходов тампона, смоченного 2\% раствором новокаина, что купирует приступ невралгии крылонебного узла. С аналогичной клинической картиной протекает невралгия Видиева нерва.

Невралгия Видиева нерва (синдром Файля) может возникать при воспалительных процессах в верхушке пирамиды и придаточных пазухах носа. Характеризуется односторонними приступообразными болями в области глазного яблока, орбиты, иррадиирующие в другие области лица, зубы, иногда шею, плечо. Продолжительность приступов от десятков минут до нескольких часов, преимущественно в ночное время. Это позволяет дифференцировать синдром Файля от НТН.

Невропатия верхних луночных нервов характеризуется постоянной ноющей болью, сопровождающейся онемением в зубах верхней челюсти, десны, слизистой оболочки полости рта в области 
$192 \mid$ Классическая невралгия тройничного нерва

щеки. Болевые пароксизмы наблюдались различной интенсивности и продолжительности, Особые трудности в дифференциальной диагностике возникали у тех больных, в анамнезе у которых пароксизмы носили кратковременный характер. В анамнезе у таких больных удается выявить факторы, травмирующие верхнечелюстной нерв: удаление больших коренных зубов, введение пломбировочного материала за пределы корневого канала, повреждение нерва иглой при выполнении проводниковой анестезии, хирургические операции и травмы верхней челюсти. Постоянный характер болей в сочетании с чувствительными расстройствами и травмирующим фактором в анамнезе позволяют избежать ошибочного диагноза НТН второй ветви.

\section{Периодическая мигренозная невропатия (синдром Хорто-} на). Болевой пароксизм проявляется очень сильной, внезапно возникающей односторонней болью в виске, глазнице с распространением на верхнюю челюсть, иногда шейно-затылочную область. Вегетативная составляющая пароксизма: гиперемия конъюнктивы, слезотечение, выделение секрета из половины носа, расширение и усиление пульсации напряженной височной артерии. Заболевание возникает преимущественно у мужчин. Пароксизмы чаще наблюдаются в ночное время. Правильная оценка всех составляющих синдрома Хортона позволяет своевременно распознать процесс и не наблюдать больного с предположительным диагнозом НТН первой и второй ветви.

Невропатия нижнего луночного нерва возникает после тех же травмирующих факторов, что и предыдущая: удаление больших коренных зубов, попадание пломбировочного материала в нижнечелюстной канал, травма нижнего луночного нерва при выполнении проводниковой анестезии этого нерва, оперативные вмешательства на нижней челюсти, травмы и пр. Боли, ноющего характера в сочетании с нарушением всех видов чувствительности в ипсилатеральной половине нижней губы, десны, подбородка. При перкуссии у ряда больных отмечалась болезненность соседних зубов, что служило поводом для их удаления. Болевые пароксизмы носят постоянный характер с периодическим обострением различной интенсивности. Заболевание может протекать годами и трудно поддается лечению. 
Ганглионит подчелюстного узла проявляется постоянными болями в подчелюстной области сменяющимися пароксизмами интенсивной боли в губах, языке, височной области. Продолжительность болевых пароксизмов от 10 до 45 минут, с частотой от нескольких раз в день до нескольких раз в неделю. Вегетативная составляющая пароксизма - увеличение слюноотделения. Хотя распространение болей охватывает зону иннервации III ветви ТН, постоянный их характер и вегетативный компонент пароксизма позволяют поставить правильный диагноз ганглионита.

Ганглионит подъязычного узла характеризуется постоянными тупыми болями в подъязычной области с периодическими болевыми пароксизмами, иррадиирующими в другие участки лица. Вегетативная составляющая - усиление слюноотделения. Кроме того, у больных выявляется болезненная точка, соответствующая месту расположения подъязычного узла, на 2,5-3 см кзади от нижнечелюстного гребешка. Эти признаки с учетом постоянного характера болей позволяют дать правильную оценку заболевания и исключить невралгию III ветви ТН.

Ганглионит уиного узла (синдром Ханта) иногда ошибочно диагностируется как НТН третьей ветви в связи с наличием у пациента болевых пароксизмов продолжительностью от 5 до 45 минут, возникающих в ушно-височной области с иррадиацией в нижнюю челюсть, зубы. Болевые пароксизмы провоцируются приемом горячей пищи, переохлаждением лица и пр. Однако, гиперсаливация, локальный гипергидроз и гиперемия ушно-скуло-височной области, иногда герпетические высыпания в области уха позволяют поставить правильный диагноз ганглионита ушного узла.

Синдром Костена. Несколько больных обратилось за консультацией после продолжительного и безуспешного лечения на поликлиническом этапе по поводу НТН. При осмотре обращало на себя внимание отсутствие триггерных зон, локализация болей в области нижнечелюстного сустава, хруст или щелчки при движении нижней челюсти, болезненность при надавливании на область сустава, отсутствие эффекта от длительного приема карбамазепина. Все это позволило отказаться от диагноза НТН и придти к вы- 
$194 \mid$ Классическая невралгия тройничного нерва

воду о патологии нижнечелюстного сустава. Существенную помощь в распознавании патологии нижнее-челюстного сустава оказывает CPKT в режиме 3D. На рис. 107 представлено СРКТ исследование больной с подвывихом головки нижней челюсти, которая на протяжении 4 лет наблюдалась и лечилась у невролога как больная невралгией тройничного нерва.

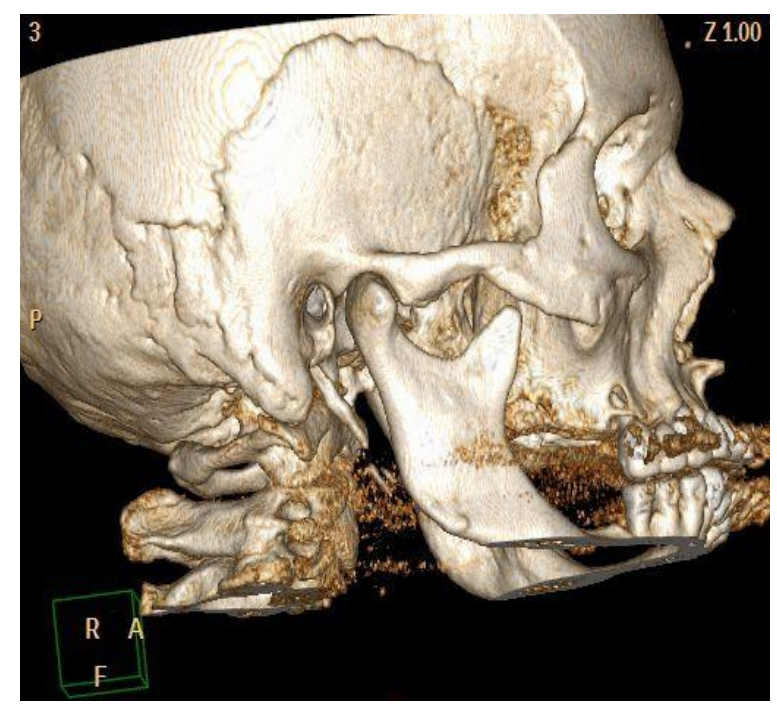

a)

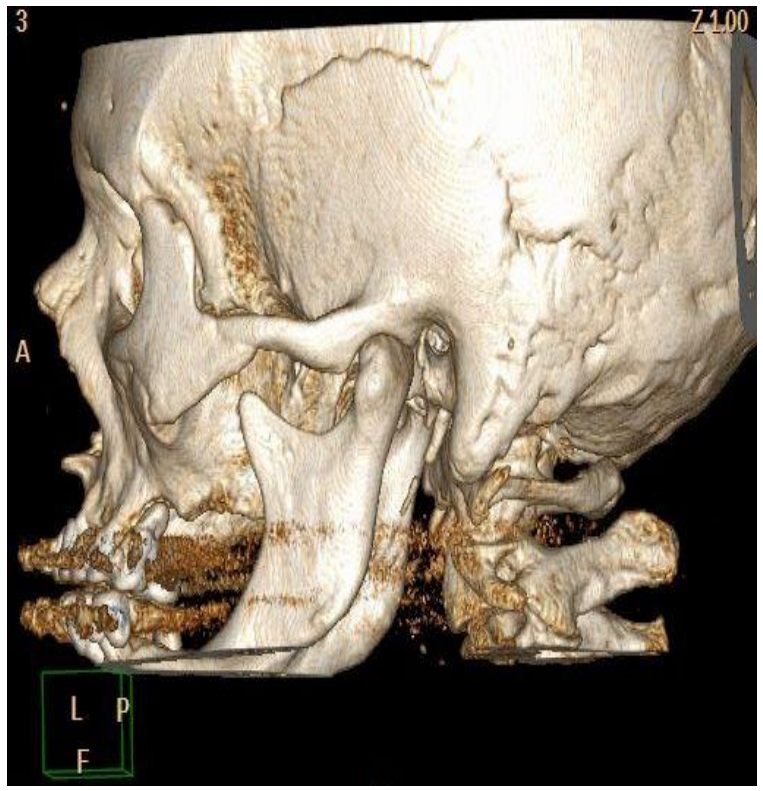

в)

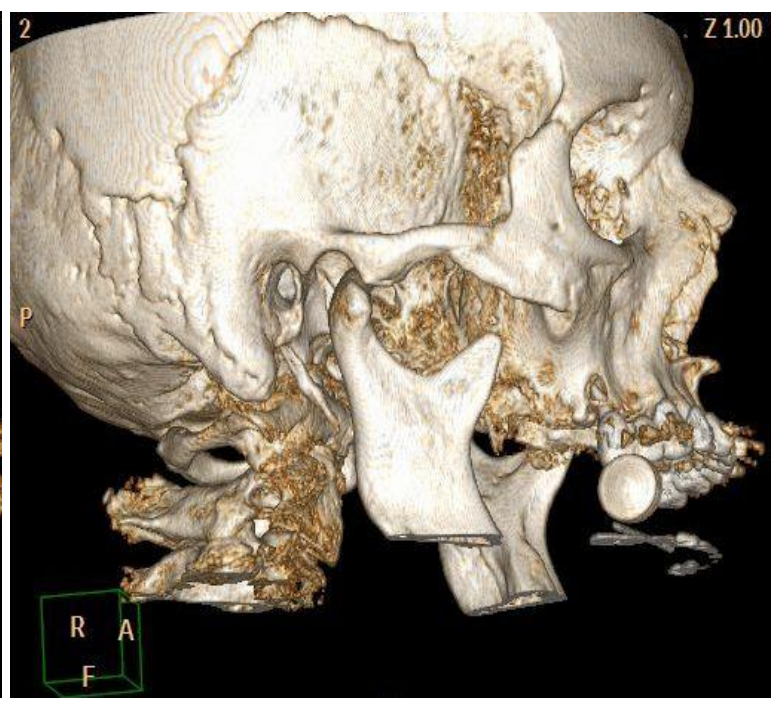

б)

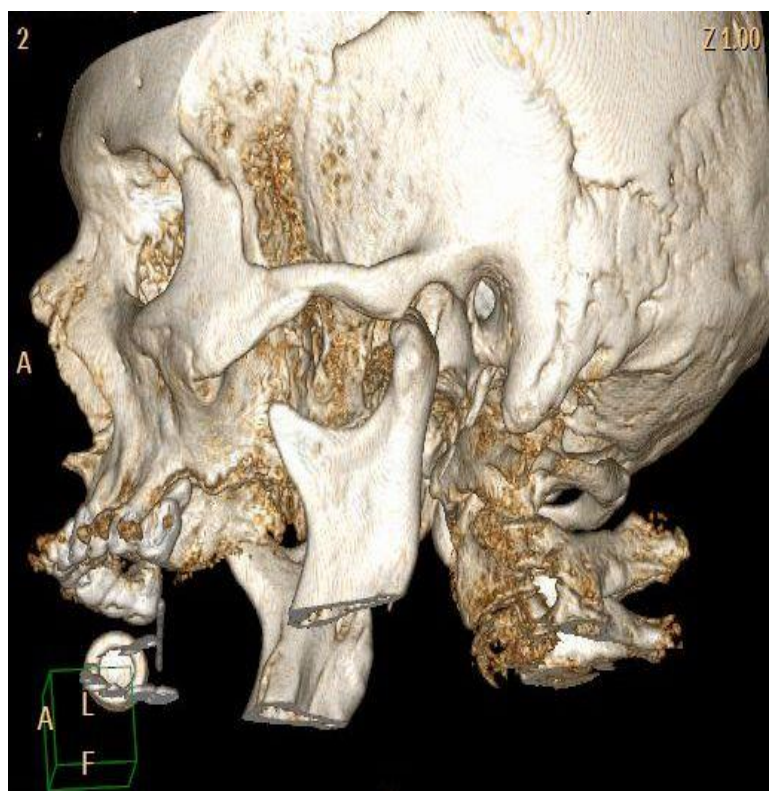

г)

Рис. 107. Больная А. Подвывих головки нижней челюсти правого и левого нижнечелюстных суставов: а) правый сустав при закрытом рте;

б) правый сустав при открытом рте; в) левый сустав при закрытом рте; 
Пациентка жаловалась на боли в области нижнечелюстного сустава, нижней и верхней челюсти, провоцирующиеся разговором, жеванием, открывание рта. Наблюдалась у стоматолога, были удалены слева зубы верхней и нижней челюстей. При этом боли носили постоянный характер и усиливались при движениях нижней челюсти в особенности при жевании твердой пищи. Триггерных зон выявлено не было. Она длительно принимала финлепсин без заметного эффекта. Однако прием НПВС приносил временное облегчение, равно как и ограничение жевательной нагрузки на нижнечелюстные суставы путем исключения приема твердой пищи и уменьшения речевой нагрузки. После установления диагноза подвывиха головки нижней челюсти обоих нижнечелюстных суставов больная переведена в челюстно-лицевое отделение. 
$196 \mid$ Классическая невралгия тройничного нерва

\section{ГЛАВА}

\section{ЛЕЧЕНИЕ КЛАССИЧЕСКОЙ НЕВРАЛГИИ ТРОЙНИЧНОГО НЕРВА}

Поиск новых методов лечения идет в двух направлениях: совершенствование медикаментозной терапии как путем внедрения все новых препаратов и их сочетаний, так и путем разработки новых хирургических приемов, воздействующих на тригеминальную систему.

Актуальность разработки новых, более эффективных методов лечения определяется еще и тем, что наряду с первичными больными НТН к неврологу возвращаются больные с рецидивом НТН после перенесенных деструктивных вмешательств и с рецидивами болей после МВД. Всем им необходима помощь - устранение боли. Нельзя не согласиться с утверждением Love S., Coakhman H.B. (2001) о том, что консервативное лечение необходимо:

1) при необнаружении конфликта во время МВД,

2) при рецидиве боли, после успешно выполненной МВД,

3) если компрессия сосудом обнаружена, но по техническим причинам невозможно провести безопасную репозицию сосуда,

4) при медицинских противопоказаниях к даче общего наркоза,

5) при отсутствии надлежащего опыта выполнения МВД.

Следует согласиться с мнением William P. Cheshire, Jr (2005) o том, что выбор консервативного или хирургического метода лечения НТН - вопрос индивидуальный для каждого больного. 


\section{1. МЕДИКАМЕНТОЗНАЯ ТЕРАПИЯ}

Группа больных, получавших консервативную терапию, включала 78 человек; из них 64 больных (82\%) не переносили никаких хирургических вмешательств, а 14 больным (18\%) в различные сроки до поступления на консервативное лечение была выполнена микроваскулярная декомпрессия корешка тройничного нерва, и в различные сроки после операции у них возник рецидив заболевания. Эти больные воздержались от повторной операции и избрали консервативную терапию. Возрастные закономерности начала заболевания и обращения в клинику представлены на рис. 108.

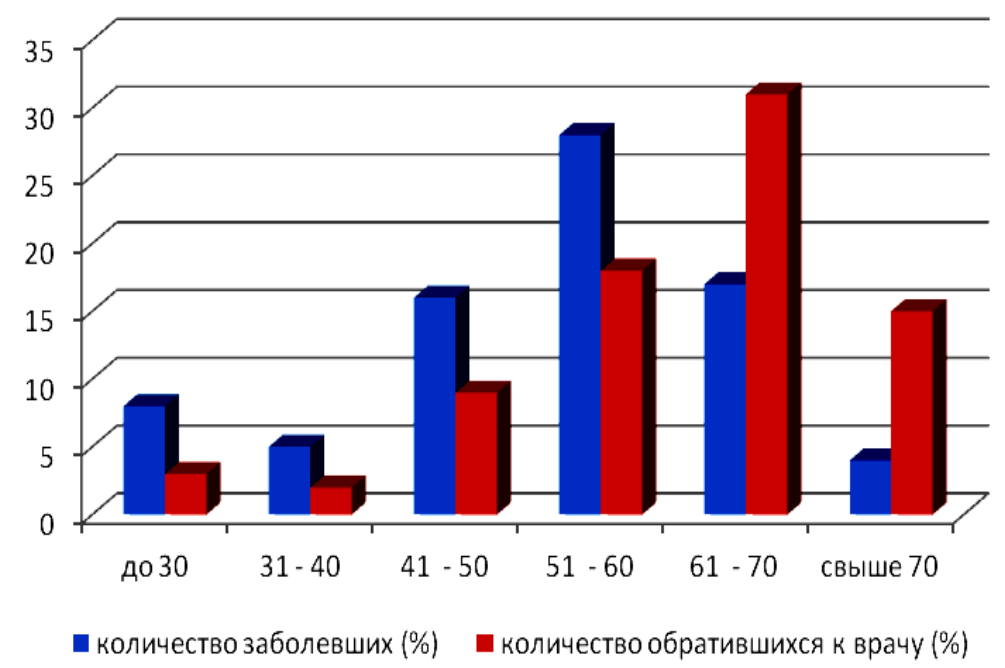

Рис. 108. Распределение (в \%) возраста больных в начале заболевания и во время обращения к исследователю $(n=78$ человек)

Количественный пик начала заболевания в обеих группах консервативного лечения приходится на возраст 51-60 лет, в то время как пик обращения в клинику РостГМУ приходился на возраст от 61

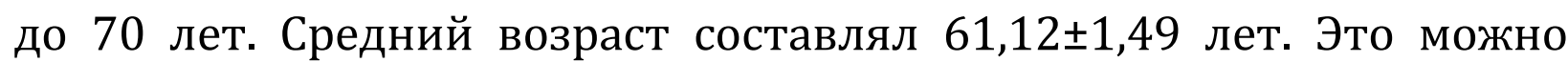
объяснить эффективностью на ранних этапах заболевания препаратов дибензоазепинового ряда, а у оперированных больных - послеоперационной ремиссией.

Соотношение мужчин 28\% и женщин 72\%, правосторонней 65\% и левосторонней 35\% локализацией болей сопоставимо с аналогичными показателями в группе хирургических больных. В табл. 44 при- 
$198 \mid$ Классическая невралгия тройничного нерва

ведены статистические показатели, отражающие особенности протекания заболевания у больных данной группы.

Продолжительность обострения до поступления в клинику РостГМУ для больных, получавших консервативное лечение, была различной (рис. 109): от 1 до 3 месяцев - у 72\% больных, от 4 до 6 месяцев - у 17\% больных, от 7 месяцев до 1 года - у 10\% больных и у $1 \%$ больных продолжительность обострения составила 2 года.

Таблица 42

\section{Характеристики заболевания у больных, получавших консервативную терапию}

\begin{tabular}{|c||c|c|}
\hline Показатели & $\boldsymbol{M \pm m}$ & $\boldsymbol{\sigma}$ \\
\hline \hline Возраст (годы) & $61,12 \pm 1,49$ & 13,16 \\
\hline $\begin{array}{c}\text { Продолжительность последнего обост- } \\
\text { рения (месяцы) }\end{array}$ & $3,19 \pm 0,38$ & 3,31 \\
\hline Продолжительность заболевания (годы) & $8,56 \pm 0,89$ & 7,89 \\
\hline Интенсивность боли по ВАШ (баллы) & $8,37 \pm 0,14$ & 1,24 \\
\hline Длительность болевого пароксизма (сек) & $23,22 \pm 6,25$ & 55,19 \\
\hline Частота приступов в течение суток & $30,40 \pm 3,38$ & 29,85 \\
\hline $\begin{array}{c}\text { Шкала оценки повседневной жизненной } \\
\text { активности больного до лечения (баллы) }\end{array}$ & $24,06 \pm 0,36$ & 3,18 \\
\hline \multicolumn{2}{|c|}{} \\
\hline \multicolumn{2}{|c|}{}
\end{tabular}

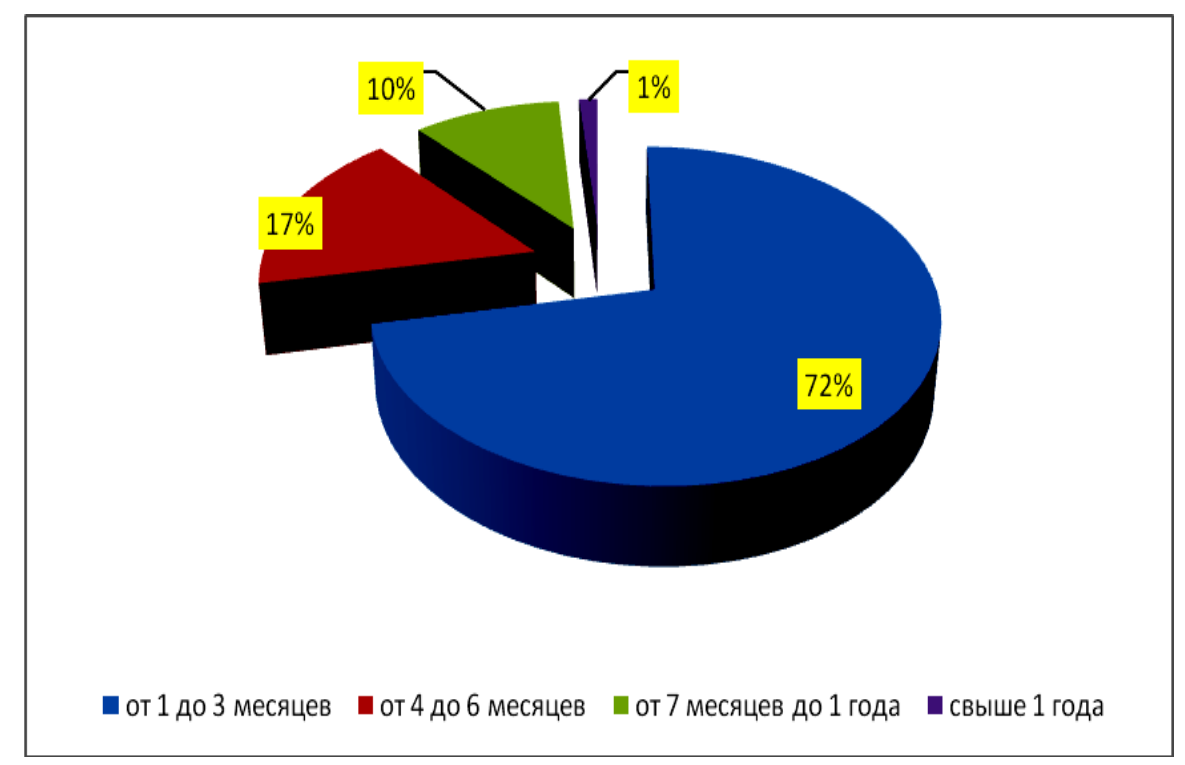

Рис. 109. Распределение больных по продолжительности обострения до поступления в клинику 
Интенсивность боли по ВАШ (рис. 110) в основном была сильная (в пределах 7-9 баллов) - у 71\% человек, очень сильная (10 баллов) - у 24\% человек, и умеренная (от 4 до 6 баллов) - у 5\% человек.

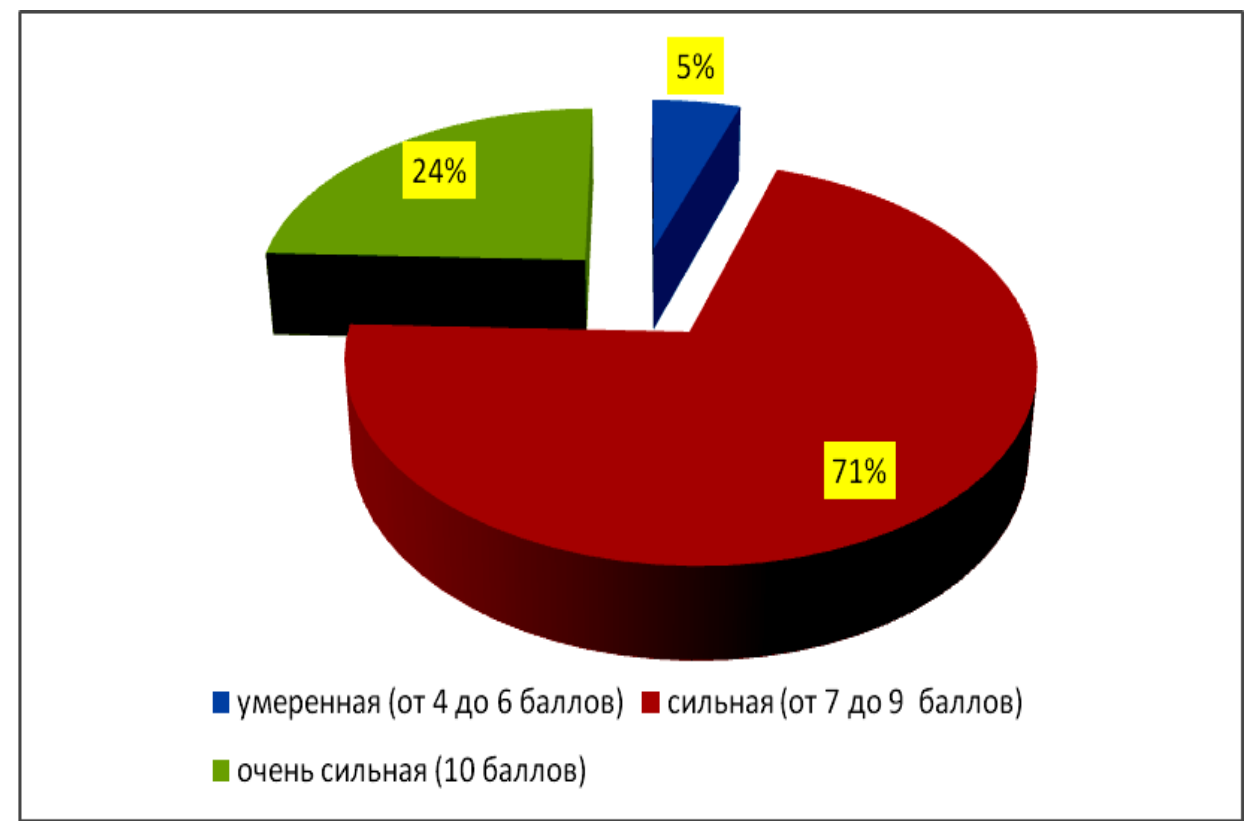

Рис. 110. Распределение больных по интенсивности боли

Продолжительность болевых пароксизмов (рис. 111) также варьировала в широких пределах: от 1 до 10 секунд - у 68\% человек, до 1 минуты - у 23\% человек, до 3 минут - у 5\% человек, и свыше 3 минут - у 4\% человек.

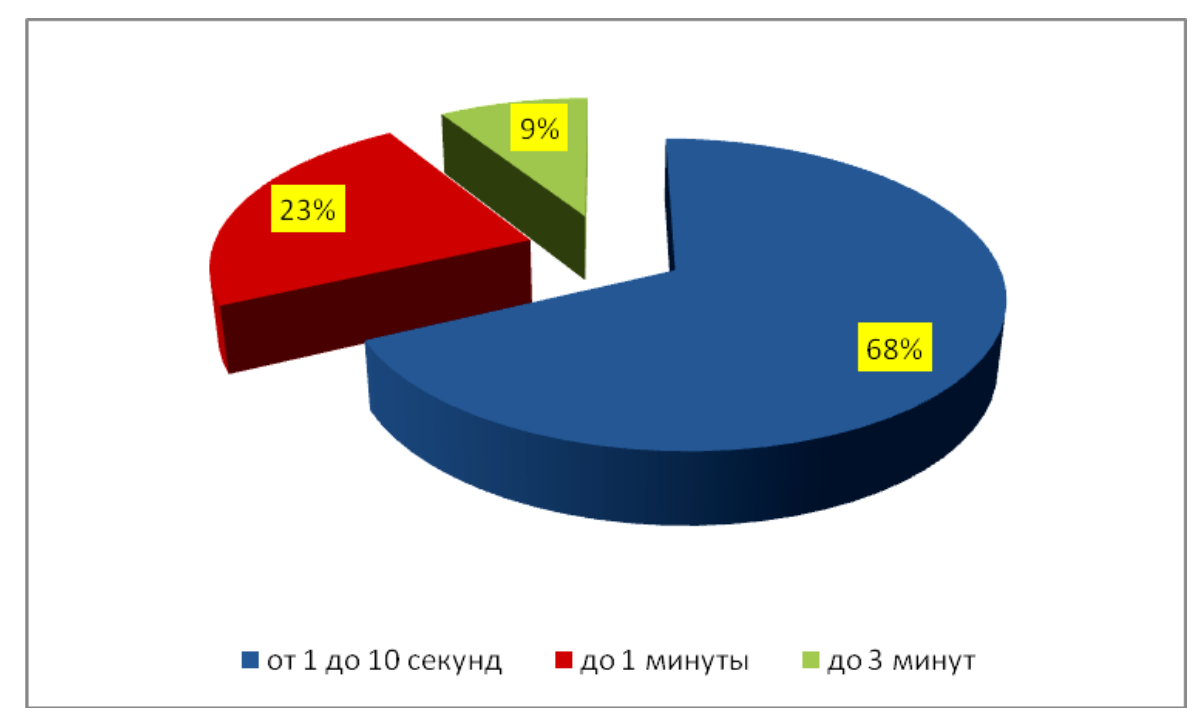

Рис. 111. Распределение больных по длительности болевых пароксизмов 
Частота приступов в день (рис. 112) также была различной: до 30 приступов наблюдалось у 69\% больных, от 31 до 50 - у 18\%, от 51 до 100 - у 12\%, и свыше 100 - у 1\% больных.

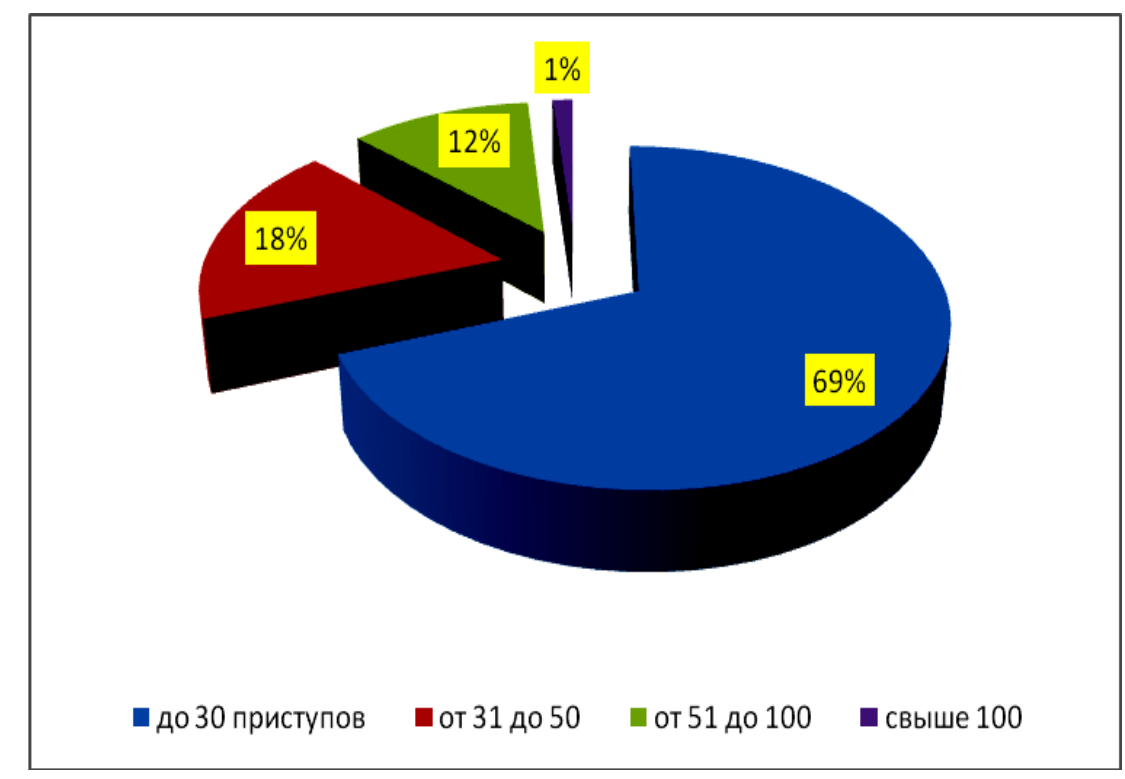

Рис. 112. Распределение больных по частоте приступов в день

Нарушение повседневной жизненной активности, обусловленное НТН, оценивалось больными в соответствии со шкалой следующим образом: от 11 до 20 баллов - 13\% больных, от 21 до 25 баллов - 40\% больных, и от 26 до 30 баллов - 47\% больных (рис. 113).

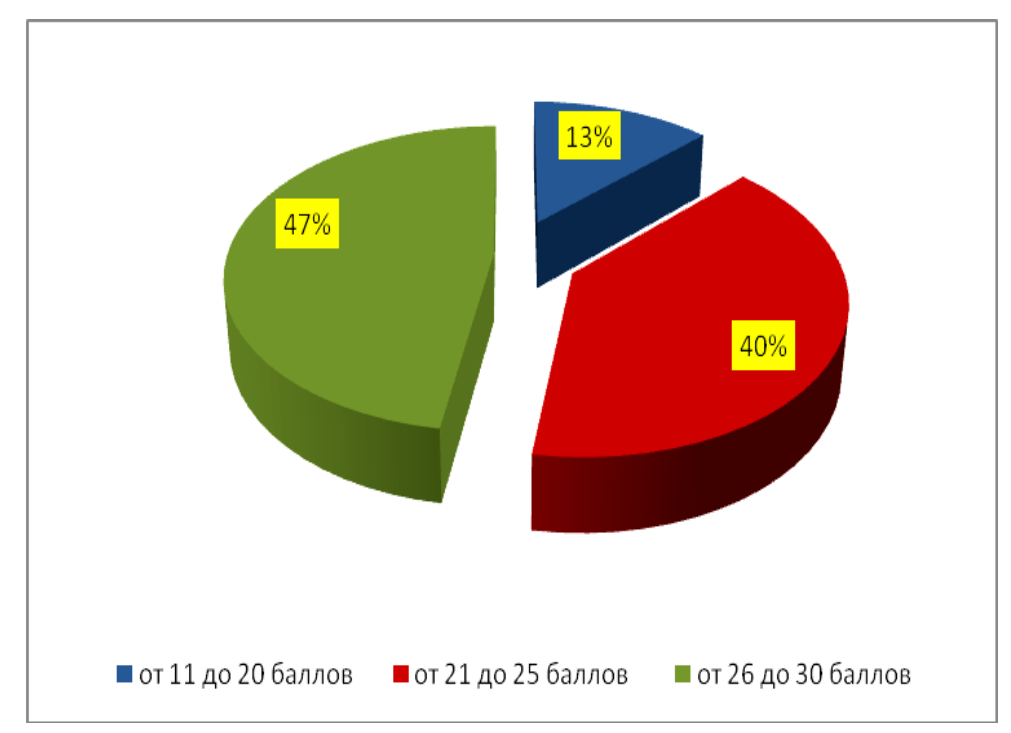

Рис. 113. Распределение больных по нарушению повседневной жизненной активности до лечения 
У больных с нарушениями повседневной жизненной активности, свыше 21 балла, мотивом для госпитализации на консервативное лечение была невозможность приема пищи и других гигиенических процедур, несмотря на прием противосудорожных препаратов. 10 больных, у которых количество баллов было менее 20, могли выполнять эти функции, но для этого требовался прием больших доз (до 3200 мг в день) карбамазепина (финлепсина). Причиной для обращения в клинику РостГМУ были нежелательные явления, обусловленные длительным приемом препарата (головокружения, головные боли, атаксия при ходьбе, потеря аппетита, тошнота).

Для выявления тесноты связи и направления связи между параметрами, отражающими особенности протекания заболевания у больных данной группы был применен корреляционный анализ. Рассчитывался ранговый коэффициент корреляции Спирмена между всеми описанными параметрами. Установлены следующие статистически значимые $(p<0,05)$ корреляционные зависимости (см. табл. 43$)$.

Таблица 43

\section{Результаты корреляционного анализа}

\begin{tabular}{|c|c|c|c|}
\hline $\begin{array}{c}\text { Параметры, между которыми } \\
\text { установлено наличие связи }\end{array}$ & $\begin{array}{l}\text { коэффициент } \\
\text { корреляции, } r\end{array}$ & $\begin{array}{c}\text { Уровень } \\
\text { значимости, } p\end{array}$ & $\begin{array}{c}\text { Характеристика } \\
\text { связи }\end{array}$ \\
\hline $\begin{array}{l}\text { Частота приступов и баллы } \\
\text { оценки повседневной жизненной } \\
\text { активности пациента до лечения }\end{array}$ & 0,353 & 0,001 & $\begin{array}{c}\text { умеренная } \\
\text { положительная }\end{array}$ \\
\hline $\begin{array}{l}\text { Частота приступов } \\
\text { и длительность приступа }\end{array}$ & $-0,304$ & 0,006 & $\begin{array}{c}\text { умеренная } \\
\text { отрицательная }\end{array}$ \\
\hline $\begin{array}{l}\text { Интенсивность боли по ВАШ } \\
\text { и баллы оценки повседневной } \\
\text { жизненной активности } \\
\text { пациента до лечения }\end{array}$ & 0,308 & 0,006 & $\begin{array}{c}\text { умеренная } \\
\text { положительная }\end{array}$ \\
\hline $\begin{array}{l}\text { Возраст пациента } \\
\text { и длительность заболевания }\end{array}$ & 0,319 & 0,004 & $\begin{array}{c}\text { умеренная } \\
\text { положительная }\end{array}$ \\
\hline $\begin{array}{l}\text { Возраст пациента } \\
\text { и интенсивность боли }\end{array}$ & 0,247 & 0,029 & $\begin{array}{c}\text { слабая } \\
\text { положительная }\end{array}$ \\
\hline $\begin{array}{l}\text { Длительность заболевания } \\
\text { и баллы оценки повседневной } \\
\text { жизненной активности } \\
\text { пациента до лечения }\end{array}$ & 0,229 & 0,043 & $\begin{array}{c}\text { слабая } \\
\text { положительная }\end{array}$ \\
\hline
\end{tabular}


$202 \mid$ Классическая невралгия тройничного нерва

Установлена умеренная положительная корреляционная зависимость между частотой приступов и баллами оценки повседневной жизненной активности больного. Чем выше частота приступов, тем выше балл оценки повседневной жизни пациента до лечения, т.е. тем ниже качество жизни.

Между частотой приступов и длительностью приступа установлена умеренная отрицательная корреляционная зависимость. Это означает, что большей частоте приступов чаще соответствует меньшая длительность приступа, и наоборот.

Умеренная положительная корреляционная зависимость установлена между интенсивностью боли по ВАШ и баллами оценки повседневной жизненной активности больного до лечения. Чем выше интенсивность боли, тем ниже качество жизни больного.

Между возрастом пациента и длительностью заболевания также установлена умеренная положительная корреляционная зависимость. Чем старше больной, тем в среднем больше длительность заболевания.

Между возрастом пациента и интенсивностью боли, а также между длительностью заболевания и баллами оценки повседневной жизненной активности пациента до лечения, установлены слабые положительные связи. С возрастом больного наблюдается тенденция увеличения интенсивности боли, а большей длительности заболевания соответствует в некоторой степени больший балл оценки повседневной жизненной активности пациента (свидетельствующий об ухудшении качества жизни).

Следовательно, основными факторами, нарушающими повседневную жизненную активность больного, являются интенсивность боли, количество болевых пароксизмов, а также в некоторой степени длительность заболевания. Этот факт объясняет стремление многих исследователей к выключению триггерных зон. Более того, они высказывают предположение о том, что выключение триггерных зон с помощью лазера, заморозки, хирургического воздействия может быть новым и эффективным методом лечения. Ясно одно, что выключение триггерных зон является одним из важных лечебных 
воздействий для достижения ремиссии. Однако, руководствуясь описанной выше концепцией патогенеза НТН, выключение триггерных зон - это воздействие только на кожные рецепторы.

До 2009 года мы применяли разработанный нами (патент РФ № 2227028 «Способ лечения невралгии тройничного нерва», 2004 г., БИПМ № 11) способ лечения, терапевтическое воздействие препаратов которого было направлено на стимулирование процесса ремиелинизации в области васкуло-неврального конфликта и подавление очага патологически усиленного возбуждения. При поступлении в клинику РостГМУ больной продолжал принимать карбамазепин в той же дозе, несмотря на то, что монотерапия этим препаратом до поступления в клинику не приносила облегчения. Карбамазепин воздействовал на центральные механизмы боли путем повышения порога возбудимости сенситизированных нейронов ствола, однако этого было недостаточно для достижения ремиссии.

На очаг демиелинизации в месте нейроваскулярного конфликта воздействовали препаратами, способствующими процессу ремиелинизации: кортикостероиды, витамины группы В (цианкобламин, тиамин, пиридоксин), $\alpha$-липоевая кислота (тиоктацид, берлитион). Кортикостероиды обладают противовоспалительным, мембранопротективным свойством, стабилизируя мембраны клеток и органелл путем угнетения активности фосфолипазы А2. Витамин В12 обладает высокой биологической активностью, являясь фактором роста, участвуя в образовании холина, метионина, нуклеиновых кислот, оказывая благоприятное влияние на функцию нервной системы (Машковский М.Д., 1993). Берлитион вводили внутривенно капельно по 600 мг в сутки. Курс лечения составлял 10 дней внутривенного введения. Препарат обладает мощным антиоксидантным действием и способствует активизации процесса ремиелинизации, улучшая трофику нейронов (Мурашко Н.К., 2010).

Мильгамму вводили по 2,0 мл внутримышечно через день, чередуя с блокадами, в количестве 5 инъекций. Включение в схему препарата мильгамма (комплекс витаминов B1, В6) продиктовано известной их эффективностью при невралгии тройничного нерва. 
$204 \mid$ Классическая невралгия тройничного нерва

Препарат обладает аналгезирующим действием, стимулирующим регенерацию нервной ткани, участвует в синтезе миелиновой оболочки, участвует в синтезе нейромедиаторов, а также способствует нормализации углеводного обмена (Машковский М.Д., 2002). Кроме того, тиамин обладает антиоксидантной активностью, регулирует проведение нервного импульса, влияя на передачу возбуждения.

Введение лекарственных средств по возможности приближали к очагу демиелинизации. Блокады выполнялись нами периневрально, к области круглого и овального отверстий. Состав блокад: кортикостероиды (Кенолог 40, позже Депо-Медрол 40 мг) в сочетании с витамином В12 500 мг и 4 мл 2\% лидокаина. Лидокаин, входящий в состав блокад, является блокатором 1,7 Na+ каналов, обладает высоким аналгетическим действием.

Воздействие на периферические ветви ТН осуществляют в просвете надглазничного, подглазничного и подбородочного отверстий (рис. 114).

Блокаду первой ветви ТН выполняют следующим образом: вторым пальцем левой кисти делят верхний край орбиты пополам и, не снимая пальца, прощупывают супраорбитальное отверстие, или супраорбитальный канал. Иглу вводят до соприкосновения с костью, затем определяют надглазничное отверстие и погружают в глубь канала не более чем на 5-6 мм, после этого вводят 1,5-2,0 мл вышеприведенного состава.

Блокада второй ветви (рис. 114, б) тройничного нерва выполняется следующим образом: вторым пальцем левой кисти определяют середину нижнего края орбиты, отступя на 1,5-2 см книзу от этого места, вводят иглу до кости. Иглу направляют чуть кверху и кнаружи, так, чтобы павильон ее почти вплотную подходил к крылу носа, определяют подглазничный канал и продвигают в его просвет на глубину 0,5 см, после чего вводят 2,0-3,0 мл лечебного состава.

Блокаду подбородочного нерва производят на нижней челюсти у выхода этого нерва через подбородочное отверстие, как показано на рис. 114, в. Для того, чтобы определить местонахождение этого отверстия, полезно учитывать, что надглазничное, подглазничное и 
подбородочное отверстие находятся на одной вертикальной линии. Определить подбородочное отверстие несложно, если учесть, что оно расположено под альвеолярной перегородкой между первым и вторым премолярами или под альвеолой премоляра, причем размещается оно точно на середине расстояния между альвеолярным краем и нижним краем челюсти. Иглу можно вводить как через кожу, так и через слизистую оболочку преддверия рта.
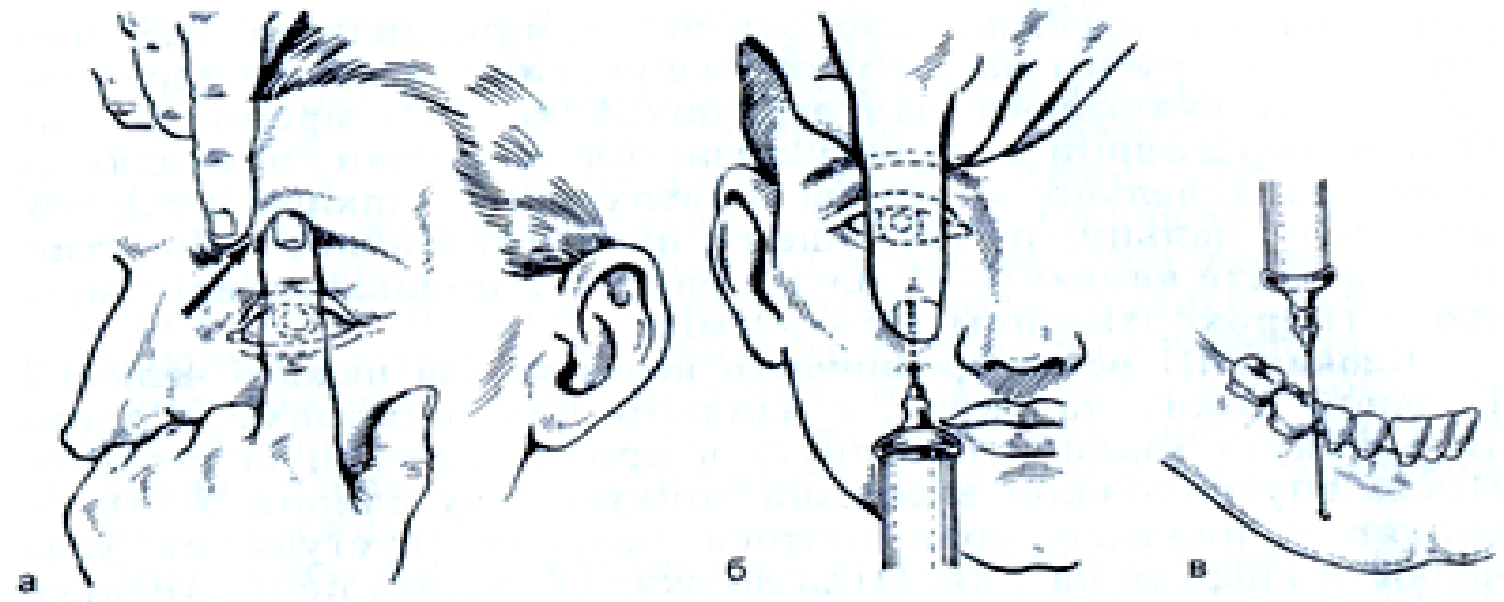

Рис. 114. Блокады ветвей тройничного нерва на лице

Блокаду 2 ветви ТН (рис. 115) мы чаще всего выполняли в области крылонебной ямки, приближая лекарственную смесь к круглому отверстию. При слегка приоткрытом рте больного определяли точку вкола иглы на 0,5-1,0 см ниже середины скуловой дуги. В эту точку вводят тонкую иглу, направляя ее перпендикулярно коже, но с небольшим, около $5^{\circ}$, уклоном вперед и вверх на глубину до 3,5 cм или до соприкосновения с крылонебным отростком. После чего вводят лекарственную смесь.

Блокаду третьей ветви ТН с максимальным приближением лекарственной смеси к очагу демиелинизации мы выполняли у овального отверстия. Точка вкола иглы определялась как при блокаде в область крылонебной ямки. Игла проводилась до упора в крылонебный отросток. Ограничитель (стерильную резиновую пластину) на 
игле смещали до поверхности кожи. Затем игла извлекалась до подкожной жировой клетчатки, и острие ее направлялось на $15^{\circ}$ кзади от перпендикулярной линии первого вкола и продвигалась кзади до соприкосновения ограничителя на игле с поверхностью кожи. После этого вводилась лекарственная смесь.

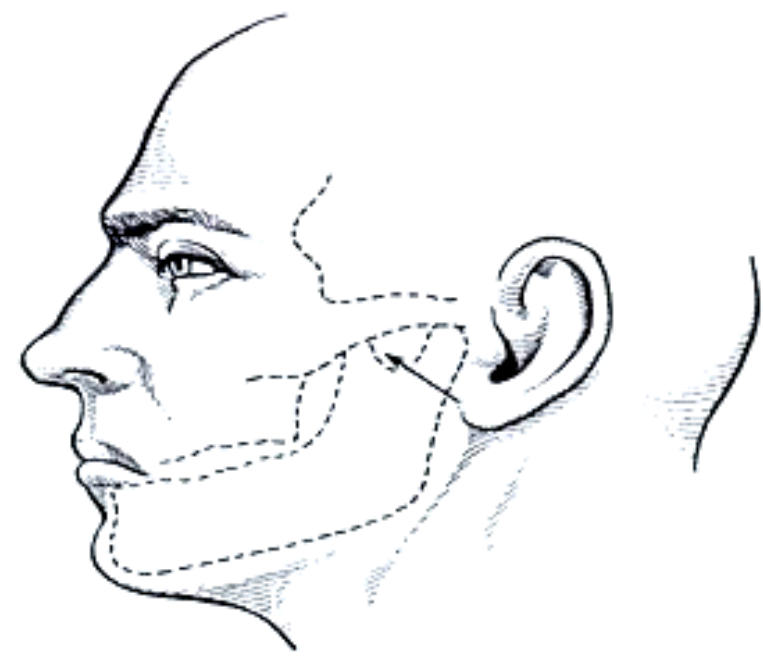

Рис. 115. Блокада второй и третьей ветвей в области крылонебной ямки

Позже эффективность и безопасность блокад с лидокаином у больных тригеминальной невралгией была описана Han K.R., et al. (2008), а эффективность применения дексаметазона в облегчении тригеминальной невропатической боли в эксперименте была доказана Han S.R., et al. (2010).

Из 78 больных 64 человека получали лечение в соответствии с методикой, описанной нами в патенте РФ № 2227028. Результаты лечения представлены на рис. 116. После третьей блокады в случаях уменьшения интенсивности и частоты приступов боли приступали к снижению дозы карбамазепина. Эффективность лечения оценивалась по двум критериям: уменьшению боли по ВАШ и уменьшению баллов по шкале повседневной активности. У больных, которые прекратили прием финлепсина и его аналогов по причине того, что в результате лечения приступы болей прошли, количество баллов по шкале повседневной активности не превышало 10, результат лечения расценивался как полная ремиссия. 


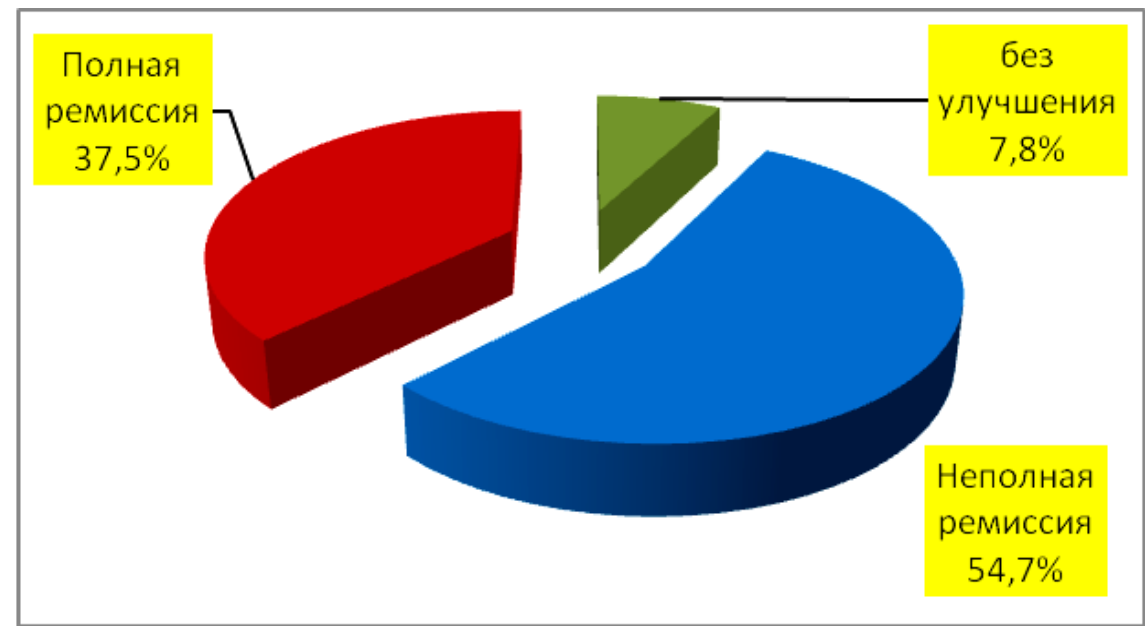

Рис. 116. Результаты лечения 64 больных в соответствии с Патентом РФ № 2227028

У больных с уменьшением интенсивности болей по ВАШ относительно исходного уровня и уменьшением количества баллов по шкале повседневной жизненной активности относительно исходных показателей, но не превышавших 20 баллов, результат лечения расценивался как неполная ремиссия. Поддерживающая доза финлепсина при этом не превышала 600 мг в сутки. Если же в результате лечения уменьшения интенсивности болей не происходило, а количество баллов по шкале жизненной активности оставалось неизменным или превышало 21 балл, то такой результат лечения расценивался как отрицательный, т.е. эффект от консервативной терапии отсутствовал.

В результате проведенного консервативного лечения у $37,5 \%$ больных наступила полная ремиссия, у 54,7\% - неполная ремиссия и у 7,8\% больных лечение оказалось безрезультатным, и они (5 человек) в ближайшие недели были прооперированы. Им была выполнена МВД. Позже, по истечении от 6 месяцев до 2 лет после неполной ремиссии, еще 6 человек вернулись с рецидивом боли, и им была выполнена МВД.

Возраст больных с полной ремиссией статистически значимо меньше, чем возраст больных в двух остальных группах $(p=0,04)$. Возраст больных с неполной ремиссией и безрезультативным лечением различается статистически незначимо (табл. 44). 
Средний возраст больных в группах с разным результатом лечения

\begin{tabular}{|c|c|c|c|c|}
\hline $\begin{array}{c}\text { № } \\
\text { групп }\end{array}$ & $\begin{array}{c}\text { Результат } \\
\text { лечения }\end{array}$ & $\boldsymbol{M \pm m , ~ г о д ы ~}$ & $\boldsymbol{\sigma , ~ г о д ы ~}$ & $\begin{array}{c}\text { Уровень } \\
\text { значимости }\end{array}$ \\
\hline 1 & Полная ремиссия & $56,88 \pm 3,36$ & 16,48 & \\
\hline 2 & $\begin{array}{c}\text { Неполная } \\
\text { ремиссия }\end{array}$ & $63,83 \pm 2,11$ & 12,50 & $p_{1,2=0,04}$ \\
\hline 3 & Без результата & $64,40 \pm 2,56$ & 5,73 & $p_{1,3}=0,04$ \\
\hline
\end{tabular}

С 2009 года к проводимой схеме лечения были добавлены аппликации на область триггерных зон с целью их выключения (Патент РФ № 2438657 «Способ лечения невралгии тройничного нерва»).

Состав аппликаций: 98\% раствор диметилсульфоксида- 20 частей, 10\% раствор лидокаина - 40 частей, $2 \%$ спиртовой раствор анестезина - 40 частей. Аппликации продолжительностью 30-45 минут производили ежедневно через каждые 3-4 часа 4-5 раз в день. Выключение с помощью аппликаций триггерных зон - это лечебное воздействие на рецепторы кожи. Результаты лечения 14 больных при воздействии на три уровня тригеминальной системы представлены на рис. 117.

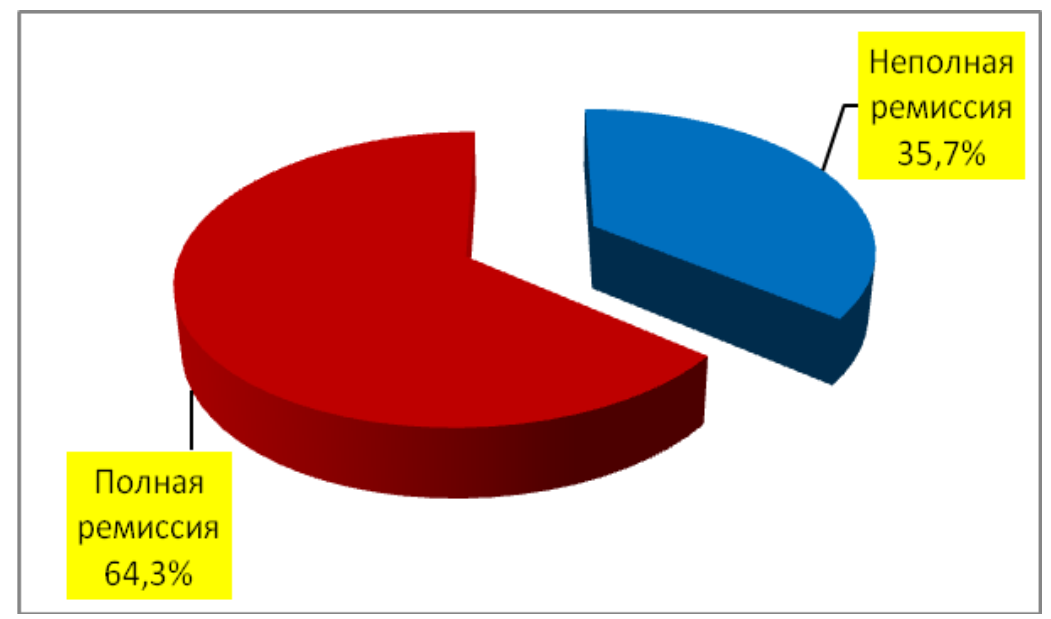

Рис. 117. Результаты лечения больных при воздействии на три уровня тригеминальной системы. Патент РФ №2438657 
В табл. 45 приведены средние значения баллов оценки повседневной жизненной активности пациента до и после лечения для двух подгрупп больных.

Различие между средними баллами до лечения в двух группах статистически незначимо $(p=0,1)$. Т.е. обе группы практически одинаковы по качеству жизни до лечения.

Таблица 45

Значения баллов оценки повседневной жизненной активности пациента до и после лечения для двух подгрупп больных

\begin{tabular}{|c|c|c|c|c|}
\hline \multirow[t]{2}{*}{ Параметры } & \multicolumn{2}{|c|}{$\begin{array}{l}\text { Больные, получавшие } \\
\text { лечение в соответствии с } \\
\text { методикой, описанной в } \\
\text { патенте РФ № } 2227028\end{array}$} & \multicolumn{2}{|c|}{$\begin{array}{l}\text { Больные, получавшие } \\
\text { лечение в соответствии с } \\
\text { методикой, описанной в } \\
\text { патенте РФ № } 2438657\end{array}$} \\
\hline & $M \pm m$ & $\sigma$ & $M \pm m$ & $\sigma$ \\
\hline $\begin{array}{l}\text { Баллы оценки повседневной } \\
\text { жизни пациента до лечения }\end{array}$ & $24,42 \pm 0,36$ & 2,90 & $23,00 \pm 1,06$ & 3,98 \\
\hline $\begin{array}{l}\text { Баллы оценки повседневной } \\
\text { жизни пациента после лечения }\end{array}$ & $13,61 \pm 0,47$ & 3,76 & $11,57 \pm 0,68$ & 2,53 \\
\hline
\end{tabular}

Различие между средними баллами после лечения в двух группах статистически значимо $(p=0,03)$. Качество жизни после лечения у пациентов, лечившихся согласно патенту РФ № 2438657, выше, чем у пациентов, получавших лечение в соответствии с методикой, описанной нами в патенте РФ № 2227028 (таб. 45).

Таблица 46

Значения средней интенсивности болей по ВАШ до и после лечения для двух подгрупп больных

\begin{tabular}{|c|c|c|c|c|}
\hline \multirow[t]{2}{*}{ Параметры } & \multicolumn{2}{|c|}{$\begin{array}{l}\text { Больные, получавшие } \\
\text { лечение в соответствии } \\
\text { с методикой, описанной } \\
\text { в патенте РФ № } 2227028\end{array}$} & \multicolumn{2}{|c|}{$\begin{array}{l}\text { Больные, получавшие } \\
\text { лечение в соответствии } \\
\text { с методикой, описанной } \\
\text { в патенте РФ № } 2438657\end{array}$} \\
\hline & $M \pm m$ & $\boldsymbol{\sigma}$ & $M \pm m$ & $\boldsymbol{\sigma}$ \\
\hline $\begin{array}{l}\text { Интенсивность болей по ВАШ } \\
\text { до лечения }\end{array}$ & $8,45 \pm 0,15$ & 1,23 & $8,00 \pm 0,33$ & 1,24 \\
\hline $\begin{array}{l}\text { Интенсивность болей по ВАШ } \\
\text { после лечения }\end{array}$ & $2,28 \pm 0,28$ & 2,26 & $1,00 \pm 0,41$ & 1,52 \\
\hline
\end{tabular}


$210 \mid$ Классическая невралгия тройничного нерва

Различие между средней интенсивностью болей до лечения в двух группах статистически незначимо $(p=0,1)$. Т.е. по этим показателям обе группы практически не различаются.

Различие между средней интенсивностью болей после лечения в двух группах статистически значимо $(p=0,03)$. У пациентов, лечившихся согласно патенту РФ № 2438657, средняя интенсивность болей после лечения ниже, чем у пациентов, получавших лечение в соответствии с методикой, описанной нами в патенте РФ № 2227028 (таб. 46).

Из 33 больных обеих групп, выписанных после консервативной терапии в состоянии полной ремиссии, трое больных вернулись с рецидивом заболевания (1 - через 7 месяцев, 2 - через 2 года). Все они избрали хирургический способ лечения - МВД. Из 30 оставшихся полная ремиссия сохранялась в течение 3 лет у 18 больных, а 7 больных в связи с обострением заболевания стали принимать финлепсин по 200 мг 2-3 раза в день с периодическими перерывами по мере утихания болей, а 5 человек избрали хирургический метод лечения (МВД).

Из 40 больных, выписанных из клиники РостГМУ в состоянии неполной ремиссии, три человека вернулись с рецидивом заболевания (1 - через 6 месяцев, 1 - через 7 месяцев, и 1 - через 10 месяцев). Все они избрали в этот раз хирургический метод лечения - МВД. Из оставшихся 37 человек в течение трех лет наблюдения 9 человек прекратили прием финлепсина в связи исчезновением приступов. Из 28 больных этой группы сведения получены от 22 человек. В осеннее-зимне-весенний период обострения у них наблюдались ежегодно. В период обострений они увеличивали дозу финлепсина до 800-1000 мг в сутки. Четверо из 22 больных вынуждены были увеличить дозу финлепсина до 1800-2200 мг в сутки, но заметного улучшения не отмечали. Они госпитализированы повторно, избрав вновь курс консервативной терапии. Трое из них выписаны в состоянии неполной ремиссии со снижением дозы финлепсина по 200 мг 2 раза в сутки, а одна больная в состоянии полной ремиссии. От 6 больных из 40, выписанных в состоянии неполной ремиссии, сведений не получено. 
Естественно, разработанный нами способ консервативной терапии НTH, несмотря на свою патогенетическую направленность, является паллиативным. Однако он позволяет достигнуть ремиссии в течение 10-12 дней стационарной терапии. В то же время результатом медикаментозной ремиссии является значительное уменьшение дозы принимаемых препаратов дибензоазепинового ряда (от 1000 до 3200 мг в начале лечения до 200 мг 2-3 раза в день и менее при выписке из клиники). Снижение дозы препаратов дибензоазепинового ряда уменьшает вероятность проявления побочных явлений. Это обстоятельство многие авторы считают очень важным не только для каждого конкретного больного, но и для всех людей в целом.

Длительный прием карбамазепина может сопровождаться развитием клиники гипотиреоза [380], поэтому авторы рекомендуют периодическое исследование функции щитовидной железы.

Высокий риск тяжелых кожных аллергических реакций в результате приема противосудорожных препаратов у больных НТН с HLA-B*1502 аллелью описаны Shakib K, Sinanan M. (2010). Среди наших больных также отмечались тяжелые кожные аллергические реакции на прием финлепсина (рис. 118).

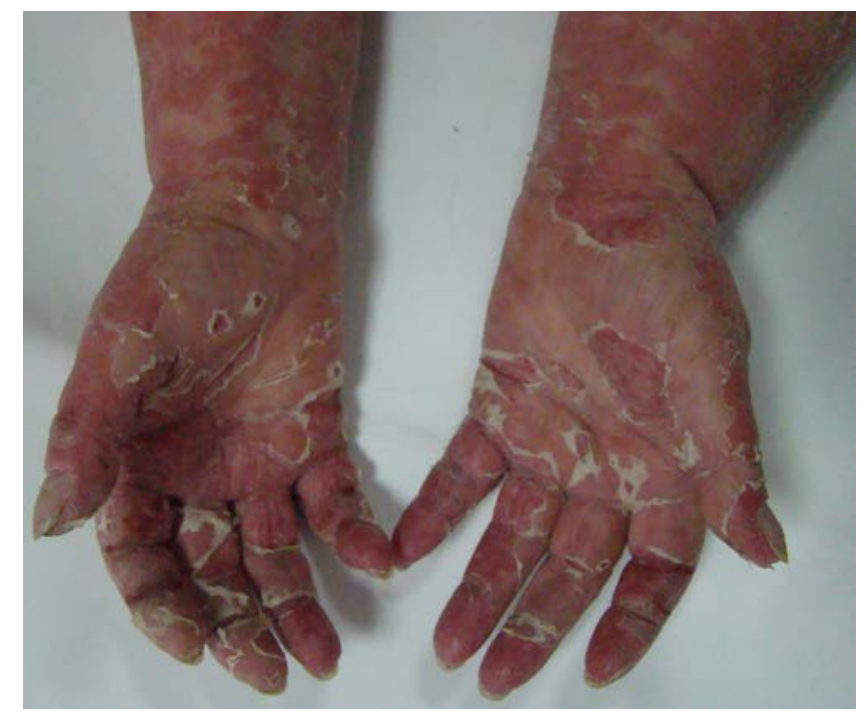

Рис. 118. Больна У. Аллергическая реакция на прием финлепсина

Токсикологи бьют тревогу относительно повышения концентрации крабамазепина в поверхностных водах Северной Америки и 
$212 \mid$ Классическая невралгия тройничного нерва

Европы (Cunnigham V.L., at al., 2010). Наряду с больными эпилепсией, длительно принимающими карбамазепин, немалую долю препарата в экосистему вносят и больные, страдающие НТН.

Соков Е.Л. и Клепиков Р.В. (1999), руководствуясь остеогенной концепцией происхождения НТН, рекомендуют внутрикостное введение в скуловую кость и в нижнюю челюсть 1-2 мл 1\% раствора лидокаина с 1-2 мг дексаметазона, получая временное уменьшение болей. Предлагают к медикаментозной терапии и спиртовым блокадам добавлять лазеротерапию [Лапченко А.С. и Кучеров А.Г., 1999; Щедренок В.В. с соавт., 2014]. Максимальная продолжительность ремиссии, по данным Щедренок В.В. с соавт. (2014) не превышает 7,8 $\pm 2,8$ месяца.

Мегдятов Р.С. с соавт. (1999) используют эндолимфатическое введение оксибутирата в количестве 5,0 мл, получая при этом у 80\% больных кратковременную ремиссию.

С целью выключения триггерных зон, в особенности при НТН с локализацией болей в области второй ветви, некоторые авторы используют лидокаиновый интранозальный спрей [261].

Для лечения хронической боли, в том числе и НТН, многие клиницисты применяют электростимуляцию коры головного мозга $[232,358]$. При безуспешности медикаментозной терапии Шаров М.Н. и соавт. (2010) применяют электросудорожную терапию в сочетании с транскраниальной магнитной стимуляцией, воздействуя таким образом на центральные механизмы HTH, а именно на повышение порога возбудимости сенситизированных нейронов коры.

Некоторые исследователи для лечения НТН используют гомеопатические средства [325]. Суматриптан в инъекциях для купирования приступов НТН применяли Kanai A., et al. (2006), а позже в виде назального спрея - Shimohata K, et al. (2009) Интересное исследование проведено Zhou C.S., et al., (2007). Авторы изучили сравнительную эффективность акупунктурного введения 2000 мкг витамина В12 и перорального карбамазепина и пришли к выводу о том, что акупунктурное применение витамина В12 более эффективно, чем пероральное использование карбамазепина. Акупунктурную терапию используют многие авторы $[296,435]$. 
В последние годы некоторые исследователи для лечения НТН (а именно, выключения триггерных зон) стали применять ботулотоксин $[104,147,332,346,414]$. Этот метод лечения направлен на выключения периферических механизмов формирования болевого пароксизма.

Недооценкой консервативных методов лечения и увлеченностью МВД является лечебный алгоритм, предлагаемый Шулевым Ю.А. и соавт. (2004), которые советуют отказаться от схемы нарастающего радикализма в лечении НТН, а переходить к МВД сразу после подтверждения наличия васкулоневрального конфликта с помощью методов нейровизуализации.

\section{2. ПУНКЦИОННЫЕ ДЕСТРУКТИВНЫЕ МЕТОДЫ ЛЕЧЕНИЯ}

Применяемые как в нашей стране, так и во многих зарубежных странах пункционные деструктивные вмешательства направлены на разрушение тригеминальных структур как механическим путем, с использованием лазера, низких или высоких температур, химических агентов, баллонная компрессия полулунного узла, так и гамма-излучением. Деструктивные вмешательства относятся к паллиативным, обеспечивающим непродолжительную ремиссию болевого синдрома и сопровождаются высоким процентом рецидивов заболевания.

С целью ускорения наступления ремиссии ряд авторов рекомендуют сочетать использование противосудорожных препаратов с лекарственными блокадами периферических ветвей тройничного нерва, либо деструктивными воздействиями - спиртовыми блокадами $[104,210,255,350,351,394,139]$. Деафферентационные осложнения после алкоголизации и отсутствие эффекта при повторных спиртовых блокадах ставят под сомнение целесообразность их использования в настоящее время. Несмотря на это многие авторы продолжают рекомендовать их в комплексной терапии НТН $[90,126,139,330]$. 
$214 \mid$ Классическая невралгия тройничного нерва

Многие стоматологи и челюстно-лицевые хирурги, обнаружив стеноз нижнечелюстного канала на стороне болевых пароксизмов, расценивают его как причину невралгии третьей ветви тройничного нерва $[75,80,84,109]$. На основании данного предположения стали применяться хирургические методы лечения, направленные на расширение канала [73]. Однако высокий процент рецидивов заболевания дает основание сомневаться в этиопатогенетической значимости этого признака. В то же время среди стоматологов и челюстно-лицевых хирургов экстракраниальный генез идиопатических лицевых болей сохраняет свои позиции до настоящего време-ни [257]. Поэтому в ряде стоматологических клиник продолжают выполнять расширение нижне-челюстного канала, подглазничного отверстия и в настоящее время [74].

Отсутствие стойкого положительного эффекта от консервативной терапии способствовало расширению и распространению различных деструктивных вмешательств на ветвях ТН и на полулунном узле: неврэктомия, феноловая, гидротермическая, радиочастотная или глицероловая деструкция [54, 91, 92, 106, 117, 129, 139 , 196, 200, 331, 370, 404].

Разработанный еще в 1912 году F. Hartel передний восходящий доступ к полулунному узлу через овальное отверстие не претерпел технических изменений до настоящего времени. Только вместо спирта в мекелеву пазуху стали вводить фенол, глицерол, либо электрод для высокочастотной деструкции или баллон для компрессии узла и корешка. Кроме нарушения чувствительности на лице, среди осложнений этих деструктивных операций наблюдается нейропаралитический кератит. У многих больных появляются деафферентационные боли, дизестезия, гиперпатия, которые больным причиняют не меньшие страдания, чем приведшая их на операцию невралгия.

B 1971 Leksell L. применил стереотаксически фокусированное излучение на область полулунного узла и прилежащую часть корешка. C 1991 года Rand R.W. начал лечить с помощью гамма-ножа больных НTH, у которых медикаментозное и хирургическое лечение оказались неэффективными. После этого появилось много работ, посвященных эффективности гамма-ножа у больных НТН $[274,275,428]$. 
Результаты и нежелательные явления этого метода лечения требуют своего дальнейшего изучения. Больным, которым по состоянию жизненно важных функций противопоказаны МВД или чрезкожные вмешательства, многими авторами рекомендуется гамма-нож как метод выбора [267, 271, 358], и даже неврэктомия периферических ветвей НТН [180]. До настоящего времени продолжают использовать такие деструктивные вмешательства как гидротермическая деструкция полулунного узла и ретрогассериальной части КТН, баллонная компрессия КТН $[100,139,182,183]$.

\section{3. КРИТЕРИИ ОТБОРА БОЛЬНЫХ ДЛЯ МИКРОВАСКУЛЯРНОЙ ДЕКОМПРЕССИИ КОРЕШКА ТРОЙНИЧНОГО НЕРВА}

Основным критерием отбора больных для хирургического лечения является отсутствие эффекта от проводимой консервативной терапии в течение 3-4 месяцев, несмотря на прием высоких доз финлепсина (карбамазепина) до 4000 мг в сутки и более. Выраженные побочные действия препарата, такие как головная боль, головокружение, атаксия при ходьбе, потеря аппетита, тошнота, иногда рвота наряду с тяжелыми болевыми пароксизмами, истощающими больного, ставят его перед необходимостью хирургического лечения. Показанием к хирургическому лечению является также невралгический статус, когда пациент из-за боли лишен возможности принимать пищу и жидкость, что приводит к потере массы тела и метаболическим нарушениям.

Вне зависимости от сроков заболевания показанием к МВД является индивидуальная непереносимость препаратов дибензоазепинового ряда. При длительном медикаментозном лечении и невозможности достигнуть полной ремиссии заболевания в течение 3-4 месяцев мы предлагаем больному спиральную компьютерную томографию для подтверждения наличия нейроваскулярного конфликта. При подтверждении нейроваскулярного конфликта больному рекомендуется микроваскулярная декомпрессия КТН как 
функциональная и органосохраняющая операция. Решение о выборе метода лечения остается за больным с учетом сопутствующей соматической патологии.

\section{4. МИКРОВАСКУЛЯРНАЯ ДЕКОМПРЕССИЯ}

При отсутствии эффекта от консервативной терапии наиболее физиологичной и органосохраняющей операцией является микроваскулярная декомпрессия КТН. Накопленный мировой опыт использования микроваскулярной декомпрессии (МВД) корешка тройничного нерва для лечения больных тригеминальной невралгией свидетельствует о высокой эффективности этой операции, обеспечивающей 100\% успех в ближайшем послеоперационном периоде при отсутствии деафферентационных осложнений, неизбежно возникающих после деструктивных вмешательств.

Через заушный разрез мягких тканей выполняется краниотомия диаметром не более 3 см. (рис. 119). Верхний край трепанационного окна ограничивается поперечным синусом, латеральный край - сигмовидным.

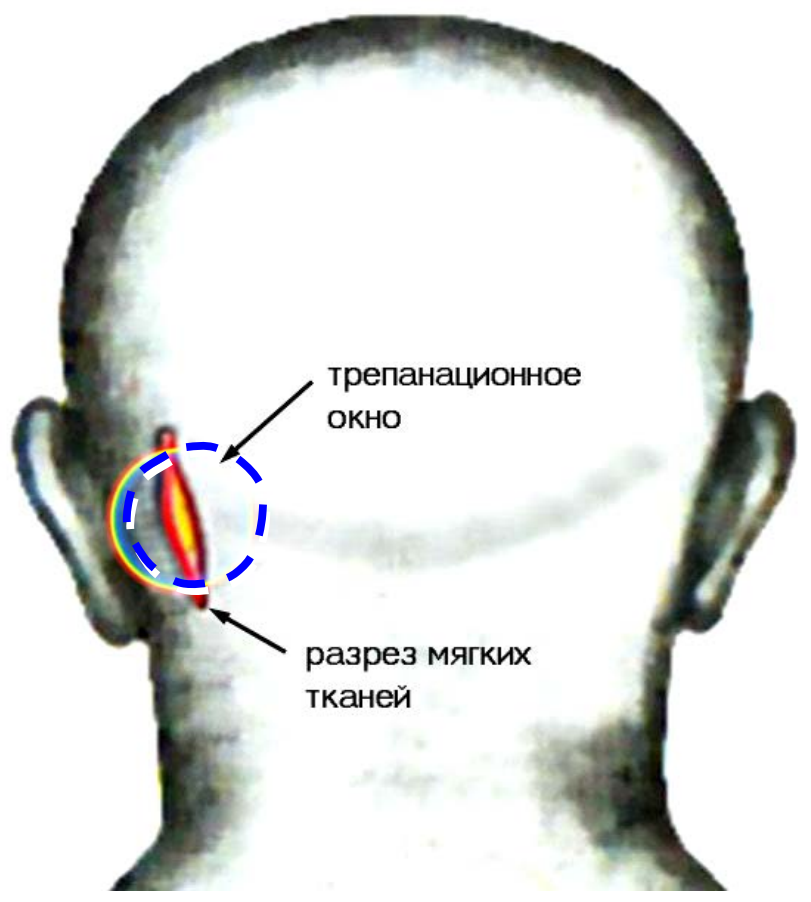

Рис. 119. Заушный доступ к корешку тройничного нерва 
Вскрывающиеся ячейки сосцевидного отростка тампонируются гемостатической губкой с антисептиком, а затем воском. После вскрытия крестообразным разрезом твердой мозговой оболочки обнаруживается, обычно, спавшийся мозжечок и значительное свободное пространство под твердой мозговой оболочкой. Без усилия мозжечок смещается медиально и поддерживается шпателем ретрактора, исключая натяжение черепных нервов. Дальнейшие этапы операции выполняются с помощью микрохирургического инструментария и операционного микроскопа с 7 или 10 кратным увеличением операционного поля. После вскрытия латерального листка паутинной оболочки боковой цистерны моста рассекаются арахноидальные спайки, нередко замуровывающие в единый блок КТН и артериальную петлю (или артериальные петли) верхней мозжечковой артерии (BMA), значительно реже передней нижней мозжечковой артерии (ПНМА). При этом необходимо стремиться сохранить верхнюю каменистую вену (рис. 122). Очень трудно бывает сохранить ее в случаях, когда близко к месту впадения в верхний каменистый синус она представлена несколькими стволами, которые препятствуют полноценной ревизии КТН. В целях адекватного доступа к корешку приходится жертвовать одним или двумя венозными стволами (рис. 120, 121).

В целях профилактики развития гипотензивного синдрома и гидропса лабиринта выполняется аутоликворотрансфузия. Сразу после вскрытия твердой мозговой оболочки и боковой цистерны моста собирается спинно-мозговая жидкость, которая в конце операции вновь возвращается в боковую цистерну моста.

При тщательной ревизии всех поверхностей КТН, особенно в воротной области, обнаруживается его конфликт с одной или несколькими артериальными ветвями. Устранение конфликта осуществляется путем перемещения артериальной петли в бесконфликтное положение - между корешком и наметом мозжечка (рис. 123, 124), либо заключением внутрь цилиндрического протектора артериальных петель, либо КТН (рис. 124). 


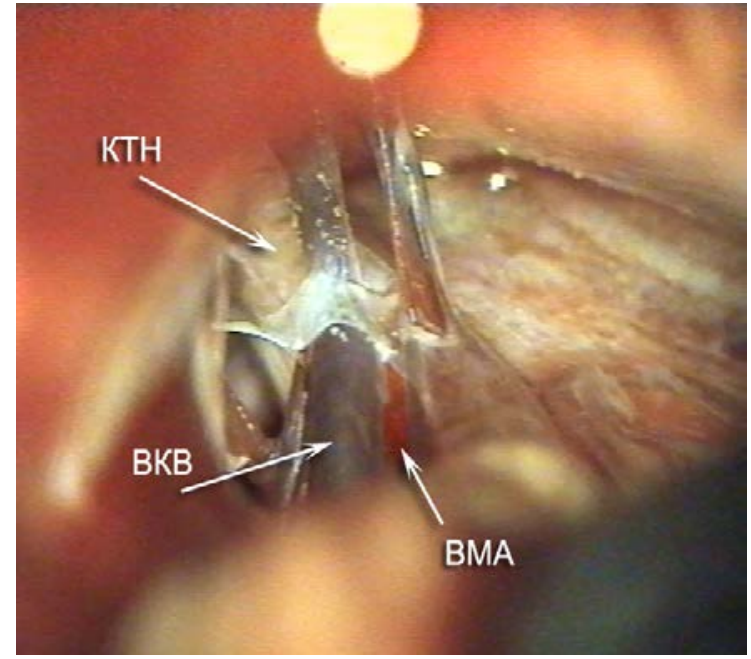

a)

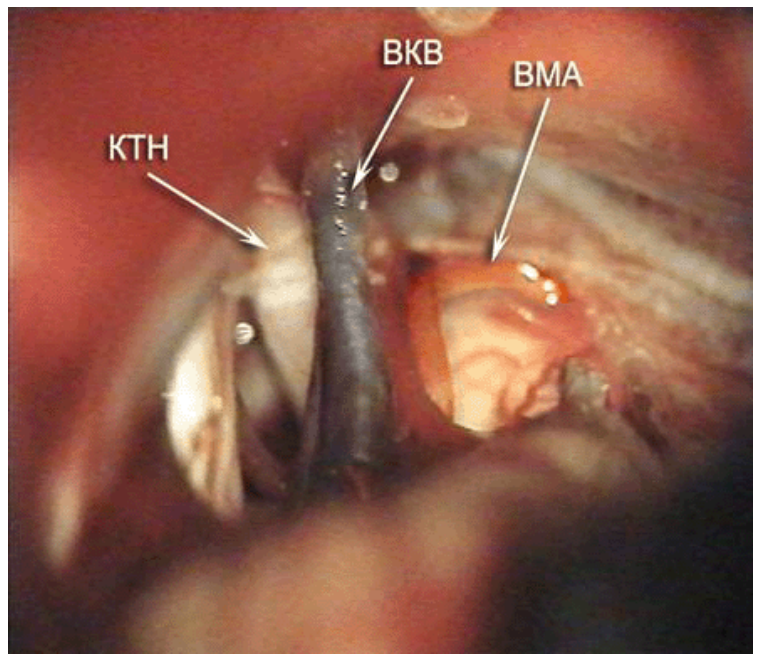

б)

Рис. 120. Васкулоневральный конфликт справа: а) один из стволов ВКВ препятствует доступу к КТН; б) после коагуляции медиального ствола ВКВ нейроваскулярный конфликт хорошо визуализирован

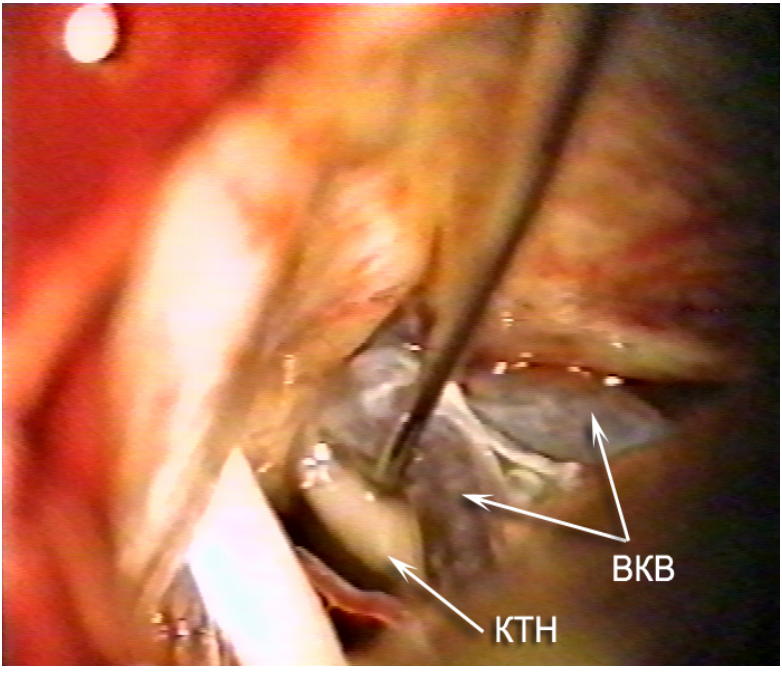

a)

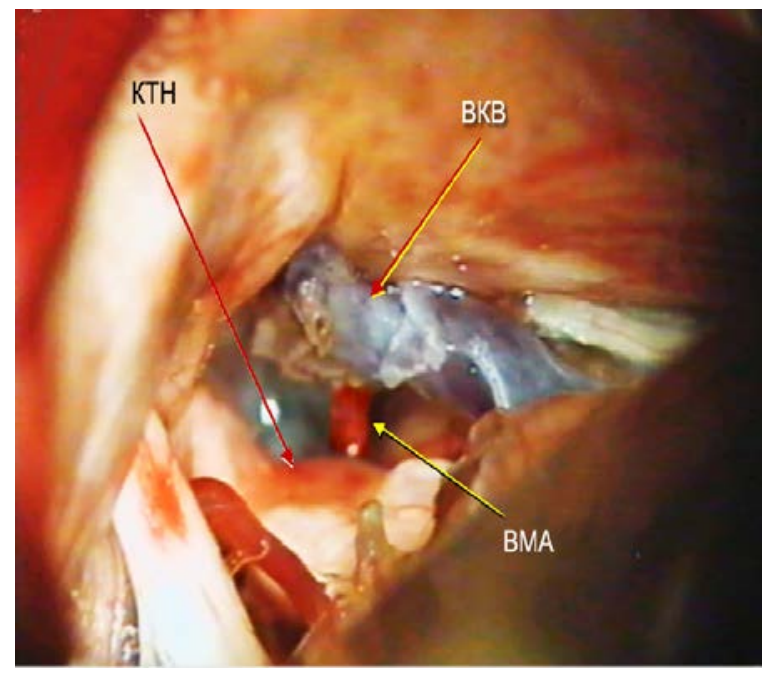

б)

Рис. 121. Васкулоневральный конфликт справа: а) оба ствола ВКВ полностью закрывают доступ к КТН; б) после коагуляции латерального ствола ВКВ визуализирован васкулоневральный конфликт

Ревизия КТН производится тщательно с целью установления особенностей васкулоневрального конфликта, а именно, количества артериальных стволов, принимающих участие в нем. Это имеет важное значение как для профилактики рецидива заболевания, так и для надежного устранения конфликта. Приведем одно из наиболее типичных наблюдений. 
Больная О. 53 лет, история болезни № 9643/1639, поступила в клинику нейрохирургии РостГМУ 27.11.07 г. с диагнозом невралгия второй и третей ветвей правого тройничного нерва.

Жалобы на боли стреляющего и пульсирующего характера в области правой щеки, нижней губы справа, которые провоцируются разговором, чисткой зубов, открыванием рта.

В 1993 году после переохлаждения, во время еды впервые появился приступ боли в области правой щеки ближе к уху по продолжительности около одной минуты. Боль ушла самостоятельно. Через 15 дней приступы болей возобновились, обратилась к стоматологу, который после проведения рентгенографии отправил пациентку к неврологу с диагнозом невралгия тройничного нерва (частота приступов боли 7-9 раз в день). В течение 24 дней получила курс стационарного лечения (финлепсин, блокады периферических ветвей ТН с ультракаином, электрофорез-полумаски, аппликации с парафином). Наступила ремиссия продолжительностью около года. После стресса возобновилась боль стреляющего характера («удар электрическим током»), повторно проведен вышеназванный курс лечения. Наступившая ремиссия продолжалась около года. После очередного стресса вновь появилась боль стреляющего характера с частотой приступов до 10-12 раз в день. Выполнявшиеся блокады и ранее назначенное лечение оказались безрезультатными. Появилась аллергия на витамин В12. В течение многих лет лечилась у народных целителей, но при этом постоянно принимала 2-3 таблетки финлепсина в сутки. Интенсивность боли нарастала, и частота приступов увеличилась до 20-25 раз в день иногда сериями до 15-20 минут. Интенсивность боли была такой, что иногда падала на колени и плакала. В 2006 году из-за выраженных болевых пароксизмов не могла открывать рот и общение с окружающими осуществляла в письменной форме. Количество таблеток финлепсина увеличивала до 5 за один прием. Аналогичное обострение возникло в октябре 2007 года. 28.11.07 г. выполнена операция МВД (рис. 122). Боли прекратились сразу же после пробуждения от наркоза. 


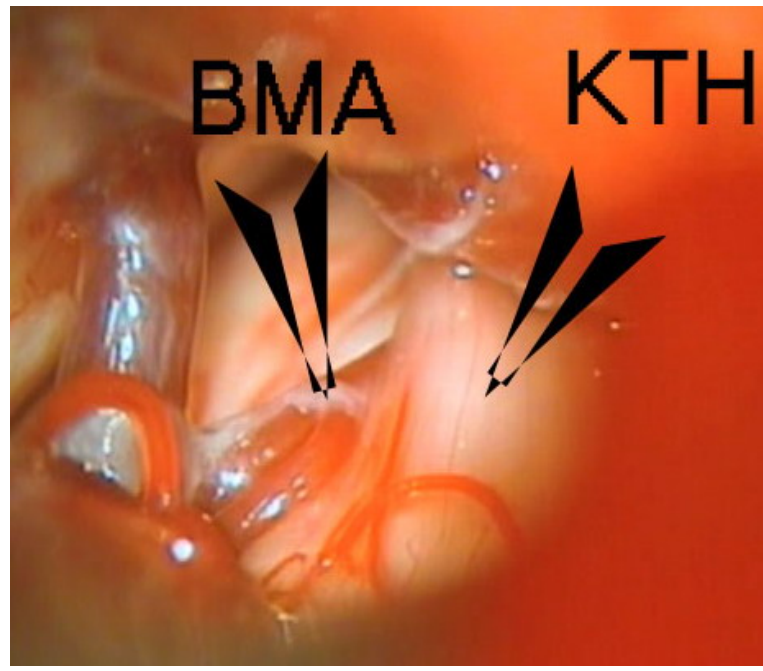

a)

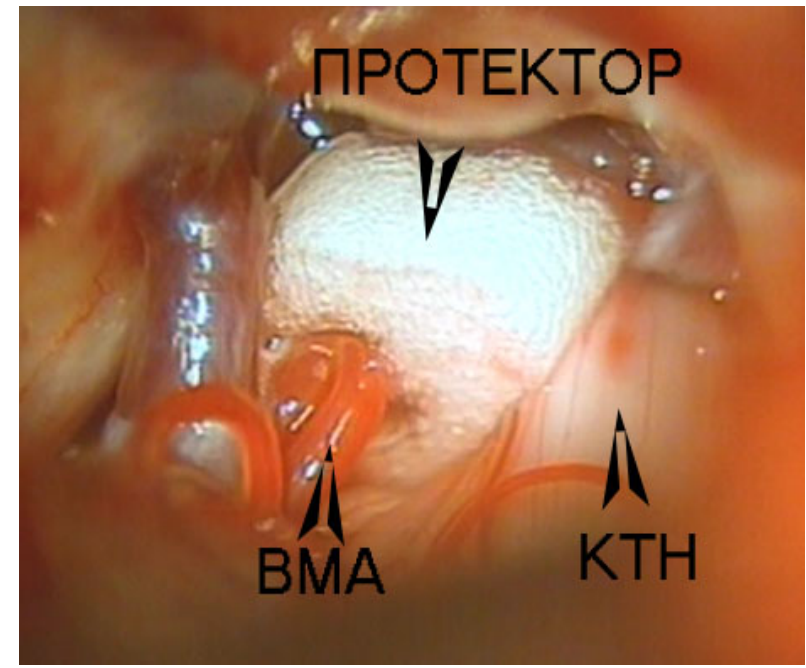

б)

Рис. 122. Верхняя каменистая вена в стороне от места нейроваскулярного конфликта; а) нейроваскулярный конфликт между КТН и ВМА, при этом латеропонтинный сегмент ВМА делится на ветви второго порядка в месте конфликта с КТН; б) оба ствола ВМА заключены в микропротектор, конфликт устранен

С целью профилактики рецидива заболевания наиболее надежным хирургическим приемом является транслокация петли верхней мозжечковой артерии в пространство между КТН и наметом мозжечка, т.е. в бесконфликтное положение (рис. 123, б).

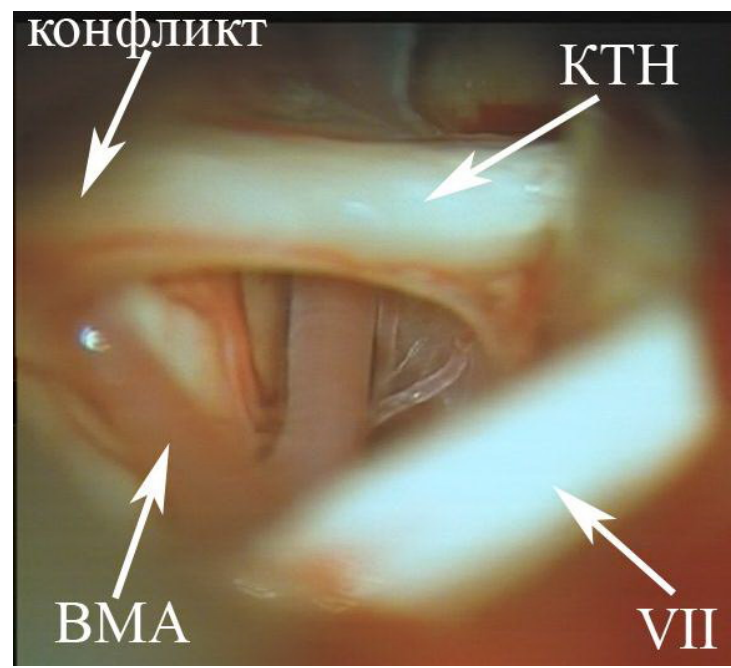

a)

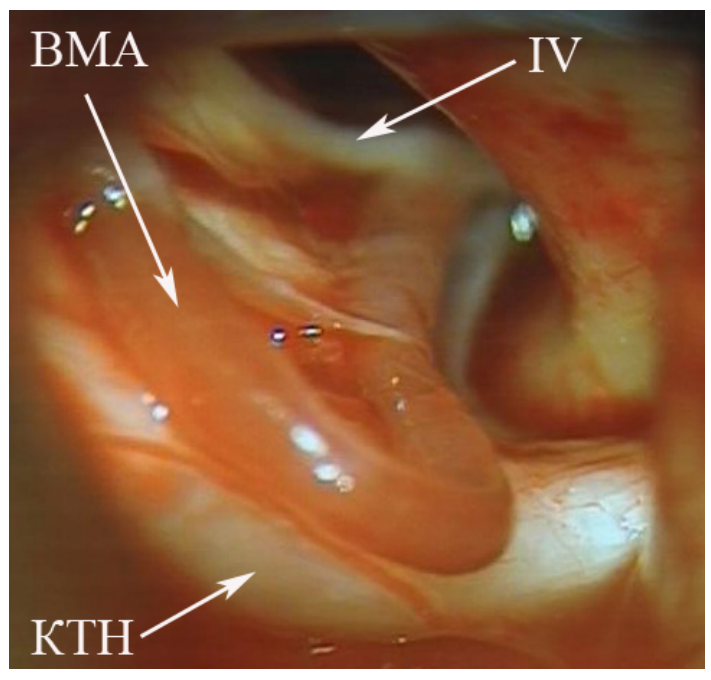

б)

Рис. 123. Невралгия правого тройничного нерва: а) конфликт КТН с ВМА; б) петля ВМА перемещена в пространство между КТН и наметом мозжечка 
В тех случаях, когда транслоцированная петля ВМА, благодаря памяти эластических свойств стенки артерии, под пульсовыми ударами может вернуться в конфликтное положение, целесообразно заключение артерии в микропротектор. С одной стороны, он препятствует возвращению артерии в конфликтное положение, с другой, благодаря положительной плавучести полиуретанового пористого микропротектора, он постоянно удерживает артерию под наметом мозжечка (рис. 124, б, в).
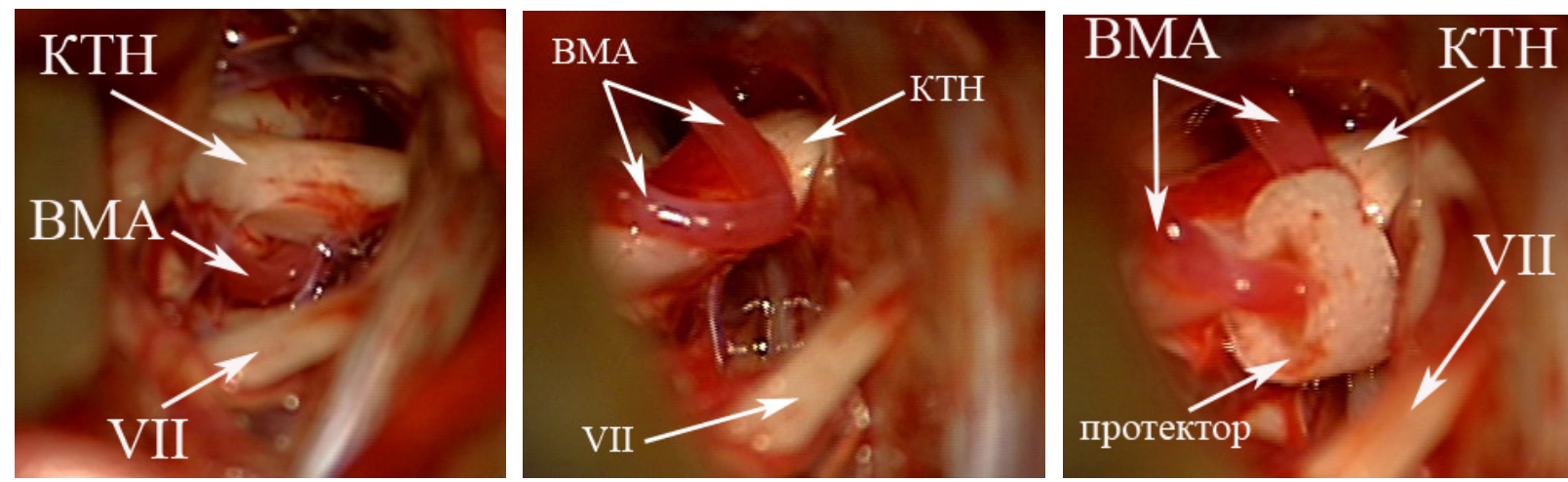

Рис. 124. Невралгия правого тройничного нерва: а) васкулоневральный конфликт между КТН и долихоэктазированной ВМА; б) петля ВМА транслоцирована в бесконфликтное положение в пространство между КТН и наметом мозжечка; в) петля ВМА заключена в микропротектор

Однако ввиду сложности топографо-анатомических взаимоотношений между КТН, ВМА и ВКВ не всегда удается осуществить этот маневр. Заключение в один цилиндрический микропротектор может быть ненадежным, поскольку при выраженной долихоэктазии BMA постоянная пульсация момуда может привести к смещению протектора из области васкулоневрального конфликта. В этих случаях, в особенности при выраженной долихоэктазии ВМА, мы используем несколько протекторов, заключая в них ВМА, наподобие «гирлянды» (рис. 125), что уменьшает риск смещения протектора вдоль артериального ствола.

После устранения васкулоневрального конфликта твердая мозговая оболочка ушивается наглухо (рис. 126). Еще раз проверяется герметичность пломбирования ячеек сосцевидного отростка. Накладываются швы на мышцы, апоневроз и кожу. 


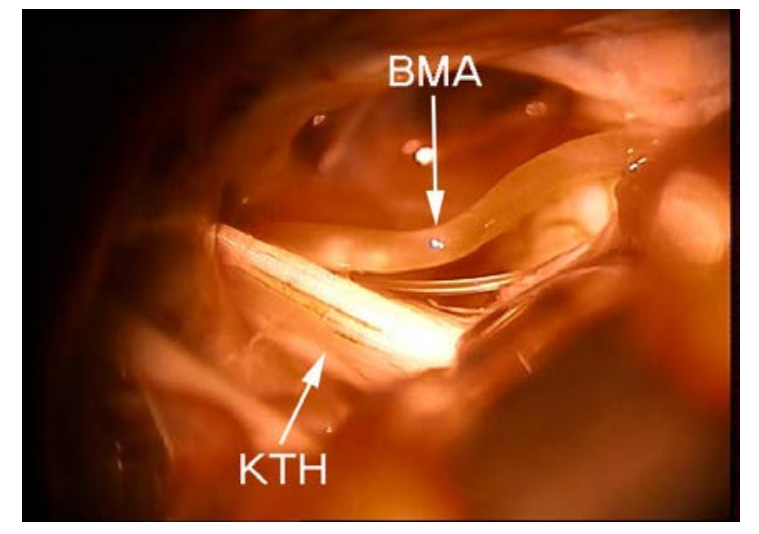

a)

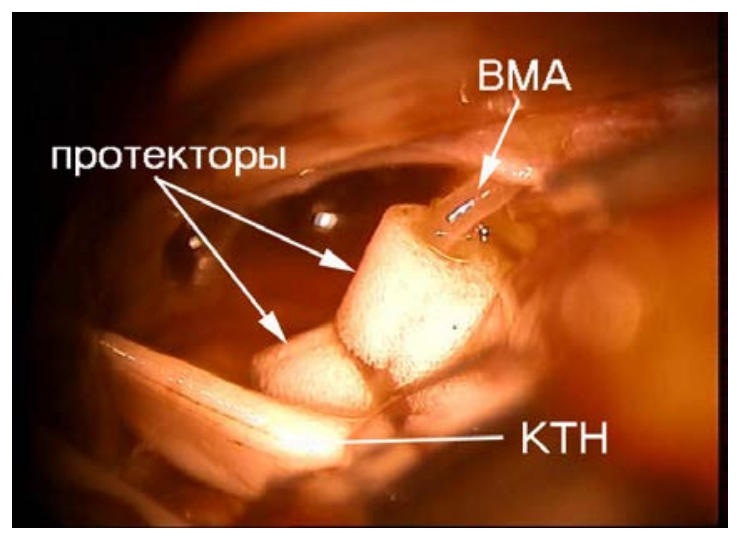

в)

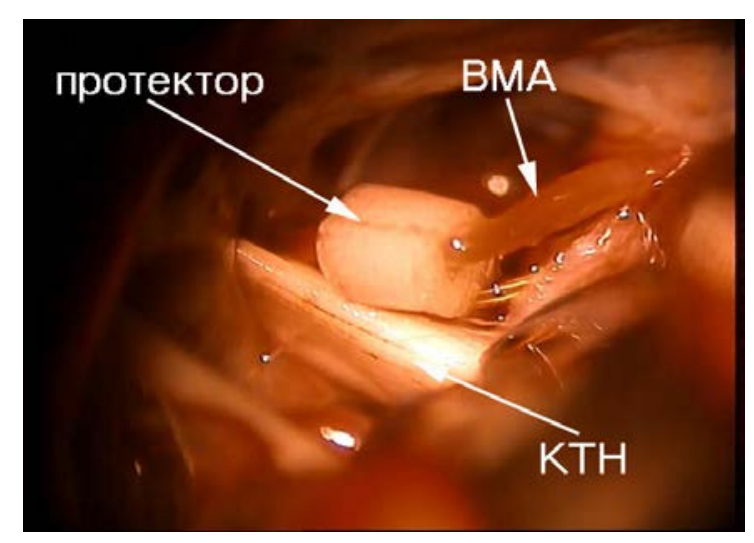

б)

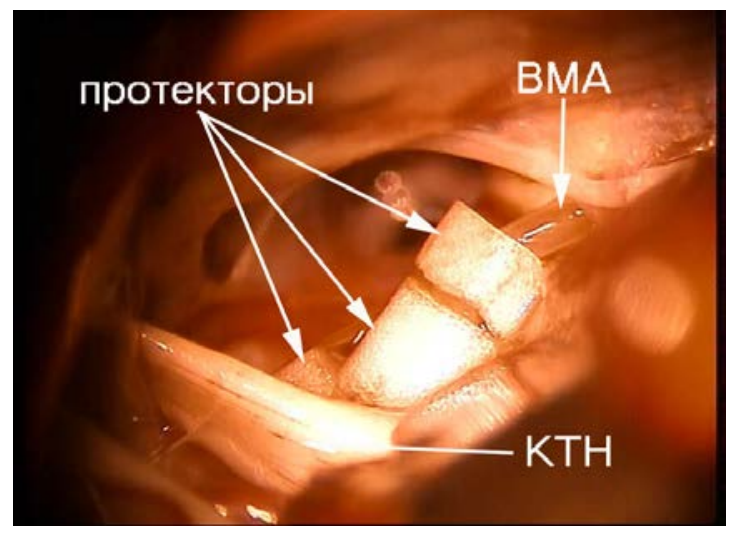

г)

Рис. 125. Невралгия левого тройничного нерва.

Конфликт с долихоэктазированной ВМА: а) выраженная долихоэктазия ВМА, б) ВМА заключена в первый микропротектор, в) ВМА заключена во второй микропротектор, г) ВМА заключена в третий микропротектор

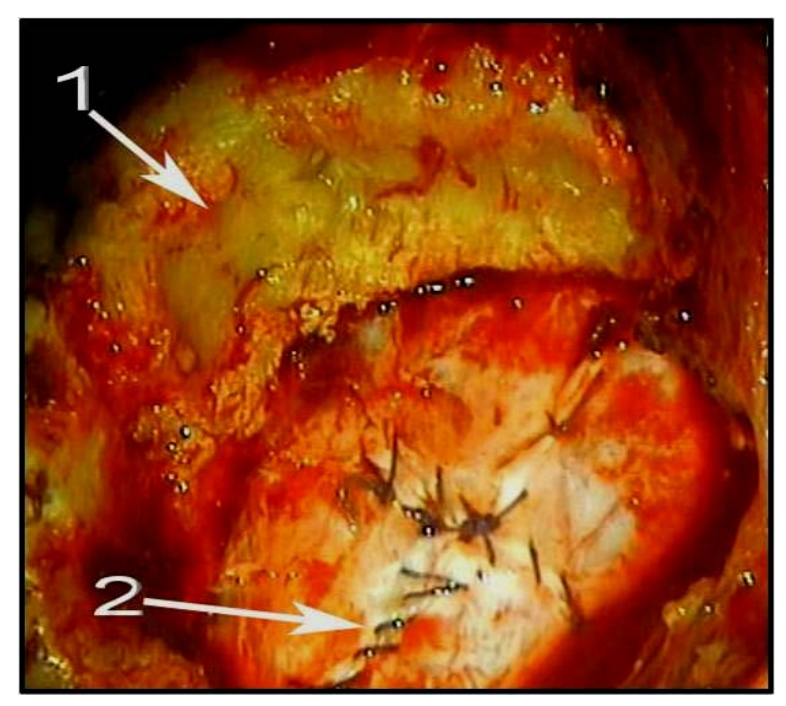

Рис. 126. Вид операционной раны после ушивания твердой мозговой оболочки (1) и контроля герметичности пломбирования ячеек сосцевидного отростка (2) 
У всех 200 больных приступы невралгии прекратились сразу же после пробуждения от наркоза. Лишь одна больная в течение 3 дней после операции просыпалась по ночам от «приступа болей в лице». Однако после пробуждения оказывалось, что боли в лице нет, и она вновь засыпала. Это свидетельствует о стойком корковом очаге патологически усиленного возбуждения.

Среди осложнений в литературе описаны: снижение слуха, снижение чувствительности на лице на стороне операции, вестибулярно-мозжечковые расстройства, ликворные свищи и др. (Judicke A., et al, 1999; Kuchta J., et al. 1998; Lovly T.J., Jannetta P.J, 1997; Walchebach R., et al., 1994, Kofler M., 2001). Очень серьезные осложнения после МВД в виде дисфункции и инфаркта ствола мозга описывают Vulcan A.W., et al. (2004) и Singh D., et al. (2006). Беспокоящим больных осложнением МВД является снижение или потеря слуха, наблюдающиеся, по данным литературы, от 1 до 23,8\% (Rath S.A., et al.,1996; Rizvi S.S., et al., 1999). Некоторые нейрохирурги считают, что это осложнение является следствием растяжения слухового нерва при оттеснении мозжечка. Другие полагают, что снижение или потеря слуха возникают в результате эндолимфатического гидропса, развивающегося вследствие уменьшения давления и объема цереброспинальной жидкости (ЦСЖ) как во время операции, так и в ближайшие дни после нее (Walsted A., et al, 1994). Клинические проявления гипотензивного синдрома хорошо известны: головная боль, усиливающаяся в вертикальном положении больного, головокружение, тошнота, рвота.

Однако количество рецидивов заболевания, по данным многих авторов, остается относительно высоким и колеблется от 4,5 до $31 \%$ $[242,282,434]$. Одной из причин рецидивов болей является использование неадекватных протекторов: жировая или мышечная ткань, тефлоновый фетр, полиуретановая губка, дакрон и пр. Подобные протекторы невозможно зафиксировать, и они нередко смещаются в ликворе под пульсовыми ударами артерий, возобновляя сосудистонервный конфликт, усугубляемый спаечным процессам [186, 273, 382, 383]. Среди других, не менее серьезных причин рецидивов на- 
$224 \mid$ Классическая невралгия тройничного нерва

зываются: необходимость правильного подбора больных для МВД, необнаружение сосудисто-нервного конфликта при ревизии КТН, развитие конфликта после МВД, предшествующие МВД деструктивные вмешательства на тройничном нерве $[14,270,337,360]$. Нейрохирурги, располагающие большим опытом МВД, подчеркивают, что при артериальной компрессии корешка отдаленные результаты лучше, чем при венозной $[14,152,153,172,173]$. Sun T., et al. и Barker F.G., et al. обнаружили, что только больные с венозной компрессией обречены на рецидив заболевания.

В целях профилактики дисциркуляторных вестибулярномозжечковых нарушений каменистую вену мы стремились сохранять и прибегали к ее коагуляции в крайних случаях, когда ввиду анатомических особенностей ее расположения она оказывалась непреодолимым препятствием для полноценной ревизии КТН и эффективного устранения конфликта. Из 200 оперированных больных у 162 каменистая вена была сохранена. Из 38 больных, у которых каменистую вену не удалось сохранить, у 17 отмечались вестибулоатактические расстройства в виде атаксии при ходьбе, головокружении, шуме в ухе. Эти расстройства постепенно, в течение 2-3 недель, регрессировали. Другой причиной появления в послеоперационном периоде вестибулярно-мозжечковых нарушений является синдром ликворной гипотензии. Падение внутричерепного давления в субарахноидальном пространстве распространяется на перелимфу лабиринта, снижение давления которой, при сохранении неизменного давления эндолимфы, способствует развитию гидропса лабиринта. Первой группе больных (168 человек) восполнение объема ликвора производилось нами путем заполнения операционной раны изотоническим раствором хлористого натрия перед ее герметизацией. Второй группе больных (32 человека) восполнение объема ликвора производилось путем возвращения собранного аутоликвора с добавлением, при необходимости, изотонического раствора хлористого натрия. В первой группе больных клиника гипотензивного синдрома наблюдалась у 71 больного (42,2\%). В легкой степени этот синдром наблюдался у 52 из них и выражался в головной боли, 
усиливающейся при переходе в вертикальное положение, головокружении, тошноте. Интенсивность головной боли по ВАШ была в пределах от 5 до 10 баллов. Больные предпочитали находиться в постели. Внутривенное капельное введение глюкозоэлектролитных растворов и обильное питье минеральной воды через 3-4 дня приводило к исчезновению симптоматики и переходу больных к активному режиму. Выраженным гипотензивный синдром был у 19 больных. Наряду с перечисленными выше симптомами у них отмечалась сонливость, заторможенность, повторные рвоты. Это потребовало внутривенного введения глюкозоэлектролитных растворов до 2-3,5 литров в сутки и соблюдения строгого постельного режима до 5-7 дней. За это время клиника гипотензивного синдрома регрессировала и больные перешли к активному режиму. У одного из этих больных в первые сутки после операции отмечалась ликворея из носа. После наложения давящей повязки на область резекции сосцевидного отростка ликворея прекратилась.

Во второй группе пациентов (32 человека) у 62,4\% головная боль отсутствовала. У остальных интенсивность головной боли по шкале ВАШ не превышала 3-5 баллов и не зависела от положения тела в пространстве.

Среди общего числа оперированных больных первой группы у 7 возникли нарушения слуха на стороне оперативного вмешательства $(4,3 \%)$. У одного из них отоларингологом диагностирован гемотимпанум. У остальных шести изменений со стороны среднего уха не обнаружено, однако была значительно выражена клиническая картина внутричерепной гипотензии. В последующем отмечено некоторое улучшение остроты слуха. Во второй группе больных, которым по завершении оперативного вмешательства произведено восполнение потерянного объема ликвора до достижения нормальных цифр внутричерепного давления, ни клиники гипотензивного синдрома, ни нарушений функции слуха у них не отмечалось. На следующие сутки после операции они переходили на активный режим. 
Из 200 оперированных больных в послеоперационном периоде у 41 из них отмечалась легкая гипестезия ипсилатеральной половины лица. К моменту выписки из стационара у подавляющего большинства из них чувствительность восстановилась.

Катамнез оперированных нами больных прослежен в сроки от 2 до 15 лет в среднем 8,5 лет. С рецидивом болевого синдрома обратилось 22 человека (11\%), у 12 из них приступы болей были редкими и контролировались приемом 1-2 таблеток карбамазепина в день. У 10 больных в сроки от 2 до 10 лет (в среднем 5,1 года) вернулась прежняя интенсивность болей, и они были подвергнуты повторной ревизии. При этом обнаружено, что у шести из них протектор сместился из области конфликта и спустился вниз вдоль вертикально стоящего дистального плеча петли ВМА. Выше сместившегося, ранее установленного протектора, артериальная петля заключена в еще один или два протектора в области возобновившегося конфликта. Трем другим выполнена частичная ризотомия. У всех больных после повторных вмешательств боли исчезли. Лишь у одного больного, страдающего невралгией I ветви правого TH, сохранились сезонные обострения заболевания, которые удается купировать с использованием разработанной нами схемы лечения (Патент № 2438657 за 2012 год). 


\section{ЗАКЛЮЧЕНИЕ}

Успешное лечение невралгии тройничного нерва прежде всего зависит от правильности и своевременности распознавания заболевания и выбора патогенетически обоснованного, органосохраняющего и эффективного способа устранения боли. Необходимо четко разграничить понятия невралгия и невропатия. Бесспорно, что кроме классической невралгии, боли в лице могут быть обусловлены компрессионным механизмом, в основе которого лежат различные процессы, локализующиеся как экстра, так и интракраниально. Тоннельные невропатии отдельных ветвей тройничного нерва в основе своей могут быть следствием анатомического сужения каналов и отверстий, через которые проходят эти ветви, перенесенной травмы лицевого скелета, неудачного лечения у стоматолога и др. Но, как известно, невропатии кроме болевого синдрома характеризуются выпадением функций ущемленного нерва, чего не наблюдается при классической невралгии. При тщательном сборе анамнеза удается выяснить предшествовавший заболеванию травмирующий фактор и т.п. Если при обследовании больного у него установлен клинический симптомокомплекс классической невралгии тройничного нерва, то его незачем подвергать рентгенкомпьютерной томографии в поисках костной аномалии, а тем более выполнять деструктивные операции на периферических ветвях или корешке, заведомо обрекая его на рецидив заболевания и еще более тяжкие деафференационные страдания. Такой больной должен получить адекватное патогенетически направленное медикаментозное лечение и только в случае его не эффективности пройти обследование для подтверждения васкулоневрального конфликта и принимать решение о выполнении ему микроваскулярной декомпрессии, как органосохраняющей и патогенетически обоснованной операции. 
$228 \mid$ Классическая невралгия тройничного нерва

Как показывает наш опыт, наиболее достоверные данные о наличии васкулоневрального конфликта обеспечивает СРКТ ангиография в режиме 3D.

Естественно, если у больного с лицевыми болями отсутствует характерный для классической невралгии ТН симптомокомплекс, то тогда расширяется круг дифференцируемых заболеваний и на первое место выступает патология вокруг экстракраниальных ветвей тройничного нерва. Таким больным показана СРКТ в режиме 3D с измерением ширины каналов и площади выходных отверстий. Если сужение их соответствует стороне болей, то появляются обоснования для декомпрессии этих ветвей. Хирург, идущий на подобные вмешательства должен тщательно изучать катамнез этих больных, с тем, чтобы в случае рецидива боли не повторять очередную деструктивную операцию, а пересмотреть свой диагноз и поискать у больного васкулоневральный конфликт. Но теперь уже не у больного с невралгий, а у больного с невропатией, обусловленной «целенаправленным разрушением периферических ветвей, ганглиолизиса или ризотомии как способа лечения НТН», по-прежнему страдающего классической невралгией тройничного нерва.

Дальнейшие научно-практические исследования проблемы классической невралгии тройничного нерва должны быть направлены на поиск способов устранения последствий васкулоневрального конфликта. Прежде всего, необходимо изучить причины запускающие механизм трансформации васкулоневрального контакта в васкулоневральный конфликт, приводящий к очередному обострению болевого синдрома у лиц имеющих подобные топографоанатомические особенности. Важным аспектом в повышении качества лечения является поиск способов и средств, способствующих ремиелинизации, с тем, чтобы изменить количественное соотношение миелинизированных и потерявших миелиновую оболочку волокон корешка ТН в сторону миелинизированных. Не менее важным аспектом является адекватный контроль артериального давления и процессов склерозирования сосудов. 
С чувством большой признательности выражаю благодарность заслуженному деятелю науки РФ, академику РАМН, доктору медицинских наук, профессору Н.Н. Яхно за полезные советы и рекомендации, доктору медицинских наук, профессору В.А. Балязину, доктору медицинских наук, доценту 3.А. Гончаровой, кандидату медицинских наук Салаху Сехвейл, врачу кабинета СРКТ И.М. Блинову за участие в обследовании и лечении пациентов с невралгией тройничного нерва и в совместных научных исследованиях по смежным темам. 


\section{БИБЛИОГРАФИЯ}

1. Афанасьева Е.В. O патогенезе тригеминальной невралгии / Е.В. Афанасьева, И.В. Балязин, В.А. Балязин // Сборник научных трудов, посвященный 100-летию со дня рождения проф. А.Н. Гордиенко. - Ростов н/Д, 2004. - С. 112-119.

2. Афанасьева Е. В. Фармакотерапия тригеминальной невралгии / Е.В. Афанасьева // БиоМедицина. Проблемы клинической фармакологии и моделирования в фармакологии и биомедицине: материалы конф. - Ростов н/Д, 2006. - Т. 3. - С. 24-25.

3. Афанасьева Е.В Роль магнитно-резонансной томографии в диагностике тригеминальной невралгии / Е.В. Афанасьева // VIII Международный семинар по магнитному резонансу (спектроскопия, томография, и экология). - Ростов н/Д, 2006. - С. 60.

4. Афанасьева Е.В. Артериальная гипертензия в патогенезе тригеминальной невралгии / Е.В. Афанасьева // Журнал неврологии и психиатрии им. С.С. Корсакова. - 2007. - Спец. выпуск. - С. 376.

5. Афанасьева Е.В. О патогенезе невралгии тройничного нерва / Е. В. Афанасьева // Головная боль: Рос. науч.-практ. конф. с междунар. участием: сб. тезисов. - М., 2007. - С. 48-51.

6. Афанасьева Е.В. Патогенетическая терапия невралгии тройничного нерва / Е.В. Афанасьева // Головная боль: Рос. науч.-практ. конф. с междунар. участием: сб. тезисов. - М., 2007. - С. 134-137.

7. Афанасьева Е.В. Роль долихоэктазии верхней мозжечковой артерии в формировании нейроваскулярного конфликта у больных тригеминальной невралгией / Е.В. Афанасьева // Избранные вопросы неврологии, нейрохирургии и психиатрии. - Саратов, 2007. C. 13-14. 
8. Афанасьева Е.В. Сосудистая патология головного мозга - патогенетическая основа тригеминальной невралгии / Е.В. Афанасьева // Актуальные проблемы психиатрии и неврологии: Всерос. юб. науч.-практ. конф. - СПб., 2007. - С. 215-216.

9. Афанасьева Е.В. Топографо-анатомические и физические слагаемые, определяющие локализацию триггерных болевых пароксизмов у больных невралгией тройничного нерва / Е.В. Афанасьева // Современные клинические проблемы в неврологии и психоневрологии: сб. науч. работ. - Ставрополь, 2007. - С. 66-69.

10. Афанасьева Е.В. Топографо-анатомические особенности, формирующие группу риска по тригеминальной невралгии / Е. В. Афанасьева // Неврологический вестник им. В.М. Бехтерева. 2007. - Т. 39, Вып. 1. - С. 46.

11. Афанасьева Е.В. Особенности нейроваскулярного конфликта с передней нижней мозжечковой артерией при невралгии тройничного нерва / Е.В. Афанасьева // Тезисы Всероссийской научнопрактической конференции VII Поленовские чтения. - СПб., 2008. - C. 112.

12. Афанасьева Е.В. Невралгия тройничного нерва / Е.В. Афанасьева. - Ростов н/Д, 2008. - 191 с.

13. Ахундов С.Г. К вопросу о симпатическом происхождении невралгии тройничного нерва / С.Г. Ахундов // Хирургия. - 1937. - №3. - С. 63-66.

14. Балязин В.А. Пути уменьшения осложнений и рецидивов после микроваскулярной декомпрессии у больных с тригеминальной невралгией / В.А. Балязин, Е.В. Балязина // Вопросы нейрохирургии им. Н.Н. Бурденко. - 2003. - № 2. - С. 6-9.

15. Балязин В.А. Почему у больных невралгией тройничного нерва боли локализуются преимущественно в зонах иннервации третьей и второй ветвей / В.А. Балязин, Е.В. Афанасьева // Головная боль: 
$232 \mid$ Классическая невралгия тройничного нерва

Рос. науч.-практ. конф. с междунар. участием: сб. тезисов. - М., 2007. - C. 51-54.

16. Балязин В.А. Головная боль как осложнение микровсакулярной декомпрессии корешка тройничного нерва / В.А. Балязин, Е.В. Балязина, Э.С. Темиров, Салах Сехвейл // Болевые синдромы в области головы, лица и полости рта: материалы конф. - Смоленск, 2010. С. 212-214.

17. Балязин В.А. Особенности микроваскулярной декомпрессии корешка тройничного нерва у больных тригеминальной невралгией с долихоэктазией базилярной артерии / В.А. Балязин, Е.В. Балязина, Салах Сехвейл. // Болевые синдромы в области головы, лица и полости рта: материалы конф. - Смоленск, 2010. - С. 210-212.

18. Балязин В.А. Невралгия тройничного нерва. Современные подходы к оперативному лечению / В.А. Балязин, Е.В. Балязина // Болевые синдромы в области головы, лица и полости рта: материалы конф. - Смоленск, 2010. - С. 166-170.

19. Балязин В.А. Хирургическая анатомия верхней каменистой вены при микроваскулярной декомпрессии корешка тройничного нерва / В.А. Балязин, Е.В. Балязина, Салах Сехвейл // Тезисы Всероссийской научно-практической конференции «Поленовские чтения». 22-24 апр. 2009 г. - СПб., 2009. - С. 110.

20. Балязин И.В. Рецидивы тригеминальной невралгии у больных после микроваскулярной декомпрессии / И.В. Балязин, Е.В. Афанасьева и др. // IV съезд нейрохирургов России: материалы. - М., 2006. - С. 448.

21. Балязин И.В. О патогенезе тригеминальной невралгии / И.В. Балязин, Е.В. Афанасьева // Сборник научных трудов, посвященный 100-летию со дня рождению проф. А.Н. Гордиенко. - Ростов н/Д, 2004. - С. $112-119$.

22. Балязин И.В. Особенности клиники и хирургии опухолей боковой цистерны моста с манифестным симптомом тригеминальной 
невралгии / И.В. Балязин, Е.В. Афанасьева // Поленовские чтения: науч. тр., посвящен. 70-летию со дня рождения засл. деят. науки России, проф. Г.С. Тиглиева. - СПб., 2004. - С. 182-190.

23. Балязин И.В. Эволюция хирургического лечения тригеминальной невралгии / И.В. Балязин, Е.В. Афанасьева // Актуальные вопросы неврологии и нейрохирургии: сб. науч. тр., посвящ, 80-летнему юбилею проф. В.В. Мартиросяна. - Ростов н/Д, 2005. С. 226-228.

24. Балязин И.В. Рецидивы тригеминальной невралгии у больных после микроваскулярной декомпрессии / И.В. Балязин, Е.В. Балязина, В.А. Балязин, Е.В. Зайцев // IV съезд нейрохирургов России: материалы съезда. - М., 2006. - С. 448.

25. Балязина Е.В. Способ лечения невралгии тройничного нерва: Пат. 2227028 Рос. Федерация. № 2003114551; зарег. 20.04.2004; приоритет 15.05.2003.

26. Балязина Е.В. Ультраструктура корешка тройничного нерва у больных тригеминальной невралгией / Е.В. Балязина, В.А. Балязин, А.Э. Мационис, П.Э. Повилайтите // V съезд нейрохирургов России: материалы съезда, Уфа 22-25 июня 2009 г. - Уфа, 2009. - С. 356-357.

27. Балязина Е.В. Особенности клиники невралгии тройничного нерва до и после микроваскулярной декомпрессии у больных, ранее перенесших деструктивные вмешательства / Е.В. Балязина // Материалы межрегиональной научно-практической конференции «Головная боль - актуальная междисциплинарная проблема». Смоленск, 2009. - С. 154-156.

28. Балязина E.В. Топографоанатомические взаимоотношения ствола тойничного нерва с верхней мозжечковой артерией у больных с невралгией тройничного нерва / Е.В. Балязина // Морфология. - 2009. - № 5. - С. 27-31.

29. Балязина Е.В. Диагностика классической невралгии тройничного нерва / Е.В. Балязина // Бюллетень Сибирской медицины. 2010. - T. 9, № 4. - С. 94-99. 
$234 \mid$ Классическая невралгия тройничного нерва

30. Балязина Е.В. Результаты микроваскулярной декомпрессии при невралгии тройничноно нерва у больных старше 65 лет. / Е.В. Балязина // Сб. научных трудов, посвященный 80-летию неврологической службы в Рязани. - Рязань, 2010. - С. 144-148.

31. Балязина Е.В. Анатомические предпосылки возникновения классической невралгии тройничного нерва / Е.В. Балязина // Сб. научных трудов, посвященный 80-летию неврологической службы в Рязани. - Рязань, 2010. - С. 13-17.

32. Балязина Е.В. Демиелинизация корешка - основа патогенеза классической невралгии тройничного нерва / Е.В. Балязина // Неврологический журнал. - 2010. - Т. 15, № 1. - С. 27-31.

33. Балязина Е.В. Инфаркт мозжечка и ствола головного мозга как осложнение микроваскулярной декомпрессии корешка тройничного нерва у больных классической невралгией тройничного нерва / Е.В. Балязина, В.А. Балязин, Сехвейл Салах // Материалы Российской научно-практ. конфер. «Нарушения мозгового кровообращения: диагностика, профилактика, лечение». - Пятигорск, 2010. - C. 49.

34. Балязина Е.В. Артерио-венозная мальформация с манифестным клиническим проявлением невралгией тройничного нерва / Е.В. Балязина // Тр. научно-практ. конфер. неврологов, нейрохирургов и детских неврологов Кировской области. - Киров, 2010. - С. 9-11.

35. Балязина Е.В. Формула диагноза классической невралгии тройничного нерва на основе патогенеза / Е.В. Балязина // Тр. научнопракт. конфер. неврологов, нейрохирургов и детских неврологов Кировской области. - Киров, 2010. - С. 11-15.

36. Балязина Е.В. Гипотензивный синдром после миткроваскулярной декомпрессии корешков черепно-мозговых нервов / Е.В. Балязина, В.А. Балязин, Сехвейл Салах // V Научная сессия Ростовского государственного медицинского университета, посвященная 95-летию высшего медицинского образования на Дону и 80-летию РостГМУ, Том 1. - Ростов-на-Дону, 2010. - С. 621-622. 
37. Балязина Е.В. Компьютерная ангиография в диагностике нейроваскулярного конфликта у больных классической невралгией тройничного нерва / Е.В. Балязина // Нейрохирургия. - 2010. -№ 4. - С. 46-49.

38. Балязин В.А. Микрохирургическая анатомия верхней каменистой вены и критерии безопасности ее коагуляции при микроваскулярной декомпрессии корешка тройничного нерва / В.А. Балязин, Е.В. Балязина, Сехвейл Салах // Нейрохирургия. - 2011. - № 1. - C. 42-47.

39. Балязин B.A. Наш опыт по диагностике и хирургии сфенопетрокливальных менингиом / В.А. Балязин, Е.В. Балязина, Э.С. Темиров, С.М. Сехвейл, Ф. Шарафеддин // Российский нейрохирургический журнал им. проф. А.Л. Поленова. - 2011. - Том III, № 1. - С. 6-11.

40. Балязина Е.В. Патогенетическая терапия классической невралгии тройничного нерва / Е.В. Балязина // Российский журнал боли: Материалы XVII Российской научно-практической конференции с международным участием «Болевые синдромы в медицинской практике». - Ростов-на-Дону, 2011. - С. 83-84.

41. Балязина Е.В. Невралгия тройничного нерва у больных рассеянным склерозом / Е.В. Балязина, 3.А. Гончарова, Сехвейл Салах // Российский журнал боли: Материалы XVII Российской научнопрактической конференции с международным участием «Болевые синдромы в медицинской практике». - Ростов-на-Дону, 2011. С. 84-85.

42. Балязина Е.В. Терапия классической невралгии тройничного нерва / Е.В. Балязина // Медицинский вестник Северного Кавказа, 2011. - Т. 22. № 2. - С. 39-41.

43. Балязина Е.В. Тактика ведения больных рассеянным склерозом с тригеминальной невралгией / Е.В. Балязина, 3.А. Гончарова, Сехвейл Салах // Нейроиммунология. - 2011. - Т. IX, № 3-4. - С. 28-29. 
44. Балязина Е.В. Особенности клинических проявлений невралгии тройничного нерва у больных с долихоэктазией основной артерии / Е.В. Балязина // Анналы клинической и экспериментальной неврологии, 2011. - Т. 5, № 2. - С. 46-48.

45. Балязина Е.В. Терапия классической тригеминальной невралгии / Е.В. Балязина // Сборник материалов Международного конгресса. - Ганновер, 2011. - С. 22-23.

46. Балязина Е.В. Способ диагностики невралгии тройничного нерва: пат. 2438578. Офф. Бюлл. «Изобретения. Полезные модели». 2012. - № 1 .

47. Балязина Е.В. Способ лечения невралгии тройничного нерва: пат. 2438657. Офф. Бюлл. «Изобретения. Полезные модели». - 2012. - № 1.

48. Балязина Е.В. Лечебная тактика при двухсторонней невралгии тройничного нерва / Е.В. Балязина // Российский журнал боли. 2012. - № 1. - C. 37-38.

49. Балязина Е.В. Анатомические предпосылки преимущественно правосторонней локализации болей у больных идиопатической невралгией тройничного нерва / Е.В. Балязина // Владикавказский медико-биологический вестник. - 2011. - Т. ХШ. Вып. 21. - С. 110-115.

50. Балязина Е.В. Особенности нейроваскулярного конфликта, предрасполагающие к развитию невралгического статуса / Е.В. Балязина // Материалы X Всероссийского съезда неврологов. - Нижний Новгород, 2012. - С. 601-602.

51. Бойцов С.Ф. Сосуды как плацдарм и мишень артериальной гипертонии / С.Ф. Бойцов // Актуальные вопросы болезней сердца и сосудов. - 2006. - № 3. - С. 35-40.

52. Варшавская Д.Я. Хирургическое лечение тяжёлых форм невралгии тройничного нерва: дис. ... канд. мед .наук / Д.Я. Варшавская. М., 1948. - 21 c. 
53. Васин Н.Я. О методике и результатах феноловых блокад гассерова узла при тяжёлых формах лицевых болей / Н.Я. Васин // Вопросы нейрохирургии. - 1973. - № 2. - С. 16-23.

54. Васин Н.Я. Операция Денди с применением мочевины в лечении невралгии тройничного нерва / Н.Я. Васин // Вопросы нейрохирургии. - 1965. - № 4. - С. 42-47.

55. Вейн А.М. Болевые синдромы в неврологической практике / А.М. Вейн. - М.: Медпресс, 1999. - 372 с.

56. Гиндце Б.К. Артериальная система головного мозга человека и животных / Б.К. Гиндце. - М.: Медгиз, 1947. - 95 с.

57. Горбач Н. Теоретическая механика (динамика) / Н. Горбач. - М.: Интерпрессервис, 2004. - 192 с.

58. Грачёв Ю.В. Патогенетические механизмы и клинические особенности тригеминальных лицевых болей / Ю.В. Грачев // Журнал неврологии и психиатрии им. С.С. Корсакова. - 1999. - Т. 99. № 8. С. $38-42$.

59. Грачёв Ю.В. Патогенетические механизмы и нейрофизиологическая диагностика невралгии тройничного нерва / Ю.В. Грачев // Журнал невропатологии и психиатрии им. С.С. Корсакова. - 1995. T. 95. № 6. - С. 20-21.

60. Грачёв Ю.В. Патогенетические механизмы пароксизмальных тригеминальных прозопалгий / Ю.В. Грачёв, В.К. Решетняк // Стоматология. - 1999. - Т. 78, № 2. - С. 8-11.

61. Грачёв Ю.В. Тригеминальные прозопалгии (патогенез, семиотика, методы диагностики, лечение): автореф. дис. ... д-ра мед. наук / Ю.В. Грачев. - М., 1996. - 31 с.

62. Гречко В.Е. Нейростоматологические заболевания и синдромы: клиника. Диагностика, основные принципы лечения / В.Е. Гречко, В.А. Синева и др. - М., 1997. - 62 с. 
63. Гречко В.Е. К вопросу о патогенезе истинной трегеминальной невралгии / В.Е. Гречко, А.В. Степанченко, М.Н. Шаров // Неврологический вестник. Журнал им. В.М. Бехтерева. - 2001. - Т. XXXIII, Вып. 1/2. - С. 56-59.

64. Григоровский И.М. Артериальное кровоснабжение мозжечка / И.М. Григоровский // Arch. F. Psychiatrie und Nervenkr. - 1930. - Bd. 89. - S. 3-4.

65. Григорян Ю.А. Нейрогенные лицевые боли (патогенез, диагностика и микрохирургия): дис. ... д-ра мед. наук / Ю.А. Григорян. - М., 1996. - 370 c.

66. Григорян Ю.А. Микрохирургическая сосудистая декомпрессия корешка тройничного нерва при тригеминальной невралгии / Ю.А. Григорян // Журнал проблемы нейростоматологии и стоматологии. - 1997. - №1. - С. 45-49.

67. Григорян Ю.А. Тригеминальная невралгия и опухоли мостомозжечкового угла / Ю.А. Григорян, А.Р. Ситников // Российский нейрохирургический журнал им. проф. А.Л. Поленова. - 2010. - Т. 2, № 1. - С. 28-41.

68. Данилов А.Б. Нейропатическая боль / А.Б. Данилов. - М.: Нейромадиа, 2004. - 60 с.

69. Данилов А.Б. Нейропатическая боль / А.Б. Данилов, О.С. Давыдов. - М.: Боргес, 2007. - 191 с.

70. Домбровский В.И. Мультиспиральная рентгеновская компьютерная томография в диагностике нейроваскулярного конфликта у больных тригеминальной невралгией / В.И. Домбровский, И.М. Блинов, Е.В. Балязина // Медицинская визуализация: Прил. Сборник тезисов 1 Съезда лучевых диагностов Южного Федерального округа. - 2009. - С. 17-18

71. Егоров Б.Г. Тригеминальная невралгия как начальный симптом про явления невриномы УШ нерва / Б.Г. Егоров // Вопросы нейрохирургии. - 1961. - № 1. - С. 45-47. 
72. Ерохина Л.Г. Лицевые боли. Невралгия тройничного нерва и другие формы прозопалгий / Л.Г. Ерохина. - М.: Медицина, 1973. $-176 \mathrm{c}$.

73. Журавлёв В.П. Диагностика и хирургическое лечение невралгии тройничного нерва при патологии подглазничного и нижнечелюстного каналов: автореф. дис. ... канд. мед. наук / В.П. Журавлев. - Пермь, 1988. - 32 с.

74. Журавлёв В.П. Этиология, патогенез, диагностика и лечение истинной невралгии тройничного нерва / В.П. Журавлев // Стоматология на пороге третьего тысячелетия: сб. тезисов. - М., 2001. - С. 341-344.

75. Зинченко А.П. Клинико-рентгенограммометрические данные о туннельной патологии в генезе невралгии тройничного нерва / А.П. Зинченко, Л.А. Кадирова, А.А. Кобец // Всесоюзный съезд невропатологов и психиатров, 7-й: материалы. - М., 1981. - Т.2. C. 406-409.

76. Ингороква Г.И. Микроваскулярная декомпрессия в лечении невралгии тройничного нерва / Г.И. Ингороква, И.А. Отарашвили, Л.Д. Хорбаладзе // Сибирский международный нейрохирургический форум. - Новосибирск, 2012. - С. 31.

77. Иоффе И.Л. Хирургическая анатомия корешка тройничного нерва / И.Л. Иоффе // Вопросы нейрохирургии. - 1949. - Т. XIII, № 1. - С. 56-64.

78. Карлов В.А. Невралгия тройничного нерва / В.А. Карлов, О.Н. Савицкая, М.А. Вишнякова. - М: Медицина, 1980. - 150 с.

79. Карлов В.А. Неврология лица /В.А. Карлов. - М: Медицина, 1991. -285 c.

80. Кобец А.А. Эффективность лечения блокадами при тяжёлых формах невралгии тройничного нерва: автореф. ... дис. канд. мед. наук / А.А. Кобец. - Харьков, 1980. - 21 с. 
$240 \mid$ Классическая невралгия тройничного нерва

81. Колесов В.Н. Применение низкоинтенсивного гелий-неонового лазерного излучения у больных с невралгией тройничного нерва / В.Н. Колесов, А.А. Чехонацкий, С.3. Скулович др. // Поленовские чтения: материалы Всерос. конф. - СПб., 2010. - С. 356-357.

82. Колычева М.В. Критерии отбора больных для васкулярной декомпрессии при невралгии тройничного нерва / М.В. Колычева, В.Н. Шиманский, У.Б. Махмудов, С.В. Таняшин // Сибирский международный нейрохирургический форум. - Новосибирск, 2012. - С. 30.

83. Коновалов А.Н. Микроваскулярная декомпрессия корешка тройничного нерва в лечении тригеминальной невралгии: Материалы 14 Российской научно-практической конференции «Нейропатическая боль» / А.Н., Коновалов, О.Р. Орлова, У.Б. Махмудов и др. // Вертеброневрология. - 2008. - Т. 15, № 1/2. - С. 81-82.

84. Короленко А.М. Хирургические методы лечения невралгии тройничного нерва, обусловленные деструктивными изменениями в нижней челюсти: методические рекомендации МЗ УССР / А.М. Короленко. - Киев, 1980. - 13 с.

85. Крыжановский Г.Н. Детерминированные структуры в патологии нервной системы. Генераторные механизмы нейропатологических синдромов / Г.Н. Крыжановский. - М: Медицина, 1980. - С. 82-89.

86. Крыжановский Г.Н. Общая патофизиология нервной системы: руководство / Г.Н. Крыжановский. - М.: Медицина, 1997. - 352 с.

87. Крыжановский Г.Н. Спонтанная активность и вызванные потенциалы в каудальном тригеминальном ядре, вентробазальном таламусе и коре головного мозга у крыс с нейропатической тригеминальной невралгией / Г.Н. Крыжановский, В.Г. Долгих, В.К. Решетняк В.К. // Бюллетень экспериментальной биологии и медицины. - 1994. - №1. - С. 26-29.

88. Крылов В.А. Неврология лица / В.А. Крылов. - М.: Медицина, 1991. - 181 c. 
89. Курбангалеев С.М. Радикальное хирургическое лечение невралгии тройничного нерва / С.М. Курбангалеев. - Л.: Медгиз, 1961. $256 \mathrm{c.}$

90. Лапченко A.С. Наш опыт лечения лицевых болей и оталгий, вызванных раздражением ветвей тройничного нерва / А.С. Лапченко, А.Г. Кучеров // Патологическая боль: тез. Рос. науч.-практ. конф. Новосибирск,1999. - С. 84-85.

91. Лившиц Л.Я. Направленная гидротермическая деструкция чувствительного корешка тройничного нерва, как метод лечения тригеминальной невралгии / Л.Я. Лившиц // Вопросы нейрохирургии. - 1965. - № 4. - С. 47-52.

92. Лившиц Л.Я. Невралгия тройничного нерва и её лечение методом направленной гидротермической деструкции чувствительного тригеминального корешка: автореф. дис. ... д-ра мед. наук / Л.Я. Лившиц. - Саратов, 1968. - 23 с.

93. Маджидов Н.М. К клинике и патогенезу невралгии тройничного нерва / Н.М. Маджидов // Медицинский журнал Узбекистана. 1964. - № 6. - С. 51-55.

94. Макаров А.В. Селективная крионейротомия чувствительного корешка тройничного нерва - операция выбора при тяжелых формах невралгии тройничного нерва / А.В. Макаров, В.Г. Полторацкая, А.Б. Головашич // Поленовские чтения: материалы Всерос. конф. СПб., 2010. - С. 359-360.

95. Мартиросян В.В. О патогенезе симптоматической тригеминальной невралгии / В.В. Мартиросян, Е.В. Балязина // Актуальные вопросы неврологии и нейрохирургии: сб. науч. тр. - Ростов н/Д, 2002. - С. 112-113.

96. Машковский М.Д. Лекарственные средства: пособие для врачей - 14 изд., перераб., испр. и доп. / М.Д. Машковский.- М.: Новая Волна, Издатель С.Б. Дивов, 2002. - Т. 2. - С. 72-84. 
$242 \mid$ Классическая невралгия тройничного нерва

97. Мегдятов Р.С. Лечение невралгии тройничного нерва методом эндолимфатического введения оксибутирата натрия / Р.С. Мегдятов // Патологическая боль: тез. Рос. науч.-практ. конф. - Новосибирск, 1999. - С. 84-85.

98. Мегдятов Р.С. Невралгия тройничного нерва / Р.С. Мегдятов. М.: Медицина, 1999. - 142 с.

99. Михеев В.В. Стоматоневрологические синдромы / В.В. Михеев, Л.Р. Рубин. - М., 1966. - 264 с.

100. Могила В.В. Современное состояние проблемы лечения невралгии тройничного нерва / В.В. Могила, С.В. Литвиненко // Нейрохирургия. - 2002. - № 4. - С. 12-14.

101. Моркунас Р.О. Невралгия второй ветви тройничного нерва тоннельного происхождения: автореф. дис. ... канд. мед. наук / P.0. Моркунас. - М., 1984. - 21 с.

102. Мурашко Н.К. Возможности использования альфа-липоевой кислоты в терапии ишемических поражений головного мозга / Н.К. Мурашко // Международный неврологический журнал. - 2010. - № 5. - C. 103-104.

103. Оглезнев К.Я. Патофизиологические механизмы возникновения и методы лечения лицевых болей / К.Я. Оглезнев, Ю.А. Григорян, С.А. Шестрериков. - Новосибирск, 1990. - 190 с.

104. Орлова О.Р. Нейропатические расстройства в области лица, возникающие после деструктивных операций на ветвях тройничного нерва: Материалы 14 Российской научно-практической конференции «Нейропатическая боль» / Л.Р. Мингазова, О.Р. Орлова // Вертеброневрология. - 2008. - Т. 15, № 1/2. - С. 54-55.

105. Пешкова О.П. Эффективность применения комплексной терапии с рефлексотерапией при невралгии тройничного нерва / О.П. Пешкова, О.И. Загорулько, Л.А. Гнездилов // IX Всероссийский съезд неврологов. - Ярославль, 2006. - С. 279. 
106. Попова Н.В. Хирургическое лечение невралгии тройничного нерва: автореф. дис. ... канд. мед. наук / Н.В. Попова. - Пермь, 1990. - 16 с.

107. Пузин М.Н. Нейростоматологические заболевания / М.Н. Пузин. - М.: Медицина, 1997. - 367 с.

108. Рубин Л.Р. Роль патологии зубочелюстной системы в патогенезе тригеминальной невралгии / Л.Р. Рубин // Журнал невропатологии и психиатрии. - 1966. - № 6. - С. 827-830.

109. Сабелис Г.И. Периферические механизмы патогенеза невралгии тройничного нерва / Г.И. Сабелис, Р.М. Моркунас Р.М. и др. // Журнал невропатологии и психиатрии им. С.С. Корсакова. - 1982. T. 82, № 4. - С. 505-509.

110. Савицкая О.Н. Невралгия тройничного нерва / О.Н. Савицкая // Врачебное дело. - 1970. - № 9. - С. 100-103.

111. Савицкая О.Н. О невралгии (неврите) тройничного нерва / 0.Н. Савицкая, С.Б. Дзугаева // Журнал невропатологии и психиатрии им. С.С. Корсакова. - 1971. - Вып. 5. - С. 690-694.

112. Савицкая О.Н. Невралгия тройничного нерва: периферичские и центральные механизмы патогенеза, вопросы клиники и лечения: автореф. дис. ... д-ра мед. наук / О.Н. Савицкая. - М., 1976. - 33 с.

113. Савицкая О.Н. Проблемы тригеминальной невралгии / О.Н. Савицкая, В.А. Карлов // Журнал невропатологии и психиатрии им. С.С. Корсакова. - 1989. - Т. 89, № 4. - С. 3-8.

114. Сапон Н.А. Вопросы патогенеза невралгии тройничного нерва (постулаты, противоречия и новые подходы) Перовое сообщение / Н.А.Сапон // Украинский нейрохирургический журнал. - 2005. № 2. - C. 54-59.

115. Сапон Н.А. Вопросы патогенеза невралгии тройничного нерва (постулаты, противоречия и новые подходы) Сообщение 2 / Н.А. Сапон // Украинский нейрохирургический журнал. - 2005. № 4 . - C. 72-76. 
$244 \mid$ Классическая невралгия тройничного нерва

116. Смирнов В.А. Заболевания нервной системы лица / В.А. Смирнов. - М.: Медицина, 1976. - 239 с.

117. Смирнов В.А. О некоторых вопросах тригеминальной невралгии / В.А.Смирнов // Журнал невропатологии и психиатрии им. С.С. Корсакова. - 1968. - Т. 68, № 5. - С. 683-687.

118. Смирнов В.А. Этиология и патогенез невралгии тройничного нерва / В.А. Смирнов // Клиническая медицина. - 1972. - № 1. C. 95-98.

119. Соков Е.Л. Лечение тригеминальной боли внутрикостными блокадами / Е.Л. Соков, Р.В. Кепиков // Патологическая боль: тез. Рос. науч.-практ. конф. - Новосибирск, 1999. - С. 85-86.

120. Соков Е.Л. Внутрикостные блокады в лечении тригеминальной невралгии / Е.Л. Соков // IX Всероссийский съезд неврологов. Ярославль, 2006. - С. 287.

121. Соков Е.Л. Применение внутрикостных блокад при тригеминальной невралгии / Е.Л. Соков, Л.Е. Карнилова, Н.И. Гарабова, Н.А. Арсюхин, Ш. Форкашди, П.Е. Соков // Болевые синдромы в области головы, лица и полости рта: материалы конф. - Ярославль, 2010. - С. $170-172$.

122. Сперанский В.С. Форма и конструкция черепа / В.С. Сперанский, А.И. Зайченко. - М.: Медицина, 1980. - С. 103-124.

123. Справочник Видаль. Лекарственные препараты в России: справочник - М.: Астра Фарм Сервис, 2004. - С. 619.

124. Степанченко А.В. Типичная невралгия тройничного нерва / А.В. Степанченко. - М.: ВXM, 1994. - 39 с.

125. Тимофеев С.И. Теоретическая механика (динамика) / С.И. Тимофеев, С.С. Савченкова. - М.: Феникс, 2005. - 442 с.

126. Троян А.Ю. Патологическая боль / А.Ю. Троян, В.В. Савченко, Ю.И. Левина и др. // Тезисы Российской научно-практической конференции. - Новосибирск, 1999. - С. 84-85. 
127. Труфанов И.Н. Пространственные координаты корешка тройничного нерва при пересечении им верхнего края пирамиды височной кости у взрослого человека / И.Н. Труфанов, М.Ю. Урываев, Т.В. Горская и др. // Успехи современного естествознания. - 2007. № 7. - С. 59-64.

128. Ходневич А.А. Микронейропротекторы в хирургии сосудистых компрессий черепных нервов: автореф. дис. ... канд. мед. наук / А.А. Ходневич. - М, 1996. - 25 с.

129. Цымбалюк В.И. Результаты хирургического лечения тяжелых форм невралгии тройничного нерва / В.И. Цымбалюк, И.П. Дмитерко, М.О. Марущенко // Сибирский международный нейрохирургический форум. - Новосибирск, 2012. - С. 30.

130. Чудаков О.П. Диагностика и хирургическое лечение стойких невралгий тройничного нерва: метод. рекомендации / О.П. Чудаков. - Минск: МГМИ, 1986. - 13 с.

131. Шаров М.Н. Использование методов транскраниальной магнитной стимуляции и электрокожной терапии у больных с пароксизмальными прозопалгиями / М.Н. Шаров, О.Н. Фищенко, Д.Н. Лопатко, Т.Ю. Хохлова // Болевые синдромы в области головы, лица и полости рта: матералы конф. - Смоленск, 2010. - С. 205-208.

132. Шаров М.Н. Лицевая боль / М.Н. Шаров // Болевые синдромы в области головы, лица и полости рта: матералы конф. - Смоленск, 2010. - С. 57-60.

133. Шмырев В.И. Современная концепция патогенеза тригеминальной невралгии / В.И. Шмырев, А.С. Рыбаков // Журнал невропатологии и психиатрии им. С.С. Корсакова. - 2006. - Т. 106, № 3. C. 64-74.

134. Шулев Ю.А. Микроваскулярная декомпрессия в лечении тригеминальной невралгии / Ю.А. Шулев, К.С. Гордиенко, О.В. Посохина // Нейрохирургия. - 2004. - № 2. - С. 7-14. 
$246 \mid$ Классическая невралгия тройничного нерва

135. Шулев Ю.А. Симптоматическая невралгия тройничного нерва при опухолях мосто-мозжечкового угла / Ю.А. Шулев, К.С. Гордиенко, А.В.Трашин, Е.Н. Черных // Российский нейрохирургический журнал им. проф. А.Л. Поленова. - 2010. - Т. 2, № 1. - С. 59-66.

136. Щедренок В.В. Нейровизуализация при тригеминальной невралгии // В.В. Щедренок, Н.В. Топольская, О.В. Могучая, К.И. Себелев // Сибирский международный нейрохирургический форум. - Новосибирск, 2012. - С. 5.

137. Щедренок В.В. Лицевая и головная боль. Клинико-лучевая диагностика и хирургическое лечение / В.В. Щедренок, Н.В. Топольская, Т.В. Захматова, О.В. Могучая, К.И. Себелев. - СПБ., 2013. - 416 с.

138. Щедренок В.В. Способы воздействия на периферические ветви тройничного нерва при его невропатии / В.В. Щедренок и др. // Вестник хирургии им. И.И. Грекова, 2009. - Т. 168. - № 2. - С. 50-52.

139. Щедренок В.В. Невралгия тройничного нерва. Клинка, диагностика и лечение/ В.В. Щедренок, Н.В. Топольская, Т.В. Захматова, О.В. Могучая, К.И. Себелев. - СПБ., 2014. - 328 с.

140. Яхно Н.Н. Головная боль / Н.Н. Яхно, В.А. Парфенов, В.В. Алексеев. - М., 2000. - 129 с.

141. Яхно Н.Н. Лечение нейропатической боли / Н.Н. Яхно, А.Н. Баринов // Русский медицинский журнал. - 2003. - № 25. - С. 1419-1422.

142. Achilli V. Petrous apex arachnoid cyst: a case report and review of the literatur / V. Achilli, G. Danesi, L. Caverni, M. Richichi // Acta Otorhinolaryngoltal. - 2005. - Vol. 25, N 5. - P. 296-300.

143. Adams C.B.T. Microvascular compression: an alternative view and hypothesis / C.B.T. Adams // J. Neurosurg. - 1989. - Vol. 57. - P. 1-12.

144. Afanasieva E.V. Physiological basis cf neurovascular conflict in patient with trigeminal neuralgia / E.V. Afanasieva, I.V. Balyzin, V.A. Balyzin // Black Sea Neurosurgical Congress. - Olginca, 2007. - P. 46-47. 
145. Alafaci C. Trigeminal pain caused by a cerebellopontine-angle lipoma. Case report and review of the literature / C. Alafaci, F.M. Salpietro, E. Puglisi et al. // J. Neurosurg. Sci. - 2001. - Vol. 45, N 2. - P. 110-113.

146. Albert H.H. Mascle relaxants in the treatment of idiopathic trigeminal neuralgia / H.H. Von Albert // Munch. Med. Wochenschr. - 1975. Vol. 117, N 35. - P. 1379-1382.

147. Allam N. Injections of botulinum toxin type a produce pain alleviation in intractable trigeminal neuralgia / N. Allam, J.P. Brasil-Neto, G. Brown, C. Tomaz // Clin J Pain. - 2005. - Vol. 21, N 2. - P. 182-184.

148. Amador N. Repeat posterior fossa exploration for patient withpersistent or recurrent idiopathic trigeminal neuralgia / N. Amador, B.E. Pollock // J. Neurosurgery. - 2008. - Vol.108, N 5. - P. 916-920.

149. Amir R. Funtional cross-excitation between afferent A- and Cneurons in dorsal root ganglia / R. Amir, M. Devor // Neuroscience. 2000. - Vol. 95. - P. 189-195.

150. Anderson W.S. Case of microarteriovenous malformation-induced trigeminal neuralgia treated with radiosurgery / W.S. Anderson, P.P. Wang, D. Rigamonti // J. Headache Pain. - 2006. - Vol. 7, N 4. P. 217-221.

151. Apfelbaum R.I. A comparison of percutaneous radiofrequencytrigeminal neurolysis and microvascular decompression of the trigeminal nerve for the treatment of tic douloureux / R.I. Apfelbaum // Neurosurgery. - 1977. - Vol.1. - P. 16-21.

152. Ashkan K. Microvascular Decompression for Trigeminal Neuralgia in the Elderly: A Review of the Safety and Efficacy / K. Ashkan // Neurosurgery. - 2006. - Vol. 58, N 4. - P. 799-803.

153. Ashkan K. Microvascular decompression for trigeminal neuralgia in the elderly: a review of the safety and efficacy / K. Ashkan, H. Marsh // Neurosurgery. - 2004. - Vol. 55. - P. 840-848. 
$248 \mid$ Классическая невралгия тройничного нерва

154. Athanasiou T.C. Arteriovenous malformation presenting with trigeminal neuralgia and treated with endovascular coiling / T.C. Athanasiou, S. Nair, H.B. Coakham, T.T. Lewis // Neurol. India. - 2005. - Vol. 53, N 2. - P. 247-248.

155. Attal N. EFNS guidelines on pharmacological treatment of neuropathic pain / N. Attal, G. Cruccu, M. Haanpaa et al. // European J. Neurol. - 2006. - Vol. 13. -P. 1153-1169.

156. Bagheri S.C. Diagnosis and treatment of patients with trigeminal neuralgia / S.C. Bagheri, F. Farhidvash, V.J. Perciaccante // J. Am. Dent Assoc. - 2004. - Vol.135, N 12. - P. 1713-1717.

157. Baily P. Neuralgia of the cranial nerves / P. Baily // The Surg. Clin. of North America. - 1931. - N 11. - P. 1.

158. Barker 2nd F.G. Long-term outcome after operation for trigeminal neuralgia in patients with posterior fossa tumors / F.G. Barker 2nd, P.J. Jannetta, D.P. Babu et al. // J. Neurosurg. - 1995. - Vol. 84, N5. P. 818-825.

159. Barker 2nd F.G. The long-term outcome of microvascular decompression for trigeminal neuralgia (see comments) / F.G. Barker 2nd, P.J. Jannetta, D.J. Nissonette et al. // N. Engl. J. Med. - 1996. - Vol. 334, N 17. - P. 1077-1083.

160. Barna D. Success of microvascular decompression with and without prior surgical therapy for trigeminal neuralgia / D. Barna, J.F. Alksne // Neurosurgery. - 1984. - Vol. 60, N 1. - P. 104-107.

161. Beaver D.L. Electron microscopy of the Gasserian ganglion in trigeminal neuralgia / D.L. Beaver // J. Neurosurg. - 1967. - Vol. 26. P. 151-156.

162. Bederson J.B. Evaluation of microvascular decompression and partial sensory rhizotomy in 252 cases of trigeminal neuralgia / J.B. Bederson, C.B. Wilson // J Neurosurg. - 1989. - Vol. 71. - P. 359-367.

163. Benes L. Is preoperative high-resolution magnetic resonance imaging accurate in predicting neurovascular compression in patients with 
trigeminal neuralgia? A single-blind study / L. Benes, K. Shiratori, M. Gurschi et al. // Neurosurg Rev. - 2005. - Vol. 28, N 2. - P. 131-136.

164. Blom S. Trigeminal neuralgia: its treatment with a new anticonvulsant drug (G-32883) / S. Blom // Lancet. - 1962. - Vol. 1. - P. 839-840.

165. Bowsher D. Trigeminal neuralgia: an anatomically oriented review / D. Bowsher // Clinical Anatomy. - 1997. - Vol. 10, N 6. - P. 409-415.

166. Bozzola J.J. Electron Microscopy: principles and techniques for biologists / J.J. Bozzola, L.D. Russel. - Boston: Jones and Bastlett Publishers, 1992. $-542 \mathrm{p}$.

167. Brito A.J. Triggeminal neuralgia / A.J. Brito // Acta Med. Port. 1999. - Vol. 12, N 4-6. - P 187-193.

168. Broggi G. Microvascular decompression for trigeminal neuralgia: comments on a series of 250 cases, including 10 patient with multiple sclerosis / G. Broggi, P. Ferroli, A. Franzini et al. // Neurosurgery. - 1999. - Vol. 45, N 6. - P. 1299-1305.

169. Broggi G. Microvascular decompression for trigeminal neuralgia: comments on a deries of 250 cases? Including 10 patients with multiple sclerosies / G. Broggi, P. Ferroli, A. Franzini, M. Pintucci et al. // J. Neurol., Neurosurg., Psychiatry.- 2000.- Vol. 68, N 6.- P. 59-64.

170. Broggi G. Operative findings and outcomes of microvascular decompression for trigeminal neuralgia in 35 patients affected by multiple sclerosis / G. Broggi, P. Ferroli, A. Franzini et al. // Neurosurgery. - 2004. - Vol. 55, N 4. - P. 830-838.

171. Burchiel K.J. Abnormal impulse generation in focally demyelinated trigeminal roots / K.J. Burchiel // J. Neurosurg. - 1980. - Vol. 53, N 5. P. 674-683.

172. Burchiel K.J. A new classification for facial pain / K.J. Burchiel // Neurosurgery. - 2003. - Vol. 53, N 5. - P. 1164-1166; discussion 1166-1167. 
$250 \mid$ Классическая невралгия тройничного нерва

173. Burchiel K.J. Pathophysiology of trigeminal neuralgia: new evidence from a trigeminal ganglion intraoperative microneurographic recording. Case report / K.J. Burchiel, T.K. Baumann // J Neurosurg. - 2004. - Vol. 101, N 5. - P. 872-873.

174. Cabyoglu M.T. The mechanism of acupuncture and clinical applications / M.T. Cabyoglu, N. Ergene, U. Tan // Int. J. Neurosci. - 2006. Vol. 116, N 2. - P. 115-125.

175. Calvin W.H. A neurophysiological theory for the pain mechanism of tic douloureux / W.H. Calvin, J.D. Loeser, J.F. Howe // Pain. - 1977. N 3. - P. 147-154.

176. Campbell F.G. Clinical trial of carbamazrpine (tegretol) in trigeminal neuralgia / F.G. Campbell, J.G. Graham, K.J. Zickha // J. of Neurolgy, Neurosurgery and Psychiatry. - 1966. - Vol. 29. - P. 265-267.

177. Canavero S. Drug therapy of trigeminal neuralgia / S. Canavero, B. Bonicalzi // Expert Rev. Neurother. - 2006. - Vol. 6, N 3. - P. 429-440.

178. Carrazana E.J. Alternative uses lamatrigine and gabapentin in the treatment of trigeminal neuralgia / E.J. Carrazana, S.C. Schachter // Neurology. - 1998. - Vol. 50, N 4. - P. 1192-1196.

179. Carrazana E.J. Rationale and evidence for the use of oxcarbazepine in neuropathic pain / E.J. Carrazana, I. Mikoshiba // J. Pain Symptom Manage. - 2003. - Vol. 25, Suppl 5. - P. S31-35.

180. Cerovic R. Neurectomy of the trigeminal nerve branches: clinical evaluation of an "obsolete" treatment / R. Cerovic, M. Juretic, M.B. Gobic // J. Craniomaxillofac Surg. - 2009. - Vol. 37, N 7. - P. 388-391.

181. Chamadoira C. Trigeminal neuralgia caused by contra lateral cerebellopontine angle tumor. A case report / C. Chamadoira, A. Cerejo, F. Duarte, R. Vaz // Neurocirugia (Astur). - 2010. - Vol. 21, N 1. - P. 50-52.

182. Chen JF. Long-Term Follow-up of Patients Treated with Percutaneous Balloon Compression for Trigeminal Neuralgia in Taiwan./ Chen JF, Tu PH, Lee ST // World Neurosurg. - 2011. - Vjl.76, N 6. - P. 586-591. 
183. Chen J, Characterization of neurovascular compression in facial neuralgia patients by 3D high-resolution MRI and image fusion technique./ Chen J, Guo ZY, Yang G, Wang X. // Asian Pac J Trop Med. - 2012. - Vol. 5, N 6. - P. 476-479.

184. Cheng J.S. Management of medically refractory trigeminal neuralgia in patients with multiple Sclerosis / J.S. Cheng, R.O. Sanchez-Mejia, M. Limbo et al. // Neurosurg Focus. - 2005. - Vol. 18, N 5. - P 13-15.

185. Cheshire W.P. Trigeminal neuralgia in wind musicians / W.P. Cheshire // Headache. - 2006. - Vol. 46, N 9. - P. 1458-1460.

186. Cho D.Y. Repeat operations in faild microvascular decompression for trigeminal neuralgia / D.Y. Cho, C.G. Chang, C.Y. Wang et al. // Neurosurgery. - 1994. - Vol. 35, N4. - P. 665-669.

187. Chole R. Drug treatment of trigeminal neuralgia: a systematic review of the literature / R. Chole, R. Patil, S.S. Degwekar, R.R. Bhowate // J. Oral Maxillofac Surg. - 2007. - Vol. 65. - P. 40-45.

188. Cleveland D. Trigeminal symptoms in acoustic nerve tumours / D. Cleveland, J.L. Garlex // Larengoscope. - 1953. - Vol. 63, N 9. - P. 778.

189. Cole C.D. Historical perspective on the diagnosis and treatment of trigeminal neuralgia / C.D. Cole, J.K. Liu, R.I. Apfelbaum // Neurosurg. Focus. - 2005. - Vol. 18, N 5. - P. 1-10.

190. Cruccu G. Idiopathic and symptomatic trigeminal pain / G. Cruccu, M. Leandri // J. Neurol. Neurosurg. and Psychiatry. - 1990. - Vol. 53. P. 1034-1042.

191. Cruccu G. Trigeminal neuralgia and orofacial pains / G. Cruccu, A. Truini // The Neurological Basis of Pain / ed. M. Pappagallo. - New York: Mc Graw-Hill, 2004. - P. 401-414.

192. Cunningham V.L. Human health risk assessment of carbamazepine in surface waters of North America and Europe / V.L. Cunningham, C. Perino, V.J. D'Aco et al. // Regul Toxicol Pharmacol. - 2010. - Vol. 56, N 3. - P. 343-351. 
$252 \mid$ Классическая невралгия тройничного нерва

193. Dandy W.E. Concerning the cause of trigeminal neuralgia / W.E. Dandy // Amer. J. Surg. - 1934. - Vol. 24. - P. 447-455.

194. Dandy W.E. Concerning the cause of trigeminal neuralgia / W.E. Dandy // John Hopkins Hosp. Bull. - Balt., 1934. - Vol. XXXVI. - P. 105.

195. Devis L. Surgical anatomy of the sensory root of the trigeminal nerve / L. Devis, H. Haven H. // Arch. Neurol.Psych. - 1933. - Vol. 29. P. 1-15.

196. Dieckmann G. Five-and-a half years' experience with percutaneous retrogasserian glycerol rhizotomy in treatment of trigeminal nevralgia / G. Dieckmann, V. Bockermann, C. Heyer // Appl. Neurophisiol. - 1987. Vol. 90, N 1-6. - P. 401-413.

197. Domingues R.B. Treatment of trigeminal neuralgia with low doses of topiramate / R.B. Domingues, G.W. Kuster, C.C. Aquino // Arq Neuropsiquiatr. - 2007. - Vol. 65. - P. 3792-3794.

198. Drzymala R.E. Gamma knife radiosurgery for trigeminal neuralgia: the Washington University initial experience / R.E. Drzymala, R.S. Malyapa, J.L. Dowling // Stereotact Funct Neurosurg. - 2005. - Vol. 83, N 4. - P. 148-152.

199. Dubner R. Idiopathic trigeminal neuralgia: sensory feature and pain mechanisms / R. Dubner, Y. Sharav, R.H. Gracely, D.D. Price // Pain. 1987. - Vol. 31. - P. 23-33.

200. Eide P.K. Relief of trigeminal neuralgia after percutaneous retrogasserian glycerol rhizolysis is dependent on normalization of abnormal temporal summation of pain, without general impairment of sensory perception / P.K. Eide, A. Stubhaug // Neurosurgery. - 1998. - Vol. 43, N 3. - P. 462-472.

201. Eller J.L. Trigeminal neuralgia: definition and classification / J.L. Eller, A.M. Raslan, K.J. Burchiel // Neurosurg. Focus. - 2005. - Vol. 18, N 5. - P. 3.

202. Erbay S.H. Association between neurovascular contact on MRI and response to gamma knife radiosurgery in trigeminal neuralgia / S.H. Er- 
bay, R.A. Bhadelia, R. Riesenburger et al. // Neuroradiology. - 2006. Vol. 48, N 5. - P. 25-30.

203. Erdem E. Peripheral glycerol injections in the treatment of idiopathic trigeminal neuralgia: retrospective analysis of 157 cases / E. Erdem, A. Alkan // J. Oral Maxillofac Surg. - 2001. - Vol. 59, N 10. P. 1176-1180.

204. Fernandez-Carballal C. Management of recurrent trigeminal neuralgia after failed microvascular decompression / C. Fernandez-Carballal, F. Garcia-Salazar, J. Perez-Calvo et al. // Neurochirugia (Astur). - 2004. Vol. 15, N 4. - P. 345-352.

205. Frazier C.H. Physiologic extirpation of the ganalion Gasser / C.H. Frazier, W.G. Spiller // J.A.M.A. - 1904. - Vol. 43. - P. 943-947.

206. Fromm G.H. Baclofen in the treatment of trigeminal neuralgia: doubleblind study and long-term follow up / G.H. Fromm, C.F. Terence, A.S. Chatha // Ann. Neurol. - 1984. - Vol. 15, N 3. - P. 240-244.

207. Fromm G.H. Trigeminal Neuralgia / G.H. Fromm, B.G. Sessle. - Boston: Butterworth-Heinemann, 1991. - P. 131-144.

208. Fromm G.H. Trigeminal neuralgia current concepts regarding etiology and patogenesis / G.H. Fromm, S.V. Terrence, J.C. Maroon // Arch. Neurolog. - 1984. - Vol. 41. - P.1204-1207.

209. Fukuda M. Trigeminal neuralgia caused by the vertebral artery associated with primitive trigeminal artery and agenesis of the internal carotid artery / M. Fukuda, S. Kameyama, H. Takahashi, R. Tanaka // Neurol. Med. Chir. - 1998. - Vol. 38, N 6. - P. 367-370.

210. Fujimaki T. Percutaneous retrogasserian glycerol injection in the management of trigeminal neuralgia: long-term follow up results / T. Fujimaki, T. Fukushima, S. Miyazaki // J. Neurosurg. - 1990. - Vol. 73, N 2. - P. 212-216.

211. Gamrot J. Neurovascular compression as a reason for neurogenic hypertension / J. Gamrot, P. Babowski, P. Zavadzki et al. // Wiad. Lek. 1999. - Vol. 52, N 5-6. - P. 280-284. 
$254 \mid$ Классическая невралгия тройничного нерва

212. Gandolfi A. Microvascular decompression for trigeminal neuralgia: a simple and effective transposition method using synthetic adhesive / A. Gandolfi, F. Salvinelli, F. Greco et al. // Clin Neurol. Neurourg. - 2005. Vol. 107, N 5. - P. 439-440.

213. Gardner W.J. Concerning the mechanism of trigeminal neuralgia and hemifacial spasm / W.J. Gardner // J. Neurosurg. - 1962. - Vol. 19, N 6. - P. 947-958.

214. Gardner W.J. Response of trigeminal neuralgia to «decompression» of sensory root. Discussion of cause of trigeminal neuralgia / W.J. Gardner, M.V. Miklos // J. Amer. Med. Ass. - 1959. - Vol. 170. - P. 1773-1776.

215. Gass A. Trigeminal neuralgia in patients with multiple sclerosis: lesion localization with magnetic resonance imaging / A. Gass, N. Ketchen, D.G. MacManus et al. // Neurology. - 1997. - Vol. 49, N 4. - P. 1142-1144.

216. Gerdner E.D. Decrease in human neurous with age / E.D. Gerdner // Anatomical record. - 1940. - Vol. 77. - P. 529-532.

217. Gilron I. Topiromate in trigeminal neuralgia: a randomized placebo controlled, multiple crossover trial in three patient / I. Gilron, S. Booher, J. Rowan et al. // Programm and Abstracts of the 19th Annual Scientific Meeting of the American Pain Society, Nov. 2-5, 2000. - Atlanta (Georgia), 2000. - Abstract 857.

218. Gnanalingham K. Trigeminal neuralgia secondary to Chiari's malformation-triatment with ventriculoperitoneal shunt / K. Gnanalingham, S.M. Joshi, B. Lopez et al. // Surg. Neurol. - 2005. - Vol. 63, N 6. P. 586-588.

219. Golby A.J. Trigeminal neuralgia resulting from infarction of the root entry zone of the trigeminal nerve: case report / A.J. Golby, A. Norbash, G.D. Silverberg // Neurosurgery. - 1998. - Vol. 43. - P. 620-622.

220. Gomez-Arguelles J.M. Oxcarbazepine monotherapy in carbamazepine unresponsive trigeminal neuralgia / J.M. Gomez-Arguelles, R. Dorado, J.M. Sepulveda et al. // J. Clin Neurosci. - 2008. - Vol. 15, N 5. - P. 516-519. 
221. Grant F.S. Result in operative treatment of major trigeminal neuralgia / F.S. Grant // Ann. Surg. - 1958. - Vol. 107. - P. 14-19.

222. Grant S.M. Oxcarbasepin. A review of its pharmacology and therapeutic potential in epilepsy, trigeminal neuralgia and affective disorders / S.M. Grant, D. Faulds // Drags. -1992. - Vol. 43, N 6. - P. 873-888.

223. Gudmundson K. Deteiled relation of the trigeminal nerve. An anatomical study with clinical correlation / K. Gudmundson, Al. Rhoton, J.G. Rushton // J. Neurosurg. - 1971. - Vol. 52. - P. 381-386.

224. Haines S.J. Arterial cross compression of the trigeminal nerve at the pons in trigeminal neuralgia. Case report with autopsy findings / S.J. Haines, A.J. Martinez, P.J. Jannetta // J. Neurosurg. - 1979. - Vol. 50, N 2. - P. 257-259.

225. Haines S.J. Microvascular relations of the trigeminal nerve. An anatomical study with clinical correlation / S.J. Haines, P.J. Jannetta, D.S. Zorub // J. Neurosurg. - 1980. - Vol. 52, N 3. - P. 383-386.

226. Hamlyn P.J. Neurovasculr relationships in the posterior cranial fossa, with special reference to trigeminal neuralgia / P.J. Hamlyn // Clinical Anatomy. - 1997. - Vol. 10, N 6. - P. 380-388.

227. Han K.R. Efficacy and safety of high concentration lidocaine for trigeminal nerve block in patients with trigeminal neuralgia / K.R. Han, C. Kim, Y.J. Chae, D.W. Kim // Int JB Clin Pract. - 2008. - Vol. 62, N 2. P. 248-254.

228. Han K.R. Brief report: the long-term outcome of mandibular nerve block with alcohol for the treatment of trigeminal neuralgia / K.R. Han, C. Kim // Anesth Analg. - 2010. - Vol. 111, N 2. - P. 550-553.

229. Han S.R. Early dexamethasone relieves trigeminal neuropathic pain / S.R. Han, S.P. Yeo, M.K. Lee et al. // J. Dent Res. - 2010. - Vol. 89, N 9. - P. 915-920.

230. Hardy D.G. Microsurgical anatomy of the superior cerebellar artery / D.G. Hardy, D.A. Peace, F. Rhotton A.L.G // Neurosurgery. - 1980. Vol. 6, N 1. - P. 10-28. 
$256 \mid$ Классическая невралгия тройничного нерва

231. Hartmann M. Trigeminal neuralgia triggered by auditory stimuli in multiple sclerosis / M. Hartmann, K.G. Rottach, W.A. Wohlgemuth, K. Pfadenhauer // Arch Neurol. - 1999. - Vol. 56. - P. 71-73.

232. Headache Classification committee of the International Headache Society // Cephalagia. - 1988. - N 7. - P. 65-73.

233. Haugh M. Trigeminal neuralgia. Pain relief in patients treated with the anticonvulsant topiromate / M. Haugh, G.S. Connor // Programm and Abstracts of the 19th Annual Scientific Meeting of the American Pain Society, Nov. 2-5, 2000. - Atlanta (Georgia), 2000. - Abstract 675.

234. Henderson J.M. Motor cortex stimulation and neuropathic facial pain / J.M. Henderson, P. Shivanand // Neurosurg Focus. - 2006. - Vol. 21, N 6. - P. 6-10.

235. Heros R.C. Results of microvascular decompression for trigeminal neuralgia / R.C. Heros // J Neurosurg. - 2009. - Vol. 110. - P. 617-619.

236. Hilton D.A. Pathological findings associated with trigeminal neuralgia caused by vascular compression / D.A. Hilton, S. Love, T. Gradidge, H.B. Coakham et al. // Neurosurgery. - 1994. - Vol. 35. - P. 299-303.

237. Horvath J. Carbamazepine encephalopathy masquerading as Creutzfeldt-Jakob disease / J. Horvath, A. Coeytaux, P. Jallon et al. // Neurology. - 2005. - Vol. 65, N 4. - P. 650-651.

238. Huibin $\mathrm{Q}$. The treatment of first division idiopathic trigeminal neuralgia with radiofrequency thermocoagulation of the peripheral branches compared to conventional radiofrequency / Q. Huibin, L. Jianxing,

H. Guangyu, F. Dianen // J. Clin Neurosci. - 2009. - Vol. 16, N 11. P. 1425-1429.

239. Iizuka O. Trigeminal neuralgia due to pontine infarction / O. Iizuka, Y. Hosokai, E. Mori // Neurology. - 2006. - Vol. 66, N 1. - P. 48.

240. Ildan F. Isolatid trigeminal neuralgia secondary to destal anterior cerebellar artery aneurysm / F. Ildan, A.I. Gocer, H. Bagdatoglu et al. // Neurosurg. Rev. - 1996. - Vol. 19. - P. 43-46. 
241. Inatoni Y. Trigeminal neuralgia caused by metastasis of malignant lymphoma to the trigeminal nerve: a case report / Y. Inatoni, T. Inoue, S. Nagata et al. // No. Shinkei Geka. - 1998. - Vol. 26, N 5. - P. 401-405.

242. Ishimori T. Virtual endoscopic images by 3D FASE cisternography for neurovascular compression / T. Ishimori, S. Nakano, M. Kagawa // Magn Reson Med. Sci. - 2003. -Vol. 2, N 3. - P. 145-149.

243. Ito M. Dural artiriovenous malformation manifesting as tic douloureux / M. Ito, T. Sonocawa, H. Mishina // Surg. Neurol. - 1996. - Vol. 45. P. 370-375.

244. Jamjoom A.B. Trigeminal neuralgia related to cerebellopontine angle tumors / A.B. Jamjoom, Z.A. Jamjoom, M. al-Fehaily et al. // Neurosurg. Rev. - 1996. - Vol. 19. - P. 237-241.

245. Jannetta P.J. Arterial compression of the trigeminal nerve at the pons in patients with trigeminal neuralgia / P.J. Jannetta // J. Neurosurg. - 1967. - Vol. 26. - P. 159-162.

246. Jannetta P.J. Neurovascular compression in cranial nervi and systemic disease / P.J. Jannetta // Ann. Surg. - 1980. - Vol. 192, N 4. - P. 518-525.

247. Jannetta P.J. Microvascular decompression of the trigeminal nerve root entry zone: theoretical considerations, operative anatomy, surgical techniques, and results // Trigeminal neuralgia / Ed. By R.I. Rovit, R. Murali, P.J. Jannetta. - Baltimore: Md: Williams\&Wilkins, 1990. - P. 201-222.

248. Jaspers G.W. Trigeminal neuralgia by an acoustic neuroma. The need of imaging / G.W. Jaspers, B. Stegenga // Ned Tijdschr Tandheelkd. - 2005. - Vol. 112, N 6. - P. 231-233.

249. Jayasekera B.A. Trigeminal neuralgia from an Arteriovenous malformation: An intra-operative diagnosis/ B.A. Jayasekera, F. Vergani, A. Gholkar, AJ. Jenkins // Br J Neurosurg. 2014 Sep 15: 1-2 [Epub ahead of print].

250. Jensen T.S. Anticonvulsant in neurupatic pain: rationale and clinical evidence / T.S. Jensen // Europian J. of Pain. - 2002. - Vol. 6. - P. 61-68. 
$258 \mid$ Классическая невралгия тройничного нерва

251. Jensen T.S. Mechanism of neuropatic pain / T.S. Jensen, P. Rasmussen, E. Reske-Nielsen // Pain 1996 - an updated review / Ed. J.N. Campbell. - Seattle, 1996. - P. 77-86.

252. Jensen T.S. Association of trigeminal neuralgia with multiple sclerosis: clinical and pathological features / T.S. Jensen // Acta neurol. Scand. - 1982. - Vol. 65. - P. 182-189.

253. Jia D.Z. Bioresonance hypothesis: a new mechanism on the pathogenesis of trigeminal neuralgia / D.Z. Jia, G. Li // Med. Hypotheses. 2010. - Vol. 74, N 3. - P. 505-507.

254. -Johonson M.C. Arteriovenous malformation presenting as trigeminal neuralgia / M.C. Johonson // J. Neurosurgery. - 1968. - Vol. 29. P. 287-289.

255. Jorns T.P. Pilot study to evaluate the efficacy and tolerability of levetiracetam (Keppra) in treatment of patients with trigeminal neuralgia / T.P. Jorns, A. Johnston, J.M. Zakrzewska // Eur J Neurol. - 2009. Vol.16, N 6. - P. 740-744.

256. Jrdicke A. Microvascular decompression as treatment of trigeminal neuralgia in the elderly patient / A. Jrdicke, M. Winking, W. Densberger, D.K. Brker // Minim. Invasiv. Neurosurg. - 1999. - Vol. 42, N 2. - P. 92-96.

257. Jurgens J. Dentogene trigeminsneuralgie / J. Jurgens // Schmerz. 1998. - Bd. 12. - S. 411-413.

258. Kakizava Y. Anatomical study of trigeminal and Facial cranial nerves with the aid of 3.0 tesla magnetic resonance imaging / Y. Kakizava, T. Seguchi, K. Kodama // J. Neurosurg. - 2008. - Vol. 108, N 3. P. 483-490.

259. Kamigachi H. Computed tomographic analysis of gemifacial spasm: narrowing of the posterior fossa as a possible facilitating factor for neurovascular compression / H. Kamigachi, T. Ohira, M. Ochini et al. // J. Neurol., Neurosurg., Psychiatry. - 1997. - Vol. 62. - P. 532-534. 
260. Kanai A. Sumatriptan alleviates pain in patients with trigeminal neuralgia / A. Kanai, A. Suzuki, S. Osawa, S. Hoka // Clin J Pain. - 2006. Vol. 22, N 8. - P. 677-680.

261. Kanai A. Intranasal lidocaine 8\% spray for second-division trigeminal neuralgia / A. Kanai, A. Suzuki, S. Osawa, S. Hoka // Br J Anaesth. 2006. - Vol. 97, N 4. - P. 559-563.

262. Kannan V. Gamma-knife radiosurgery for trigeminal neuralgia / V. Kannan, C.E. Deopujari, B.K. Misra et al. // Australas Radiol. - 1999. Vol. 43, N 3. - P. 339-431.

263. Kanoto M. Focal Deformity of the Cranial Nerves Observed on Multislice Motion-Sensitized Driven Equilibrium (MSDE) i n Patients With Neurovascular Compression / M. Kanoto, T. Hosoya, A. Oda, T. Honma, Y. Sugai // J Comput Assist Tomogr. - 2012. - Vol. 36, N 1. - P. 121-124.

264. Kanpolat Y. Evaluation of platybasiain patients with idiopathic trigeminal neuralgia / Y. Kanpolat, M. Tatli, H.C. Ugur et al. // Surg Neurol. - 2007. - Vol. 67, N 1. - P. 78-81.

265. Karibe H. Intrinsic artiriovenous malformation of the trigeminal nerve in a patient with trigeminal neuralgia / H. Karibe, R. Shirane, H. Jokura, T. Yoshimoto // Neurosurgery. - 2004. - Vol. 55, N 6. - P. 1433.

266. 266. Kato T. Trigeminal neuralgia caused by a cerebellopontineangle lipoma: case report / T. Kato, Y. Savamura, H. Abe, T. Kato // Surg. Neurol. - 1995. - Vol. 44. - P. 33-35.

267. Kim Y.H. Is it effective to raise the irradiation dose from 80 to $85 \mathrm{~Gy}$ in gamma knife radiosurgery for trigeminal neuralgia? / Y.H. Kim, D.G. Kim, J.W. Kim, Y.H. Kim // Stereotact Funct Neurosurg. - 2010. - Vol. 88, N 3. - P. 169-176.

268. Kinoshita Y. Isolated trigeminal sensory neuropathy due to pontine infarction in the root entry zone-report of two cases / Y. Kinoshita, A. Harada, H. Yasukouchi et al. // Brain Nerve. - 2008. - Vol. 60, N 2. P. 175-179. 
$260 \mid$ Классическая невралгия тройничного нерва

269. Kitt C.A. Trigeminal neuralgia: opportunities for research and treatment / C.A. Kitt, K. Gruber, M. Davis et al. // Pain. - 2000. - Vol. 85. - P. 3-7.

270. Klun B. Microvascular relations of the trigeminal nerve: an anatomic study / B. Klun, B. Prestor // Neurosurgery. - 1992. - Vol. 30. - P. 49-52.

271. Knafo H. Trigeminal neuralgia: outcomes after gamma knife radiosurgery / H. Knafo, B. Kenny, D. Mathieu // Can J Neurol Sci. - 2009. Vol. 36, N 1. - P. 78-82.

272. Kofler M. Postoperative hearing loss due to venous congestion at the inferior colliculous, or cochlear dysfunction? / M. Kofler // J. Neurol. Neurosurg. Psychiatry. - 2001. - Vol. 71, N 1. - P. 135.

273. Kondo A. Mecrovascular decompression surgery for trigeminal neuralgia / A. Kondo // Stereoract Funct Neurosurg. - 2001. - Vol. 77, N 1-4. - P. 187-189.

274. Kondziolka D. Gamma-knife radiosurgery for trigeminal neuralgia / D. Kondziolka, V. Peres, J.C. Flickinger et al. // Arch. Neurol. - 1998. - Vol. 55, N 12. - P. 1524-1529.

275. Kondziolka D. Gamma Knife stereotactic radiosurgery for idiopathic trigeminal neuralgia / D. Kondziolka, 0. Zorro, J. Lobato-Polo et al. // J. Neurosurg. - 2010. - Vol. 112, N 4. - P. 758-765.

276. Kraemer J.L. Vertebrobasilar dolichoectasia as a cause of trigeminal neuralgia: the role of microvascular decompression. Case report / J.L. Kraemer, A. Pereira Filho Ade, G. David // Arq. Neuropsiquiatr. - 2006. Vol. 64, N 1. - P. 128-131.

277. Krause F. Resection des Trigeminus innerhalb der Schadelhohle / F. Krause // Arch Klin Chir. - 1892. - Vol. 44. - P. 821-832.

278. Kress B. Trigeminal neuralgia: how often are trigeminal nervevessel contacts fornd by MRI in normal volunteers / B. Kress, M. Schindler, D. Rasche et al. // Rofo. - 2006. - Vol. 178, N 3. - P. 313-315. 
279. Kumar G.K. When is facial pain trigeminal neuralgia? / G.K. Kumar, A.J. Vartanian, A. Albi // Postgrad. Med. - 1998. - Vol. 104, N 4. P. 155-156.

280. Kuncz A. Comparison of clinical symptoms and magnetic resonance angiographic (MRA) results in patients with trigeminal neuralgia and persistent idiopathic facial pain. Medium-term outcome after microvascular decompression of cases with positive MRA findings / A. Kuncz, E. Voros, P. Barzo et al. // Cephalalgia. - 2006. - Vol. 26, N 3. - P. 266-276.

281. Kuncz A. Management of trigeminal neuralgia by microvascular decompression / A. Kuncz, Z. Mencer, E. Vurus, M. Bodosi // Orv. Hetil. 1997. - Vol. 138, N 33. - P. 2051-2055.

282. Kuncz A. The role of MR angiography in predicting operative results of microvascular decompression in patients with trigeminal neuralgia / A. Kuncz, E. Voros, P. Barzo et al. // Orv Hetil. - 2005. - Vol. 146, N 51. - P. 2595-2602.

283. Kuroki A. Removal of petrous apex meningioma and microvascular decompression for trigeminal neuralgia through the anterior petrosal approach. Case report / A. Kuroki, T. Kayama, J. Song, S. Saito // Neurol. Med. Chir. (Tokyo). - 1999. - Vol. 39, N 6. - P. 447-452.

284. Lagares A. Central demyelination in the pathogenesis of trigeminal neuralgia associated with cerebellopontine angle tumors: case report with ultrastructural trigeminal root analysis / A. Lagares, J.J. Rivas, L. Jimŭnez et al. // Neurosurgery. - 2010. - Vol. 66, N 4. - P. 841-842.

285. Lang E. Neurovascular relationship at the trigeminal root entry zone in persistent idiopathic facial pain: findings from MRI 3D visualization / E. Lang, R. Naraghi, L. Tanrikulu et al. // J. Neurol. Neurosurg. Psycheatry. - 2005. - Vol. 76, N 11. - P. 1470-1471.

286. Laurent B. Clinical aspects of trigeminal neuralgia / B. Laurent, Y. Keravel, M. Sindou // Neurochirurgie. - 2009. - Vol. 55, N 2. P. 181-184. 
$262 \mid$ Классическая невралгия тройничного нерва

287. Lazar M.L. Trigeminal neuralgia and multiple sclerosis: demonstration of the plaque in an operative case / M.L. Lazar, J.X. Kirkpatrick // Neurosurgery. - 1979. - N 5. - P. 711-717.

288. Lee K.H. Microvascular decompression and percutaneous rhizotomy in trigeminal neuralgia / K.H. Lee, J.W. Chang, Y.J. Park et al. // Stereotact. Funct. Neurosurg. - 1997. - Vol. 68, N 1. - P. 196-199.

289. Lee S.H. Recurent trigeminal neuralgia attributable the veins after microvascular decompression / S.H. Lee, E.I. Levy, A.M. Scarrow et al. // Neursurgery. - 2000. - Vol. 46, N 2. - P. 356-361.

290. -Lemos L. Gabapentin supplemented with ropivacain block of trigger points improves pain control and quality of life in trigeminal neuralgia patients when compared with gabapentin alone / L. Lemos, S. Flores, P. Oliveira, A. Almeida // Clin JB Pain. - 2008. - Vol. 24, N 1. - P. 64-75.

291. -Levy E.I. Microvascular decompression / E.I. Levy, P.J. Jannetta // Burchiel K (ed): Surgical Management of Pain. - New York: Thieme, 2002. - P. 878-888.

292. Li S.T. Trigeminal neuralgia: what are the important factors for good operative outcomes with microvascular decompression / S.T. Li, Q. Pan, N. Liu et al. // Surg Neurol. - 2004. - Vol. 62, N 5. - P.400-404.

293. Liang Y.C. Therapeutic potential of cannabinoids in trigeminal neuralgia / Y.C. Liang, C.C. Huang, K.S. Hsu // Curr Drug Targets CNS Neurol Disord. - 2004. - Vol. 3, N 6. - P. 507-514.

294. Liao J.J. Reoperation for recurrent trigeminal neuralgia after microvascular decompression / J.J. Liao // Surg. Neurol. - 1997. - Vol. 47, N 6. - P. 562-568.

295. Liebel J. T., Minger N., Langof H. Oxcarbazepine in der Behandlung der trigeminus neuralgie // Nervenheilkunde.- 2000.- Vol. 20.- P. 461-465.

296. Lin M. Therapeutic effects of the point-injection therapy on primary trigeminal neuralgia- an observation of 103 cases / M. Lin // J. Tradit Chin. Med. - 2003. - Vol. 23, N 3. - P. 195-196. 
297. Liu J.K. Treatment of trigeminal neuralgia. Neurosurg / J.K. Liu, R.I. Apfelbaum // Clin N Am. - 2004. - Vol. 15. - P. 319-334.

298. Lorenzoni J.G. Neurovascular compression anatomy and pain outcome in patient with classic trigeminal neuralgia / J.G. Lorenzoni, N. Massager, P. David et al. // Neurosurgery. - 2008. - Vol.62, N. 2. P. 368-375.

299. Love S. Central demielinization of the 5 th nerve root in trigeminal neuralgia associated with vascular compression / S. Love, D.A. Hilton, H.B. Coakham // Brain Pathol. - 1998. - Vol. 8, N 1. - P. 1-11.

300. Love S. Trigeminal neuralgia: pathology and pathogenesis / S. Love, H.B. Coakhman // Brain. - 2001. - Vol. 124, N 12. - P. 2347-2360.

301. Love S. Trigeminal neuralgia: pathology and pathogenesis / S. Love, S. Coakham // Brain. - 2002. - Vol. 125, N 3. - P. 687-693.

302. Love S. Trigeminal neuralgia due to multiple sclerosis: ultrastructural findings in trigeminal rhizoromy speciment / S. Love, T. Gradidge, H.B. Coachman // Neuropatol Appl Neurobiol. - 2001. - Vol. 27. - P. 1-8.

303. Lu X. Tentorial dural arteriovenous fistula manifesting as contralateral trigeminal neuralgia: resolution after transarterial Onyx embolization / X Lu , X Qin , L Ni , J Chen , F Xu .// J Neurointerv Surg. 2013 Dec 2. doi: 10.1136 / neurintsurg-2013-010984. rep. [Epub ahead of print].

304. Lunardi G. Clinical effectiveness of lamotrigine and plasma levels in essential and symptomatic trigeminal neuralgia / G. Lunardi, M. Leandri, C. Albano et al. // Neurology. - 1997. - Vol. 46, N 6. - P. 1714-1717.

305. La Mantia L. Role Microvascular decompression in trigeminal neuralgia and multiple sclerosis (letter) / L. La Mantia, C. Milanese // Lancet. - 1999. - Vol. 354, N 9193. - P. 1878-1879.

306. Maarbjerg S. Concomitant Persistent Pain in Classical Trigeminal Neuralgia - Evidence for Different Subtypes / S. Maarbjerg, A. Gozalov, J. Olesen, L. Bendtsen // Headache. - 2014. May 20. doi: 10.1111 / head.12384 [Epub ahead of print]. 
$264 \mid$ Классическая невралгия тройничного нерва

307. Marinković S. Ultrastructure and immunohistochemistry of the trigeminal peripheral myelinated axons in patients with neuralgia / S. Marinković, H. Gibo, V. Todorović et al. // Clin Neurol Neurosurg. 2009. - Vol. 111, N10. - P. 795-800.

308. Matsushima T. The microsurgical anatomy of the infratentorial lateral supracerebellar approach to the trigeminal nerve for tic douloureux / T. Matsushima, M. Fukui, S. Susuki, Al. Rhton // Neurosurgery. - 1989. - Vol. 24, N 6. - P. 890-895.

309. Matsushige T. Tentorial dural arteriovenous malformation manifesting as trigeminal neuralgia treated by stereotactic radiosurgery: a case report / T. Matsushige, M. Nakaoka, K. Ohta et al. // Surg. Neurol. 2006. - Vol. 66, N 5. - P. 519-523.

310. Manzoni G.C. Epidemiology of typical and atypical craniofacial neuralgias / G.C. Manzoni, P. Torelli // Neurol. Sci. - 2005. - Vol. 26, Suppl 2. - P. 65-67.

311. Martinez-Moreno N.E. Gammaknife (R) radiosurgery treatment of trigeminal neuralgia and atypical facial pain / N.E. Martinez-Moreno, R. Martinez-Alvarez, G. Rey-Portoles et al. // Rev. Neurol. - 2006. - Vol. 42, N 4. - P. 195-201.

312. McLeod N.M. Peripheral alcohol injections in the management of trigeminal neuralgia / N.M. McLeod, D.W. Patton // Oral Surg Oral Med Oral Pathol Oral Radiol Endod. - 2007. - Vol. 104, N 1. - P. 12-17.

313. Meaney J.F. Demonstration of neurovascular compression in trigeminal neuralgia with magnetic resonans imaging. Comparison with surgical findings in 52 consecutive operative cases / J.F. Meaney, P.R. Eldridge, L.T. Dunn et al. // J. Neurosurg. - 1995. - Vol. 83. - P. 799-805.

314. Meaney J.F. Association between trigeminal neuralgia and multiple sclerosis: role of magnetic resonance imaging / J.F. Meaney, W.J. Watt, P.R. Eldridge et al. // J. Neurol. Neurosurg. Psychiat. - 1995. - Vol. 59. P. 253-259. 
315. Meaney J.F. Vascular contact the fifth cranial nerve at the pons in patients with trigeminal neuralgis: detection with 3D FISP imaging / J.F. Meaney, B.J. Miles, T.E. Nixon et al. // Am. J. Roengenol. - 1994. Vol. 163, N 6. - P. 1447-1452.

316. Mekula I. Dfferences of blink-reflex abnormalities in patients suffering from idiopathic and symptomatic trigeminal neuralgia / I. Mekula, Z. Trkanjec, R. Negovetic et al. // Wien Klen. Wochenschr. - 2005. Vol. 117, N 11-12. - P. 417-422.

317. Melzack R. Pain mechanisms: a new theory. A gate control system modulates sensory input from the skin before it evokes pain perception and response / R. Melzack, P.D. Wall // Sciense. - 1965. - Vol. 150. P. 971-979.

318. Mendoza N. Trigeminal neuralgia treated by microvascular decompression a long-term follow-up study / N. Mendoza, R.D. Illingworth // Br. J. Neurosurgery. - 1996. - Vol. 9, N 1. - P. 13-19.

319. Meng L. Cerebellopontine angle epidermoids presenting with trigeminal neuralgia / L. Meng, L. Yuguana, L. Feng // J. Clin. Neurosci. 2005. - Vol. 12, N 7. - P. 784-786.

320. Michelucci R. Intracranial microvascular decompression for "cryptogenic" hemifacial spasm, trigeminal and glossopharyngeal neuralgia, paroxysmal vertigo and tinnitus: II. Clinical study and long-term follow up / R. Michelucci, C.A. Tassinari, G. Samoggia et al. // Ital. J. Neurol. Sci. 1986. - Vol. 7, N 3. - P. 367-374.

321. Miller J.P. Classification of trigeminal neuralgia: clinical, therapeutic, and prognostic implications in a series of 144 patients undergoing microvascular decompression / J.P. Miller, F. Acar, K.J. Burchiel // J Neurosurg. - 2009. - Vol. 111, N 6. - P. 1231-1234.

322. Missios S. Percutaneous Treatments for Trigeminal Neuralgia / S. Missios, A.M. Mohammadi, G.H. Barnett / Neurosurg Clin N Am. 2014 Oct;25(4): 751-762. doi: 10.1016 / j.nec.2014.06.008. Epub 2014 Aug 3. 
$266 \mid$ Классическая невралгия тройничного нерва

323. Mitsos A.P. Arachnoid cyst of quadrigeminal cistern presenting al trigeminal neuralgia / A.P. Mitsos, A.I. Samelis, H.M. Panteleakou-Sameli et al. // Acta Neurocher (Wien). - 2006. - Vol. 148, N 1. - P. 93-94.

324. Monstad P. Microvascular decompression as a treatment for cranial nerve hyperactive dysfunction a critical view / P. Monstad // Acta Neutol. - 2007. - Vol. 187, Suppl 2. - P. 30-33.

325. Mojaver Y.N. Individualized homeopathic treatment of trigeminal neuralgia: an observational study / Y.N. Mojaver, F. Mosavi, A. Mazaherinezhad et al. // Homeopathy. - 2007. - Vol. 96, N 2. - P. 82-86.

326. Mori Y, Trigeminal Neuralgia Caused by Nerve Compression by Dilated Superior Cerebellar Artery Associated with Cerebellar Arteriovenous Malformation: Case Report./ Y. Mori, T. Kobayashi, S Miyachi, C. Hashizume, T. Tsugawa, Y. Shibamoto // Neurol Med Chir (Tokyo). 2013. Nov 20 [Epub ahead of print].

327. Muller H. Neuroplastizitat und schmirzchronifizierung / H. Muller // Anesthesiol. Intesivemed. Notfallmed. Schmerzthed. - 2000. - Bd 35. S. 274-284.

328. Murali R. A Peripheral neurectomies of value in the treatment of trigeminal neuralgia? An analysis of new cases and cases involving previous radiofrequency gasserean termocoagulation / R. Murali, R.L. Rovit // J. Neurosurg. - 1996. - Vol. 85, N 3. - P. 435-437.

329. Al Musaed A.A. Carbamazepin and folic acid in trigeminal neuralgia patients / A.A. Al Musaed, J.M. Zakrzewska, B.J. Bain // J. Soc. Med. 1992. - Vol. 85, N 1. - P. 19-22.

330. Naja M.Z. Repeated nerve blocks with clonidine, fentanyl and bupivacaine for trigeminal neuralgia / M.Z. Naja, M. Al-Tannir, H. Naja et al. // Anaesthesia. - 2006. - Vol. 61, N 1. - P. 70-71.

331. Nakamura K. Small medullary infarction presenting as painful trigeminal sensory neuropathy / K. Nakamura, T. Yamomoto, M. Yamashita // J. Neurol. Neurosurg. Psychiat. - 1996. - Vol. 61. - P. 138. 
332. Ngeow W.C. Injection of botulinum toxin type A (BOTOX) into trigger zone of trigeminal neuralgia as a means to control pain / W.C. Ngeow, R. Nair // Oral Surg Oral Med Oral Pathol Oral Radiol Endod. 2010. - Vol. 109, N 3. - P. 47-50.

333. Nurmikko T.J. Trigeminal neuralgia - pathophysiology, diagnosis and current treatment / T.J. Nurmikko // Br. J. Anesth. - 2001. - Vol. 87, N 1. - P. 117-132.

334. Nurmikko T.J. Multiple sclerosis-related central pain disorders / T.J. Nurmikko, S. Gupta, K. MacIver // Curr Pain Headache Rep. - 2010. Vol. 14, N 3. - P. 189-195.

335. Obermann M. Impaired trigeminal nociceptive processing in patients with trigeminal neuralgia / M. Obermann, M.S. Yoon, D. Ese et al. // Neurology. - 2007. - Vol. 69, N 9. - P. 835-841.

336. Ogiwara M. Surface rendered three-dimensional MR imaging for the evaluation of trigeminal neuralgia and gemiafcial spasm / M. Ogiwara, T. Shinizu // J. Clin. Neuroci. - 2004. - Vol. 11, N 8. - P. 840844.

337. Olson S. Microvascular decompression for trigeminal neuralgia: recurrences and complications / S. Olson, L. Atkinson, M. Weidmann // J. Clin. Neurosci. - 2005. - Vol. 12, N 7. - P. 787-789.

338. Papanagiotou P. Vascular anomalies of the cerebellopontine angle / P. Papanagiotou, I.Q. Grunwald, M. Politi et al. // Radiologe. - 2006. Vol. 46, N 3. - P. 216-222.

339. Patsalos P.N. Protein bindings of oxcarbasepin and its primary active metabolite, 10-hydroxycarbasepin, in patients with trigeminal neuralgia / P.N. Patsalos, A.A. Elias, J.M. Zakrzewska // Eur. J. Clin. Pharmacol. - 1990. - Vol. 39, N 4. - P. 413-415.

340. Patwardhan R.V. Neurosurgical treatment of multiple sclerosis / R.V. Patwardhan, A. Menagar, R.E. Kelley, A. Nanda // Neurol. Res. 2006. - Vol. 28, N 3. - P. 320-325. 
$268 \mid$ Классическая невралгия тройничного нерва

341. Peker S. Microanatomy of the central myelin-peripheral myelin transition zone of the trigeminal nerve / S. Peker, O. Kurtkaya, I. Uztjn, M.N. Pamir // Neurosurgery. - 2006. - Vol. 59, N 2. - P. 354-359.

342. Peker S. Vascular compression of the trigeminal nerve is a frequent finding in asymptomatic individuals: 3-T MR imaging of 200 trigeminal nerves using 3D CISS sequences / S. Peker, A. Dinzer, M. Necmettin Pamir // Acta Neurochir (Wien). - 2009. - Vol. 5. - P. 231-235.

343. Pereira E.A. Trigeminal neuralgia-divided but not classified / E.A. Pereira // Anesth Pain Med. 2012 Fall; 2(2): 101-2. doi: 10.5812 / aapm. 3761. Epub 2012. Sep 13.

344. Perez C. Patient-reported outcomes in subjects with painful trigeminal neuralgia receiving pregabalin: evidence from medical practice in primary care settings / C. Perez, A. Navarro, M.T. Saldana et al. // Cephalalgia. - 2009. - Vol. 29, N 7. - P. 781-790.

345. Pihut M. Differential Diagnostics of Pain in the Course of Trigeminal Neuralgia and Temporomandibular Joint Dysfunction / M. Pihut, M. Szuta, E. Ferendiuk, D. Zeńczak-Więckiewicz // Biomed Res Int. 2014; 2014: 563786. Epub 2014 Jun 4.

346. Piovesan E.J. An open study of botulinum-A toxin treatment of trigeminal neuralgia / E.J. Piovesan, H.G. Teive, P.A. Kowacs et al. // Neurology. - 2005. - Vol. 65, N 8. - P. 1306-1308.

347. Puca A. Typical trigeminal neuralgia associated with posteriorcranial fossa tumors / A. Puca, M. Meglio // Ital. J. Neurol. Sci. - 1993. Vol. 14, N 7. - P. 549-552.

348. Pyen J.S. Tic convulsive caused by cerebellopontine angle schwannoma / J.S. Pyen, K. Whang, C. Hu et al. // Yonsei Med. J. - 2001. - Vol. 42, N 2. - P. 255-257.

349. Quay H.Mc. Anticonvulsant drugs for management of pain: a systematic review / H.Mc. Quay, D. Carroll, A.R. Jadad et al. // BMJ. - 1995. Vol. 311. - P. 1047-1052. 
350. Ramirez H. Pharmacotherapy of trigeminal neuralgia / H. Ramirez, C. Martinez, J. Oliva, C. Montini // Odontol. Chil. - 1989. - Vol. 37, N 2. P. 264-269.

351. Ramirnovin C.D. Multimodality treatment If trigeminal neuralgia / C.D. Ramirnovin, J.S. Neimat, J.A. Roberts, E.N. Eskandar // Stereoract Funct Neurosurg. - 2005. - Vol. 83, N. 5-6. - P. 197-201.

352. Rappoport Z.H. An electron-microscope analysis of biopsy samples of the trigeminal root taken during microvascular decompressive surgery / Z.H. Rappoport, R. Govrin-Lippmann, M. Devor // Stereotact funct neurosurg. - 1997. - Vol. 68. - P. 182-186.

353. Rappoport Z.H. Trigeminal neuralgia: the role of self sustaining discharge in the trigeminal ganglion / Z.H. Rappoport, M. Devor // Pain. 1994. - Vol. 56. - P. 127-138.

354. Rasche D. Treatment of trigeminal neuralgia associated with multiple sclerosis: case report / D. Rasche, B. Kress, C. Schwark et al. // Neurology. - 2004. - Vol. 63, N 9. - P. 1714-1715.

355. Rath S.A. Findings and long-term results of subsequent operations after faild microvascular decompression for trigeminal neuralgia / S.A. Rath, J.H. Klein, P.H. Richter // Neurosurgery. - 1996. - N 5. - P. 933-938.

356. Rhotton Al. Jr. The cerebellar arteries / Al. Jr. Rhotton // Neurosurgery. - 2000. - Vol. 47, N 3. - P. 7-27.

357. Revuelta-Gutierrez R. Cerebellopontine angle epidermoid cysts. Experience of 43 cases with long-term follow-up / R. Revuelta-Gutierrez, R.F. Diaz-Romero Paz, L.O. Vales-Hidalgo // Cir Cir. - 2009. - Vol. 77, N 4. - P. 257-265.

358. Riesenburger R.I. Outcomes following single-treatment Gamma Knife surgery for trigeminal neuralgia with a minimum 3-year follow-up / R.I. Riesenburger, S.W. Hwang, C.M. Schirmer, V. Zerris // J Neurosurg. - 2010. - Vol. 112, N 4. - P. 766-771. 
$270 \mid$ Классическая невралгия тройничного нерва

359. Rogers C.L. Gamma-knife radiosurgery for trigeminal neuralgia / C.L. Rogers, A.G. Shetter, J.A. Fiedler et al. // Int. J. Radiat. Onccol. Biol. Phys. - 2000. - Vol. 47, N 4. - P. 1013-1019.

360. Romansky K. Result of treatment for trigeminal neuralgia by microvascular decompression of the 5th nerve at its root entry zone / K. Romansky, N. Stoianchev, E. Dinev, I. Iliev // Arch. Physiol. Biochim. 1998. - Vol. 106, N 5. - P. 392-396.

361. Rosetti P. Arnold Chiari Type I malformation resenting as a trigeminal neuralgia: case report / P. Rosetti, N.O. Ben Taib, J. Brotchi et al. // Neurosurgery. - 1999. - Vol. 44, N 5. - P. 1122-1123.

362. Rushton J.G: Trigeminal neuralgia; one hundred fifty years of nonsurgical treatment / J.G. Rushton // Minn Med. - 1957. - Vol. 40. P. 702-706.

363. Sami H. Tic doulereux in basilar artery ectasia / H. Sami, C.I. Prodan // Neurology. - 2003. - Vol. 61, N 5. - P. 713.

364. Sanchez-Mejia R.O. Recurent or refractorytrigeminal neuralgia after microvascular decompression, radiofrequencyablation, or radiosurgery / R.O. Sanchez-Mejia, M. Limbo, J.S. Cheng et al. // Neurosurg. Focus. - 2005. - Vol.18, N 5. - P.12.

365. Sandell T. The effect of microvascular decompression in patients with multiple sclerosis and trigeminal neuralgia / Sandell T., Eide P.K. //. Neurosurgery. - 2010. - Vol. 67, N3. - P. 749-53.

366. Sarlani E. Trigeminal neuralgia in a patient with multiple sclerosis and chronic inflammatory demyelinating polyneuropathy / E. Sarlani, E.G. Grace, B.A. Balciunas, A.H. Schwartz // J Am Dent Assoc. - 2005. Vol. 136, N 4. - P. 469-476.

367. Sarsam Z. The long-term outcome of microvascular decompression for trigeminal neuralgia / Z. Sarsam, M. Garcia-Ficana, T.J. Nurmikko et al. // Br. J. Neurosurg. - 2010. - Vol. 24, N 1. - P. 18-25. 
368. Sato J. Diagnostic significance of carbamazepine and trigger zones in trigeminal neuralgia / J. Sato, T. Saitoh, K. Notqni et al. // Oral Surg. Oral Med. Oral Pathol. Oral Radiol. Endod. - 2004. - Vol. 97, N 5. - P. 544-545.

369. Sepehrnia A. Trigeminal neuralgia caused by contralateral cerebellopontine angle meningioma - case report / A. Sepehrnia, T. Schulte // Zentralbl Neurochir. -2001. - Vol. 62, N 2. - P. 62-64.

370. Scrivani S.J. Percutaneous stereotactic differential radiofreqency thermal rhizotomy for the treatment of trigeminal neuralgia / S.J. Scrivani, D.A. Keith, E.S. Mathews et al. // J. Oral Maxillofac. Surg. - 1999. - Vol. 57, N 2. - P. 104-111.

371. Schmidt M. Case of carbamasepin indused interstitial pneumonia / M. Schmidt, E. Brugger // Med. Klin. - 1980. - Vol. 75, N 1. - P. 29-31.

372. Shakib K. Stratification of the risk of serious allergic cutaneous reactions with therapeutic management of trigeminal neuralgia / K. Shakib, M. Sinanan // Br. J. Oral. Maxillofac. Surg. - 2010. - Vol. 27. P. 108-112.

373. Shehata H.S. Botulinum toxin-type A: could it be an effective treatment option in intractable trigeminal neuralgia? / Shehata H.S., El-Tamawy M.S., Shalaby N.M., Ramzy G. // J. Headache Pain. - 2013. Nov 19; 14(1): 92 [Epub ahead of print].

374. Shetter A.G. Microvascular decompression after gamma-knife surgery for trigeminal neuralgia: intraoperative findings and treatment outcomes / A.G. Shetter, J.M. Zabramski, B.L. Speiser // J. Neurosurg. - 2005. - Vol. 102. - P. 259-261.

375. Shelden C.H. Compression rather than decompression for trigeminal neuralgia / C.H. Shelden, R.H. Pudenz, D.B. Freshwater et al. // J. Neurosurg. - 1955. - Vol. 12. - P. 123-126

376. Shimohata K. Nasal sumatriptan as adjunctive therapy for idiopathic trigeminal neuralgia: report of three cases / K. Shimohata, T. Shimohata, R. Motegi, K. Miyashita // Headache. - 2009. - Vol. 49, N 5. - P. 768-770. 
$272 \mid$ Классическая невралгия тройничного нерва

377. Sicard A. Neuralgic faciale et sympathalgia faciale / Sicard A. // J. Prat. (Paris). - 1925. - Vol. 39. - P. 50-53.

378. da Silva C.J. Trigeminal involvement in multiple sclerosis: magnetic resonance imaging findings with clinical correlation in a series of patients / C.J. da Silva C.J., A.J. da Rocha, M.F. Mendes et al. // Mult Scler. - 2005. - Vol. 11, N 3. - P. 282-285.

379. Silver M. Double-blind, placebo-controlled trial of lamotrigine in combination with other medications for neuropathic pain / M. Silver, D. Blum, J. Grainger et al. // J. Pain Symptom Manage. - 2007. - Vol. 34, N 4. - P. 446-454.

380. Simko J. Carbamazepine and risk of hypothyroidism: a prospective study / J. Simko, J. Horacek // Acta Neurol Scand. - 2007. - Vol. 116, N 5. - P. 317-321.

381. Simone de R.A clinical comparison of trigeminal neuralgic pain in patients with and without underlying multiple sclerosis / R. de Simone, E. Marano, V. Brescia Morra V. et al. // Neurol. Sci. - 2005. - Vol. 26, Suppl 2. - P. 150-151.

382. Sindou M. Microvascular decompression for primary trigeminal neuralgia: long-term effectiveness and prognostic factors in a series of 362 consecutive patients with clear-cut neurovascular conflicts who underwent pure decompression / M. Sindou, J. Leston, E. Decullier, F. Chapuis // J. Neurosurg. - 2007. - Vol. 107, N 6. - P. 1144-1153.

383. Sindou M. Trigeminal neuralgia: a plea for microvascular decompression as the first surgical option. Anatomy should prevail.// Acta Neurochir (Wien). - 2010. - Vol. 152. - N 2. - P. 361-364.

384. Sindrop S.H. Pharmacotherapy of trigeminal neuralgia / S.H. Sindrop, T.S. Jensen // Clin. J. Pain. - 2002. - Vol. 18. - P. 22-27.

385. Singh D. Brain stem infarction: a complication of microvascular decompression for trigeminal neuralgia / D. Singh, A. Jagetia, S. Sinha // Neurol. India. - 2006. - Vol. 54, N 3. - P. 325-326. 
386. Singla V. Dolichoectasa of vertebrobasilar system: a rare cause of tic douloureux / V. Singla, M. Modi, P. Singh // Indian J. Med. Sci. - 2007. - Vol.61, N 1. - P. 30-31.

387. Siqueira S.R. Abnormal expression of voltage-gated sodium channels Nav1.7, Nav1.3 and Nav1.8 in trigeminal neuralgia / S.R. Siqueira, B. Alves, H.M. Malpartida et al. // Neuroscience. - 2009. - Vol. 164, N 2. P. 573-577. .

388. Skrap M. Use of the arachnoid membrane of the cerebellopontine angle to transpose the superior cerebellar artery in microvascular decompression for trigeminal neuralgia: technical note / M. Skrap, F. Tuniz // Neurosurgery. - 2010. - Vol. 66, N 3, Suppl Operative. - P. 88-91.

389. Smith K.J. The restoration of conduction by central remyelination / K.J. Smith, F.W. Blakemore, W.I. McDonald // Brain. - 1981. - Vol. 104. P. 383-404.

390. Smith K.J. Spontaneous and evoked electrical discharges from a central demyelinating lesion / K.J. Smith, W.I. McDonald // J. Neurol. Sci. - 1982. - Vol. 55. - P. 39-47.

391. Solaro C. Topiramate relieves idiopathic and symptomatic trigeminal neuralgia / C. Solaro, M.M. Uccelli, G. Brichetto et al // J. Pain Symptom Manage. - 2001. -Vol. 21. - P. 367-368.

392. Soyka D. Etiology and therapy of trigeminal neuralgia / D. Soyka // Neuroghirurgia (Stuttg). - 1990. - Vol. 33, Suppl 1. - P. 11-13.

393. Spiller W. Tic douloureux? Anatomic and clinical basis for subtotal section of sensory root of trigeminal nerve / W. Spiller, Ch. Frazier // Arch. Neurol. Psych. - 1933. - Vol. 29. - P. 50-55.

394. Stajcic Z. Peripheral streptomycin ledocain versus ledocaine alone in the treatment of idiopathic trigenenal neuralgia / Z. Stajcic, R.P. Juniper, L. Todorovich // J. Craniomaxillofac. Surg. - 1990. - Vol. 18, N 6. P. 243-246. 
$274 \mid$ Классическая невралгия тройничного нерва

395. Steardo L. Efficacy of baclofen in trigeminal neuralgia and some other painful conditions. A clinical trial / L. Steardo, A. Leo, E. Marano // Eur. Neurol. - 1984. - Vol.23, N 1. - P. 51-55.

396. Stookey B. Trigeminal Neuralgia: Its History and Treatment / B. Stookey, J. Ransohoff. - Springfield, IL: Charles C. Thomas, 1959.

397. Sun S.Y. Microvascular decompression for trigeminal neuralgia / S.Y. Sun, J.Z. Yin, L.L. Qiu // Clin. Med. J. (Engl). - 1994. - Vol. 107, N 4. P. 286-288.

398. Sun T. Long-term result of microvascular decompression for trigeminal neuralgia with reference to probability of recurrence / T. Sun, S. Saito, O. Nakai // Acta Neurochir. (Wien). - 1994. - Vol. 126, N 2-4. P. 144-148.

399. Taarnhoj P. Decompression of the posterior trigeminal root in trigeminal neuralgia. A 30-year follow-up review / P. Taarnhoj // J. Neurosurg. - 1952. - Vol. 52, N 1. - P. 14-17.

400. Taha J.M. A prospective 15-year follow up of 154 consecutive patients with trigeminal neuralgia triated by percutaneous stereotactic radiofrequency thermal rhizotomy / J.M. Taha, J.M. Tew, C.R. Buncher // J. Neurosurg. - 1995. - Vol. 83, N6. - P. 989-993.

401. Tanaka T. Utility of magnetic resonance cisternography using three-dimensional fast asymmetric spin-echo sequences with multiplanar reconstruction: the evaluation of sites of neurovascular compression of the trigeminal nerve / T. Tanaka, Y. Morimoto, S. Shiiba et al. // Oral Surg. Oral Med. Oral Pathol Oral Radial Endod. - 2005. - Vol. 100. P. 215-225.

402. Tanaka T. Relationship between the curative effects of carbamazepine administration and the neurovascular compression volume of the trigeminal nerve measured using magnetic resonance cisternography / T. Tanaka, E. Sakamoto, S. Shiiba et al. // Clin. J. Pain. - 2009. - Vol.25, N 9. - P. 752-759. 
403. Tashiro H. Trigeminal neuralgia caused by compression from arteries transfixing the nerve. Report of three cases / H. Tashiro, A. Kondo, I. Aoyama et al. // J. Neurosurgery.- 1991.- Vol. 75, N 5.- P. 783-786.

404. Taylor J.C. Long-term treatment of trigeminal neuralgia with carbamasepin / J.C. Taylor, S. Brauer, M.L. Espir // Postgrad. Med. J. - 1981. - Vol. 57, N 663. - P. 16-18.

405. Teo C. Resolution of trigeminal neuralgia following thirk ventriculostomy for hydrocephalus associated with Chiari I malformation: case report / C. Teo, P. Nakaji, D. Serisier et al. // Minim Invasive Neurosurg. 2005. - Vol. 48, N 5. - P. 302-305.

406. Thomas K.L. The anatomy of vascular compression in trigeminal neuralgia/ K.L. Thomas, J.A. Vilensky // Clin Anat. 2013 Feb 5. doi: 10.1002/ca.22157 [Epub ahead of print].

407. Truini A. New insight into trigeminal neuralgia / A. Truini, F. Galeotti, G. Cruccu // J. Headache Pain. - 2005. - Vol. 6, N 4. - P. 237-239.

408. Tucker S.M. Intraorbital surgery for trigeminal neuralgia / S.M. Tucker, E.C. Tarlov // Ophthal. Plast. Reconstr. Surg. - 2005. - Vol. 21, N 1. - P. 11-15.

409. Turk U. Botulinum toxin and intractable trigeminal neuralgia / U. Turk, S. Ilhan, R. Alp, H. Sur // Clin Neuropharmacol. - 2005. - Vol. 28, N 4. - P. 161-162.

410. Ueda F. In vivo anatomical analysis of arterial contact with trigeminal nerve: detection with three-dimensional spoiled grass imaging / F. Ueda, M. Suzuki, Y. Fujianaga et al. // Br. J. Radiology. - 1999. - Vol. 72, N 861. - P. 838-845.

411. Ugur H.C. Trigeminal neuralgia in a patient with Dandy-Walker malformation / H.C. Ugur, F. Torun, E. Yilmaz // J. Clin. Neurosci. - 2005. - Vol. 12, N 7. - P. 815-817. 
$276 \mid$ Классическая невралгия тройничного нерва

412. Vulcan A.W. Transient global brainstem dysfunction after microvascular decompression of the trigeminal nerve / A.W. Vulcan, R.D. Ferch, P.J. Teddy // Br. J. Neursurg. - 2004. - Vol. 18, N 3. - P. 275-277.

413. Walchebach R. Mecrovascrlar decompression for trigeminal neuralgia: a critical reappraisal / R. Walchebach, J.H. Voormolen, J. Hermans // Clin. Neurol. Nrurosurg. - 1994. - Vol. 96, N 4. - P. 290-295.

414. Wanke I. Endovascular treatment of trigeminal neuralgia caused by arteriovenous malformation: is surgery really necessary / I. Wanke, U. Dietrich, F. Oppel, M.J. Puchner // Zentralbl Neurochir. - 2005. - Vol. 66, N 4. - P. 213-216.

415. Warren H.G. Trigeminal and concurrent glossopharyngeal neuralgia secondary to lateral medullary infarction / H.G. Warren, A.L. Kotsenas, L.F. Czervionke // Am. J. Neuroradiol. - 2006. - Vol. 27, N 3. - P. 705-707.

416. Watson J.C. From paroxysmal to chronic pain in trigeminal neuralgia: implications of central sensitization / J.C. Watson // Neurology. 2007. - Vol. 69, N 9. - P. 817-818.

417. Weldman M.J. Trigeminal neuralgia. Surgical treatment by microsurgery decompression of trigeminal nerve root / M.J. Weldman // Med. J. Aust. - 1979. - Vol. 2, N 12. - P. 628-630.

418. Wiffen P.J. Anticonvulsant drugs for acute and chronic pain / P.J. Wiffen, S. Collins, H.J. McQuay et al. // Cochrane Database Syst Rev. 2010. - Vol. 20, N 1. - P. 113-133.

419. Wiffen P.J. Carbamazipine for acute and chronic pain / P.J. Wiffen, H.J. Mc Quay, R.A. Moore // Cochrane Database Syst. Rev. - 2005. Vol. 20, N 3. - CD005451.

420. Wilkins R.H. Historical perspectives / R.H. Wilkins // Rovit R.L., Murali R., Jannetta P.J. (eds) Trigeminal Neuralgia. - Baltimore: Williams\& Wilkins, 1990. - P. 1-25.

421. Wilkins R.H. Trigeminal neuralgia: historical overview, with emphasis on surgical treatment / R.H. Wilkins // Burchiel K. (ed) Surgical Management of Pain. - New York: Thieme, 2002. - P. 288-301. 
422. William P. Cheshire Jr. Trigeminal Neuralgia: Diagnosis and Treatment / William P., Cheshire Jr. // Current Neurology and Neuroscience Reports. - 2005. - Vol. 5, P. 79-85.

423. Winkelmuller W. Classifecation of trigeminal neuralgia and its effect on the results of surgical treatment / W. Winkelmuller // Neurochirurgia (Stuttg). - 1990. - Vol. 33, N 2. - P. 54-57.

424. Xia L. Effectiveness and Safety of Microvascular Decompression Surgery for Treatment of Trigeminal Neuralgia: A Systematic Review / L. Xia, J. Zhong, J. Zhu, Y.N. Wang, N.N. Dou, M.X. Liu, M. Visocchi, S.T. Li // J. Craniofac Surg. - 2014. Jun 20 [Epub ahead of print].

425. Yamada Y. Trigeminal neuralgia associated with an anomalous artery originating from the persistent primitive trigeminal artery / Y. Yamada, A. Kondo, H. Tamabe // Neurol. Med. Chir (Tokyo). - 2006. Vol. 46, N 4. - P. 194-197.

426. Yanagi S. Developmental studies on the foramen rotundum, foramen ovale and foramen spinosum of the human sphenoid bone // The Hokkaido Journal of Medical Science. - 1987. - 62 (3). - P. 485-496.

427. Yoshino N. Trigeminal neuralgia: evaluation of neuralgic manifestation and site of neurovascular compression with 3D CISS MR imaging and MR angiography / N. Yoshino, H. Akimoto, I. Yamada et al. // Radiology. - 2004. - Vol. 231, N 1. - P. 284.

428. Young R.F. Gamma-knife radiosurgery for trigeminal neuralgia / R.F. Young, S. Vermulen, A. Posewitz // Sterotact. Funct. Neurosurg. 1998. - Vol. 70, Suppl 1. - P. 192-199.

429. Zakrzewska J.M. Trigeminal neuralgia / J.M. Zakrzewska // Prim. Dent. Care. - 1997. - Vol. 4, N 1. - P. 17-19.

430. Zakrzewska J.M. Drafs used in the management of trigeminal neuralgia / J.M. Zakrzewska, P.M. Patsalos // Oral Surg. Oral Med. Oral Patol. - 1992. - Vol. 74, N 4. - P. 439-450.

431. Zakrzewska J.M. Lamotriqine (lamictal) in refractory trigeminal neuralgia: results from a double-blind placebo controlled crossover trial 
/ J.M. Zakrzewska, Z. Chaudhry, T.J. Nurmikko et al. // Pain. - 1997. Vol.73, N 2. - P. 223-230.

432. Zakrzewska J.M. A prospective, longitudinal study on patient with trigeminal neuralgia who andewent radiofreqvency thermocoagulation of the Gasserian ganglion / J.M. Zakrzewska, S. Jassim, J.S. Bulman // Pain. - 1999. - Vol. 79, N 1. - P. 51-58.

433. Zakrzewska J.M. Medical management of trigeminal neuropathic pains / J.M. Zakrzewska // Expert Opin Pharmacother. - 2010. - Vol. 11, N 8. - P. 1239-1254.

434. Zakrzewska J.M. Microvascular decompression for trigeminal neuralgia: update./ Zakrzewska J.M., Coakham H.B. // Curr Opin Neurol. 2012. - Vol. 25, N 3. - P. 296-301.

435. Zhang Z Observation on therapeutic effects of blood-letting puncture with cupping in acute trigeminal neuralgia / Z. Zhang // J. Tradit. Chin. Med. - 1997. - Vol. 17, N 4. - P. 272-274.

436. Zhou C.S. Clinical observation on acupoint injection of VitB12 for treatment of trigeminal neuralgia / C.S. Zhou, D.Q. Kong, Z.Y. Han // Zhongguo Zhen Jiu. - 2007. - Vol. 27, N 9. - P. 668-670.

437. Ziyal I.M. Microanatomy of the central myelin-peripheral myelin transition zone of the trigeminal nerve / I.M. Ziyal, T. Ozgen // Neurosurgery. - 2006. - Vol. 59, N 2. - P. 354-359. 
Балязина Елена Викторовна

\title{
КЛАССИЧЕСКАЯ НЕВРАЛГИЯ ТРОЙНИЧНОГО НЕРВА
}

\author{
Монография \\ Редактор С.Г. Студенникова \\ Подписано в печать 21.10.2015 \\ Формат 60×80 1/16. Бумага офсетная. \\ Печать оперативная. Усл. п.л. 17,3. Уч.-изд. л. 18 \\ Тираж 500 экз. Заказ № 47-4256 \\ Издательство «Лик» \\ 346430, г. Новочеркасск, пр. Платовский, 82 Е \\ тел.: 8(8635)226-442 \\ Отпечатано в издательско-полиграфическом комплексе «Колорит» \\ 346430 , г. Новочеркасск, пр. Платовский, 82 Е \\ тел.: 8(8635)226-442, 8-918-518-04-29, 8-952-603-0-609 \\ e-mail: center-op@mail.ru
}

